\title{
EVOLUÇÃO DA MINERALIZAÇÃO PRIMÁRIA ESTANÍFERA ASSOCIADA AO MACIÇO GRANÍTICO SANTA BÁRBARA, RONDÔNIA
}

\author{
IRENA SPARRENBERGER
}

Orientador: Prof. Dr. Jorge Silva Bettencourt

TESE DE DOUTORAMENTO

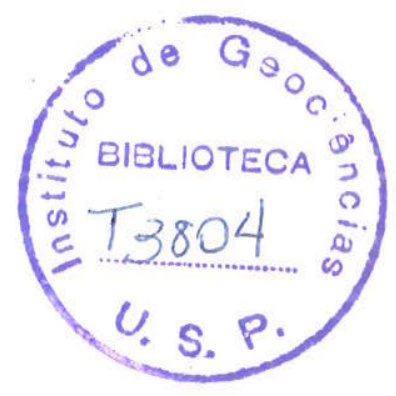

COMISSÃO JULGADORA

Nome

Assinatura

Presidente: $\quad$ Prof. Dr. Jorge Silva Bettencourt

Examinadores: Prof. Dr. Alcides Nóbrega Sial

Prof. Dr. Nilson Francisquini Botelho
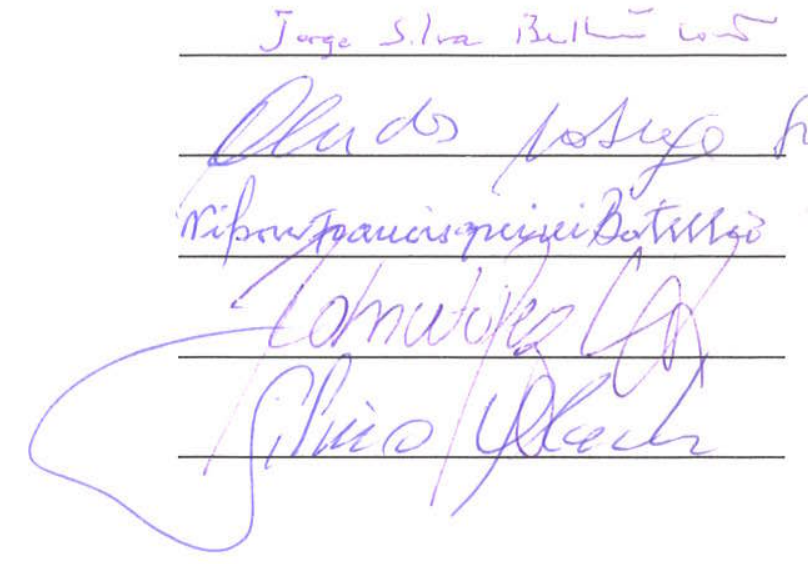

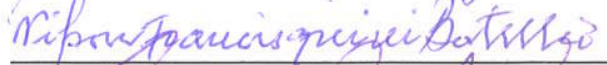

Prof. Dr. Roberto Perez Xavier

Prof. Dr. Silvio Roberto Farias Vlach

SÃO PAULO

2003 


\title{
UNIVERSIDADE DE SÃO PAULO INSTITUTO DE GEOCIÊNCIAS
}

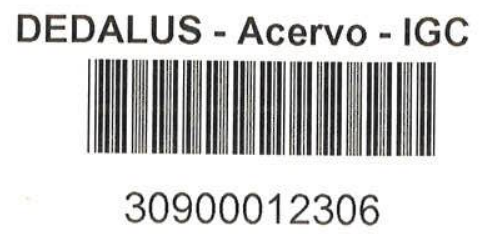

\section{EVOLUÇÃO DA MINERALIZAÇÃO PRIMÁRIA ESTANÍFERA ASSOCIADA AO MACIÇO GRANÍTICO SANTA BÁRBARA, RONDỐNIA}

Irena Sparrenberger

Orientador: Prof. Dr. Jorge Silva Bettencourt

\section{TESE DE DOUTORAMENTO}

Programa de Pós-Graduação em Recursos Minerais e Hidrogeologia

\author{
SÃO PAULO \\ 2003
}

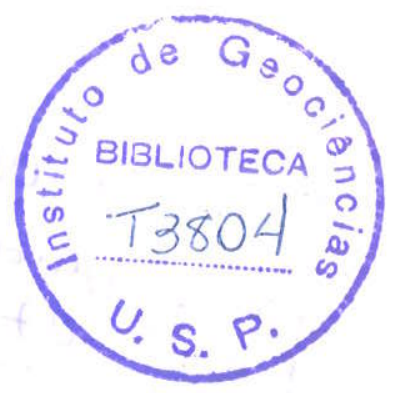




\section{AGRADECIMENTOS}

A execução desta T'ese contou com a valiosa colaboraçăo de diversás pessoas, a quem a autora agradece profundamente.

Inicialmente, ao Prof. Dr. Jorge Silva Bettencourt, amigo e orientador, que não poupou esforços na tentativa de conduzir a autora pelas veredas da ciência. Seu critério científico e brilhantismo intelectual são incomuns.

À Companhia Estanífera do Brasil, especialmente na pessoa do diretor da empresa no ano de 1998, St. Antônio Gomes Angeiras, que autorizou a realização dos estudos e a utilização dos arquivos da empresa por parte da autora. Igualmente, a Chefe do Setor de Geologia da companhia, geólogo José Antônio Jerônymo Vian, que providenciou toda a base e a infra-estrutura para a execução dos trabalhos, inclusive deliciosos e reconfortantes caldos de peixes amazônicos. Pela sua amizade.

A todos os funcionários da empresa que, carinhosamente, tomatam minha longa estada nas paragens amazônicas muito agradáveis. Em especial, a Mara Lis S. Cordeiro Costa, Ildemberg $\mathrm{N}$. Costa, João Vicente Soares Filho, Ramilde Zegarma Aguiar, Murilo Pereira dos Reis, Antônio Gomes da Costa, Antonio Joaquim Paiva, Maria do Carmo de Souza Viana, José Ernesto Viana, Leandro Rocha de Oliveira, Gilberto Ferreira da Rocha e ao engenheiro Romildo Ribeiro Patriota Júnior.

A Dra. Rosa Maria da Silveira Bello, que participou efetivamente de todas as etapas do estudo de inclusões fluidas, desde a execução das medidas microtermométricas até a interpretação dos dados e mesmo a redação do texto final. Sem sua ajuda, o capítulo relativo ao uso dessa técnica certamente não sería o mesmo.

A garotada que, desprendidamente, participou comigo dos trabalhos de mapeamento e de descrição de testemunhos de sondagem, por vezes extrematmente maçantes: Carolina Almeida Michelin, Carolina Rodrigues de Araújo Corrêa, Juliana Baitz Viviani, Daniel Andreas Klein e Fabrício Barteto. Hoje, orgulhosamente, posso chamá-los de amigos.

Aos geólogos e amigos, participantes da equipe de pesquisa da Província Estanífera de Rondônia comandada pelo Prof. Bettencourt, Washington Barbosa L.eite Júnior e Bruno Lconello Payolla. Boas foram as cervejas e os sucos de cupuaçu tomados juntos.

Ao Dr. Anthony Edward Fallick, do Solish Universities Environmental Research Centre, que acolheu entusiasticamente a proposta de colaboração científica no estudo dos isótopos estáveis e me recepcionou atenciosamente no seu centro de pesquisa. Pelo tempo despendido e pelo envolvimento demonstrado. Também à Maria da Glória Motta Garcia, cujo incentivo possibilitou minha ida à Escócia.

Ao Prof. Dr. Nilson Pinto Teixeira, colega da pós-graduação nos primeiros anos desta empreitada, e que sempre me deu uns "toques" sobre esses granitos tão especiás.

Aos Profs. Drs. Caetano Juliani e Sílvio Vlach, do Departamento de Geoquímica e Geotectônica do Instituto de Geociências da Universidade de São Paulo, que colaboraram muito para a melhoria desta tese por meio de críticas e sugestões no Exame de Qualificação.

Ao Dr. Kazuo Fuzikawa, do CDNT, que muito gentilmente me recepcionou em Belo Horizonte para a execução das análises por microespectrometria Raman. Pelas proveitosas discussões, pela delicadeza e generosidade, pelo empenho.

Ao Prof. Dr. Gérgely Szabó do Departamento de Mineralogia e Geoctectônica deste instituto, pelas orientações cuidadosas sobre o uso do Laboratório de Ótica do mesmo departamento.

Ao corpo técnico do Laboratório de Caracterização T'ecnológica da Escola Politécnica da Universidade de São Paulo, pela execução das análises no microscópio eletrônico de varredura.

A todo corpo de funcionários do Instituto de Geociências dá Universidade de São Paulo, especialmente ao José Paulo Sertek (LTA), ao Flávio Machado de Carvalho, do Laboratório de Difração de Raios-X, à Angélica Morente, do Laboratório de Ótica do Departamento de Mineralogia 
e Geotectônica, ao Marcos Mansueto, do Laboratório de Microssonda Eletrônica, às meninas da biblioteca - Brenda Mascarenhas, Maristela Prestes Severino, Érica do Nascimento e Maria Aparecida Bezerra, aos rapazes da gráfica e da laminação, e à Ana Paula Cabanal e Magali Fernandes Rizzo, da Secretaria da Pós-Graduaçào. Também ao Tadeu Caggiano.

Aos Profs. Drs. João Batista Moreschi e Gianna Maria Garda, pela orientação sobre o uso do microscópio ótico do Laboratório de Ótica do Departamento de Geologia Sedimentar e Ambiental deste instituto.

A Richard Tosdal e Joe Wooden, pelo acompanhamento e execução de análises de SHRIMP-RG em zircão.

Ao corpo técnico do IAPEGE, na UNESP, Campus Rio Claro, pelo auxílio no procedimento de separção de zircão para datação.

Ao Laboratório de Geocronologia do Instituto de Geociências da Universidade de Brasília, na pessoa do Prof. Dr. Márcio Martins Pimentel, pela execução das análises geocronológicas pelo método $\mathrm{Sm}-\mathrm{Nd}$.

Muito carinhosamente, aos amigos de outros tempos, que permaneceram: Artur Takashi Onoe, Liliane Aparecida Petronilho e Walter Maurício Sprösser. A Claúdia Regina Passarelli, pela presteza.

Ao Laboratório de Química e ICP-AES do GMG-IGC-USP, pela determinação do conteúdo de lítio em rochas e minerais, bem como limpeza dos concentrados de minerais para análise de isótopos estáveis.

Ao corpo técnico do Laboratório de Informática Geológica, em todas as suas fases.

Ao grande número de amigos que cultivei durante minha estada nesta instituição, incluindo Mestrado e Doutorado. Enumerar qualquer um deles seria correr o risco de esquecer alguém. Assim, aqui fica meu profundo carinho para toda a galera.

Finalmente, ao meu marido, Marco Aurélio Bonfá Martin, cuja inestimável ajuda durante a confecção e correção do mapa geológico, durante a impressão deste volume, bem como ao longo dos difíceis meses de conclusão desta T'ese, foram indispensáveis para que essa empreitada fosse levada a cabo.

Ao Sérgio Gaino, "cadista", que deu ao meu mapa geológico uma "cara" muito legal.

Dedico esta T"ese de à minha família. 


\section{SUMÁRIO}

RESUMO

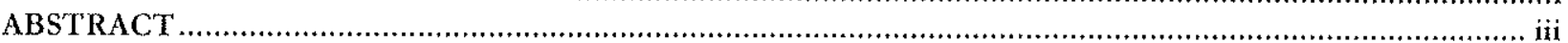

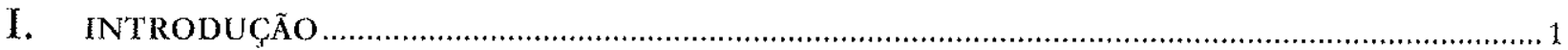

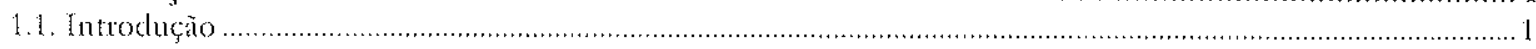

1.2. As tendências atuais de estudo de sistemas graníticos com metais raros ....................................................2

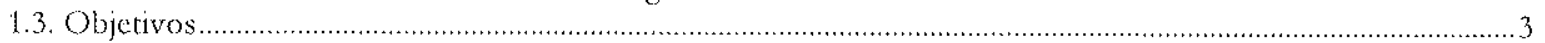

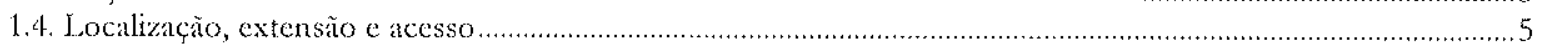

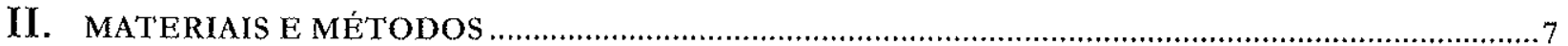

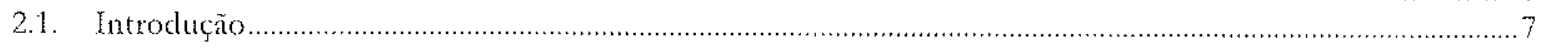

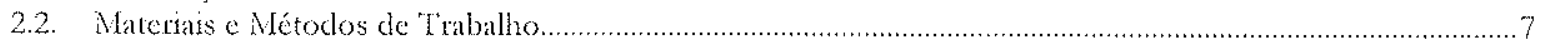

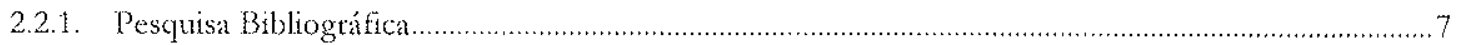

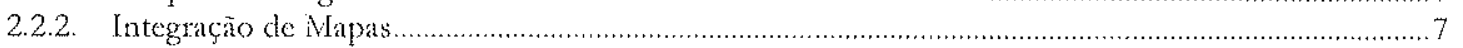

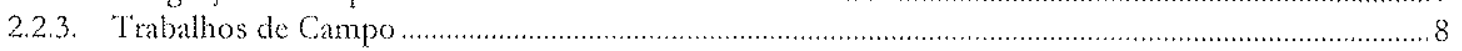

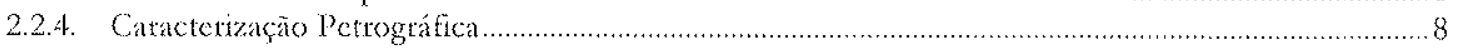

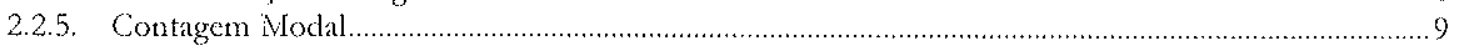

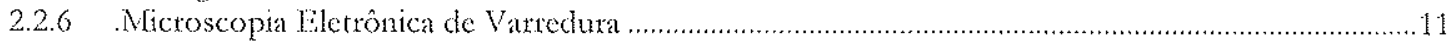

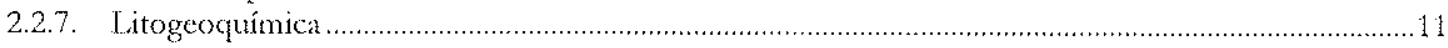

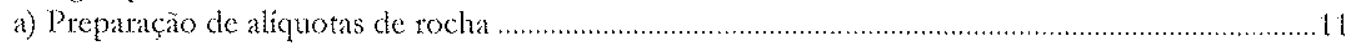

b) Abertuma e análise química de amostas ..................................................................................... 12

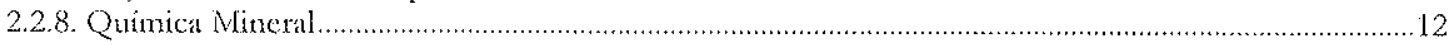

2.2.9. Determinação do Conteúdo de Litio em Rochas e Micas ................................................................12

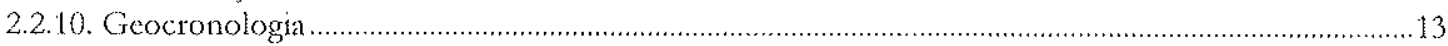

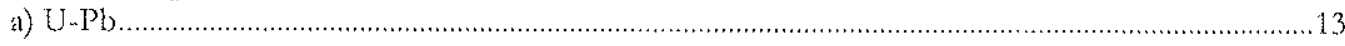

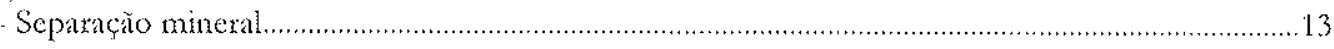

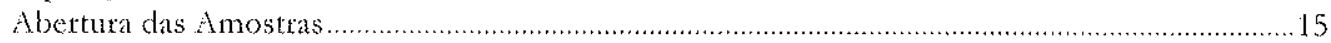

- Espectrometria de Massa por Ionização Térmica e Cálculos das Idades........................................16

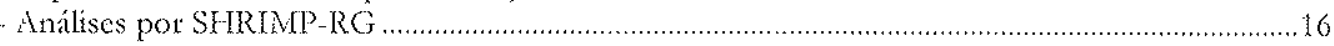

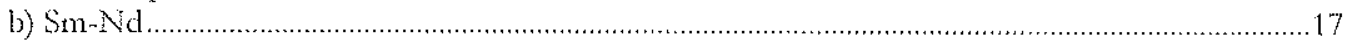

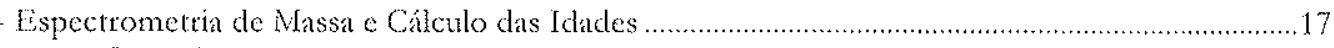

2.2.11. Petrografí e mictoternometra de inclusōes fluidas......................................................................17

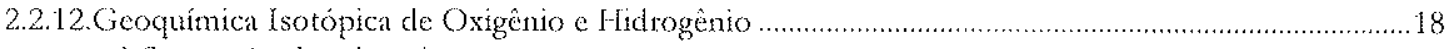

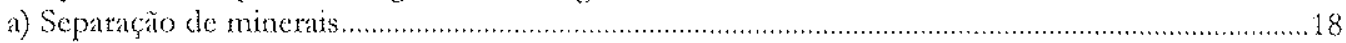

b) Análises isotópicas por criogenia e laser fluorination ................................................................... 19

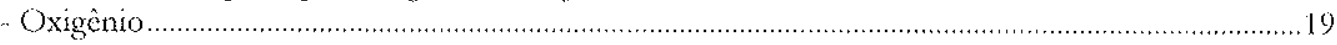

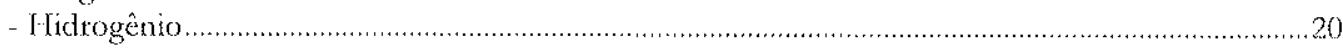

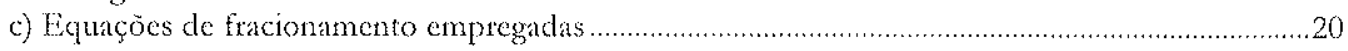

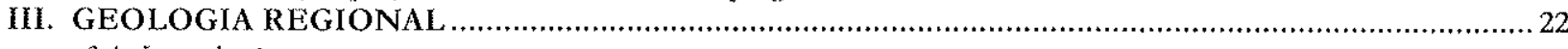

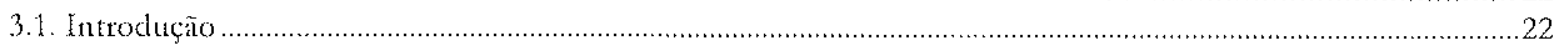

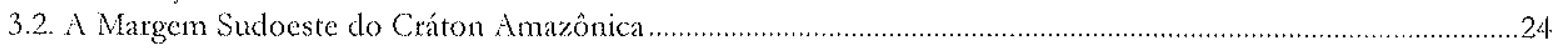

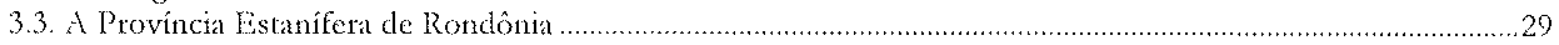

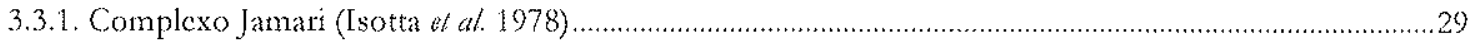

3.3.2. Formação Mutum.Patana (l.obato et al 1966) ...................................................................................33

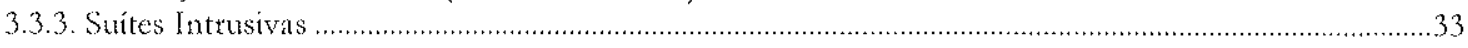

a) Súte Intrusiva Seraa da Providência (T'assinari at al 1984) ..............................................................33

b) Súte Intrusiva Santo Antônio (Payolla 1994) .............................................................................

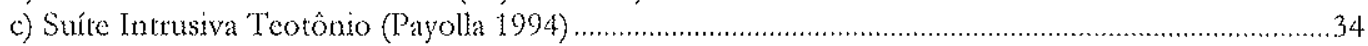

d) Suíte Intrusiva Alto Candelas (Bettencourt of al. 1997) ..................................................................35

e) Súte Intrusiva Sũo Loutenço-Caripunas (Bettencourt dt al. 1997) ....................................................35

f) Suite Intrusiva Santa Clata (Bettencourt ef al. 1997) ......................................................................36

g) Suíte Granitos Últimos de Rondônia (Bettencourt et al. 1997) .........................................................36

3.3.4. Formaçăo Nova filotesta (Leal et al. 1978) .........................................................................................40

3.3.5. Formaşăo Palmeital (Lobato of al. 1966) .......................................................................................40

3.3.6. Formação Ptospetança (Caputo et al. 1971) ............................................................................................40

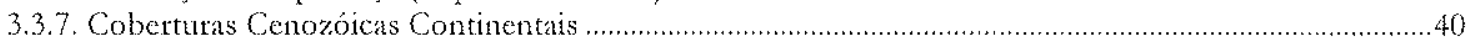

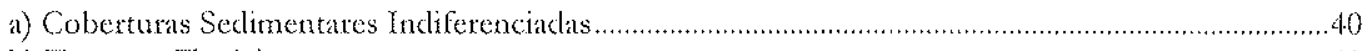

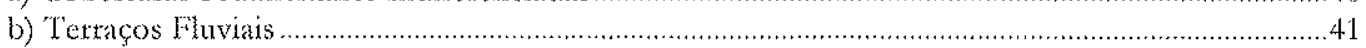

c) Depósitos de Planície de Inundação/ Canal Fluvial ...................................................................41 


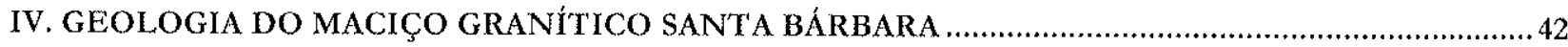

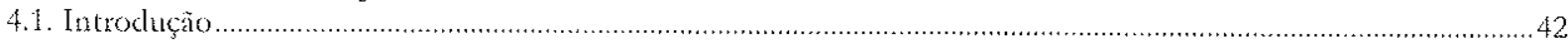

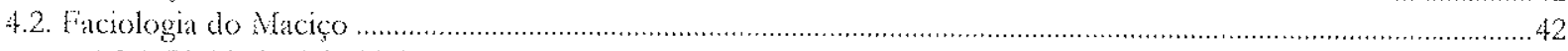

4.2.1. Unidades Litológicas Magmáticas...............................................................................................45

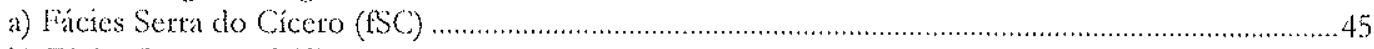

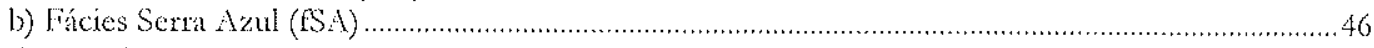

c) Associaçào de Fácies Santa Bárbara (afSB) …………..................................................................46

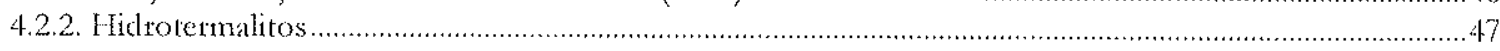

4.3. Aramjo tridimensional de fácies magmáticas e hidrotermais............................................................................50

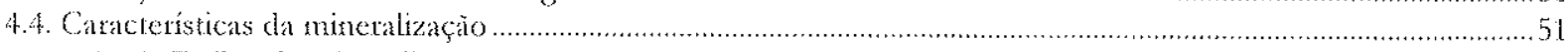

4.4.1. Estilos da mineralização .......................................................................................................

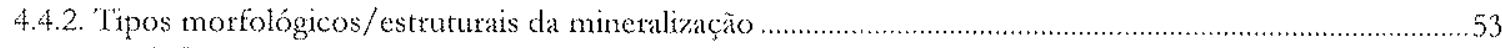

a) Corpos tabulares de topizio-siderofilita-quartzo greaten ..................................................................53

b) Stockmork de topázio-siderotilita-quatzo greisen..........................................................................53

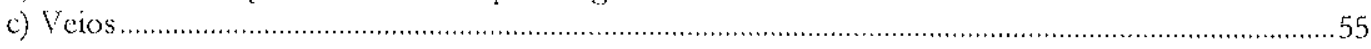

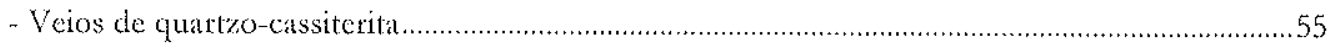

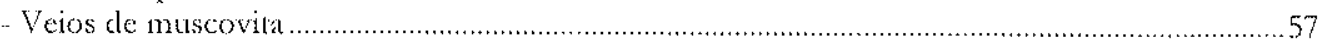

- Veios de quartzo estéteis ......................................................................................................57

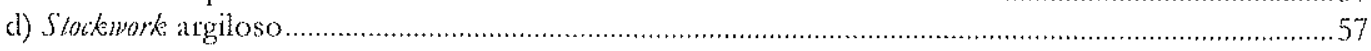

4.5. As estruturas platrares rúpteis no contexto regional .....................................................................................57

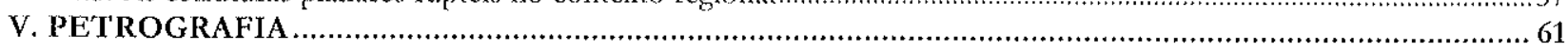

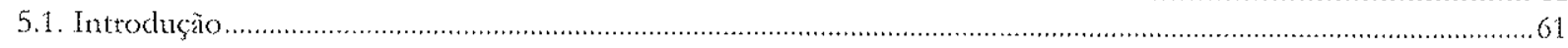

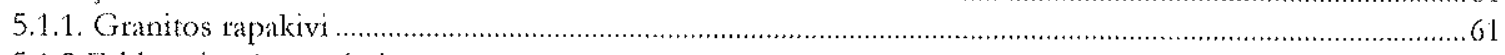

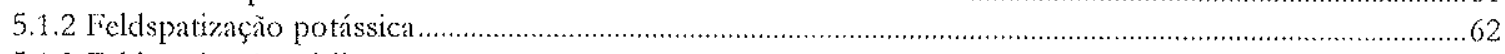

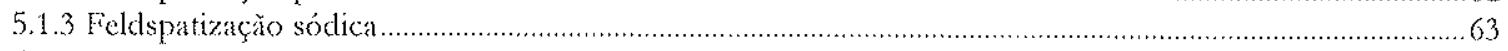

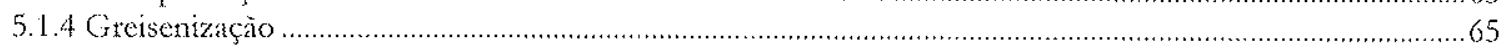

5.2. Caracterização petrográfica do Maciço Granítico Santa Bárbara .................................................................................66

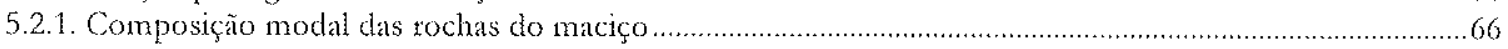

5.2.2. Unidades Eitológicas Magmáticas ..........................................................................................................66

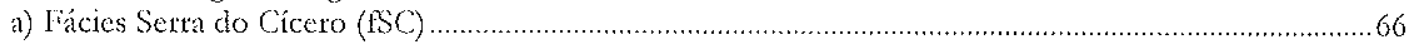

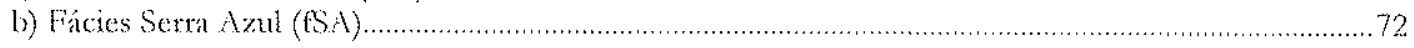

c) Associação de fácies Santa Bárbara (afSB) …………………..............................................................

Fácies Santa Bárbara média (fSBm) …………………....................................................

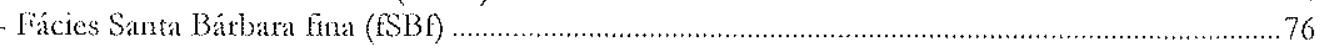

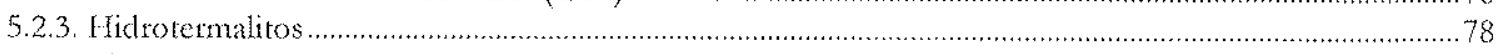

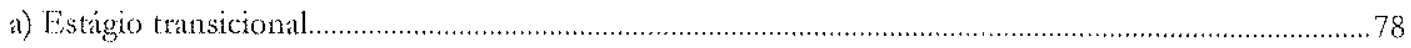

- Granitos greisenizados e greisens .........................................................................................

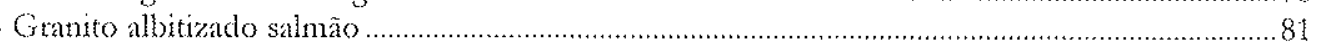

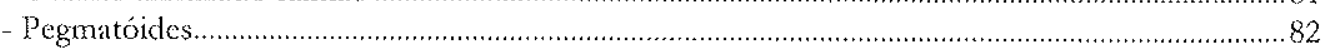

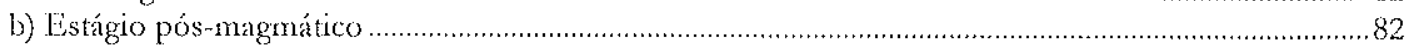

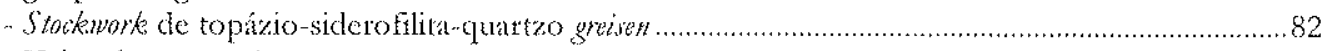

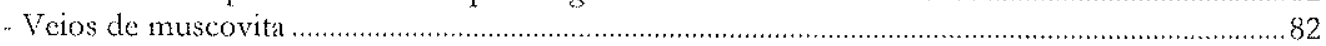

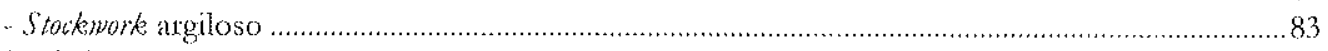

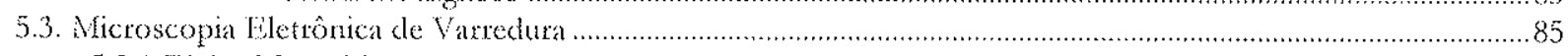

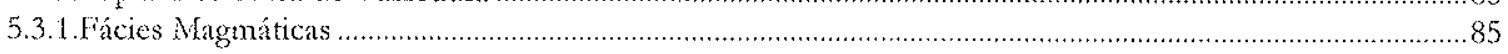

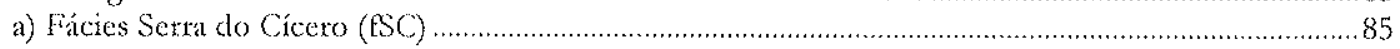

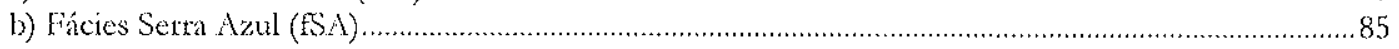

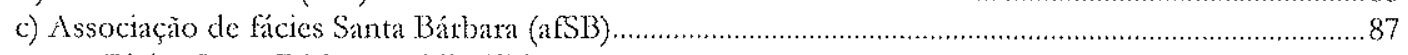

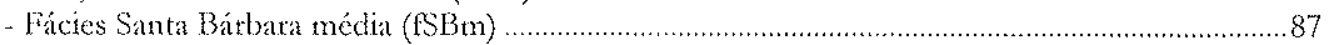

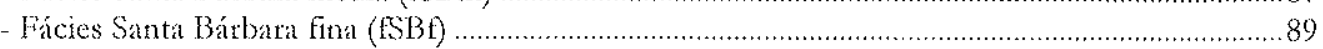

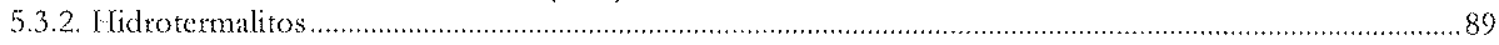

a) Estágio transicional.

.. Topázio siderofilita-cuturtzo greisen ..................................................................................89

b) Estágio pós-magmático ……………....................................................................................... 89

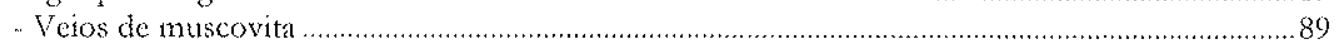

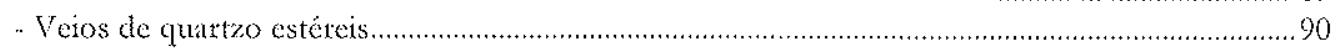

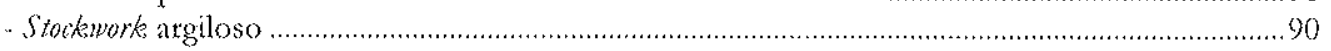

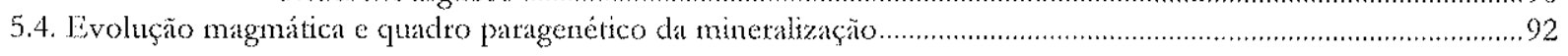




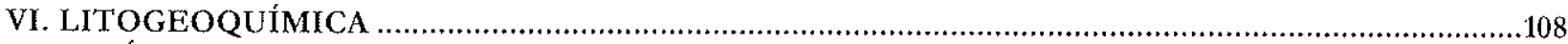

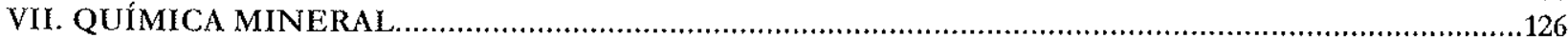

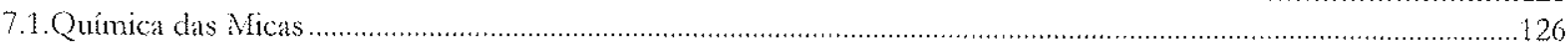

7.1.1. Introdução

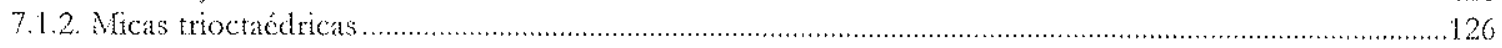

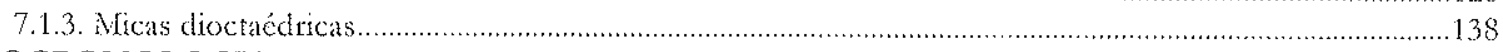

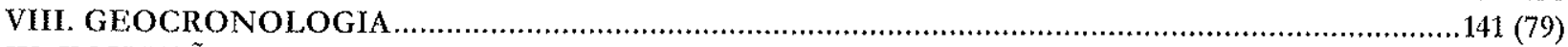

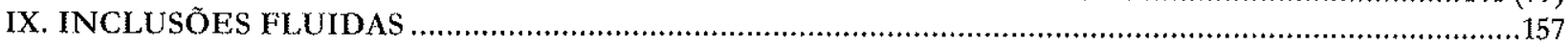

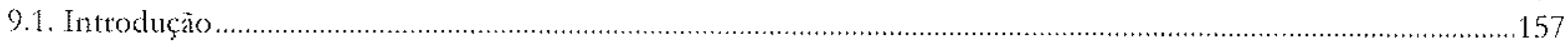

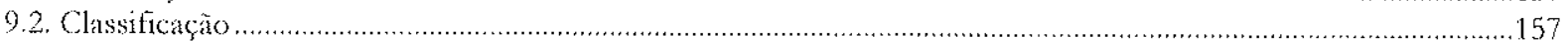

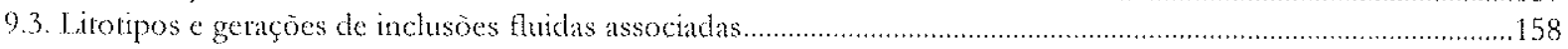

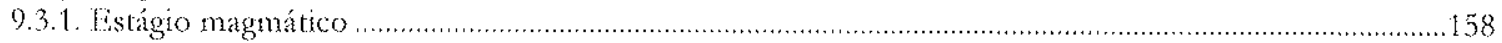

a) Abita-tricroclínio granito fino branco ………………...........................................................158

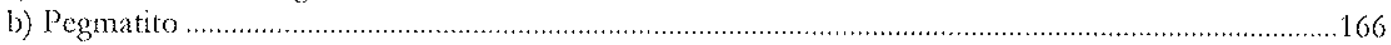

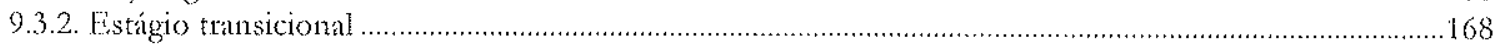

a) Bolsào de quatzo com siderofilita e topázio …………................................................................168

b) Topázio-siderofilita quartzo greien tabular............................................................................177

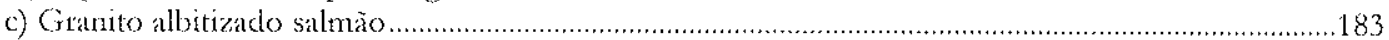

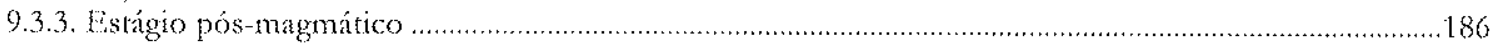

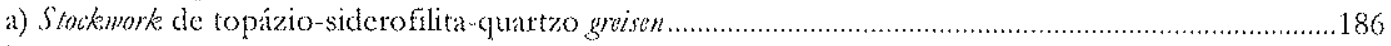

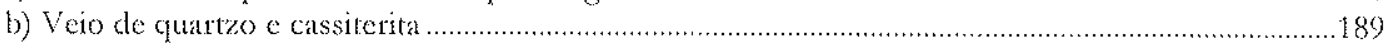

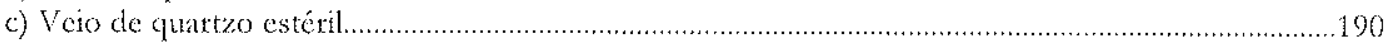

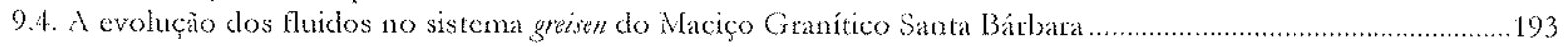

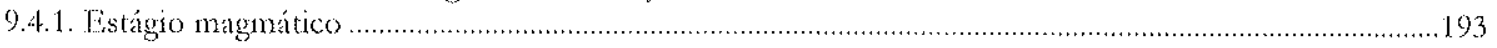

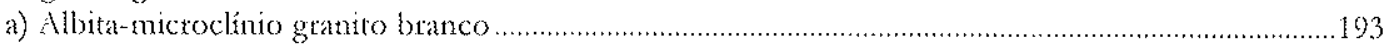

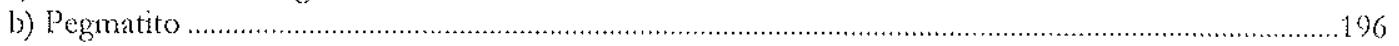

9.4.2. Estágio transicional ................................................................................................................

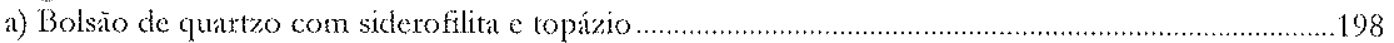

b) Topázio-siderofilita-quartzo greisen tabulat.................................................................................200

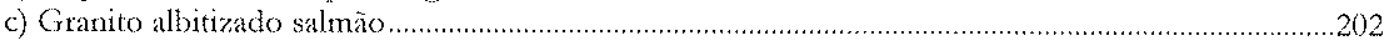

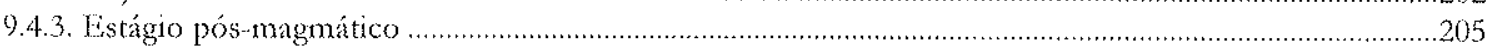

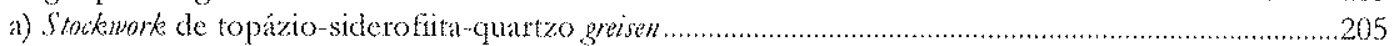

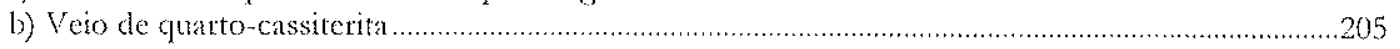

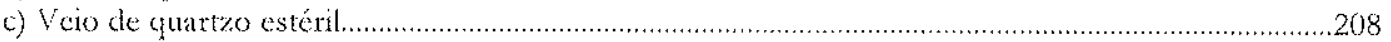

9.4.4 Evoluçào geral do sistema greigen .....................................................................................................2.208

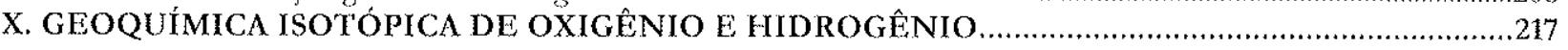

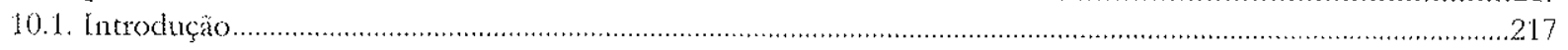

10.2. Isótopos Estáveis no Estudo de Granitóides e Minetalizações Associadas.......................................................2.218

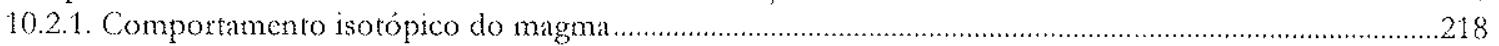

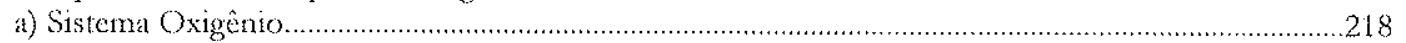

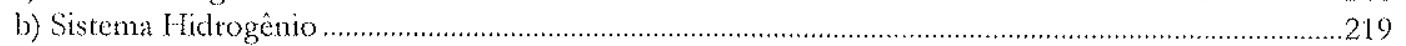

10.2.2. Comportamento isotópico dos fluidos magmáticos ......................................................................219

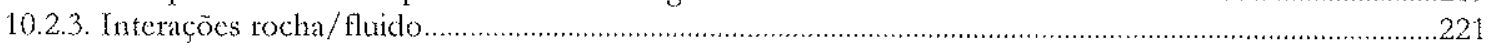

10.2.4. Uso dos isótopos de Oe H na pesquisa metalogenética .....................................................................222

10.3. Resultados Parciais e Consideraçòes Preliminates...................................................................................222

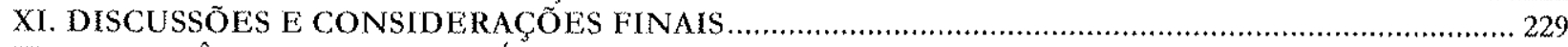

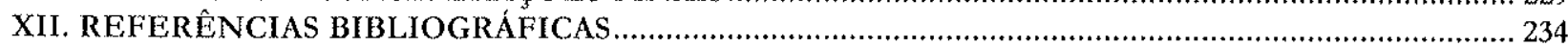

ANEXO I - Mapa geológico da área da mina - Greisen Taboquinha e Morro Santa Bárbara

ANEXO II - Dados de composição química das micas obtidos com EPMA

ANEXO III - Dados microtermométricos das inclusões fluidas

\section{LISTA DE FIGURAS}

Figura 1.1 - Mapa de localizacão da átea de estudo.

Trigura 3.1 - Estrututação geocronológica do Cráton Amazônico mostrando a localização da Provincia Estanífera de Rondônia (PER). Adaptado de Tassinari (1996). Mapa interno: CA - Cráton Amazônico (Ca1 - Escudo da

Guiana, Ca2 - Escudo do Brasil Centtal (Guaporé)) ……………...............................................................2.

Figura 3.2. Mapa tectônico do sudoeste do Cráton Amazônico. Adaptado de Litherland \& Bloomfield (1981), Litherland et al. (1986, 1989), Tassinari (1996), Tassinari \& Macambira (1999), Scandolara (1999a, 2001), 
Van Schnus et al. (1999), Rizzotto (2001a e b), Tassinari et al. (2000, 2001), Getaldes et al. (2001), Bettencout \& Geraldes (em preparaçăo)

Rigura 3.3 - Mapa geológico esquemático da Provincia Estanifera de Rondónia (PLER) e áreas adjacentes, mostrando a distribuição das suítes de granitos rapakivi com 1,60 a 0,97 Ga. Modificado de Leal et al. (1978), Bettencout et al. $(1995,1996)$ e Bettencourt et al. (1999a).

riguta 3.4 - Mapa de associaçoes litológicas da região centro-leste da Ptovíncia Estanífen de Rondôna. Simplificado de

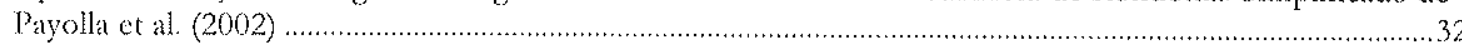

Figura 4.1 - Mapa geológico do Maciço Granitico Sanca Bátbara. Compilado e modifrado de lank (1990), CESBRA (1994), e Payolla et al. (2002)....

lïguta 4.2. Petfil geológico de sondagens rotativas no Greisen Taboquinha ao longo da linha $7 \mathrm{~N}$ (vide Anexo I). Abreviaçoes: N, E- coordenadas; Z - cota da boca do furo; C - comprimento do furo ...............................48

Figura 4.3 - Perfil geológico do furo de sondagem rotativa 22,15, liaha 1,8N, localizado no Morto Santa Bárbata, em que se observa estratificação magmática definida pela intercalação centimétrica de albita-microclínio granito e

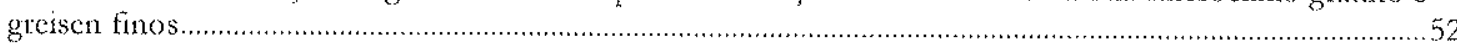

Figura 4.4 - Mapa geológico parcial de detalhe do stockwork de topázio siderofilita-quartzo greisen do Morro Santa Bádbara. A esquerda, diagramas de roseta dos a) veios de greisen, b) veios de quattzo, e c) fraturas ............54

Figura 4.5 - Diagramas en roseta das direções de veios e vênulas de a) topázio siderofilita-quartzo greisen de granulação média; b) topázio-siderofilita-quatzo greisen de ganulação fina; c) quartzo; e d) muscovita; e) diagrama de Schmidt-Lambert, hemisfério inferior, dos polos de planos das vêtulas de caulinita....................................56

Figura 5.1 - a) Diagrana QAP (Streckeisen 1976) exibindo a composição modal das rochas das facies Serra do Ciceto, Serra Azul e associação de facies Santa Bárbata - subdividida nas facies média, fina, e branca. b) Diagtama de Kuhne et al. (1972) para a classificação de greisens, mostrando a composição modal daqueles que ocotrem na forma de corpos tabulares, de veios de granulaçăo média e de veios de granulaçăo funa. Nomenclatura: I. quartzo; II e VI .. topázio; III e VII - mica-topázio; IV e VIII - topázio-mica; V e IX mica. Adiciona-se a palavra quartzo aos nomes dos greisens dos campos II a $V$

Figura 5.2 - Espectros de difração de nios. $\mathrm{X}$ de a) nódulos manganesíferos associados com a alteraçẫo muscovítica. pós-magmática e, b) das vênulas do stockemork argiloso......

Figura 5.3. - Espectros de dispersão de energia obtidos por microscopia eletrônicá de vatreduta, modo composicional, de a) xenotima e b) monazita na fSC (AM-52B); c) cerianita associada com fluorita na fSA (AM-53B); zircão da fSA (M.53B) d) na regiào límpida, com faces de crescimento preservadas, e e) ná região turva, que compoe grande parte do núcleo e da borda do cristal; f) cerianita inclusa em fluorita na fSBm (AM$224 \mathrm{~B})$

Figuta 5.4 - Espectros de dispersão de energia obtidos por microscopia eletrônica de varredura, modo composicional, de a) columbita inclusa em mica na fSBm (AM-224B); b) e c) de torita presente na fSBm (AM-224B); d) e e) de óxiclo de La e Nd incluso em mica no albita-microclinio granito branco da fSBf (AM-134)..................88

Figura 6.1 - a) Padrio de ETR notmalizado pelo condrito (Boynton 1984); b) diagrama multi-elementar aomalizado pelo condrito (Thompson et al. 1982); c) diagtama $M / C \mathrm{NK} \times \mathrm{A} / \mathrm{NK}$ (Maniar \& Piccoli 1989) para os granitos do maciço. Símbolos na Fíg. 6.1.c.............................................................................................................113

Figura 6.2 - Diagramas de $10000 \mathrm{Ga} / \mathrm{Al}$ versus a) $\mathrm{K} 2 \mathrm{O}+\mathrm{Na} 2 \mathrm{O}$, b) $\mathrm{FeO} \mathrm{T} / \mathrm{MgO}$, c) Zn, d) Y, e) $\mathrm{Nb}$, e f) Ce de Whalen et al. (1987) para a discriminação de granitos do tipo A. Símbolos: círculos verdes . ESC; rriângulos ciano. ASA quadrados mangenta preenchidos - ASBm; quadrados magenta vazios - fSBF; xizes magenta - $\mathrm{FSBfb} . .114$

Fïgura 6.3 - Diagtamas de $10000 \mathrm{Ga} / \mathrm{Al}$ versus a) $\mathrm{K2O}+\mathrm{Na2O}, \mathrm{b}) \mathrm{FeOF} / \mathrm{MgO}, \mathrm{c}$ ) $\mathrm{Zr}$, d) $\mathrm{Y}$, e) $\mathrm{Nb}$, ef Ce de Whalen et al. (1987) para a discriminaçăo de granitos do tipo A. Símbolos: circulos verdes - ASC; triangulos ciano $\mathrm{ESA}$; quadrados magenta preenchidos - $\mathrm{SB}$; quadrados magenta vazios - $\mathrm{SBBF}$; xizes magenta -.. $\mathrm{FBB}$ fo ..115

Figuta 6.4 - a) Dingrama $\mathrm{SiO} 2$ versus $\mathrm{FeO} T /(\mathrm{FeOT}+\mathrm{MgO}$ ) (Frost et al. 2001) para a classificaçăo de rochas gxańticas; b) diagrama Fersus $\mathrm{P} 2 \mathrm{O} 5$ (Förster et al. 1998) para a classificação de granitos. As tochas do Maciço Granítico Santa Bátbaxa situam-se no campo dos granitos do tipo A nos dois diagramas. Legenda para a Fig. b: ćrculos verdes - $\mathrm{BC}$; triangulos azuis invertidos - $\mathrm{ASA}$; quadrados tosa - $\mathrm{SBM}$; triângulos invertidos rosa - $\mathrm{SBBF}$; xizes rosa - $\mathrm{ASBA}$

Figura 6.5 - a) Diagrama $Y$ versus Nb para a discriminação tectónica de gtanitos (Pearce et al 1984); b) diagtama La versus Yb para a discriminaçăo entre granitos taxdi- e pós-colisionais (Fötster et al. 1995) ….....................117

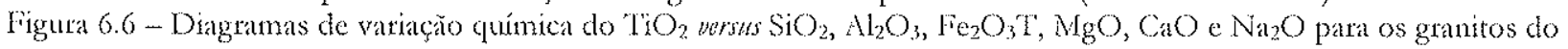

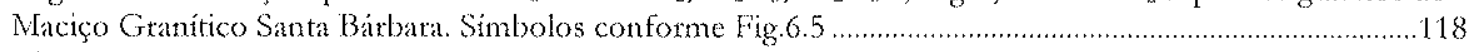

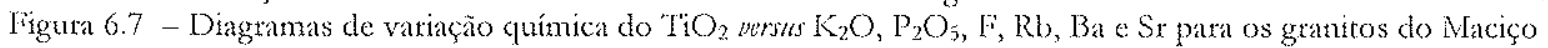
Granítico Santa Bárbata. Símbolos conforme Fig. 6.5 .................................................................................119

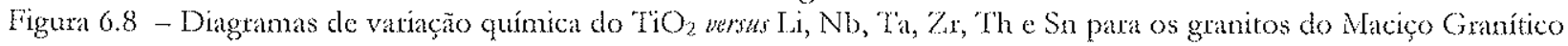
Santa Bárbata. Súmbolos conforme Fig. 6.5 .........................................................................................120

Figura 6.9 - Diagramas de variação química do $\mathrm{THO}_{2}$ versa $\mathrm{Y}, \mathrm{La}, \mathrm{Ce}, \mathrm{K}_{2} \mathrm{O} / \mathrm{Na}_{2} \mathrm{O}, \mathrm{K} / \mathrm{Rb}$ e $\mathrm{Rb} / \mathrm{Sr}$ para os granitos do Maciço Granítico Santa Bátbara. Simbolos conforme Fig. 6.5 . 


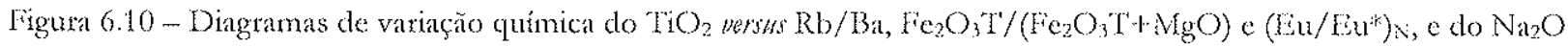
versus Sr, CaO e F para os granitos do Maciço Granitico Santa Bárbara. Simbolos conforme Fig. 6.5........122

Figum 6.11 - a) Diagramas de covariaça $S \mathrm{r}$ versus $\mathrm{Rb} / \mathrm{Sr}$, b) Sn versus TiO2 e c) Sn versus Rb/Sr para as rochas do maciço. Campos de Lehmann \& Mahavat (1989): retângulos cinza - área onde os teotes de Sn cstão abaixo do limite analítico de deteção; campos tosa - tendencias de diferencíção magnática extrapoladas; linha vermelha - limite entre granitos menos alterados e aqueles a fetados por intexação rochá- fluido. Legenda conforme lig. a.

Figura 6.12 - Diagramas de covariação a) Sn versus $\mathrm{Na2O}$ e b) fi versus Sn para as tochas do Maciço Granítico Santa Bárbara........

Figura 6.13 - Composição normativa dos granitos do Maciço Granítico Santa Bárbara em termos de quartzo, ortoclásio e albita. As composiçoes experimentais de fusōes de rempetatuta minima são exilidos para comparação: losangos roxos - sistema NaASi3O8-KASi3O8-(CaA2Si2O8)-SiO2-H2O a 1 kbar (futtle \& Bowen, 1958, James \& Hanilon 1969); cruz vermelha circunscrita e asteriscos martons - sistema haplogranito. H2O a 1 kbar com 0,5\% de T.i (Mattin 1983) e 1 e $2 \%$ de F (Manning 1981), respectivamente. Símbolos conforme Fig. 6.4.b...

Figura 7. 1 - Classificaça das micas estudadas conforme os diagramas de a) AlIV $\mathrm{Fe} /(\mathrm{F} \mathrm{e}+\mathrm{Mg}$ ) e b) AlVI $\mathrm{x}$ $\mathrm{Fe} /(\mathrm{F} \mathrm{c}+\mathrm{Mg})$; c) diagrama de Nockolds (1947) ilustrando a paragênese máfica associada com a biotita esperada em função dos seus conteúdos de $\mathrm{MgO}, \mathrm{FeO}$ (total) e $\mathrm{Al} 2 \mathrm{O}$ 3. Campos: $\mathrm{L}$ ) muscovita, topázio, espodumênio e outros minerais alutuinosos; II) biotta ocortendo como única fase máfica; (III) hornblenda, piroxênio on olivina. Símbolos para os pontos analíticos das composições das mica obticlos com EPMA e química analítica - facies Serra do Cícero (AM-52): núcleo, borda; facies Serra Azul (AM-53): mica primária (?), mica secundára; facies Santa Bárbara fina (AM-145): núcleo, borda; facies Santa Bárbara média (AM224B): núcleo, botda; albita-microclínio granito branco (AM-134): núcleo, borda; granito pegmatóde (AM211A): núcleo, borda; granito albitizado salmão (AM-14A): núcleo, borda.

Figua 7.2 . Diagrama de Gokhale (1968) para distinçăo entre biotitas de origem ígnea dáquelas metamórfico metassomáticas. Bin cinza - campo das micas ígneas. Símbolos conforme Fig. 7.1.

Fïgura 7.3 - a) Diagrama Li x Fe, que demonstta que as substituição $1: 1$ dos referidos elementos não é o mecanismo operante nas micas do Maciço Granítico Santa Bárbara; b) diagrama (Li, Al) x (Fe, Ti) de Stone et al. (1988), que ilustra que esse mecanismo de substitutção é mais adequado para explicar a evolução das micas do maciço

Fïgura 7.4 - a) Correlação negativa entre $\mathrm{A} 2 \mathrm{O} 3$ e SiO2 no estágio magmático, em contraposição à correlação positiva existente nos estágios transicional e pós-magmático. Em ambos, a tendencia é a de perda de FeO, como indicado em b.

Figura 7.5 - a) Diagrama mgli-feal modificado de Tischendorf et al. (1997) pela exclusão do campo da protolitionita e inclusão de outro limite entre zinnwaldita e siderofilita, conforme parâmetros de Rieder (1970) e Stone et a. (1988); b) diagrama Fi x fe (Kenderson et al. 1989) ilustrando a substitucição das micas do estágio transicional, predominantemente, pela muscovita, com pronunciada perda de Fe e F. Símbolos conforme Fig. 7.3 acrescidos do círculo amarelo, representativo das micas

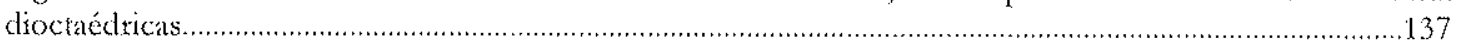

Figura 9.1. Histogramas dos dados microtermométricos de a) salinidade, b) temperatura do ponto eutético, ec) remperatua de homogeneização para o líquido ou para o gás/vapor das inclusões aquosas e aquocarbônicas hospedadas em quartzo e topázio do albita-mictoclinio granito branco (AM-134). Legenda conforme Fig. 9.1."

Figuta 9.2- Diagramas de correlaçăo da Tle persus a) salinidade; e b) Th. c) Espectro de efeito Raman da fase gasosa das inclusōes aquo-catbônicas primárias presentes no quartzo do abita-microclínio granito fino branco (AM-134).

Figura 9.3- - T'empetatura de fusão do $\mathrm{CO} 2$ nas inclusões aquo-carbônicas primátras em quartzo e aquo-carbônicas secundárias em topázio do albita-microclínio granito branco (AM-134)

Figura 9.4 - Fistogramas dos dados microtemonétricos de a) temperatura de homogeneização pata o líquido ou pata o gás/vapor, b) temperatura do ponto eutético, e c) salinidade das inclusóes aquosas é aquo-carbonteas hospedadas em quartzo do pegmatito (AM-213). Legenda conforme Fig. 9.4.a .........................................167

Figuta 9.5. Espectros de efeito Raman demonstrando a presença de a) $\mathrm{CO}_{2}$ e de b) CH nas inclusões aquo-carbônicals secundátias do tipo $3 \mathrm{em}$ quartzo do pegmatito (AM-213); c) de sólido presente em inclusão fluida aquosa multifásica no topázio do bucho de quartzo com siderofilita e topázio (AM-168A) ................................169

Fïgura 9.6 - Histogramas dos dados microtermométricos de a) salinidade, b) temperatura do ponto cutético, e c) temperatua de homogeneização para o liquido ou para o vapor das inclusões açuosas hospedadas $\mathrm{cm}$ topázio (AM..168A) do bucho de quartzo com siderofilita e topázio. Legenda conforme fig. 9.6.a............171

Figura 9.7 - Diagrama de covariaçáo salinidade versus temperatura do ponto cutético (TE) pata o topázio (AM-168A) do

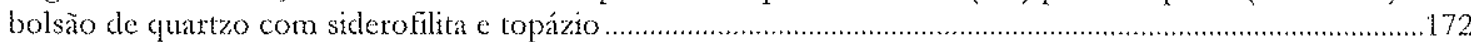


Figura 9.8 - Histogramas dos dados microtermométricos de a) salinidade, b) temperatuta do ponto ettélico, e c) temperatura de homogeneização para o líquido ou para o gás das inclusòes aquosas e aquo carbonicas hospedadas em quartzo (AM-168C) do bolsão de quatzo com siderofilita e topázio. Legenda conforme Fig. 9.8.a. Baras incolores .... inclusöes sem classificaçào......

Figura 9.9. Espectros de efeito Raman de a) sólido em inclusão aquo-carbônica primária hospedada no quarzo do bolsão de quatzo com siderolilita e topázio (AM-168C); b) e c) dos gases presentes na fase gasosa das

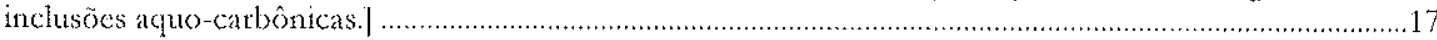

Figura 9.10 - Temperaturas de fusão do $\mathrm{CO} 2(\mathrm{TfCO}$ ) das inclusoes aq̨qu-carbônicas hospedadas no quartzo (AM.

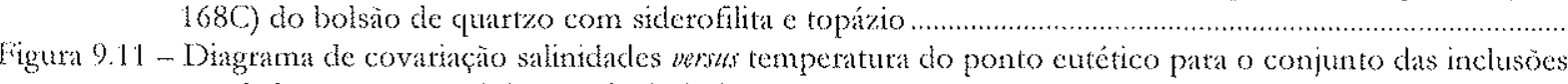
estudadas no ctuatzo ( MM-168C) do bolsào de quartzo com siderofilita e topázio .....................................177

Figura 9.12. Histogramas dos dados microtermométricos de a) salinidade, b) temperatura do ponto eutético, ec) remperatura de homogeneizaçăo para o líquido ou para o vapor/gás das inclusões aquosas e aquocarbônicas hospedadas em ropázio e quatzo do topázio siderofilita-quartzo greisen tabular (AM-35). Legenda conforme rig. 9.12.a.

Figura 9.13 - a) Histograma das temperaturas de fusão do $\mathrm{CO}_{2}\left(\mathrm{~T}_{\mathrm{CO}}\right)$ das inclusões aquo-carbônicas hospedadas em topázio e quartzo. Espectros de efeito Raman demonstrando a presença b) do $\mathrm{CO}_{2}$ e c) do Cl. nas inclusǒes aquo-carbônicas hospedadas em topázio. Dados telativos ao topázio-siderofilita-quartzo greisen tabular (AN-35)

Espectros de efeito Raman da fase gasosa das inclusões aquo-carbônicas hospedadas no quartzo mostrando a presença de a) $\mathrm{CO}_{2}$ e b) de $\mathrm{CF}$. c) Diagrama de co-vatiaçăo dá salinidade versus a temperatura do ponto eutético (Te) da totalidade das inclusoes analisadas na amostra. Dados relativos ao topázio-siderofilia. quartzo greisen acamadado (AM-35).

ligura 9.15 - Espectro de efeito Raman da fase gasosa de inclusão aquo carbônica bifásica hospedada em quatzo do granito albitizado salmão $(A M-14 B)$

Figura 9.16- Histogramas dos dados microtemométricos de a) salinidade, b) temperatura do ponto eutético, e c) temperatura de homogeneização para o líquido ou para o gás/vapor das inclusões aquosas hospedadas em quartzo do granito albitizado salmão (AM-14B). Legenda conforme Fig. $9.16 . a \ldots \ldots \ldots \ldots \ldots \ldots \ldots \ldots \ldots \ldots \ldots \ldots \ldots . . .185$

Figuta 9.17 - Diagrama de covariação da salinidade versu a temperatura do ponto eutético (TH) para as inclusões aquosas primátas e pseudo-secundárias hospedadas em quaxtzo do granito albitizado salmão (AM-14B) 186

Figura 9.18 -. - Tistograma das temperaturas de fusño do $\mathrm{CO} 2$ ('TCOO2) nas inclusóes aquo-catbônicas hospedadas no topázio do stockwork de topázio-side wofilita quartzo greisen (AM-130) ..................................................187

Figura 9.19. Histogramas dos dados microtermométricos de a) salinidade, b) temperatura do ponto eutético (lE), e c) temperatura de homogeneizaça (Th) para o liquido ou para o vapot/gás das inclusōes aquosas e aquocabbonicas hospedadas em topázio e quartzo do veio de topázio-siderofilta-quartzo greisen (AM-130). Legenda conforme Fig. 9.19.a.

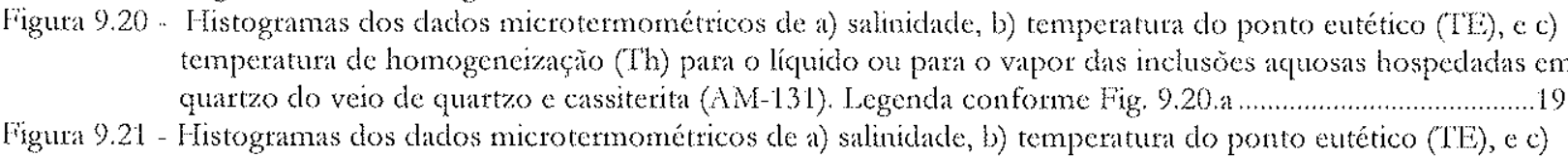

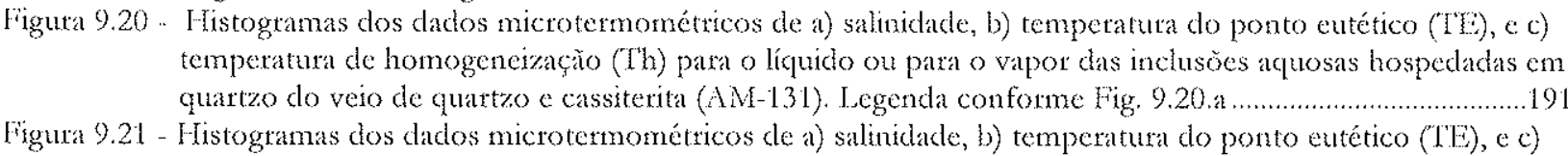

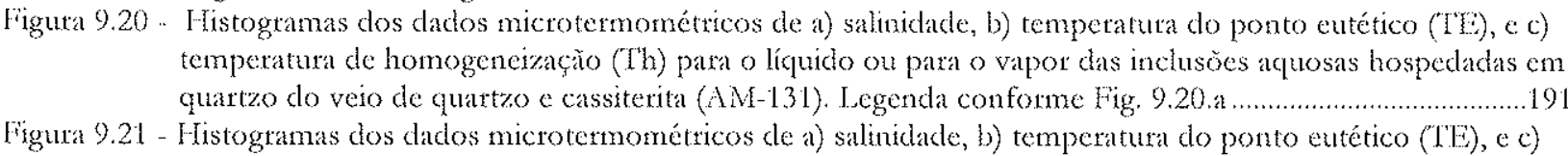
temperatura de homogeneizaçăo (l'h) pata o líquido ou para o vapor das inclusôes aquosas hospedadas em quartzo do veio de quatzo estéril (AM-159). Legenda conforme lig. 9.21."

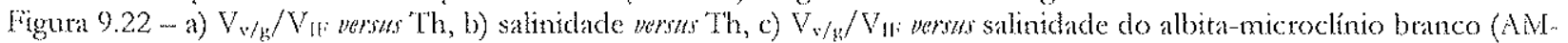
134)

Figura 9.23 - a) $V_{v / g} / V_{\text {tr }}$ versus $T$ h, b) salinidade versus $T h$, c) $V_{s / g} / V_{11}$ versus salinidade do pegmatito (AM -213) ...........197

Figura 9.24 - Diagrama salinidade versh 'Th das inclusões fluidas aquosas e aquo-carbônicas presentes no a) topazio e b) no quartzo do bolsão de quatto com siderofilita e topázio (AM-168 A e AM168C, respectivamente)......199

Figura 9.25-Diagrama Th wersas $\mathrm{V} / \mathrm{g} / \mathrm{VIF}$ pata as inclusōes aquosas e aquo-carbonicas presentes no quatto (AM168C) do bolsão de quartzo com siderfilita e topazio

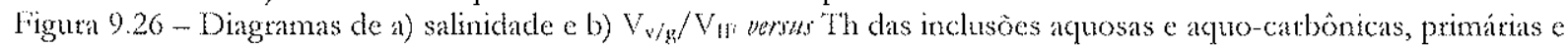
secundárias, do topázio-siderofilita-quattzo grisen tabular (AM-35) ......................................................201

Figura 9.27 - a) Diagrama $V_{\mathrm{V}} / \mathrm{g} / \mathrm{VIF}$ versus salinidade e b) densidade wersu' Th dás inclusòes aquosas e aquo carbônicas, primárias e secundárias, do topázio-siderofilita-quartzo greisen tabular (AM-35). Tegenda conforme Fig. 9.26.a

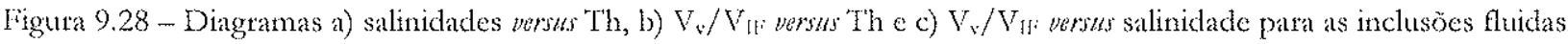
do quarto do granito albitizado salmão (AM-14B) ...........................................................................204

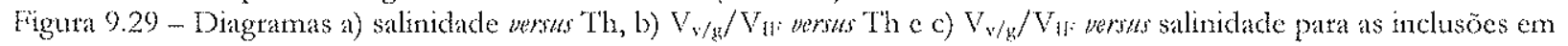
quartzo e topázio do veio de topázio-siderofilita-quartzo greisen $(\mathrm{AM}-130)$...........................................206

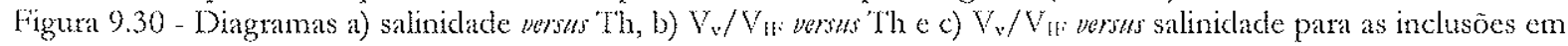
quartzo do veio de quartzo-cassiterita (AM-131) 


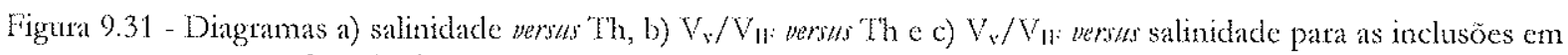
quartzo do veio de quartzo estétil (AM-159).

Figura 9.32 - Diagramas 'Th versur salinidade para as inclusoes primárias aquosas e aquo-carbônicas a) no topázio do bolsão de quartzo com siderofilita e ropázio, b) no quartzo e no topázio do greisen tabular e, c) no quartzo e no topázio do stockimork de greisth. As isóbaras são de Bodnar el al (1985) ....................................................213

Figura 10.1 -.. Dagrama da composiçăo isotópica da água em equilibrio com a mica nas diversas fácies do Maciço Granílico Santa Bárbara. Campo da composição isotópica da água magmática e linha da água meteórica atual de Sheppard (1986)......

\section{LIST'A DE 'TABELAS E QUADROS}

Tabela II.1 - Amostras e métodos empregados na contagem modal.

Tabela II.2 - Equaçōes de fracionamento isotópico empregadas neste estudo .................................................................21

Tabela IV.1 - Estágios de formação de rochas no Maciço Granítico Santá Bárbara ........................................................44

Tabelá V.1 - Proporçoes modais dos litotipos magmáticos do Maciço Granítico Santa Bátbata ........................................67

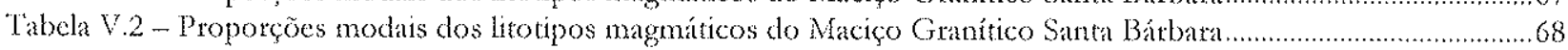

Quadro V.1 - Quadto paragenético da mineralizaçăo estanífera primátia do Naciço Gratútico Sánta Bátbata ..................93

Tabela VI.1 -. Dados de análises químicas dos granitos do Maciço Granítico Sauta Bátráta ............................................126

Tabela VII.1 -... Médias das composições das micass do Maciço Granítico Santa Bárbata obtidas com EPMA (L.i.O) determitado por química analítica)

Tabela VII.2 -. Médaas das composiçoes das micas do Maciço Santa Bárbara obtidas com EPMA com JizO calculado conforme Tischendorf et th. (1997) …............................................................................................1.36

T'abela VIX 3 - Médias das composiçóes das micas dioctaédricas do Maciço Santa Bárbata obtidas com EPMA incluindo Li2O medido por quéricica analítica.

Quadro LX.1 -... Catacterísticas microtermométricas das inclusões fluidas estudadas no Maciço Granítico Santa Bátbata159

Tabela X.1 ... Dados de composição isotópica de oxigênio en minerais c rocha total ..................................................226

Tabela X.2 ... Dádos de composição isotópica de hidrogênio em minerais ...................................................................222

Tabela X.3 - Composição isotópica do fluido calculada com base em equações de equilíbrio mineral đigua ....................22...

\section{LISTA DE PRANCHAS}

Prancha 4.1 - a) Contato vertical abrupto ente a fácies Serra Azul, à escueteda, e a fácies Santa Bárbara fina, à direilat, em seçäo vertical. Ambas säo cortahas pelo sistema slakemork argiloso; b) enctave elipsoidal com 6 con de eixo thaior, de contatos difusos e irregulares, de granito da fácies Santa Bárbara fina dentro de granito da fácies Serra Azul, em seçăo horizon tal; c) arranjo estratificado horizonal da alteraçăo hidrotermal a diteita de corpo tabular de topázio-siderofilita quattzo greisen que aparece na extema esquerda da foto, em cinza; d) estrutura estratificala encimando colpo tabular de topázio-sidecofilita greisen pobre em quartzo na tratısição entre os greisem e o granito da fácies Santa Bârbata fina năo alterado, na potção superior do perfil. Compreende greisens (verde-escuros), ganitos finos (tosal) e pegmatóides (brancos, com quartzo e siderofilita) em corpos de 5 a $20 \mathrm{~cm}$ de espessura, alternados. No topo da estrutura ocorrem bolsōes arredondados, de extensão métrica, dos mesmos pegmatóides; e) bolsão pegmatóde de quartzo, com topázio (amarelo) e siderofilita (preta) subordinados, com 1,7 m de exo maior, circundado por botda centimétrica de sidcrofilita; f) nódulos manganesíferos associados com a altenação muscovítica. Seção vertical

Prancha 4.2 - a) Alteraça muscovítica tatdia, controlada por fratura subvertical. Observa se escape lateral na base do corpo tabular de topázio sideroflita-cuartzo greisen, localizado no topo da seça, sugerindo que o mesmo agiu como tampão para essa alteraçăo hidrotermal; b) visăo do pit do Greisen Taboquinha, que destaca corpo tabular de topázio-siderofilita-quatzo greisen equigranular médio, na porção superior do corte, hospedado em granito albitizado e greisenizado, $\mathrm{cm}$ tons amatelados, na parte inferior; c) aspecto lenticular dos corpos tabulates de topázio-siderofilita-quartzo gruten; d) limites laterais bruscos, de alto âtngulo (N77\%, 74SE), entre corpo tabular de topazio siderofilita-quattzo greisen, à direita, e as encaixantes hidrotermalizadas, à escuetch; e) stockmork de topázio-siderofilita-quartzo greisen em seção horzontal. A

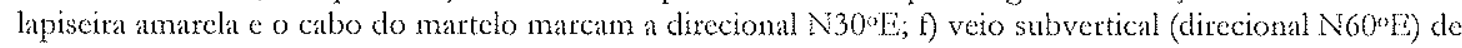
quartzo grosso com cassiterita subordinada em seçào vettical; g) zona de alteração muscovítica no núcleo de veio de greisen (direcional N15\%E), em seção vertical. Compreende porção central verde, muscovítica equigranular fuar, com $15 \mathrm{~cm}$ de espessuxa, um nivel intermediário de topázio siderofilita-quartzo greisen muscovitizado, equigranular médio, com $11 \mathrm{~cm}$ de espessura, e borda externa de topázio-siderofilitaquartzo greisen com muscovita Feldspatizaçăosubordinada, equigranular médio, de $30 \mathrm{~cm}$ de espessura; $\mathrm{h}$ ) aspecto do stockmork caulinítico em seção vertical.

Prancha 5.1 - a) Granito rosá, maciço, homogêneo, leucocrático, porfiritico de matriz média, com megactistais euédricos, subédricos e ovóides de feldspato potássico de até $2,5 \mathrm{~cm}$ de comprimento em matriz de feldspato potássico e plagioclásio rosa, cuartzo e sideroflita. Facies Serra do Cícero (ESC); b) granito rosa, maciço, 
homogêneo, leucocrático, inequigranular, médio, composto por feldspato potássico e plagioclásio rosa, quartzo e siderofilita. Facies Serta Azul ( $\mathrm{SSA}$ ); c) granito tosa, maciço, homogêneo, leucocrático, porfíítico de matriz média, com megacristais de feldspato potássico enédricos, subédricos e ovóides esparsos com 1 cm de comprimento em média, em matriz de feldsparo potássico e plagioclásio tosa, quartzo e sideroflita, Facies Santa Bátbara média ( $\mathrm{fSB} \mathrm{m})$; d) granito rosa esbrancuiçado, maciço, homogêneo, leucocrático, equigranular médio, composto por feldspato potássico e plagioclásio rosa, quartzo e siderofilita. Facies Santa Bátbata fina ( $(\mathrm{SBF})$; e) granito branco, maciço, homogêneo, leucoctático, micropotfítítico fino, composto por feldspatos brancos, quartzo e siderofilita (ESBP).

Prancha 5.2 ... a) Megacristal mesopertitico ovóde com abundantes inclusoes anédricas de quartzo e poucas inclusoes de mica na borda, fácies Serta do Cúcero. Nicóis cruzados. Amosta AM-52B; b) megacristal ovóde de microclínio manteado pot plagioclásio sericitizado na fácies Serra do Cícero - textura wiborgítica. Nicóis cruzados. Amostra $A M-52 B$; c) aspecto da matriz de gxanito da fácies Serta do Cícero, com cristais de microdínio subédricos e anédricos, com macla en grade distinta, cristais de plagioclásio com núcleo sericitizado e borda de albita límpida sobrecrescida, além de quattzo e mica. Nicóis cruzados. Amostra AM $52 \mathrm{~B}$; d) inclusōes de zircâo euédrico pardo, à esquerda, e de zircão incolox, à direita, na mica primátia da fácies Sera do Cícero. Nicóis cruzados. Amostra AM-52B; e) mica primáría da fácies Sera do Cícero, de cor marrom, substifuída por clorita verde nas bordas. Nicóis paralelos. Amostra AM-52B; f) hábito euédrico a subédrico, hexagonal, das inclusōes de quatzo $\mathrm{cm}$ microclínó Pertitus de substituição em gânglios no microclínio e coroas trocadas (swapped rims) de albita entre cristais de nuctoclínio adjacentes. Nicóis cruzados. Amostra AN-53B; g) botda de intercrescimento de microclínio, quartzo e mica sobte megacristal subédrico de microclínio da fácies Santa Bárbara média. Nicóis cruzados. Amostra AM-119; h) aspecto da matriz da fúcies Santa Bárbara média. Nicóis cruzados. Amostãa AM-119.............................95

Prancha 5.3 - a) Agregados cúspides de mica marrom-esverdeada primáta na fácies Santa Bárbara média. Nicóis paralelos. Amostra $\triangle \mathrm{M}$ M 125; b) presença de cassiterita na fácies Santa Bátbara média. Nicóis cruzados. Amostra AM-170; c) diminutas inclusóes subédricas de albita ortentadas paralelanente aos planos de clivagem do megacristal de microclinio. Fúcies Santa Bárbata fina. Nicóis cruzados. AM $-38 ;$ d) intercrescimento granofírico de feldspato potássico e quartzo na matriz de granito da fácies Santa Bárbara fina. Nicóis cruzados. AM-145; e) textura alotronóótica do albita-microclíno granito branco da fácies Santa Bárbara fina. Maclas da albita acunhadas e desencontradas no plagioclásio. Nicóis cruzados. Amostra AM-134; f cavidade miarolitica precnchida por topázio no albiamicroclínio granito báanco. Nicóis cruzados. AM $134 ; \mathrm{g}$ ) aspecto microscópico dos pols de greisenizaçăo incipiente nucleados sobre megacristais de microclínio. A diteita, observa-se megacristal fortemente substituído por siderofilita e muscovita (microcristalina). À esquerda, autéola adjacente ao megacristal onde o plagioclásio está inteiramente substituido por mica branca. Nicóis cruzados. AM $260 ; \mathrm{h}$ ) megacristal de mictoclinio em granito greisenizado fortemente substituído por sideroflita, muscovita e fluorita. Nicóis ctuzados. Ai-1996

Prancha 5.4 - a) Granito porfiritico de matriz média da fácies Santa Bátbaza média cujos megactistais de feldspato potássico e diversos cristais de feldspatos da matriz exibem pigmentaço branca que denota composição albítica. Amostra AM.224; b) ocorrência, na fotma de manchas de contatos difusos, de porçòes de albitamicroclínio granito branco na fácies Santa Bárbara média. Amosta AM-237; c) granito greisenizado, tosaacinzentado, equigranular de granulaçio média, composto pot feldspatos, quartzo e mica. AM-190; d) greisenização incipiente na forma de spols nucleados sobre megacristais de feldspato potássico da fácies Santa Bárbara néda AM-263; e) quartzo greisen equigranular médio. Anostra AM-227; f) topázio-. siderofilita-quartzo greisen equigranular médio cinza. Amosta AM-35; g) mica greisen pobre em quatzo, equigranular médio, preto. Amostra AM-74; h) granito abbitizado salmão, leucocrático, equigranulat médio, cujos cristais de quartzo mostram-se bem formados e arredondados enquanto que a matriz feldspática carece de contornos cristalinos définidos. Amostra AM $14 \mathrm{~B}$.

Prancha 5.5 - a) Pronunciada substitução de microclínio por sidetofilita nos granitos greisenizados. Nicóis cruzados. Amostra $\triangle \mathrm{M}-19$; b) ropázio siderofilita-quartzo greisen com cristais de cassiterita marrom escura no centro. Nicóis parálelos. Amostra AN-35; c) aspecto microscópico dos topáziomica grésers pobres en quartzo. Nicóis paralelos. Amostra AM-72; d) abundância de albita chestboard no granto albitizado salmào. Forma irregular da mica. Nicóis cruzados. Amostra AM 14B; c) composição monominerálica dos fronts de albitização. Nicóis cruzados. Amostra AM-273C; f) inclusóes ripiformes de plagioclísio orientada segundo as superficies de crescimento do quartzo hospedeiro, configutando textura snomball. Quartzo dos pegmatóides. Amostra AM-212; g) muscovitizaçăo extensiva de topázio-siderofilita-quartzo greisen, gepólostanfáciesdfáciesofúcies rocha de textura fina quase monominerálica. Nicóis paralelos. Amosta AM12

Prancha 5.6 - a) Aspecto macroscópico do front irregular de albitização, representado pela porção salmão hololencocrática da tocha. Amostra AM.273; b) pegmatóide com cristais de feldspato potássico de textura "plumosa", mica e quartzo intercrescidos. Amostra AM-240; c) pegmatóide composto por feldspato potássico euédrico, além de mica e quartzo intercristalinos. Amostra AM-247; d) granito greisenizado 
afetado por muscovitização, mais intensa nas regiões amarela. Amostra $A M-1 ;$ e) quartzo greiren equigtanular médio afetado por muscovitzaģà t) ropázio-siderofilita quatro greizen in teiramente substituido por muscovita, com cassiterita (preta) abundante. Amostra AM-307.

Prancha 5.7 - a) Associaçăo freqüente de monazita com a mica primária na fácies Serra do Cícero. A xenotima está associada a thonazita como produto de substitução da mica; b) zircäo associado com monazita e com sobrecrescimento de xenotima na fácies Serta do Cícero; c) aspecto de granito da fácies Serra do Cícero mostrando grandes e abundantes cristais prismáticos de zircão sem zonação aparente, fraturados. Substituição da mica primátia por anátásio subédrico; d) tipo de zircão predominante na fácies Serra do Cícero, caracterizado pelo hábito prismático curto e pela ausência de faces de crescimento aparentes. Associação com fluorita

Prancha 5.8 - a) Tipo de zircão de ocorrência subordinada na fácies Serra do Cíceto, caracterizado pela forma prismática com terminaçōes bipiramidais, intercescimento com xenotima no nucleo e faces de crescimento bem marcadas; b) cerianita en associação com mica secundátia substitúndo mica primátia ná fácies Serra Azul; c) ceranita granular anédrica inclusa em fluotita con zonação concêntrica na fácies Serta Azul; d) ceranita prismática cm agregados de cristais associada à fluotita è mica na fácies Sexa Azul.

prancha 5.9. a) Grande cristal de fluorita en associação com mica e quatzo, com padräo de zonação irregular e diversas inclusões de zircão. Fúcies Serta Azul; b) cristal de zircão com faces de crescimento parcialmente destruídas nas regiões de núcleo e borda, onde apresenta aspecto turvo; c) ocorrência de óxido de ETR incluso náa fuotita tatclia associada com mica na fácies Santa Bárbata; d) presença de columbita em associação com mical e fuorita na fúcies Santa Bátara

Prancha 5.10 - a) Zircão parciamente substitudo por torita na fácies Santa Bárbara; b) zircão in teiramente psendomorfazado por torita na fácies Santa Bárbara; c) diversas inclusòes de óxido de La, Nd e Y na mica secundária do granito albitizado branco; d) presença de columbita inclusa na mica secundátia doalbita. microclínio granito branco.

Prancha 5.11 - a) Aspecto dos topázio-mica-quartzogreisens com fluoria, topázio, mica e cuatzo, podendo tambétm estar ptesente a cassiterita. A monazita e a columbita são acessótias, inclusas na fluorita e na mica, respectivamente; b) cassiterita anédrica e isenta de inclusões, substituída por óxido de ferro qas fraturas, associada com quartzo e mica zonada cujo núcleo é mais pobre em ferro do que a boxda. "Topázio-mica greisen; c) pseudomorfismo de volframita por scheelita em topázio-mica greisen; d) precipitação de óxido de ferro associada ao pseudomorfismo de volfumita por scheelita em topázio-mica greisen.

Prancha 5.12 - a) Associação textural de dois tipos de mica nos topázio-nica greisens pobtes em quatzo, onde a mais escura e mais pobre em ferro substitu a precoce a partir das bordas, gerando segregações de óxido de ferro; b) fengitazação de topázio-nica greisen, promovendo a substitução da mica original, mas data, por fengita (cinza médio), c a precipitaçăo de fluorita; c) zonaçăo da fengita com núcleo mais rico em ferro e borda mais pobre; d) consumo de topázio nos topáziomica greisens devido à alteração fengítica superposta

Ptancha 5.13 - a) Rocha composta por fengita e cassiterita oriunda da fengitzaçao extensiva de topázio-mica greisen; b) e c) associação de fengita com litioforila, hollandita e cerianita nos nódulos manganesíferos oriundos da altetaçăo fengítica; d) óxido de ferro como peliculas e fotmas botrioidais sobte as terminaçóes de cristais de quartzo, na porçăo central dos veios de quartzo estéreis .

Prancha 5.14 - a) Carbonato (buracos negros), pixita, barita, óxido de ferro e fluotita presentes nas bordas de alteração das encaixantes getadas pelos veios de quartzo estéteis; b) substitução pronunciada da mica primária por óxido de ferro nas bandas de alteração latetais aos veios de quarto estéreis. Neste exemplo, a cncaixante alterada e um granito da fícies Serra Azul; c) cualinita, predominante, e haloysita do stockwork argiloso 107

Prancha 9.1 -. a) Inclusōes primátas aquosas c aquo-carbónicas em quatto do albita-microclínio granito branco (AM134); b) inclusòes aquo-carbônicas secundárias no táciesopfáciesázáciesiofácies do albita mictoclinio granito branco; c) plano de pequenas inclusões aquosas secundárias da população 2 (porção direita da foto) no quartzo do pegmatito (AM-213) e grupo de inclusões secundátias aquo catbônicas da população 3 (maiores, de forma irregular, no centro da foto); d) detalhe das inclusóes aquosas secundárias da populaçŭo 2 da foto anterior; e) detalhe da inclusões aquo-carbontricas secundátias da população 3 da foto c; $\mathrm{fl}$ ) inclusòes aquosas primátias, orientadas, presentes no topázio do bolsão de quartzo com siderofilta e ropázio (AM-168A);g) inclusóes aquosals pseudo-secundárias, năo orientadas, presentes no topázio do bolsão de quarzo com siderofila e topázio ( AM-168A); h) inclusões aquosas secundátias presentes no quartzo do bolsão de quatzo com siderofiliá e topázio (AM-168C)

Prancha $9.2-$ a) Inclusöes aquosas "primárias" localizadas nas faces de crescimento do cuartzo do bolsão de quartzo com siderofilita e topázio (AM-168C); b) detalhe da foto anterior; c) melt inclusion com fase vapor de composição aquo-cabônica aquo-carbônicasptesente no topázio do topázio-siderofilita-quartzo greisen tabular (AM-35covariaçăo); d) aspecto geral da distributçăo de melt inctusions, inclusões aquosas e aquo. carbônicas primárias no topázio do topázio-siderofilita-quartzo greiset tabulat (AM-35); e) inclusões aquosas e aquo-carbonicas primárias presentes no quarzo (campo 5) do topázio-siderofilita-quartzo greisen tabular 
(AM-35); f) inclusões aquosas pseudo-secundáras presentes no quartzo (campo 3) do topázio-sideroflitaquartzo greisen tabular (AN-35); g) inclusöes aquosas primátias e mell inclusions em quartzo do granito albitizado salmăo (AM-14B); h) detalhe da foto anterioz.

Pancha 9.3 -... a) Aspecto getal da distribuição de inclusões aquosas e aquo-carbônicas primárias no topázio do stockwork de topazio-siderofilia-quartzo greisen (AM-130); b) idem foto anterior, em outro foco; c) inclusoes aquosas primátras do tipo $1 \mathrm{em}$ topázio do wockmork de topázio-siderofilia-quartzo greden (AM-130); d) inclusóes compostas cujas fase vapor aparenta escape iminente durante o trapeamento - quatzo do stockmork de

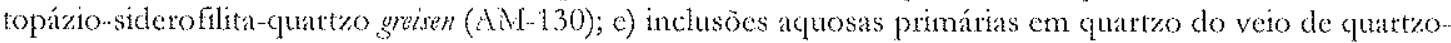
cassiterita (AM-131); ) detalhe da porção direita da foto anterior; g) inclusoes aquosas primáras distribuídas ao longo das faces de crescimento de quartzo do veio de quartzo estéril (AM-159); siderofilitah) micasdetalhe da foto anterior. 


\section{RESUMO}

O Maciço Granítico Santa Bárbara integra a Suíte Granitos Últimos de Rondônia, que compreende rochas com idades entre 998 e $974 \mathrm{Ma}$ e afinidade geoquímica com granitos rapakivi, intraplaca, do tipo $A$, intrusivas em embasamento de médio a alto grau metamórfico de idades entre 1,75 e 1,43 Ga. Ocorre como um stock semicircular com cerca de $7 \mathrm{~km}$ de diâmetro médio, localizado no Distrito Minciro de Santa Bárbara, norte de Rondônia. Apresenta três unidades magmáticas subsoluus: fácies Serra do Cícero, fácies Serra Azul e associação de fácies Santa Bárbara. A fácies Serra do Cícero compreende sienogranito rosa porfirítico de matriz média, com textura wiborgítica e caráter metaluminoso. A fácies Serra Azul é composta por albita-microclínio granito rosa equi a inequigranular de matriz média a grossa e natureza peraluminosa. Duas fácies de albita-microclínio granito de contato transicional fazem parte da associação de fácies Santa Bárbara: uma rosa porfirítica de matriz média com textura piterlítica (fácies Santa Bárbata média); e outra, restrita à porção de cúpula da unidade, de granito equigranular ou microporfúítico rosa-esbranquiçado a branco, de matriz fina (fácies Santa Bárbara fina), todos peraluminosos. Em todas clas, o mineral máfico presente é a siderofilita com teores decrescentes de ferro e crescentes de lítio e flúor da fácies Serra do Cícero para a associação de fácies Santa Bárbara, e ocorrem fluorita e topázio magmáticos como minerais acessórios. Outras fases acessórias são a monazita, o zircão, a xenotima, e a cassiterita. Datações U-Pb convencional em monazita forneceram idades de $993 \pm 5 \mathrm{Ma}$

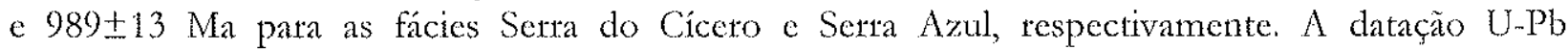
SHRIMP em zircão da fácies Santa Bárbara fina apontou uma idade média de $978 \pm 13 \mathrm{Ma}$. Em todos as unidades, reconheceu-se a participação de núcleos herdados com idades mínimas cortelacionáveis à Suíte Intrusiva Santa Clara (1042 a $1096 \mathrm{Ma}$ ) e aos orto e paragnaisses do embasamento (1335 Ma, 1617 a $1651 \mathrm{Ma}, 1979$ a $2067 \mathrm{Ma}$ ). As idades Sm-Nd T $\mathrm{T}_{\mathrm{DM}}$ são crescentes da fácies Serra do Cícero (1711 Ma) para a fácies Serra Azul $(1846 \mathrm{Ma})$ e para a fácies Santa Bárbara fina (2220 Ma), enquanto que os valores de $\xi_{\mathrm{Nu(1)}}$ são de $-2,95,-3,69$ e $-4,58$, respectivamente. A mineralização estanífera está hospedada na associação de fácies Santa Bárbara, restrita a uma região de cerca de $500 \times 150 \mathrm{~m} \mathrm{em}$ planta, e ocorre associada a corpos de topázio-siderofilita-quartzo greisens tabulares, com grande extensão lateral e até $40 \mathrm{~m}$ de espessura, configurando modelo de greisens acanadados. Na fácies Santa Bárbara fina são reconhecidos bolsões pegmatóides de até $2 \mathrm{~m}$ de diâmetro compostos por quartzo, siderofilita e topázio, estruturas estratificadas do tipo magmatic layering e unidirectional solidification lextures, além de cavidades miarolíticas e as texturas snowball e granofírica, que indicam condiçòes de saturação em $\mathrm{H}_{2} \mathrm{O}$ durante sua cristalização. Aumento do volume de albita, dos teores de lítio e flúor na siderofilita, e enriquecimento em $Y$ e ETR nos granitos da fácies Santa Bárbara fina relativamente aos da fácies Santa Bárbara média também diferenciam essas fácies. A alteração hidrotermal que afeta essas rochas é subdividida nos estilos pervasivo e pervasivo fissural. $O$ primeiro tem como produtos os corpos de topázio-siderofilita-quartzo greisens tabulares com até $0,5 \%$ de cassiterita (greisenização I) e os granitos albitizados salmão (feldspatização sódica), ambos espacialmente associados e dispostos concordantemente, configurando uma estratificação concordante com o contato superior do granito. A alteração pervasiva fissural, representada por greisenização II, silicificação I, muscovitização, silicificação II e argilização, compreende, como tipos morfológicos, stockuork de topázio-siderofilita-quartzo greisen, veios de quartzo-cassiterita, veios de muscovita, veios de quartzo estéreis e stocknork argiloso, os dois primeiros tipos portadores de cassiterita. São predominantemente verticais e subverticais e ocorrem alojados principalmente na fácies Santa Bárbara fian. Os fluidos mineralizantes são de origem principalmente magmática no estágio transicional, aquo-carbônicos, com salinidades de 6 a $14 \%$ em peso $\mathrm{NaCl}$ eq., observando-se a incidência de misturas com fluidos meteóricos aquosos de baixa salinidade $(0$ a $13 \% \mathrm{~cm}$ peso $\mathrm{NaCl}$ eq.) já nas etapas finais desse estágio. Condições de imiscibilidade operaram no sistema no intervalo térmico de $370-390^{\circ} \mathrm{C}$. Dados isotópicos de oxigênio apontam temperaturas da ordem de 570 e $500^{\circ} \mathrm{C}$ para a gênese dos bolsões de quartzo da fácies Santa Bárbara fina e para os corpos tabulares 
de greisen, respectivamente. Para os veios de quartzo-cassiterita, a temperatura de cristalização foi estimada em cerca de $415^{\circ} \mathrm{C}$. As composiçóes isotópicas da água em equilíbrio com os diversos hidrotermalitos $\left(\delta^{18} \mathrm{O}_{\mathrm{H} 20}=3,3\right.$ a $10,4 \%$ ) situam-se no intervalo composicional das águas magmáticas,

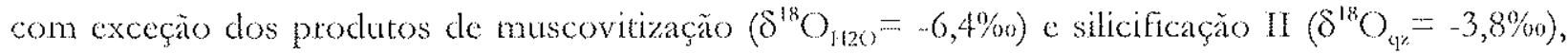
bem como os mica greisens $\left(\delta^{18} \mathrm{O}_{122}=1,6 \%\right)$ e o stockuork argiloso $\left(\delta^{18} \mathrm{O}_{120}=2,6 \% 0\right)$, que sugerem mistura com fluidos metéricos, aquosos, de baixa salinidade ( 0 a $13 \%$ em peso $\mathrm{NaCl}$ eq.). $\mathrm{O}$ controle da deposição da cassiterita no sistema estudado tem três vias: 1) o processo de imiscibilidade, com alto grau de interação rocha/fluido, no caso dos corpos de greisen tabulares e no sistema stockenork de greisen, 2) o boiling de fluidos aquosos sódicos nos veios de quartzo-cassiterita, e 3) a mistura dos fluido magmáticos de alta temperatura, mais salinos, com grandes proporçòes de fluidos meteóricos, frios, de baixa salinidade, nos veios de muscovita. 


\section{ABSTRACT}

The Santa Bárbara massif is part of the Younger Granites of Rondonia (998.974 Ma), composed of granitic rocks which show geochemical affinities with within-plate A-type rapakivi granites. The massif is located in the Santa Bárbata mining district, northern Rondônia, and is semicircular in shape with diameter of $7 \mathrm{~km}$. It comprises three subsolvus magmatic units, emplaced into medium to high-grade metamorphic rocks $(1.75$ and $1.43 \mathrm{Ga}$ ), such as: Serra do Cícero facies, Serra Azul facies, and Santa Bárbata facies association. The Serra do Cícero fácies is a metaluminous pink medium-grained porphysitic syenogranite, wich shows wiborgitic texture. The Serra Azul facies is a peraluminous pink medium to coarse-grained albite-microcline-granite. Two albite-microcline granite facies, with transitional contacts, are distinguished in the Santa Bárbara facies association: a pink-medium grained porphyritic pyterlite granite (medium-grained Santa Bárbara facies), restricted to the granite cupola system, and an even-grained or tmicroporphyritic whitish to pink-whitish finegrained granite (fine-grained Santa Bárbara facies), both described as peraluminous in character. Siderophyllite is the dominant mafic mineral, which exhibit decreasing fe contents, and increasing $\mathrm{Li}$ and $\mathrm{F}$ values from the Serra do Cícero facies toward the Santa Bárbara facies. Fluorite, magmatic topaz, monazite, zircon, xenotime and cassiterite are the accessory mineral phases. U-Pb monazite conventional dating of the early-stage Serra do Cícero facies and late-stage Serra Azul facies, yielded ages of $993 \pm 5 \mathrm{Ma}$ and $989 \pm 13 \mathrm{Ma}$, respectively. SHRIMP U-Pb ages for the Santa Barbata facies association yielded a weighted-mean age of $978 \pm 13$ Ma. Preservation of inherited older zircons are remarkable in all the granitic rock units, and the minimum SHRIMP U-Pb zircon ages are correlatable to the Santa Clara Intrusive Suite (SHRIMP U-Pb zircon ages: 1042 to $1096 \mathrm{Ma}$ ), and to the ortho and paragneiss associations of the basement rocks (1335 Ma, 1617 to $1651 \mathrm{Ma}$, and 1979 to $2067 \mathrm{Ma})$. Sm-Nd model ages increase from the Serra do Cícero facies $(1711 \mathrm{Ma}$ ) and Serra Azul facies (1846 Ma) to the fine-grained Santa Bárbara facies $(2220 \mathrm{Ma})$, whereas the $\varepsilon_{\text {vill }}(\mathrm{T})$ values are $-2,95,-3,69$ and $-4,58$, respectively. The tin mineralization is closely related to the Santa Bárbara facies, covers a $500 \mathrm{~m}$ by $150 \mathrm{~m}$ zone, and is mainly expressed by horizontal to subhorizontal lensshaped topaz-siderophyllite-quartz greisen (up to $40 \mathrm{~m}$ thick) which define a bedded-greisen cupola model. Within the fine-grained Santa Bárbara facies pegmatoid pods (up to $2 \mathrm{~m}$ ) composed of quartz, siderophyllite and topaz, as well as prominent manifestations of magmatic layering, unidirectional solidification textures, miarolitic cavities, snowball and granophyric textures, have been found in the upper part of the cupola system. They indicate $\mathrm{H}_{2} \mathrm{O}$ saturation conditions during their formation. Enrichment in albite, $\mathrm{Fi}$ and $\mathrm{Li}$ contents in siderophyllite, and $\mathrm{Y}$ and $\mathrm{REE}$ in the fine grained Santa Bárbara facies are additional features of importance to distinguish this facies from the medium grained Santa Bárbara facies. The hydrothermal alteration, which affected the grantes, can be divided into: 1) pervasive alteration style which is represented by sheet-like bodies of topazsiderophyllite-quartz greisens $\left(0.5 \% \mathrm{SnO}_{2}\right)$ (greisenization I), and albitized salmon granite (sodic feldspathization). Both metasomatites are spatially associated, denoting a concordant layering in relation to the granite upper contact, 2) pervasive fissural alteration style is well exemplified by greisenization II, silicification I, muscovitization, silicification II and argillization, which encompass morpho-structural bodies, such as: cassiterite-bearing topaz-siderophyllite-quartz greisen stockwork, and cassiterite-quartz veins, muscovite veins, barten-quartz veins and argillic stockwork. These structures are vertical to subvertical and are mainly developed within the fine-grained Santa Bárbara facies. 'The mineralizing fluids related to the transitional stage, are dominantly magmatic, aqueouscarbonic, have salinities varying from 6 to $14 \mathrm{wt} \% \mathrm{NaCl} \mathrm{eq}$, but at the end of this stage, low-salinity (1 to $3 \mathrm{wt} \% \mathrm{NaCl}$ eq. ) meteoric fluids partly mixed with magmatic fluids are largely confirmed. Immiscibility conditions prevailed in the system at temperatures varying from 370 to $390^{\circ} \mathrm{C}$. Oxygen isotope data for the quartz-pods and sheet-like greisens, of the fine grained Santa Bárbara facies, indicate temperatures of the order of $570^{\circ} \mathrm{C}$ and $500^{\circ} \mathrm{C}$, respectively, for the ore genesis. The 
crystallization temperature for the quartz-cassiterite veins is $415^{\circ} \mathrm{C}$. The isotopic composition of the water $\left(\delta^{18} \mathrm{O}_{120}=3.3\right.$ to 10.4 permil), in equilibrium with metasomatites, plot in the magmatic water field, save the muscovitization $\left(\delta^{18} \mathrm{O}_{120}=-6.4\right.$ permil), and silicification II products $\left(\delta^{18} \mathrm{O}_{\mathrm{q} z}=-3.8\right.$ permil), as well as mica greisens $\left(\delta^{18} \mathrm{O}_{\mathrm{V} / 2 \mathrm{O}}=1.6\right.$ permil $)$ and argilic stockwork $\left(\delta^{18} \mathrm{O}_{122}=2.6\right.$ permil $)$ which suggest mixture with aqueous low-salinity $(0$ to $3 \% \mathrm{wt} \% \mathrm{NaCl} \mathrm{eq}$.) meteoric fluids. 'Three processes are responsable for cassiterite genesis: 1) immiscibility in conditions of high degree of rock/fluid interaction in bedded-greisen bodies and greisen stockwork, 2) boiling of sodic aqueous fluids in quartz-cassiterite veins, and 3) mixing of saline magmatic fluids with high proportions of cold low-salinity meteoric fluids, in muscovite veins. 


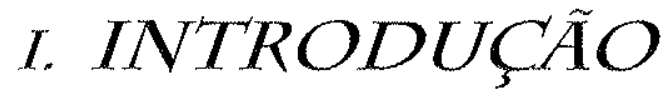

\subsection{Introdução}

A Província Estanífera de Rondônia, com uma produção acumulada de estanho da ordem de 222.000 toneladas (Dall'Igna 1996) detém, atualmente, a segunda posição de maior produtor nacional de estanho, com uma produção de 7.250 toneladas em 1995 (DNPM 1996). Segundo o DNPM (1994), haverá necessidade de se investir em pesquisa mineral para estanho um montante da ordem de US $\$ 70$ milhões, apenas para repor as reservas que deverão set consumidas até o ano de 2010 .

Os depósitos secundários do tipo placer raso, com profundidade menor que 20 metros, têm contribuído com a maior parte dessa produção na província. Porém, com a expectativa de exaustão desses depósitos a médio prazo, a sobrevivência da indústria mineira na região dependerá da potencialidade dos placeres profundos (mais que 20 metros de profundidade) e dos depósitos primários, ambos ainda bastante desconhecidos em termos geológicos e econômicos.

O Maciço Granítico Santa Bárbara ostenta um dos poucos campos estaníferos atualmente em operações de lavta, iniciadas em 1971 (Franke 1994), na Província Estanífera de Rondônia. Desde então até o ano de 1999, a mina produziu mais de 40.000 toneladas de estanho contido. Foi pioneira no desenvolvimento dos métodos de lavra e beneficiamento na província, bem como na lavra da rocha dura (greisens) (Bates 1999).

A mina tem capacidade de produção anual de 1.000 toneladas de estanho, com teor de $0,32 \%$ de $\mathrm{Sn}$. Os recursos estimados somam cerca de 100.000 toneladas, que garantem a produção por mais vinte anos. Além da jazida em explotação, denominada Greisen Taboquinha, há os paleoaluviões Taboquinha, com profundidades da ordem de 42 a $45 \mathrm{~m}$, e Village (Bates 1999).

As fases intrusivas tardias do Maciço Granítico Santa Bárbara, representadas pela associação de fácies Santa Bárbara, hospedam minério estanífero, com tungstênio subordinado, segundo o modelo dos greisens acamadados, contidos nas zonas apicais de granitos estaníferos (Sparrenberger \& Bettencourt 2000).

Esse tipo de sistema "contido", ou seja, cuja circulação dos fluidos e alteração hidrotermal e 
mineralização decorrentes não são controlados por fraturas rúpteis, constitui "a melhor oportunidade para observar a evolução fluidal próximo ao seu ponto de origem". O maior problema na interpretação genética desse tipo de sistema é a questão da fonte e do acesso dos fluidos hidrotermais (Pollard et al. 1988).

\subsection{As tendências atuais de estudo de sistemas graníticos com metais raros}

Depósitos de elementos raros ocorrem fteqüentemente em complexos intrusivos rasos, polifásicos e pós-cinemáticos, e a mineralização está geralmente em associação espacial com as zonas apicais das últimas fases intrusivas de batólitos e stocks de rochas graníticas (Pollard 1983; Taylor \& Pollard 1988). Em depósitos estaníferos do tipo disseminado, a cassiterita forma-se como mineral de preenchimento de cavidades ou de substituição em granitos alterados pervasivamente (Pollard \& Taylor 1986).

Os granitos rapakivi constituem batólitos e stocks múltiplos e epizonais em contato abrupto com as encaixantes metamórficas. Não raro ocorrem em associação com rochas máficas. Podem hospedar depósitos de estanho polimetálicos e de Fe-Cu. Depósitos de Sn (-W-Be-Zn-Pb-Ag) dos tipos greisen, escarnito e veios estão associados com microclínio-albita granitos com topázio especializados geoquímica e mineralogicamente, que exibem expressivas reações subsolidus e podem mostrar-se inteiramente alterados hidrotermalmente (Haapala 1977; Rämö \& Haapala 1995).

As alterações hidrotermais que afetam granitos mineralizados com elementos raros incluem, principalmente, os estilos feldspatização potássica, feldspatização sódica, e greisenização (Pollard 1983).

Cabe ressaltar que, historicamente, os pesquisadores russos (e.g., Serebryakov 1961; Beus \& Zalashkova 1964) atribuíam todos esses processos de alteração ao estágio pós-magmático, denominando-os, conjuntamente, autometassomatismo. Devem-se a cles os modelos clássicos de alteração de granitóides mineralizados, com uma estruturação vertical das diferentes zonas e tipos de alteração, bem como a definição das relaçôes temporais relativas desses processos como microclinização precoce, albitização precoce, greisenização, albitização tardia e microclinização tardia. Essa seqüência corresponderia a uma evolução da atividade máxima relativa de cátions nas soluções pós-magmáticas do tipo $\mathrm{K} \rightarrow \mathrm{Na} \rightarrow \mathrm{Si} \rightarrow \mathrm{Al} \rightarrow \mathrm{Na} \rightarrow \mathrm{K}$. A maior parte do minério primário, em depósitos de metais ratos, ocorre associada à greisenização. 
O estudo de sistemas graníticos mineralizados com metais raros, hoje, baseia-se em trabalhos experimentais focalizados na evoluçăo de magmas ricos em voláteis e aos sistemas hidrotermais magmáticos associados. Os aspectos de interesse dizem respeito:

a) à identificação e análise de inclusões de fundidos (vidros) em granitos a metais raros (Kovalenko \& Yarmolyulk 1995), uma vez que as mesmas demonstram a existência de magmas com utma composição global similar aos granitos com metais taros;

b) ao papel da alteração pós-magmática e alteração petvasiva resultante de fluidos hidrotermais magmáticos;

c) à formação de metassomatitos com Ta, Nb, Be, Zr, ETR, etc. em zonas de cisalhamento;

d) aos avanços alcançados na modelagem de pegmatitos com metais raros;

e) aos estudos das relações de fases líquidas saturadas em vapor, com adição de componentes (F, Li) (Manning 1981; Pichavant 1981, 1987; London et al. 1993), bem como aos experimentos em ambientes saturado e subsaturado, a vapor, usando materiais naturais com composição muito similar aos granitos com metais raros e pegmatitos (London et al. 1988, 1989).

Além disso, o conhecimento dos mecanismos que conduzem ao ultrafracionamento magmático e composição quítnica extrema dos magmas residuais é de muito interesse, pois esses processos levam à partição e precipitação elementar metálica.

Finalmente, deixa-se evidente que a questão central a ser resolvida em relação a esses sistemas ultrafracionados é saber, em face do conhecimento dos fatores físicos e químicos do magma (composição, estado de oxidação, timing de cristalização, ascensão, exsolução da fase volátil magmática, profundidade de posicionamento, etc.), se a natureza química e a especialização metálica são devidas ao estágio magmático, às modificações no estado subsólido ou, então, à presença de uma fase fluida aduzida ao sistema.

A preocupação maior da linha de pesquisa à qual a tese está vinculada é de estar em consonância com estas tendências de pesquisa, obedecidas pelos principais grupos de pesquisa desses sistemas em nível mundial.

\subsection{Objetivos}

A pesquisa desenvolvida durante este Doutoramento visou à caracterização da gênese do depósito de estanho e metais associados do distrito Santa Bárbata, com enfoque na origem dos metais e fluidos mineralizantes, bem como na cronologia, mecanismos, e condições 
termobarométricas da deposição desses metais. Assim, pretende-se contribuir para a elaboração de um modelo metalogenético geral para os depósitos primários de estanho associados aos Granitos Últimos de Rondônia.

Os objetivos mais específicos deste estudo, para que se cumprissem as metas últimas do projeto, constaram de:

- caracterização petrográfica, petroquímica e geocronológica das rochas magmáticas do Maciço Granítico Santa Bárbara, bem como de hidrotermalitos telacionados à mineralização de metais raros;

- identificação e caracterização das fácies de alteração hidrotermal associadas à mineralização primária, no que diz respeito à petrografia, quimismo e condições de hidrotermalismo;

- identificação e caracterização química e petrográfica das fases minerais presentes nos granitos e hidrotermalitos associados, visando à determinação da evolução do sistema granítico nos estágios magmático e tardi a pós-magmático;

- identificação e caracterização química e petrográfica das fases minerais da mineralização e estabelecimento de paragêneses;

- caracterização da natureza, origem e evolução da fase fluida, mais especificamente em relação ao entendimento das condições físico-químicas reinantes e da origem e condições de precipitação metálica no sistema mineralizante;

- estabelecimento da cronologia relativa das fácies magmáticas e hidrotermais do complexo e da mineralização correlata;

- esboço preliminar de modelo genético da mineralização de metais raros como fertamenta fundamental a contribuir para a melhoria de modelos de pesquisa mineral aplicados à Província Estanífera de Rondônia.

O tratamento petrológico e geoquímico das fácies magmáticas do maciço foi desenvolvido com vistas à caracterização geral e classificação tectônica e geoquímica desses granitos, visando à obtenção de subsídios para o enquadramento do depósito em um modelo metalogenético. A ênfase, entretanto, ficou por conta da caraterização físico-química dos fluidos mineralizantes, desde a definição de sua provável origetn até a elucidação de sua evolução e dos processos em que estiveram envolvidos, na intenção de contribuir para a definição do mecanismo que governou a gênese desse depósito. 
Cabe ressaltar que o depósito Santa Bárbara constitui o único exemplo conhecido, até a presente data, de mineralização estanífera de interesse econômico em greisens acamadados na Província Estanífera de Rondônia e no Brasil, daí a importância de seu estudo.

A possibilidade de que os demais maciços da suíte e, quiçá, da província, representem sistemas mais profundamente erodidos, onde a parcela da cúpula granítica, exemplificada no Maciço Granítico Santa Bárbara, tenha sido removida, não pode ser descartada. O depósito Santa Bárbara, portanto, constitui um testemunho raro e bastante completo dos mecanismos envolvidos nas concentrações econômicas de metais raros na província.

\subsection{Localização, extensão e acesso}

O Maciço Granítico Santa Bárbara está localizado na região norte do estado de Rondônia, cerca $116 \mathrm{~km}$ a sudeste da capital, Porto Velho.

O acesso à área é feito pela BR-364, a partir de Porto Velho, até a cidade de Itapuã D'Oeste $(\mathrm{km}$ 601,5), de onde se toma estrada vicinal com cerca de $15 \mathrm{~km}$ de extensão até a sede da Companhia Estanífera do Brasil (CESBRA).

O maciço caracteriza-se pela forma semi-circular, com diâmetro máximo de cerca de $10 \mathrm{~km}$ na direção norte-sul e $6 \mathrm{~km}$ leste-oeste. A ênfase durante os trabalhos de campo foi dada à área da mina propriamente dita e suas adjacências. 


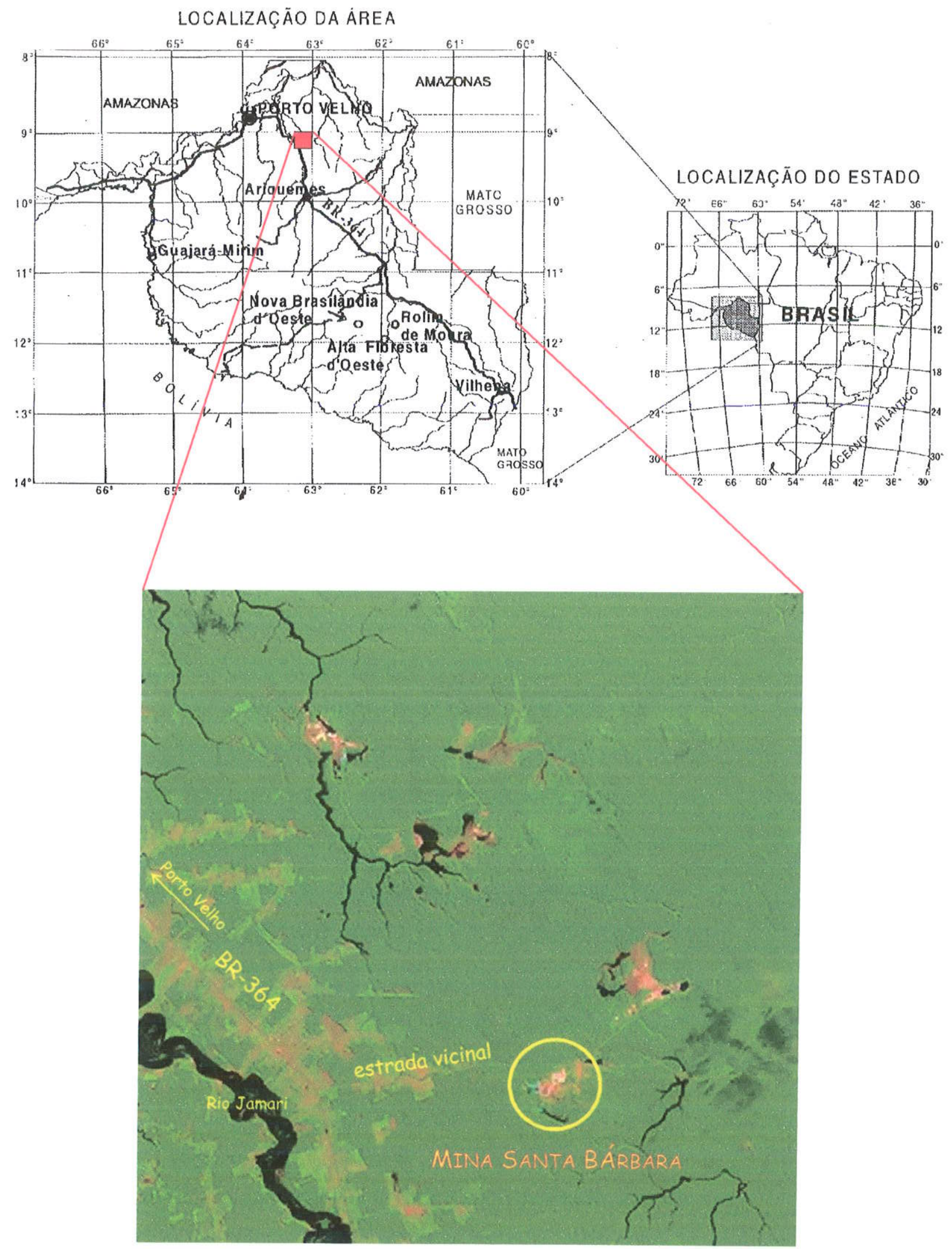

Figura 1.1 - Mapa de localização da área de estudo. 


\section{MATERIAIS E MÉTODOS}

\subsection{Introdução}

Os métodos de trabalho empregados nesta pesquisa envolveram: 1) pesquisa bibliográfica; 2) mapeamento geológico com prancheta e alidade na escala 1:500 das zonas mineralizadas principais; 3) amostragem e descrição sistemáticas de afloramentos e de testemunhos de sondagem rotativa; 4) análises petrográficas de seções delgadas, além de contagens modais; 5) análises químicas em rocha total de elementos maiores, menores e traços; 6) análises em fases minerais com microssonda eletrônica; 7) análises texturais de fases minerais com microscópio eletrônico de varredura; 8) análises petrográficas e microtermométricas de inclusões fluidas; 9) análises de isótopos de O e H em rochas e minerais; e 10) análises geocronológicas através dos métodos U-Pb em zircão e Sm-Nd em rocha total. A maior parte das técnicas foram aplicadas em litotipos tanto magmáticos quanto hidtotermais.

\subsection{Materiais e Métodos de Trabalho}

\subsubsection{Pesquisa Bibliográfica}

Consistiu de ampla compilação bibliográfica sobre a geologia regional e local da área de estudo, além de levantamento c acompanhamento bibliogtáfico do conhecimento geológico acerca da petrologia, litogeoquímica, geoquímica isotópica, alterações hidrotermais e mineralizações de granitóides, visando à obtenção de parâmetros comparativos para aplicação na área de estudo.

\subsubsection{Integração de Mapas}

Compreendeu a integração das informações geológicas existentes em mapas prévios, especialmente os de Frank (1990) e da CESBRA (1994), além daquelas obtidas dutante os trabalhos de mapeamento da presente pesquisa. 


\subsubsection{Trabalhos de Campo}

Os trabalhos de campo desta pesquisa de Doutoramento foram realizados entre os anos de 1998 e 2001, em quatro etapas, totalizando 88 dias.

Dentre outras, as atividades desenvolvidas envolveram excursões de cunho regional, incluindo visitas ao depósito do Morro Potosi e a afloramentos ao longo das linhas de assentamento do INCRA, mapeamento de reconhecimento de fácies e contatos na área da mina e adjacências, e caminhamentos ao longo de picadas em serras contíguas à mina.

Quarenta e nove testemunhos de sondagem rotativa, de um acervo de cento e setenta e cinco, foram descritos e amostrados na presente pesquisa. 'Tratam-se de testemunhos predominantemente verticais, de até $95 \mathrm{~m}$ de profundidade, executados pela Companhia Estanífera do Brasil (CESBRA) no ano de 1987.

A aluna procedeu também ao mapeamento em escala 1:100 de quadrícula de $10 \times 15$ metros visando à elucidar a distribuiç̃o e as relações angulares e temporais dos diversos sistemas de veios e fraturas presentes no depósito.

Finalmente, os trabalhos de campo da presente pesquisa envolveram o mapeamento 1:500 com prancheta e alidade das faces verticais das bancadas dentro do pit da mina no intervalo de cotas entre 100 e 132 metros, totalizando uma área de $400 \times 200$ metros coberta por 800 pontos de leitura topográfica.

O total de amostras coletadas, incluindo exemplares de afloramentos e de testemunhos de sondagem, foi de cerca de 310 .

A notação adotada para a representação de medidas de direção tomadas com bússola é a de rumo.

\subsubsection{Caracterização Petrográfica}

Com o objetivo de padronizar e uniformizar as descrições dos testemunhos de sondagem, estabelecendo correlações com os logs de descrição dos testemunhos confeccionados pelos geólogos da CESBRA, e de identificar e caracterizar os principais litotipos do Maciço Granítico Santa Bárbatra, efetuou-se a descrição petrográfica de 129 seções delgadas de rochas julgadas representativas das principais fácies magmáticas e hidrotermais do maciço.

Adotou-se a classificação granulométrica de Heinrich (1972), que admite granulação fina para 
rochas que contenham cristais menores que $1,0 \mathrm{~mm}$, média para aquelas cujos cristais situam-se no intervalo de 1,0 a $10,0 \mathrm{~mm}$, grossa quando concentram-se no intervalo de $10 \mathrm{~mm}$ a $30 \mathrm{~mm}$, e muito grossa quando predominantemente maiores que $30 \mathrm{~mm}$.

Para a medida do teor de anortita do plagioclásio utilizou-se o método do ângulo de extinção na seção normal a " $d$ " (Trögger 1929). Já a estimativa da composição das micas foi feita com base na tabela 2 de Wilcox (1984).

A classificação dos granitos seguiu as recomendações da IUGS, em Streckeisen (1976).

A classificação dos greisens teve como base a proporção modal de quartzo, mica e topázio fluorita, conforme o diagrama ternário de Kühne et al. (1972 in Stemprok 1987).

\subsubsection{Contagem Modal}

A moda dos granitos e hidrotermalitos do Maciço Granítico Santa Bárbara foi estimada através de contagem de pontos em fatias de rocha, em lâmina delgada, ou ainda pela combinação dos dois métodos, no caso dos litotipos inequigranulares, porfiríticos, ou com granulação superior a $3 \mathrm{~mm}$, conforme ilustrado na 'T'abela II.1.

Na contagem modal em fatias de rocha foram empregados ladrilhos previamente tingidos com cobaltinitrito de sódio ( $\leftrightarrow$. Gabriel e Cox 1929, Nold e Erickson 1967), que permite a pronta diferenciação entre o fellspato potássico, que fica amarelo, e o plagioclásio, que se torna esbranquiçado. A área de contagem mínima foi de $10 \times 8 \mathrm{~cm}$, sobre a qual aplicou-se folha plástica transparente contendo malha de pontos espaçados de $2 \mathrm{~mm}$, para as rochas das fácies cuja granulação é menor do que $2 \mathrm{~mm}$, e $4 \mathrm{~mm}$, para rochas com granulação maior do que $3 \mathrm{~mm}$. O total de pontos foi de 1566 a 3250 e de 547 a 708 , respectivamente.

Para a contagem em lâmina delgada utilizou-se o método de Neilson e Brockman (1977), que preconiza a leitura dos pontos em diversos conjuntos aleatoriamente dispostos sobre a lâtmina. Os espaçamentos dos pontos foram de 0,8 e 1,0 mm, para rochas de granulação menor do que $2 \mathrm{~mm}$, e $1,2 \mathrm{~mm}$, para aquelas de granulação maior, configurando conjuntos de 36,30 e 20 pontos, respectivamente. O total de conjuntos contados foi de 12 a 38 , utilizando-se de uma até duas seções delgadas por amostra. A porcentagem dos minerais etra cada amostra, a variância e o erro das medidas $(2 \sigma)$ a $95 \%$ de confiança foram calculados conforme as fómulas dos autores, listadas abaixo:

$p=100\{\Sigma(x) / k N\}$ 
$s^{2} p=\left\{10^{4} /\left[(k-1) N^{2} k\right]\right\}\left\{\Sigma\left(x^{2}\right)-(\Sigma x)^{2} / k\right\}$

erro $= \pm 2\left(s^{2} p\right)^{1 / 2}$

onde $p$ é a porcentagem do mineral na lâmina, $x$ é número de pontos contados para 0 mineral em questão, $k$ é o número de conjuntos, $N$ é o número de pontos em cada conjunto, e $s^{2} p$ é a variância.

TABELA II.1 - Amostras e métodos empregados na contagem modal.

\begin{tabular}{|c|c|c|c|c|}
\hline \multirow[b]{2}{*}{ AMOSTRA } & \multirow[b]{2}{*}{ ROCHA } & \multicolumn{3}{|c|}{ MÉTODO } \\
\hline & & FATIA DE ROCHA & $\begin{array}{c}\text { LÄMINA } \\
\text { DELGADA }\end{array}$ & COMBINADO \\
\hline$A M-8$ & greisen equigranular & & & \\
\hline$A M-13 A$ & hidrotermalito equig. & & & \\
\hline $\mathrm{AM}-14 \mathrm{~B}$ & hidrotermalito equig. & & & \\
\hline$A M-34$ & greisen equigranular & & & \\
\hline AM-35 & greisen equigranular & & & \\
\hline$A M-38$ & granito equigranular & & 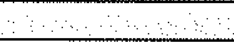 & \\
\hline $\mathrm{AM}-41 \mathrm{~A}$ & greisen equigranular & & & \\
\hline$A M-50 A$ & granito equigranular & & 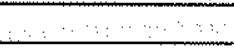 & \\
\hline$A M-52 B$ & granito porfirítico & & & \\
\hline AM-53B & $\begin{array}{l}\text { granito } \\
\text { inequigranular }\end{array}$ & & & \\
\hline AM-102A & hidrotermalito equig. & & & \\
\hline$A M-119$ & granito porfiritico & & & \\
\hline $\mathrm{AM}-121$ & granito equigranular & & & \\
\hline$A M-125$ & granito porfirítico & & & \\
\hline$A M-130$ & greisen equigranular & & $\cdots$ & \\
\hline $\mathrm{AM}-134$ & granito equigranular & & & \\
\hline AM-144 & granito porfiritico & & & \\
\hline$A M-145$ & granito porfirítico & & & \\
\hline AM-149 & $\begin{array}{l}\text { granito } \\
\text { inequigranular }\end{array}$ & & & \\
\hline$A M-159$ & $\begin{array}{l}\text { granito } \\
\text { inequigranular }\end{array}$ & & & \\
\hline$A M-170$ & granito equigranular & & $\ldots$. & \\
\hline AM-188 & greisen equigranular & & & \\
\hline$A M-203$ & greisen equigranular & & & \\
\hline$A M-221$ & granito porfirítico & & & $\ldots$ \\
\hline$A M-224 B$ & granito porfiritico & & & $\ldots \ldots$ \\
\hline$A M-239$ & granito equigranular & & & \\
\hline AM-252 & granito porfirítico & & & . \\
\hline AM-275 & granito equigranular & & & \\
\hline $\mathrm{AM}-278$ & granito equigranular & & 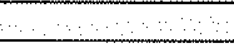 & \\
\hline$A M-282$ & granito porfirítico & & & \\
\hline $\mathrm{AM}-287$ & granito porfirítico & & & 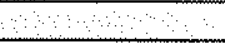 \\
\hline$A M-288$ & granito equigranular & & 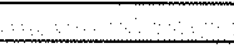 & \\
\hline AM-291 & granito porfirítico & & & \\
\hline
\end{tabular}

A moda das rochas porfiríticas foi estimada conforme o método de Nesbitt (1964), em que os megacristais com diâmetros maiores do que $3 \mathrm{~mm}$ foram contados em ladrilhos de rocha tingidos, e a matriz ( $\leq 3 \mathrm{~mm}$ ) em lâmina delgada, e ambos os resultados integrados para o cálculo da moda final. 


\subsubsection{Microscopia Eletrônica de Varredura}

As análises ao microscópio eletrônico de varredura com espectrometria de raios-X por dispersão de energia (EDS) foram efetuadas em equipamento Leica Stereoscan 440/Quantimet $600 \mathrm{~S}$, com voltagem de $20 \mathrm{KeV}$, utilizando-se lâminas delgadas polidas cobertas com carbono. Tiveram lugar no Laboratório de Caracterização Tecnológica (LCT) da Escola Politécnica da Universidade de São Paulo.

Foram caracterizadas 15 seções delgadas e o enfoque foi dado às fases varietais e acessórias.

\subsubsection{Litogeoquímica}

\section{a) Preparação de alíquotas de rocha}

Vinte e sete amostras foram selecionadas para análises litogeoquímicas totais, incluindo clementos maiores, menores e traços (com ETR). Destas, 10 constituem exemplares de afloramentos isolados, enquanto que 17 fazem parte de dois testemunhos de sondagem representativos da seqüência completa de fácies da alteração hidrotermal que afeta o Maciço Granítico Santa Bárbara. A análise das amostras desses testemunhos tem como objetivo a construção de um perfil litogeoquímico vertical integrado que elucide a entrada e saída de elementos propiciada pelo evento mineralizante, bem como cálculos de balanço de massa.

Os procedimentos foram executados no Laboratório de Tratamento de Amostras (LTA) do Departamento de Mineralogia e Geotectônica (GMG) do Instituto de Geociências da Universidade de São Paulo.

Na etapa de britagetn, as amostras de afloramentos, com pesos da ordem de 3,5 a $8 \mathrm{Kg}$, passaram pelo britador de mandíbulas 2 vezes. Foram então passadas em peneira com 8 \# de malha, e a porção retida na peneira foi cominuída em prensa hidráulica até tornar-se $100 \%$ passante. A seguir, foram homogeneizadas 50 vezes em membrana plástica e quarteadas até $1 / 8$ do seu volume $(1 / 16$ no caso da amostra de $8 \mathrm{Kg})$, repetindo-se a homogeneização antes de cada quarteamento. Já as amostras de testemunhos de sondagem foram britadas diretamente na prensa hidtáulica, por apresentarem volume bem menor e porque o procedimento diminui significativamente a possibilidade de contaminação.

A moagem das 24 amostras para a granulação $\leq 0,105 \mathrm{~mm}$ (150\#, Tyler) foi efetuada em moinho de ágata. 


\section{b) Abertura e análise química das amostras}

Subseqüentemente, as aliquotas das amostras foram enviadas ao Activation Laboratories Ltd., no Canadá, que efetuou as análises químicas conforme procedimentos em totina.

\section{c) Tratamento dos dados}

O tratamento dos dados e construção de diagramas foram executados com auxílio dos programas Minpet (Richard 1988-1995) e Excel for Windows, da Microsoft.

\subsubsection{Química Mineral}

As análises de minerais com Microssonda Eletrônica foram executadas no Laboratório de Microssonda Eletrônica do Instituto de Geociências da Universidade de São Paulo em duas etapas. Grosso modo, a primeira etapa contemplou basicamente o estudo de micas (66 pontos) e feldspatos (97 pontos) das fácies magmáticas e metassomático-hidrotermais do Maciço Granítico Santa Bárbara. A última etapa privilegiou o estudo da cassiterita (27 pontos) e da monazita (2 pontos). $O$ equipamento utilizado foi o Superprobe JXA-8600, da marca JEOL.

Para as micas e feldspatos empregou-se voltagem de $15 \mathrm{kV}$, corrente do feixe de $20,1 \mathrm{nA} \mathrm{c}$ diâmetro do feixe de $10 \mu \mathrm{m}$. Para a cassiterita, a voltagem foi de $20 \mathrm{kV}$ e o diâmetro do feixe de 5 $\mu \mathrm{m}$, mantida a mesto corrente de feixe. As análises de monazita diferiram daquelas da cassiterita unicamente pela corrente de feixe empregada, que foi de $50,1 \mathrm{nA}$. As correções necessárias foram efetuadas pelo programa PROZA.

\subsubsection{Determinação do Conteúdo de Lítio em Rochas e Micas}

Para a determinação dos conteúdos de lítio selecionaram-se 17 das 24 amostras submetidas às análises litogeoquímicas no Actlabs e 11 concentrados de micas. As primeiras já estavam devidamente cominuídas a $\leq 0,105 \mathrm{~mm}$, enquanto que os concentrados de micas necessitaram do uso de almofariz e pistilo de ágata para diminuição da granulação ao tamanho silte. A massa de material submetido foi de $500 \mathrm{mg}$.

O procedimento foi executado no Laboratório de Química e ICP-AES do Instituto de Geociências da Universidade de São Paulo.

A abertura das amostras foi feita via ataque ácido, com emprego de $\mathrm{HF} 48 \%, \mathrm{HNO}_{3} 65 \% \mathrm{e}$ 
$\mathrm{HCl} 37 \%$, a quente (aquecimento em forno de microondas por 1 hora e quarenta e cinco minutos). Seguiu-se, então, a eliminação do $\mathrm{HF}$ a quente $\left(100-110^{\circ} \mathrm{C}\right)$, por evaporação, a adição de $\mathrm{HNO}_{3}$ l:1 c de $\mathrm{HCl} 1: 1$, e a diluição da amostra até o volume final de $100 \mathrm{~mL}$.

Estas soluções, juntamente com aquelas oriundas da preparação dos materiais de referência (MA-N e YG-1) e os brancos, tiveram seus teores de lítio aferidos no Espectrômetro de Emissão Atômica com Plasma Induzido Acoplado (ICP-AES), modelo 3410, da Applied Research Laboratories (ARL). As micas foram analisadas com Nebulizador tipo Meinhard, enquanto que as amostras de rocha foram analisadas com Nebulizador Ultrassônico da CETAC, modelo U5000AT:

Treze amostras apresentaram resíduo branco insolúvel (provavelmente zircão) após o ataque ácido em microondas. Foram, então, filtradas e submetidas a microfusão com tetraborato de sódio. Seus teores de lítio foram somados ao valores aferidos nas soluções provenientes do ataque ácido.

\subsubsection{Geocronologia}

a) $\mathrm{U}-\mathrm{Pb}$

\section{$\checkmark$ Sepatação minetal}

Efetuou-se a separação de zircão no Laboratório de Preparação de Amostras Geológicas e Pedológicas (LAPEGE) do Instituto de Geociências e Ciências Exatas da Universidade Estadual Paulista, Campus Rio Claro. Utilizaram-se três amostras, uma de cada fácies magmática do Maciço Santa Bárbara.

No LAPEGE, as amostras sofreram cominuição em dois britadores. A seguir, foram peneiradas em peneirador elétrico por 30 minutos, utilizando-se três peneiras com malhas no intervalo de 80 a 270\#, e então submetidas à separação gravimétrica em bateador mecânico. Procedeu-se, então, à separação dos minerais fortemente magnéticos com auxílio de ímã, seguida da separação dos minerais patramagnéticos attavés do Separador Isodinâmico de Frantz, inicialmente com 0,5 ampète de corrente elétrica, $8^{\circ}$ de inclinação lateral e $20^{\circ}$ de inclinação frontal. Haja vista constatat-se a presença de zircão na fração magnética, a mesma foi repassada no Frantz, desta vez com 1,5 ampère de corrente. O material retido no aparelho foi descartado, enquanto que as frações magnética e não-magnética resultantes foram reunidas com a não-magnética da primeira passada. Finalmente, procedeu-se à separação dos minerais leves e pesados (fração concentradota de zitcão), com o uso de bromofómio $\left(\mathrm{d}=2,8899 \mathrm{~g} / \mathrm{cm}^{3}\right)$. Aquelas amostras que apresentaram percentual significativo de impurezas foram ainda classificadas granulometricamente com um conjunto de 
quatro minipeneiras com 100, 115, 150 e 200\# de malha, tendo o zircão concentrado-se preferencialmente da fração mais fina (200\#).

A conclusão da separação dos minerais para datação U-Pb teve lugar nas dependências do Centro de Pesquisas Geocronológicas (CPGeo) do Instituto de Geociências da Universidade de São Paulo. Constou de uma etapa adicional de separação gravimétrica com líquidos densos, tendo-se utilizado desta vez o iodeto de metileno $\left(\mathrm{d}=3,325 \mathrm{~g} / \mathrm{cm}^{3}\right)$, com o objetivo primordial de eliminar o topázio presente nas amostras. Esse mineral, entretanto, apresenta um intervalo de densidades extenso $\left(d=3,174\right.$ a $\left.3,500 \mathrm{~g} / \mathrm{cm}^{3}\right)$ em função da substituição $\mathrm{OH} \Rightarrow \mathrm{F}$, e que abrange valores tanto maiores quanto menores que a densidade do iodeto de metileno. Lamentavelmente, grande parte do topázio incorporou a fração pesada, que contém também zircão, monazita, cassiterita, xenotima e, ocasionalmente, anatásio.

Os concentrados de minerais pesados foram então acondicionados em savillex de teflon com $\mathrm{HNO}_{3}$ concentrado e aquecidos a uma temperatura de $60-70^{\circ} \mathrm{C}$ durante 4 horas, visando à eliminação de incrustações e superfícies oxidadas. Após este período, foram lavados abundantemente com $\mathrm{H}_{2} \mathrm{O}$ Milli-Q em filtto de papel e secos sob lâmpada incandescente.

A separação dos concentrados em alíquotas foi feita em Separador Isodinâmico de Frantz e compreendeu uma purificação inicial para separação de xenotima e monazita conforme Hutchinson (1974, pg. 119), em que foram empregados $15^{\circ}$ de inclinação frontal, $25^{\circ}$ de inclinação lateral e 1,0 ampère de corrente elétrica. $O$ zircão incorpora a fração não-magnética resultante desse procedimento, enquanto que a xenotima e a monazita concentram-se na fração magnética. Volume significativo de material foi retido na fração magnética da amostra AM-52B (fácies Serra do Cícero), ao passo que na amostra AM-53B a quantidade de material retido foi muito pequena, indicando a pouca abundância desses minerais na fácies Serra Azul.

A separação final dos concentrados seguiu o método de Krogh (1982a), e constou de passagens sucessivas da fração não-magnética do procedimento descrito anteriormente e das frações não magnéticas geradas a cada uma das passagens sucessivas no Separador Isodinâmico de Frantz, regulado com inclinação frontal e corrente elétrica constantes de $20^{\circ}$ e 1,5 ampère, respectivamente, e inclinações laterais progressivamente decrescentes de $10,6,4,3,2,1,0,-1,-2,-3,-4$ e $-5^{\circ}$, até não restar mais material na fração não-magnética. As amostras AM-53B e AM-145 foram submetidas a split até a inclinação lateral -5 , enquanto que a amostra $A M-52 B$ atingiu apenas a inclinação -3 . De modo geral, volume significativo das amostras ficou retido na fração $M(10)$ (magnética da passada com $10^{\circ}$ de inclinação lateral), e as frações $M(-4)$ e $M(-5)$ concentratam predominantemente o 
topázio, sendo muito pobres em zircão.

A preparação final das amostras compreendeu a seleção dos melhores cristais sob lupa binocular. Em todas as amostras foram identificados dois tipos principais de zircão: um predominantemente translúcido, incolor, cinza, amarelo ou amarelo-alaranjado, freqüentemente muito turvo e com faces rugosas, com superficies de crescimento distintas quando límpido, sem inclusòes fluidas ou sólidas e com raras fraturas, euédrico e com arestas vivas, pertencente aos tipos D e P de Pupin (1980); e outro límpido e transparente, incolor até amarelo, com abundantes inclusões fluidas e raras fraturas, euédrico com faces lisas e arestas vivas, predominantemente do tipo D de Pupin (1980).

O primeiro tipo de zircão predomina largamente na fácies Serta Azul (AM-53B), enquanto o segundo compreende a maior parte dos cristais na fácies Serra do Cícero (AM-52B). O tipo predominante em cada uma das fácies foi utilizado para datação.

Para a fácies Serra Azul selecionaram-se cristais das fraçôes $M(6), M(4)$ e as composições $M(1)+M(0) B+M(-1)$ e $M(0) A+M(-2)+M(-3)$, compreendendo alíquotas com massas variáveis de cerca de 70 até $110 \mu \mathrm{g}$. A fração $\mathrm{M}(6)$ foi submetida à abrasão, conforme Krogh (1982b).

Concentrados de zircão das frações $M(-1), M(-2), M(-3)$ e $N M(-3)$, com massas de 60 a 120 $\mu \mathrm{g}$, foram escolhidos para a datação U-Pb da fácies Serra do Cícero.

A fácies Santa Bárbara (AM-145) possui pouco zircão, provavelmente em conseqüência de sua substituição por torita, descrita a posteriori. Dentre os cristais presentes, é mais abundante o zircão do primeiro tipo, porém exemplares de ambos os tipos foram selecionados e encaminhados para datação U..Pb pelo método SHRIMP.

Adicionalmente, selecionou-se monazita das três fácies, constituindo alíquotas de 10 a $30 \mu \mathrm{g}$.

\section{$\checkmark$ Abertuta das Amostras}

As análises U-Pb em zircão por espectrometria de massa por ionização térmica (TIMS) foram executadas no CPGeo, conforme os procedimentos descritos em Krogh (1973) e Corfu e Stott (1986), que estão sintetizados em Basei et al. (1995).

$O$ ataque do zircão é feito com 0,5 $\mathrm{mL}$ de ácido fluorídrico concentrado, em bombas de teflon ${ }^{\circledR}$ mantidas em jaquetas de aço a $180^{\circ} \mathrm{C}$ por oito dias. Após esse período, o ácido é evaporado e adiciona-se $0,5 \mathrm{~mL}$ de $\mathrm{HCl} 6 \mathrm{~N}$ sobre o resíduo, que retorna ao forno, a temperatura de $180^{\circ} \mathrm{C}$, por mais uma noite. No caso da monazita, o ataque é feito em bombas Savilex ${ }^{(}$, sobre chapas 
aquecedoras $\left(100\right.$ a $\left.120^{\circ} \mathrm{C}\right)$, por 5 dias.

A solução resultante é dividida nas alíquotas para análise por diluição isotópica (DI; determinação dos conteúdos de chumbo e de urânio) e de medição da composição isotópica do chumbo (CI).

A separação do $\mathrm{Pb}$ e do U é feita em colunas de troca iônica, pela passagem da solução cloridrica através da resina AG-1-X-8 (200-400 mesh), utilizando-se $\mathrm{HCl} 6 \mathrm{~N}, 3 \mathrm{~N}$ e $1 \mathrm{~N}$ como reagentes, $\mathrm{HCl} 1 \mathrm{~N}$ para a coleta do chumbo e $\mathrm{H}_{2} \mathrm{O}$ para a coleta do urânio.

Ao concentrado final da amostra são adicionados uma gota de $\mathrm{H}_{3} \mathrm{PO}_{4}$ e $2 \mu \mathrm{I}$. de $\mathrm{SiO}_{3}$ (sílica gel). A solução é, então depositada sobre filamento simples de rênio e encaminhada ao espectrômetro de massa.

\section{$\checkmark$ Espectromettia de Massa por Ionização Térmica e Cálculo das Idades}

A determinação das composições isotópicas foi feita em espectrômetro de massa de fonte sólida do tipo Finnigan MAT 262.

Os resultados finais das análises foram calculados e plotados com auxílio do programa ISOPLOT/Ex, versão 2.10, de Ludwig (1999), observando-se as constantes recomendadas pela IUGS (Stciger e Jäger 1977).

\section{$\checkmark$ Análises por SHRIMP-RG}

As datações U-Pb em zircão da amostra AM-145, fácies Santa Bárbara, pelo método SHRIMP-RG, foram executadas no Stanford USGS Mirro Analysis Center (SUMAC), na Universidade de Stanford, Califórnia, por Jorge Silva Bettencourt, Richard M. Tosdal e Joseph Wooden.

Os cristais de zircão selecionados foram montados em fatias circulares de epóxi com 2,54 centímetros de diâmetro e 6 milímetros de espessura, dispostos ao longo de até seis fileiras de 1 centímetro juntamente com os padrões. Essas fatias foram polidas em ambas as faces e cobertas com $10 \mathrm{~nm}$ de ouro naquela onde é feita a leitura. Imagens de catodoluminescência em equipamento JEOL 5600LV SEM foram tomadas para a caracterização dos cristais e escolha dos pontos para análises, bem como observações ao microscópio petrográfico em luz transmitida e refletida.

O equipamento utilizado foi o SHRIMP-RG (Sensitive High Resolution Ion Micro Probe - Reverse Geometry) e os procedimentos seguiram os mesmos preconizados em Compston et al. (1984) e Williams (1997). 


\section{b) $\mathrm{Sm}-\mathrm{Nd}$}

As análises Sm-Nd em rocha total para obtenção das idades $\mathrm{T}_{\mathrm{DM}}^{\prime} \mathrm{e}$ do $\xi_{\mathrm{Nd}}(\mathrm{T})$ foram efetuadas no Laboratório de Geocronologia do Instituto de Geociências da Universidade de Brasília, segundo os procedimentos descritos em Gioia e Pimentel (2000). O material utilizado foram os mesmos pós de rocha preparados para análises litogeoquímicas.

\section{$\checkmark$ Espectrometria de Massa e Cálculo das Idades}

As razões isotópicas foram medidas em espectrômetro de massa Finnigan MAT' $262 \mathrm{com}$ multicoletor. O cálculo das idades foi efetuado conforme o modelo do Manto Empobrecido de DePaolo (1981).

Demais detalhes a respeito dos métodos empregados na geocronologia podetn ser consultados no Capítulo VIII.

\subsubsection{Petrografia e microtermometria de inclusôes fluidas}

Esse estudo foi efetuado no Laboratório de Inclusões Fluidas do Departamento de Mineralogia e Geotectônica do Instituto de Geociências, Universidade de São Paulo, sob a supervisão da Di.3. Rosa Maria da Silveira Bello, conforme as técnicas descritas em Roedder (1962, 1963).

Utilizaram-se nove seções delgadas polidas em ambas as faces de oito litotipos magmáticos e hidrotermais. A petrografia das inclusões e a obtenção das medidas microtermométricas foi realizada em quartzo e topázio, em microscópio Leitz, com objetivas de 50 e 80x, ao qual está acoplada uma platina de resfriamento/aquecimento marca Chaixmeca, modelo MTM 85, conectada a uma unidade controladora de temperatura e a um sistema de circulação de $\mathrm{N}_{2}$ líquido. O intervalo térmico abrangido pelas medidas efetuadas nesse tipo de sistema é dos -180 aos $600^{\circ} \mathrm{C}$. A taxa de aquecimento nos intervalos térmicos de interesse foi de cerca de $1^{\circ} \mathrm{C} / \mathrm{min}$. A reprodutibilidade das medidas no ciclo de aquecimento é de $0,2^{\circ} \mathrm{C}$.

A calibração do ponto triplo do $\mathrm{CO}_{2}\left(-56,6^{\circ} \mathrm{C}\right)$ foi feita com amostra natural proveniente de Calanda, Suíça, enquanto que água deionizada fó utilizada para o ponto triplo da $\mathrm{H}_{2} \mathrm{O}$. Para as temperaturas no intervalo de 100 a $398^{\circ} \mathrm{C}$, utilizaram-se os padrões MSP (Merck Schmelzkörper Product) $\mathrm{n}^{\text {os }} 9700,9735,9780,9800$ e 9847 , bem como o $\mathrm{KNO}_{3}$ e o $\mathrm{K}_{2} \mathrm{Cr}_{2} \mathrm{O}_{7}$ (Merck 4864).

Os cálculos dos parâmetros de salinidade, densidade, pressão e ponto crítico dos sistemas, 
bem como de concentração dos solutos, foram executados no programa FLINCOR (Brown 1989), com as equações de estado de Brown \& Lamb (1989).

O estudo de espectrometria Raman foi efetuado no Laboratório de Ótica do Departamento de Física, Instituto de Ciências Exatas, da Universidade Federal de Minas Gerais pelo Dr. Kazuo Fuzikawa, do Laboratório de Inclusões Fluidas e Metalogênese, Serviço de Física Aplicada e T'écnicas Especiais, do Centro de Desenvolvimento da Tecnologia Nuclear (CDTN), em Belo Horizonte, conjuntamente com a autora desta tese.

O equipamento utilizado foi o Triplo-espectrômetro micro-Raman DILOR XY, acoplado a microscópio Olympus com detector CCD refrigerado por $\mathrm{N}_{2}$ líquido. O laser é de Ar-Kr. modelo Coherent Innova - 70. Empregou-se a raia verde do laser (Ar), potência média de $350 \mathrm{mw}$ e 10 acumulações com contagens de $10 \mathrm{~s}$.

\subsubsection{Geoquímica Isotópica de Oxigênio e Hidrogênio}

\section{a) Separação de minerais}

Para análises de isótopos estáveis em minerais foram separados quartzo, feldspato potássico, mica, cassiterita e topázio segundo procedimentos específicos para cada um desses minerais. Análise em rocha total foi efetuada em dois litotipos magmáticos bem como em material proveniente de vênula, composto em mais de $95 \%$ por caulinita e halloysita, que não sofreu nenhum tratatnento prévio.

O material de partida foram os excedentes do quarteamento das rochas preparadas para análises litogeoquímicas, que foram peneirados. O intervalo utilizado para a separação minetal foi definido primordialmente em função da fase de interesse: 14 a 60 no caso daquele destinado à obtenção de quartzo e cassiterita, e $60 \#$ a $100 \#$ quando a pretensão era a separação de mica. Como o feldspato de interesse era o potássico cristalizado na forma de megacristais, foi extraído principalmente das amostras de rocha, utilizando-se para tanto brocas odontológicas.

Com exceção das micas, procedeu-se à catação manual de cristais e de fragmentos desses com auxílio de lupa binocular para a geração de concentrados puros de minerais. Mesmo os fragmentos de feldspato separados das rochas por meio das brocas foram observados com a lupa, na tentativa de eliminar aqueles ricos em inclusões.

As micas sofreram tratamento diverso, pois sua separação é muito eficiente quando efetuada com o Separador Isodinâmico de Frantz. Primeiramente, uma inclinação lateral de $15^{\circ}$ e uma 
inclinação frontal de $20^{\circ}$, aliadas à corrente elétrica de $0,5 \mathrm{~A}$, proporcionaram a separação delas dos demais minerais presentes na rocha. As outras passadas (duas ou três) foram efetuadas com corrente significativamente menor $(0,3$ ou $0,25 \mathrm{~A}$, dependendo do tipo de mica), o que permitiu a exclusão de agregados da fase com outros silicatos para a fração não-magnética, gerando concentrados com alto grau de pureza.

Nesta fase, procurou-se a obtenção de concentrados com massa mínima de 100 mg para análises de $\delta^{18} \mathrm{O}$ (quartzo, cassiterita, topázio e mica; no caso do feldspato, pelo menos $200 \mathrm{mg}$ ), e de $500 \mathrm{mg}$ para análises de $\delta \mathrm{D}$ (mica e topázio; no caso do feldspato, pelo menos $300 \mathrm{mg}$ ).

O procedimento final da separação foi a limpeza dos concentrados. Como alguns dos tipos de mica foram supostamente cristalizados a temperaturas relativamente baixas (da ordem de 250 a $300^{\circ} \mathrm{C}$ ), preferiu-se limpá-las unicamente com água destilada em um banho de ultra-som por vinte minutos, após os quais foram abundantemente lavadas com água destilada em funis forrados com papel filtro e secas sob lâmpada incandescente.

$\mathrm{O}$ quartzo e a cassiterita foram lavados com $\mathrm{H}_{2} \mathrm{SO}_{4} 50 \%$, a quente, até a eliminação de películas de óxido de ferro sobre os cristais, bem como minimização do volume de eventuais e raríssimas incrustações de feldspatos e micas. O feldspato potássico e o topázio não necessitatam limpeza.

\section{b) Análises isotópicas por criogenia e laser fluorination}

As análises de isótopos estáveis foram efetuadas no Isotope Geosciences Unit do Scottish Universities Environmental Research Centre (SUERC), em East Kilbride, Escócia, e também no Geochron Laboratorier, em Cambridge, Estados Unidos da América.

\section{$\checkmark$ Oxigênio}

A análise de isótopos de oxigênio em silicatos por laser fluorination, conforme realizada no SUERC, está descrita em Macaulay et al. (2000).

Resumidamente, compreende a utilização de alíquota de cerca $1,0 \mathrm{mg}$ de rocha pulverizada ou de cristais, que é acondicionada em platina motorizada, operada remotamente, no interior de câmara de policarbonato dotada de sistema de vídeo-câmera e monitor de televisão acoplado. A amostra é então aquecida com laser de $\mathrm{CO}_{2}(\lambda=10640 \mathrm{~nm})$ na presença do gás clorotrifluoreto $\left(\mathrm{CIF}_{3}\right)$, para liberação do oxigênio. $\mathrm{O}$ oxigênio é convertido $\mathrm{em} \mathrm{CO}_{2}$ por meio de reação com um pequeno cilindro de carbono aquecido (degaseificado). $\mathrm{O}_{2} \mathrm{O}_{2}$ é coletado com nitrogênio líquido 
$\left(\mathrm{T}=-196^{\circ} \mathrm{C}\right)$ e transferido online para o espectrômetro de massa VG PRISM III, onde a razão ${ }^{18} \mathrm{O} /{ }^{16} \mathrm{O}$ é medida. A precisão analítica é de $\pm 0,2 \%$.

\section{$\checkmark \quad$ Hidrogênio}

A análise de isótopos de hidrogênio em minerais no SUERC é feita a partir de alíquotas de cerca de $40 \mathrm{mg}$ de amostra, previamente aquecidas a $120^{\circ} \mathrm{C}$ por uma noite para remoção de voláteis adsorvidos (ff. Fallick et al. 1993). As alíquotas são então aquecidas por indução até $1400^{\circ} \mathrm{C}$ para desidroxilação. O vapor de água e o $\mathrm{CO}_{2}$ são coletados e posteriormente separados criogenicamente, ficando retido o primeiro, que é reduzido a $\mathrm{H}_{2} \mathrm{em}$ forno de cromo a $830^{\circ} \mathrm{C}$ ( $c f$. Donnnelly et al. 2001). $\mathrm{O} \mathrm{H}_{2}$ é coletado e transferido para o espectrômetro de massa VG Optima, da Micromass. A precisão analítica é $\leq 0,5 \%$.

As análises isotópicas iniciais dos gases liberados das micas por este procedimento resultaram valores de $\delta \mathrm{D}$ inesperados, tanto altos quanto baixos, além de baixa precisão interna durante as análises. As altas razões entre a pressão de gás da amostra e a pressão do gás de referência no espectrômetro para o pico de intensidade relativo à razão massa/carga igual a 2 sugeritam a presença de outros gases juntamente com $\mathrm{H}_{2}$. Tais gases foram interpretados como produtos de reação química do flúor presente nas micas, que não foram completamente separados do hidrogênio pelo método criogênico tradicional. Alternativamente, procedeu-se ao congelamento desses gases com nitrogênio líquido no tubo de amostra, previamente à liberação do seu conteúdo para análise no espectrômetro. Obtiveram-se, assim, pressões de gás idênticas para amostra e referência, e precisão interna aceitável. A reprodutibilidade dos dados foi de 6 ou menos $(1 \sigma)$ para 5 de 7 amostras.

\section{c) Equações de fracionamento empregadas}

Os dados isotópicos de oxigênio e de hidrogênio são apresentados em permil como valores de $\delta^{18} \mathrm{O}$ e de $\delta \mathrm{D}$, respectivamente, onde

$\delta=(($ razão isotópica da amostra/ razão isotópica do padrão $)-1$ - $) \times 1000$.

As razões isotópicas exibem o isótopo mais pesado no numerador e o mais leve no denominador. O padrão adotado na presente pesquisa é o V-SMOW (Vienna Standard Mean Ocean Water).

Duas fases A e B em equilíbrio isotópico têm suas composições isotópicas governadas por um fator de fracionamento, expresso pela letra $\alpha$ :

$$
\alpha_{A B}=\text { razão isotópica de } A / \text { razão isotópica de } B \text {. }
$$


Como o ln $(1+x) \cong x$, se $x<<1$, pode-se utilizar a relação aproximada

$1000 \ln \alpha \cong \delta_{\Lambda}-\delta_{B}$, ou $\Delta_{\mathrm{A}-\mathrm{B}}$,

onde $1000 \ln \alpha$ é proporcional a $1 / \mathrm{T}^{2}$ e $1 / \mathrm{T}$ a altas e baixas temperaturas, respectivamente (Urey 1947, Bigeleisen e Mayer 1947), e assume a forma de uma equação de segundo grau do tipo

$1000 \ln \alpha=\mathrm{A} \times 10^{6} / \mathrm{T}^{2}+\mathrm{B} \times 10^{3} / \mathrm{T}+\mathrm{C}$.

As equações de fracionamento isotópico empregadas para o cálculo de temperaturas e de composiçào isotópica de fases estão listadas nas Tabelas II.2 e II.3.

Tabela II.2. Equações de fracionamento isotópico de oxigênio empregadas neste estudo.

\begin{tabular}{l|c|c|c|c|c}
\hline Par Isotópico & Temperatura $\left({ }^{\circ} \mathrm{C}\right)$ & $A$ & $B$ & $C$ & Referência \\
\hline quartzo-felds. alc. & $0-1200$ & 0,16 & 1,50 & $-0,62$ & Zheng (1993a) \\
\hline \multirow{2}{*}{ quartzo- $\mathrm{H}_{2} \mathrm{O}$} & $250-500$ & 3,34 & 0 & $-3,31$ & Matsuhisa et al. (1979) \\
\cline { 2 - 6 } & $500-800$ & 2,05 & 0 & $-1,14$ & \\
\hline quartzo- $\mathrm{H}_{2} \mathrm{O}$ & $500-800$ & 4,10 & 0 & $-3,70$ & Bottinga e Javoy (1973) \\
\hline felds. alc. $\mathrm{H}_{2} \mathrm{O}$ & $350-800$ & 2,91 & 0 & $-3,41$ & O'Neil e Taylor (1967) \\
\hline felds. alc. $-\mathrm{H}_{2} \mathrm{O}$ & $500-800$ & 3,13 & 0 & $-3,70$ & Bottinga e Javoy (1973) \\
\hline felds. alc.- $\mathrm{H}_{2} \mathrm{O}$ & $0-1200$ & 4,32 & $-6,27$ & 2,00 & Zheng (1993a) \\
\hline biotita- $\mathrm{H}_{2} \mathrm{O}$ & $0-1200$ & 3,84 & $-8,76$ & 2,46 & Zheng (1993b) \\
\hline quartzo-topázio & $0-1200$ & 0,30 & 2,41 & $-1,00$ & Zheng (1993b) \\
\hline topázio- $\mathrm{H}_{2} \mathrm{O}$ & $0-1200$ & 4,18 & $-7,18$ & 2,17 & Zheng (1993b) \\
\hline quartzo-cassiterita & $400-500$ & $-6,87$ & 26,29 & $-15,49$ & Zhang et al. (1994) \\
\hline cassiterita- $\mathrm{H}_{2} \mathrm{O}$ & $250-370$ & 10,13 & $-26,09$ & 12,58 & Zhang et al. (1994) \\
\hline caulinita- $\mathrm{H}_{2} \mathrm{O}$ & $0-350$ & 2,76 & 0 & $-6,75$ & Sheppard e Gilg (1996) \\
\hline muscovita- $\mathrm{H}_{2} \mathrm{O}$ & $0-1200$ & 4,10 & $-7,61$ & 2,25 & Zheng (1993b) \\
\hline
\end{tabular}

Tabela II.3. Equações de fracionamento isotópico de hidrogênio empregadas neste estudo.

\begin{tabular}{l|c|c|c|c|c}
\hline Par Isotópico & Temp. $\left({ }^{\circ} \mathrm{C}\right)$ & $\boldsymbol{A}$ & $\boldsymbol{B}$ & $\boldsymbol{C}$ & Referência \\
\hline mica- $\mathrm{H}_{2} \mathrm{O}$ & $400-850$ & $-22,4$ & 0 & $\begin{array}{c}26,3+\left(2 \mathrm{X}_{\mathrm{Al}}-4 \mathrm{X}_{\mathrm{Mg}^{-}-68 \mathrm{X}_{\mathrm{Fe} \mathrm{H}^{-}}}\right. \\
30,1 \mathrm{X}_{\left.\mathrm{Fe} 3+^{-}-4,4 \mathrm{X}_{\mathrm{Ti}}\right)}\end{array}$ & Jenkin (1988) \\
\hline caulinita- $\mathrm{H}_{2} \mathrm{O}$ & $0-330$ & $-2,20$ & 0 & $-7,70$ & $\begin{array}{c}\text { Gilg e Sheppard } \\
(1979)\end{array}$ \\
\hline
\end{tabular}

onde " $X$ " é a fração molar dos cátions no sítio octaédrico. 


\section{GEOLOGIA REGIONAL}

\subsection{Introdução}

A evolução geológica do Cráton Amazônico (Almeida 1974, 1978) remonta ao Arqueano, tendo-se estabelecido condições de plataforma estável no Neoproterozóico. Alguns dos modelos evolutivos, de concepção fixista, consideram o cráton como uma vasta plataforma arqueana/ paleoproterozóica sucessivamente retrabalhada e reativada durante o Mesoproterozóico e o Neoproterozóico (Almeida 1974, 1978; Amatal 1974, 1984; Issler 1977; Santos 1984; Santos \& Loguércio 1984; Hasui et al. 1984; Hasui e Almeida 1985; Montalvão \& Bezerra 1985; Jones 1985; Costa \& Hasui 1991, 1997). Outros modelos, de concepção mobilista, admitem evolução do cráton via acréscimos episódicos de material juvenil a um núcleo continental antigo durante o Proterozóico, bem como retrabalhamento de crosta continental (Cordani et al. 1979; Cordani \& Brito Neves 1982; Gibbs \& Barron 1983; Gaudette \& Olszewski 1985; I.itherland ot al. 1986, 1989; Teixeira et al. 1989; Tassinari 1996; Tassinari et al. 1996, 2000; Sato \& Tassinari 1997; Scandolara et al. 1998; Tassinari \& Macambira 1999; Santos et al. 1999, 2000; Scandolara 1999; Amorim \& Scandolara 1999; Scandolara \& Amorim 1999; Geraldes et al. 2001).

Na margem sudoeste do Cráton Amazônico, onde está inserida a área de estudo, as idades Rb-Sr e K-Ar inicialmente obtidas permitiram identificar os eventos Paraense $(1,70$ a 1,55 Ga), Madeirense $(1,40$ a 1,25 Ga) e Rondoniense (1,05 a 0,90 Ga) (Amatal 1974), e Parguazense (1,60 a 1,50 Ga; Bellizzia 1972), no caso dos modelos fixistas.

Segundo os modelos mobilistas, essas mesmas idades indicam migtação dos regimes tectônicos de NE para SW e definem um zoneamento regional em províncias geocronológicas de direção NW-SE, denominadas Rio Negro-Juruena (1,80 a 1,55 Ga), Rondoniana-San Ignacio (1,50 a 1,30 Ga) e Sunsás (1,25 a 1,00 Ga) (Cordani et al. 1979; Litherland et al. 1986; Teixeira \& Tassinari 1984; Teixeira et al. 1989; Tassinari 1996; Tassinari et al. 1996; Tassinari \& Macambira 1999), ou províncias Rondônia-Juruena (1,75 a 1,47 Ga) e Sunsás (1,25 a 0,99 Ga) segundo Santos at al. (1999a, b; 2000), conforme ilustrado na Figura 3.1. A proposta mobilista é adotada no presente estudo. 


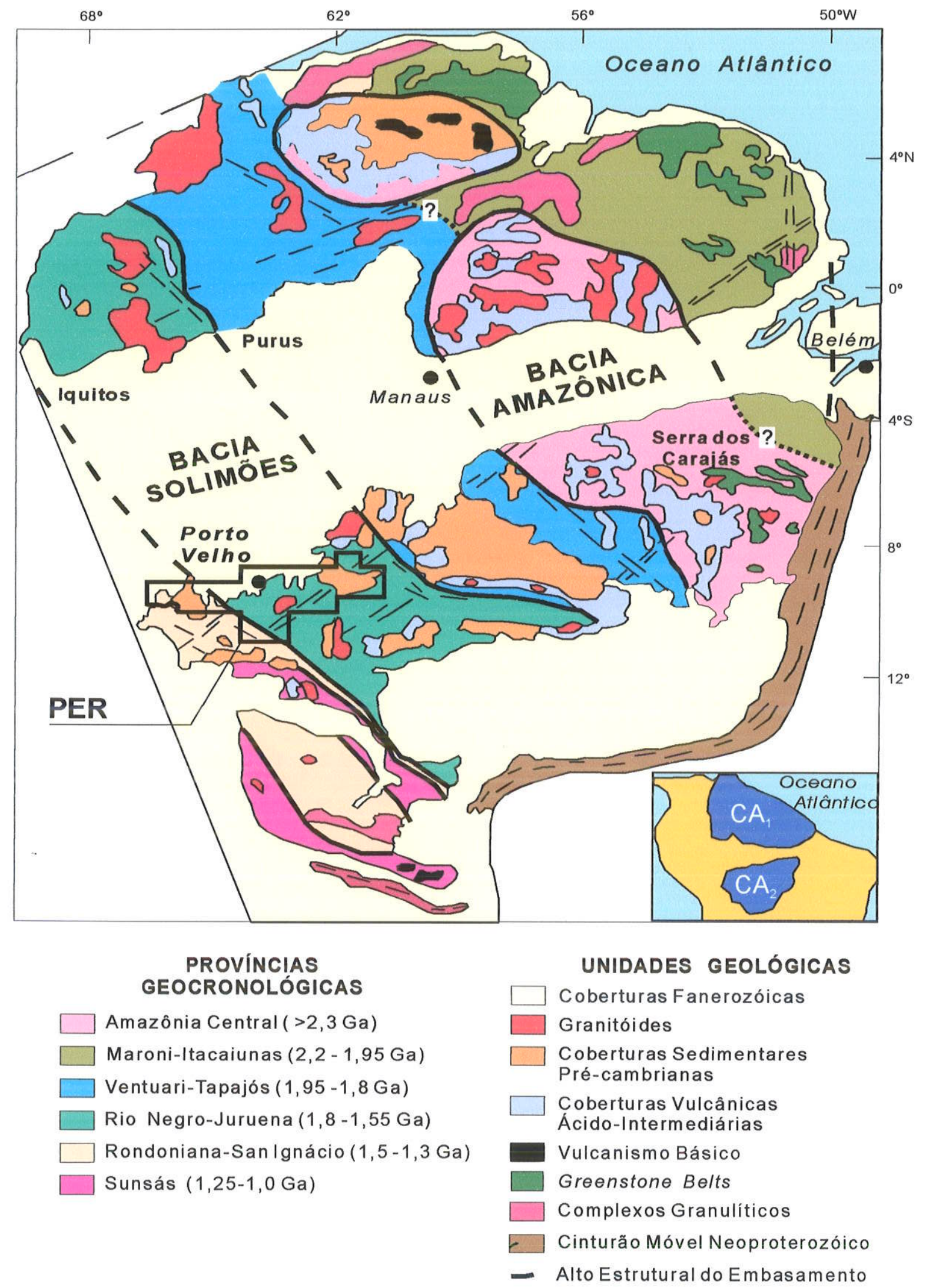

Figura 3.1 - Estruturação geocronológica do Cráton Amazônico mostrando a localização da Província Estanífera de Rondônia (PER). Adaptado de Tassinari (1996). Mapa interno: CA - Cráton Amazônico ( $\mathrm{Ca}_{1}$ - Escudo da Guiana, $\mathrm{Ca}_{2}$-Escudo do Brasil Central (Guaporé)). 


\subsection{A Margem Sudoeste do Cráton Amazônico}

A região sudoeste do Cráton Amazônico é considerada um multi-orógeno em que magmatismo, metamorfismo e deformação sucessivos ocorretam no intervalo entre 1,8 e $1,0 \mathrm{Ga}$. Abrange as províncias geocronológicas Rio Negro-Juruena, Rondoniana-San Ignacio e Sunsás, com limites de idade redefinidos e compartimentadas nas seguintes unidades (Tassinari et al. 2000; Bettencourt \& Geraldes, em preparação; Fìg. 3.2):

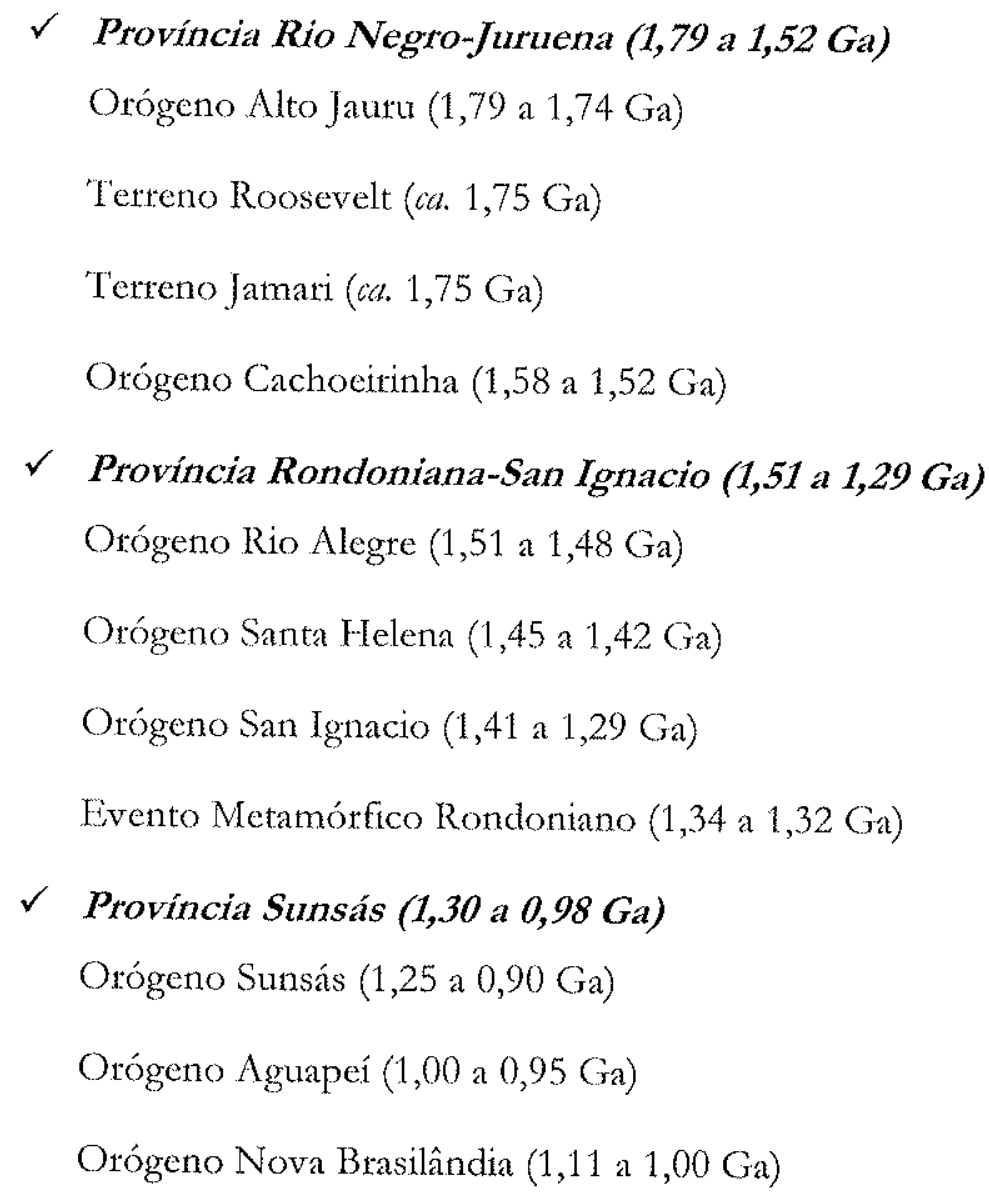

O Orógeno Alto Jauru (Van Schmus et al. 1999), previamente considerado um greenstone belt (Monteiro et al. 1986), localiza-se no Mato Grosso e compreende cinturões de rochas metavulcânicas e metassedimentares entremeados por tonalitos e intrudidos por doleritos e granitóides. Rochas metavulcânicas básicas, intermediárias e ácidas, xistos, metacherts e magnetititos granatíferos (BIF's), são descritos na unidade. Datações U-Pb em zircão no intervalo de 1,79 a 1,72 Ga, e idades Sm-Nd $\mathrm{T}_{\mathrm{DM}}$ de 1,93 a 1,78 Ga, com $\xi_{\mathrm{Nd}}$ de $+2,0$ a $+2,8$ (Ruiz 1992; Pinho 1996; Van Schmus et al. 1998; Geraldes et al. 1999, 2001; Geraldes 2000), levaram Geraldes ot al. (1999) a interpretar a unidade como uma possível extensão sudeste da Província Rio Negro-Juruena. 


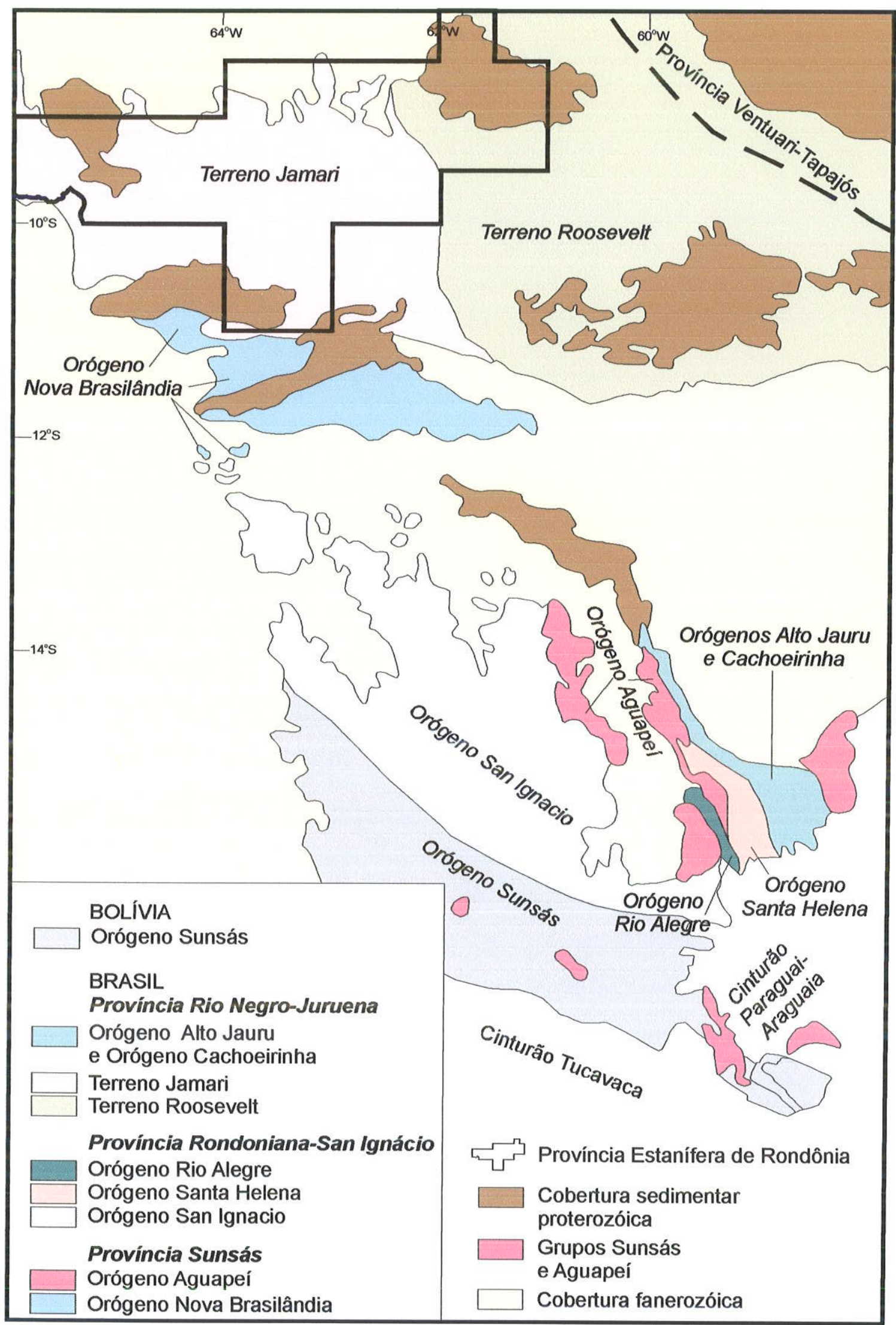

Figura 3.2 - Mapa tectônico do sudoeste do Cráton Amazônico. Adaptado de Litherland \& Bloomfield (1981), Litherland et al. (1986, 1989), Tassinari (1996), Tassinari \& Macambira (1999), Scandolara (1999a, 2001), Van Schmus et al. (1999), Rizzotto (2001a e b), Tassinari et al. (2000, 2001), Geraldes et al. (2001), Bettencourt \& Geraldes (em preparação). 
Na região norte de Rondônia, a Província Rio Negro-Juruena está representada pelos terrenos Jamari e Roosevelt (Fig. 3.2), definidos por Scandolara et al. (1999a, 2001). O Terreno Jamari ocupa a porção centro-norte e noroeste do estado, e inclui o Complexo Jamari (Isotta et al. 1978), as suítes intrusivas Rio Crespo (Payolla et al. 2001a e b, 2002), Santo Antônio, T'eotônio, Alto Candeias, São Lourenço-Caripunas, Santa Clara e Granitos Últimos de Rondônia (Payolla 1994; Bettencourt et al. 1997, 1999), além das formações Mutum-Paraná e Palmeiral (Lobato et al. 1966), descritos no item 3.3. Caracteriza-se pela superposição de cisalhamento tangencial com tensor compressivo $\mathrm{N} 50^{\circ} / 60^{\circ} \mathrm{E}$ sobre bandamento gnáissico relacionado a tensor compressivo $\mathrm{N} 10^{\circ} / 15^{\circ} \mathrm{E}$ (Scandolara et al. 2001).

O Terreno Roosevelt localiza-se no setor nordeste do estado, e consiste de megalentes e megaxenólitos do Complexo Jamari, além da Seqüência Metavulcano-sedimentar Roosevelt (Rizzotto ot al. 1995), de granitos rapakivi da Suíte Intrusiva Serra da Providência (Tassinari et al. 1984, Bettencourt et al. 1999), de rochas máficas da Suíte Básica-Ultrabásica Cacoal (Scandolata 1999b), bem como coberturas sedimentares indeformadas da Formação Palmeiral. A idade U-Pb SHRIMP para rochas metavulcânicas dacíticas é de 1,74 Ga (Santos et al. 1999a, b), enquanto que a idade $T_{D M}$ é de $1,70 \mathrm{Ga}$ (Sato \& Tassinari 1997).

Granitóides gerados em ambiente de arco magmático, intrusivos no Orógeno Alto Jauru, foram inclúdos no denominado Orógeno Cachoeirinha (Tassinari et al. 2000; Geraldes et al. 2001). Idades U-Pb em zircão limitam esse episódio tectônico ao período de 1,56 a 1,54 Ga. As idades Sm-Nd $T_{D M}$ situam-se no intervalo de 1,88 a $1,75 \mathrm{Ga}, \operatorname{com} \xi_{\mathrm{Nd}}$ variável entre $-0,8 \mathrm{e}+1,0$. Granitos $\mathrm{e}$ granodioritos anorogênicos da região foram datados em 1,48 a $1,39 \mathrm{Ga}$, com idades $T_{D M}$ de 1,77 a 1,74 Ga e $\xi_{N d}$ de $-1,3$ a $+1,7$. A unidade é considerada parte da Província Rio Negro-Juruena (Van Schmus et al. 1998; Geraldes et al. 1999; Geraldes 2000; Geraldes et al. 2001).

A leste do Orógeno Alto Jauru afloram tochas metaplutônicas máfico-ultramáficas, metavulcânicas básicas a intermediárias, BIF's, rochas metassedimentares químicas e clásticas, além de metacherts, incluídos na Seqüência Vulcano-sedimentar Rio Alegte (Matos 1992), elevada à categoria de Orógeno Rio Alegre por Tassinari et al. (2000). As idades U-Pb em zircão das metavulcânicas concentram-se no intervalo de 1,52 a 1,51 Ga, enquanto que as idades $\mathrm{T}_{\mathrm{DM}}$ variam de 1,54 a 1,48 Ga, com $\xi_{\mathrm{Nd}}$ entre $+4,3$ e $+4,7$. Rocha metabásica plutônica foi datada em 1,45 Ga, com idade $\mathrm{T}_{\mathrm{DM}}$ de $1,68 \mathrm{Ga}$ e $\xi_{\mathrm{Nd}}$ de $+2,5$. Tonalitos intrusivos na seqüência têm idades U-Pb em zircão entre 1,48 e 1,46 Ga, idades $\mathrm{T}_{\mathrm{DM}}$ variáveis de 1,53 a $1,50 \mathrm{Ga}$ e $\xi_{\mathrm{Nd}}$ entre $+3,8 \mathrm{e}+4,1$. O conjunto dos dados Sm-Nd aponta caráter juvenil para essas rochas (Matos et al. 2001, Geraldes et al. 2001). 
O Orógeno Santa Helena (Tassinari et al. 2000) compreende granitóides com assinatura geoquímica variável entre granitos do tipo $I$ e do tipo $A$ (Geraldes et al. 2001), primeiramente incluídos no Batólito Santa Helena (Saes et al. 1984). É limitado a leste pelos orógenos Alto Jauru e Cachocirinha, e a oeste pelos orógenos Rio Alegre e Aguapeí. Suas idades U-Pb em zircão variam de 1,45 a 1,42 Ga. Idades Sm-Nd $\mathrm{T}_{D M}$ situam-se no intervalo de 1,70 a 1,50 Ga, enquanto que os valores de $\xi_{\mathrm{N} d}$ são de $+2,6$ a $+4,1$, representativos de crosta juvenil. T'endo em vista a assinatura geoquímica e isotópica das tochas do batólito, Geraldes et al. (2001) propuseram gênese relacionada à subducção para leste, sob as rochas recém-acrescidas do Orógeno Rio Alegre.

A definição da Orogênese Santa Helena (Geraldes 2000), cuja evolução se deu em ambiente de arco magmático com acresção de material juvenil, permitiu o desmembramento de outro evento orogênico na Província Rondoniana-San Ignacio, representado pela Orogênese San Ignacio (Tassinari et al. 2001).

Na Bolívia, a Orogênese San Ignacio (Litherland \& Bloomfield 1981; Litherland et al. 1986, 1989; Teixeira \& Tassinari, 1984) é reconhecida por idades Rb-Sr do metamorfismo, de fácies anfibolito a granulito, de cerca de $1344 \pm 18$ Ma e de magmatismo cálcio-alcalino sin a pós-tectônico entre 1,38 e 1,28 Ga. Idades-modelo Sm-Nd desses granitos (Darbyshire 1979, 2000) variam entre 2,09 a $1,51 \mathrm{Ga}$, com valores de $\xi_{\mathrm{Na}}$ desde levemente negativos até $+3,9$. Granitos tardi a pósorogênicos apresentam idades ' $\mathrm{I}_{\mathrm{DM}}$ de 1,73 a 1,69 Ga e $\xi_{\mathrm{N} d}$ de $+1,0 \mathrm{a}+1,4$, enquanto que os pulsos finais, alcalinos, possuem idade-modelo de $1,88 \mathrm{Ga} \operatorname{com} \xi_{\mathrm{Nal}}$ de $-0,9$, todos com idade de cristalização, estimada por Rb-Sr, em 1,29 Ga (Darbyshite 1979, 2000).

A Orogênese San Ignacio foi estendida ao território brasileiro por Tassinari et al. (2001) com base em idades de cristalização U-Pb em zircão (SHRIMP e TTMS) entre 1,41 e 1,38 Ga, bem como idades de metamorfismo de cerca de 1,31 Ga, obtidas em granitóides do Mato Grosso. As idades $\mathrm{Sm}-\mathrm{Nd} \mathrm{T}_{\mathrm{DM}}$ situam-se no intervalo de 1,69 a 1,52 Ga, com valores de $\xi_{\mathrm{Nd}}$ de $+3,4 \mathrm{a}+3,6$. É entendida como desenvolvida em ambiente de arco magmático.

Em Rondônia, eventos cronocorrelatos envolvem volumosa granitogênese anorogênica, representada pela Suíte Intrusiva Rio Crespo (Payolla et al. 2001a e b, 2002) e pelas suítes rapakivi Santo Antônio, Teotônio, Alto Candeias e São Lourenço-Caripunas (Bettencourt et al. 1999), além de metamorfismo, efeitos térmicos e sedimentação. A Súte Intrusiva Rio Crespo, composta por gnaisses graníticos e granulitos charnockíticos finos, tem idades U-Pb em zircão de 1,43-1,42 Ga, idades Sm-Nd $\mathrm{T}_{\mathrm{DM}}$ de 1,75 a 1,73 Ga e valores de $\xi_{\mathrm{Nal}}$ entre $+0,6$ e $+1,2$, sendo considerada 
cronocorrelata ao Orógeno Santa Helena. As suítes rapakivi apresentam idades de cristalização U..Pb em zircão de 1,41 a 1,31 Ga, idades $\mathrm{Sm}-\mathrm{Nd}^{\prime} \mathrm{T}_{\mathrm{DM}}$ de 1,87 a $1,52 \mathrm{Ga}$, e valores de $\xi_{\mathrm{Nd}}$ entre 0 e $+2,7$ (Bettencourt et al. 1999a e b). O thetamorfismo, de fácies anfibolito alto, foi datado por U-Pb (zircão e monazita) em 1,36-1,30 Ga (Tassinari et al. 1996, 1999, 2000; Payolla et al. 2002; Bettencourt et al. 2002, Rizzotto et al. 2002a, b), bem como por ${ }^{40} \mathrm{Ar} /{ }^{39} \mathrm{Ar}$ em hornblenda e muscovita $(1,31 \mathrm{Ga})$ das rochas da Suíte Metamórfica Colorado, definida recentemente (Rizzotto et al. 2002a, b). A sedimentação está representada pelas formações Palmeiral e Prosperança, cuja gênese é atribuída a ambiente de rift (Geraldes $t$ al. 2001, Saes et al. 2002).

O desenvolvimento do Cinturão Móvel Sunsás (Litherland \& Bloomfield 1981), na Bolívia, envolveu distensão continental, plutonismo alcalino e deposição dos sedimentos continentais e marinhos dos grupos Sunsás e Vibosi, posteriormente deformados e metamorfizados sob condições de fácies xisto-verde, com ocorrência de magmatismo básico e ácido, sin e pós-tectônico, associado. Metamorfismo, deformação e plutonismo ocorreram no período de 1,28 a 0,95 Ga (Litherland \& Bloomfield 1981; Litherland et al. 1986).

O Cinturão de Cavalgamento Aguapeí (Saes \& Fragoso Cesar 1996), ou Orógeno Aguapeí (Rizzotto 2001a e b), compreende conglometados, arenitos e pelitos fluviais e marinhos, deformados em ambiente cratônico (Figueiredo et al. 1974; Souza \& Hildred 1980; Saes et al. 1992; Menezes et al. 1993), correlatos ao Grupo Sunsás, da Bolivia (Litherland \& Bloomfield 1981; Litherland et al. 1986; Saes 1999). A idade máxima de quartzito da unidade foi estimada em $1231 \pm 14 \mathrm{Ma}$ (Santos et al. 2001). Datações ${ }^{41} \mathrm{Ar} /{ }^{39} \mathrm{Ar}$ em homblenda e biotita das rochas do cinturão indicam idade de deformação entre $970 \pm 6$ e $957 \pm 2 \mathrm{Ma}$, e $912 \pm 12$ e $890 \pm 2 \mathrm{Ma}$, respectivamente (T'ohver ot al. 2000). O magmatismo granítico do tipo $S$, controlado por zonas de cisalhamento e gerado no final do evento Aguapé, foi datado por U-Pb em zircão em 939 e $914 \mathrm{Ma}$, e apresenta idades Sm- Nd ' $\mathrm{T}_{\mathrm{DM}}$ de 2,21 $\mathrm{Ga}\left(\xi_{\mathrm{Nd}}\right.$ de -7,1 e 7,6). Magmatismo anotogênico bimodal apresenta idade Sm-Nd de 1,29 Ga e $\xi_{\mathrm{Nd}}$ de $+1,27$, que sugere a contribuição de material juvenil e crustal na geração do magma (Geraldes 2000).

O Orógeno Nova Brasilândia (Rizzotto 2001b) inclui uma seqüência de rochas metaplutono-sedimentares e metavulcâncias predominantes na área, denominada Grupo Nova Brasilândia (Rizzotto 1999), granitos das Suítes Rio Pardo e Costa Marques e do Granito Rio Branco, além de coberturas continentais (Formação Primavera e grupos Palmeiral e Vilhena). O Grupo Nova Brasilândia compreende uma unidade metaturbidítica terrígeno-carbonática, e outra de rochas ígneas bimodais com intercalações subordinadas de gnaisses cálcio-silicáticos, cuja formação 
e evolução se deram por extensão e instalação de rift intracontinental, seguidos por transpressão e espessamento crustal. Finalmente, houve nova extensão por colapso pós-orogêenico, com geração de bacias e cratonização (Rizzotto 1999, 2001 a e b; Rizzotto et al. 1999a, b).

A idade máxima da sedimentação dos metaturbiditos é estimada em $1215 \pm 20 \mathrm{Ma}$ (Rizzotto 2001a e b), enquanto que o magmatismo bimodal se deu em dois pulsos: um de cerca de $1110 \mathrm{Ma}$, representado por rochas metabásicas plutonticas e granitos do tipo A; e outro de $1005 \mathrm{Ma}$, de granitos epizonais do tipo $A$ contemporâneos aos Granitos Últimos de Rondônia, além de basaltos e gabros. No primeiro caso, as idades $\mathrm{Sm}-\mathrm{Nd} \mathrm{T}_{\mathrm{DM}}$ das rochas graníticas concentram-se no intervalo de 1,66 a 1,63 Ga, e os valores de $\xi_{N_{d}}$ variam de -...0,4 a -..1,5, indicando derivação crustal pata o magma com alguma participação de material mantélico. Valores de $\xi_{\mathrm{Na}}$ para a unidade metabásica, caracterizadas como do tipo P-MORB, variam de $+3,1$ a $+5,0$, sugerindo acresção de material juvenil nesta porção do Cráton Amazônico. Os dados Sm-Nd para os granitos tardi a pós-tectônicos $\left(\mathrm{T}_{\mathrm{DM}}\right.$ de $1,5 \mathrm{Ga}$ e $\xi_{\mathrm{Nd}}$ de $\left.+0,5\right)$ relacionados ao segundo pulso revelam fusão de crosta mais antiga com forte contribuição juvenil e curto tempo de residência crustal (Rizzotto 2001a e b; Rizzotto et al. 2001). Uma idade U-Pb em zircão de $1110 \pm 10 \mathrm{Ma}$ para metagabro foi interpretada como a idade do metamorfismo da unidade (Rizzotto 1999), enquanto que a deformação relacionada ao desenvolvimento de falhas transcorrentes tardias foi estimada em 970-966 Ma (Tohver et al. 2000) e $965 \pm 23 \mathrm{Ma}$ (Tassinari 1993).

No entendimento de Santos et al. (2002), a Orogênese Sunsás corresponde a um ciclo orogênico completo, desenvolvido no intervalo de 1,45 a 1,09 Ga, composto pelas orogêneses Santa Helena (1,45 Ga), Candeias (1,32 Ga), pré-Nova Brasilândia (1,19 Ga) e Nova Brasilândia (1,11 Ga), as duas primeiras relacionadas a ambiente de arco e as duas últimas de caráter colisional.

\subsection{A Província Estanífera de Rondônia}

\subsubsection{Complexo Jamari (lsotta et al. 1978)}

O Maciço Granítico Santa Bárbara integra a Província Estanífera de Rondônia (PER; Fig. 3.3), cujo embasamento é constituído predominantemente pelas rochas ortoderivadas de composição granítica, granodionítica, tonalítica e diorítica, com rochas básicas e paraderivadas menos expressivas, metamorfizadas sob condições de fácies anfibolito até granulito, do Complexo Jamari (Isotta et al. 1978). 


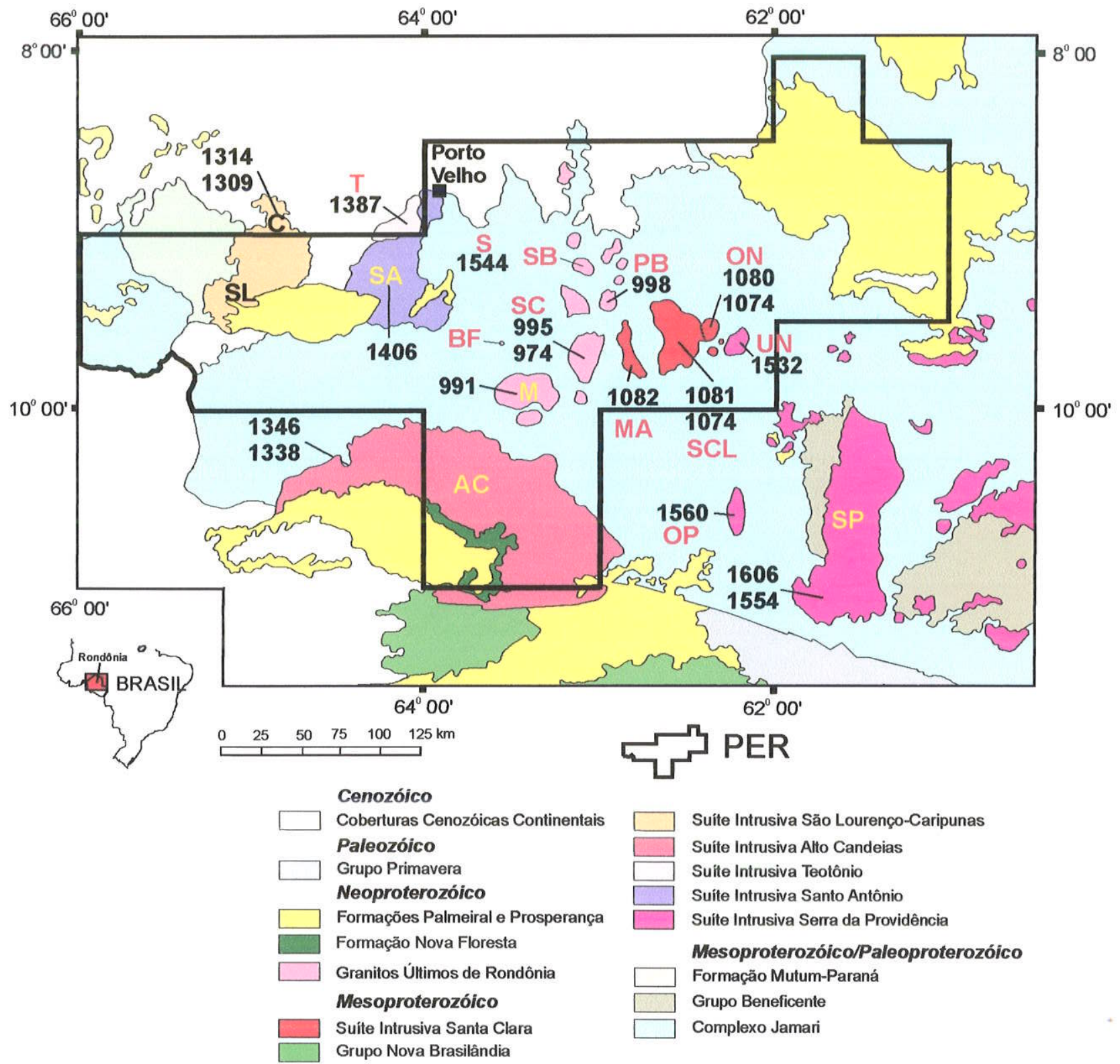

\section{MACıÇO/BATÓLITO}

$\begin{array}{llll}\text { S - Samuel } & \text { T - Teotônio } & \text { SCL - Santa Clara } & \text { PB - Pedra Branca } \\ \text { SP - Serra da Providéncia } & \text { AC - Alto Candeias } & \text { ON - Oriente Novo } & \text { BF - Bom Futuro } \\ \text { UN - Uniăo } & \text { SL - Săo Lourenço } & \text { MA - Manteiga } & \text { M - Massangana } \\ \text { OP - Ouro Preto } & \text { C - Caripunas } & \text { SC - São Carlos } & \text { SB - Santa Bárbara } \\ \text { SA - Santo Antônio } & & & \end{array}$

Figura 3.3 - Mapa geológico esquemático da Província Estanífera de Rondônia (PER) e áreas adjacentes, mostrando a distribuição das suítes de granitos rapakivi com 1,60 a 0,97 Ga. Modificado de Leal et al. (1978), Bettencourt et al. $(1995,1996)$ e Bettencourt et al. (1999a). 
Payolla et al. (2001b; 2002a) identificaram cinco associações litológicas no embasamento da porção centro-leste da PER: 1) gnaisses tonalíticos (1,75 Ga; $\xi_{\mathrm{N} d}(\mathrm{I})-1,5$ a $+0,1 ; \mathrm{T}_{\mathrm{DM}}$ 2,2 a 2,1 Ga); 2) granulitos enderbíticos $\left(1,73 \mathrm{Ga} ; \xi_{\mathrm{Nd}}(\mathrm{T})-0,6 \mathrm{a}+0,1 ; \mathrm{T}_{\mathrm{DM}} 2,1 \mathrm{Ga}\right)$; 3) paragnaisses (idade incerta; ' $\mathrm{T}_{\mathrm{DM}}^{\prime} 2,2$ a $\left.\left.2,1 \mathrm{Ga}\right) ; 4\right)$ augen-gnaisses graníticos e charnockíticos $\left(1,57\right.$ a $1,53 \mathrm{Ga} ; \xi_{\mathrm{N}}(\mathrm{T})+0,6$ a $+2,0$; $\mathrm{T}_{\mathrm{DM}} 1,9$ a $\left.1,8 \mathrm{Ga}\right)$; e 5) gnaisses graníticos e granulitos charnockíticos finos $\left(1,43\right.$ a $1,42 \mathrm{Ga}$; $\xi_{\mathrm{N} \alpha}(\mathrm{T})$ $+0,7 \mathrm{a}+1,2 ; \mathrm{T}_{\mathrm{DM}} \xi_{\mathrm{NC}_{1}(\mathrm{I})} 1,8$ a $1,7 \mathrm{Ga}$ ) (Fig. 3.4).

As duas primeiras associações apresentam afinidade geoquímica cálcio-alcalina, e são interpretadas como produtos de ambiente de margem continental do tipo andino. A associação de paragnaisses tem seu intervalo de deposição limitado entre 1,65 e 1,57 Ga, com contribuição da crosta da Província Geocronológica Ventuari-Tapajós, definida por Tassinari (1996), e das associações dos gnaisses tonalíticos e dos granulitos enderbíticos (Payolla et al. 2002a, b). Essas três associações estão relacionadas ao desenvolvimento da Província Rio Negro-Juruena, e representam a crosta mais antiga da região (Payolla et al., 2002a).

Os angen-gnaisses graníticos e charnockíticos têm afinidades geoquímicas com granitos do tipo $A$, intraplaca, e são interpretados como derivados de mistura de magma do manto empobrecido com crosta mais antiga. Payolla et al. (2002a) os correlacionam à Suíte Intrusiva Serra da Providência (Bettencourt et al. 1999b), uma associação MCG (de mangerito-charnockito-granito rapakivi; Emslie 1991; Rizzotto et al. 1996) contemporânea ao Orógeno Cachoeirinha (Tassinari et al. 2000; Geraldes et al. 2001), reconhecido no Estado do Mato Grosso.

Os gnaisses graníticos e granulitos charnockíticos finos constituem o primeiro registro de magmatismo do tipo $A$, intraplaca, no norte de Rondônia relativo a intervalo de 1,43-1,42 Ga. Foram denominados Suíte Intrusiva Rio Crespo (Payolla et al. 2001a, b). Payolla et at. (2002) propöem fonte a partir de mistura de material juvenil e crosta antiga para essas rochas, e defendem serem expressões inboard dos processos acrescionários de margem continental reconhecidos por Geraldes et al. (2001) no Mato Grosso e responsáveis pelo Orógeno Santa Helena.

A região centro-leste da PER foi submetida a um episódio tectono-metamórfico de fácies anfibolito alto entre 1,36-1,30 Ga, que é interpretado como o pico metamórfico da orogênese Rondoniana-San Ignacio (Tassinari et al. 1996, 1999, 2000; Payolla et al. 2002; Bettencourt et al. 2002). 


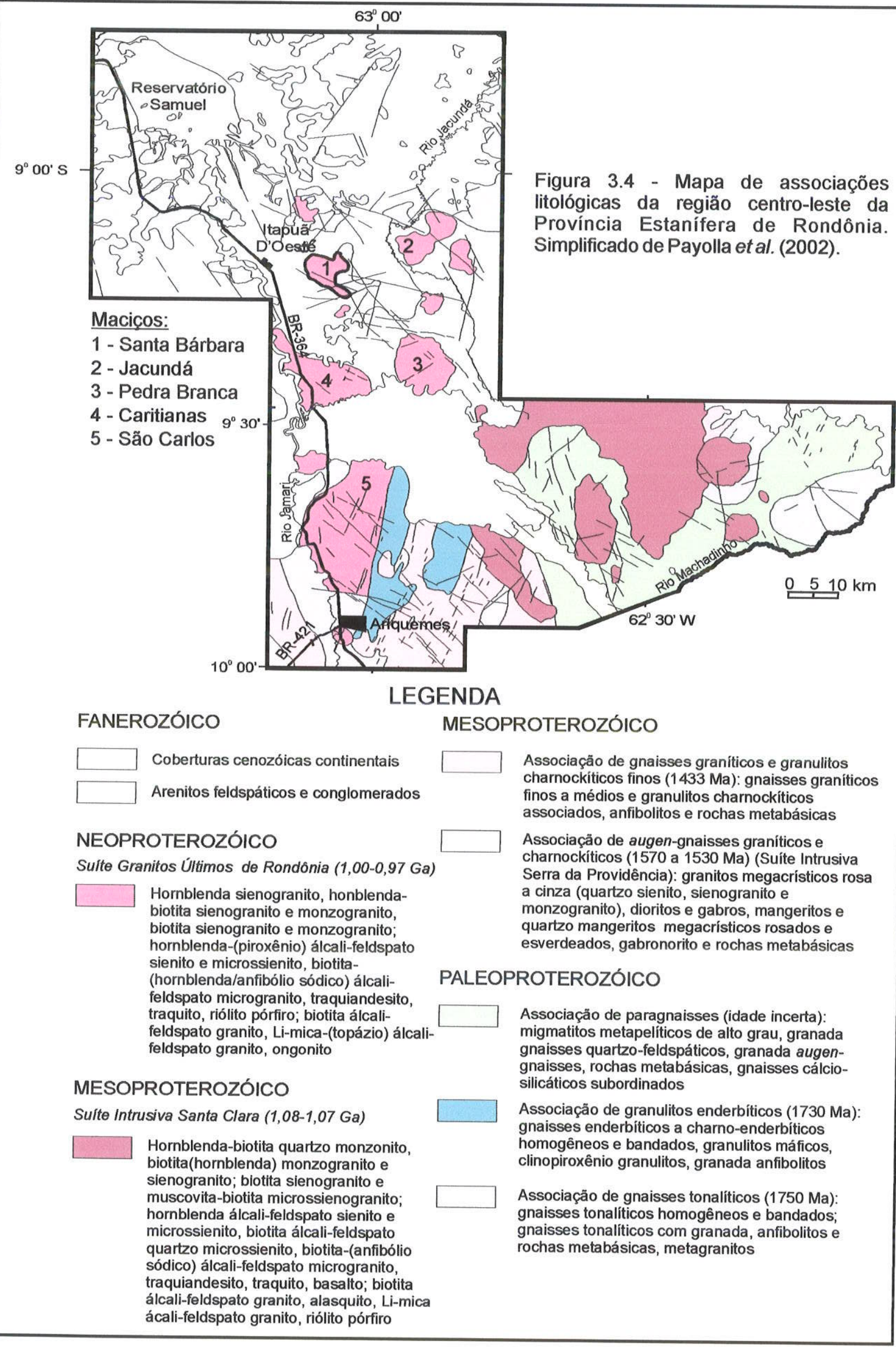


Outro evento tectono-metamórfico, responsável pelo retrabalhamento das rochas do embasamento no intervalo de 1,2-1,1 Ga, foi identificado na região por Bettencourt ef al. (1996, 2002) e Tohver et al. (2001) e atribuído à Orogênese Sunsás, reconhecida por Tassinari et al. (2000).

\subsubsection{Formação Mutum-Paraná (Lobato et al. 1966)}

Compreende quartzo-arenitos, siltitos, filitos, ardósias, argilitos, arenitos arcoseanos, quartzitos, metacherh, e metatufos de cinza, depositados em mar raso, epicontinental, com episódios de deposição continental restritos a porções da seqüência. Os litotipos mostram-se afetados por metamorfismo de contato resultante da intrusão dos Granitos Últimos de Rondônia (Scandolara 1999b). Recentemente, Santos et al. (2001) dataram cristais de zircão de um tufo félsico da unidade, obtendo uma idade concordante de $1751 \pm 16 \mathrm{Ma}$, interpretada como sendo a da cristalização da rocha, além de componentes herdados com idades variáveis entre 1800 e $2720 \mathrm{Ma}$.

\subsubsection{Suites Intrusivas}

Sete suítes de granitos rapakivi e rochas máficas associadas, gerados durante seis episódios magmáticos entre 1,6 e 0,9 Ga, foram identificadas no sudoeste do Cráton Amazônico por: Bettencourt et al. (1997, 1999b): Suíte Intrusiva Serra da Providência (1,60 a 1,53 Ga), Suíte Intrusiva Santo Antônio (1,41 Ga), Suíte Intrusiva Teotônio (1,39 Ga), Súte Intrusiva Alto Candeias (1,34 Ga), Suíte Intrusiva São Lourenço-Caripunas (1,31 Ga), Suíte Intrusiva Santa Clara (1,08-1,07 Ga), e Suíte Granitos Últimos de Rondônia (1,00-0,97 Ga). A primeira é entendida como magmatismo rapakivi inboard relacionado à Orogênese Cachocirinha (Tassinari et al., 2000; Geraldes et al. 2001). As suítes intrusivas Santo Antônio, Teotônio, Alto Candeias e São Lourenço-Caripunas são interpretadas como magmatismo inboard relacionado ao desenvolvimento da Província Rondoniana-San Ignacio, enquanto que as suítes Santa Clata e Granitos Últimos de Rondônia são consideradas magmatismo inboard relacionado ao estágio colisional da Orogênese Sunsás.

\section{a) Suíte Intrusiva Serra da Providência (Tassinari et al. 1984)}

A denominação dessa unidade foi proposta por Tassinari et al. (1984) para designar o batólito Serra da Providência e diversos corpos satélites, originalmente descritos por Leal at al. $(1976,1978)$. Gabros, charnockitos e mangeritos foram posteriormente incluídos na suíte por Bettencourt et al. (1987, 1995) e Rizzotto et al. (1996). Os augen gnaisses graníticos e charnockíticos identificados no embasamento da porção centro-leste da PER são correlacionados à essa suíte (Bettencourt el al. 
1999b).

O batólito propriamente dito compreende gabros, charnockitos e mangeritos, além de quatro fácies graníticas reconhecidas por Rizzotto et al. $(1995,1996)$. São elas monzogranito porfirítico piterlítico com wiborgito subordinado, monzogranito porfirítico, sienogranito equigranular, e granito pórfiro. São rochas predominantemente maciças, mas ocorrem casos de superposição de foliação milonítica sobre foliação ígnea.

Os granitos da suíte são subalcalinos, metaluminosos a fracamente peraluminosos, e tardi a pós-orogênicos.

\section{b) Suíte Intrusiva Santo Antônio (Payolla 1994)}

As rochas da Suíte Intrusiva Santo Antônio compõem a maior parte do batólito Santo Antônio, e foram pioneiramente identificadas por Souza e Marques (1974).

Adamy e Romanini (1990) descreveram a presença de wiborgitos, piterlitos, granitos porfiríticos e equigranulares, além de pórfiros, no batólito.

Payolla (1994) reconheceu duas unidades graníticas principais: (1) monzo e sienogranitos grossos, seriados a localmente porfiríticos, com texturas rapakivi e anti-rapakivi esparsas, e (2) monzogranito médio equigranular. Fácies menos abundantes incluem quartzo-monzonito, diques de rochas híbridas, e diques de diabásio sinplutônicos. Predominam os granitos subsolyus, subalcalinos, metaluminosos a peraluminosos, intraplaca e do tipo $A$.

\section{c) Suíte Intrusiva Teotônio (Payolla 1994)}

Aparentemente, a Suíte Intrusiva Teotônio compõe uma pequena parte do batólito Santo Antônio. Suas rochas foram descritas, originalmente, por Leal et al. (1978) e Adamy e Romanini $(1990)$.

Payolla (1994) propôs a atual denominação, incluindo na unidade rochas granitóides e sieníticas bipersolvus portadoras de olivina e clinopiroxênio e subdivididas nas fácies: (1) álcali-feldspato granito grosso maciço, (2) álcali-feldspato granito médio bandado, e (3) álcali-feldspato quartzo-sienito e sienogranito grosso a médio. Cortam as duas primeiras fácies corpos tabulares de álcali-feldspato sienitos finos a médios e diques sinplutônicos de rochas intermediárias, enquanto que diques de monzogranitos subsolvus finos cortam todas os litotipos anteriores. 
Os granitos dessa suíte são alcalinos e metaluminosos (Payolla 1994).

\section{d) Suíte Intrusiva Alto Candeias (Bettencourt et al. 1997)}

As rochas granitóides da região do Alto Candeias foram primeiramente descritas por Lobato et al. (1966), Kloosterman (1968), Waghorn (1974), Souza et al. (1975), Isotta et al. (1978) e Leal et al. (1978). Os últimos autores delimitaram, por imagens de radar, o batólito Alto Candeias e dois plútons satélites, mas incluíram-nos no Complexo Jamari.

A Suíte Intrusiva Alto Candeias é composta predominantemente por granitos grossos a médios, porfiríticos e piterlíticos, com contribuições menores de granitos equigranulares médios a finos, aplitos, sienitos e charnockitos, todos de caráter subalcalino. Hospeda minétio estanífero nos granitos equigranulates com biotita na forma de veios de quartzo com cassiterita, volframita e sulfetos.

\section{e) Suíte Intrusiva São Lourenço-Caripunas (Bettencourt et al. 1997)}

Kloosterman (1966), Lobato et al. (1966), Isotta et al. (1978) e Leal et al. (1978) foram os primeiros a descrever as rochas da tegião de São Lourenço, enquanto que Bettencourt e Kaedei (1984) identificaram-nas na região de Caripunas.

Leal et al. (1978) chamaram-nas Efusivas Ácidas do Caripunas. Tassinari et al. (1984) propuseram a denominação Suíte Intrusiva São Lourenço-Macisa com base em uma isócrona de referência Rb-Sr para todas as rochas igneas silícicas da região. Posteriormente, Bettencourt e Dall'Agnol (1987) incluíram o plúton São Lourenço na unidade Granitos Rapakivi Jovens de Rondônia (1,30-1,25 Ga), por eles definida. Bettencourt et al. (1995) cunharam a denominação Complexo São Lourenço-Caripunas, incluindo no mesmo os corpos São Sebastrão, Abunã e Igarapé Pteto. A Suíte Intrusiva São Lourenço-Caripunas, conforme a definição atual (Bettencourt et al. 1997), inclui rochas cuja idade, tedeterminada, é mais antiga do que aquela fornecida pela isócrona Rb-Sr de Tassinari et al. (1984).

A suíte compreende principalmente sienogranitos e álcali-feldspato granitos com texturas piterlítica, porfirítica, equigranular e wiborgítica. Rochas félsicas vulcânicas e subvulcânicas, quartzo-feldspato pórfiros e gabros também ocorrem. Hospeda minério nos sienogranitos equigranulares médios a finos com biotita e nos álcali-feldspato granitos, na forma de corpos de greisen com cassiterita e de veios de quartzo com cassiterita, volframita e sulfetos de Cu-Zn-Pb-Fe. 


\section{f) Suíte Intrusiva Santa Clara (Bettencourt et al. 1997)}

Com base em dados petrológicos, geoquímicos e geocronológicos, Bettencourt et al. (1997, 1999b) e Leite Júnior et al. (2001) definiram a Suíte Intrusiva Santa Clara, que compreende o batólito Santa Clara e diversos batólitos menores e stocks (Oriente Velho, Oriente Novo, Primavera), previamente considerados parte dos Younger Granites of Rondônia de Kloosterman (1967, 1968).

Esta suíte é composta por várias intrusões precoces e tardias. As precoces compreendem dois grupos: (1) biotita (hornblenda) quartzo monzonitos porfúticos, monzogranitos e sienogranitos, todos com granulação grossa a média, texturas rapakivi e caráter predominantemente metaluminoso a fracamente peraluminoso; (2) biotita sienogranitos e muscovita-biotita microsienogranitos peraluminosos subordinados (Leite Júnior et al. 2001).

As intrusões tardias, volumetricamente menos expressivas, também são subdivididas em dois grupos: (1) hornblenda álcali-feldspato sienitos, biotita álcali-feldspato quartzo sienitos, traqui-andesitos, traquitos, biotita (anfibólio sódico) álcali-feldspato granitos, e basaltos subordinados, metaluminosos a peralcalinos; (2) biotita álcali-feldspato granitos, Li-mica álcali-feldspato granitos e riólitos pórfiros (ongonitos), peraluminosos (Leite Júnior et al. 2001).

As rochas da Suíte Intrusiva Santa Clara apresentam características de granitos do tipo $A$, intraplaca. Dados isotópicos sugerem que as intrusões precoces representam fusões anatéticas crustais, enquanto que as tardias são interpretadas como produtos do fracionamento de magmas máficos derivados do manto com contribuição crustal em proporções variáveis. Os depósitos de estanho polimetálicos estão associados às intrusões tardias peraluminosas (Leite Júnior et al. 2001).

Priem et al. (1971) e Leite Júnior et al. (2001b) efetuaram datações K-Ar em micas de greisen e veio de quartzo da mina Oriente Novo e de greisen da mina Rio Branco, ambas em rochas da Suíte Intrusiva Santa Clara. Os dados, no intervalo de 1006 a $980 \mathrm{Ma}$, são pelo menos $70 \mathrm{Ma}$ mais jovens do que a idade de cristalização dos granitos tardios peraluminosos da unidade (1074 Ma), e provavelmente refletem perda de argônio devida ao efeito térmico produzido pela intrusão dos Granitos Últimos de Rondônia (Leite Júnior et al. 2001b), reconhecida na biotita dos granitos do Maciço Oriente Novo (Priem et al. 1971) e por datações ${ }^{4(0} \mathrm{Ar} /{ }^{30} \mathrm{Ar}$ em rochas do embasamento da porção centro-leste da PER (Bettencourt at al. 1996).

\section{g) Suíte Granitos Últimos de Rondônia (Bettencourt et al. 1997)}

Revisões sumariadas sobre as características gerais dos Granitos Últimos de Rondônia e do 
minério estanífero associado foram elaboradas por Bettencourt et al. (1987, 1996, 1997). Neste tópico serão expostos, sucintamente, apenas os principais fatos, hipóteses e sugestões que contribuíram de modo decisivo para o estágio atual do conhecimento sobre o tema, após mais de três décadas dos primeiros trabalhos científicos publicados.

Os granitos estaníferos de Rondônia foram notoriamente descritos por Kloosterman (1967, 1968, 1970), o qual denominou-os Younger Granites of Rondônia, em analogia àqueles reconhecidos na Nigéria. A primeira datação dessas rochas deve-se a Priem et al. (1966), que relataram idades Rb-Sr e K-Ar de $930 \pm 25,950 \pm 30$ e $960 \pm 30$ Ma em biotita, e Rb-Sr de $895 \pm 40$ e $955 \pm 40$ Ma em rocha total para o Granito Jacundá, situado a nordeste do Maciço Granítico Santa Bárbara. Segundo os autores, esses dados permitiram estabelecer a época de colocação dos granitos da suíte em $940 \pm 20 \mathrm{Ma}$. Posteriormente, Priem et al. (1971) dataram os Younger Granites of Rondônia, por meio de isócrona de referência $\mathrm{Rb}-\mathrm{Sr}$, em $977 \pm 20 \mathrm{Ma}$.

A Suíte Granitos Últimos de Rondônia, redefinida por Bettencourt ct al. (1997, 1999b), mantém a denominação clássica de Kloosterman (1967, 1968, 1970), porém os maciços Santa Clara, Oriente Velho, Oriente Novo, Manteiga e Primavera, entre outros, foram excluídos e passaram a integrar a Suite Intrusiva Santa Clara.

Outras contribuiçōes importantes foram de Waghorn (1974), que identificou traquitos e sienitos associados aos granitos estaníferos, que posteriormente foram separados em duas suites: uma de natureza subalcalina e outra de afinidade alcalina (e.g., Leite Júnior 1992; Leite Júnior et al. 1993, 1996). Isotta et al. (1978) caracterizaram os granitos como sendo do tipo rapakivi, cujo caráter: foi confirmado por Bettencourt et al. (1996). Priem et al. (1989) identificaram, com base em idades Rb-Sr, dois cronogrupos de granitos crustais: um mais antigo, com idade de $1025 \mathrm{Ma}\left(\mathrm{r}_{\mathrm{i}}=0,712\right)$, e outro mais jovem, com idade de $955 \mathrm{Ma}\left(\mathrm{r}_{i}=0,710\right)$, os quais são correlacionados às idades U-Pb em zircão de $1080 \mathrm{Ma}$ e $990 \mathrm{Ma}$, respectivamente, de Tosdal et al. (1996). Teixeira et al. (1989) revelaram a contemporaneidade entre os Granitos Últimos de Rondônia e o desenvolvimento da Província Sunsás, cuja correlação foi estendida aos granitos da Província Grenville por Sadowski e Bettencourt (1996). Leite Júnior (1992) reconheceu a presença de fácies magmáticas ricas em albita, com os termos mais diferenciados da suíte subalcalina, cujos prováveis representantes subvulcânicos (topázio riólitos ou ongonitos) foram identificados por Villanova \& Franke (1995).

Datações U-Pb em zircão para os maciços Pedra Branca ( $998 \pm 5 \mathrm{Ma}$ ), São Carlos (974 $\pm 6 \mathrm{Ma}$ ) e Massangana (991 $\pm 14 \mathrm{Ma}$ ) permitiram limitar o episódio de intrusão dos Granitos Últimos de Rondônia entre 998 e $974 \mathrm{Ma}$ (Bettencourt et al. 1999b). 
Bettencourt et al. (1999a) dividiram as suítes rapakivi presentes na PER em dois grupos, com base em dados de rocha total e isotópicos de $\mathrm{Nd}$, $\mathrm{Sr}, \mathrm{O}$ e $\mathrm{Pb}$ : o primeiro compreende os granitos mais velhos do que 1,3 Ga, enquanto que o mais jovem inclui aqueles com idades inferiores a 1,1 Ga. O segundo grupo, ao qual pertence o maciço em estudo, apresenta valores de $\xi_{\mathrm{N} d}(\mathrm{~T})$ entre $+0,33$ e $-3,25$ e de idades ' $T_{13 M}$ entre 1,73 e 1,66 Ga.

Sobre o minério primário de estanho e metais associados (W, Nb, Ta, $\mathrm{Zn}, \mathrm{Cu}$ e $\mathrm{Pb}$ ), poucos foram os avanços que podem ser destacados nestes últimos anos, com exceção dos vários tipos morfológicos e petrográficos que foram amplamente reconhecidos. Kloosterman $(1968,1970)$ reconheceu que o minério estanífero relacionado aos Granitos Últimos de Rondônia ocorre em filões de quartzo e cassiterita associados a corpos de greisen com topázio e/ou fluorita, porém sem turmalina. Isotta et al. (1978) relacionaram as zonas de ocorrências do minério primário de estanho com a presença de granitos rapakivi equigranulares. Korperschoek et al. (1980) propuseram uma sobreposição de fases de mineralização (telescoped style) para explicar a presença de sulfetos associados com greisen portador de cassiterita na jazida Morro do Potosi, hipótese ainda não confirmada por trabalhos posteriores (e.g., Yokoi et al. 1987).

Acerca da evolução dos fluidos nos depósitos estaníferos, Pinho (1987) sugeriu ausência de boiling e um sistema hidrotermal aberto na formação dos principais greisens e veios de quartzo do Maciço Caritianas, cujos fluidos mineralizantes (mistos?), eminentemente aquosos, exibiriam uma salinidade moderada ( $a$. de $18 \%$ em peso de $\mathrm{NaCl}$ eq.) e uma temperatura de aproximadamente $425^{\circ}$ C no início do processo greisenizante. Souza et al. (2002) caracterizaram os fluidos envolvidos na gênese de topázio gemológico presente em pegmatitos mineralizados do Complexo Granítico Massangana como aquosos, de salinidades entre 6,5 e 9,2\% em peso de $\mathrm{NaCl}$ eq., para o sistema de inclusões fluidas bifásicas, e de 42 a $42,5 \%$ para o sistema de inclusões trifásicas. Tais fluidos foram aprisionados a uma temperatura mínima de $375^{\circ} \mathrm{C}$ sob pressão de 0,2 kbar. Finalmente, Souza \& Botelho $(2002 a$, b) caracterizaram o sistema vulcano-plutônico do depósito de Bom Futuro, cujos veios apresentam zonamento composicional e microtermométrico interno que indica a evolução de um fluido aquo-carbônico, aprisionado entre 400 e $435^{\circ} \mathrm{C}$, para um fluido aquoso, aprisionado entre 325 e $355^{\circ} \mathrm{C}$. Nos greisens, o fluido é aquo-carbônico, aprisionado a temperaturas mínimas entre 355 e $425^{\circ} \mathrm{C}$. Conjuntamente, esses dados apontam para a deposição do estanho sob condições mínimas de 0,2 kbar e entre 320 e $420^{\circ} \mathrm{C}$, com maior freqüência entre 360 e $400^{\circ} \mathrm{C}$, compatíveis com ambiente subvulcânico (Souza \& Botelho 2002a, b).

A mineralização ocorreu imediatamente após a cristalização dos granitos tardios 
peraluminosos da Suíte Granitos Últimos de Rondônia (974 Ma), conforme indicam as datações K-Ar das micas das minas Santa Bárbara e Bom Futuro em $961 \pm 19$ e $969 \pm 27$ Ma, respectivamente (Leite Júnior et al. 2001b).

Os Granitos Últimos de Rondônia ocorrem como batólitos e stocks epizonais polifásicos, cratogênicos e subvulcânicos (Bettencourt 1992). Seu alojamento foi controlado por falhas dos tipos Y ou D orientadas a N70W, de movimento sinistrogiro, e falhas normais do tipo T, orientadas a N70E, que configuram estruturas rúpteis do tipo duplexes divergentes/bacias romboédricas (rhombo-chasms) geradas em resposta a fluxo de massa rochosa de ENE para WSW limitado por uma forte componente vertical (Veneziani et al. 2001a, b; Okida 2001). A intrusão desses corpos teria provocado a inversão de baixos para altos estruturais, subseqüentemente realçados como altos topográficos pela erosão (Isotta et al. 1978, Romanini 1982, Leite Júnior 1992, Okida 2001).

Apresentam características geoquímicas de granitos rapakivi, do tipo $A$, intraplaca (Bettencourt et al. 1995). Recentemente, a suíte foi subdividida em dois subgrupos (Leite Jr. et al. 2000, 2001b): precoce, de caráter metaluminoso a levemente peraluminoso; e tardio, subdividido em um grupo metaluminoso a peralcalino, e outro peraluminoso. O subgrupo tardio peraluminoso hospeda a mineralização primária de $\mathrm{Sn}, \mathrm{W}, \mathrm{Ta}, \mathrm{Nb}, \mathrm{Zn}, \mathrm{Cu}$ e $\mathrm{Pb}$, na forma de cassiterita disseminada em albita granitos com Li-mica, cassiterita em pegmatitos e corpos de greisen, veios de quartzo com cassiterita e volframita, e veios de quartzo com sulfetos de $\mathrm{Cu}-\mathrm{Pb}-\mathrm{Zn}-\mathrm{Fe}$ (Bettencourt et al. 1995,1997$)$.

Predominam litotipos equigranulares e porfiríticos, ocorrendo, subordinadamente, equivalentes (sub)rulcânicos (Payolla \& Pinho 1981; Pinho \& Payolla 1982; Almeida Fillho et al. 1984; Pinho 1987; Bettencourt \& Dall'Agnol 1987; Bettencourt et al. 1991).

Dados isotópicos de estrôncio (Priem et al. 1989; Teixcira et al. 1989) e chumbo (Tosdal et al. 1995) destes maciços indicam origem crustal para os granitos rapakivi e rochas relacionadas.

A associação espacial dos maciços graníticos com rochas mangeríticas, charnockíticas e gabróicas levou Bettencourt (1992) a propor a existência de uma suíte AMCG (anortosito-mangerito-charnoquito-granito rapakivi; Emslie 1991) nesta região do Cráton Amazônico.

Conforme Dardenne \& Schobbenhaus (2001a, b), a mineralização dos Granitos Últimos de Rondônia representa a Época Metalogenética do Estanho, de idade neoproterozóica, reconhecida na Província Rondônia, Escudo Brasil-Central. 


\subsubsection{Formação Nova Floresta (Leal et al. 1978)}

Descritas pioneiramente por Souza et al. (1975), as rochas da Formação Nova Floresta foram assim denominadas por Leal et al. (1978) como uma associação de rochas basálticas tholeíticas (Rizzotto 1999), na forma de sills, intercaladas com arenitos arcoseanos. Ocorrem também, de forma subordinada, olivina gabros. Foram datadas por ${ }^{40} \mathrm{Ar} /{ }^{39} \mathrm{Ar}$, em biotita e plagioclásio, em 1,19 a 1,21 Ga (Tohver ot al. 2002).

\subsubsection{Formação Palmeiral (Lobato et al. 1966)}

Essa formação é constituída por ortoconglomerados polimíticos e quartzo-arenitos finos, com amplo predomínio dos últimos, depositados por sistema fluvial entrelaçado em sinéclise interior, atualmente representada pelos grábens de Pacaás-Novos, São Lourenço e Uopianes. Tiveram as rochas do Complexo Jamari e do Grupo Nova Brasilândia como fontes (Babia et al. 1998; Bahia 2002).

Sua evolução tectônica é relacionada ao desenvolvimento de rifts como manifestações inboard ao Orógeno San Ignacio por alguns autores (Geraldes et al. 2001), ao desenvolvimento do Ciclo Sunsás por outros (Bahia et al. 1998), ou mesmo aos estágios pós-Sunsás (Santos et al. 2001), com base na ausência de dobras e de metamorfismo regional.

\subsubsection{Formação Prosperança (Caputo et al. 1971)}

Compreende arenitos arcoseanos, localmente ortoquartzíticos, intercalados com conglomerados polimíticos, arcóseos, siltitos, argilitos e quartzitos, correlacionáveis à frormação Palmeiral (Scandolara 1999b).

\subsubsection{Coberturas Cenozóicas Continentais}

"As Coberturas Cenozóicas do estado de Rondônia reúnem os depósitos terciários e quaternários continentais, distribuídos principalmente ao longo do sistema fluvial Guaporé-MamoréAlto Madeira" (Scandolara 1999b).

\section{a) Coberturas Sedimentares Indiferenciadas}

Depósitos pliocênicos a pleistocênicos de ambientes de leques aluviais, canais fluriais, planícies de inundação, e lacustres. 


\section{b) Terraços Fluviais}

Sedimentos mal selecionados compostos por cascalho, areia e argila, mineralizados com ouro, com níveis de turfa, posicionados acima do nível médio das águas dos rios atuais. São de idade pleistocênica.

\section{c) Depósitos de Planície de Inundação/Canal Fluvial}

Depósitos fluviais e/ou flúvio-lacustres relacionados às drenagens atuais. Freqüentemente hospedam minério aurífero, e são mais expressivos nas planícies de inundação dos rios Guaporé, Mamoré, Madeira e seus maiores afluentes. 


\section{GEOLOGIA DO MACIÇO GRANÍTICO SANTA BÁRBARA}

\subsection{Introdução}

O Maciço Granítico Santa Bárbara tem como encaixante a associação dos augen-gnaisses graníticos e charnockíticos (Payolla el al. 2002), a leste, e é recoberto pelas rochas das Coberturas Cenozóicas Continentais (Scandolara 1999b) no entorno norte, oeste e sul (Fig. 4.1).

A associação dos angen-gnaisses graníticos e charnockíticos compreende quartzo sienitos, sieno e monzogranitos porfiríticos, rosa a cinza, que predominam no setor norte da região centro-leste da PER, entre o Reservatório Samuel e o Rio Jacundá, e sầo encaixantes diretos do maciço (Fig. 3.4). Essas rochas contêm hornblenda e/ou biotita como mineral varietal, além de titanita e allanita como fases minerais acessórias. Possuem, localmente, encraves ou enxames de diques máficos e de rochas híbridas. Podem apresentar foliação magmática ou estrutura S-C desenvolvida em zonas de cisalhamento. Sua idade de cristalização é estimada em 1570-1530 Ma. Hornblenda e/ou biotita monzo e sienogranitos rosa, porfiríticos ou não, bem como dioritos, gabros, mangeritos e quartzo mangeritos porfiríticos rosados e esverdeados, gabronoritos e rochas metabásicas, também compõem a unidade (Payolla $e$ al., 2002).

\subsection{Faciologia do Maciço}

A organização faciológica do Maciço Granítico Santa Bátbata é resultado de processos desde magmáticos até bidrotermais (Tabela 4.I). Os magmáticos incluem a cristalização de rochas diretamente a partir dos magmas graníticos e os processos de diferenciação, interação cristaisfundido granítico e saturação em $\mathrm{H}_{2} \mathrm{O}$ (líquida) responsáveis pela geração das rochas tardias mais evoluídas da associação de fácies Santa Bárbara. 


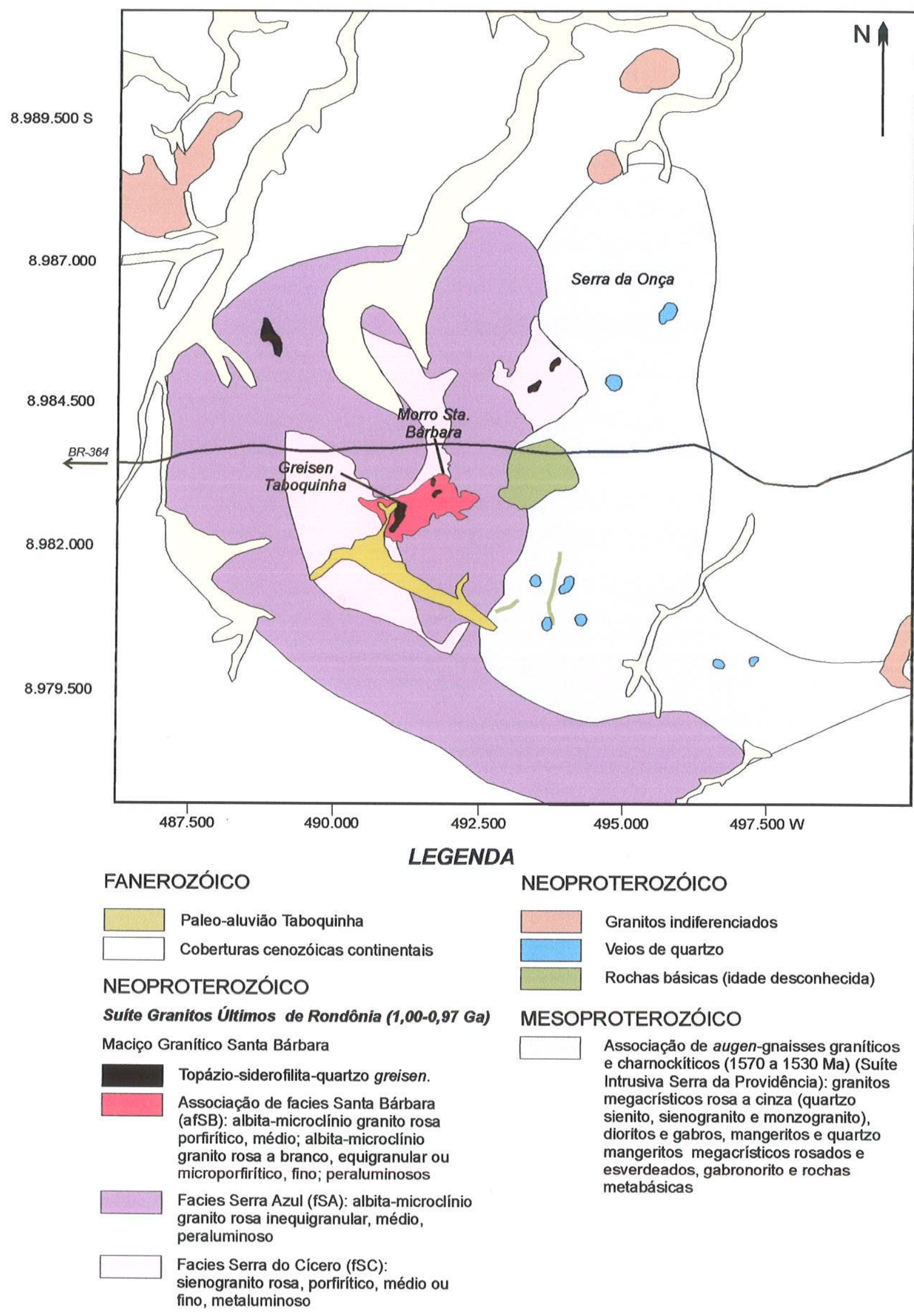

Figura 4.1 - Mapa geológico do Maciço Granítico Santa Bárbara. Compilado e modificado de Frank (1990), CESBRA (1994), e Payolla et al. (2002). 
Os processos de alteração magmático-hidrotermal, desenvolvidos sobre a associação de fácies Santa Bárbara, são subdivididos em transicionais e hidrotermais, na acepção de Burnham \& Ohmoto (1980). Os autores definem como transicionais aqueles ocorridos após a formação de uma fase volátil magmática separada e que operam em sistemas onde coexistem cristais e $\mathrm{H}_{2} \mathrm{O}$. Tais processos são dominados pelo equilibrio fundido-voláteis e pelas mudanças de volume que acompanham a reação de second boiling "fundido saturado em $\mathrm{H}_{2} \mathrm{O} \Rightarrow$ cristais $+\mathrm{H}_{2} \mathrm{O}$ ". No contexto do maciço estudado, esses processos compreendem a evolução, pelo menos em parte, da associação de fácies Santa Bárbara, especialmente nas suas porções mais apicais (fácies Santa Bárbara fina) e todos os tipos de alterações pervasivas (greisenização I, feldspatização sódica; Tabela 4.I).

Processos hidrotermais, pós-magmáticos, são aqueles ocorridos abaixo da curva solidus do magma saturado em $\mathrm{H}_{2} \mathrm{O}$, dominados pelo equilíbrio entre cristais e voláteis (Burnham \& Ohmoto 1980). Incluem-se nesta categoria as alterações pervasivas fissurais (sen:H Taylor \& Pollard 1988): greisenização II, silicificação I e II, muscovitização e argilização (Tabela 4.I).

Tabela 4.I - Estágios de formação de rochas no Maciço Granítico Santa Bárbara.

\begin{tabular}{|c|c|c|}
\hline & Rocha, fácies ou tipo morfológico & $\begin{array}{l}\text { Estilo de } \\
\text { alteração }\end{array}$ \\
\hline \multirow{5}{*}{$\begin{array}{l}\text { ESTÁGIO } \\
\text { MAGMÁTICO }\end{array}$} & fácies Serra do Cícero (fSC) & \\
\hline & fácies Serra Azul (fSA) & \\
\hline & fácies Santa Bárbara de granulação média (fSBm) & \\
\hline & fácies Santa Bárbara de granulação fina (fSBf) & \\
\hline & pegmatito & \\
\hline \multirow{3}{*}{$\begin{array}{l}\text { ESTÁGIO } \\
\text { TRANSICIONAL }\end{array}$} & bolsão de quartzo & \\
\hline & granito albitizado salmão & feldspat. sódica \\
\hline & topázio-siderofilita-quartzo greisen tabular & greisenização I \\
\hline \multirow{8}{*}{$\begin{array}{l}\text { ESTÁGIO } \\
\text { PÓS- } \\
\text { MAGMÁTICO }\end{array}$} & $\begin{array}{c}\text { stockwork de topázio-siderofilita-quartzo greisen de granulação } \\
\text { média }\end{array}$ & greisenização |l \\
\hline & $\begin{array}{l}\text { stockwork de topázio-siderofilita-quartzo greisen de granulação } \\
\text { fina }\end{array}$ & greisenização ॥ \\
\hline & veio de topázio-siderofilita-quartzo greisen de granulação grossa & greisenização II \\
\hline & bolsão de siderofilita greisen & greisenização II \\
\hline & veio de quartzo-cassiterita & silicificação I \\
\hline & veio de muscovita & muscovitização \\
\hline & veio de quartzo estéril & silicificação II \\
\hline & vênula da caulinita & argilização \\
\hline
\end{tabular}




\subsubsection{Unidades Litológicas Magmáticas}

Deve-se a Frank (1990) a identificação e mapeamento das fácies primárias do Maciço Granítico Santa Bárbara, denominadas Granito Serra do Cícero, Granito Serra Azul e Granito Santa Bárbara. Doravante, serão referidas como fácies Serra do Cícero (fSC), fácies Serra Azul (fSA) e associação de fácies Santa Bárbara (afSB), respectivamente (Fig. 4.1), conforme Sparrenberger \& Bettencourt (2002).

Relações de contato foram identificadas unicamente entre a fácies Serra Azul e a associação de fácies Santa Bárbara. O referido contato é abrupto e irregular (Prancha 4.1.a), com ocorrência esporádica de apófises ou bolsões da primeira unidade dentro da segunda. O oposto também se verifica até cerca de $150 \mathrm{~m}$ dele, na forma de encraves elipsoidais, de limites difusos e irregulares e dimensôes desde poucos até cerca de $30 \mathrm{~cm}$, de granito da associaçâo de fácies Santa Bárbara dentro da fácies Serra Azul (Prancha 4.1.b). Esta alternância de relações de inclusão de um litotipo no outro sugere contemporaneidade entre os dois.

Estruturas descontínuas com até $10 \mathrm{~cm}$ de espessura, grosseiramente bandadas, foram identificadas localizadamente ao longo desse contato. São constituídas por uma banda da ordem de $1 \mathrm{~cm}$ de espessura onde observa-se concentração predominante de cristais anédricos de quartzo grosso associados a cristais euédricos de feldspato potássico com até $7 \mathrm{~cm}$ de comprimento, os últimos dispostos perpendicularmente em relação ao contato e projetando-se da banda de quartzo para o interior da associação de fácies Santa Bárbara. Conhecidas como UST's (unidirectional solidifíation textures; Shannon et al. 1982), são feições de magmatic layering típicas de stockes graníticos subvulcânicos mineralizados com Mo, W e Sn, e refletem cristalização da rocha a partir da banda de quartzo rumo aos cristais de feldspato (Breiter 2002).

O contato sul da associação de fácies Santa Bárbara com a fácies Serra Azul é localizadamente gradacional, marcado por uma faixa de transição de cerca de $15 \mathrm{~m}$ de largura em planta onde blocos angulosos, principalmente losangulares, de granito equigranular ora médio, mais a sul, ora fino, mais a norte, ocorrem imersos em uma "matriz" equigranular muito fina, sugerindo estrutura brechada. Entretanto, dado o avançado grau de alteração intempética do afloramento, não foi possível identificar claramente a natureza dessa matriz.

\section{a) Fácies Serra do Cícero (fSC)}

Ocupa cerca de $26 \%$ da área central do maciço (Fig. 4.1), e aflora na forma de lajeados e matacões de $6 \mathrm{~m}$ de diâmetro médio (Frank 1990). 
É composta por granito maciço, rosa, homogêneo, porfirítico de matriz média a fina, com megacristais de feldspato potássico, predominantemente, e de plagioclásio, de até $2,5 \mathrm{~cm}$ de comprimento. Os megacristais de plagioclásio via de regra são verdes ou esverdeados, refletindo sericitização (Prancha 5.1.a).

\section{b) Facies Serra Azul (fSA)}

É a unidade com átea mais expressiva no Maciço Granítico Santa Bárbara, constituindo cerca de 54\% do corpo. Ocupa toda a região periférica do plúton (Fig. 4.1), e aflora como lajeados e matacões (『rank 1990).

É constituída por granito maciço, rosa, homogêneo, equi a inequigranular, médio a grosso. Os cristais maiores, de feldspato potássico, atingem até $4 \mathrm{~cm}$ de comprimento (Prancha 5.1.b). Sua textura evolui de equigtanular média nas regiões de contato com a associação de fácies Santa Bárbara, até granulações mais grossas e inequigranulares longe desse contato.

\section{c) Associação de fácies Santa Bárbara (afSB)}

Ocupa $10 \%$ da área do maciço, na sua porção central (Fỉig. 4.1), mas inclui, também, diques de até $3 \mathrm{~m}$ de espessura que cortam as fácies Serra Azul e Serta do Cícero. Aflora como lajeados ou como matacões de 0,5 a 1,0 m de diâmetro (Frank 1990). Hospeda a mineralização estanífera.

Duas fácies não mapeáveis, transicionais, fazem parte da associação de fácies Santa Bárbara: uma rosa porfirítica de matriz média (Prancha 5.1.c), identificada principalmente em testemunhos de sondagem (fácies Santa Bárbara média); e outra de granito equigranular, microporfirítico ou porfirítico, rosa, rosa-esbranquiçado ou branco, de matriz fina (fácies Santa Bárbara fina) (Prancha 5.1.d e e). Sua distribuição espacial é controlada pela profundidade em relação à cúpula granítica, ocupada nas porções mais apicais pela fácies Santa Bárbara fina. A fácies Santa Bárbara média é mais freqüentemente encontrada em cotas equivalentes ou mais profundas do que aquelas onde ocorrem os corpos tabulares de greisen, abaixo de 100-110 m.

$\mathrm{Na}$ fácies Santa Bárbara média, os megacristais podem ser ovóides, caso em que se mostram bem formados e com diâmetros de 1 a $3 \mathrm{~cm}$; ou angulosos, subédricos até mal formados, com comprimento de $1 \mathrm{~cm}$ em média. Ambos os tipos de megacristais coexistem na mesma rocha. $\mathrm{Na}$ fácies Santa Bárbara fina, os megacristais, quando presentes, são predominantemente angulosos. 


\subsubsection{Hidrotermalitos}

Hidrotermalitos são reconhecidos no domínio da associação de fácies Santa Bárbara. São produtos de alterações hidrotermais dos tipos pervasiva e pervasiva fissural.

A distribuição espacial dos hidrotermalitos oriundos de alteração pervasiva obedece um arranjo estratificado, ou acamadado, em que produtos de metassomatismo ácido, na forma de corpos tabulares de greisen cinza, de granulação média a fina, horizontais ou de baixo mergulho, portadores de cassiterita ou não, ocorrem associados, em contato gradacional, com granitos greisenizados e granitos albitizados, os últimos de cor salmão e entendidos como produtos de metassomatismo alcalino (Fig. 4.2). As referidas alterações são denominadas greisenização I e feldspatização sódica (Tabela 4.1), e estão restritas à área do pit da mina, denominada Greisen Taboquinha.

Lateralmente aos corpos de greisen, essa distribuição tabular resulta da alternância das cores amarela e rosa do granito hospedeiro acompanhada de discreta mudança da granulação da rocha. Encimando a porção estratificada, o granito apresenta aspecto mosqueado, dado pela profusão de spots de greisen com 1 a $2 \mathrm{~cm}$ de diâmetro (Prancha 4.1.c).

Outra feição hidrotermal observada na transição das fácies de alteração para o granito hospedeiro não alterado (cota 118-122 m) consiste de corpos suborizontais de greisens, granitos finos e pegmatóides (quartzo com siderofilita) alternados, cada um deles com espessuras de 5 a $20 \mathrm{~cm}$. O conjunto atinge cerca de $2 \mathrm{~m}$ de espessura, e está colocado acima de um corpo tabular de topáziosideroflita greisen pobre em quartzo, paralelamente à sua superfície superior, configurando estrutura estratificada. Imediatamente acima desses corpos são observados, ainda, bolsões arredondados e isolados, decimétricos, de pegmatóides com quartzo e siderofilita (Prancha 4.1.d). Em cotas superiores (148 m, ponto 168), esses mesmos bolsões ou buchos pegmatóides atingem até $2 \mathrm{~m}$ de diâmetro, com bordas delineadas por bandas de siderofilita e o núcleo composto predominantemente por quartzo. Estão presentes também poucos cristais prismáticos de topázio de até $10 \mathrm{~cm}$ de comprimento, inteiramente circundados por siderofilita. No interior do bolsão observam-se bandas com poucos cm de espessura de material granítico de granulação média. Nas imediações dessas estruturas, as rochas da fácies Santa Bárbara fina mostram-se greisenizadas num raio quase tão extenso quanto o do próprio bolsão (Prancha 4.1.e). 


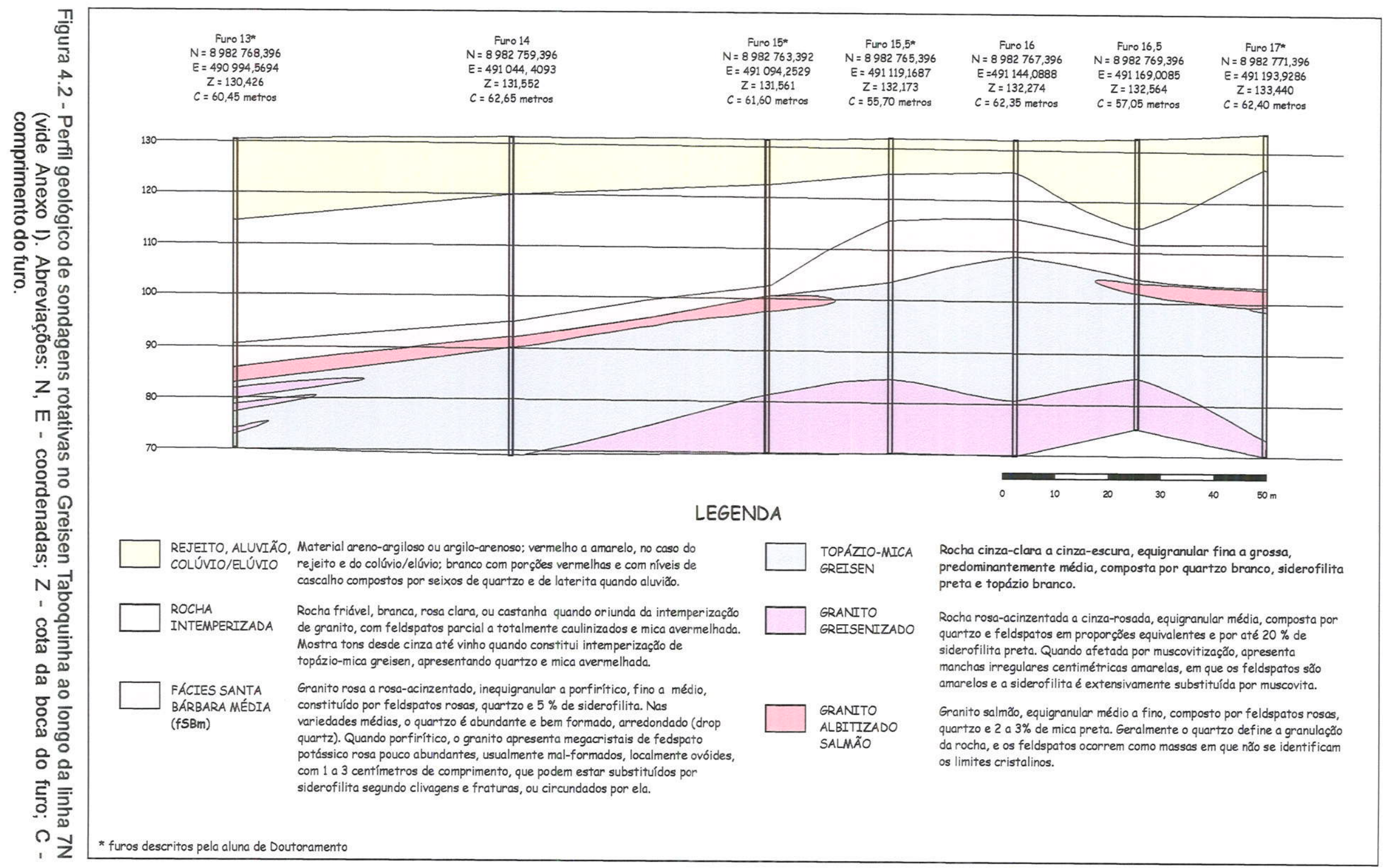


A transição entre a porção alterada e aquela primária da fácies Santa Bárbara fina é marcada por aspecto manchado irregular, onde a cor original da rocha acha-se modificada para tons variados de cinza, denotando diferentes graus de greisenização pervasiva da rocha primária.

Estruturas elípticas em planta, com eixo maior da ordem de $90 \mathrm{~cm}$, que apresentam zonação interna concêntrica constituída por um núcleo de muscovita-quartzo greisen, seguida por uma banda intermediária de quartzo grosso e siderofilita-quartzo greisen na porção externa, são observadas junto ao contato da associação de fácies Santa Bárbara com a fácies Serra Azul, e representam estruturas do tipo pipe.

A alteração pervasiva fissural é representada por greisenização JI, silicificação, muscovitização e argilização (Tabela 4.1). É comum nas regiôes de cota mais elevada da área aflorante da fácies Santa Bárbara fina, como o denominado Morro Santa Bárbara.

A greisenização II também tem como produtos topázio-siderofilita quartzo greisens, pobres ou não em quartzo, com ou sem cassiterita, de granulação fina a grossa, alojados em sistema fissural cerrado do tipo stockmork.

A silicificação I é posterior à greisenizaçào II, e comporta um importante sistema de veios de quartzo com cassiterita. O quartzo ocorre em cristais prismáticos orientados perpendicularmente em relação às paredes dos veios (estrutura bongy comb).

A muscovitização foi reconhecida no Greisen Taboquinha e no Morro Santa Bárbara, controlada predominantemente por fraturas. Tem como produto greisen verde, de granulação média a fina, monominerálico a olho nu. A muscovitização afeta as salbandas de fraturas, além de núcleos de veios de topázio-siderofilita-quartzo greisens, ou ainda se desenvolve no entomo de veios de greisen e de quartzo-cassiterita, como halos de alteração da rocha encaixante, de espessuras centimétricas a decimétricas. Quando essas fraturas ocorrem com espaçamento pequeno, centimétrico, observam-se nódulos pretos de óxidos de manganês associados à essa alteração muscovítica (Prancha 4.1.).

Localmente, os corpos tabulares de greisen parecem ter agido como tampões à muscovitização, porque os veios passam a não estar mais preenchidos por muscovita quando atravessam os corpos, sendo observada apenas a descontinuidade física, na forma de fraturas. A alteração muscovítica das encaixantes relacionada a esses veios também não atinge o greisen e parece sofrer um escape lateral na base do corpo, configurando feiçôes na forma de "prato" (Prancha 4.2.a). Mais comumente, porém, o greisen está intensamente afetado pela muscovitização, situação em que se observam concentrações significativas de cassiterita. 
A silicificação II compreende o preenchimento de fraturas por quartzo na fácies Santa Bárbara fina. Esses veios são pouco espessos, escassos e tardios em relação a todas as estruturas descritas acima, ou são observados preenchendo sistemas de diáclases que cortam a fácies Serra Azul localizadamente. No segundo caso, as rochas encaixantes apresentam discreta alteração avermelhada nas salbandas dos veios. O quartzo configura estrutura em honey comb, onde as porções centrais do veio exibem espaços vazios, freqüentemente preenchidos por óxidos vermelhos.

Finalmente, a argilização é a mais tardia das alterações hidrotermais, e se apresenta na forma de um sistema do tipo stockenork de vênulas de caulinita com halloysita.

\subsection{Arranjo tridimensional de fácies magmáticas hidrotermais}

A organização tridimensional das fácies magmáticas e hidrotermais na associação de fácies Santa Bárbara respeita uma gradação vertical (Anexo I). Da base do sistema rumo ao topo, granito porfirítico, com textura piterlítica hipidiomórfica de granulação média (fácies Santa Bárbara média) dá lugar a granito porfirítico, microporfirítico ou equigranular, de granulação fina e cor rosa a rosaesbranquiçada (fácies Santa Bárbara fina). O ápice do sistema compreende granito branco, de textura alotriomórfica (fácies Santa Bárbara fina), típico de cúpulas graníticas albitizadas. Os produtos de alteração hidrotermal pervasiva, como corpos tabulates de espessura métrica a decamétrica de greisen e granitos albitizados correlatos, ocupam, aparentemente, as porções apicais do sistema, juntamente com a fácies Santa Bárbara fina. Essa distribuição espacial de rochas está bem exemplificada no Greisen Taboquinha (Anexo 1).

No domínio da fácies Santa Bárbara fina (fSBf), estruturas típicas de magmatic layering, representadas por granitos finos e greisens em intercalações centimétricas (Fig. 4.3), são observadas, e indicam proximidade em relação à cúpula da intuusão (cf. Baluj 1995 e Zarajsky et al. 1997 in Breiter 2002). Essa fácies hospeda predominantemente os diferentes sistemas de veios e stockinorks presentes no depósito, produtos da alteração hidrotermal pós-magnática, de caráter fissural. Está bem exposta no Morro Santa Bárbara e adjacências (Anexo 1).

Arranjos similates têm sido descritos em granitos minexalizados com Sn-W da República Tcheca (Jarchosvský et al. 1994, Jarchovský 1998), onde albita granitos leucocráticos de textura aplítica apresentam porções apicais greisenizadas em graus variáveis e corpos de greisen cuja distribuição espacial é paralela ao contato do granito com o embasamento metamórfico encaixante. Em profundidade, esses albita granitos contêm diversos corpos suborizontais de feldspatitos de 
espessuras entre dezenas de centímetros e dezenas de metros, compostos por ortoclásio e albita, além de quantidades subordinadas de quartzo e apatita. Todo esse conjunto encima I.i-F granito de granulação média, não alterado.

A evolução do conjunto é tida como desenvolvida em sistema fechado, no estágio tardimagmático, com disponibilidade precoce de fluidos. Nesse sentido, os elementos alcalinos liberados pela dissolução dos feldspatos teriam neutralizado, localmente, os fluidos ácidos envolvidos na greisenização, culminando com a geração dos feldspatitos (Jarchosvský et al. 1994, Jarchovský 1998).

No caso do Maciço Granítico Santa Bárbara, os corpos de greisen tabulares apresentam uma distribuição suborizontal, provavelmente concordante com o contato superior entre o maciço e o embasamento erodido. O denominado granito albitizado salmão é tido como análogo aos feldspatitos descritos acima, embora seja predominantemente mais rico em quartzo e mica. Assim, uma evolução intramagmática é assumida para o estágio transicional.

\subsection{Características da mineralização}

A mineralização primária no Maciço Granítico Santa Bárbara pode ser classificada como dos tipos endogreisen, com veios de quartzo associados, e exogreisen ( $\%$. Shcherba 1970a). As principais jazidas do tipo endogreisen são o Greisen Taboquinha e o Morro Santa Bárbara. Quanto aos exogreisens, existem ocorrências na jazida Serra da Onça, junto ao contato NE do granito com o Complexo Jamari (Fig. 4.1). Trata-se de uma faixa de direção N070 com 7,5 km de extensão, caracterizada pela presença de veios de quartzo-cassiterita-topázio que podem apresentar concentrações subeconômicas de cassiterita, bismutinita, pirita e esfalerita. Observam-se ainda lentes mineralizadas (até 38\% de Sn) de greisen, alongadas segundo a direção da faixa (Frank 1990).

\subsubsection{Estilos da mineralização}

A mineralização estanífera no Maciço Granítico Santa Bárbara pertence aos estilos disseminado, acamadado, sistemas de stocknork/veios subparalelos, e sistemas de veios.

O estilo disseminado está relacionado ao estágio magmático, e compreende o albitamicroclíno granito branco da fácies Santa Bárbara fina, portador de columbita e óxidos de ETR inclusos em mica.

O estilo acamadado é representado pelos corpos tabulares de greisen, mineralizados com cassiterita \pm volframita, e pelos granitos albitizados salmão correlatos. 


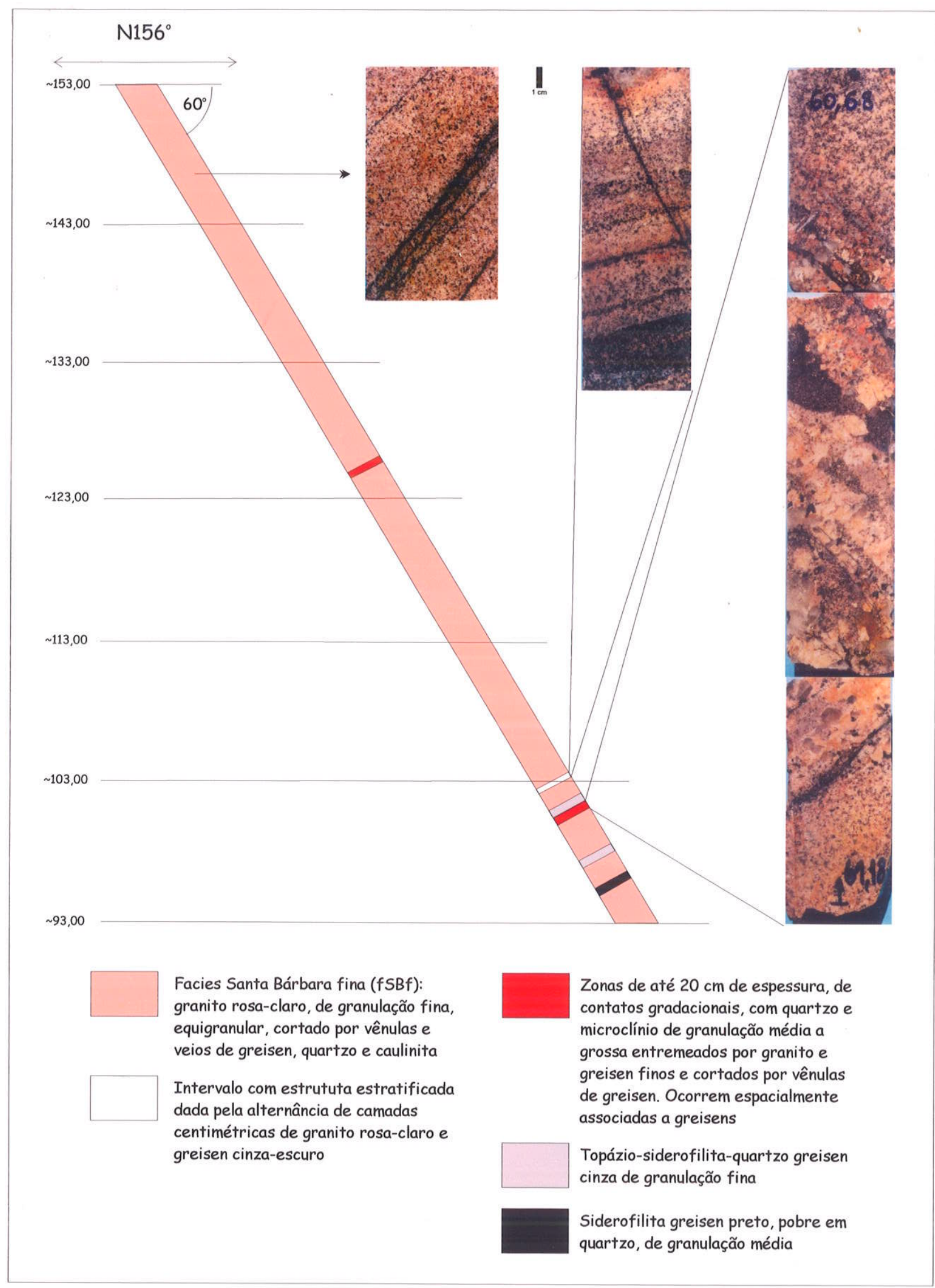

Figura 4.3 - Perfil geológico do furo de sondagem rotativa 22,15, linha 1,8N, localizado no Morro Santa Bárbara, em que se observa estratificação magmática definida pela intercalação centimétrica de albita-microclínio granito e greisen finos. 
O estilo stockmork inclui dois sistemas cerrados de veios e vênulas, que representam os produtos do estágio pós-magmático mais precoce e mais tardio, respectivamente. O sistema precoce consiste de veios de topázio-siderofilita-quartzo greisen com cassiterita \pm volframita, enquanto que o mais tardio está representado por vênulas de caulinita com halloysita.

O sistema de veios de quartzo com cassiterita representa o terceiro estilo de mineralização, desenvolvido no estágio pós-magmático posteriormente ao sistema stockiwork de greisen. Também a esse estilo estão relacionados o desenvolvimento da alteração muscovítica e dos veios de cuartzo estéreis, tardios.

\subsubsection{Tipos morfológicos/estruturais da mineralização}

Quanto aos tipos morfológicos, a mineralização está representada pela porção mais apical da fácies Santa Bárbara fina, onde o albita-mictoclínio granito branco se dispõe em contato irregular: gradacional sobre as rochas menos alteradas da fácies, bem como por corpos tabulates de topáziosiderofilita-quartzo greisen, stockework, de topázio-siderofilita-quartzo greisen e de argila, além de veios de quartzo e de muscovita.

\section{a) Corpos tabulares de topázio-siderofilita-quartzo greisen}

Os corpos tabulares de greisen são horizontais ou de baixo mergulho (da ordem de 0 a $27^{\circ}$ para NE e para SW), com poucas dezenas de centímetros até cerca de $40 \mathrm{~m}$ de espessura, e limites superior e inferior gradacionais para granitos greisenizados e albitizados cuja disposição respeita á dos corpos de greisen (Prancha 4.2.b, Fig. 4.2). Lateralmente, se comportam de duas maneiras: ou têm sua espessura progressivamente diminuída dos dois lados, configutando lentes ou bolsões nas seções verticais (Prancha 4.2.c), ou limitam se bruscamente com os granitos greisenizados e albitizados, por meio de fraturas subverticais, muitas vezes preenchidas por veios de espessura centimétrica de topázio-siderofilita-quartzo greisen (Prancha 4.2.d). Distribuem-se em uma área de $500 \times 150 \mathrm{~m} \mathrm{em}$ planta, denominada Greisen Taboquinha.

\section{b) Stockwork de topázio-siderofilita-quartzo greisen}

Está melhor representado no Morro Santa Bárbara, onde foi elaborado um mapa 1:100 de uma quadrícula de $10 \times 15 \mathrm{~m}$ (Fig. 4.4) que elucida as relações angulares e temporais de cerca de 100 estruturas planares de alto ângulo a verticais, $50 \%$ delas pertencentes a esse sistema stockwork... 


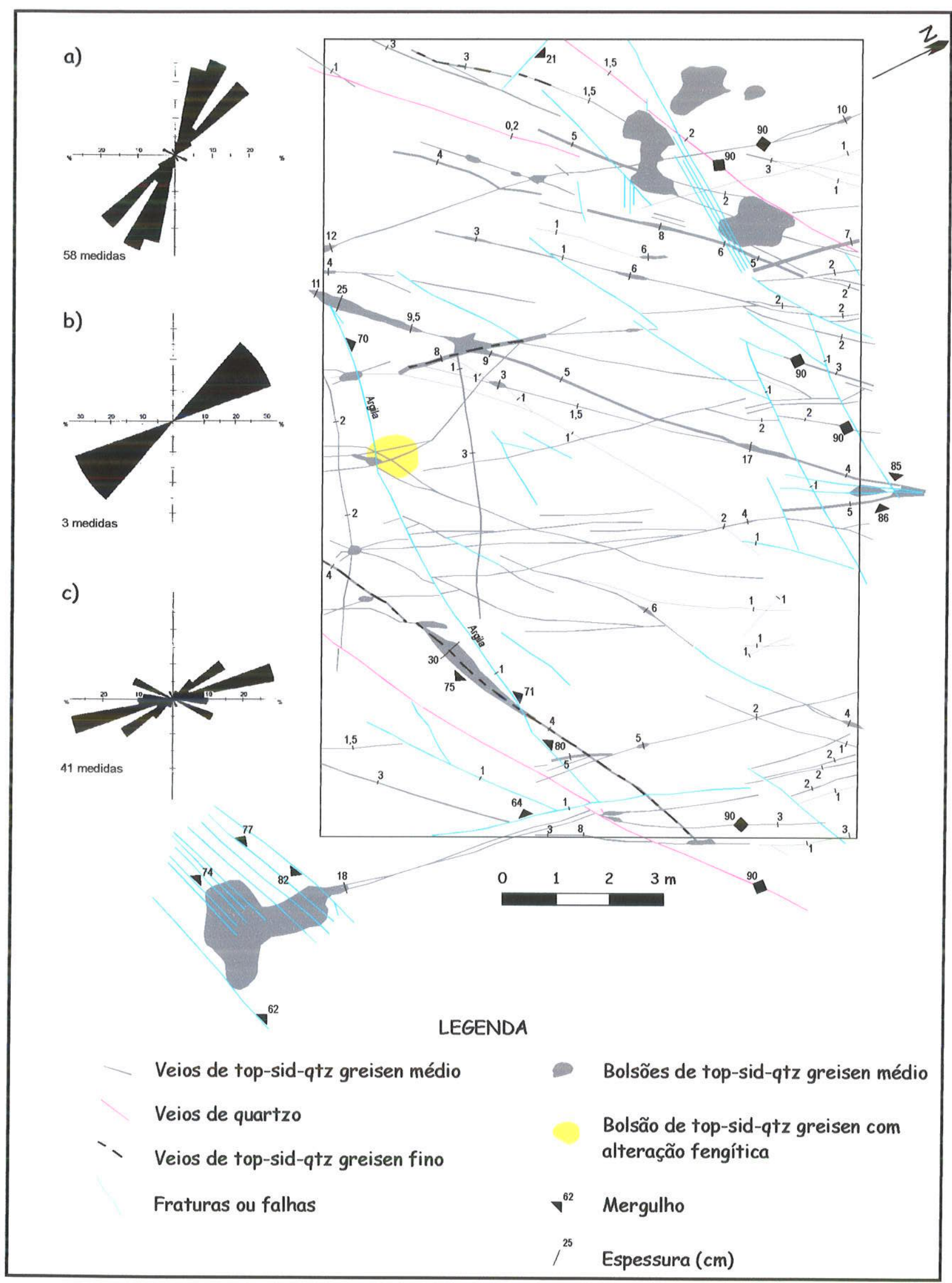

Figura 4.4 - Mapa geológico parcial de detalhe do stockwork de topázio-siderofilita-quartzo greisen do Morro Santa Bárbara. À esquerda, diagramas de roseta dos a) veios de greisen, b) veios de quartzo, e c) fraturas. 
Compreende veios verticais ou de alto ângulo (mergulhos entre 70 e $90^{\circ}$ ), com espessuras entre 1 e $30 \mathrm{~cm}$, de granulação média a grossa, no caso da geração mais antiga, e fina, no caso da geração mais jovem. São compostos por siderofilita, quattzo, topázio e cassiterita ( \pm volframita) (Prancha 4.2.e).

Na área do Morro Santa Bárbara, são pouco espessos (1 a $8 \mathrm{~cm}$ ) e pertencem a três familias

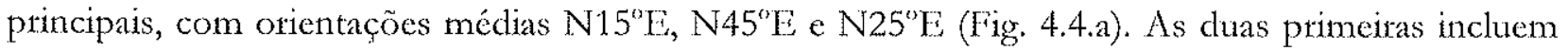
as estruturas mais expressivas, de comprimentos entre 1 e $12 \mathrm{~m}$ dentro da quadrícula mapeada e espessuras de 1 a $8 \mathrm{~cm}$, predominando aquelas de 2 a $3 \mathrm{~cm}$. As estruturas da família de orientação $\mathrm{N} 25^{\circ} \mathrm{E}$ são tão freqüentes quanto as das outras duas famílias, porétn ocorrem predominantemente com 1,5 a $2,5 \mathrm{~m}$ de comprimento e espessuras entre 1 e $3 \mathrm{~cm}$ sendo, conseqüentemente, menos expressivas.

Ocorrem ainda três famílias de estruturas menos freqüentes, com orientações médias $\mathrm{N} 30^{\circ} \mathrm{E}$, N050 E e $570^{\circ} \mathrm{E}$. Apresentam comprimentos de 1,6 a $8,5 \mathrm{~m}$ e espessuras entre 2 e $4 \mathrm{~cm}$. Os veios de topázio-siderofilita-quartzo greisen de granulação fina ocorrem no núcleo de três dos veios descritos

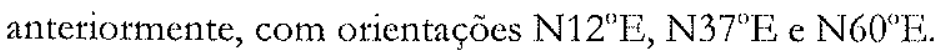

Em todos as famílias, os veios sofrem alargamentos localizados, especialmente no cruzamento de dois ou mais veios, e chegam a atingir espessuras da ordem de $30 \mathrm{~cm}$ em alguns casos.

No Greisen Taboquinha, predominam amplamente as orientações da família N30 $40^{\circ} \mathrm{E}$, seguidas pelas $\mathrm{N} 50-60^{\circ} \mathrm{E}$, a última representada principalmente pelos veios de greisen fino, mais jovens (Fig. 4.5.a e b). Os veios têm espessuras de 1 a $30 \mathrm{~cm}$ e cortam os corpos tabulares de greisen. Podem ser compostos, com bordas de granulação média ou grossa e núcleos de granulação fina, ou núcleos de quartzo, e chegam a atingir $70 \mathrm{~cm}$ de espessura.

\section{c) Veios}

\section{$\checkmark \quad$ Veios de quartzomcassiterita}

Os veios de quartzo-cassiterita apresentam espessuras de 2 a $30 \mathrm{~cm}$, têm mergulhos entre 70 e $90^{\circ}$, principalmente para NE, e orientação $\mathrm{N} 50^{\circ} \mathrm{E}$ a $\mathrm{N} 80^{\circ} \mathrm{E}$, com predomínio em $\mathrm{N} 60-80^{\circ} \mathrm{E}$ (Fig. 4.5.c; Prancha 4.2.f). Iateralmente a eles, observam-se halos de alteração das encaixantes, incluindo, da borda do veio rumo à rocha hospedeira, greisenização e muscovitização. Essa seqüência não ocorre em todos eles, podendo estar ausente ou incompleta. Manifesta-se também junto aos veios de greisen. 


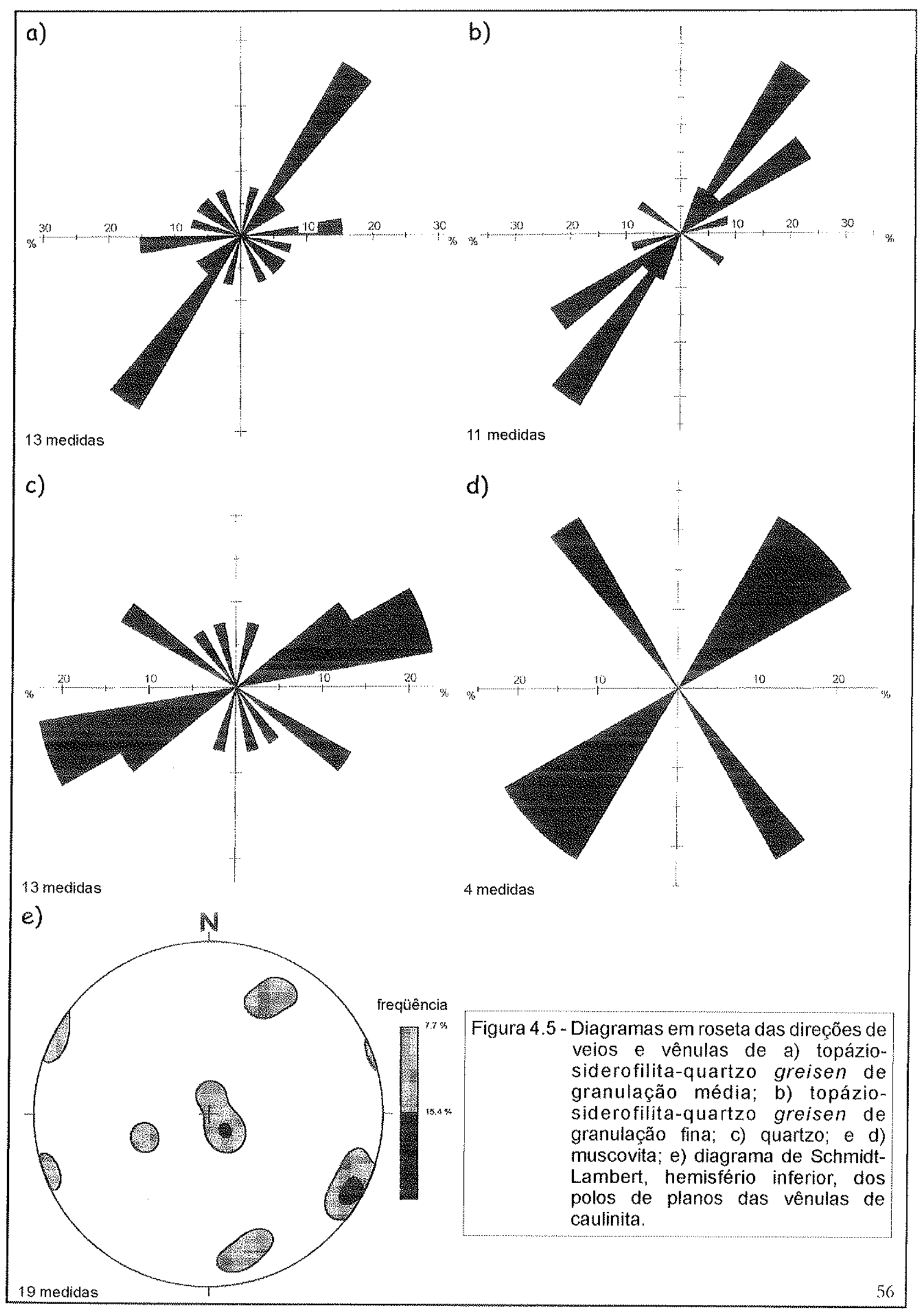




\section{$\checkmark \quad$ Veios de muscovita}

São de alto mergulho a verticais, com espessuras entre 2 e $65 \mathrm{~cm}$, verde-claros, e de granulação fina a média, ocasionalmente com cassiterita (Prancha 4.2.g). Apresentam-se com direções preferenciais $\mathrm{N} 35^{\circ} \mathrm{E}$ a $\mathrm{N} 52^{\circ} \mathrm{E}$, mais taramente $\mathrm{N} 32^{\circ} \mathrm{W}$ (Fig. 4.5.d). Manifestações na forma de bolsões centimétricos a decimétricos artedondados, com a mesma composição mineral, são observadas.

\section{$\checkmark \quad$ Veios de quartzo estéreis}

Cortando os veios de topázio-siderofilita-quartzo greisen, de quartzo-cassiterita e de muscovita ocorrem os veios de quartzo estéreis, com mica escassa e espessuras variando de 3 a 10 cm. No domínio da quadrícula mapeada, três deles foram identificados com orientações $N 45^{\circ} \mathrm{E}$, $\mathrm{N} 56^{\circ} \mathrm{E}$ e N64'E (Fig. 4.4.b), 5 a $10 \mathrm{~m}$ de comprimento espessuras entre 0,2 e $2 \mathrm{~cm}$.

Veios de quartzo não mineralizados ocorrem, localizadamente, preenchendo juntas na fácies Serra Azul, onde possuem orientação preferencial N-S.

\section{d) Stockwork argiloso}

O stockenork, caulinítico exibe vênulas de caulinita com halloysita, de espessuras milimétricas e comprimentos da ordem de poucas dezenas de centímetros (Ptancha 4.2.h). Medidas de orientação dessas vênulas agrupam-se em $\mathrm{N} 40^{\circ} \mathrm{E} /$ suborizontais, $\mathrm{S} 75^{\circ} \mathrm{W} / 68$ a $75^{\circ} \mathrm{NW}$, e N020W"32 a $87^{\circ} \mathrm{NE}$ (Fig. 4.5.e).

\subsection{As estruturas planares rúpteis no contexto regional}

Além dos veios, fraturas e falhas são observadas no Morro Santa Bárbara e adjacências, as primeiras algumas vezes preenchidas por caulinita. São tardias em relação a todos os tipos de veios, ora meramente cortando-os, ora deslocando-os.

As fraturas apresentam orientações preferenciais $\mathrm{N} 70-80^{\circ} \mathrm{E}$, com mergulhos de 62 a $80^{\circ} \mathrm{NW}$ (Figs. 4.4.c). Diáclases são menos comuns, e comportam três orientações preferenciais: duas de alto ângulo a subverticais, orientadas a $\mathrm{N} 20-30^{\circ} \mathrm{E}$ e $\mathrm{N} 90^{\circ} \mathrm{E}-\mathrm{S} 80^{\circ} \mathrm{E}$, e outra de baixo ângulo $\left(0\right.$ a $\left.16^{\circ}\right)$, orientada a $\mathrm{N} 20^{\circ} \mathrm{W}$.

Basculamento normal de blocos (poucas dezenas de centímetros) é observado na área do Greisen Taboquinha, controlado por falhas normais de alto mergulho $\left(70\right.$ a $\left.80^{\circ}\right)$ e de orientação geral N20-30 E, predominantemente. Freqüentemente, tais planos estão preenchidos por muscovita. 
Sistemas de falhas são observados localizadamente. Apresentam orientação geral N60\%, mergulhando cerca de $85^{\circ}$ para NW. A componente direcional do cisalhamento dessas falhas, dextrogira, não excede poucos centímetros.

No Maciço Granítico Santa Bárbara, as orientações principais de alojamento de veios, bem como de distribuição de estruturas planares não preenchidas, compreendem as direções N15 $\mathrm{E}$ a $\mathrm{N} 45^{\circ} \mathrm{E}$ e $\mathrm{N} 60^{\circ} \mathrm{E}$ a $\mathrm{N} 80^{\circ} \mathrm{E}$, ao longo das quais observa-se, com pouca freqüência, componentes de rejeito direcional dextrogiro centimétrico (Fig. 4.4). Elas coincidem com as direçôes das principais linhas de fraqueza crustal identificadas em outros maciços da Suíte Granitos Últimos de Rondônia e nas demais suítes intrusivas presentes na Província Estanífera de Rondônia, bem como em rochas do embasamento (Romanini 1982; Pinho 1987; Bettencourt et al. 1991; Payolla ot al. 1991; Leite Júnior 1992, 1998; Veneziani et al. 2001a e b; Okida 2001 e referências). Correspondem a falhas R1 e $\mathrm{X}$, além de fraturas do tipo ' $\mathrm{T}$, desenvolvidas durante a denominada $3^{a}$ fase de movimentação (1,40 a 0,99 Ga), de natureza transtensiva $\left(\sigma_{1} \mathrm{em}\right.$ torno de $\left.\mathrm{N} 70^{\circ} \mathrm{E}\right)$, reativadas durante o Mesozóico e o Terciário (movimentos normais) (Veneziani et al. 2001a e b; Okida 2001). 
Prancha 4.1 - a) Contato vertical abrupto entre a fácies Serra Azul, à esquerda, e a fácies Santa Bárbara fina, à direita, em seção vertical. Ambas são cortadas pelo sistema stockwork argiloso; b) encrave elipsoidal com $6 \mathrm{~cm}$ de eixo maior, de contatos difusos e irregulares, de granito da fácies Santa Bárbara fina dentro de granito da fácies Serra Azul, em seção horizontal; c) arranjo estratificado horizontal da alteração hidrotermal à direita de corpo tabular de topázio-siderofilita-quartzo greisen que aparece na extrema esquerda da foto, em cinza; d) estrutura estratificada encimando corpo tabular de topázio-siderofilita greisen pobre em quartzo na transição entre os greisens e o granito da fácies Santa Bárbara fina não alterado, na porção superior do perfil. Compreende greisens (verde-escuros), granitos finos (rosa) e pegmatóides (brancos, com quartzo e siderofilita) em corpos de 5 a $20 \mathrm{~cm}$ de espessura, alternados. No topo da estrutura ocorrem bolsões arredondados, de extensão métrica, dos mesmos pegmatóides; e) bolsão pegmatóide de quartzo, com topázio (amarelo) e siderofilita (preta) subordinados, com 1,7 $\mathrm{m}$ de eixo maior, circundado por borda centimétrica de siderofilita; f) nódulos manganesíferos associados com a alteração muscovítica. Seção vertical. 


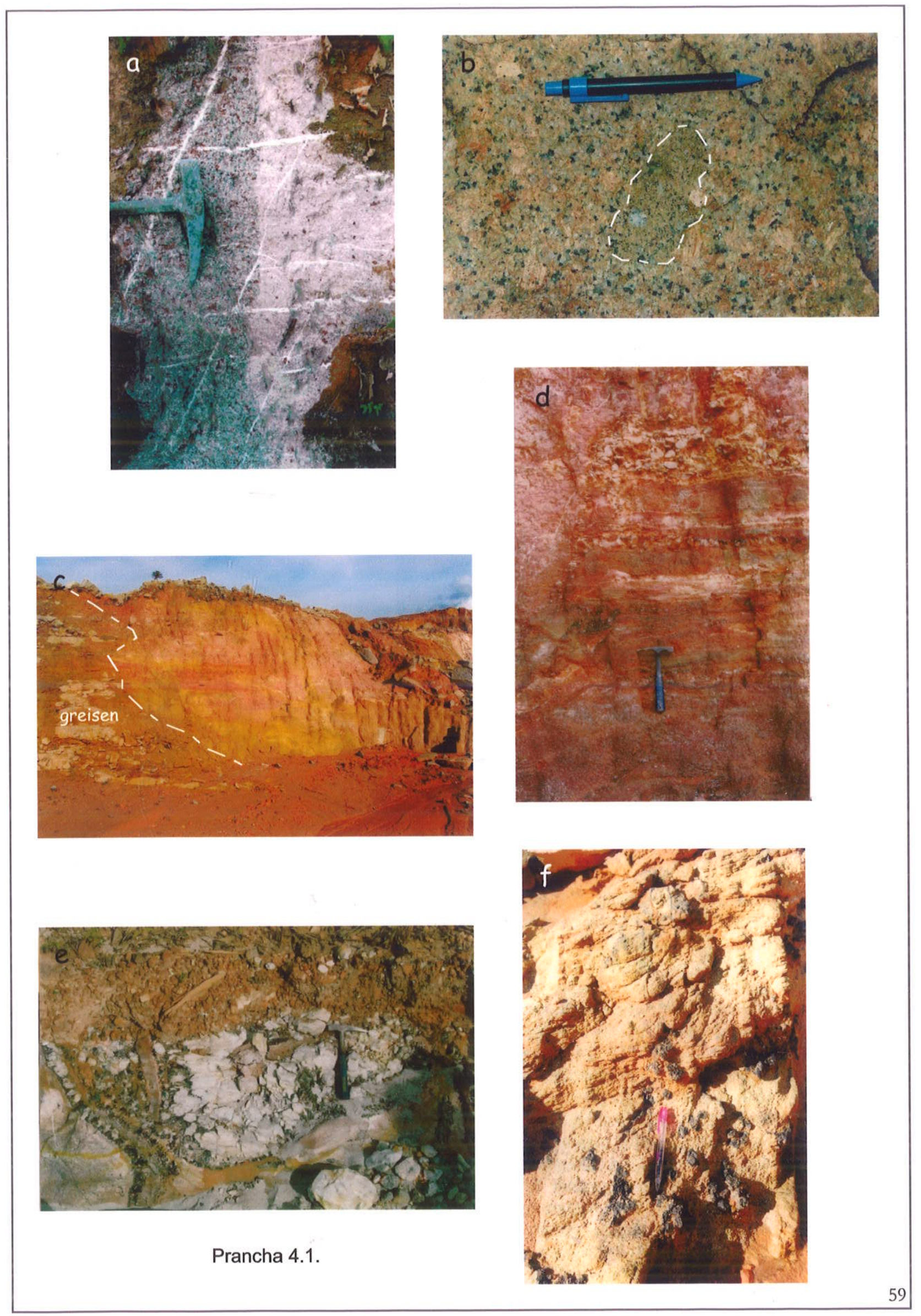


Prancha 4.2 - a) Alteração muscovítica tardia, controlada por fratura subvertical. Observa-se escape lateral na base do corpo tabular de topázio-siderofilita-quartzo greisen, localizado no topo da seção, sugerindo que o mesmo agiu como tampão para essa alteração hidrotermal; b) visão do pit do Greisen Taboquinha, que destaca corpo tabular de topázio-siderofilitaquartzo greisen equigranular médio, na porção superior do corte, hospedado em granito albitizado e greisenizado, em tons amarelados, na parte inferior; c) aspecto lenticular dos corpos tabulares de topázio-siderofilita-quartzo greisen; d) limites laterais bruscos, de alto ângulo $\left(\mathrm{N} 77^{\circ} \mathrm{E}, 74 \mathrm{SE}\right)$, entre corpo tabular de topázio-siderofilita-quartzo greisen, à direita, e as encaixantes hidrotermalizadas, à esquerda; e) stockwork de topáziosiderofilita-quartzo greisen em seção horizontal. A lapiseira amarela e o cabo do martelo marcam a direcional $\mathrm{N} 30^{\circ} \mathrm{E}$; f) veio subvertical (direcional $\mathrm{N} 60^{\circ} \mathrm{E}$ ) de quartzo grosso com cassiterita subordinada em seção vertical; g) zona de alteração muscovítica no núcleo de veio de greisen (direcional $\mathrm{N} 15^{\circ} \mathrm{E}$ ), em seção vertical. Compreende porção central verde, muscovítica equigranular fina, com $15 \mathrm{~cm}$ de espessura, um nível intermediário de topázio-siderofilita-quartzo greisen muscovitizado, equigranular médio, com $11 \mathrm{~cm}$ de espessura, e borda externa de topázio-siderofilita-quartzo greisen com muscovita subordinada, equigranular médio, de $30 \mathrm{~cm}$ de espessura; h) aspecto do stockwork caulinítico em seção vertical. 


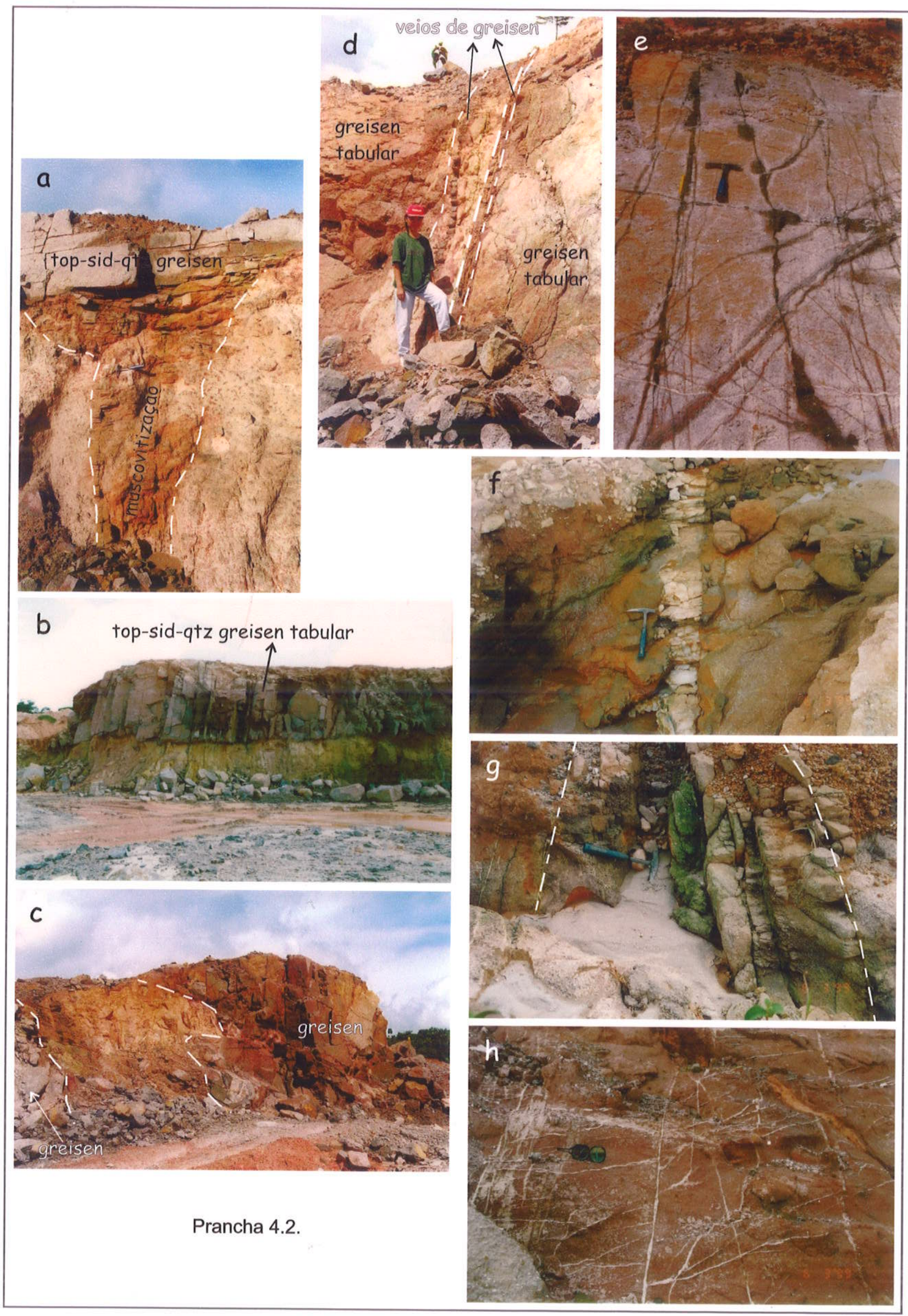




\section{PETROGRAFIA}

\subsection{Introdução}

\subsubsection{Granitos rapakivi}

Granitos rapakivi são granitos do tipo $A$ caracterizados pela presença de variedades graníticas com textura rapakivi, pelo menos nos batólitos maiores. Apresentam diferentes tipos texturais, incluindo wiborgitos (com ovóides manteados), piterlitos (com ovóides não manteados), granitos porfiríticos com megacristais de feldspato potássico não manteados, angulares ou subangulares, e granitos equigranulares (Rämö \& Haapala 1995).

As variedades mais precoces são biotita-hornblenda granitos com fayalita, enquanto que as mais jovens compreendem microclínio-albita granitos com topázio, cuja fase mineral varietal é representada pela siderofilita litinífera. Fluorita, zircão, allanita, apatita, anatásio, magnetita, ilmenita, monazita, topázio, bastnaesita, cassiterita e columbita estão entre os minerais acessórios típicos. As fases precoces geralmente cristalizaram a partir de magmas subsaturados em $\mathrm{H}_{2} \mathrm{O}$, enquanto que o inverso se verifica para as fases tardias (Haapala \& Rämö 1990)

A textura rapakivi, conforme originalmente definida por Vorma (1976) para os granitos escandinavos, caracteriza-se pela forma ovóide dos megacristais de feldspato alcalino, pelo manteamento da maior parte desses ovóides por oligoclásio-andesina, e pela presença de duas gerações de feldspato alcalino e quartzo, sendo o quartzo mais antigo euédrico e cristalizado como quartzo $\beta$. Tem-se observado ocasionalmente na literatura, entretanto, a descrição de mantos de plagioclásio sobre cristais angulares de feldspato alcalino como textura rapakivi (Rämö \& Haapala 1995).

Segundo Rämö \& Haapala (1995), os ovóides podem consistir de cristais isolados, com ou sem geminação Carlsbad, ou intercrescimentos complexos de vários cristais. São comuns inclusões de plagioclásio, quartzo, hornblenda, biotita e zircão em uma ou mais zonas concêntricas.

Os mantos de plagioclásio podem formar uma ou várias zonas, contínuas ou descontínuas, inclusive dentro dos megacristais de feldspato alcalino, e consistir de um único cristal de 
oligoclásio-andesina em continuidade ótica com as lamelas de albita da pertita do ovóide, ou de vários cristais de plagioclásio com orientações distintas. Na parte externa dos ovóides, próximo ao manto de plagioclásio, são comuns inclusões do último com a mesma orientação ótica do manto e da albita das pertitas.

As primeiras fases minerais formadas neste tipo de granito são megacristais intratelúricos, enquanto que a matriz dos granitos porfiríticos e diques de quartzo-feldspato pórfiro evidencia cristalização rápida ao nível da colocação do corpo. Biotita e anfibólio são geralmente anédricos e intersticiais aos cristais de quartzo e feldspato (Rämö \& Haapala 1995).

Depósitos de $\mathrm{Sn}(-\mathrm{W}-\mathrm{Be}-\mathrm{Zn}-\mathrm{Pb}-\mathrm{Ag})$ dos tipos greisen, escarnito e veios em granitos rapakivi estão associados com microclínio-albita granitos com topázio especializados geoquímica e mineralogicamente, que exibem expressivas reações subsolidus e podem mostrar-se inteiramente alterados hidrotermalmente (Haapala 1977; Rämö \& Haapala 1995).

As alterações hidrotermais que afetam granitóides mineralizados com elementos raros incluem, principalmente, feldspatização potássica, feldspatização sódica e greisenização (Pollard 1983).

Cabe ressaltar que, historicamente, os pesquisadores russos (e.g., Serebryakov 1961, Beus e Zalashkova 1964, Beus 1982) atribuíam todos esses processos de alteração ao estágio pós-magmático, denominando-os conjuntamente autometassomatismo. Devem-se a eles os modelos clássicos de alteração de granitóides mineralizados, com uma estruturação vertical das diferentes zonas e tipos de alteração, bem como a definição das relações temporais relativas desses processos como microclinização precoce, albitização precoce, greisenização, albitização tardia e microclinização tardia. Essa sequêencia corresponderia a uma evolução da atividade máxima relativa de cátions nas soluções pós-magmáticas do tipo $\mathrm{K} \rightarrow \mathrm{Na} \rightarrow \mathrm{Si} \rightarrow \mathrm{Al} \rightarrow \mathrm{Na} \rightarrow \mathrm{K}$.

\subsubsection{Feldspatização potássica}

A feldspatização potássica magmática geralmente não é reconhecida, mas a mesma desenvolvida em condições pós-magmáticas manifesta-se pela substituição de plagioclásio por microclínio, de plagioclásio e de matriz fina por microclínio, de plagioclásio por ortoclásio e substituição parcial de minerais ferro-magnesianos (Serebryakov 1961, Beus \& Zalashkova 1964, Pollard 1983). 


\subsubsection{Feldspatização sódica}

A feldspatização sódica comumente culmina com a geração de minerais ricos em flúor e lítio. Em condições magmáticas, consiste da cristalização de fusões ricas em sódio, sendo o quartzo snowball uma textura típica (Xu et al. 1987; Pollard 1988; Schwartz 1992). 'Thata-se de megacristais de quattzo com abundantes inclusões de albita ripiforme e de mica arranjadas concentricamente, segundo os planos de crescimento do hospedeiro. Feição semelhante é descrita por Schwartz (1992) em feldspato potássico, gerando um padrĩo romboédrico.

Em condições pós-magmáticas, a feldspatização sódica é expressa pela substituição do feldspato potássico por albita, comumente na forma de crescimento de pertitas de substituição a expensas de pertitas de exsolução pré-existentes, pela substituição direta do feldspato potássico por cristais de albita neoformados segundo as clivagens $(010)$ e (001), gerando a albita chessboard, e pelo desenvolvimento de swapped rims sobre cristais de feldspato alcalino adjacentes (Serebryakov 1961, Pollard 1983). Também a formação de mirmequita é atribuída por Serebryakov (1961) à feldspatização sódica.

Haapala (1997) enfatiza que, em granitos, a albita pode ser formada por 1) cristalização magmática, 2) exsolução do feldspato alcalino, 3) de-anortização do plagioclásio e 4) albitização metassomática. Os processos 2 a 4 são pós-magmáticos, mas somente o quarto processo envolve aporte de sódio e, portanto, metassomatismo alcalino, e tem como característica o avanço ao longo de fissuras e fraturas, a partir das quais ocorre substituição parcial ou total do feldspato alcalino por albita chessboard.

Segundo Richardson (1988 e referências nele), a distinção entre pertita de exsolução e de substituição baseia-se na forma irregular da pertita de substituição, independente de orientações estruturais ou cristalográficas do feldspato potássico hospedeiro; na ocortência de pertita de substituição tipo bleb unicamente nas margens e segundo fratutas e planos de macla do hospedeiro; no fato de a albita secundária poder penetrar e substituir outros minerais; na presença de albita patchwork ou chessboard no restante do cristal de feldspato potássico, e na alteração das fases associadas para mica branca, estando a albita secundátia isenta de alterações.

O plagioclásio que substitui o feldspato potássico tem um conteúdo de anortita nunca superior a $\mathrm{An}_{29}$. Os produtos extremos desse processo são rochas compostas predominantemente por albita e quartzo, onde o plagioclásio tem um conteúdo máximo de anortita de $\mathrm{An}_{12}$ (Serebryakov 1961; Beus e Zalashkova 1964). 
As primeiras vatiedades de plagioclásio formadas por feldspatização sódica seriam, segundo Serebryakov (1961), grãos primásios inteiramente albitizados, com um grande número de produtos secundários e extinção ondulante sutil. A seguir, ocorreria uma variedade de plagioclásio com maclas da albita finas e médias, contínuas. Mais tardia no processo seria a albita chessboard, e finalmente, sob condições de baixa temperatura, plagioclásio com maclas da albita finas, descontínuas e acunhadas, com áreas de albita chessboard incipiente.

Ao estudar a substituição de plagioclásio primário em sistemas pórfiros, Leitch (1981) identificou os seguintes tipos de feldspatos alcalinos secundários em ordem de intensidade crescente de alteração hidrotermal: albita límpida $\left(A \mathrm{n}_{10}\right)$, albita patchwork $\left(A \mathrm{n}_{5-10}\right)$, albita chessboard $\left(A \mathrm{n}_{0-10}\right)$, albita irregular $\left(A n_{0} A b_{100}\right.$ a $\left.A b_{90} O r_{10}\right)$, anoralbita $\left(A b_{90} O r_{10}\right.$ a $\left.A b_{70} O r_{30}\right)$, e ortoclásio $\left(A b_{401} O r_{60}\right.$ a $\left.O r_{100}\right)$. Segundo o autor, os feldspatos alcalinos secundários mais sódicos caracterizariam depósitos subeconômicos ou zonas marginais de depósitos maiores, enquanto que aqueles mais potássicos constituiriam indicativo da existência de zonas mais fortemente mineralizadas.

O primeiro passo na alteração do plagioclásio primário seria sua substituição pela albita límpida, nas bordas, e por albita com maclas da albita finas, em domínios, levando à destruição da zonação magmática do plagioclásio. A seguir, dar-se-ia a substituição do plagioclásio oriundo do processo anterior por albita patchwork, na forma de vários pequenos domínios quadrangulares de albita com maclas finas, orientados perpendicularmente uns em relação aos outros. Um tipo menos comum de alteração seria a substituição da andesina oligoclásio primário por albita ao longo dos planos de macla (albita chessboard). Todos os tipos anteriores seriam substituídos por grãos anédricos, com maclas geralmente ausentes ou pouco visíveis, de albita irregular. Essa variedade se caracterizaria pela abundância de inclusões diminutas de hematita e argilominerais, conferindo-lhe uma aparência nebulosa ou suja em nicóis cruzados e descruzados, respectivamente, e uma cor vermelha ou pink em amostra de mão. A ocorrência de flocos de sericita randomicamente orientados também é observada. Ao perder seus planos de macla, no intervalo composicional $A b_{90} O r_{10}-$ $A b_{70} \mathrm{Or}_{30}$, a albita é denominada anoralbita. Finalmente, o ortoclásio substitui todos os tipos descritos anteriormente, apresentando, comumente, diminutas e múltiplas inclusões de hematita e argilominerais, da mesma maneira que a albita irregular. Geralmente exibe cor pink em amostra de mão. É o único tipo a assumir coloração amarela no tratamento com ácido fluorídico e cobaltinitrito de sódio. Em seção delgada, a anoralbita e o ortoclásio são indistinguíveis.

Destes, a albita límpida e parte da albita patchuork são considerados por Leitch (1981) como possivelmente tardi-magmáticos ou deutéricos, não necessariamente vinculados a processos mineralizantes. A parte mais tardia da albita patchıyork já representaria uma transição para condições 
hidrotermais.

\subsubsection{Greisenização}

A greisenização se dá através da substituição dos feldspatos e da mica por quartzo, micas, minerais de flúor, topázio, fluorita e apatita (Beus e Zalashkova 1964; Pollard 1983). A maior parte da minérlização primário em depósitos de metais raros ocorre associada à greisenização.

Conforme Stemprok (1987), a greisenização é um processo metassomático relacionado à origem de granitos leucocráticos ricos em sílica, que age sobre rochas sólidas e causa a decomposição de biotita e feldspatos, que são substituídos por agregados de micas, quartzo, topázio, fluorita e turmalina, e remobilização de sílica e alumina com considerável aporte de estanho, tungstênio, molibdênio ou berílio. Pode ser precedida ou seguida por processos de feldspatização sódica e potássica, e diferenciada em greisenização controlada por fissuras ou greisenização pervasiva.

No progtesso da substituição metassomática dos minerais primários, observa-se uma tendência geral de dissolução da biotita em primeiro lugar, seguida de plagioclásio e de feldspato potássico, no caso dos greisens desenvolvidos sobre protólitos gtaníticos. Numa primeira etapa, a substituição desses minerais tende a preservar a forma original dos grãos, mas durante a reação progressiva essa tendência é gradualmente perdida e a rochá é completamente reconstituída. Finalmente, em rochas com diferenças granulométricas significativas, os cristais menores tendem a ser alterados primeiramente que os maiores (Stemprok 1987).

Em greisens controlados por fissuras, um zoneamento mineral é observado a partir do conduto, com transições de centros ricos em topázio, turmalina, mica ou quartzo para zonas intermediárias de quartzo-topázio-mica e quartzo-mica, passando para rochas greisenizadas. Zoneamentos verticais também podem ser observados, e caracterizam-se pelo desenvolvimento das zonas internas dos greisens nas partes inferiores do sistema e das zonas externas nas regiões superiores. Mas essa zonação vertical pode ser extremamente complexa e de difícil reconhecimento, dada a pulsação dos fluidos greisenizantes (Stemprok 1987).

Em alguns depósitos pode ocorrer ainda feldspatização sódica e potássica pós-greisenização, representadas por veios tardios e substituiçôes de topázio e micas por albita, e pelo crescimento de novos feldspatos potássicos ou recristalização dos pré existentes, gerando feldspatos isentos de pertita. A caulinização também é comum (Beus e Zalashkova 1964; Pollard 1983). 


\subsection{Caracterização Petrográfica do Maciço Granítico Santa Bárbara}

\subsubsection{Composição modal das rochas do maciço}

Os resultados da contagem modal de 33 amostras de gratitos e hidrotermalitos do Maciço Gtanítico Santa Bárbara estão integralizados nas Tabelas 5.I e 5.II.

A classificação modal das rochas magmáticas do Maciço Granítico Santa Bárbara segundo Streckeisen (1976) encontra-se ilustrada na Fig. 5.1.a. Os critérios de Ramsay et al. (1986) foram levados em consideração na escolha do vértice (A ou P) para o cômputo dos teores de plagioclásio, bem como na escolha dos nomes das rochas.

A classificação modal dos greisens conforme Kühne et al. (1972 in Stemprok 1987) está ilustrada na Fig. 5.1.b.

\subsubsection{Unidades Litológicas Magmáticas}

Os granitos do maciço ocupam o campo das rochas graníticas do tipo $A$ (cf. Bowden et al. 1984) no diagrama QAP. As rochas da fácies Serra do Cícero são classificadas como sienogranitos, ao passo que os litotipos da fácies Serra Azul e da associação de fácies Santa Bábara ocupam a aresta dos álcali-feldspato granitos, ou albita-microclínio granitos conforme os critérios de Ramsay ct al. (1986). As rochas das fácies Santa Bárbata média e Santa Bárbara fina não diferem significativamente em termos de composição modal (Fig. 5.1.a).

\section{a) Fácies Serra do Cícero (fSC)}

As rochas da fácies Serra do Cícero são maciças e homogêneas, rosa, leucocráticas, hipidiomórficas e porfiríticas de granulação média (Prancha 5.1.a). Microclínio pertítico, albita-oligoclásio e quartzo compõem sua mineralogia essencial, enquanto que a mica é a fase varietal e zircão, monazita, fluorita e topázio são acessórios.

O conteúdo de megacristais desses granitos varia de cerca de 5 a $12 \%$. Estes megacristais têtn comprimentos de até $2,5 \mathrm{~cm}$, e são de microclínio, predominantemente, e de plagioclásio. Quando de microclínio, ocorrem isolados ou em agregados de 3 ou 4 cristais. Se de plagioclásio, é comum exibirem cor verde à vista desarmada em função da intensa substituição por sericita. 
Tabela 5.1. Proporções modais dos lítotipos magmáticos do Macico Granítico Santa Bárbara

\begin{tabular}{|c|c|c|c|c|c|c|c|c|}
\hline MINERAI. & $p(\%)$ & erro $\%$ & $p(\%)$ & erro $6 \%$ & $p(\%)$ & erro $\%$ & $p(\%)$ & erro $(\%)$ \\
\hline Quartzo & 274 & 5,6 & 375 & 6,6 & 314 & 4,5 & 307 & 4,9 \\
\hline Microclínio & 47,4 & 6,5 & 53,2 & 7,3 & 508 & 7,1 & 47.0 & 5.9 \\
\hline Plagioclásio & 178 & 3.5 & 8,5 & 3,2 & 13,4 & 4.5 & 19,9 & 3,3 \\
\hline Siderofilita & 5,9 & 2,6 & 3.8 & 2,0 & 2,8 & 1,3 & 6,9 & 25 \\
\hline Topázio & 0,1 & 0,3 & 2,5 & 25 & 0,0 & 0,0 & 0.0 & 0,0 \\
\hline Fengita & 0,0 & 0,0 & 0.0 & 00 & 0,4 & 0,5 & 0,3 & 0,4 \\
\hline Fiuorita & 0.8 & 07 & 0,5 & 0,6 & 0.7 & 0,6 & 10 & 0,7 \\
\hline Monazita & 0.5 & 0,6 & 0,0 & 0,0 & 00 & 0,0 & 0,0 & 0.0 \\
\hline Opacos & 0.0 & 00 & 0,0 & 0,0 & 0,0 & 00 & 0,0 & 0,0 \\
\hline Zircão & 0,1 & 0,3 & 0,0 & 0,0 & 0,0 & 0,0 & 0,1 & 0,3 \\
\hline Cassiterita & 0,0 & 0,0 & 0,0 & 0,0 & 0,0 & 0.0 & 0.0 & 0,0 \\
\hline \% Megacristais & 123 & $=$ & 8,9 & - & 9,3 & 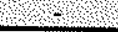 & 5,0 & - \\
\hline
\end{tabular}

\begin{tabular}{|c|c|c|c|c|c|c|c|c|}
\hline AMOSTRA & & $3 \mathrm{~B}$ & & & & 59 & & 19 \\
\hline FACIES & & & & & & & & edia \\
\hline MINERAL & $p(\%)$ & erro (\%) & $p(\%)$ & erro (\%) & $p(\%)$ & erro (\%) & $p(\%)$ & erro $(\%)$ \\
\hline Quartzo & 33,5 & - & 38,9 & - & 34,2 & $\therefore$ & 39,0 & 5,3 \\
\hline Microcilínio & 43,9 & - & 43,8 & . & 45,7 & - & 29,8 & 3,7 \\
\hline Plagioclásio & 15,4 & - & $\uparrow 1,1$ & . & 13,7 & - & 24,7 & 5,0 \\
\hline Siderofilita & 6,8 & - & 6,3 & - & 4,8 & . & 42 & 16 \\
\hline Topázio & - & - & - & - & . & - & 15 & 10 \\
\hline Fengita & - & - & & - & - & * & 0,3 & 0,4 \\
\hline Fluorita & - & - & - & - & - & - & 0,3 & 0,4 \\
\hline Monazita & - & $\sim$ & - & - & - & - & 0,0 & 0,0 \\
\hline Opacos & - & - & - & - & - & - & 0,1 & 0,3 \\
\hline Zircão & - & - & - & - & - & . & 0,0 & 00 \\
\hline Cassiterita & - & - & - & - & - & 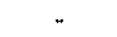 & 0,0 & 0,0 \\
\hline$\%$ Megacristais & - & - & - & - & . & - & 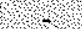 & (1) \\
\hline
\end{tabular}

\begin{tabular}{|c|c|c|c|c|c|c|c|c|}
\hline $\begin{array}{l}\text { AMOSTRA } \\
\text { FACIES }\end{array}$ & & & & & & & & \\
\hline MINERAL & $0(\%)$ & erro $(\%)$ & $p . \%)$ & $\frac{\mathrm{d} l i a}{\text { orro } \%}$ & & & & \\
\hline Quartzo & 35,4 & $47 \%$ & 343 & $\frac{e r r o(\%)}{47}$ & $p(\%)$ & erro $(\%)$ & $p(\%)$ & erro $(\%)$ \\
\hline Microcínio & 26,0 & 3 & 28.3 & $4 \%$ & 36,1 & 77 & 40,4 & 4,9 \\
\hline Plagioclásio & 32,4 & 38 & 29,3 & 3,6 & 32.0 & 5,9 & 26.7 & 5,3 \\
\hline Siderofilita & 4,0 & 13 & 47 & 5,0 & 28,0 & 5.5 & 216 & 3,1 \\
\hline Topázio & 0,8 & 05 & 40 & 2,6 & 3,3 & 11 & 5,3 & 1,1 \\
\hline Fengita & 10 & 06 & 190 & 0,9 & 04 & 0.5 & 12 & 10 \\
\hline Filuorita & 0,2 & 0,3 & 12 & 07 & 0,2 & 0,4 & 41 & 16 \\
\hline Monazita & 0,0 & 0,0 & 10 & 0,9 & 0,0 & 0,0 & 0,4 & 0,4 \\
\hline Opacos & 0,1 & 0,2 & 00 & 0,0 & 0,0 & 0,0 & 0,0 & 0,0 \\
\hline Zircão & 0,0 & 0.0 & 0,0 & 0,0 & 0,0 & 0,0 & 0,0 & 0,0 \\
\hline Cassiterita & 0,0 & 0,0 & 0,0 & 00 & 0,0 & 0,0 & 0,0 & 0,0 \\
\hline$\%$ Megacristais & ) & sis & 3,6 & ; & vie & 0.0 & 28 & 02 \\
\hline
\end{tabular}

\begin{tabular}{|c|c|c|c|c|c|c|c|c|}
\hline \multirow{2}{*}{$\begin{array}{l}\text { AMOSTRA } \\
\text { FACIES } \\
\text { MINERAL }\end{array}$} & \multirow{2}{*}{\multicolumn{2}{|c|}{$\begin{array}{l}\mathrm{AM} 224 \\
\mathrm{TSB} \text { média }\end{array}$}} & \multicolumn{2}{|c|}{$\begin{array}{l}\mathrm{AM} 252 \\
\mathrm{SB} \text { médla }\end{array}$} & \multicolumn{2}{|c|}{$\frac{A M \sim 38}{\text { fSB fina }}$} & \multicolumn{2}{|c|}{ AM-50A } \\
\hline & & & & édla & $p(\%)$ & erro $(\%)$ & $p(\%)$ & $\frac{\text { ina }}{\text { erro }(\%)}$ \\
\hline Microclínio & 30,3 & 45 & 481 & 6,3 & 23,8 & 3,1 & 17,2 & 3,6 \\
\hline Plagioclásio & 24.6 & 29 & 154 & 3,4 & 30,9 & 2,5 & 34,4 & 3,9 \\
\hline Siderofilita & 5.8 & 1,8 & 4,4 & 17 & 4,5 & 1,4 & 5,6 & 1,7 \\
\hline Topázio & 0.6 & 0.5 & 16 & 11 & 2,7 & 1,1 & 2,4 & 1,6 \\
\hline Fengita & 3,8 & 12 & 21 & 0,9 & 3,5 & 1,2 & 1,8 & 1,5 \\
\hline Fluorita & 0,3 & 0,3 & 0.8 & 0,6 & 0,2 & 0,3 & 0,4 & 0,5 \\
\hline Monazita & 0.0 & 0,0 & 0,0 & 0,0 & 0,0 & 0,0 & 0,0 & 0,0 \\
\hline Opacos & 0,4 & 0,3 & 0,6 & 0,6 & 0,0 & 0,0 & 0,0 & 0,0 \\
\hline Zircão & 0,0 & 00 & 00 & 0,0 & 0,0 & 0,0 & 0,0 & 0,0 \\
\hline Cassiterita & 0,0 & 00 & 0,0 & 0,0 & 0,0 & 0,0 & 0,0 & 0,0 \\
\hline$\%$ Megacristais & 17 & 4 & 2,7 & 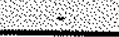 & 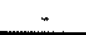 & - & - & $\sim$ \\
\hline
\end{tabular}


Tabela 5.1. Proporçöes modais dos litotipos magmáticos do Macico Granítico Santa Bárbara.

\begin{tabular}{|c|c|c|c|c|c|c|c|c|}
\hline \multirow{3}{*}{$\begin{array}{l}\text { AMOSTRA } \\
\text { FACIES } \\
\text { MINERAL }\end{array}$} & \multirow{2}{*}{\multicolumn{2}{|c|}{$\begin{array}{r}\text { AM-144 } \\
\text { fSB fina }\end{array}$}} & \multirow{2}{*}{\multicolumn{2}{|c|}{$\frac{\mathrm{AM}-145 \mathrm{~A}}{\mathrm{fSB} \text { fina }}$}} & \multirow{2}{*}{\multicolumn{2}{|c|}{$\frac{\mathrm{AM}-275}{\mathrm{fSB} \text { fina }}$}} & \multirow{2}{*}{\multicolumn{2}{|c|}{$\begin{array}{l}\text { AM-278 } \\
\text { fSB fina }\end{array}$}} \\
\hline & & & & & & & & \\
\hline & $p(\%)$ & erro (\%) & $p(\%)$ & erro (\%) & $p(\%)$ & erro (\%) & $p(\%)$ & erro (\%) \\
\hline Quartzo & 38,0 & 3,9 & 31,3 & 3,9 & 34,8 & 3,7 & 40,7 & 3,5 \\
\hline Microclínio & 29,9 & 3,3 & 39,6 & 4,3 & 29,2 & 3,6 & 29,8 & 3,5 \\
\hline Plagioclásio & 25,2 & 3,7 & 22,4 & 4,1 & 28,8 & 2,3 & 24,7 & 3,1 \\
\hline Siderofilita & 5,0 & 1,5 & 4,5 & 1,3 & 3,0 & 1,1 & 3,4 & 1,4 \\
\hline Topázio & 1,0 & 0,7 & $\uparrow, 5$ & 0,9 & 1,2 & 0,8 & 0,8 & 0,6 \\
\hline Fengita & 0,3 & 0,3 & 0,0 & 0,0 & 0,4 & 0,4 & 0,1 & 0,3 \\
\hline Fluorita & 0,6 & 0.5 & 0,7 & 0,6 & 0,0 & 0,0 & 0,0 & 0,0 \\
\hline Monazita & 0,0 & 0,0 & 0,0 & 0,0 & 0,0 & 0,0 & 0,0 & 0,0 \\
\hline Opacos & 0,0 & 0,0 & 0,0 & 0,0 & 0,2 & 0,4 & 0,0 & 0,0 \\
\hline Zircão & 0,1 & 0,2 & 0,0 & 0,0 & 0,0 & 0,0 & 0,0 & 0,0 \\
\hline Cassiterita & 0,0 & 0,0 & 0,0 & 0,0 & 0,0 & 0,0 & 0,0 & 0,0 \\
\hline$\%$ Megacristais & 3,1 & - & 2,0 & - & - & - & - & - \\
\hline
\end{tabular}

\begin{tabular}{|c|c|c|c|c|c|c|}
\hline AMOSTRA & & & & 34 & & 39 \\
\hline FACIES & & & & & & branca \\
\hline MINERAL & $p(\%)$ & erro (\%) & $p(\%)$ & erro $(\%)$ & $p(\%)$ & erro $(\%)$ \\
\hline Quartzo & 37,4 & 4,4 & 35,7 & 4,1 & 36,1 & 3,4 \\
\hline Microclínio & 27,3 & 3,0 & 264 & 3,7 & 28,3 & 3,4 \\
\hline Plagioclásio & 21,7 & 2,6 & 307 & 3,9 & 28.6 & 3.2 \\
\hline Siderofilita & 7,8 & 2,4 & 49 & 14 & 5,6 & 16 \\
\hline Topázio & 0,0 & 0,0 & 21 & 12 & 11 & 0,8 \\
\hline Fengita & 3,7 & 1,5 & 0,0 & 0,0 & 0,1 & 0,2 \\
\hline Fluorita & 0,5 & 0,5 & 0,0 & 0,0 & 0,1 & 0,2 \\
\hline Monazita & 0,0 & 0,0 & 0,0 & 00 & 0,0 & 0,0 \\
\hline Opacos & 0,6 & 0,5 & 00 & 0,0 & 0,0 & 0,0 \\
\hline Zircão & 0,0 & 0,0 & 0.0 & 0,0 & 0,0 & 0,0 \\
\hline Cassiterita & 0,0 & 0,0 & 00 & 0.0 & 0,0 & 0,0 \\
\hline$\%$ Megacristais & + & $\sim$ & 1,4 & 4 & 4 & , \\
\hline
\end{tabular}

Tabela 5.11. Proporcẽes modais dos hidrotermalitos do Maciço Granítico Santa Bárbara.

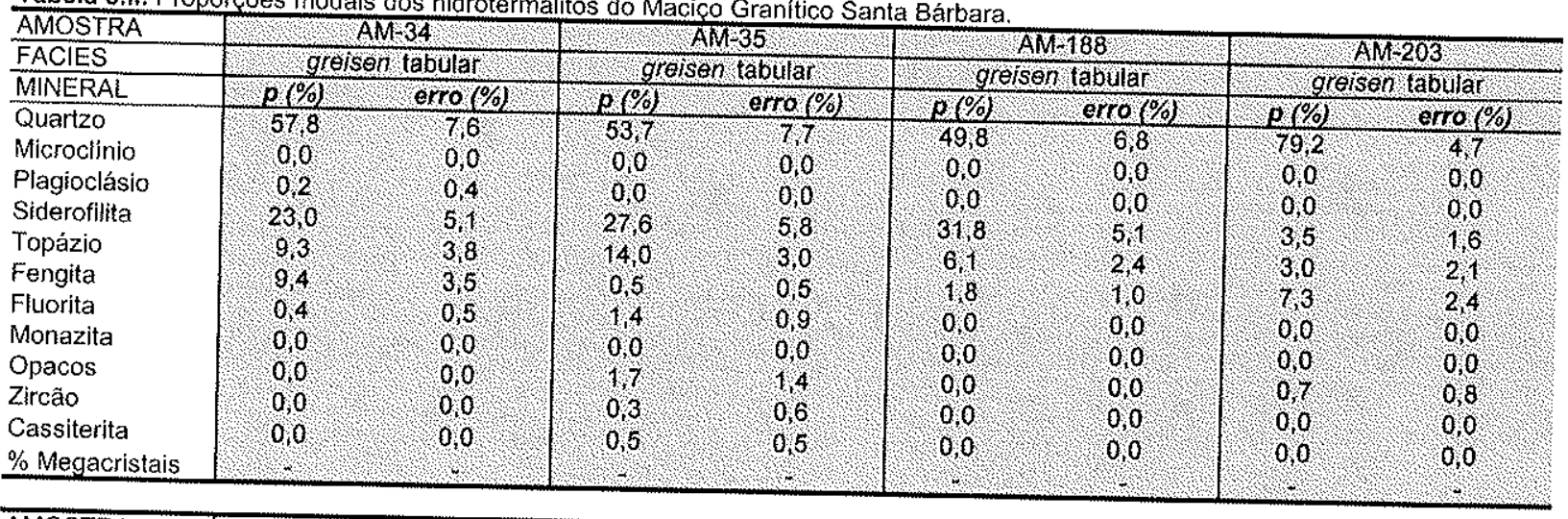

\begin{tabular}{|c|c|c|c|c|c|c|c|c|}
\hline AMOSTRA & \multicolumn{2}{|c|}{$\mathrm{AM}-13 \mathrm{~A}$} & \multicolumn{2}{|c|}{$\mathrm{AM}-14 \mathrm{~B}$} & \multicolumn{2}{|c|}{$A M-102 A$} & \multicolumn{2}{|c|}{$A M+130$} \\
\hline FACIES & & & & salmão & gran & salmâo & & \\
\hline MINERAL & $p(\%)$ & erro (\%) & $p(\%)$ & erro (\%) & $p(\%)$ & erro $(\%)$ & $p \%$ & erro $\%$ \\
\hline Quartzo & 28,1 & 5.1 & 38,1 & 6,0 & 25,9 & 4,4 & 49.8 & 43 \\
\hline Microclínio & 18,5 & 3,2 & 18,8 & 2,8 & 22,7 & 4,6 & 0,0 & 0,0 \\
\hline Plagioclásio & 36,3 & 4,0 & 30,1 & 3,6 & 36,4 & 4,5 & 00 & 0,0 \\
\hline Siderofilita & 6,7 & 2,6 & 4,8 & 1,7 & 5,7 & 2,0 & 30,6 & 4,4 \\
\hline Topázio & 1,0 & 0,9 & 1,5 & 1,0 & 1,5 & 1,8 & 8,3 & 2,2 \\
\hline Fengita & 7,9 & 2,2 & 5,0 & 2,0 & 6,4 & 1,6 & 0.9 & 10 \\
\hline Fluorita & 1,5 & 1,5 & 0,6 & 0,5 & $\uparrow, 0$ & 0,9 & 0,0 & 0,0 \\
\hline Monazita & 0,0 & 0,0 & 0,0 & 0.0 & 0,0 & 0,0 & 0,0 & 00 \\
\hline Opacos & 0,0 & 0,0 & 0,0 & 0,0 & 0,3 & 0,4 & 0,0 & 0,0 \\
\hline Zircão & 0,0 & 0,0 & 0,0 & 0,0 & 0,0 & 0,0 & 0,0 & 0,0 \\
\hline Cassiterita & 0,0 & 0,0 & 0,0 & 0,0 & 0,0 & 0,0 & 0,0 & 0,0 \\
\hline$\%$ Megacristais & - & . & - & - & $\sim$ & - & 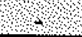 & - \\
\hline
\end{tabular}


Tabela 5.II. Proporcões modais dos hidrotermalitos do Maciço Granítico Santa Bárbara. AMOSTRA

\begin{tabular}{|c|c|c|c|c|}
\hline \multirow{2}{*}{$\begin{array}{l}\text { AMOSTRA } \\
\text { FACIES } \\
\text { MINERAL }\end{array}$} & \multicolumn{2}{|c|}{ V. } & \multicolumn{2}{|c|}{ AM-8 } \\
\hline & Velo & isen fino & bols & greisen \\
\hline Quartzo & $P(\%)$ & erro $(\%)$ & $p(\%)$ & erro (\%) \\
\hline Microclínio & 519 & 4,4 & 0,3 & 0,6 \\
\hline Plagioclásio & 0,2 & 0.5 & 0,0 & 0,0 \\
\hline Plagioclásio & 18,3 & 3,5 & 0,0 & 0,0 \\
\hline Siderofilita & 22,5 & 44 & 80,0 & 3,9 \\
\hline Topázio & 5,6 & 3,0 & 2,4 & 2,9 \\
\hline Fengita & 0,9 & 1,0 & 12,6 & 4,5 \\
\hline Fluorita & 0.7 & 0.7 & 0,0 & 0,0 \\
\hline Monazita & 0.0 & 0.0 & 0,0 & 0,0 \\
\hline Opacos & 0.0 & 0,0 & $\uparrow, 2$ & 1,4 \\
\hline Zircão & 0.0 & 0.0 & 0,0 & 0,0 \\
\hline Cassiterita & 0,0 & 0,0 & 0,0 & 0,0 \\
\hline$\%$ Megacristais & & & & \\
\hline
\end{tabular}

p-percentual modal; erro - refere-se às contagens de pontos em seçöes deigadas. 
a)
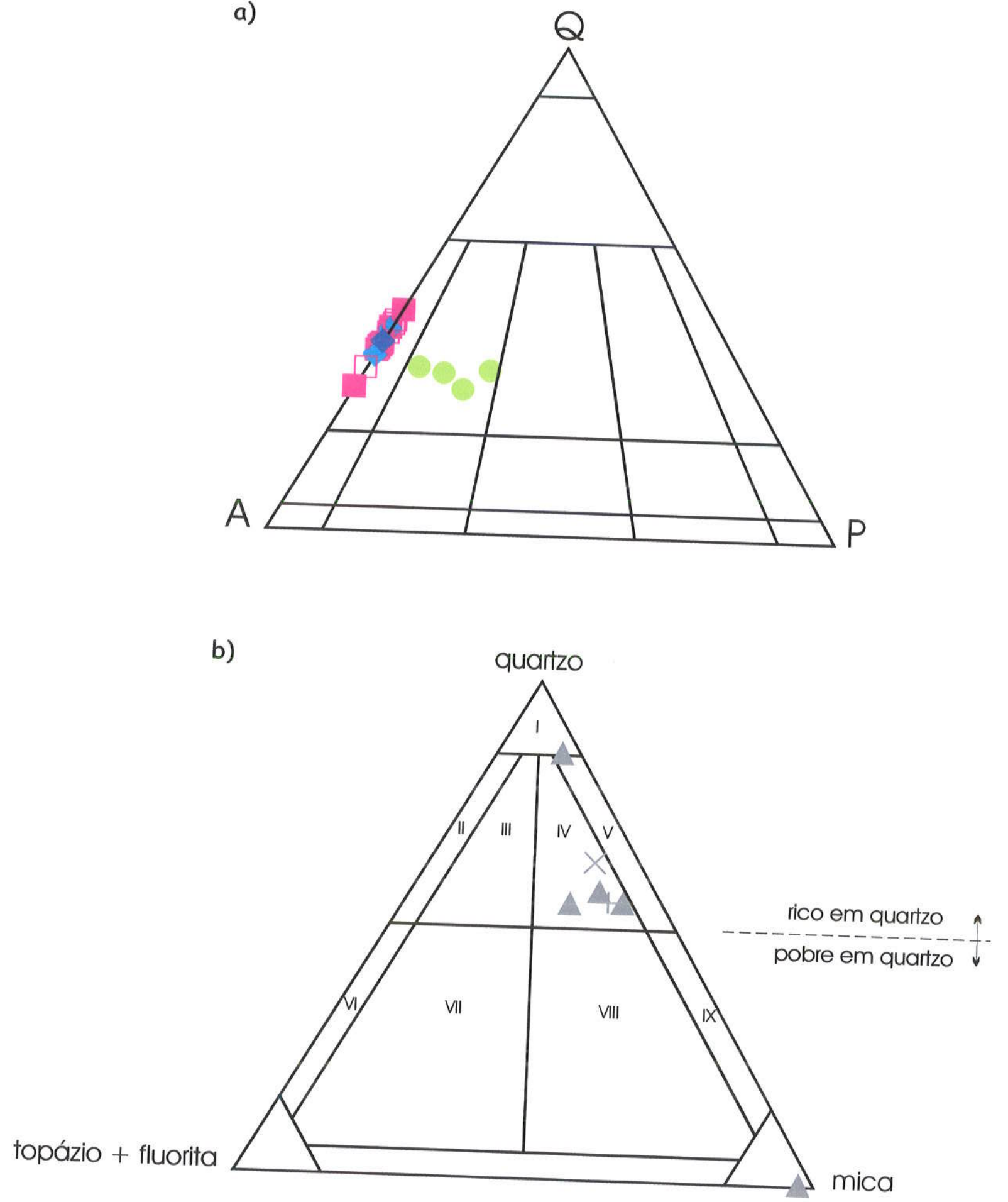

Figura 5.1. a) Diagrama QAP (Streckeisen 1976) exibindo a composição modal das rochas das facies Serra média $\square$, fina $\square$, e branca e associação de facies Santa Bárbara - subdividida nas facies greisens, mostrando a composição modal daqua de Kuhne et al. (1972) para a classificação de , de veios de granulação média + e de veios dequeles que ocorrem na forma de corpos tabulares VI - topázio; III e VII - mica-topázio; IV e VIII - topázioção fina X. Nomenclatura: I - quartzo; II e quartzo aos nomes dos greisens dos campos II a V. 
Os megacristais de microclínio são subédricos e anédricos, de dois tipos: mesopertita, caso em que podem ocorrer os agregados de 3 ou 4 indivíduos, e microclínio pertítico.

Os megacristais mesopertíticos são predominantemente arredondados e ovóides, raramente angulosos, e podem apresentar macla do tipo Carlsbad. A mesopertita é do tipo braid (Prancha 5.2.a).Via de regta, exibem manteamento de plagioclásio, configurando textura wiborgítica (Ptancha 5.2.b). Podem apresentar borda de 0,6 a $1,5 \mathrm{~mm}$ de largura onde ocorrem intercrescidos com quartzo vermicular. Inclusões de plagioclásio com núcleos fortemente sericitizados e bordas límpidas, albíticas, são comuns, e variam de $\sim 0,03$ a $0,7 \mathrm{~mm}$ de comprimento. Também ocorrem inclusões de mica.

O plagioclásio que ocorre como manto sobre os megacristais de mesopertita apresenta maclas da albita finas e regulares. Sua porção interna mostra forte sericitização, enquanto que a borda externa é límpida. Os mantos de plagioclásio são formados por mais de um cristal, e têm espessura vatiável entre 0,8 e $1,2 \mathrm{~mm}$ nas suas porções contínuas, monocristalinas. Englobam também agregados finos de mica, quartzo, fluorita, apatita e zircão, a última fase em quantidades acessórias, observada também inclusa no microclínio e no plagioclásio rapakivi. O limite entre o microclínio e o manto de plagioclásio é marcado pela presença de alguns cristais alongados e esfarrapados de mica paralelos ao contorno do primeiro. A mica também ocorre inclusa no manto de plagioclásio.

Os conteúdos de microclínio nas rochas da fácies Serra do Cícero vatiam de 41 a $53 \%$, incluídos os megacristais. O microclínio da matriz é predominantemente anédrico, mas cristais subédricos são comuns (Prancha 5.2.c). Mostra uma distribuição seriada dos comprimentos, variáveis desde 0,5 até $10,0 \mathrm{~mm}$. Alguns dos cristais maiores são ovóides. Exibe macla em grade, especialmente distinta nos cristais menores. Estabelece contatos planos e côncavo-convexos como quartzo e suturados com outros cristais de microclínio e com o plagioclásio. Exibe pertita de substituição em gânglios em graus variáveis.

O plagioclásio tem abundância de 8 a $20 \%$ na fácies Serra do Cícero, incluídos os megacristais. Na matriz, ocorre em cristais isolados, subédricos, e varia entre 0,3 e $6,5 \mathrm{~mm}$ de comprimento. Apresenta zonação magmática normal, núcleo geralmente sericitizado e borda límpida (Prancha 5.2.c). Sua composição situa-se no intervalo de $A n_{06}$ a $A n_{14}$, no núcleo, e entre $A n_{00}$ e $A n_{11}$, na borda.

O quartzo tem abundância de 27 a $32 \%$. É predominantemente subédrico e equidimensional, de hábito hexagonal, ocasionalmente arredondado. Pode ocorrer incluso no microclínio da matriz, 
raramente no plagioclásio. Ocorre em agregados de diversos cristais que variam de 0,1 a $2,5 \mathrm{~mm}$, mas são predominantemente menores que $0,6 \mathrm{~mm}$. Uma geração tardia, muito subordinada, ocorre na forma de grandes cristais anédricos, de contatos suturados, com extinção ondulante, que substitui a matriz da rocha. Varia de 0,4 a $6,5 \mathrm{~mm}$.

A mica presente na rocha ocorte como cristais subédricos e anédricos isolados ou $\mathrm{cm}$ agregados de até 5 indivíduos, e perfaz cerca de 3 a $7 \%$ do volume. Varia de 0,03 a 1,8 mm de comprimento paralelamente à clivagem (001). É pleocróica do amarelo ao castanho-avermelhado, e tem cores de interferência ocre, salmão e verde de $4^{\mathrm{a}}$ ordem, correspondentes a uma birrefringência máxima $/ 0,057$. Seu ângulo $2 \mathrm{~V}$ varia de 0 a $10^{\circ}$. É intercristalina aos feldspatos e ao quartzo, substituíndo incipientemente os primeiros a partir das bordas. Contém abundantes inclusões de monazita e zircão com fortes halos pleocróicos (Prancha 5.2.d). Mostra substituição em gxaus variáveis por fluorita e quartzo segundo os planos de clivagem, clorita verde (Prancha 5.2.e) e anatásio. Suas características óticas são compatíveis com composição siderofilítica.

Como mineral acessório ocorre fluorita incolor $(0,5$ a $0,8 \%)$, intercristalina, comumente em associação espacial com a siderofilita. Varia de 0,3 a $0,9 \mathrm{~mm}$ de diâmetro. $O$ zircão é comumente euédrico e ocorre em dois tipos bem distintos, um incolor e outro pardo. A monazita, em cristais incolores, anédricos a subédricos, é relativamente abundante (até $0,5 \%$ ), mas não freqüente.

O topázio é pouco freqüente, porém atinge abundância de até $2,5 \%$. Apresenta-se como cristais equidimensionais de até $2,5 \mathrm{~mm}$, de contatos planos.

A albita secundária tem sua ocorrência limitada às bordas sobre o plagiclásio precoce e à pertita de substituição em gânglios, localmente evoluídas para albita patch, no microclínio. Muito raramente, ocorre como bordas de albita sobre microclínio, ou como pequenos cristais neoformados intercristalinos, inteiramente límpidos.

\section{b) Fácies Serra Azul (fSA)}

Trata-se de rocha maciça e homogênea, rosa, leucocrática, hipidiomórfica, seriada ou equigranular de granulação média a grossa, composta essencialmente por microclínio pertítico, albita-oligoclásio e quartzo, tendo a mica como mineral varietal e fluorita, zircão, topázio e monazita como acessórios. É classificada como albita-microclínio granito (Fig. 5.1.a; Prancha 5.1.b).

O microclínio pertítico é a fase predominante, ocupando 43 a $46 \%$ da rocha. Compreende cristais anédricos e subédricos que variam de $1,2 \mathrm{~mm}$ a $4,0 \mathrm{~cm}$ (predominantemente $>5 \mathrm{~mm}$ ) de comprimento, o que confere freqüentemente textura seriada ̀̀ rocha. Ocorre freqüentemente 
maclado segundo a lei de Carlsbad, porém é isento da macla em grade. Apresenta-se turvo em nicóis paralelos e cruzados. Mostra extensa substituição por albita na forma de pertitas de substituição em gânglios e manchas (patch albite, conforme Richardson 1988), sendo as albitas patchwork e chessboard mais raras. Bordas de albita (albite rims), ocasionalmente com feições em dedos, e coroas trocadas (swapped rims) também são observadas. Contém inclusões hexagonais de quartzo subédrico e euédrico, de mica, e diminutas $(\sim 0,15$ a $0,30 \mathrm{~mm})$ inclusões de albita subédrica (Prancha 5.2.f).

O plagioclásio tem abundância de cerca de 11 a $15 \%$ nas rochas da fácies Serra do Cícero. É subédrico, variando de 0,4 a $5,0 \mathrm{~mm}$ de comprimento. Ocorre maclado segundo a lei da albita, ocasionalmente combinada com a da periclina e a de Carlsbad. Suas maclas da albita são finas e regulares, por vezes acunhadas. Pode apresentar núcleo substituído por fluorita + apatita e borda límpida. Sua composição é estimada como pertencente no intervalo $A_{n}(x)$ até $\operatorname{An}_{(4)}$, predominantemente, nas suas porções centrais, e $\mathrm{An}_{00}$ nas bordas límpidas. É tara a ocorrência de cristais com composição da ordem de $A \mathrm{n}_{26}$ no núcleo. Localmente, observa -se albita tardia na forma de pequenos $(0,3$ a $1,2 \mathrm{~mm})$ cristais subédricos, intergranulares ao plagioclásio precoce, e inteiramente límpidos, com maclas da albita extremamente finas e regulares.

O quartzo, em abundância de 33 a 38\%, ocorre em pelo menos duas gerações: uma precoce, de cristais isolados ou agregados, subédricos e euédricos, no último caso especialmente quando inclusos em microclínio, de formas hexagonais (Prancha 5.2.f); e outra tardia, na forma de agregados de grãos anédricos de contatos suturados, com extinção ondulante distinta. Aquele da primeira geração estabelece contatos planos e côncavo-convexos com outros cristais de quartzo da mesma geração e com microclínio, e varia de 0,6 a 7,0 $\mathrm{mm}$ de diâmetro. O quartzo tardio tem abundância subordinada. Exibe embainhamentos quando em contato com plagioclásio ou inclusões desse mineral parcial a totalmente substituídos por mica branca microcristalina. Inclusões de quartzo primitivo também ocorrem. Varia de 0,8 a $3,8 \mathrm{~mm}$ de diâmetro e contém abundantes inclusões de zircão.

A mica ocorte predominantemente em cristais isolados, compreendendo cerca de 4 a $7 \%$ das rochas. É subédrica a anédrica e tem hábito cúspide, intercristalino em relação aos feldspatos e ao quartzo. Substitui parcialmente os primeiros a partir das bordas. Apresenta características óticas transicionais desde um tipo primário, marrom, até um secundário, verde-claro. O tipo primário é pleocróico do amarelo-alaranjado ao marrom-sépia. Tem cor de interferência verde de $4^{3}$ ordem, correspondente a uma birrefringêtncia máxima /0,057. A mica secundária exibe pleocroísmo do incolor ao verde-claro e cores de interferência desde o amarelo passando pelo laranja, vermelho e 
rosa de $1^{a}$ ordem até o anil e o azul-esverdeado de $2^{a}$ ordem, correspondentes a uma birrefringência máxima de 0,023 . Ambas apresentatn $2 \mathrm{~V}$ de 0 a $10^{\circ}$, inclusões de zircão com proeminentes halos pleocróicos, e variam de 0,45 a $3,0 \mathrm{~mm}$. Podem ser classificadas como siderofilita. Fluorita anédrica incolor ocorre espacialmente associada com as micas.

As fases minerais acessórias são a fluorita e o zircão euédrico, pardo, incluso em quartzo e mica. A monazita ocorre muito subordinadamente. Topázio ocorre associado ao quartzo II.

Os processos de alteração tardi-magmática compreendem, além da geração de pertita patich sobre o microclínio e da substituição da mica, a substituição do microclínio por topázio intergranular na forma de agregrados de cristais anédricos e subédricos com 0,1 a $1,25 \mathrm{~mm}$ de diâmetro. Alterações deutéricas incluem substituição das micas supracitadas por outra amatela, não pleocróica, microcristalina a fina, com cores de interferência azul até amarela e rosa de $2^{\mathfrak{a}}$ ordem (birrefringência máxima de 0,037$), 2 \mathrm{~V}=0$, acompanhada ou não de fluorita e óxido de ferro, clssificada como muscovita.

Clorita verde a marrom, não pleocróica, com birrefringência de 0,007 e $2 \mathrm{~V}<10^{\circ}$ (Fe-clorita ou chamosita) é observada a expensas da mica, e pode estar acompanhada por fluorita e quartzo precipitados ao longo das clivagens da mica hospedeira.

\section{c) Associação de fácies Santa Bárbara (afSB)}

Duas fácies de albita-microclínio granito (Fig. 5.1.a), de contato transicional, fazem parte da associação de fácies Santa Bárbara: uma rosa porfirítica de matriz média com textura piterlítica (fácies Santa Bárbara média) (Prancha 5.1.c); e outra, restrita à porção apical da unidade, de granito equigranular, microporfirítico ou porfirítico, rosa, rosa-esbranquiçado ou branco (Prancha 5.1.d e e), de matriz fina (fácies Santa Bárbara fina).

\section{$\checkmark \quad$ Fácies Santa Bárbara média (SBm)}

Na fácies Santa Bárbara média, os megacristais são menos abundantes do que na fácies Serra do Cícero, ocupando cerca de 2 a 4\% do volume da rocha. Podem ser ovóides, caso em que se mostram bem formados e com diâmetros de 1 a $3 \mathrm{~cm}$; ou angulosos, subédricos até mal formados, com comprimento de $1 \mathrm{~cm}$ em média. Ambos os tipos de megacristais coexistem na mesma rocha (Prancha 5.1.c).

Quando ovóides, apresentam macla de Carlsbad e possuem uma borda concêntrica ao contorno do cristal onde ocorrem inclusões de mica, quartzo e plagioclásio; ou de mica e quartzo unicamente, o último intercrescido com o microclínio hospedeiro num padrão granofírico; ou ainda 
somente de quartzo e plagioclásio. As inclusões de quartzo $(0,1$ a $0,6 \mathrm{~mm})$ são geralmente goticulares ou vermiculares, enquanto que as de plagioclásio $(0,1$ a $1,0 \mathrm{~mm})$ são anédricas e subédricas, concentradas preferencialmente na região marginal da banda. As de mica são anédricas.

Quando angulosos, os megacristais são subédricos e euédricos, e também apresentam macla de Carlsbad. Podem conter inclusões subédricas ou anédricas de microclínio mesmo, e euédricas de mica, além de diversas pequenas $(0,06$ a $0,2 \mathrm{~mm})$ inclusões de plagioclásio sem orientação preferencial. Franjas de intercrescimento granofírico ocorrem ocasionalmente (Prancha 5.2.g). O plagioclásio raramente constitui megacristais.

O microclínio ocupa 26 a $48 \%$ do volume da rocha, incluídos os megacristais. Na matriz, é predominantemente anédrico, mas cristais subédricos com maclas de Carlsbad são comuns. Varia de 0,5 a $2,5 \mathrm{~mm}$ de comprimento. Contém pertitas em filme esparsas, incipiente e raramente evoluídas para pertitas em gânglios e patch albite (Prancha 5.2.h). Faz contatos predominantemente planos com o quartzo precoce e com o plagioclásio.

Os conteúdos de plagioclásio variam de 15 a 32\%. É subédrico, com comprimentos de 0,20 a 3,7 mm, e exibe maclas da albita de larguras variáveis desde finas até grossas, regulares ou acunhadas (Prancha 5.2.h). Sua composição situa-se no intervalo de $A_{0}$ a $A n_{15}$, raramente da

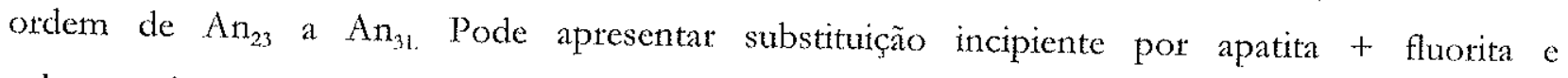
sobrecrescimentos de bordas límpidas de albita $\left(A \mathrm{n}_{0(0)}\right.$ a $\left.A \mathrm{n}_{(16)}\right)$.

O quartzo perfaz mais de 26 a $40 \%$ do volume da rocha. Ocorre em cristais precoces subédricos, equidimensionais, hexagonais, livres ou inclusos em mictoclínio, que variam de 0,25 até $2,5 \mathrm{~mm}$ e exibem contatos predominantemente planos e côncavo-convexos com as demais fases, ou, predominantemente, como agregados de cristais intercristalinos aos feldspatos, de contatos fortemente suturados e com extinção ondulante, que variam de 0,15 a $5,0 \mathrm{~mm}$.

A mica (3 a $6 \%$ ) ocorre em cristais isolados ou agregados. Varia de 0,2 a $1,8 \mathrm{~mm}$. Sempre intercristalina aos feldspatos e ao quartzo, possui formas esfarrapadas ou cúspides. Substitui incipientemente os feldspatos a partir das bordas. É pleocróica do amarelo ao marrom-esverdeado, com cores de interferência desde amarela e rosa de $2^{\mathrm{a}}$ ordem até verde-pálida de começo de $4^{a}$ ordem, correspondentes a uma birrefringência máxima de 0,057 . O ângulo $2 \mathrm{~V}$ é de $0^{\circ}$ (Prancha 5.3.a). É classificada como siderofilita.

O zircão acessório é euédrico, em cristais da ordem de 0,06 a $0,20 \mathrm{~mm}$, e ocorre incluso em microclínio, plagioclásio, quartzo e mica. É incolor amarelado, com cor de interferência amarela-esbranquiçada de $2^{i}(?)$ ordem. 
A fluorita também é um acessótio abundante $(0,2$ a $1,0 \%)$, de cristalização tardi a pós-magmática, ocorrendo sempre associada à mica. É anédrica e intercristalina, incolor.

O topázio $(0,4$ a $1,5 \%)$ é uma fase de cristalização tardi a pós-magmática, que ocorre na forma de pequenos $(0,15$ a $0,60 \mathrm{~mm})$ cristais subédricos ou euédricos, isolados ou agregados, intercristalinos aos feldspatos e ao quartzo ou disseminados como produto de alteração sobre o microclínio e o plagioclásio, ou ainda como cristais anédricos, também intercristalinos ou intercrescidos com o quartzo tardio, que substituem o microclínio a partir das bordas.

Observa-se a presença esporádica de cassiterita traço (Prancha 5.3.b).

\section{$\checkmark$ Fácies Santa Bátbata fina (ASBf)}

A fácies Santa Bárbara fina é constituída por granitos maciços e homogêneos, leucocráticos, hipidiomórficos a alotriomótficos, de textura equigranular, microporfirítica ou porfirítica fina, rosaclaros a brancos (Prancha 5.1.d e e). Microclínio, albita, quartzo e mica são as fases minerais predominantes, seguidas de topázio, fluorita e zircão.

As variedades porfiríticas apresentam 2 a $3 \%$ de megactistais de microclínio euédricos, angulosos, de até $2 \mathrm{~cm}$ de comprimento, enquanto que as microporfiríticas têm megacristais de 2,5 a $3,0 \mathrm{~mm}$.

O microclínio compreende 17 a $40 \%$ do volume desses granitos, inclúídos os megactistais. Na matriz, é anédrico e intergranular, com dimensões de 0,5 a $5,0 \mathrm{~mm}$. Não apresenta macla em grade e as pertitas, em filme, são esparsas. Pode conter diminutas inclusões subédricas ripiformes de albita, dispostas paralelamente às faces do cristal, sugerindo textura snowball (f. Schwartz 1992) (Prancha 5.3.c). Apresenta, localmente, texturas de intercrescimento granofírico com quartzo (Prancha 5.3.d).

O plagioclásio (22 a 34\%) é subédrico ou anédrico, com maclas da albita desde finas até largas, acunhadas. Pode apresentar núcleo alterado por mica branca, apatita e fluorita, bem como sobrecrescimento de albita límpida. Seu contéudo de anortita é estimado em 3 a 11\%.

Cristais subédricos equidimensionais de quartzo, com 0,25 a $1,0 \mathrm{~mm}$ de diâmetro, são observados, porém a fase é predominantemente anédrica, com 0,5 a $3,0 \mathrm{~mm}$ de diâmetro, distribuída em agregados de cristais de contatos suturados com extinção ondulante. Tem abundância de 31 a $41 \%$.

A mica (3 a 8\%) é anédrica e intercristalina, com comprimentos de 0,2 a 1,2 $\mathrm{mm}$. Pleocróica do amarelo ao verde-pardo, apresenta birrefringência máxima de 0,057. Contém minerais opacos e 
incolores, aciculares, inclusos, com halos pleoctóicos pronunciados. Tem composição siderofilítica.

A fluorita $(0$ a $0,7 \%)$ é tardia, associada à mica.

O topázio ( 0 a $2,7 \%$ ) se apresenta como pequenos cristais subédricos e euédricos, isolados ou agregados, intercristalinos aos feldspatos e ao quartzo, ou como cristais anédricos maiores (até 1,3 $\mathrm{mm}$ ), e pode ser produto de substituição dos feldspatos. Exibe contatos lobados com o quartzo.

O albita-microclínio branco da fácies Santa Bárbara fina caracteriza-se, entre outros fatores, pela ocorrência de columbita e de óxidos de elementos terras raras inclusos na mica, pela presença de cavidades miarolíticas preenchidas por topázio e pela substituição pronunciada da mica primária por outra do intervalo composicional siderofilita-zinnwaldita.

É o produto extremo da gradação vertical de cor e textura das rochas, reconhecida na associação de fácies Santa Bátbara e tida como resultante de cristalização de magma granítico sob condições de saturação em $\mathrm{H}_{2} \mathrm{O}$. As menos intensamente alteradas dessa seqüência compreendem granitos com feições texturais típicas da fácies Santa Bárbara média, cujos megacristais de mictoclínio e diversos cristais de feldspatos da matriz apresentam pigmentação branca (Prancha 5.4.a). Rochas submeticlas a graus mais avançados de interação com o fluido magmático caracterizam-se pela destruição completa da textura granítica original e pela mudança total de cor para o branco. A textura é aparentemente equigranular (os megacristais são raros e pequenos), fina. A rocha distribui-se de forma localizada, como manchas ou zonas de limites difusos (Prancha 5.4.b) e ocupando a pequena região, de cota mais alta, no Morro Santa Bárbara (Anexo 1).

Ao microscópio petrográfico o albita-microclínio granito branco I caracteriza-se pela textura alotriomórfica (Prancha 5.3.e). O microclínio pertítico (26 a $28 \%$ da rocha) ocorre em cristais subédricos e anédricos na matriz, ou como megacristais subédricos e euédricos que mostram macla em grade difusa e pertita em filme muito esparsa. Os megacristais têtm entre 2,5 e $3,8 \mathrm{~mm}$ de comprimento e apresentam macla de Carlsbad. O microclínio da matriz varia de 0,45 a $1,8 \mathrm{~mm}$, e mostra macla em grade melhor desenvolvida. Exibe albitização desde muito incipiente até avançada, na forma de albita patchwork ocupando até $40 \%$ do cristal.

O plagioclásio compreende cerca de $30 \%$ da rocha. É predominantemente subédrico, mas também anédrico. Varia de 0,2 a $2,0 \mathrm{~mm}$, e tem composição no intervalo de $\mathrm{An}_{(01}$ a $\mathrm{An}_{11}$, predominantemente. Quando em cristais isolados, apresenta maclas da albita finas, acunhadas e geralmente desencontradas, núcleo alterado para apatita + fluorita e borda límpida; ou é inteiramente límpido e intergranular. As formas de substituição compreendem bordas límpidas de albita sobre plagioclásio precoce, borda de albita em dedos sobre microclínio, albita patchwork e albita 
chessboard.

O quartzo $(\sim 35 \%)$ ocorre em uma geração primitiva, subédrico e euédrico incluso em microclínio, ou em agregados de cristais de contatos planos e côncavo-convexos, que variam de 0,1 a 1,0 $\mathrm{mm}$ de diâmetro. O quartzo tardio é anédrico, com 0,6 até $3,7 \mathrm{~mm}$, e estabelece contatos suturados com as demais fases.

A mica $(\sim 5 \%)$ é predominantemente intercristalina, de hábito esfarrapado. Apresenta pleocroísmo do verde-claro ao verde-pardo, e cores de interferência azul-esverdeada, amarela, laranja e rosa de $2^{3}$ ordem, e birrefringência máxima de 0,037 . Finalmente, seu ângulo $2 \mathrm{~V}$ é de $0^{\prime \prime}$. Trata-se de mica secundária, haja vista encontrarem-se ratos cristais reliquiares da mica original, marrom. Pertence ao intervalo composicional siderofilita-zinnwaldita.

Apatita abundante, prismática curta ou longa, euédrica, com dimensão máxima de $0,1 \mathrm{~mm}$, ocorre comumente como produto de alteração do plagioclásio ou associada à mica.

O topázio (1 a $2 \%$ ) é uma fase mineral de cristalização tardi a pós-magmática, intercristalino aos feldspatos ou intercrescido com quartzo tardio. É observado ainda preenchendo cavidades (Prancha 5.3.f). É subédrico ou anédrico, com 0,2 até 1,2 mm de diâmetro.

\subsubsection{Hidrotermalitos}

\section{a) Estágio Transicional}

\section{$\checkmark$ Granitos greisenizados e greisens}

A greisenização progressiva das rochas da associação de fácies Santa Bárbara é representada pelo aumento gradativo dos conteúdos de quartzo, mica e topázio, e pela diminuição do conteúdo de feldspatos. As rochas greisenizadas mostram cores rosa-acinzentadas e granulação geralmente média (Prancha 5.4.c). Quando em grau incipiente, o processo pode manifestar-se também pela presença de bolsões ou manchas arredondados, de dimensões centímetricas, de rocha parcial ou totalmente greisenizada. Em alguns casos, a greisenização se desenvolve nucleada em megacristais de feldspato potássico da rocha primária (Prancha 5.4.d), inicialmente através da substituição do mestno por mica ao longo de clivagens e fraturas, que evolui até sua destruição completa, restando bolsas de mica e quartzo no seu lugar. Ao microscópio petrográfico, tais megacristais mostram intensa substituição por mica branca microcristalina a partir da pertita, e o plagioclásio está pseudomorfizado pela mesma fase mineral numa larga auréola ao redor deles (Prancha 5.3.g). O halo mais externo da feição, geralmente observada em granito albitizado salmão, compreende granito 
greisenizado.

Os granitos greisenizados são rochas holoctistalinas, hipidiomórficas, de granulação predominantemente média e textura equigranulat, compostas por quartzo, plagioclásio e mica, com microclínio subordinado.

O quartzo geralmente compõe até cerca de $50 \%$ da rocha e tem diâmetros de ordem de 0,4 a $5,0 \mathrm{~mm}$. Ocorre em grãos equidimensionais agregados, predominantemente anédricos, mas também subédricos, isentos de extinção ondulante. Os cristais subédricos exibem contonos hexagonais. Seus contatos com outros cristais de quartzo são planos ou concavo-convexos, enquanto que com os feldspatos são reativos, com freqüentes embainhamentos observados no plagioclásio. Com a mica, seus contatos são desde planos até suturados.

O microclínio está presente exclusivamente como testitos de megacristais com 1,8 a $3,5 \mathrm{~mm}$ de comprimento, anédricos, com bordas corró́das, fortemente substituídos por mica (Prancha 5.3.h). Quando na matriz, o microclínio constitui um substrato reliquiar, uma massa no interior da qual encontram-se os cristais de plagioclásio dispostos caoticamente. Apresenta forte substituição por mica, quartzo e topázio. Totaliza 10 a $20 \%$ da rocha.

O plagioclásio compreende de 20 a $30 \%$ da rocha. É subédrico, e varia de 0,4 a $2,5 \mathrm{~mm}$. Está presente na forma de agregados de cristais de orientação caótica e tamanhos variados que ocupam os espaços não substituídos pelo quartzo. Usualmente, apresenta maclas da albita desde finas até largas, acunhadas, ocasionalmente combinadas com a macla de Carlsbad.

A mica é, em grande parte, produto de forte substituição do microclínio e, em menor grau, do plagioclásio. Getalmente tem formas esqueletais incipientemente desenvolvidas, pseudomórficas sobre o microclínio (Prancha 5.5.a). Quando bem formada, atinge até 2,5 $\mathrm{mm}$ de comprimento, é pleocróica do incolor ao verde-claro no núcleo e matrom-claro até marrom-escuro nas bordas. Tem cores de interferência desde o vermelho de $1^{3}$ ordem até o amarelo de $2^{2}$ ordem (birrefringência máxima $=0,028)$ no núcleo, e verde até laranja de $3^{a}$ ordem na borda (birrefringência máxima $=0,050$ ). Sua abundância é de 5 a $10 \%$. Tém composição no intervalo siderofilita-zinnwaldita.

Topázio, com abundância modal inferior a 1\%, anédrico, intercrescido ou não com quartzo, substitui os feldspatos.

Entre os acessórios observam-se opacos aciculares $<0,1 \mathrm{~mm}$ inclusos etn quartzo e mica, além de cassiterita em diminutos cristais.

Os greisens propriamente ditos podem ser classificados como quartzo greisens, topázio-mica- 
quartzo greisens e mica greisens, conforme Kuhne et al. (1972 in Stemprok 1987; Fig. 5.1.b). Os conteúdos da mica são muito variáveis, ocortendo exemplares de greisen com cerca de $3 \%$ do máfico até com mais de $90 \%$, os últimos usualmente configurando veios e bolsões centimétricos a decimétricos, que cortam os outros tipos (Pranchas 5.4.e, f, g e 5.5.b e c). Predominam largamente, entretanto, os topázio-mica-quartzo greisens, com 50 a $58 \%$ de quartzo, 23 a $32 \%$ de mica, 6 a $14 \%$ de topázio, 0,4 a $1,4 \%$ de fluorita, além de cassiterita traço $(\sim 0,5 \%)$ ou ausente. T'êm granulação predominantemente média, podendo ocorrer também variedades finas ou grossas, com cores em diferentes tons de cinza.

Ao microscópio petrográfico (Prancha 5.5.b), os topázio-mica-quartzo greisens possuem quartzo anédrico, com 0,5 a 5,0 milímetros, predominando os cristais entre 1,5 e 2,5 mm. O quartzo estabelece contatos predominantemente suturados com outros cristais de quartzo e com a mica, enquanto que com o topázio e a cassiterita seus contatos são principalmente planos até côncavo-convexos. Ocotre em duas gerações: a primeita de raros cristais hexagonais subédricos a euédricos menores que $0,5 \mathrm{~mm}$ inclusos em cristais anédricos de quartzo da $2^{\sharp}$ geração. $O$ quartzo da segunda geração, análogo àquele presente nos granitos greisenizados, pode conter diminutas inclusões de plagioclásio ripiformes e é atravessado por abundantes trilhas de inclusões fluidas secundátias.

A mica presente é fortemente zonada, apresentando discretos núcleos pleocróicos, do incolor ao verde-claro, circundados por amplas regiões marginais ou próximas aos planos de clivagem (001) pleocróicas do marrom-claro ao marrom-escuro. Os núcleos têm cores de interferência desde o rosa de $1^{1}$ ordem até o amarelo-alaranjado de $2^{3}$ (birrefringência máxima de 0,028), enquanto que as bordas as têm esverdeadas a ocres de $3^{3}$ ordem (birrefringência máxima 0,050). Seu 2V é de $10^{\circ}$. Sua composição pertence no intervalo siderofilita-zinnwaldita.

O topázio está presente em agregados de cristais anédricos e subédricos, intercristalinos ao quartzo ou inclusos em suas bordas, com dimensão média de 0,2 milímetros. Cristais isolados com até 2,0 milímetros também são observados.

Intercristalinamente ao topázio observa-se ainda a presença de fluorita, que ocorre também inclusa nesse e no quartzo ou substituindo a mica segundo as clivagens.

Os topázio-siderofilita-quartzo greisens são o principal litotipo hospedeiro do minério estanífero. Neles, a cassiterita está presente como pequenos cristais $(\sim 0,5$ milímetros) subédricos ou anédricos, via de regra maclados. Predominantemente intercristalina ao quartzo, pode ocorrer também inclusa nele. Comumente está associada à mica e ao topázio (5.4.b). 


\section{$\checkmark$ Granito albitizado salmão}

É produto de feldspatização sódica, e está geneticamente relacionado ao processo da greisenização, haja vista sua associação espacial com os corpos tabulares de greisen.

O granito albitizado salmão é maciço e homogêneo, leucoctático e inequigranular. A olho nu, o quartzo aparece com granulação média, comumente em cristais perfeitamente distintos, arredondados, e os feldspatos consistem de uma massa sem contornos cristalinos definidos (Prancha 5.4.h).

Observado ao microscópio petrográfico (Prancha 5.5.d), o microclínio se apresenta como cristais $(0,8$ a $5,0 \mathrm{~mm}$ ) subédricos e anédricos, pertíticos (pertita em filme esparsa), em abundância de 18 a $23 \%$. É isento da macla em grade e apresenta abundantes inclusões de albita na forma de cristais subédricos e límpidos disseminados no interior do microclínio hospedeiro, muitas vezes em arranjos ortogonais de cristais semelhantes à albita chessboard, conforme ilustrada em Richardson (1988). Coroas trocadas (swapped rims) também podem ser observadas.

O plagioclásio $(30$ a $36 \%$ ) tem dimensão de 0,15 a $1,2 \mathrm{~mm}$ na maior parte, mas até $5,0 \mathrm{~mm}$ em alguns casos. Quando primário, apresenta pronunciada substituição por diminutos cristais de apatita e fluorita. Pode ter bordas límpidas e tende a ocorrer em grandes cristais de composição entre $A n_{06}$ e $A n_{10}$. As formas de substituição (patchwork e chessboard) são predominantemente <0,8 mm e têm maclas da albita finas e médias, bem definidas, freqüentemente acunhadas e desencontradas.

O quartzo (25 a $38 \%)$ tem tamanhos variados $(0,15$ até $5,0 \mathrm{~mm})$, e ocorre freqüentemente como agregados de grãos poligonais, com contatos desde planos até lobados e levemente suturados. Ocasionalmente, contém inclusões de plagioclásio que exibem embainhamentos por vezes proeminentes, em que mais de $50 \%$ do cristal encontra-se reabsorvido. Ocorrem também inclusões de mica. Também o topázio pode exibir essas inclusões.

A mica (5 a 7\%) é subédrica e apresenta faces planas e contorno na forma dos mais diversos polígonos irregulares, denotando seu caráter tardio aos feldspatos. Está presente isolada ou em agregados de 2 ou 3 cristais, e varia de 0,3 a $2,5 \mathrm{~mm}$. Não taro, contém abundantes inclusões de plagioclásio englobadas poiquiliticamente. Estabelece contatos reativos com os feldspatos, especialmente o microclínio, o qual substitui parcialmente a partir das bordas. Cristais de microclínio completamente pseudomorfizados pela mica podem ser observados localizadamente. Apresenta finas bordas e zonas adjacentes aos planos de clivagem (001) $\mathrm{em}$ tons thatrons, enquanto que o núcleo é pleocróico do incolor ao verde-claro, com cores de interferência azul-esverdeada até 
rosa-amarelada de $2^{3}$ ordem (birrefringência máxima de 0,035) e $2 \mathrm{~V}$ entre 0 e $10^{\circ}$. As bordas são pleocróicas do amarelomalaranjado ao marrom e têm cor de interferência verde de $3^{3}$ ordem (birrefringência máxima /0,057). Sua composição situa-se no intervalo siderofilita-zinnwaldita.

Em associação espacial com a mica ocorre fluorita anédrica. A mica contém ainda inclusões de opaco acicular e zircão.

A albitização extrema é materializada por fronts ou manchas irregulares hololeucocráticas de cor salmão constituídas de albititos, em que a mica e o quartzo totalizam menos de $5 \%$ do volume da rocha (Pranchas 5.6.a e 5.5.e).

\section{$\checkmark$ Pegtmatóides}

Rochas de granulação grossa até muito grossa, dispostas em níveis de até $20 \mathrm{~cm}$ de espessura em contatos gradacionais com os litotipos circundantes, são ocasionais na transição entre greisens e granitos albitizados salmão e entre os últimos e granitos não alterados. São compostas predominantemente por microclínio, quartzo e mica, os dois primeiros freqüentemente euédricos, embora intercrescimentos de mica e quartzo ou $\mathrm{K}$-feldspato e quartzo também ocorram. A mica é a mesma dos greisens. Tais estruturas também podem ser afetadas por muscovitização (Pranchas 5.6.a e b).

Evidências de vinculação a processos de albitzzação magmática são a ocorrência esporádica de textura snowball em quartzo (Prancha 5.5.6)

\section{b) Estágio pós-magmático}

\section{$\checkmark$ Stockwork de topázio-siderofilita-quartzo greisen}

Os greisens que ocorrem nesse stockwork testringem-se unicamente ao campo composicional dos topázio-mica-quartzo greisens. No que tange às características microscópicas, são semelhantes aos greisens tabulares descritos anteriormente.

\section{$\checkmark \quad$ Veios de muscovita}

A muscovitização é observada sobre todos os outros litotipos, porém é mais intensa sobre os granitos greisenizados e os granitos albitizados salmão. Gera rochas de aspectos diversos, dependendo do protolito, mas que têm em comum uma pigmentação heterogênea amarelada ou avermelhada dos feldspatos e esverdeada da siderofilita.

Granitos greisenizados afetados por muscovitização apresentam aspecto manchado irregular em tons de amarelo e vermelho, onde as regiōes amarelas mostram-se mais intensamente alteradas 
que as vermelhas (Prancha 5.6.d). Ao microscópio petrográfico, o plagioclásio das regiões vermelhas apresenta abundância de óxido de ferro precipitado nas clivagens e fraturas, enquanto que o microclínio está intensamente substituído por mica e também pelo óxido de ferto na forma de diminutos cristais anédricos. A mica, de composição muscovítica, é amarela, de hábito radiado, e possui cores de interferência desde azul-esverdeada até latanja e rosa de $2^{3}$ ordem, birrefringência máxima de $0,037 \mathrm{e} 2 \mathrm{~V} \leq 10^{\circ}$. As regiões amarelas diferem das vermelhas principalmente pela ausência dos opacos. Também observa-se que a mica original está mais fortemente substituída e que a fluorita é abundante.

A muscovitização incipiente dos granitos albitizados salmão é identificada pela substituição das porções albíticas da pertita, tanto de exsolução quanto de substituição, presentes nos cristais ou megacristais de microclínio, por um agregado microcristalino de mica branca. Por fim, essa mica pseudomorfiza inteiramente o plagioclásio da matriz.

Em ambos os casos, a mica original, seja ela qual for, mostra graus variáveis de substituição a partir dos planos de clivagem, substituição topotaxial e sobrecrescimento epitaxial, por muscovita, que pode ou não ser acompanhada da precipitação de óxido de ferro. Além disso, fluorita intensamente violeta pode ou não estar associada aos feldspatos e mica substituídos. Pinckston \& Smith (1995) atribuetn a pigmentação de fluorita a danos estruturais oriundos do decaimento de Th presente em minerais associados.

Greisens muscovitizados são rochas verde-clatas de textura equigranular (Prancha 5.6.f). Em alguns casos, a substituição é tão extensiva que consome também o quartzo, deixando um agregado fino praticamente monocristalino de muscovita (Prancha 5.5.g).

Os nódulos negros, manganesíferos, freqüentemente associados com a alteração muscovítica, compreendem óxidos e hidróxidos de $\mathrm{Mn}$ com $\mathrm{Ba}, \mathrm{Fe}, \mathrm{Na}, \mathrm{Al}$ e Li, identificados por difração de raios-X como hollandita, todorokita e litioforita (Fig. 5.2).

Porções ricamente mineralizadas com cassiterita comumente correspondem a bolsões ou fraturas preenchidas, de espessura centimétrica a decimétrica, de greisen fino a médio composto por mais de $90 \%$ de muscovita, distribuídos no interior dos corpos de topázio-mica-quartzo greisen médio.

\section{Stockwork argiloso}

Análise por difração de raios-X das vênulas argilosas desse sistema stockenork indicaram a presença largamente predominante de argilo-minerais do grupo da caulinita (Fig. 5.2). 

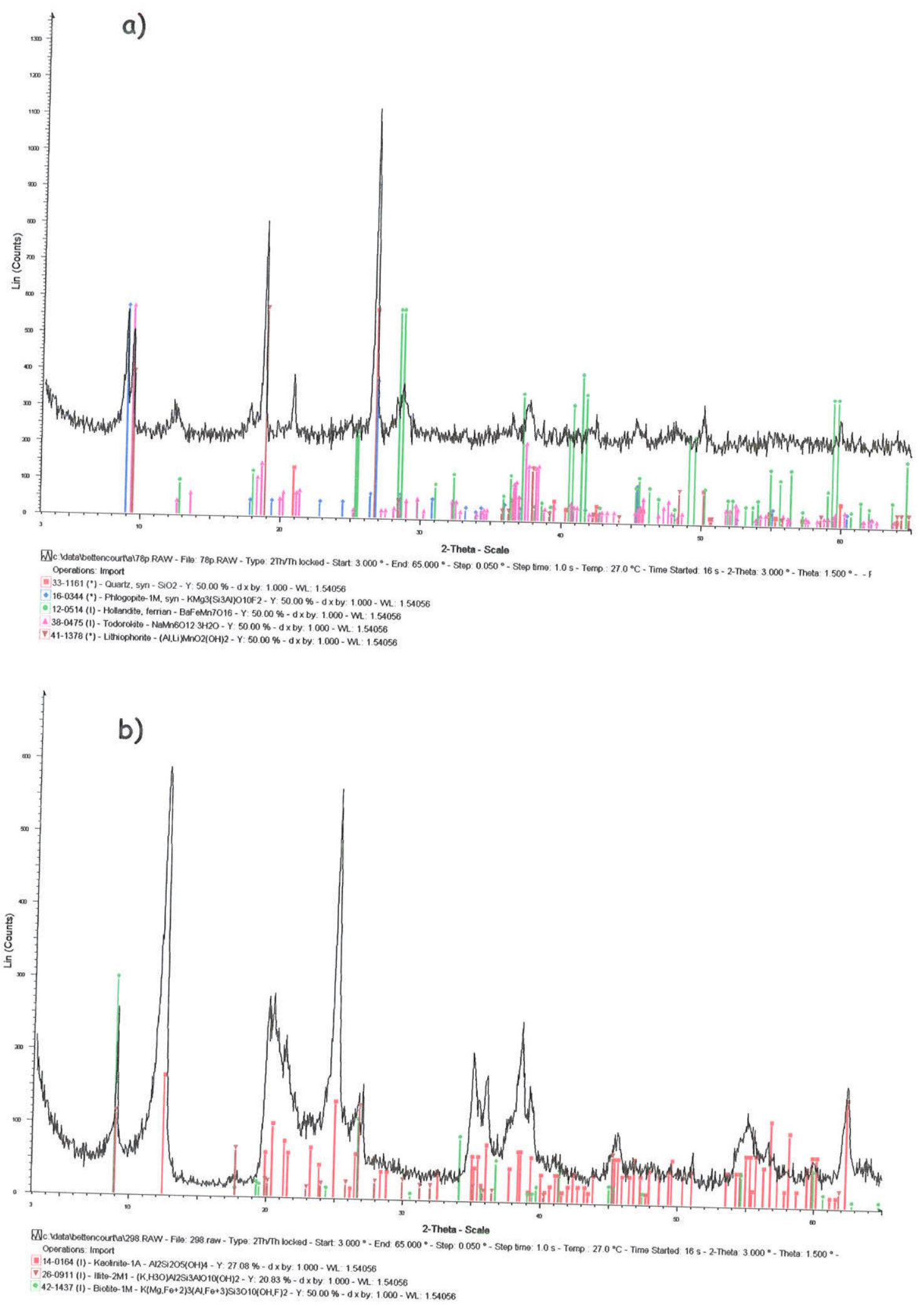

Figura 5.2 - Espectros de difração de raios-X de a) nódulos manganesíferos associados com a alteração muscovítica pós-magmática e, b) das vênulas do stockwork argiloso. 


\subsection{Microscopia Eletrônica de Varredura}

\subsubsection{Fácies Magmáticas}

\section{a) Fácies Serra do Cícero (fSC)}

A fácies Serra do Cícero possui monazita abundante, inclusa em mica. A associação de xenotima (Fig. 5.3.a) com monazita (Fig. 5.3.b) e/ou com zircão é comum. Em alguns casos, a xenotima é uma fase deutérica, que substitui a mica (Prancha 5.7.a e b)

O zircão é uma fase acessória abundante na fácies Serra do Cícero, e se apresenta em cristais prismáticos curtos (relação comprimento:largura de $2: 1$ a 3:1), grandes (até $300 \mu \mathrm{m}$ ), e predominantemente límpidos e isentos de faces de crescimento (Prancha 5.7.b, c, d). Esse tipo é muito comum incluso em mica e quartzo ou associado com fluorita .

Outro tipo de zircão, de freqüência muito subordinada, é observado incluso em mica, e caracteriza-se pela forma euédrica prismática bipiramidal com faces de crescimento perfeitamente preservadas e intercrescimento com xenotima no núcleo (Prancha 5.8.a).

\section{b) Fácies Serra Azul (fSA)}

A microscopia eletrònica de varredura indicou a presença abundante de um óxido de Ce, La, Nd e Th, conhecido como cerianita, na fácies Serra Azul (Fig. 5.3.c). Essa fase ocorre substituíndo mica (Prancha 5.8.b) ou predominantemente em associação com fluorita (Prancha 5.8.c e d).

Ao substituir a mica, é anédrica e dispõe-se em massas alongadas segundo a clivagem daquela, denotando claramente seu caráter deutérico. Concentra-se junto a uma mica aparentemente secundária, crescida a expensas da magmática. Quando em associação com fluorita, ocorre em cristais subédricos equidimensionais com cerca de 20 a $30 \mu \mathrm{m}$ (Prancha 5.8.c) ou como pequenos prismas com até $20 \mu \mathrm{m}$ de comprimento (Prancha 5.8.d). Sua ocorrência como mineral de substituição sobre feldspato também foi observada. 
cps

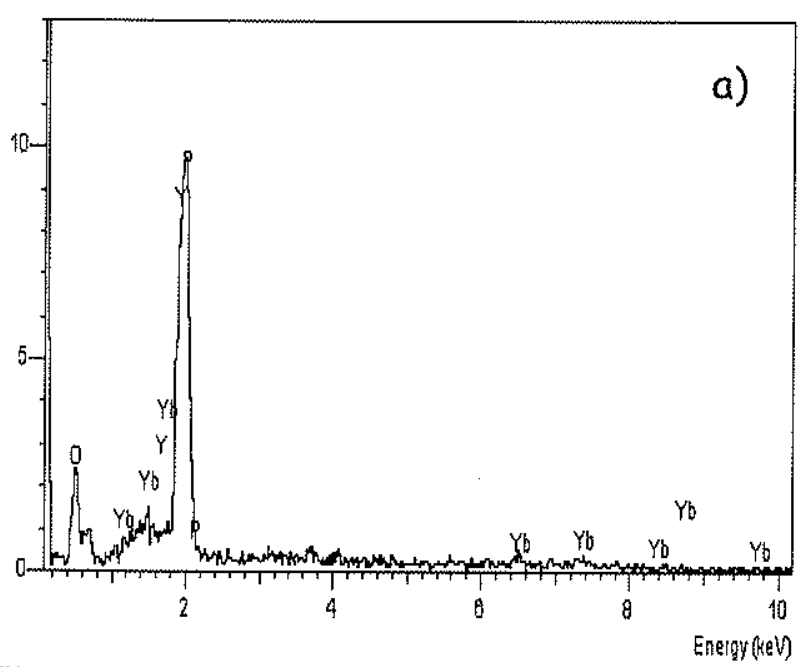

sps

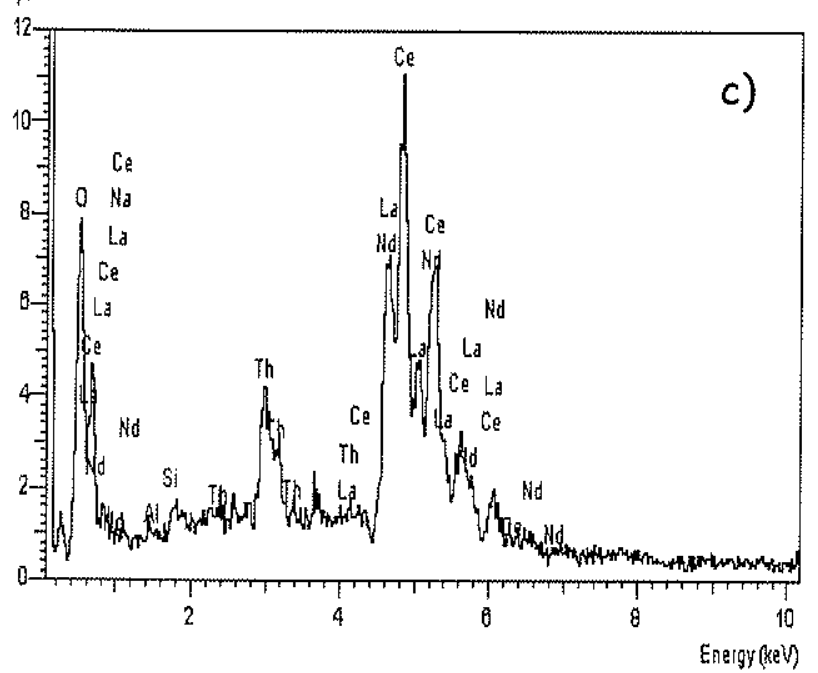

cps

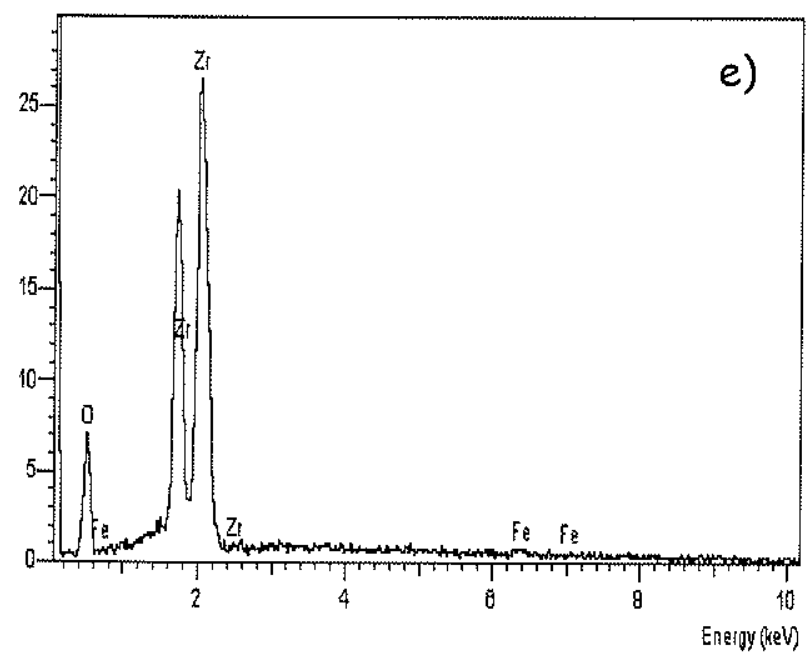

cps

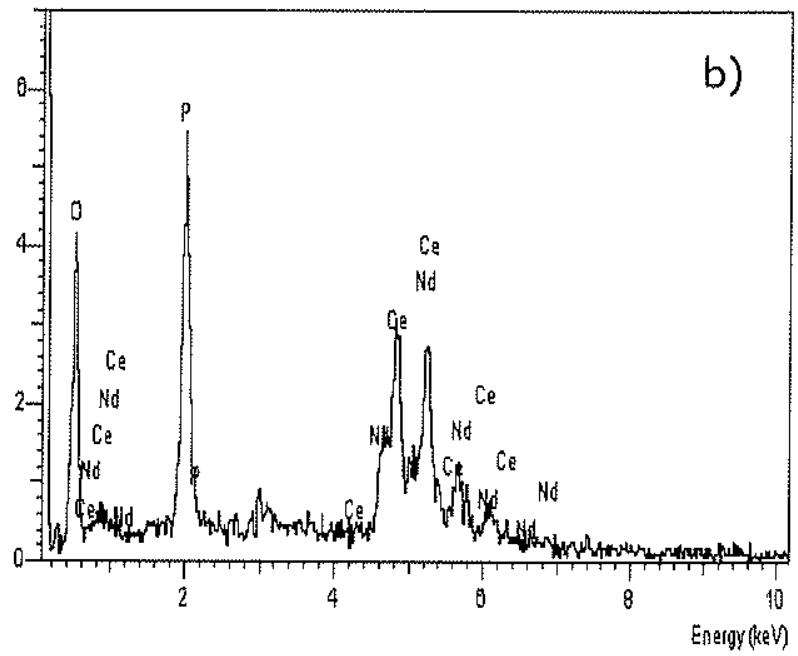

sps

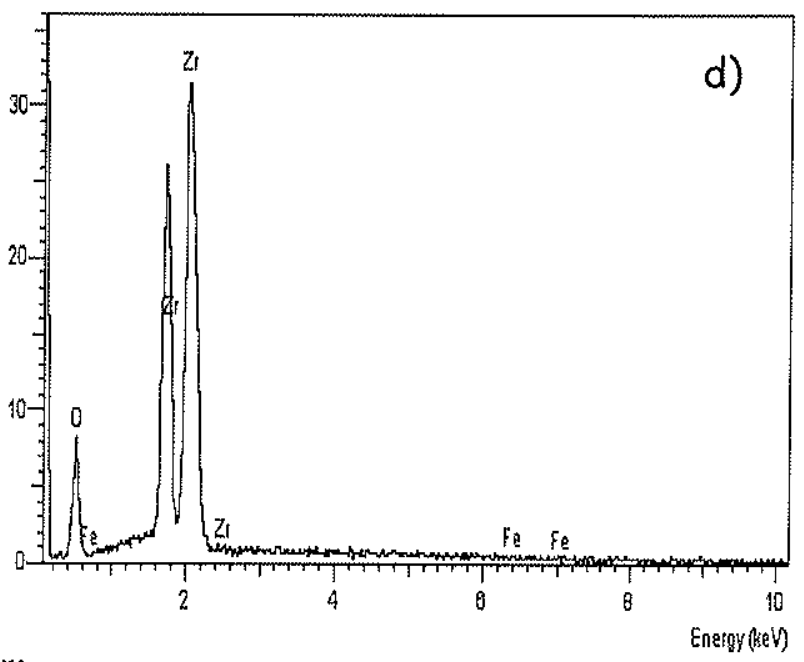

$\cos$

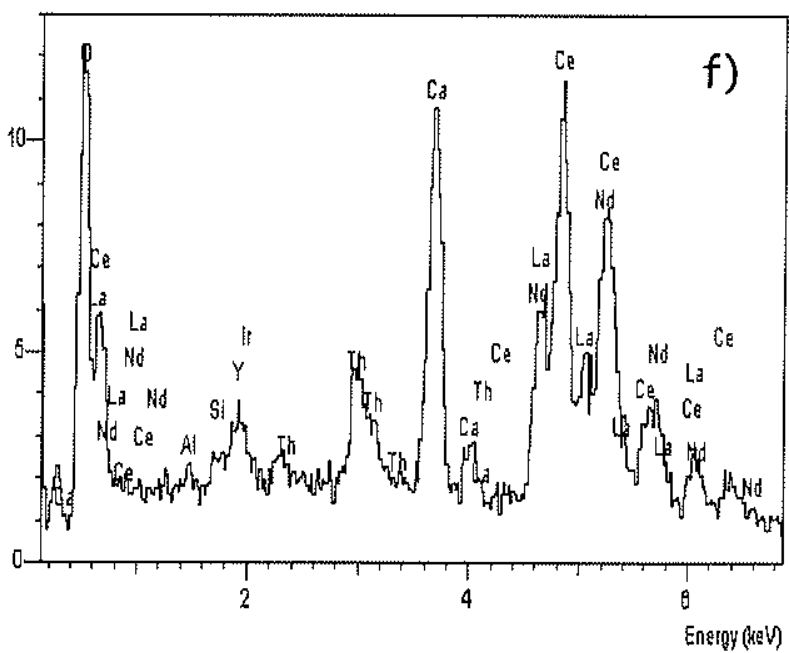

Figura 5.3. - Espectros de dispersão de energia obtidos por microscopia eletrônica de varredura, modo composicional, de a) xenotima e b) monazita na fSC (AM-52B); c) cerianita associada com fluorita na fSA (AM-53B); zircão da fSA (M-53B) d) na região límpida, com faces de crescimento preservadas, e e) na região turva, que compõe grande parte do núcleo e da borda do cristal; f) cerianita inclusa em fluorita na fSBm (AM-224B). 
A cerianita natural geralmente é uma mistura de óxidos de Ce e outros elementos terras aaras, e forma solução sólida com torianita. Ocorre em pegmatitos, granitos e rochas ígneas subsaturadas em sílica como produto de alteração de fluocerita e/ou de bastnaesita ou intercrescida com ambas. Associação com torita, fluorita, zircão, britholita, catapleiíta, silicatos de Ca e Zr, apatita e hidrohetaerolita também é reportada. Freqüentemente, a cerianita ocorte em cristais tão pequenos que sua presença é confirmada somente em estudos de difratometria de raios-X. Sua geração implica a presença de fluidos hidrotermais oxidantes, capazes de transformar o $\mathrm{Ce}^{3+}$ da fluocerita e da bastnaesita em Ce ${ }^{4+-}$ (Styles \& Young 1983; Lahti \& Suominen 1988; Pinckston \& Smith 1995).

A fluorita é um acessório comum e abundante na fácies Serra Azul, sempre associada à siderofilita. Forma desde pequenos cristais, da ordem de 10 a $20 \mu \mathrm{m}$, até grandes, usualmente manchados, com cerca de 1,0 $\mathrm{mm}$ (Prancha 5.9.a). As manchas podern se distribuir concêntrica (Prancha 5.8.c) ou aleatoriamente (Prancha 5.9.a), e refletem provavelmente diferenças nas concentrações de elementos traços. Os grandes cristais de fluorita podem conter diversas inclusões euédricas de zircão (Prancha 5.9.a).

O zircão da fácies Serra Azul, especialmente aquele presente na amostra utilizada para datação (AM-53B), é prismático curto (2:1) e ocorre freqüentemente incluso em quartzo, mica e fluorita. Exibe aspecto turvo, com abundantes buracos, e suas faces de crescimento estão apenas parcialmente preservadas (Prancha 5.9.b). Espectros das regiões límpida (com faces de crescimento preservadas) e turva (Figs. 5.3.d e e, respectivamente) revelam conteúdo ligeiramente maior de ferro na última.

\section{c) Associação de fácies Santa Bárbara (afSB)}

\section{$\checkmark$ Fácies Santa Bárbata média (\$SBm)}

Novamente nesta fácies aparece o óxido de Ce, La e Nd com Th, desta vez portando também Ca e Y, incluso em fluorita (Prancha 5.9.c). O cálcio pode representar interferência do mineral hospedeiro, dada a dimensão diminuta do óxido, o que conduz à possibilidade de se tratar, também neste caso, de cerianita (Fig. 5.3.f).

Columbita (Fig. 5.4.a) prismática, com até $300 \mu \mathrm{m}$ de comprimento, também ocorre inclusa em fluorita tardi a pós-magmática (Prancha 5.9.d).Quanto ao zircão, o que se observá na amostra analisada (AM-224B), é que encontra-se parcial (Prancha 5.10.a; Fig. 5.4.b) a totalmente substituído por torita (Prancha 5.10.b; Fig. 5.4.c). 
$\operatorname{cps}$

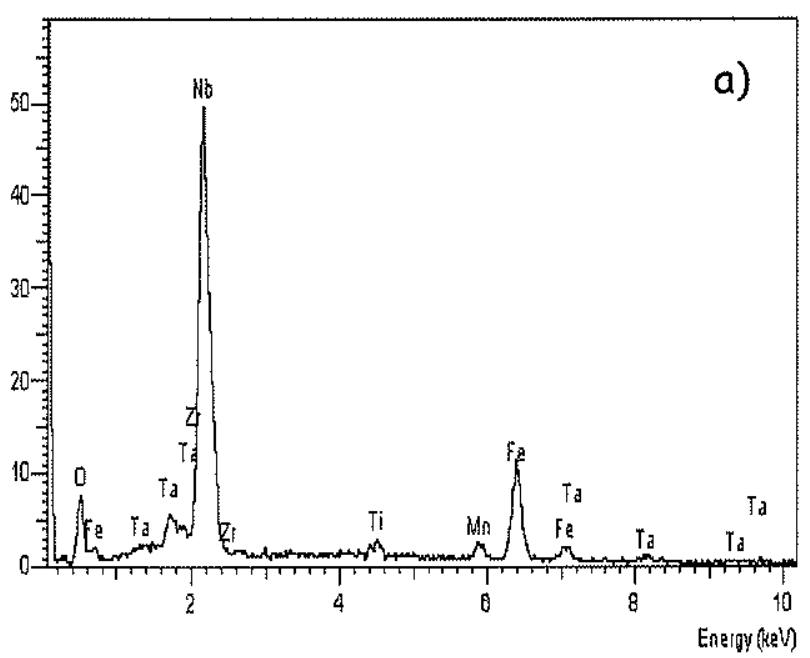

cos

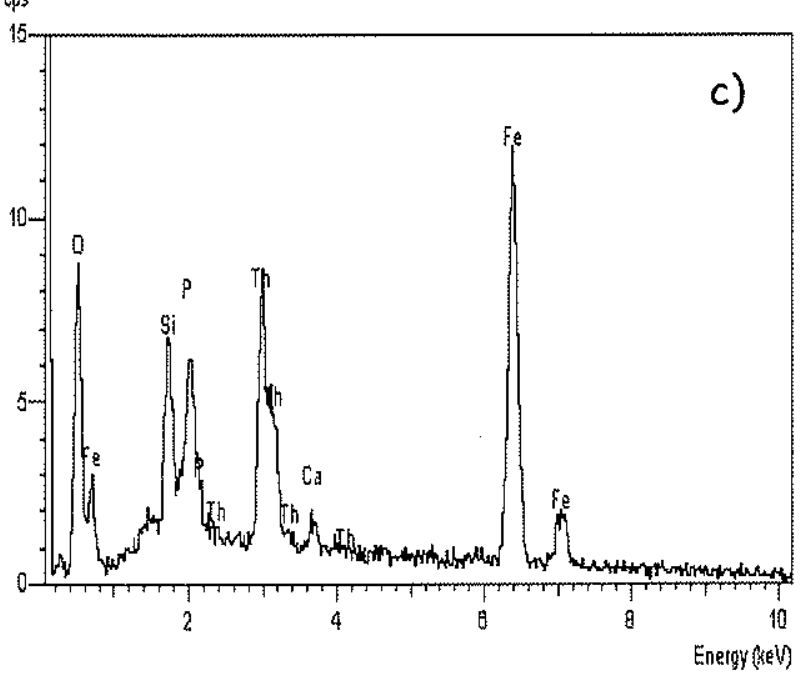

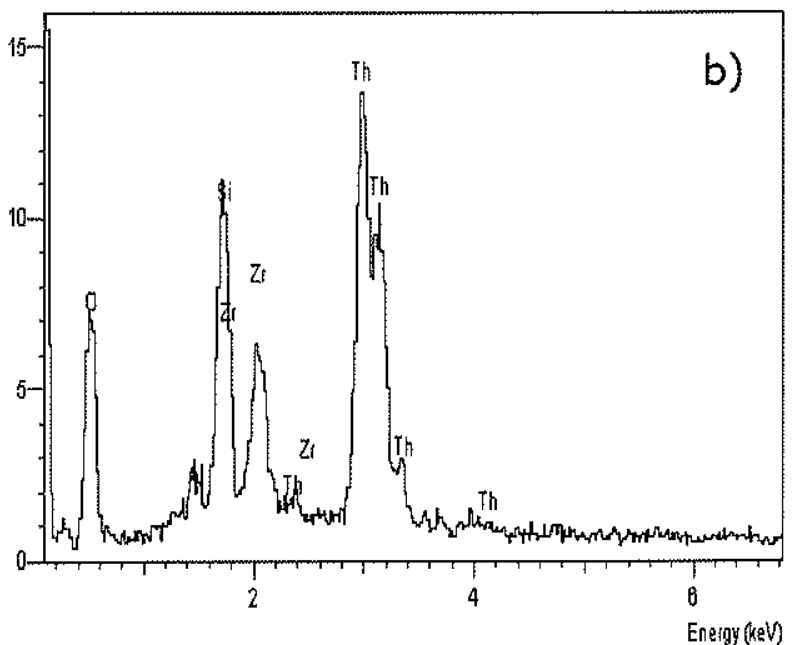

cops

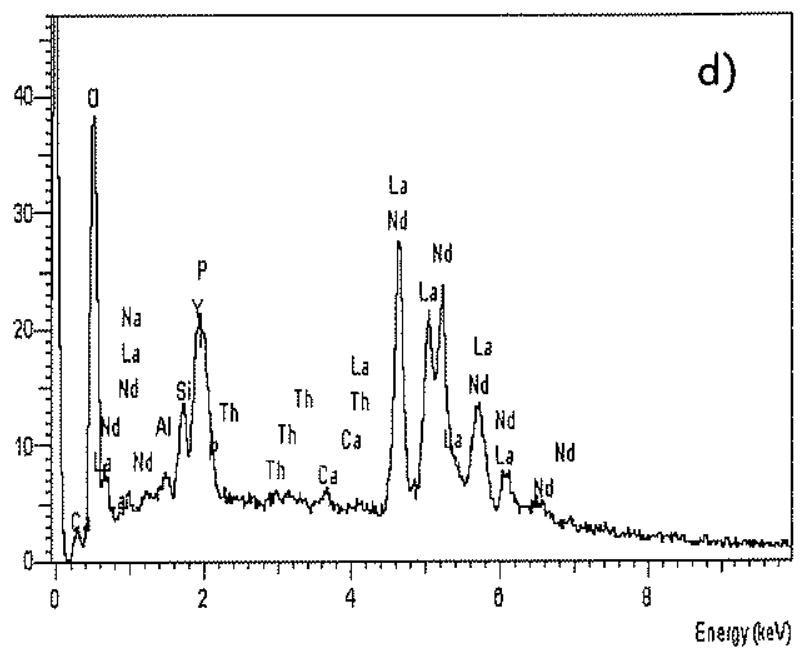

e)

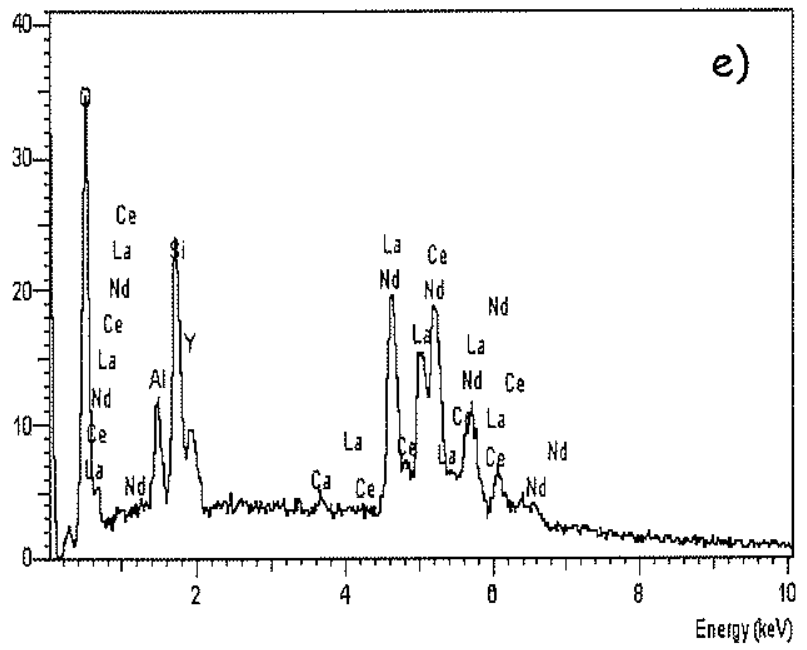

Figura 5.4 - Espectros de dispersão de energia obtidos por microscopia eletrônica de varredura, modo composicional, de a) columbita inclusa em mica na fSBm (AM-224B); b) e c) de torita presente na fSBm (AM-224B); d) e e) de oxido de La e Nd incluso em mica no albitamicroclínio granito branco da fSBf (AM-134). 


\section{Fácies Santa Bárbara fina (fSBf)}

Foi analisado ao microscópio eletrônico de varredura unicamente o albita-microclínio granito branco. Como acessório de origem magmática, a rocha apresenta o zircão, sempre menor que 50 $\mu \mathrm{m}$. Outros acessórios incluem um óxido de $\mathrm{La}, \mathrm{Nd}$ e $\mathrm{Y}$, com teores variáveis de Ce, Si e P (Fig. 5.4.d, e), e columbita, ambos inclusos em mica (Prancha 5.10, c, d), que é inteiramente secundária nessa rocha.

\subsubsection{Hidrotermalitos}

\section{a) Estágio transicional}

\section{$\checkmark$ Topázio-siderofilita-quartzo greisens}

Os topázio-mica greisens contêm columbita e monazita (Prancha 5.11.a) como fases acessórias.

A mica apresenta zonação (Prancha 5.11.a, b), com termos mais pobres em Fe no núcleo (Fig. 5.5.a) e mais ricos em Fe nas bordas e junto aos planos de clivagem (Fig. 5.5.b).

A cassiterita é isenta de inclusões, e sua zonação observada em microscopia ótica não é aparente nas imagens eletrônicas. Apresenta óxido de Fe precipitado em fraturas (Prancha 5.11.b).

Bem mais rara que a cassiterita, a volframita também está presente nos greisens, ocasionalmente pseudomorfizada por scheelita (Prancha 5.11.c e d). Essa substituição dá lugar à segregação de óxido de Fe. Inclusões de zircão e de diminutas palhetas de mica são observadas na scheelita (Prancha 5.11.d).

Volumetricamente menos significativos, os topázio-mica greisens pobres em quartzo possuem mais de $90 \%$ de mica, além de quartzo (Prancha 5.12.a). Cassiterita e volframita são ocasionais. Na realidade, a mica compreende uma intrincada relação textural entre duas composições distintas em termos de Fe e Al, basicamente. A mica mais tardia, mais pobre em Fe, substitui a primitiva gerando segregações de óxidos do referido elemento.

\section{b) Estágio pós-magmático}

\section{$\checkmark \quad$ Veios de muscovita}

Caracteriza-se pela substituição da mica e feldspatos prévios por muscovita, predominantemente microcristalina, acompanhada ou não de fluorita (Prancha 5.12.b). 
Quando em cristais maiores, é possivel verificar que a muscovita é zonada (Prancha 5.12.c). Análises semi-quantitativas de borda e núcleo revelaram conteúdos discretamente superiores de $\mathrm{Fe}$ no núcleo da muscovita.

Da mesma forma, a fluorita pode exibir zonação, aparentemente dada por diferença nos conteúdos de $\mathrm{Y}$ e $\mathrm{Yb}$ entre a borda, mais tica nesses elementos, e o núcleo.

A muscovitização consome o topázio, conforme demonstra a Prancha 5.12.d e, em estágios avançados, também o quartzo. A muscovitização avançada sobre os topázio-siderofilita-quartzo greisens tem como produtos rochas biminerálicas compostas por cassiterita e muscovita (Prancha 5.13.a).

A mica contém inclusões ocasionais de zircão (Prancha 5.12.c) e columbita. Monazita, na forma de pequenos $(\sim 60 \mu \mathrm{m})$ prismas alongados inclusos em quartzo, é comum. Raramente, xenotima é observada inclusa em mica.

Nos nódulos manganesíferos associados, hollandita (Fig. 5.5.c) e cerianita (Fig. 5.5.d) são intercristalinas à litioforita (Fig. 5.5.e) (Prancha 5.13.b e c).

\section{$\checkmark \quad$ Veios de quartzo estéreis}

Dentre os diversos tipos de veios existentes na zona mineralizada da associação de fácies Santa Bárbara, os veios de quartzo estéreis foram os únicos estudados por microscopia eletrônica de varredura em função de conterem uma borda de alteração da encaixante imediatamente adjacente ao veio e de largura milimétrica onde foi dificil a identificação dos minerais ao microscópio ótico.

O veio propriamente dito contém apenas quartzo em estrutura bony comb. No centro dele, onde as terminações piramidais dos cristais se encontram, observa-se óxido de ferro precipitado sobre as faces do quartzo, muitas vezes configurando estruturas botrioidais (Prancha 5.13.d).

A borda de alteração milimétrica caracteriza-se pela presença de carbonato, arrancado da lâmina durante o polimento (buracos pretos na imagem), quartzo, fluorita, óxido de ferro, mica, pirita e barita (Prancha 5.14.a). Além dessa borda, substituição da mica magmática presente no granito encaixante por carbonato e óxido de ferro foram as alterações observadas (Prancha 5.14.b).

\section{$\checkmark$ Stockwork argiloso}

Juntamente com a caulinita, está presente a halloysita nas vênulas do sistema stockenork argiloso (Prancha 5.14.c). 
$\cos$

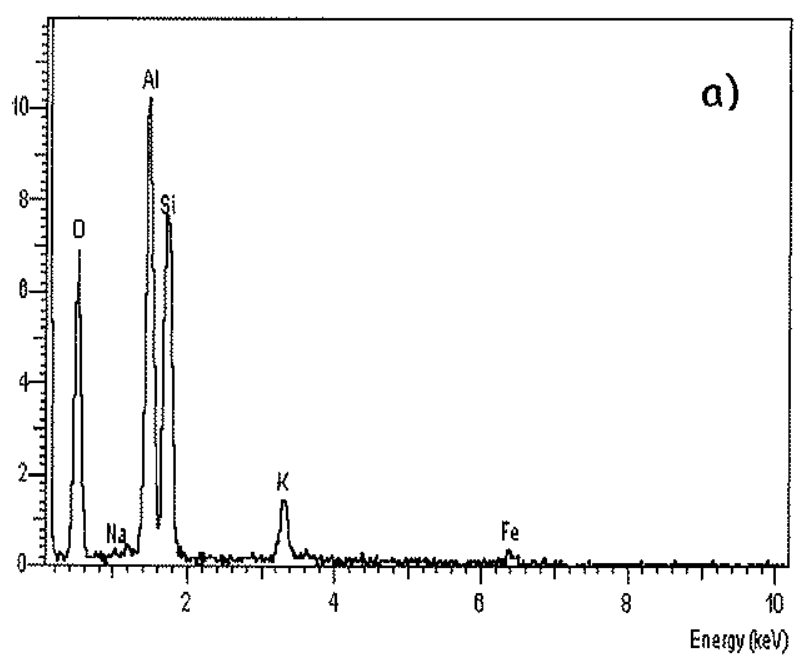

ips

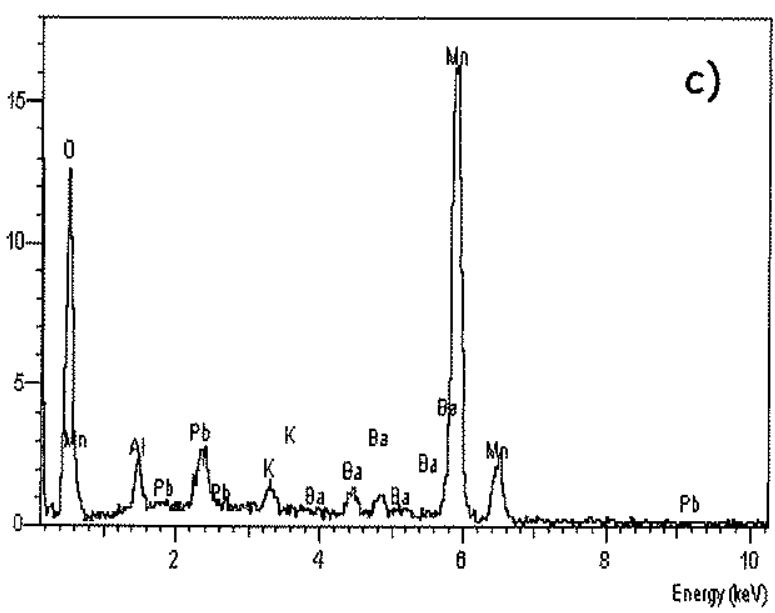

$\cos$

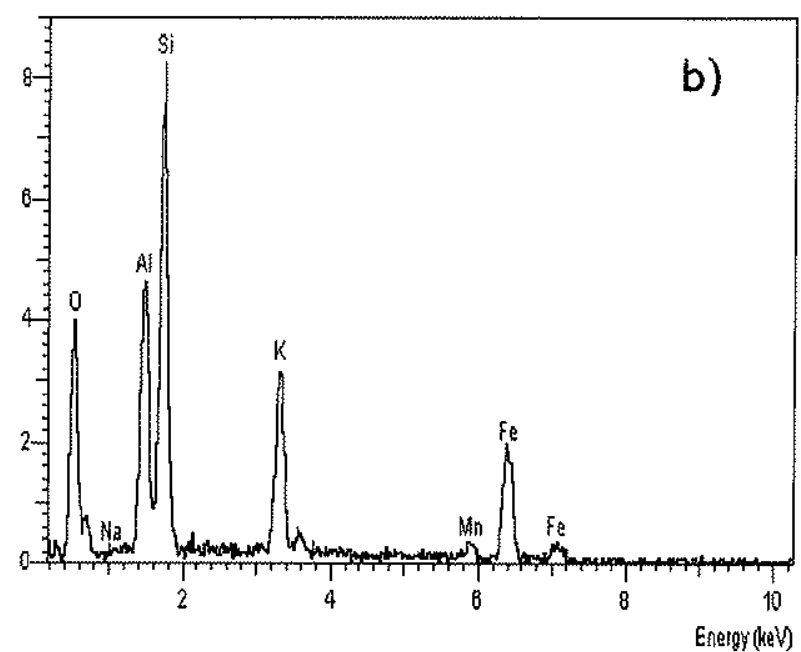

cps

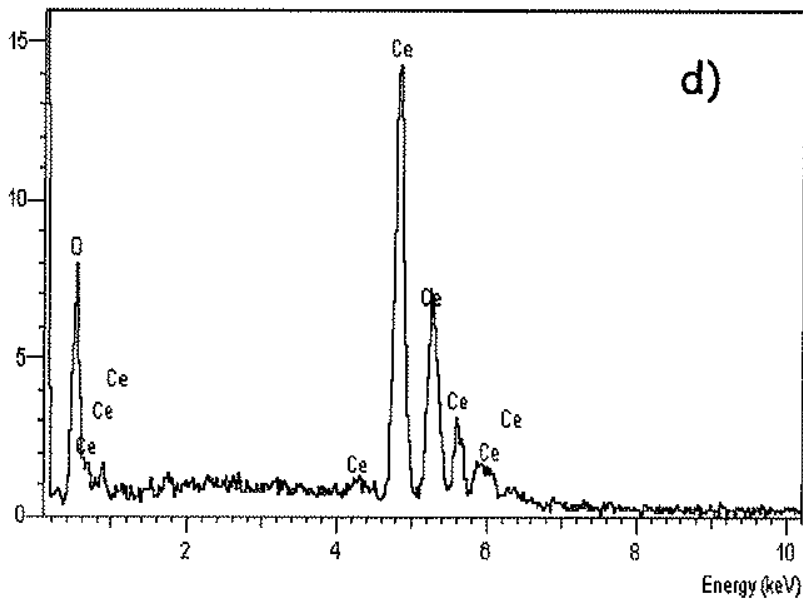

ops

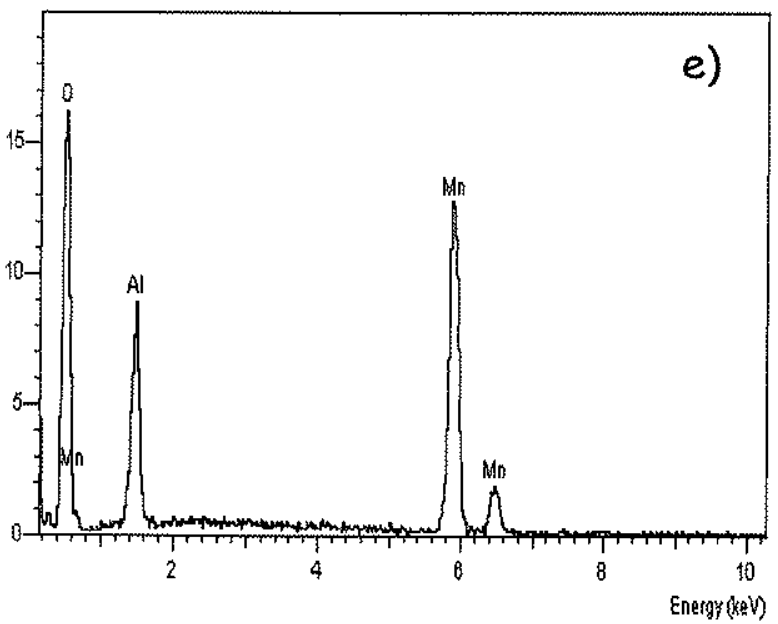

Figura 5.5 - Espectros de dispersão de energia obtidos por microscopia eletrônica de varredura, modo composicional, de a) núcleo e b) borda da mica zonada dos topázio-siderofilita-quartzo greisens; c) da hollandita, d) da cerianita e e) da litioforita presentes nos nódulos manganesíferos associados à muscovitização. 


\subsection{Evolução magmática e quadro paragenético da mineralização}

A evolução magmática do Maciço Granítico Santa Bárbara está representada pela diminuição das quantidades de microclínio e de oligoclásio e aumento das quantidades de albita, quartzo e topázio da fácies mais precoce (fácies Serta do Cícero) rumo às mais tardias (associação de fácies Santa Bárbara), bem como à transição da composição das micas de tipos mais ricos em Fe até aquelas enriquecidas em Li.

Internamente à associação de fácies Santa Bárbara (associação de fácies Santa Bárbara), observa-se diminuição da granulação da rocha dos níveis mais profundos aos mais rasos, bem como transição de textura porfirítica para microporfirítica ou equigranular e aparição de textura granofírica e cavidades miarolíticas rumo às porções apicais.

Em termos gerais, a alteração hidrotermal pervasiva está representada pela greisenização parcial ou total dos granitos hospedeiros e pelo metassomatismo alcalino correlato.

No estágio pós-magmático, a alteração pervasiva fissural tem como produtos stockzpork. de greisen e de argilas, bem como veios de quartzo, com ou sem cassiterita

As paragêneses observadas nos diversos hidrotermalitos do Maciço Granítico Santa Bárbara estão ilustradas no Quadro 5.I. 
Quadro 5.1. Quadro paragenético da mineralização estanifera primária do Maciço Granítico Santa Bárbara.

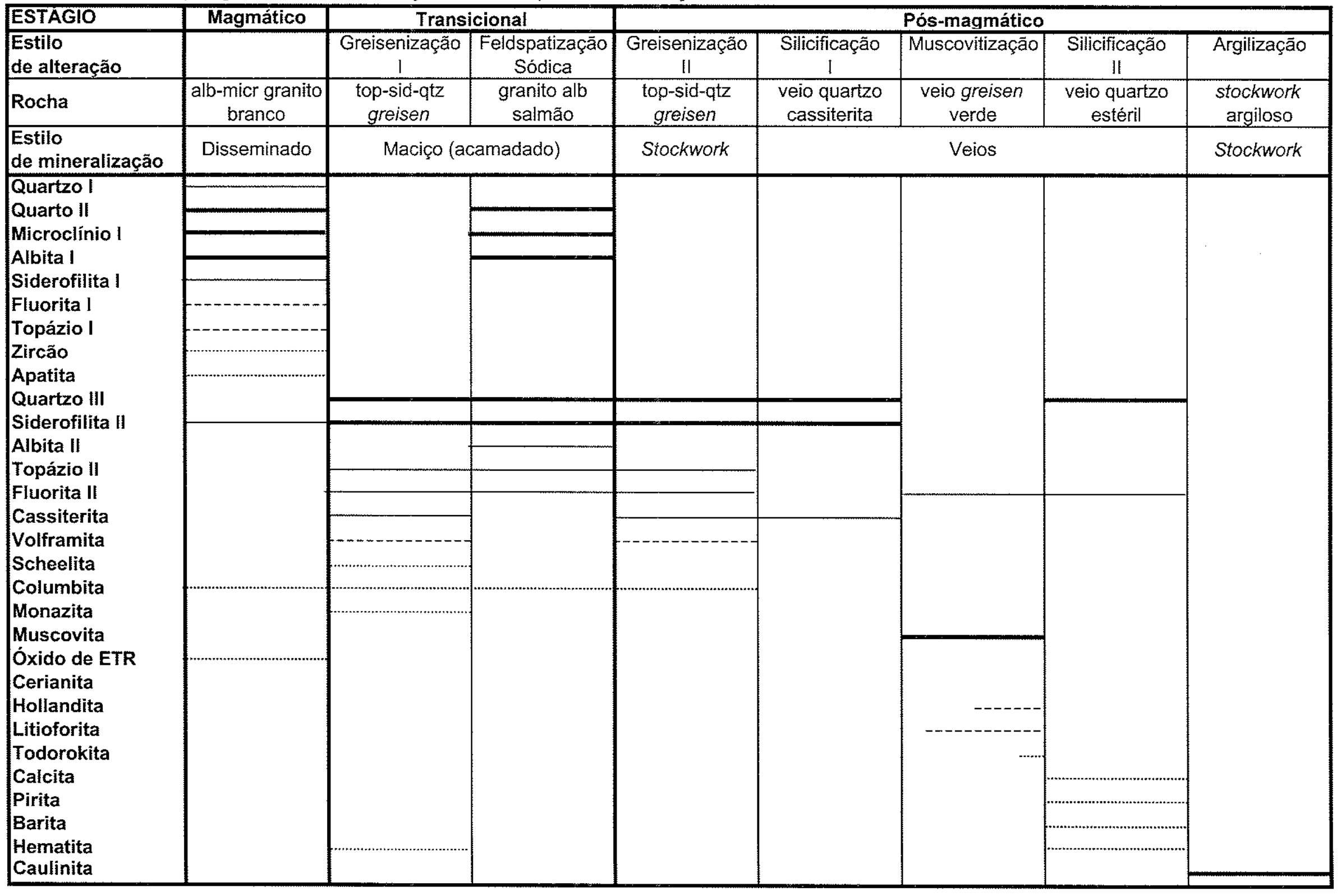



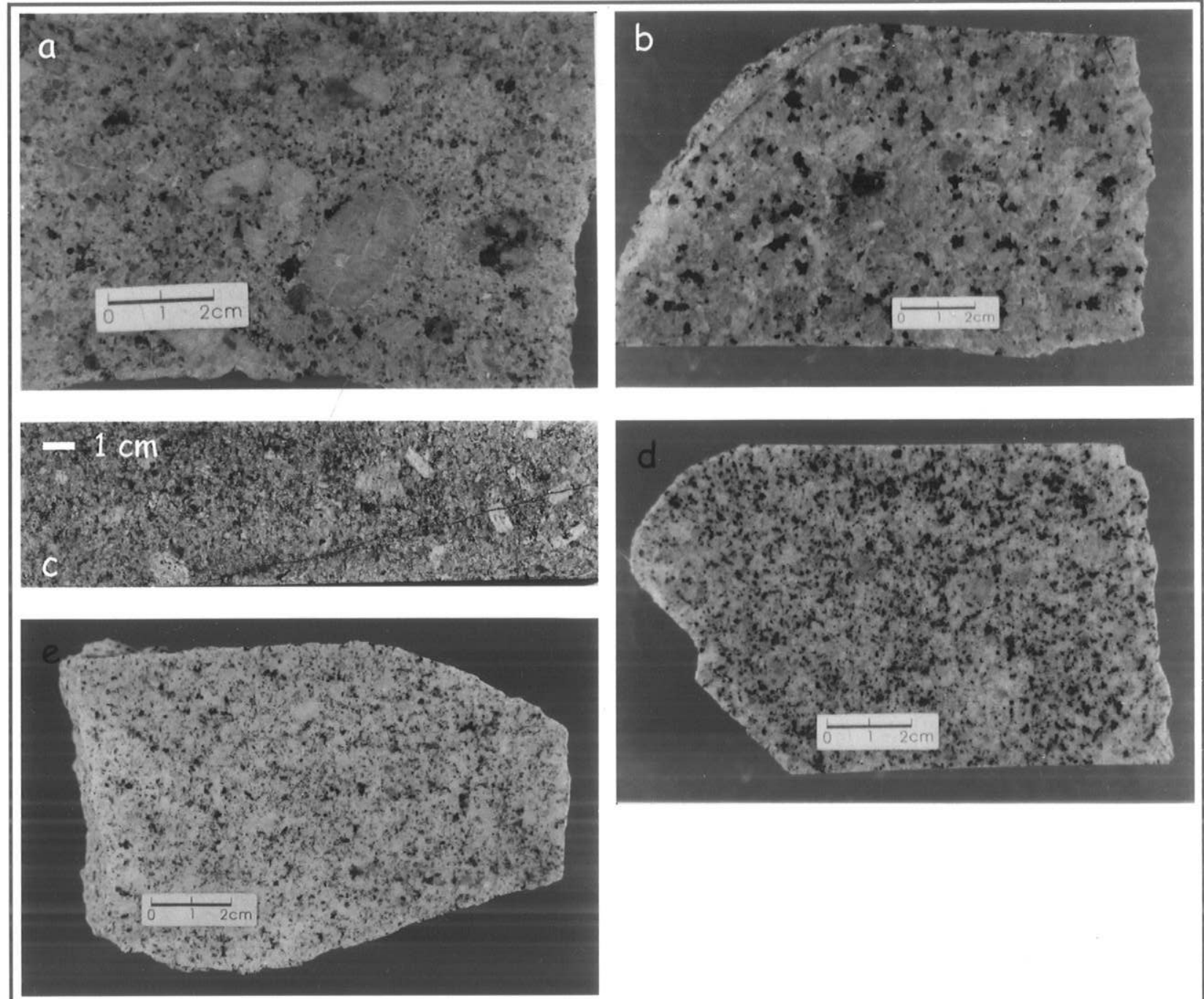

Prancha 5.1 - a) Granito rosa, maciço, homogêneo, leucocrático, porfirítico de matriz média, com megacristais euédricos, subédricos e ovóides de feldspato potássico de até $2,5 \mathrm{~cm}$ de comprimento em matriz de feldspato potássico e plagioclásio rosa, quartzo e siderofilita. Facies Serra do Cícero (fSC); b) granito rosa, maciço, homogêneo, leucocrático, inequigranular, médio, composto por feldspato potássico e plagioclásio rosa, quartzo e siderofilita. Facies Serra Azul (fSA); c) granito rosa, maciço, homogêneo, leucocrático, porfirítico de matriz média, com megacristais de feldspato potássico euédricos, subédricos e ovóides esparsos com $1 \mathrm{~cm}$ de comprimento em média, em matriz de feldspato potássico e plagioclásio rosa, quartzo e siderofilita, Facies Santa Bárbara média (fSBm); d) granito rosa-esbranquiçado, maciço, homogêneo, leucocrático, equigranular médio, composto por feldspato potássico e plagioclásio rosa, quartzo e siderofilita. Facies Santa Bárbara fina (fSBf); e) granito branco, maciço, homogêneo, leucocrático, microporfirítico fino, composto por feldspatos brancos, quartzo e siderofilita (fSBf). 
Prancha 5.2 - a) Megacristal mesopertítico ovóide com abundantes inclusões anédricas de quartzo e poucas inclusões de mica na borda, fácies Serra do Cícero. Nicóis cruzados. Amostra AM-52B; b) megacristal ovóide de microclínio manteado por plagioclásio sericitizado na fácies Serra do Cícero - textura wiborgítica. Nicóis cruzados. Amostra AM-52B; c) aspecto da matriz de granito da fácies Serra do Cícero, com cristais de microclínio subédricos e anédricos, com macla em grade distinta, cristais de plagioclásio com núcleo sericitizado e borda de albita límpida sobrecrescida, além de quartzo e mica. Nicóis cruzados. Amostra AM-52B; d) inclusões de zircão euédrico pardo, à esquerda, e de zircão incolor, à direita, na mica primária da fácies Serra do Cícero. Nicóis cruzados. Amostra AM-52B; e) mica primária da fácies Serra do Cícero, de cor marrom, substituída por clorita verde nas bordas. Nicóis paralelos. Amostra AM-52B; f) hábito euédrico a subédrico, hexagonal, das inclusões de quartzo em microclínio. Pertitas de substituição em gânglios no microclínio e coroas trocadas (swapped rims) de albita entre cristais de microclínio adjacentes. Nicóis cruzados. Amostra AM-53B; g) borda de intercrescimento de microclínio, quartzo e mica sobre megacristal subédrico de microclínio da fácies Santa Bárbara média. Nicóis cruzados. Amostra AM-119; h) aspecto da matriz da fácies Santa Bárbara média. Nicóis cruzados. Amostra AM-119. 


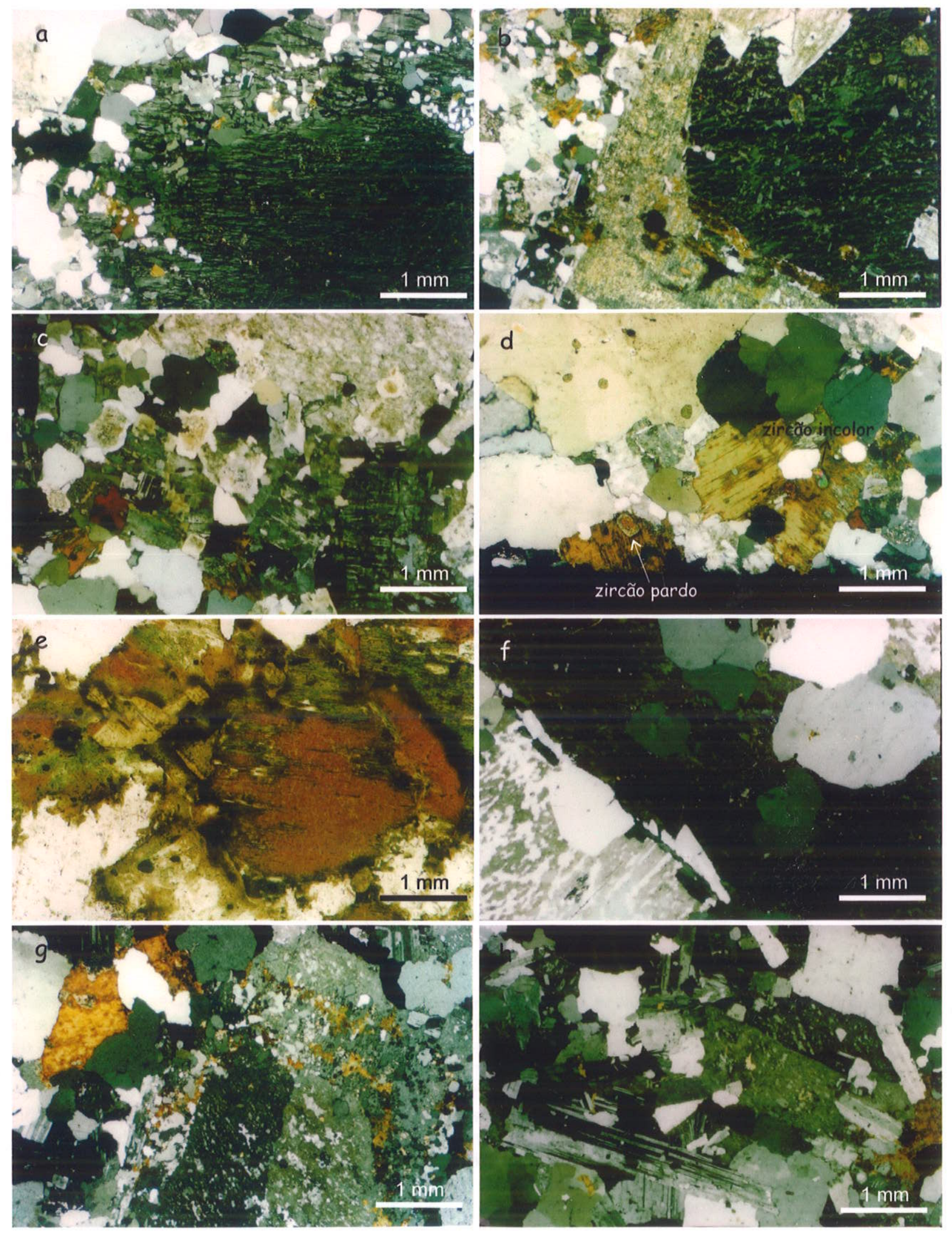

Prancha 5.2 
Prancha 5.3 - a) Agregados cúspides de mica marrom-esverdeada primária na fácies Santa Bárbara média. Nicóis paralelos. Amostra AM-125; b) presença de cassiterita na fácies Santa Bárbara média.Nicóis cruzados. Amostra AM-170; c) diminutas inclusões subédricas de albita orientadas paralelamente aos planos de clivagem do megacristal de microclínio. Fácies Santa Bárbara fina. Nicóis cruzados. AM-38; d) intercrescimento granofírico de feldspato potássico e quartzo na matriz de granito da fácies Santa Bárbara fina. Nicóis cruzados. AM-145; e) textura alotriomórfica do albita-microclínio granito branco da fácies Santa Bárbara fina. Maclas da albita acunhadas e desencontradas no plagioclásio. Nicóis cruzados. Amostra AM-134; f) cavidade miarolitica preenchida por topázio no albita-microclínio granito branco. Nicóis cruzados. AM-134; g) aspecto microscópico dos spots de greisenização incipiente nucleados sobre megacristais de microclínio. À direita, observa-se megacristal fortemente substituído por siderofilita e muscovita (microcristalina). À esquerda, auréola adjacente ao megacristal onde o plagioclásio está inteiramente substituído por mica branca. Nicóis cruzados. AM-260; h) megacristal de microclínio em granito greisenizado fortemente substituído por siderofilita, muscovita e fluorita. Nicóis cruzados. AM-19. 


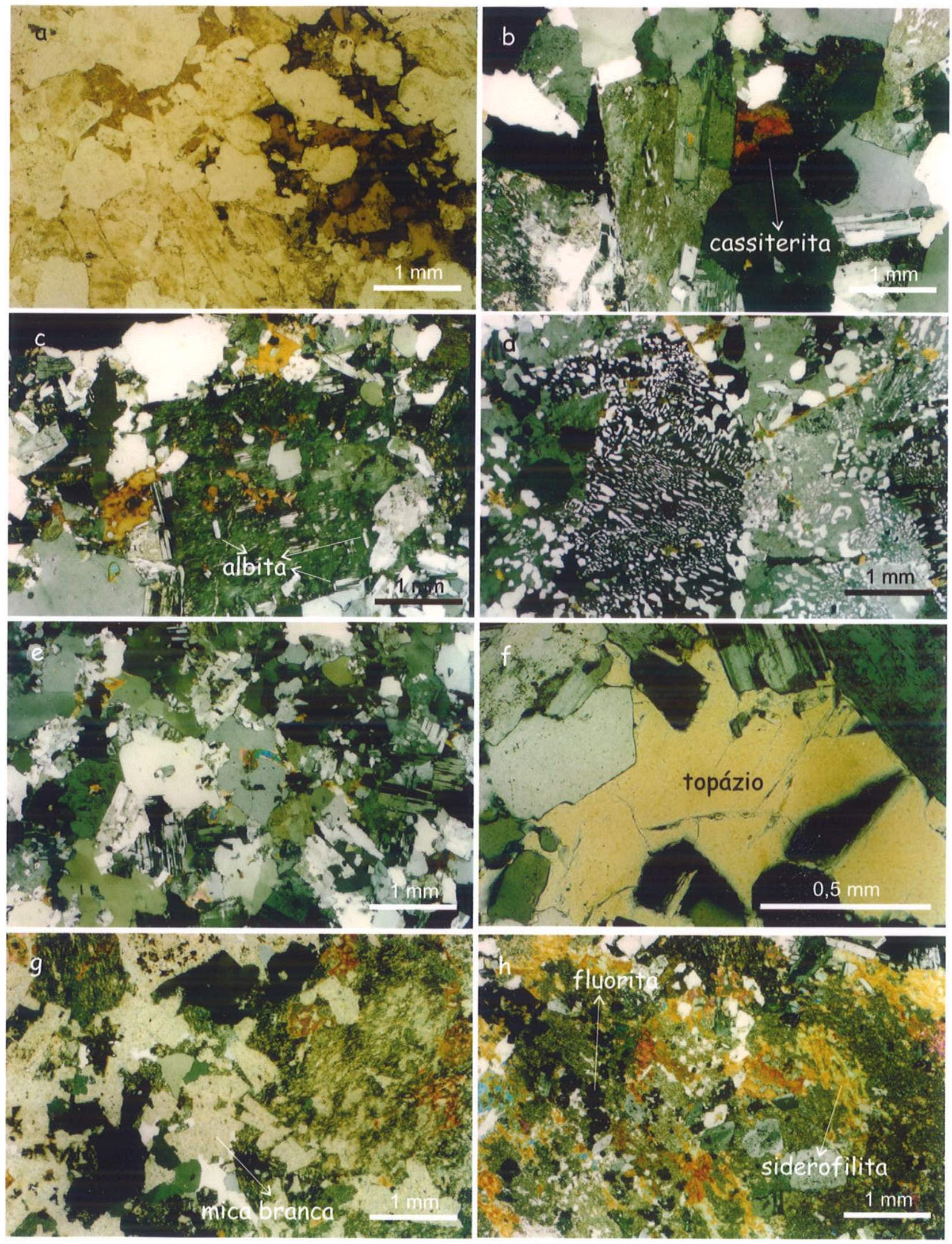

Prancha 5.3 
Prancha 5.4 - a) Granito porfirítico de matriz média da fácies Santa Bárbara média cujos megacristais de feldspato potássico e diversos cristais de feldspatos da matriz exibem pigmentação branca que denota composição albítica. Amostra AM-224; b) ocorrência, na forma de manchas de contatos difusos, de porções de albita-microclínio granito branco na fácies Santa Bárbara média. Amostra AM-237; c) granito greisenizado, rosa-acinzentado, equigranular de granulação média, composto por feldspatos, quartzo e mica. AM-190; d) greisenização incipiente na forma de spots nucleados sobre megacristais de feldspato potássico da fácies Santa Bárbara média. AM-263; e) quartzo greisen equigranular médio. Amostra AM-227; f) topázio-siderofilita-quartzo greisen equigranular médio cinza. Amostra AM- 35 ; g) mica greisen pobre em quartzo, equigranular médio, preto. Amostra AM-74; h) granito albitizado salmão, leucocrático, equigranular médio, cujos cristais de quartzo mostram-se bem formados e arredondados enquanto que a matriz feldspática carece de contornos cristalinos definidos. Amostra AM-14B. 

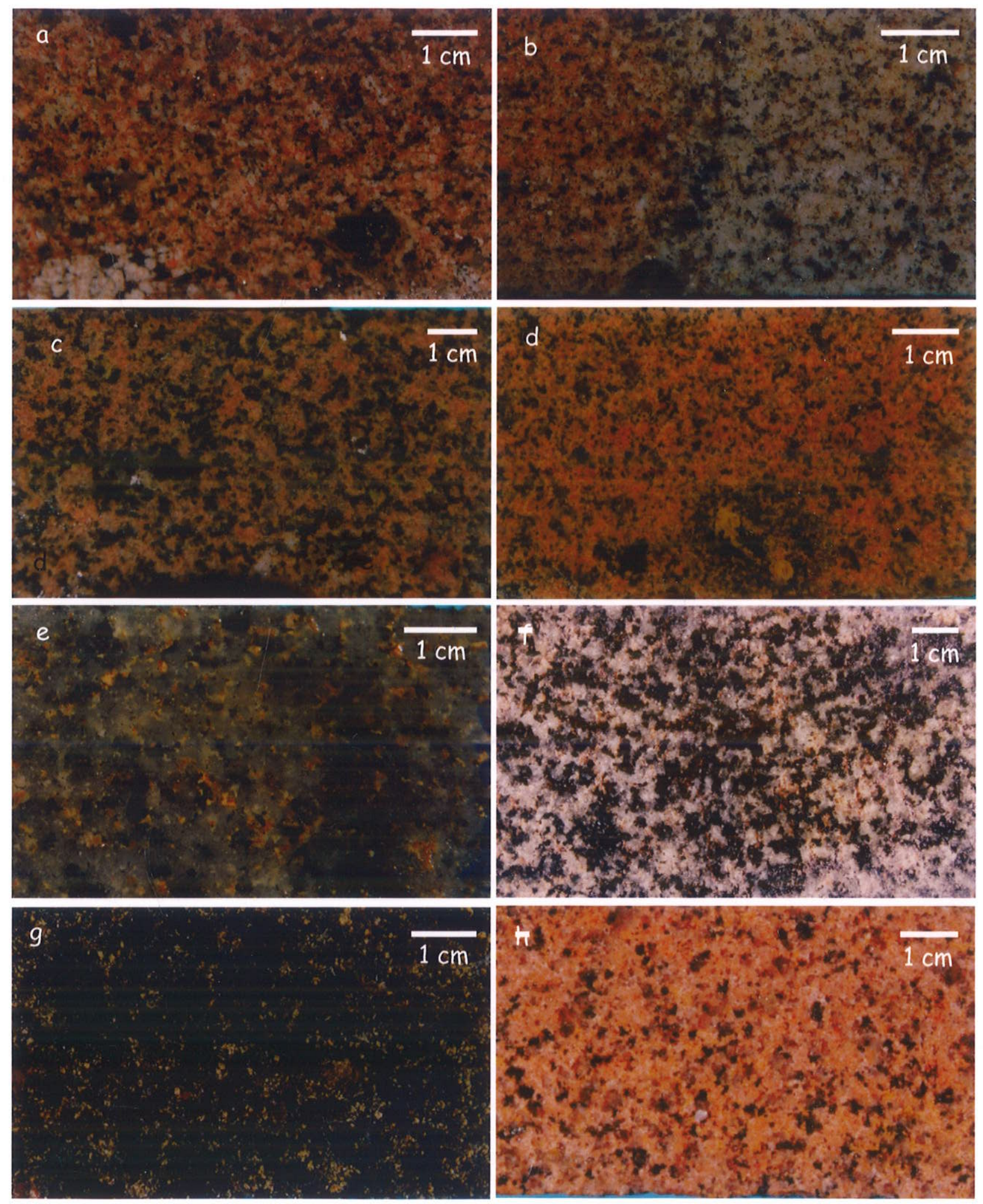

Prancha 5.4 
Prancha 5.5 - a) Pronunciada substituição de microclínio por siderofilita nos granitos greisenizados. Nicóis cruzados. Amostra AM-19; b) topázio-siderofilita-quartzo greisen com cristais de cassiterita marrom-escura no centro. Nicóis paralelos. Amostra AM-35; c) aspecto microscópico dos topázio-mica greisens pobres em quartzo. Nicóis paralelos. Amostra AM-72; d) abundância de albita chessboard no granito albitizado salmão. Forma irregular da mica. Nicóis cruzados. Amostra AM-14B; e) composição monominerálica dos fronts de albitização. Nicóis cruzados. Amostra AM-273C; f) inclusões ripiformes de plagioclásio orientada segundo as superfícies de crescimento do quartzo hospedeiro, configurando textura snowball. Quartzo dos pegmatóides. Amostra AM-212; g) muscovitização extensiva de topázio-siderofilita-quartzo greisen, gerando rocha de textura fina quase monominerálica. Nicóis paralelos. Amostra AM-12. 

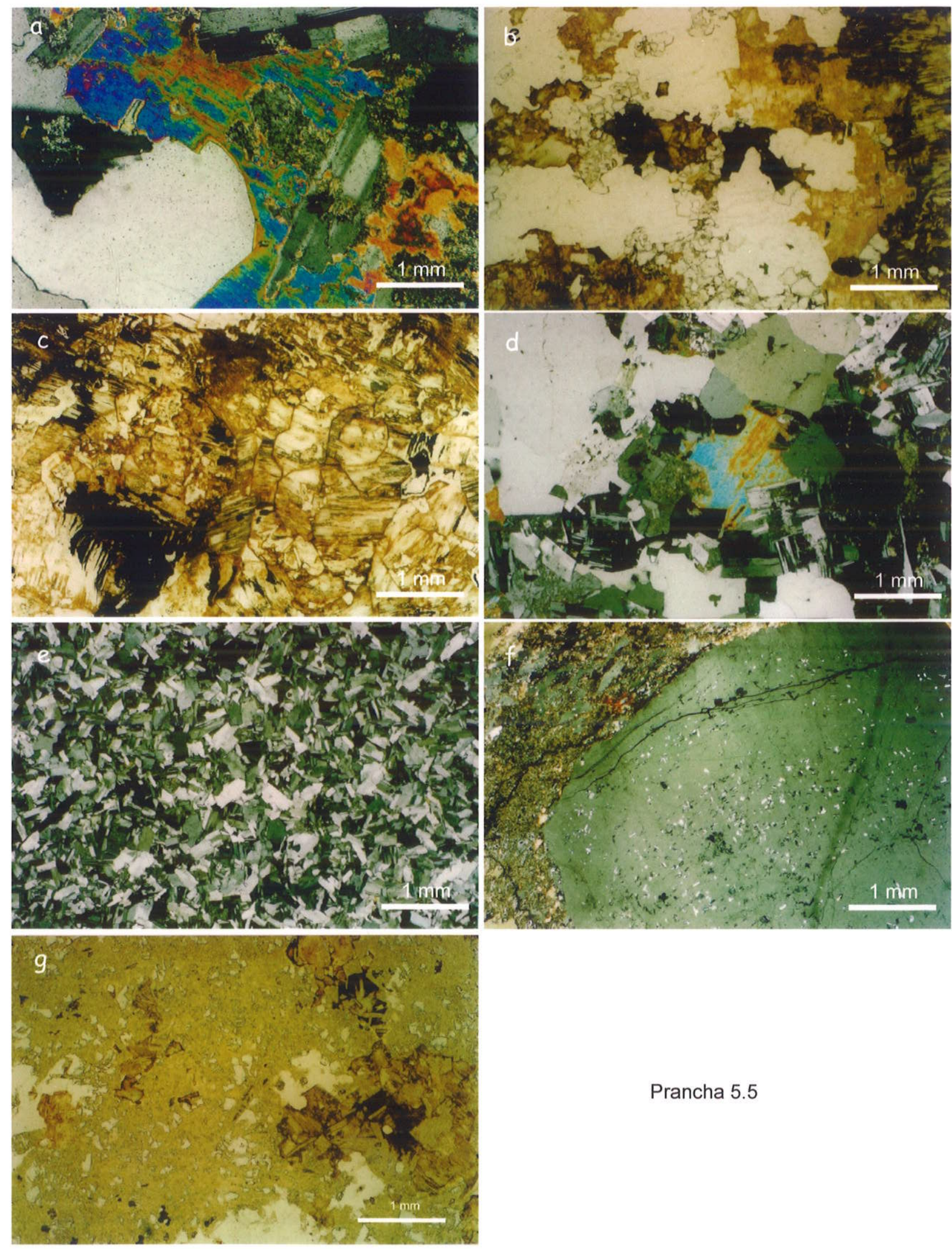

Prancha 5.5 
Prancha 5.6 - a) Aspecto macroscópico do front irregular de albitização, representado pela porção salmão hololeucocrática da rocha. Amostra AM-273; b) pegmatóide com cristais de feldspato potássico de textura "plumosa", mica e quartzo intercrescidos. Amostra AM240 ; c) pegmatóide composto por feldspato potássico euédrico, além de mica e quartzo intercristalinos. Amostra AM-247; d) granito greisenizado afetado por muscovitização, mais intensa nas regiões amarela. Amostra AM-1; e) quartzo greisen equigranular médio afetado por muscovitização; f) topázio-siderofilita-quartzo greisen inteiramente substituído por muscovita, com cassiterita (preta) abundante. Amostra AM-307. 

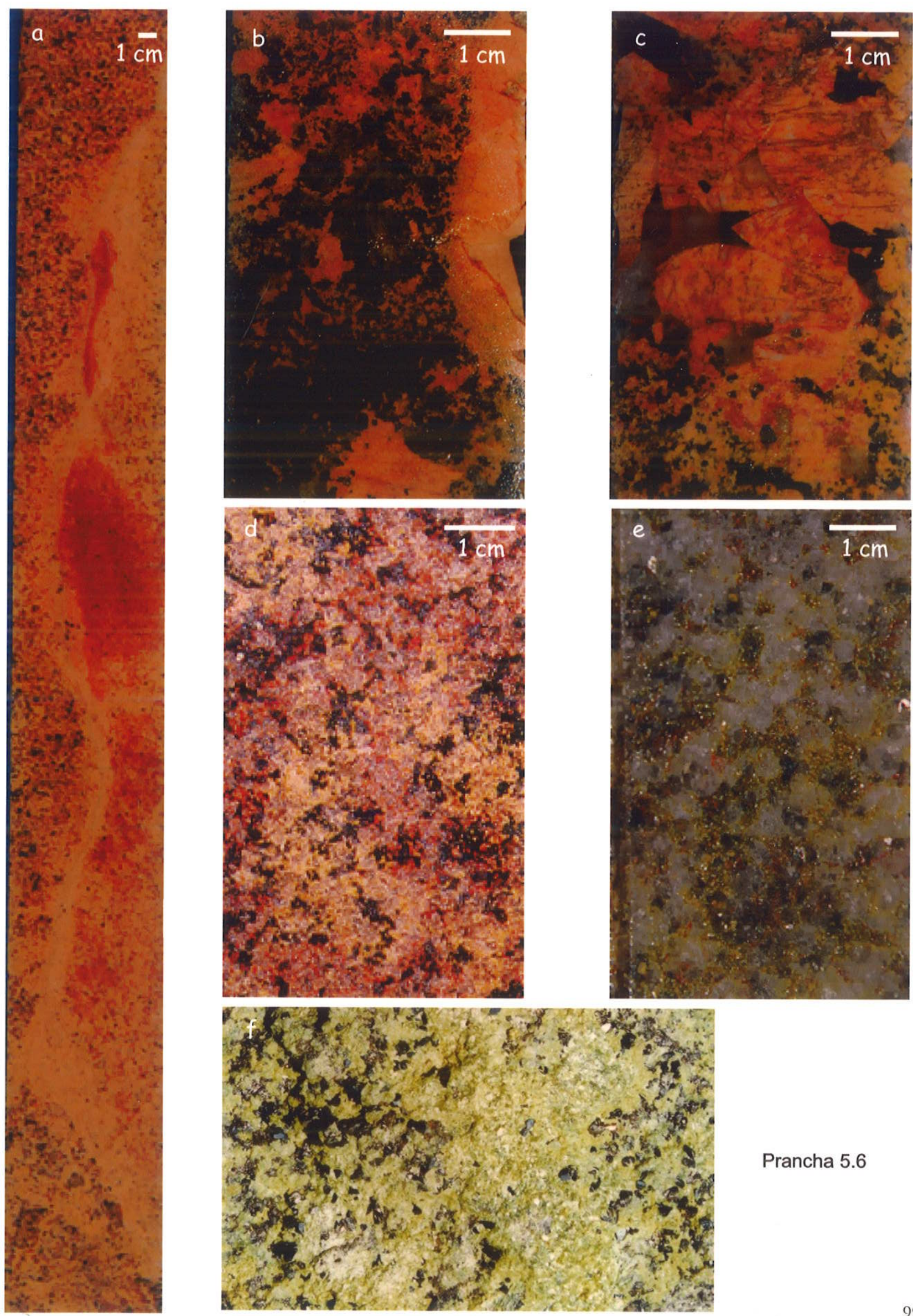

Prancha 5.6 

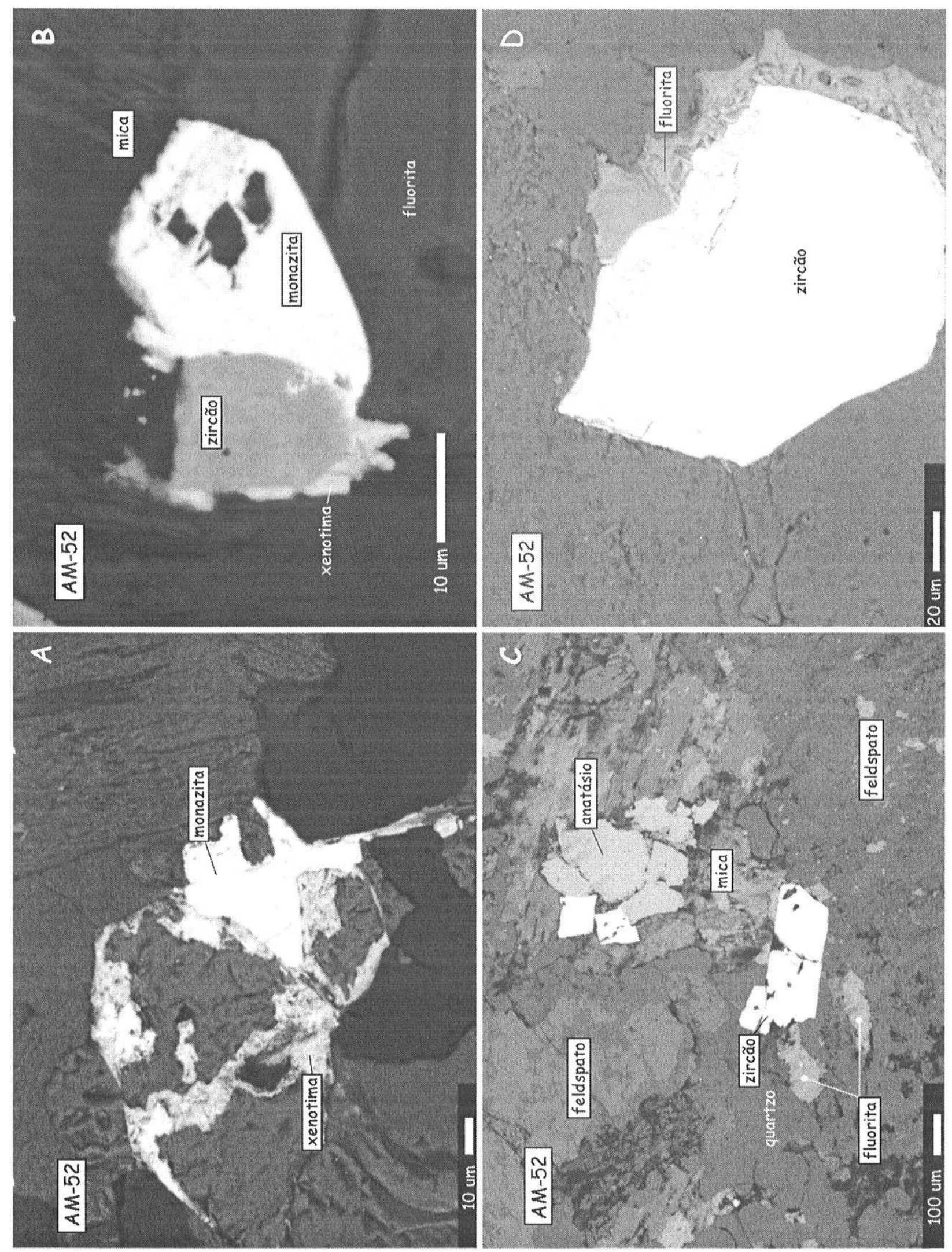

Prancha 5.7 - a) Associação freqüente de monazita com a mica primária na fácies Serra do Cícero. A xenotima está associada à monazita como produto de substituição da mica; b) zircão associado com monazita e com sobrecrescimento de xenotima na fácies Serra do Cícero; c) aspecto de granito da fácies Serra do Cícero mostrando grandes e abundantes cristais prismáticos de zircão sem zonação aparente, fraturados. Substituição da mica primária por anatásio subédrico; d) tipo de zircão predominante na fácies Serra do Cícero, caracterizado pelo hábito prismático curto e pela ausência de faces de crescimento aparentes. Associação com fluorita. 


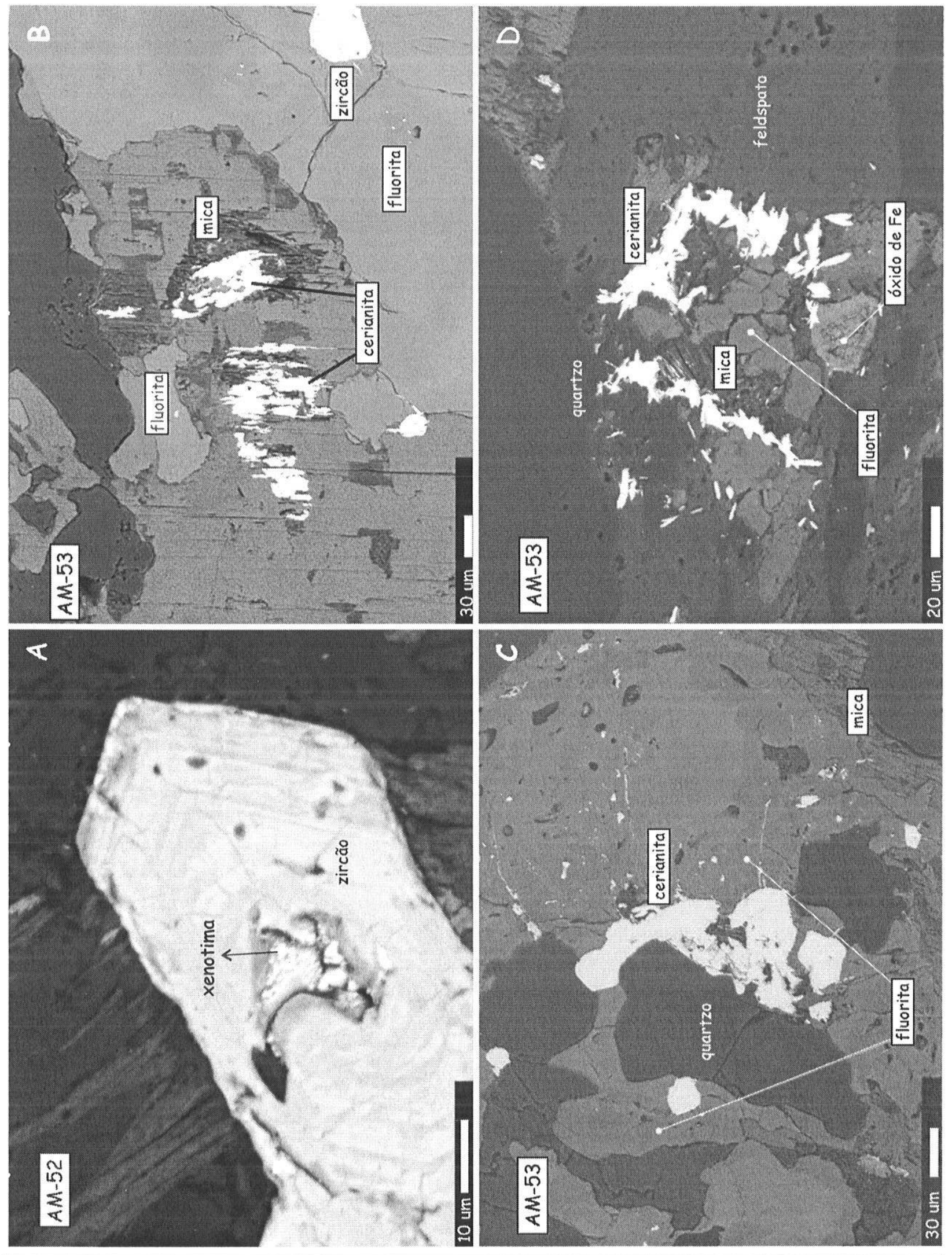

Prancha 5.8 - a) Tipo de zircão de ocorrência subordinada na fácies Serra do Cícero, caracterizado pela forma prismática com terminações bipiramidais, intercrescimento com xenotima no núcleo e faces de crescimento bem marcadas; b) cerianita em associação com mica secundária substituíndo mica primária na fácies Serra Azul; c) cerianita granular anédrica inclusa em fluorita com zonação concêntrica na fácies SerraAzul; d) cerianita prismática em agregados de cristais associada à fluorita e à mica na fácies SerraAzul. 

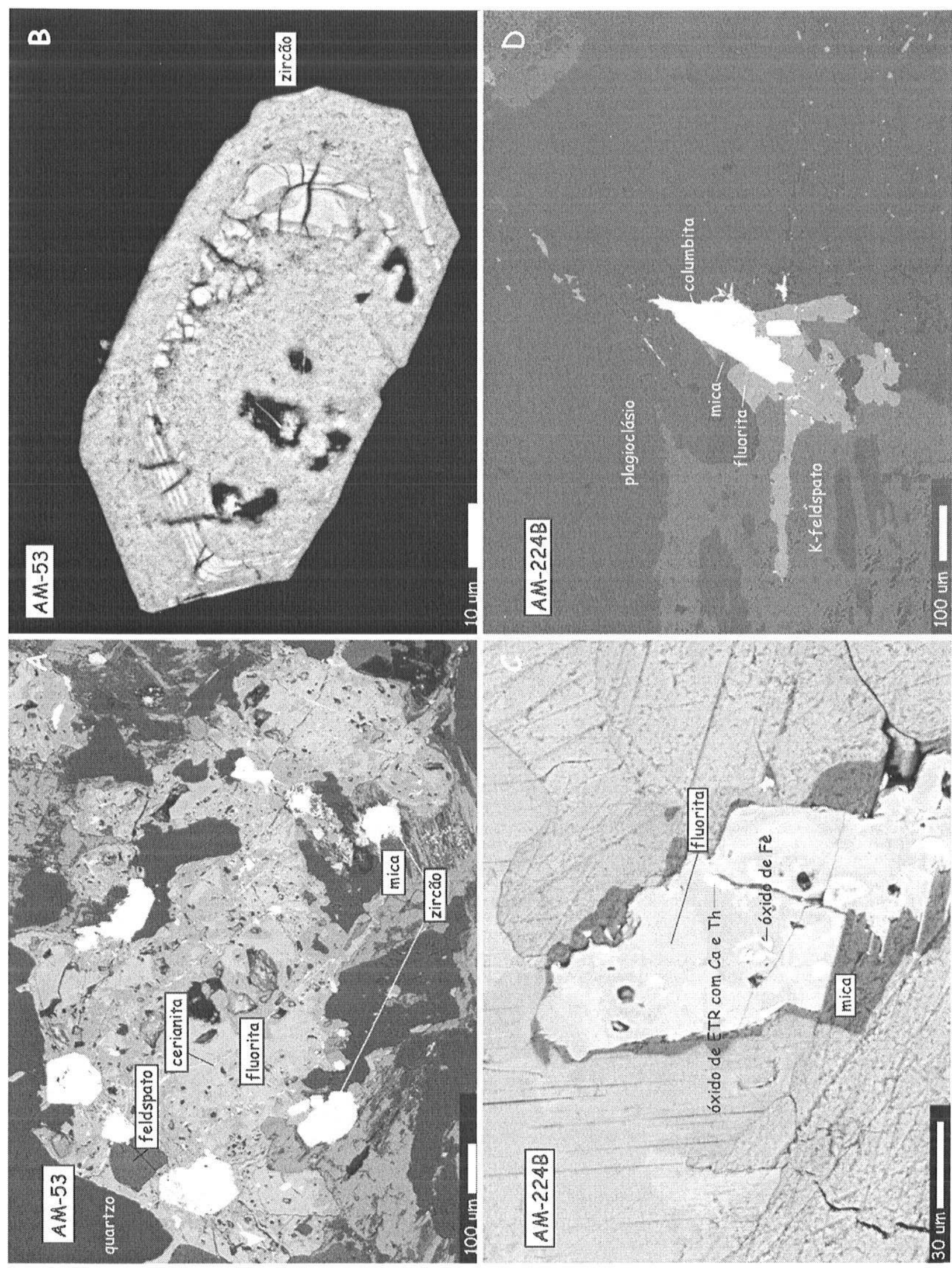

Prancha 5.9 - a) Grande cristal de fluorita em associação com mica e quartzo, com padrão de zonação irregular e diversas inclusões de zircão. Fácies Serra Azul; b) cristal de zircão com faces de crescimento parcialmente destruídas nas regiões de núcleo e borda, onde apresenta aspecto turvo; c) ocorrência de óxido de ETR incluso na fluorita tardia associada com mica na fácies Santa Bárbara; d) presença de columbita em associação com mica e fluorita na fácies Santa Bárbara. 

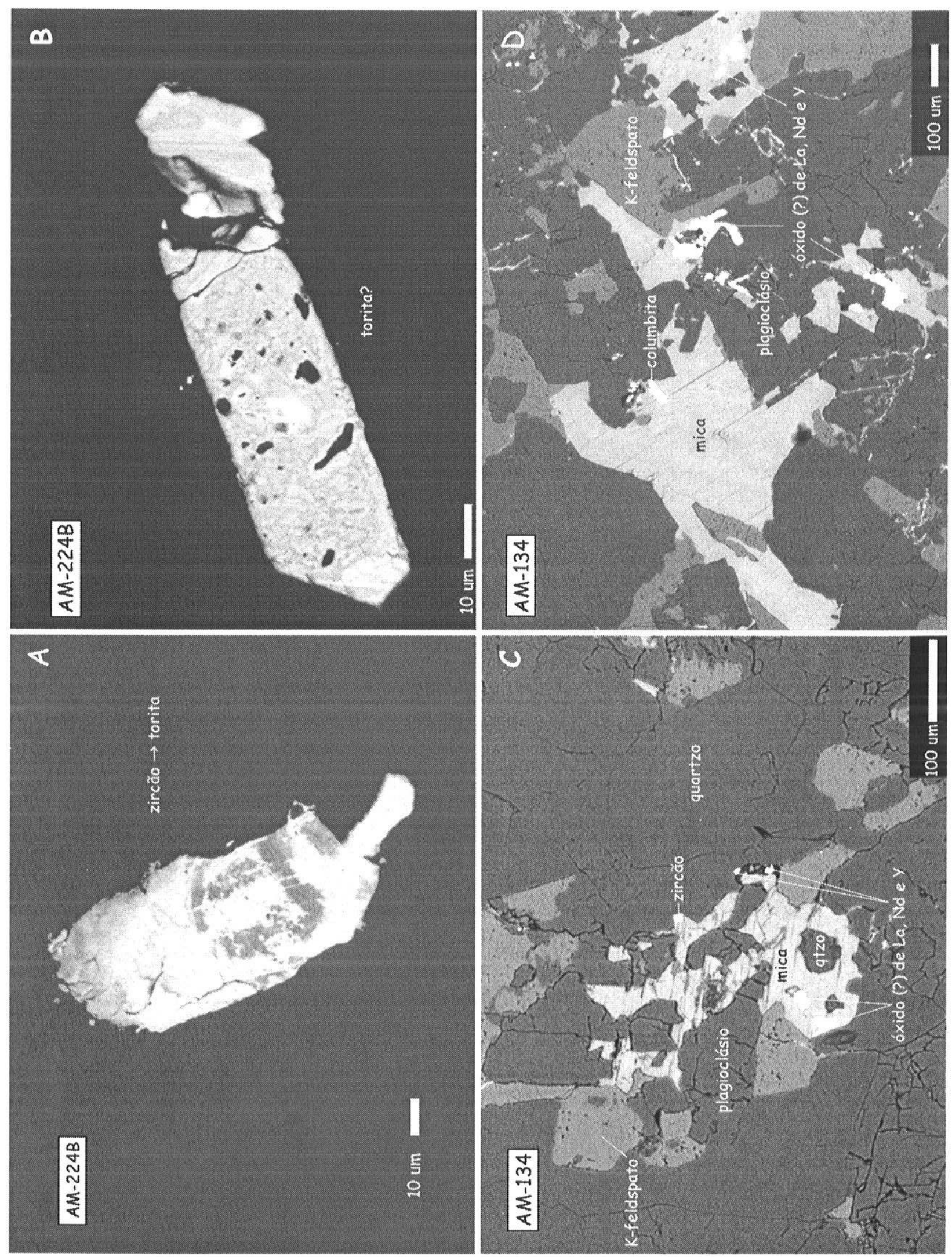

Prancha 5.10 - a) Zircão parcialmente substituído por torita na fácies Santa Bárbara; b) zircão inteiramente pseudomorfizado por torita na fácies Santa Bárbara; $c$ ) diversas inclusões de óxido de La, Nd e Y na mica secundária do granito albitizado branco; d) presença de columbita inclusa na mica secundária doalbita-microclínio granito branco. 


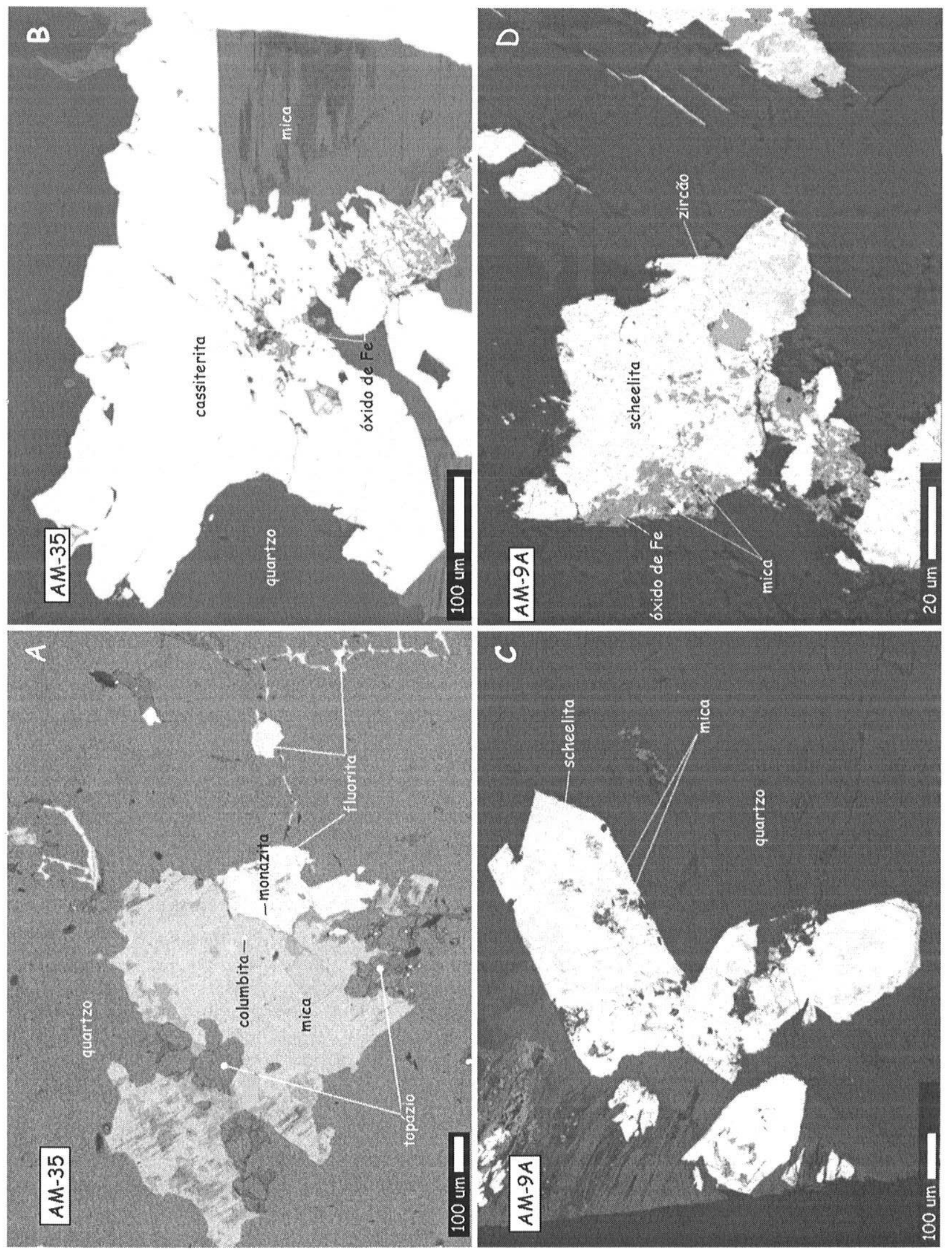

Prancha 5.11 - a) Aspecto dos topázio-mica-quartzogreisens com fluorita, topázio, mica e quartzo, podendo também estar presente a cassiterita. A monazita e a columbita são acessórias, inclusas na fluorita e na mica, respectivamente; b) cassiterita anédrica e isenta de inclusões, substituída por óxido de ferro nas fraturas, associada com quartzo e mica zonada cujo núcleo é mais pobre em ferro do que a borda. Topázio-mica greisen; c) pseudomorfismo de volframita por scheelita em topázio-mica greisen; d) precipitação de óxido 


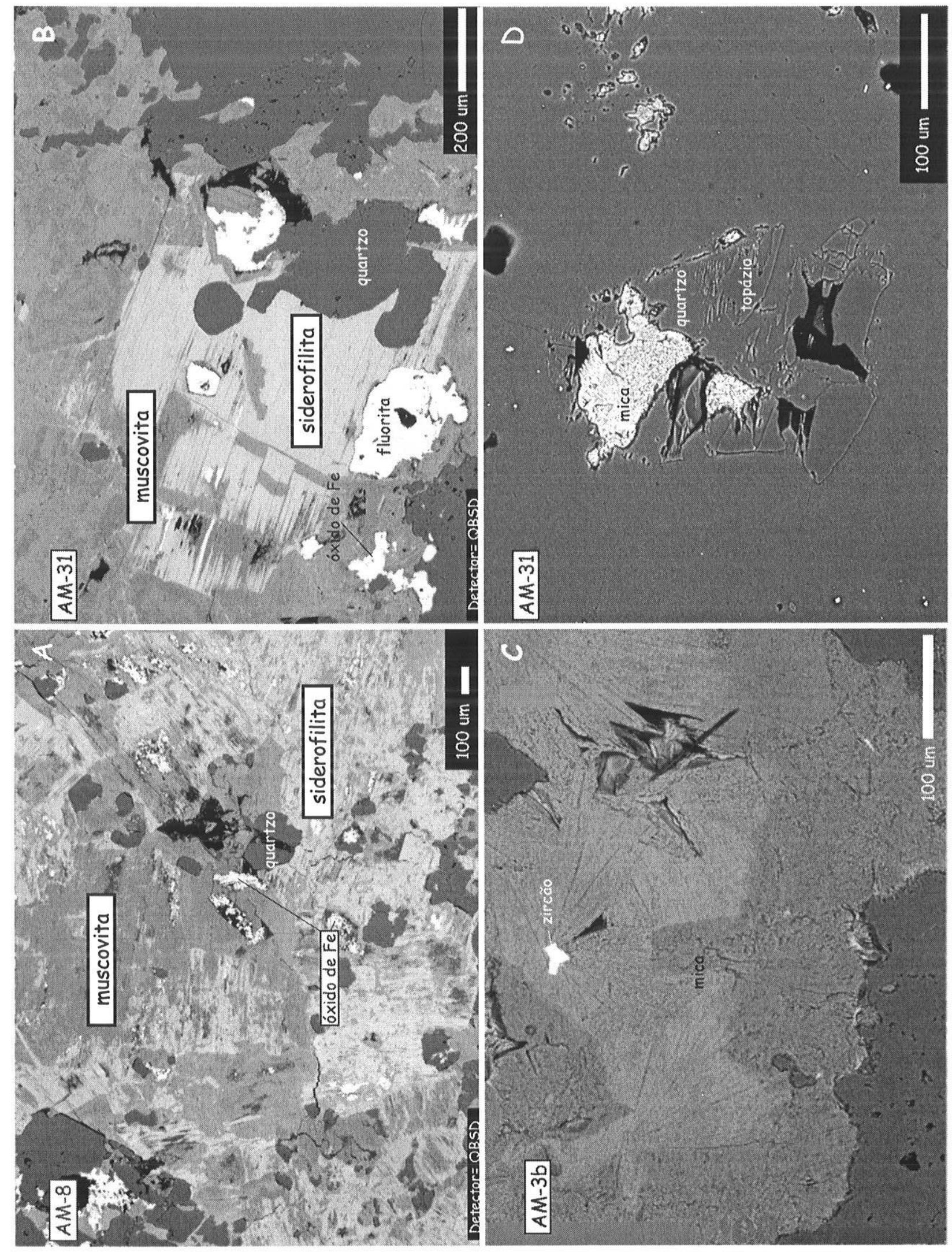

Prancha 5.12 - a) Associação textural de dois tipos de mica nos topázio-mica greisens pobres em quartzo, onde a mais escura e mais pobre em ferro substitui a precoce a partir das bordas, gerando segregações de óxido de ferro; b) fengitização de topázio-mica greisen, promovendo a substituição da mica original, mais clara, por fengita (cinza médio), e a precipitação de fluorita; c) zonação da fengita com núcleo mais rico em ferro e borda mais pobre; d) consumo de topázio nos topázio-mica greisens devido à alteração fengítica superposta. 

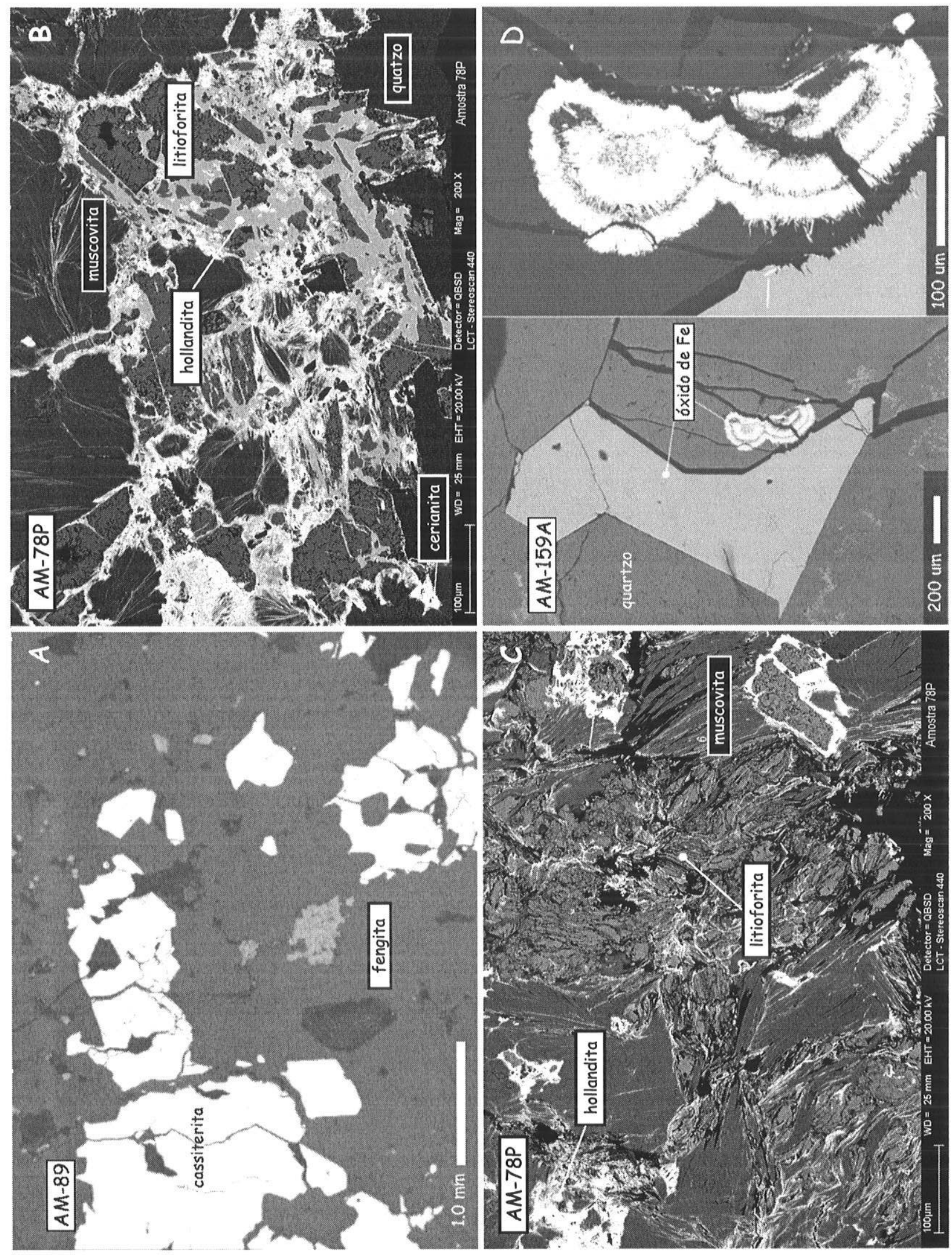

Prancha 5.13 - a) Rocha composta por fengita e cassiterita oriunda da fengitização extensiva de topázio-mica greisen; b) e c) associação de fengita com litioforita, hollandita e cerianita nos nódulos manganesíferos oriundos da alteração fengítica; d) óxido de ferro como películas e formas botrioidais sobre as terminações de cristais de quartzo, na porção central dos veios de quartzo estéreis. 

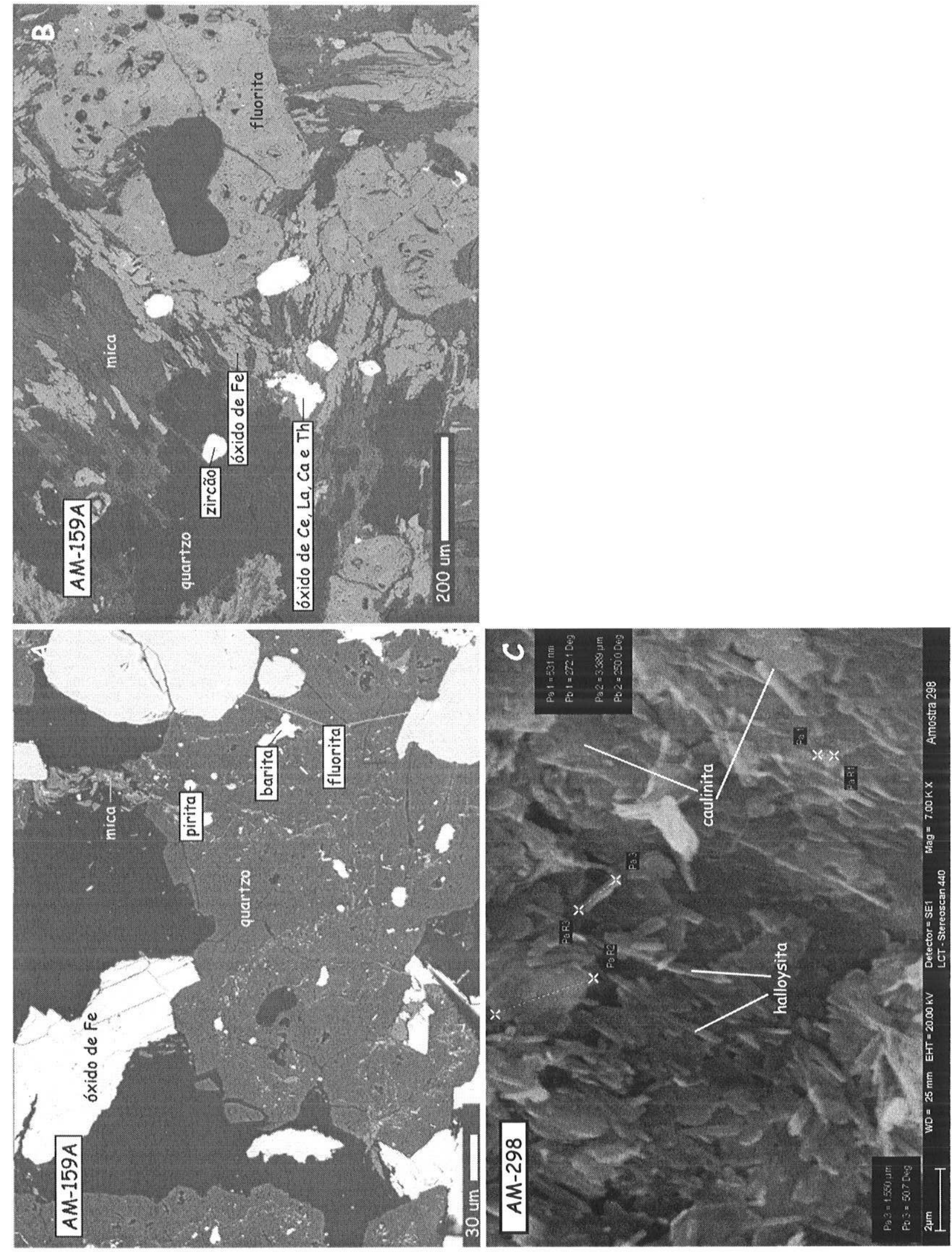

Prancha 5.14 - a) Carbonato (buracos negros), pirita, barita, óxido de ferro e fluorita presentes nas bordas de alteração das encaixantes geradas pelos veios de quartzo estéreis; b) substituição pronunciada da mica primária por óxido de ferro nas bandas de alteração laterais aos veios de quartzo estéreis. Neste exemplo, a encaixante alterada e um granito da fácies SerraAzul; c) cualinita, predominante, e haloysita do stockwork argiloso. 


\section{LITOGEOQUIMICA}

As rochas do Maciço Granítico Santa Bárbara caracterizam-se pela grande similaridade composicional (Tabela 6.1).

Apresentam altos teores de $\mathrm{SiO}_{2}(74,40$ a $78,05 \%), \mathrm{K}_{2} \mathrm{O}(4,16$ a $5,81 \%), \mathrm{Na}_{2} \mathrm{O}(2,95$ a $3,98 \%), \mathrm{K}_{2} \mathrm{O}+\mathrm{Na}_{2} \mathrm{O}(7,55$ a 8,80\%), Sn (11 a $230 \mathrm{ppm}), \mathrm{Rb}(368$ a $1070 \mathrm{ppm}), \mathrm{Ce}(90$ a $331 \mathrm{ppm})$, $\mathrm{Nb}(80$ a 113 ppm), Ga (27 a 40 ppm) e Y (102 a 914 ppm), e baixos teores de CaO $(0,05$ a 1,05\%), $\mathrm{Ba}(0$ a $229 \mathrm{ppm})$ e Sr (0 a $33 \mathrm{ppm})$, comparáveis aos valores reportados por Whalen et al. (1987) para a média do granitos do tipo $A$. Tais características geoquímicas, conjuntamente com os altos teores de U (4 a $24 \mathrm{ppm}$ ) e de Th (40 a $65 \mathrm{ppm}$ ) presentes nas rochas do maciço, são comuns também aos granitos rapakivi (Haapala \& Rämö 1990).

São subalcalinos, com altas razões $\mathrm{Fe}_{2} \mathrm{O}_{3} \mathrm{~T} / \mathrm{Fe}_{2} \mathrm{O}_{3} \mathrm{~T}+\mathrm{MgO}(0,96$ a 0,99$)$, e conteúdos baixos a moderados de ETR ( 86 a 194 vezes o condrito, em geral). Apresentam forte anomalia negativa de Eu e fraco enriquecimento dos ETRL em relação aos ETRP (Fig. 6.1.a). Em diagramas multielementares, são pronunciadas as anomalias negativas de Ba, Sr, P e Ti para todas as fácies, com fracas anomalias negativas de $\mathrm{K}, \mathrm{Nb}$ e $\mathrm{Zr}$ e positivas de $\mathrm{Y}$ e $\mathrm{Yb}$ (Fig. 6.1.b). Seu padrão de distribuição multi-elementar superpõe-se, em grande parte, àquele do Maciço Oriente Novo, pertencente à Suíte Intrusiva Santa Clara ( $f$. Leite Júnior 2002), da Província Estanífera de Rondônia. Assemelha-se muito, também, ao granito rapakivi Eurajöki, da Finlândia (Figg. 6.2).

Exibem características geoquímicas comuns aos granitos rapakivi reduzidos, como conteúdos de $\mathrm{K}_{2} \mathrm{O}>5 \%$ em peso (aos $70 \%$ em peso de $\mathrm{SiO}_{2}$ ) e razões $\mathrm{K} / \mathrm{Na}>1$, no caso das fácies Serra do Cícero e Serra Azul ( $f$. Frost \& Frost 1997). Fatores como $P_{\mathrm{CO} 2}$ e $P_{\mathrm{H} 2 \mathrm{O}}$ influenciam a razão $\mathrm{K} / \mathrm{Na}$ ( $f$. Ebadi \& Johannes 1991), sendo que o aumento da $P_{H 2 O}$ é uma causa provável para a diminuição dessa razão abaixo de 1 nas rochas da associação de fácies Santa Bárbara (ff. Frost \& Frost 1997).

Os granitos da fácies Serra do Cícero diferenciam-se daqueles das demais unidades do Maciço Granítico Santa Bárbara pelos índices de saturação em alumina $(\mathrm{A} / \mathrm{CNK})$, restritos a valores de 0,99 a 1,00, que os enquadram na categoria das rochas metaluminosas. Os granitos das fácies Serra Azul, Santa Bárbara média e Santa Bárbara fina, incluído o albita-microclínio granito fino 
branco, aqui representado por $\mathbf{f S B f b}$, são leve a francamente peraluminosos, com índices $\mathrm{A} / \mathrm{CNK}$ de 1,02-1,03, 1,03 1,10,1,06-1,16 e 1,16-1,29, respectivamente, bem como conteúdos de coríndon normativo variáveis entre $0,26-0,35,0,35-1,13,0,65-1,73$ e 1,78-3,10 (Fig. 6.1.c).

Outras características distintivas da fácies Serra do Cícero são seus conteúdos ligeiramente superiores de $\mathrm{TiO}_{2}, \mathrm{Fe}_{2} \mathrm{O}_{3} \mathrm{~T}, \mathrm{MgO}, \mathrm{K}_{2} \mathrm{O}, \mathrm{CaO}$ e $\mathrm{P}_{2} \mathrm{O}_{5}$ (Figs. 6.6 e 6.7) em relação ìs demais unidades, bem como teotes significativamente maiores de Ba (214 a $229 \mathrm{ppm})$, Sr (27 a 33 ppm) e Zr (227 a $316 \mathrm{ppm})$, e menores de Rb (368 a $479 \mathrm{ppm}), \mathrm{Ga}(27$ a $32 \mathrm{ppm}), \mathrm{li}(60 \mathrm{ppm})$, Ta (7 a $8 \mathrm{ppm}), \mathrm{Cs}(3$ a 4 ppm) e F (0,53 a 0,83\%) (Figs. 6.7, 6.8 e 6.9). As razões elementares $10000 \mathrm{Ga} / \mathrm{Al}(4,03$ a 4,72), $\mathrm{Rb} / \mathrm{Sr}\left(13,63\right.$ a 15,11) e $\mathrm{Rb} / \mathrm{Ba}\left(1,61\right.$ a 2,24) são menores, enquanto que $\mathrm{K}_{2} \mathrm{O} / \mathrm{Na}_{2} \mathrm{O}(1,59$ a 1,94$) \mathrm{e}$ $\mathrm{K} / \mathrm{Rb}(94,81$ a 131,07) são maiores (Figs. 6.9 e 6.10). No que tange aos conteúdos de ETR, são marcantes sua riqueza relativa de ETRL em relação aos ETRP $\left((\mathrm{La} / \mathrm{Yb})_{\mathrm{N}}\right.$ de 3,52 a 4,67) e a anomalia negativa de Eu menos pronunciada $\left(\left(\mathrm{Eu} / \mathrm{Eu}^{*}\right)_{N}\right.$ de 0,19 a 0,20) (Figs. 6.1.a e 6.10.c).

A fácies Serra Azul distingue-se das demais unidades pelos conteúdos menores de $\mathrm{Al}_{2} \mathrm{O}_{3}$ $\left(11,53\right.$ a 11,58\%) e $\mathrm{Na}_{2} \mathrm{O}(2,95$ a 2,99\%) (Fig. 6.6.b e f). De resto, apresenta composições intermediárias entre a fácies Serra do Cícero e a associação de fácies Santa Bárbara, com teores de $\mathrm{Rb}(585$ a $669 \mathrm{ppm}), \mathrm{Ga}(32 \mathrm{ppm})$ e Ta (9 a $10 \mathrm{ppm})$ menores do que aqueles da associação de fácies Santa Bárbara, e maiores de Zr (187 a 282 ppm) e f (1,13 a 1,51\%).

As rochas da associação de fácies Santa Bárbara são as mais evolutídas no Maciço Granítico Santa Bárbara. São moderada a fortemente entiquecidas em $\mathrm{Na}_{2} \mathrm{O}(3,10$ a 3,98\%, Fig. 6.6.f; $\mathrm{K}_{2} \mathrm{O} / \mathrm{Na}_{2} \mathrm{O}$ de 1,05 a 1,62, Fig. 6.9.d), Rb (462 a 1070 ppm), Ga (32 a 46 ppm), Li (148 a 258 ppm), $\mathrm{Nb}(80$ a $113 \mathrm{ppm})$ e $\mathrm{Ta}(11$ a $19 \mathrm{ppm})$, e empobrecidas em Zr (66 a $188 \mathrm{ppm}$ ) em relação às demais fácies (Figs. 6.7 e 6.8). Suas razões Rb/Sr (52,62 a 285,00, Fig. 6.9.f) e Rb/Ba $(6,06$ a 92,40, Fig. 6.10.a) atingem valores extremamente altos, e são também pronunciados os baixos teores de ETRL. $\left((\mathrm{La} / \mathrm{Yb})_{\mathrm{N}}\right.$ de 1,57 a 3,48) e as anomalias negativas de $\mathrm{Eu}\left(\left(\mathrm{Eu} / \mathrm{Eu}^{*}\right)_{\mathrm{N}}\right.$ de 0,02 a 0,12 (Fig. 6.10.c). Internamente à associação de fácies Santa Bárbara, são particulares os maiores conteúdos de Ga e menores de Sn da fácies Santa Bárbara fina (33 a $40 \mathrm{ppm}$ e 14 a $26 \mathrm{ppm}$, respectivamente) em relação à fácies Santa Bárbara média (32 a 37 ppm e 19 a 230 ppm, respectivamente), e os conteúdos extremamente elevados de Ga (46 ppm), Li (366 ppm), Ta (34 ppm), Y (914 ppm) e ETR (1927 vezes o condrito), com forte enriquecimento dos ETRL $\left(\left(\mathrm{L}_{\mathrm{A}} / \mathrm{Yb}\right)_{\mathrm{N}}\right.$ de 10,93$)$, na fácies Santa Bárbara fina (AM-134). Os conteúdos de $\mathrm{CaO}(0,05 \%$, Fig. 6.6.e) e de $\mathrm{Ce}$ (331 ppm; anomalia negativa, Fig. 6.1.a) são relativamente muito baixos nesta amostra.

As características acima descritas, especialmente no que tange aos conteúdos de $\mathrm{Nb}$, Ce e $\mathrm{Y}$, 
à razão $10000 \mathrm{Ga} / \mathrm{Al}$, e ao padrão de distribuição dos ETR em relação ao condrito, permitem classificar os granitos do Maciço Gtanútico Santa Bárbara como do tipo A (Loiselle \& Wones 1979; Whalen et al. 1987, Fig. 6.3). Os diagramas discriminantes de granitos que relacionam $\mathrm{FeOT} /\left(\mathrm{FeOT}+\mathrm{MgO}\right.$ ) versus $\mathrm{SiO}_{2}$ (Frost ot al. 2001, Fig. 6.4.a) e $\mathrm{P}_{2} \mathrm{O}_{5}$ versus $\mathrm{F}$ (Förster et al. 1998 in Seltmann et al. 1998, Fig. 6.4.b) apontam para a mesma tendência. Cabe ressaltar a dificuldade de classificação de granitos félsicos $\left(\mathrm{SiO}_{2}>74 \%\right)$, dada a convergência das composições químicas e mineralógicas de diferentes tipos de granitos nesse intervalo composicional (Whalen et al. 1987).

Os pontos analíticos representativos das fácies Serra do Cícero, Serra Azul, Santa Bárbara média e Santa Bárbara fina localizam-se no campo dos granitos intraplaca (Pearce et at. 1984, Fig. 6.4.c), pós-colisionais (Förster é al. 1995 in Seltmann et al. 1998, Fig. 6.4.b).

As correlações entre elementos e óxidos com o $\mathrm{TiO}_{2}$ são bem definidas, e indicam a cogeneticidade das rochas das diversas fácies do maciço. Observa-se diminuição dos teores de $\mathrm{TiO}_{2}$, $\mathrm{Fe}_{2} \mathrm{O}_{3} \mathrm{~T}, \mathrm{MgO}, \mathrm{CaO}, \mathrm{K}_{2} \mathrm{O}$ e $\mathrm{P}_{2} \mathrm{O}_{5}, \mathrm{Ba}, \mathrm{Sr}, \mathrm{Zr}, \mathrm{Ce}, \mathrm{K}_{2} \mathrm{O} / \mathrm{Na}_{2} \mathrm{O}$ e K/Rb com o grau de diferenciação, ao passo que os conteúdos de $\mathrm{SiO}_{2}, \mathrm{Rb}, \mathrm{Ta}, \mathrm{F}, \mathrm{Li}, \mathrm{Rb} / \mathrm{Sr}, \mathrm{Rb} / \mathrm{Ba}$ e $\mathrm{Fe}_{2} \mathrm{O}_{3}{ }^{\circ} \mathrm{T} /\left(\mathrm{Fe}_{2} \mathrm{O}_{3} \mathrm{~T}+\mathrm{MgO}\right)$ aumentam (Figs. 6.6 a 6.10 ).

A diminuição da razão $\mathrm{K} / \mathrm{Rb}$ e o aumento da razão $\mathrm{Rb} / \mathrm{Sr}$ (Fïg. 6.9.e e f) indicam o fracionamento de feldspato alcalino e plagioclásio, respectivamente, corroborado pela diminuição da razão $\mathrm{K}_{2} \mathrm{O} / \mathrm{Na}_{2} \mathrm{O}$ (Fig. 6.9.d).

A diminuição acentuada dos teores de Zr (Fig. 6.8.d) e Ce (Fig. 6.9.c) como $\mathrm{TiO}_{2}$ refletem o fracionamento de zircão e monazita, respectivamente. Os teotes de Th (Fig. 6.8.e) não são significativamente perturbados em função da estabilização da torita nas fácies mais evoluídas. No albita-microclínio granito branco (fácies Santa Bárbara fina), o extremo enriquecimento em Ta e Lá $+Y+Y b$ (Figs. 6.1.b, 6.8.c e 6.9.a e b) em relação às fácies menos evoluídas reflete a cristalização de columbita-tantalita e de óxidos de ETR, respectivamente.

As tendências evolutivas do $\mathrm{Al}_{2} \mathrm{O} 3$ e do $\mathrm{Na}_{2} \mathrm{O}$ apresentam inflexões nos diagramas de correlação com o $\mathrm{TiO}_{2}$, marcadas pela diminuição dos conteúdos dos dois óxidos da fácies Serra do Cícero até a fácies Serra Azul e inversão dessa tendência rumo à associação de fácies Santa Bárbara (Fig. 6.6.b e f). Esses fatores, aliados ao aumento dos conteúdos de Li e Fi, controlado pelo aumento dos teores desses elementos nas micas (Capítulo VII), e ao fracionamento dos feldspatos discutido acima, indicam a estabilização crescente de paragêneses do tipo albita + micas de Fe-Li + topázio, com contribuição gradativamente menos significativa do feldspato potássico.

A correlação negativa dos conteúdos de $\mathrm{Sr}, \mathrm{CaO}$ e Fi com o $\mathrm{Na}_{2} \mathrm{O}$ em diagramas logarítmicos 
(Figs. 6.10.d, e e f) corrobora a origem magmática desse enriquecimento em $\mathrm{Na}_{2} \mathrm{O}$ (cf. Schwartz. 1992), que é característico de diferenciação magmática envolvendo fracionamento de plagioclásio e pressupòe empobrecimento em $\mathrm{CaO}$ e $\mathrm{Sr}^{2 \cdot 1}$ no magma residual. Schwartz (1992) postula que a tendência, nos casos de albitização metassomática, seria a manutenção ou o aumento dos teores de Sr e $\mathrm{CaO}$ em relação ao protólito não hidrotermalizado, em função da fixação desses elementos na albita e na fluorita (se F/CaO $\langle 0,68$ ) neoformadas em equilibrio com o fluido hidrotermal.

A diferenciação por cristalização fracionada das rochas do maciço também é indicada pela correlação bem definida dos pontos em diagrama Sr versus Rb/Sr (Fig. 6.11.a). As tendências de evolução magmática em termos de $\mathrm{Sn}$ versus $\mathrm{TiO}_{2}$ e $\mathrm{Sn}$ versus $\mathrm{Rb} / \mathrm{Sr}$, entretanto, não são observadas nas fácies Santa Bárbara média e Santa Bárbara fna, o que indica interação rocha-fluido segundo os critérios definidos por Lehamnn \& Mahavat (1989; Fig. 6.11.b e c) para haplogranitos mineralizados com Sn da Tailândia. Os autores postulam um empobrecimento em Sn dessas rochas relativamente aos conteúdos esperados em função do seu grau de diferenciação magmática, empobrecimento esse devido à remoção do Sn pela interação rocha-fluido. Esse fluido pode ser cogenético/comagmático, ou de fonte externa.

Não há relação aparente entre os teores de $\mathrm{Sn}$ e $\mathrm{Na}_{2} \mathrm{O}$ nas rochas do maciço (Fig. 6.12.a). A correlação positiva entre os teores de F e Sn, entretanto, é indicada no respectivo diagrama (Fïg. 6.12.b), apesar de uma certa dispersão.

As rochas das fácies Serra Azul, Santa Bárbara média e Santa Bárbara fina, incluindo o albitamicroclínio granito fino branco, têm composição normativa CIPW próxima aos pontos mínimos dos sistemas $\mathrm{NaAlSi}_{3} \mathrm{O}_{8}-\mathrm{KAlSi}_{3} \mathrm{O}_{8}-\left(\mathrm{CaAl}_{2} \mathrm{Si}_{2} \mathrm{O}_{8}\right)-\mathrm{SiO}_{2}-\mathrm{H}_{2} \mathrm{O}$ a $1 \mathrm{kbar}$, com teor de An entre 0 e $3 \%$ (Tuttle \& Bowen 1958; James \& Familton 1969, Fig. 6.10). Un discreto trend de enriquecimento em albita da fácies Serra Azul no sentido da associação de fácies Santa Bátbara é aparente, e parece refletir a influência mista do Li e do F no deslocamento do ponto mínimo do sistema haplogranítico (cf. Martin 1983, Manning 1981).

Em suma, as rochas mineralizadas do Maciço Granítico Santa Bárbara (associação de fácies Santa Bárbara) apresentam afinidades geoquímicas com granitos do tipo $A$ e com granitos rapakivi. São peraluminosas, derivadas de precursoras de características redutoras (fácies Serra do Cícero e Serra Azul).

Relativamente aos granitos ditos normais, as rochas da associação de fáceis Santa Bárbara são entiquecidas em $\mathrm{SiO}_{2}, \mathrm{~K}_{2} \mathrm{O}, \mathrm{Na}_{2} \mathrm{O}, \mathrm{Sn}, \mathrm{Rb}, \mathrm{Ce}, \mathrm{Nb}, \mathrm{Ga}, \mathrm{Y}, \mathrm{F}, \mathrm{U}$ e Th, e empobrecidas em $\mathrm{CaO}$, Ba e Sr. Podem ser classificadas como granitos fracionados (Rb/Sr entre 10 e 100; Pollard 1995). 
Comparativamente às demais fácies do maciço, possuem maiores conteúdos de $\mathrm{Na}_{2} \mathrm{O}, \mathrm{Rb}, \mathrm{Ga}, \mathrm{Li}$, $\mathrm{Nb}$ e Ta e as mais extremas razões $\mathrm{Rb} / \mathrm{Sr}$ e Rb/Ba, com menores conteúdos de Zr e de ETRL, excetuado o albita-microclínio granito branco.

Suas caracterísiticas petrográficas, geoquímicas e metalogenéticas são similares àquelas identificadas nas fácies mineralizadas da Suíte Intrusiva Santa Clara, em Rondônia ( $c$. Leite Júnior 2002), bem de exemplos clássicos de granitos mineralizados, como o maciço rapakivi Eurajöki, da Finlândia, conforme ilustra a Fig. 6.2. 

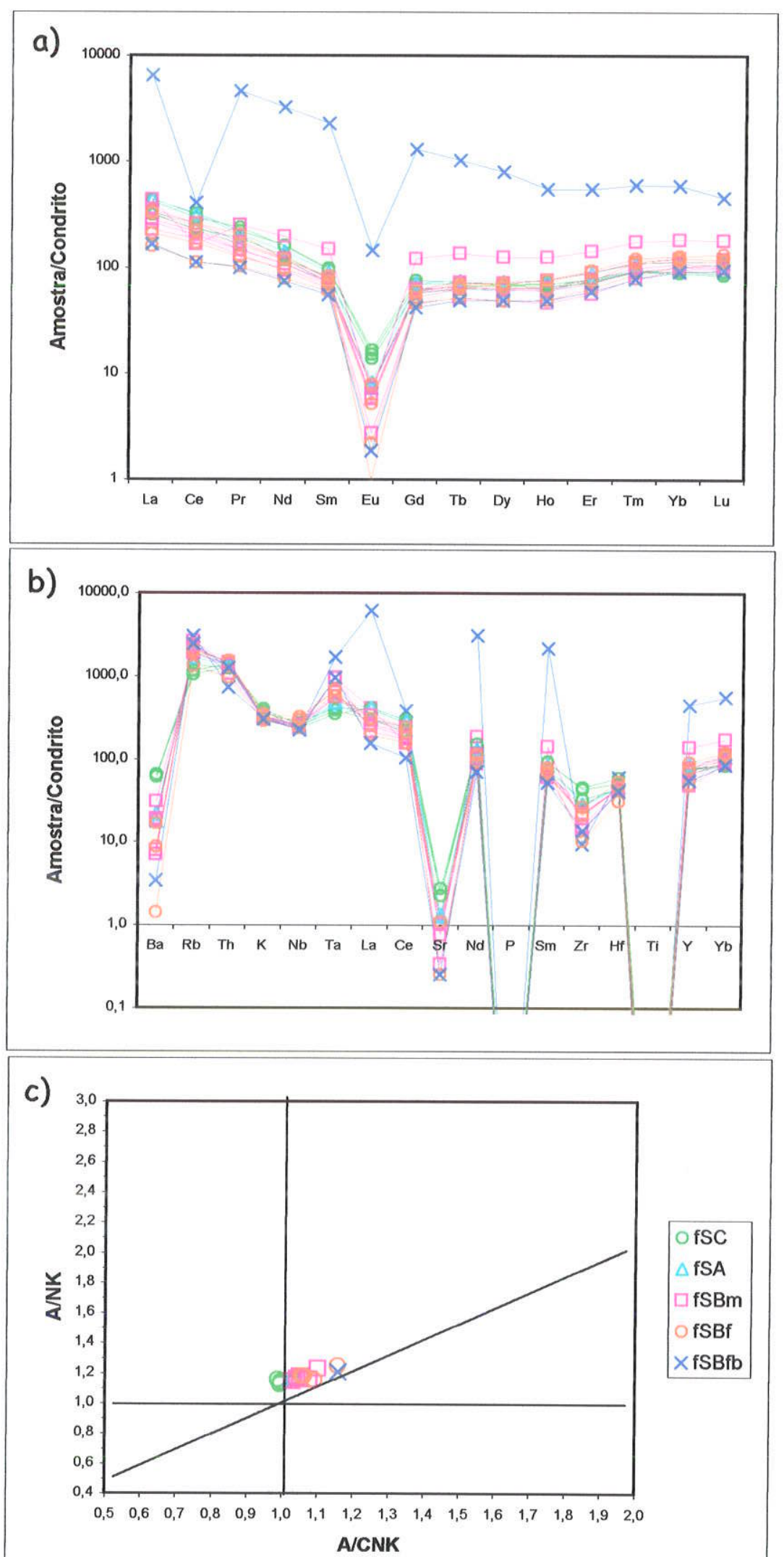

Figura 6.1 - a) Padrão de ETR normalizado pelo condrito (Boynton 1984); b) diagrama multielementar normalizado pelo condrito (Thompson et al. 1982); c) diagrama A/CNK x A/NK (Maniar \& Piccoli 1989) para os granitos do maciço. Símbolos na Fig. 6.1.c. 

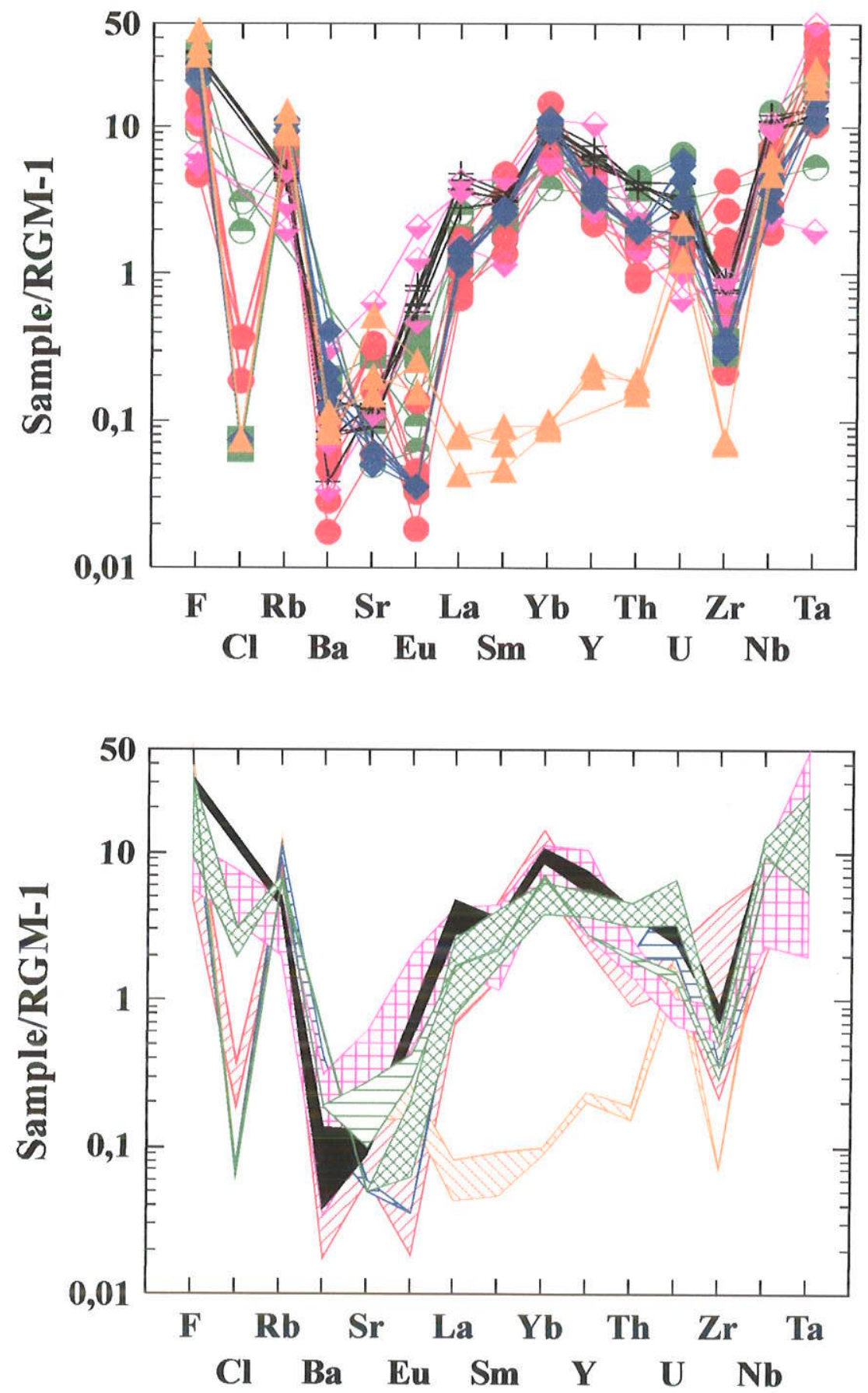

Granito St. Austell

Granito Eurajöki

Granito Pleasant Ridge
+ Maciço Santa Bárbara (afSB) Maciço Oriente Novo

Maciço Correas

\section{Topázio-riólito Spor Mountain}

Figura - 6.2 - Diagramas multi-elementares, modificados de Goraieb (2001) e Bettencourt et al. (em preparação), para as rochas da afSB do Maciço Granítico Santa Bárbara em comparação com as fácies mais evoluídas de granitos mineralizados no Brasil e exterior. Com base em dados de Christiansen et al. (1986), Taylor (1992), Goraieb (2001) e Leite Júnior (2002). 

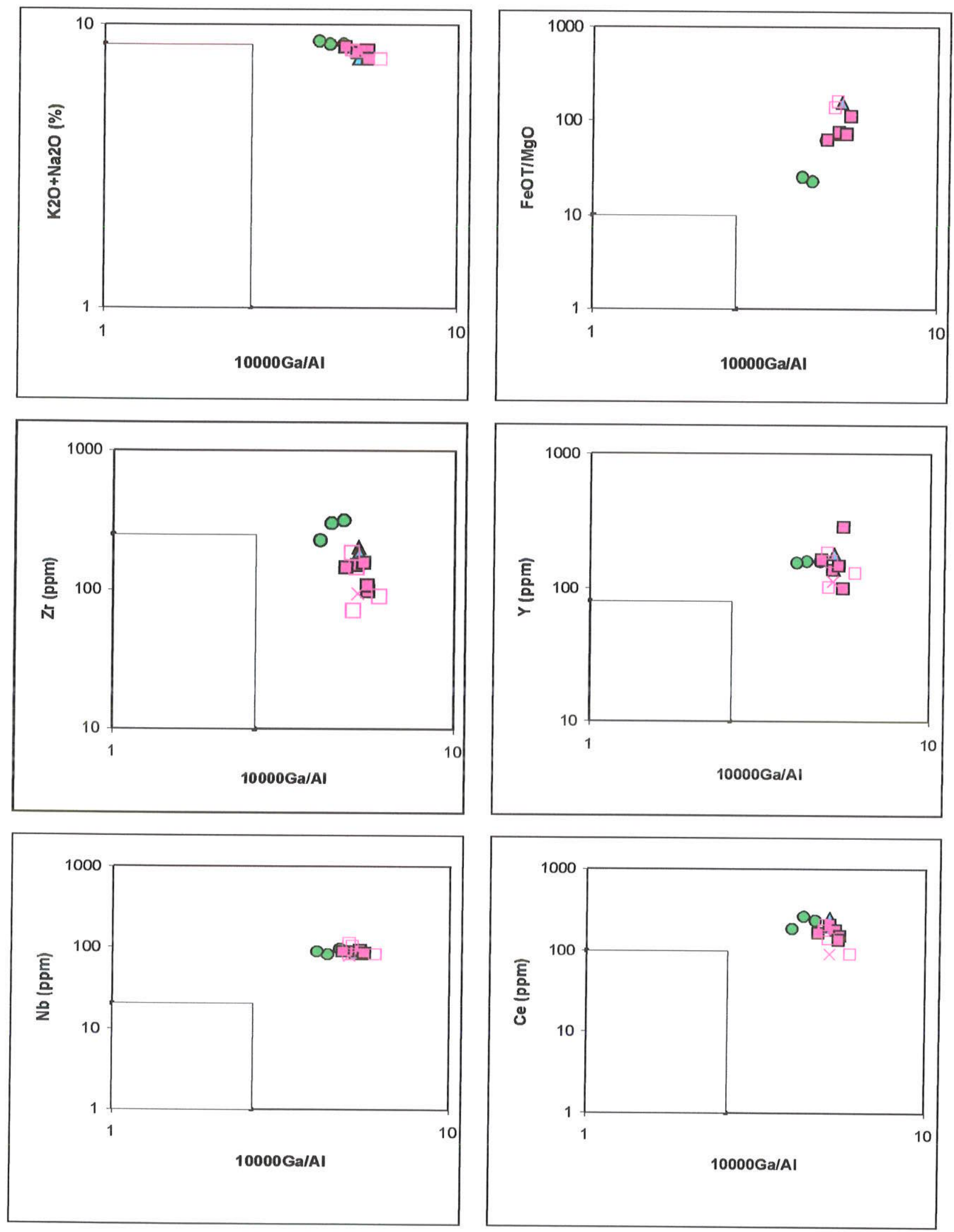

Figura 6.3 - Diagramas de $10000 \mathrm{Ga} / \mathrm{Al}$ versus a) $\mathrm{K}_{2} \mathrm{O}+\mathrm{Na}_{2} \mathrm{O}$, b) FeOT/MgO, c) $\mathrm{Zr}$, d) $\mathrm{Y}$, e) $\mathrm{Nb}$, e f) $\mathrm{Ce}$ de Whalen et al. (1987) para a discriminação de granitos do tipo $A$. Símbolos: círculos verdes - fSC; triângulos ciano - fSA; quadrados magenta preenchidos - fSBm; quadrados magenta vazios fSBf; xizes magenta - fSBfb. 

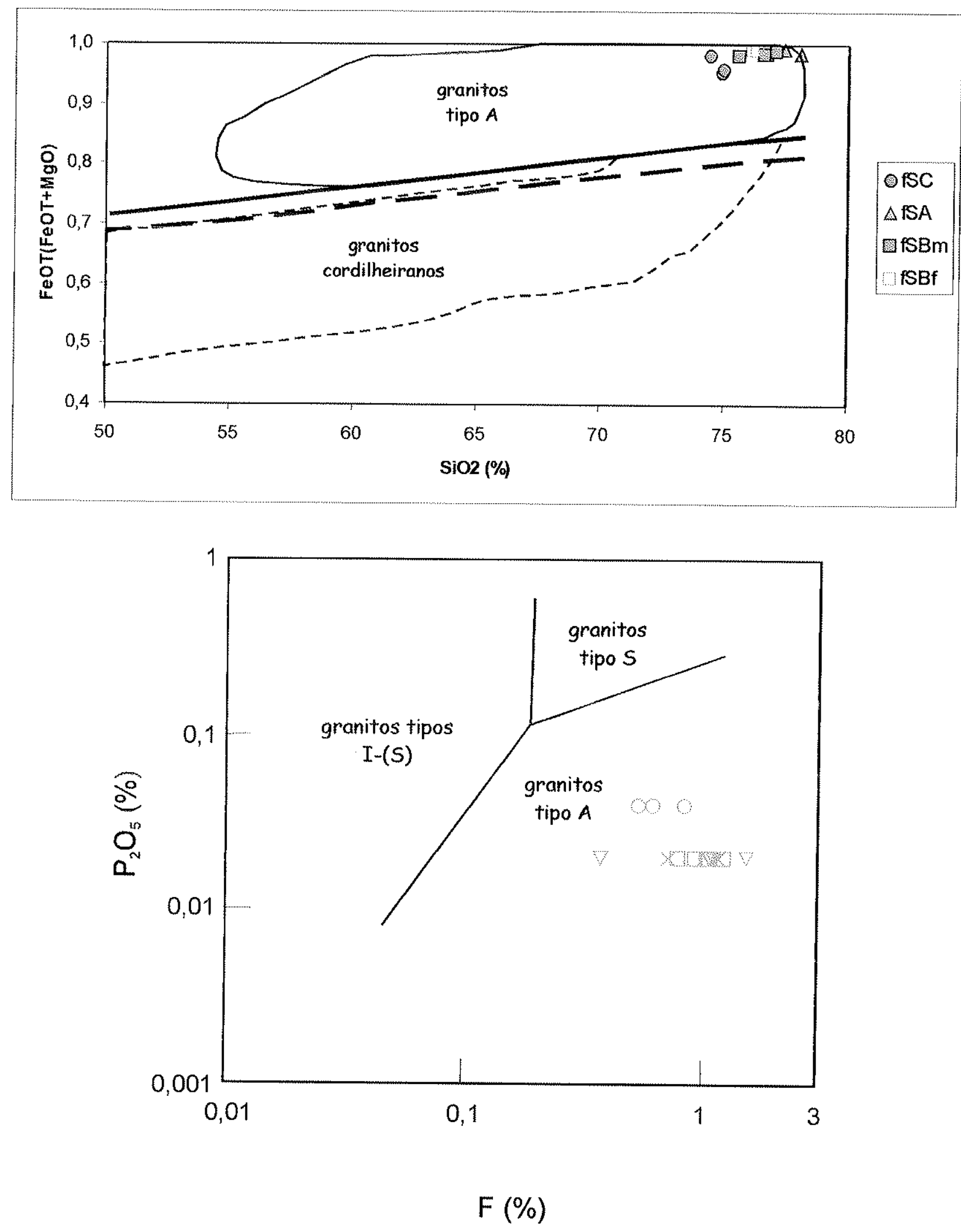

Figura 6.4 - a) Diagrama $\mathrm{SiO}_{2}$ versus $\mathrm{FeOT} /(\mathrm{FeOT}+\mathrm{MgO}$ ) (Frost et al. 2001) para a classificação de rochas graníticas; b) diagrama $\mathrm{F}$ versus $\mathrm{P}_{2} \mathrm{O}_{5}$ (Förster et al. 1998) para a classificação de granitos. As rochas do Maciço Granítico Santa Bárbara situam-se no campo dos granitos do tipo $A$ nos dois diagramas. Legenda para a Fig. b: círculos verdes - fSC; triângulos azuis invertidos - fSA; quadrados rosa - $\mathrm{fSBm}$; triângulos invertidos rosa - $\mathrm{fSBf}$; xizes rosa - fSBfb. 

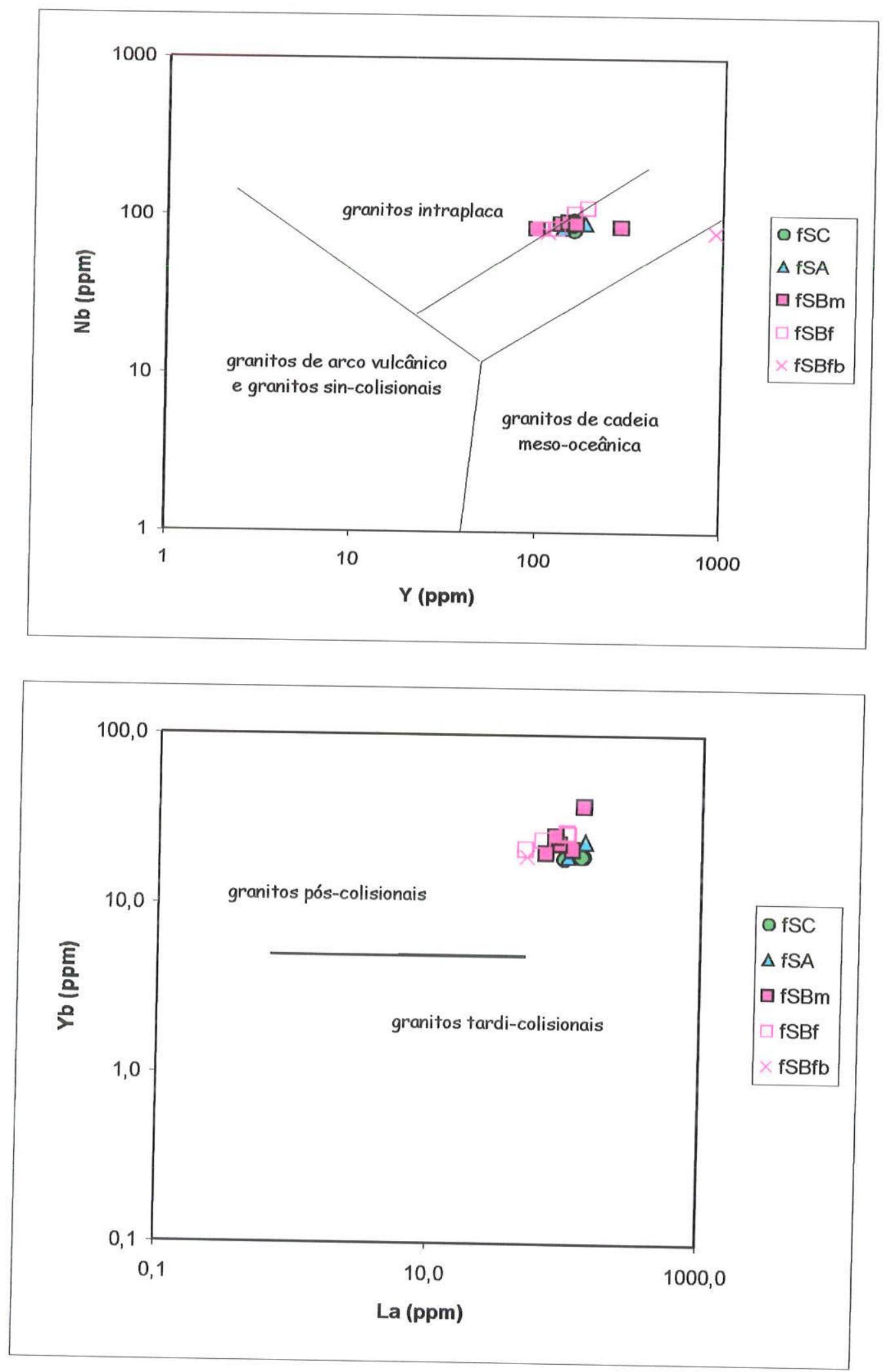

Figura 6.5 - a) Diagrama Y versus Nb para a discriminação tectônica de granitos (Pearce et al. 1984); b) diagrama La versus Yb para a discriminação entre granitos tardi- e pós-colisionais (Förster et al. 

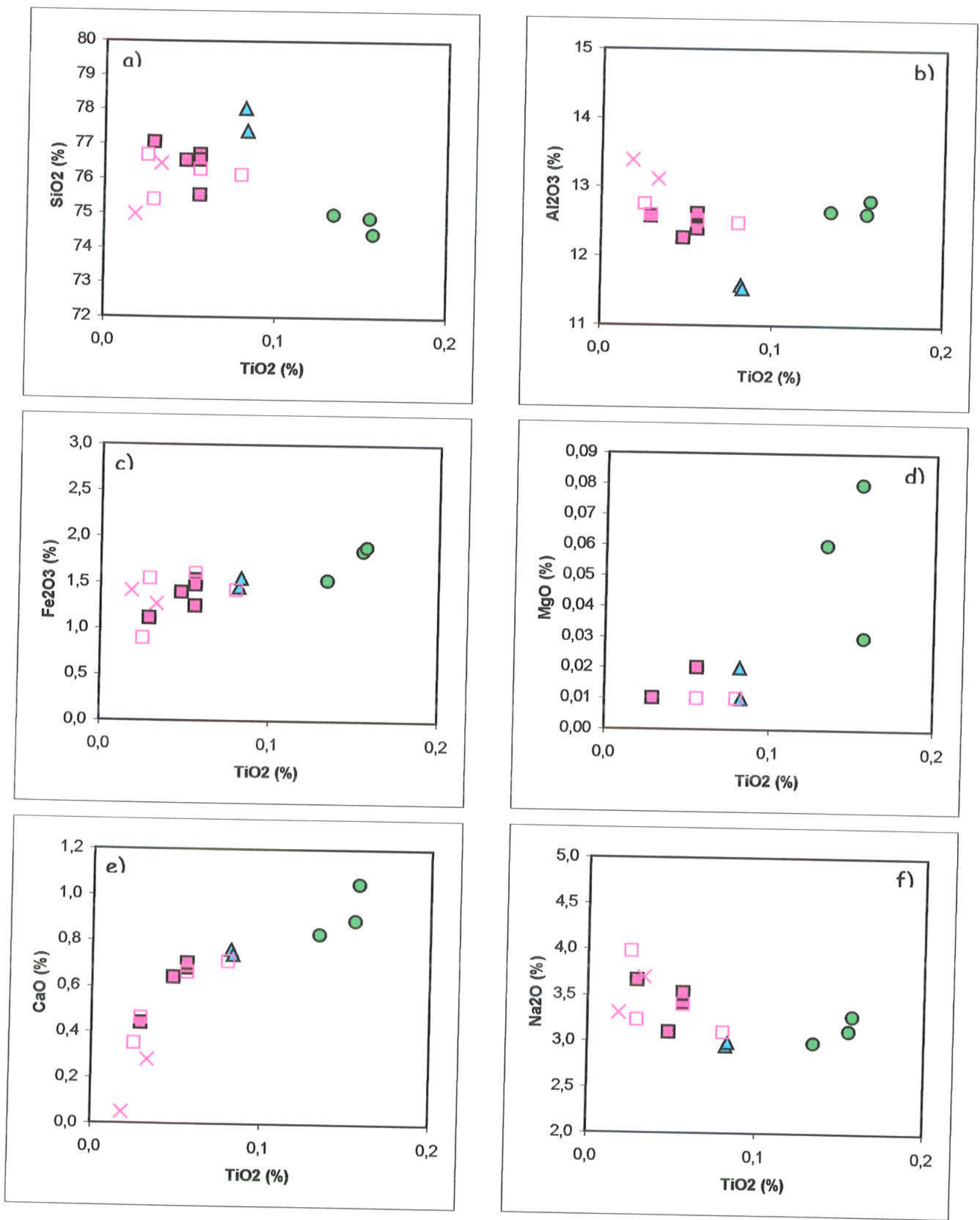

Figura 6.6 - Diagramas de variação química do $\mathrm{TiO}_{2}$ versus $\mathrm{SiO}_{2}, \mathrm{Al}_{2} \mathrm{O}_{3}, \mathrm{Fe}_{2} \mathrm{O}_{3} \mathrm{~T}, \mathrm{MgO}, \mathrm{CaO}$ e $\mathrm{Na}_{2} \mathrm{O}$ para os granitos do Maciço Granítico Santa Bárbara. Símbolos conforme Fig.6.5. 

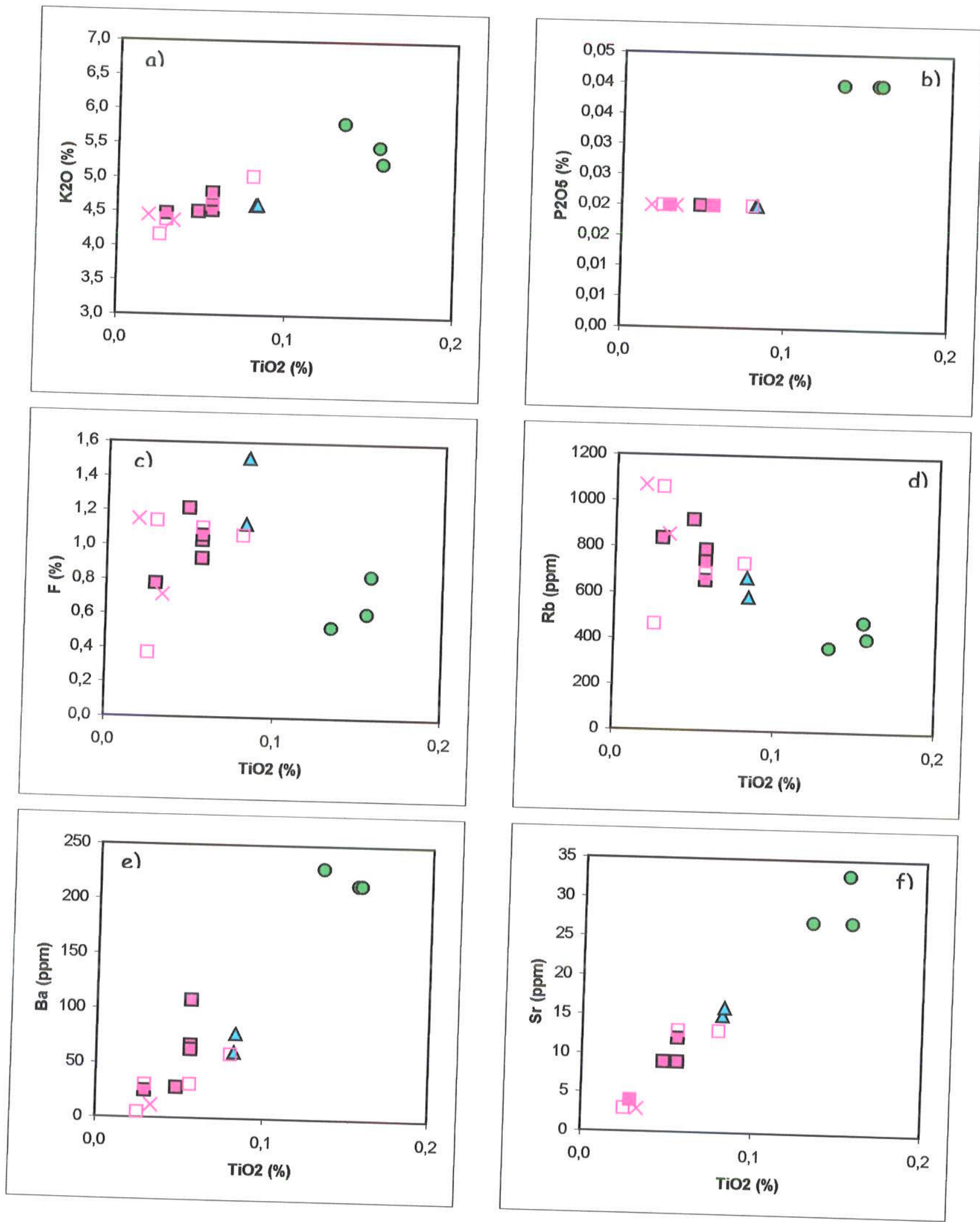
Figura 6.7 - Diagramas de variação química do $\mathrm{TiO}_{2}$ versus $\mathrm{K}_{2} \mathrm{O}, \mathrm{P}_{2} \mathrm{O}_{5}, \mathrm{~F}, \mathrm{Rb}, \mathrm{Ba}$ e $\mathrm{Sr}$ para os granitos
do Maciço Granítico Santa Bárbara. Símbolos conforme Fig. 6.5. 

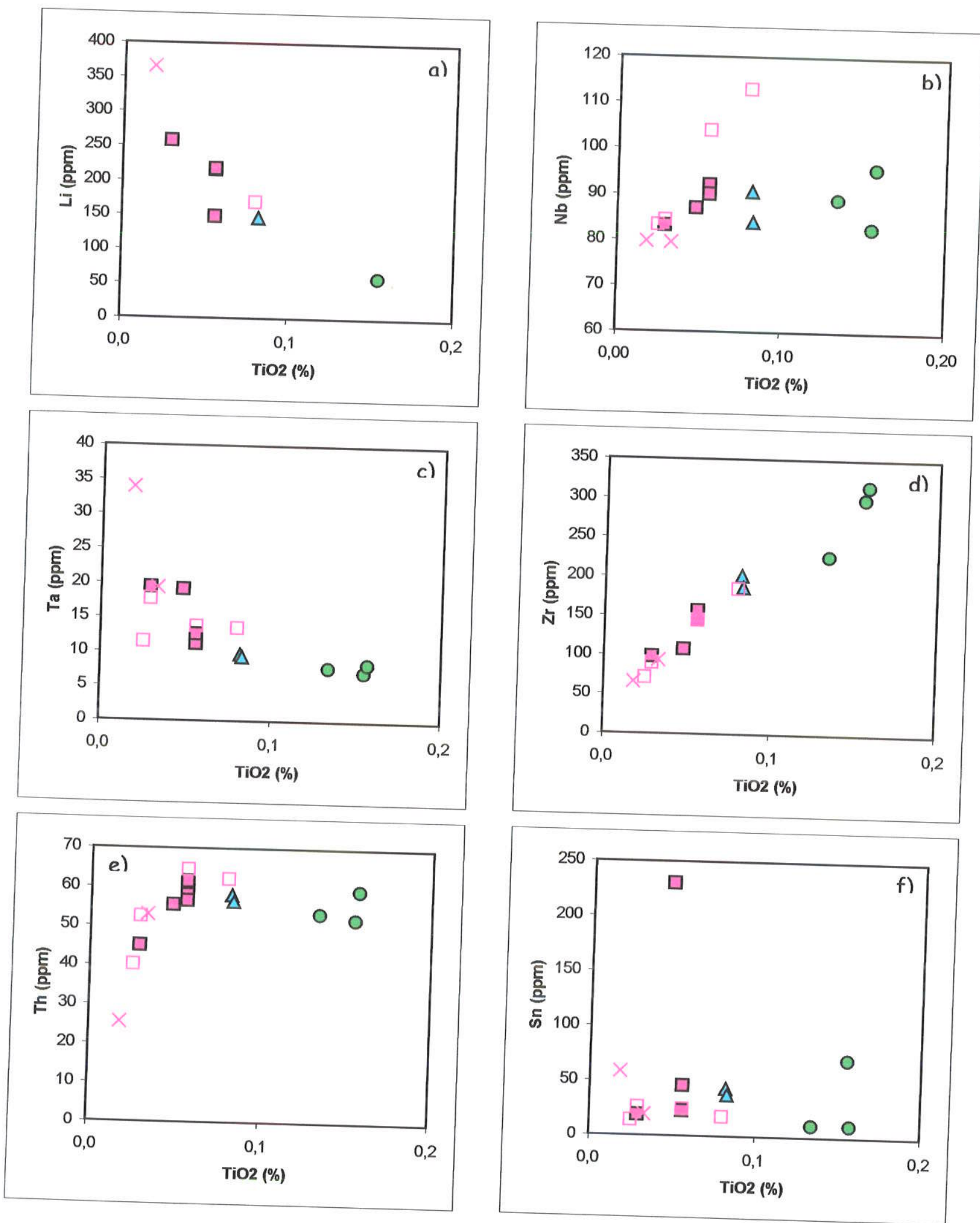

Figura 6.8 - Diagramas de variação química do $\mathrm{TiO}_{2}$ versus $\mathrm{Li}, \mathrm{Nb}, \mathrm{Ta}, \mathrm{Zr}$, Th e $\mathrm{Sn}$ para os granitos do Maciço Granítico Santa Bárbara. Símbolos conforme Fig. 6.5. 

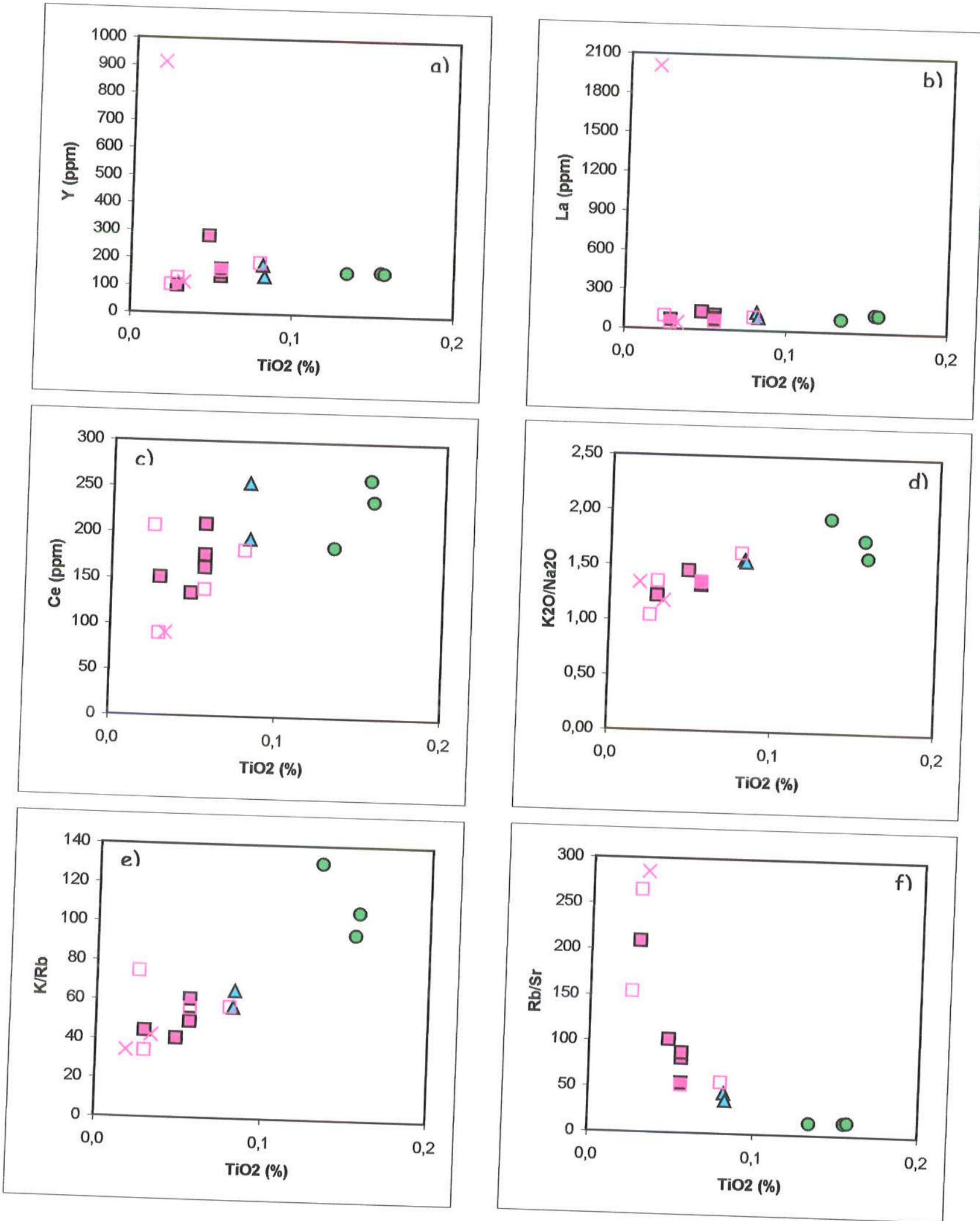

Figura 6.9 - Diagramas de variação química do $\mathrm{TiO}_{2}$ versus $\mathrm{Y}, \mathrm{La}, \mathrm{Ce}, \mathrm{K}_{2} \mathrm{O} / \mathrm{Na}_{2} \mathrm{O}, \mathrm{K} / \mathrm{Rb}$ e Rb/Sr para os
granitos do Maciço Granítico granitos do Maciço Granítico Santa Bárbara. Símbolos conforme Fig. 6.5. 

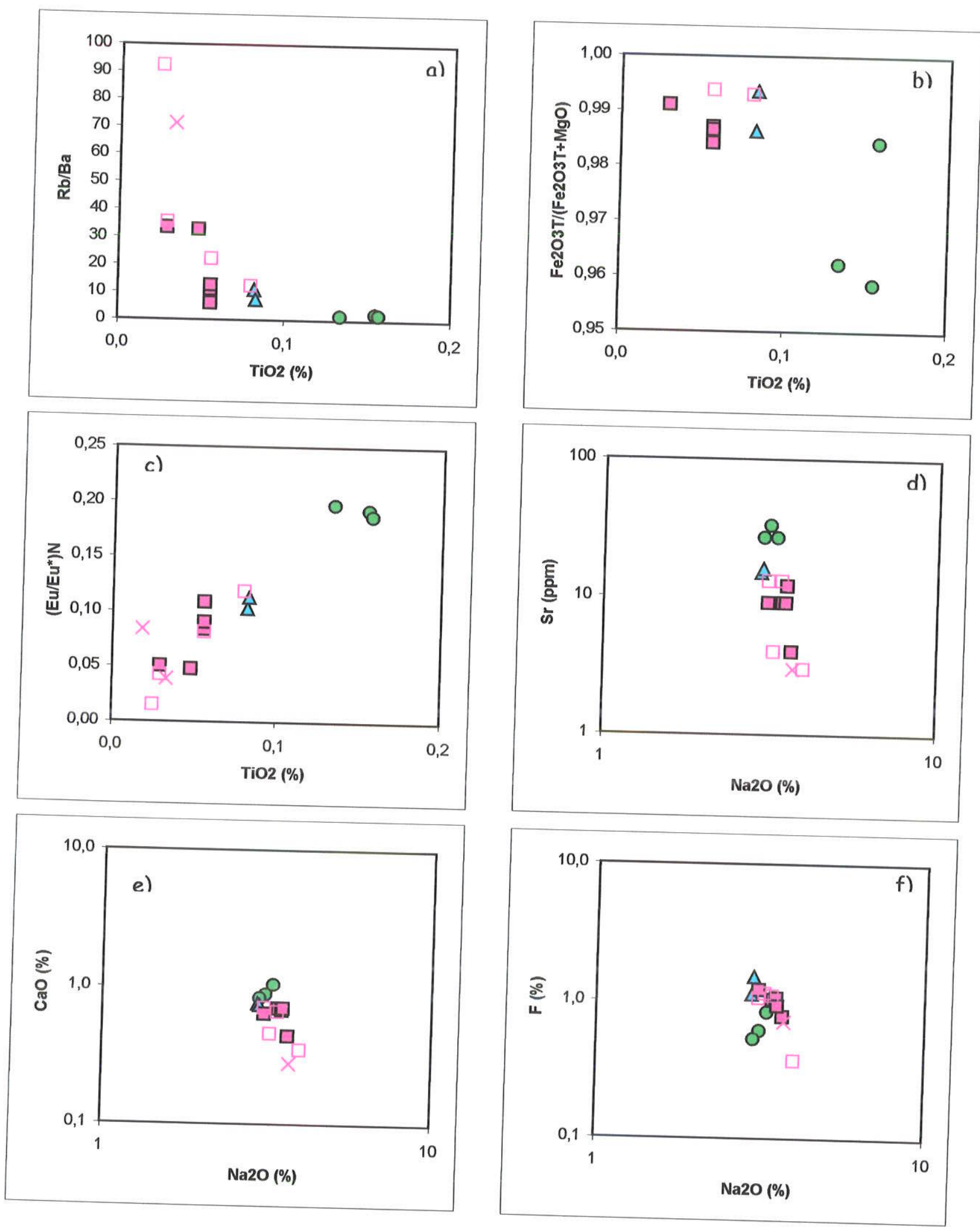

Figura 6.10 - Diagramas de variação química do $\mathrm{TiO}_{2}$ versus $\mathrm{Rb} / \mathrm{Ba}, \mathrm{Fe}_{2} \mathrm{O}_{3} \mathrm{~T} /\left(\mathrm{Fe}_{2} \mathrm{O}_{3} \mathrm{~T}+\mathrm{MgO}\right)$ e $\left(\mathrm{Eu} / \mathrm{Eu}^{*}\right)_{\mathrm{N}}$, e do $\mathrm{Na}_{2} \mathrm{O}$ versus $\mathrm{Sr}$, CaO e $\mathrm{F}$ para os granitos do Maciço Granítico Santa Bárbara. Símbolos conforme Fig. 6.5. 

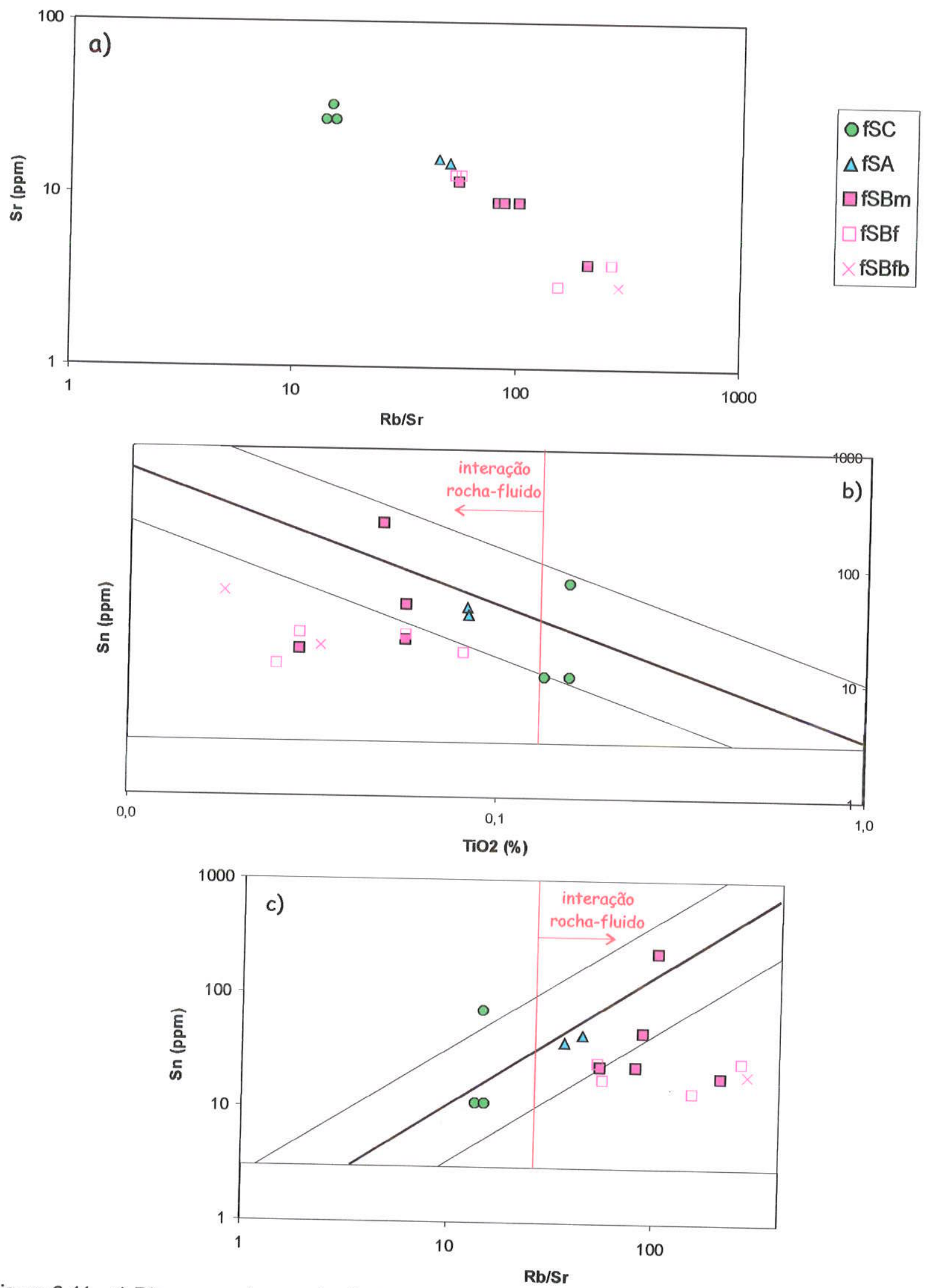

Figura 6.11 - a) Diagramas de covariação Sr versus $\mathrm{Rb} / \mathrm{Sr}$, b) $\mathrm{Sn}$ versus $\mathrm{TiO}_{2}$ e c) $\mathrm{Sn}$ versus $\mathrm{Rb} / \mathrm{Sr}$ para as rochas do maciço. Campos de Lehmann \& Mahavat (1989): retângulos cinza - área onde os teores de Sn estão abaixo do limite analítico de detecção; campos rosa - tendências de diferenciação magmática extrapoladas; linha vermelha - limite entre granitos menos alterados e aqueles afetados por interação rocha- fluido. Legenda conforme Fig. a. 

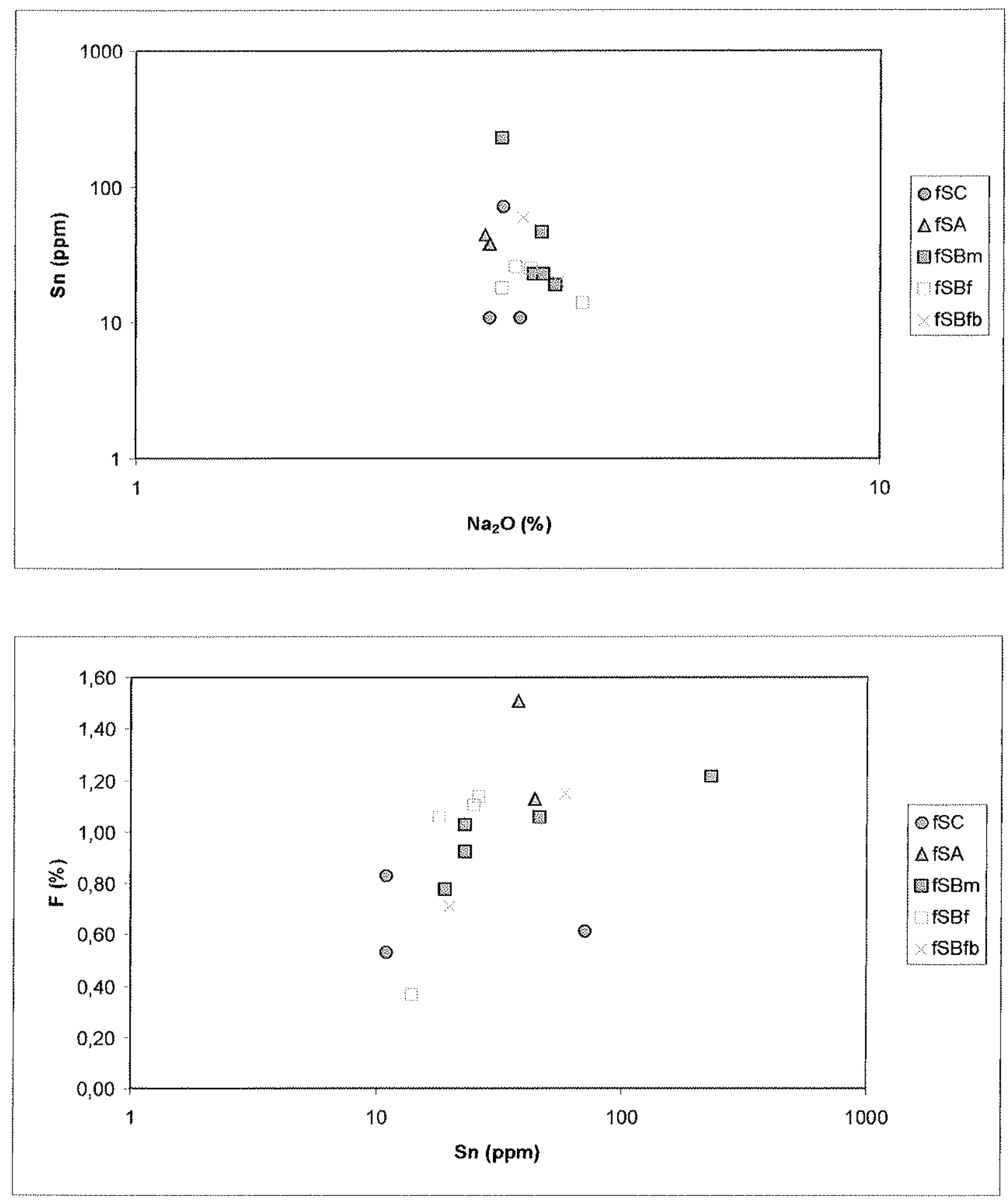

Figura 6.12 - Diagramas de covariação a) $\mathrm{Sn}$ versus $\mathrm{Na2O}$ e b) $\mathrm{F}$ versus $\mathrm{Sn}$ para as rochas do Maciço Granítico Santa Bárbara. 


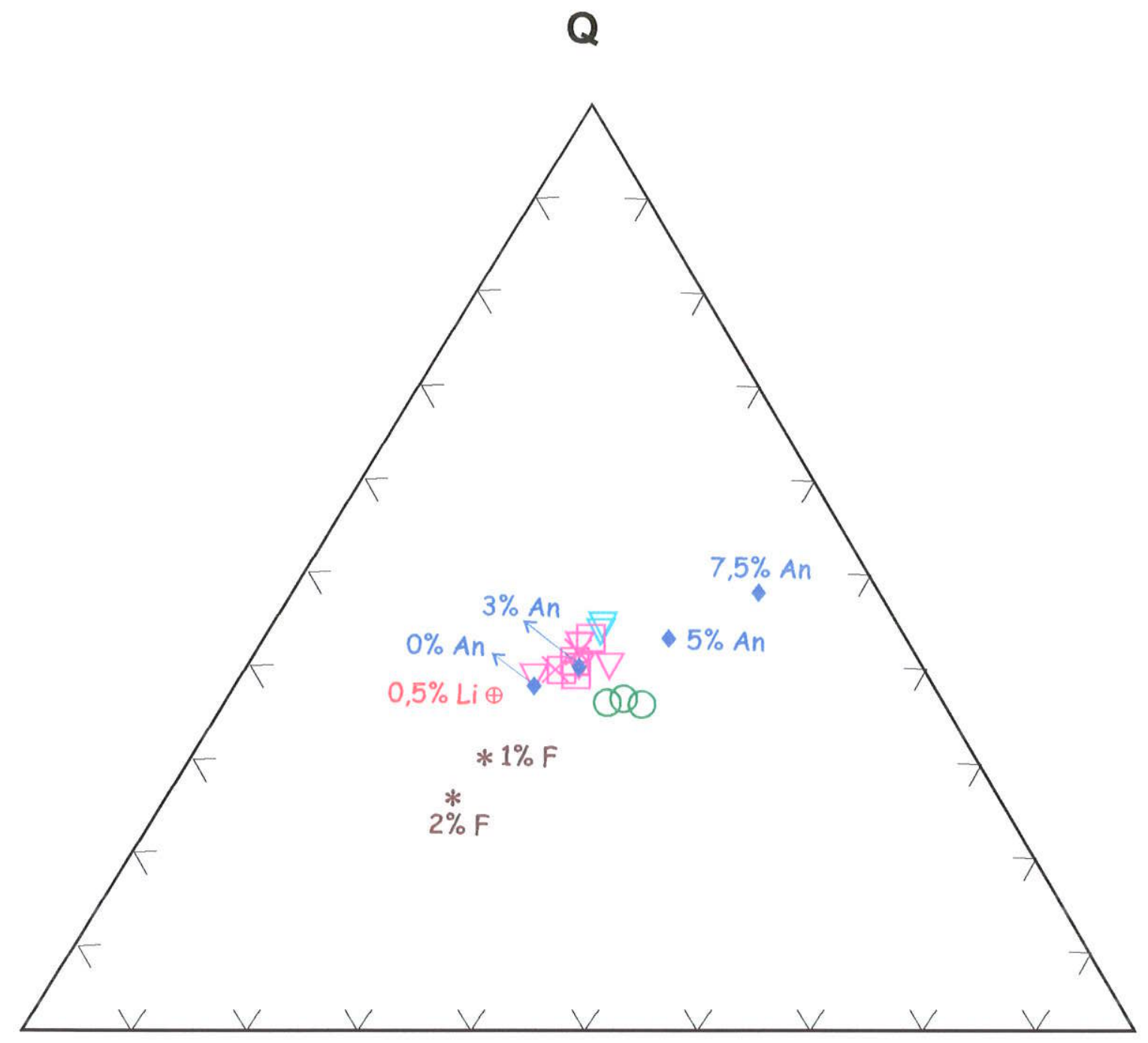

Ab

Figura 6.13 - Composição normativa dos granitos do Maciço Granítico Santa Bárbara em termos de quartzo, ortoclásio e albita. As composições experimentais de fusões de temperatura mínima são exibidos para comparação: losangos roxos - sistema NaAlSi $\mathrm{O}_{8}-\mathrm{KAISi}_{3} \mathrm{O}_{8}-\left(\mathrm{CaAl}_{2} \mathrm{Si}_{2} \mathrm{O}_{8}\right)-\mathrm{SiO}_{2}-$ $\mathrm{H}_{2} \mathrm{O}$ a 1 kbar (Tuttle \& Bowen, 1958, James \& Hamilton 1969); cruz vermelha circunscrita e asteriscos marrons - sistema haplogranito- $\mathrm{H}_{2} \mathrm{O}$ a 1 kbar com 0,5\% de Li (Martin 1983) e 1 e $2 \%$ de F (Manning 1981), respectivamente. Símbolos conforme Fig. 6.4.b. 
Tabela 6.l - Dados de análises químicas dos granitos do Macico Granítico Santa Bárbara.

\begin{tabular}{|c|c|c|c|c|c|c|c|c|c|c|}
\hline AMOSTRA & $\begin{array}{c}A M-52 B \\
\text { fSC }\end{array}$ & $\begin{array}{c}A M-287 \\
\text { fSC }\end{array}$ & $\begin{array}{l}A M-29 t \\
\mathrm{FSC}\end{array}$ & $\begin{array}{c}A M-53 B \\
f S A\end{array}$ & $\begin{array}{c}\text { AM-159 } \\
\text { fSA }\end{array}$ & $\begin{array}{l}\text { AM-108 } \\
\text { ISBm }\end{array}$ & $\begin{array}{r}\text { AM-119 } \\
\text { fSBm }\end{array}$ & $\begin{array}{c}\text { AM- } 121 \\
\text { fSBin }\end{array}$ & $\begin{array}{l}\text { AM-126 } \\
\text { fSBm }\end{array}$ & $\begin{array}{c}A M-170 \\
\text { fSBm }\end{array}$ \\
\hline $\mathrm{SiO}_{2}(\%$ erl peso $\}$ & 74,88 & 74,98 & 74,40 & 78,05 & 77,39 & 76,70 & 76,55 & 77,05 & 75,53 & 76,53 \\
\hline $\mathrm{TiO}_{2}$ & 0,16 & 0,3 & 0,16 & 0,08 & 0,08 & 0,06 & 0,06 & 0,03 & 0,06 & 0,05 \\
\hline $\mathrm{Al}_{2} \mathrm{O}_{3}$ & 12,62 & 12,65 & 12,81 & 11,58 & 11,53 & 12,39 & 12,59 & 12,57 & 12,61 & 12,26 \\
\hline $\mathrm{Fe} 2 \mathrm{O} 3 \mathrm{~T}$ & 1,85 & 153 & 1,89 & 1,45 & 1,55 & 1,53 & 1,47 & 1,11 & 1,24 & 1,39 \\
\hline Mno & 0,03 & 0,02 & 0,03 & 0,03 & 0,03 & 0,04 & 0,04 & 0,04 & 0,03 & 0,06 \\
\hline $\mathrm{MgO}$ & 0,08 & 0,06 & 0,03 & 0.02 & 0,01 & 0,02 & 0,02 & 0,01 & 0,02 & $<0,01$ \\
\hline $\mathrm{CaO}$ & 0,89 & 0,83 & 1,05 & 0,76 & 0,74 & 0,70 & 0,68 & 0,44 & 0,70 & 0,64 \\
\hline $\mathrm{Na}_{2} \mathrm{O}$ & 3,12 & 2,99 & 3,28 & 2,95 & 2,99 & 3,42 & 3,51 & 3,66 & 3,53 & 3,10 \\
\hline $\mathrm{K}_{2} \mathrm{O}$ & 5,47 & 5,81 & 5,23 & 4,60 & 4,61 & 4,52 & 4,67 & 4,47 & 4,78 & 4,50 \\
\hline $\mathrm{P}_{2} \mathrm{O}_{5}$ & 0,04 & 0,04 & 0,04 & 0,02 & 0,02 & 0,02 & 0,02 & 0,02 & 0,02 & 0.02 \\
\hline P.F. & 0,94 & $1,0\}$ & 1,17 & 0,82 & 1,06 & 0,87 & 0,75 & 0,58 & 0,80 & 1,01 \\
\hline TOTAL. & 100,07 & 100,05 & 100,08 & 100,36 & 100,02 & 100,27 & 100,36 & 99,97 & 99,32 & 99.56 \\
\hline Sc (ppm) & 6 & 8 & 4 & 4 & 4 & 5 & 4 & 4 & 5 & 5 \\
\hline $\mathrm{Pb}$ & 97 & 41 & 28 & 42 & 41 & 32 & 41 & 41 & 27 & 22 \\
\hline $\mathrm{Zn}$ & $88:$ & 54 & 49 & 80 & 64 & 63 & 80 & 54 & 36 & 128 \\
\hline Sn & 71 & 11 & 11 & 44 & 38 & 23 & 46 & 10 & 23 & 230 \\
\hline$w$ & 7 & 4 & 5 & 10 & 11 & 14 & 18 & 8 & 10 & 18 \\
\hline Mo & 5 & 3 & 6 & 6 & 5 & 3 & 2 & 2 & 2 & 2 \\
\hline $\mathrm{Rb}$ & 479 & 368 & 408 & 669 & 585 & 737 & 787 & 837 & 654 & 917 \\
\hline $\mathrm{Ba}$ & 214 & 229 & 214 & 61 & 78 & 87 & 63 & 25 & 108 & 28 \\
\hline $\mathrm{Sr}$ & 33 & 27 & 27 & 15 & 16 & 9 & 9 & 4 & 12 & 9 \\
\hline $\mathrm{Be}$ & 9 & 8 & 9 & 13 & 12 & 6 & 8 & 10 & 12 & 7 \\
\hline Ga & 29 & 27 & 32 & 32 & 32 & 34 & 36 & 37 & 32 & 36 \\
\hline $\mathrm{Ge}$ & 2 & 2 & 2 & 3 & 2 & 3 & 3 & 3 & 2 & 3 \\
\hline Li & 60 & $\mathrm{NA}$ & N.A & 147 & N.A & 216 & 217 & 258 & 148 & N.A \\
\hline $\mathrm{Nb}$ & 83 & 89 & 96 & 91 & 84 & 90 & 92 & 83 & 90 & 87 \\
\hline $\mathrm{Ta}$ & 7 & 8 & 8 & 10 & 9 & 12 & 11. & $19:$ & 13 & 19 \\
\hline $\mathrm{Hf}$ & 10 & 9 & 12 & 9 & 9 & 9 & 9 & 9 & 9 & 9 \\
\hline $\mathrm{Zr}$ & 300 & 227 & 316 & 202 & 187 & 151 & 157 & 98 & 145 & 108 \\
\hline$Y$ & 159 & 155 & 156 & 179 & 137 & 135 & 148 & 98 & 161 & 282 \\
\hline Th & 52 & 53 & 59 & 58 & 57 & 62 & 58 & 45 & 57 & 56 \\
\hline $\mathrm{U}$ & 44 & 17 & 13 & 17 & 18 & 18 & 20 & 15 & 14 & 22 \\
\hline Cs & 4 & 4 & 3 & 7 & 6 & 7 & 7 & 7 & 6 & 8 \\
\hline TI & 2 & 2 & 2 & 3 & 2 & 2 & 3 & 2 & 2 & 4 \\
\hline $\mathrm{Bi}$ & 3 & 0 & 0 & 14 & 7 & 8 & 3 & 9 & 7 & 10 \\
\hline $\mathrm{F}^{-1}$ & 0,61 & 0.53 & 0,83 & 1.13 & 1.51 & 1,03 & 1,06 & 0,78 & 0,92 & 1,21 \\
\hline La & 135,00 & 97,50 & 130,00 & 137,00 & 102,00 & 110,00 & 87,10 & 70,20 & 82,50 & 134,00 \\
\hline $\mathrm{Ce}$ & 260,00 & 186,00 & 237,00 & 255,00 & 194,00 & 209,00 & 176,00 & 151,00 & 162,00 & 134,00 \\
\hline $\mathrm{Pr}$ & 27,00 & 23,00 & 29,10 & 25,20 & 20,00 & 20,90 & 18,00 & 16,00 & 17,70 & 30.70 \\
\hline Nd & 96,10 & 76,60 & 96,00 & 84,80 & 70,50 & 72,30 & 64,60 & 55,60 & 64,70 & $1+8,00$ \\
\hline $\mathrm{Sm}$ & 19,20 & 15,40 & 18,50 & 17,70 & 14,00 & $15 ; 40$ & 13,80 : & 12,40 & 14,30 & 29,20 \\
\hline Ëu & 1,22 & 1,01 & 1,12 & 0,61 & 0,53 & 0,43 & 0,42 & 0,20 & 0,54 & 0.47 \\
\hline $\mathrm{Gd}$ & 19,60 & 15,90 & 18,10 & 18,50 & 14,70 & 16,20 & 15,00 & 12,00 & 16,10 & 31,10 \\
\hline $\mathrm{Tb}$ & 3,48 & 3,15 & 3,40 & 3,56 & 2,97 & 3,09 & 3,03 & 2,44 & 3,42 & 6,41 \\
\hline Dy & 22,30 & 21,70 & 22,60 & 24,10 & 19,50 & 19,90 & 20,20 & 15,90 & 23,00 & 40,50 \\
\hline Ho & 4,99 & 4,78 & 5,05 & 5,52 & 4,47 & 4,33 & 4,69 & 3,35 & 5,50 & 9,05 \\
\hline $\mathrm{Er}$ & 16,50 & 15,30 & 15,90 & 18,90 & 15,70 & 15,10 & 16.50 & 11,90 & 19,00 & 30,00 \\
\hline $\mathrm{Tm}$ & 3,06 & 2,97 & 3,01 & 3,56 & 2,96 & 3,03 & 3,20 & 2,57 & 3,66 & 5,72 \\
\hline$Y b$ & 19,50 & 18,70 & 19,40 & 23,60 & 19,50 & 21,30 & $22 ; 80$ & 20,10 & 25,70 & 38,60 \\
\hline$L 13$ & 2,99 & 2.74 & 2.83 & 3,60 & 2.99 & 3,29 & 3,42 & 318 & 390 & 5.84 \\
\hline
\end{tabular}

\begin{tabular}{|c|c|c|c|c|c|c|c|c|c|c|}
\hline $\begin{array}{l}\mathrm{Fe} 2 \mathrm{O} 3 \mathrm{Tl} \\
\mathrm{Fe} 2 \mathrm{O} \mathrm{T}+\mathrm{MgO}\end{array}$ & 0,96 & 0,96 & 0,98 & 0,99 & 0.99 & 0,99 & 0,99 & 0,99 & 0,98 & \\
\hline A/CNK & 1,00 & 0,99 & 0,99 & 1,03 & 1,02 & 1,05 & 1,04 & 1,08 & 1,03 & 1,10 \\
\hline A/NK & 1,14 & 1,13 & 1,16 & 1,18 & 1,16 & 1,18 & 1,16 & 1,16 & 1,15 & 1,23 \\
\hline $10000 \mathrm{Ga} / \mathrm{Al}$ & 4,34 & 4,03 & 4,72 & 5,22 & 5,24 & $5 ; 18$ & 5,40 & 5,56 & 4,79 & 5,55 \\
\hline $\mathrm{K} / \mathrm{Na}$ & 1,15 & 1,28 & 1,05 & 1,03 & 1,01 & 0,87 & 0,88 & 0,80 & 0,89 & 0,96 \\
\hline $\mathrm{K} / \mathrm{Rb}$ & 94,81 & 131,07 & 106,42 & 57,08 & 65,42 & 50,92 & 49,26 & 44,34 & 60,68 & 40,74 \\
\hline $\mathrm{Rb} / \mathrm{Sr}$ & 14,52 & 13,63 & 15,11 & 44,60 & 36,56 & 81,89 & 87,44 & 209,25 & 54,50 & 101,89 \\
\hline $\mathrm{Rb} / \mathrm{Ba}$ & 224 & 1.61 & 1,91 & 10,97 & 7.50 & 11,00 & 12,49 & 33,48 & 6,06 & 32.75 \\
\hline SOMA ETR & 630,94 & 484,75 & 602,01 & 621,65 & 483,82 & 514,27 & 448,76 & 376,84 & 442,02 & 613,59 \\
\hline $\mathrm{LaN} / \mathrm{YbN}{ }^{2}$ & 4,67 & 3,52 & 4,52 & 3,91 & 3,53 & 3,48 & 2,58 & 2,35 & 2,16 & 2,34 \\
\hline EuN/Eu ${ }^{*^{2}}$ & 0,19 & 0,20 & 0,19 & 0.10 & 0,11 & 0,08 & 0,09 & 0,05 & 0,11 & 0,05 \\
\hline
\end{tabular}

\begin{tabular}{l|l|l|l|l|l|l|l|l|l|l|l}
\hline Q & 34,14 & 33,89 & 33,57 & 41,85 & 41,21 & 38,24 & 36,95 & 37,96 & $35,73,40,52$ \\
Or & 32,65 & 34,71 & 31,29 & 27,34 & 27,56 & 26,90 & 27,74 & 26,60 & 28,70 & 27,01 \\
Ab & 26,61 & 25,53 & 28,04 & 25,05 & 25,54 & 29,08 & 29,79 & 31,13 & 30,29 & 26,59 \\
An & 4,27 & 3,93 & 4,79 & 3,79 & 3,71 & 3,50 & 3,39 & 2,20 & 3,53 & 3,22 \\
C & 0,00 & 0,00 & 0,00 & 0,35 & 0,26 & 0,59 & 0,51 & 0,90 & 0,35 & 1,13 \\
\hline
\end{tabular}


Tabela 6.1 - Dados de análises químicas dos granitos do Maciço Granítico Santa Bárbara (cont.)

\begin{tabular}{|c|c|c|c|c|c|c|}
\hline AMOSTRA & $\begin{array}{c}\text { AM-144 } \\
\text { fSBf }\end{array}$ & $\begin{array}{c}\text { AM-145 } \\
\text { fSBf }\end{array}$ & $\begin{array}{c}A M-238 \\
\text { fSBf }\end{array}$ & $\begin{array}{c}\text { AM-278 } \\
\text { fSBf }\end{array}$ & $\begin{array}{l}\text { AM-134 } \\
\text { ISBf }\end{array}$ & $\begin{array}{l}A M-239 \\
f S B f^{*}\end{array}$ \\
\hline$\overline{\mathrm{SiO}_{2}(\% \text { empeso }\}}$ & 76,12 & 76,28 & 75,40 & 76,69 & 74,98 & 76,44 \\
\hline $\mathrm{TiO}_{2}$ & 0.08 & 0,06 & 0.03 & 0,03 & 0,02 & 0,03 \\
\hline $\mathrm{Al}_{2} \mathrm{O}_{3}$ & 12,48 & 12,51 & 12,59 & 12,75 & 13,39 & 13,11 \\
\hline $\mathrm{Fe} 2 \mathrm{O} 3_{\mathrm{T}}$ & 1,42 & 1.60 & 1.54 & 0,89 & 1,41 & 1,27 \\
\hline Mno & 0,03 & 0,04 & 0,05 & 0,02 & 0,05 & 0,04 \\
\hline $\mathrm{MgO}$ & 0,01 & 0,01 & $<0,01$ & $<0,01$ & $<0,01$ & $<0,01$ \\
\hline $\mathrm{CaO}$ & 0.71 & 0,66 & 0.46 & 0,35 & 0,05 & 0.28 \\
\hline $\mathrm{Na}_{2} \mathrm{O}$ & 3,10 & 3,40 & $3,2.3$ & 3,98 & 3,31 & 3,70 \\
\hline $\mathrm{K}_{2} \mathrm{O}$ & 5,02 & 4,61 & 4,38 & 4,16 & 4,45 & 4,37 \\
\hline $\mathrm{P}_{2} \mathrm{O}_{5}$ & 0,02 & 0,02 & 0,02 & 0,02 & 0,02 & 0,02 \\
\hline P.F. & 0,90 & 0,73 & 0.98 & 0,68 & 1,13 & 0,77 \\
\hline TOTAL. & 99,89 & 99,91 & 98,68 & 99,56 & 98,76 & 100,03 \\
\hline Sc (ppm) & 3 & 5 & 5 & 4 & 4 & 5 \\
\hline $\mathrm{Pb}$ & 39 & 30 & 15 & 43 & 61 & 31 \\
\hline $\mathrm{Zn}$ & 78 & 62 & 122 & 37 & 66 & 73 \\
\hline Sn & 18 & 25 & 26 & 14 & 59 & 20 \\
\hline w & 6 & 17 & 9 & 4 & $\$ 1$ & 6 \\
\hline Mo & 7 & 3 & $<2$ & $<2$ & $3:$ & $<2$ \\
\hline $\mathrm{Rb}$ & 730 & 684 & 1060 & 462 & 1070 & 855 \\
\hline $\mathrm{Ba}$ & 59 & 31 & 30 & 5 & $<3$ & 12 \\
\hline $\mathrm{Sr}$ & 13 & 13 & 4 & 3 & $<2$. & 3 \\
\hline $\mathrm{Be}$ & 12 & 11 & 4 & 55 & 8 & 7 \\
\hline $\mathrm{Ga}$ & 33 & 34 & 40 & 34 & 46 & 36 \\
\hline $\mathrm{Ge}$ & 3 & 3 & 3 & 3 & 4 & 3 \\
\hline $\mathrm{Li}$ & N.A & 170 & N.A & N.A & 366 & N.A \\
\hline $\mathrm{Nb}$ & 113 & 104 & 84 & 83 & 80 & 80 \\
\hline $\mathrm{Ta}$ & 14 & 14 & 18 & 12 & 34 & 19 \\
\hline $\mathrm{Hf}$ & 11 & 9 & 8 & 6 & 12 & 8 \\
\hline $\mathrm{Zr}$ & 185 & 145 & 90 & 71 & 66 & 94 \\
\hline$Y$ & 185 & 158 & $\uparrow 28$ & 102 & 914 & 113 \\
\hline Th & 62 & 65 & 53 & 40 & 26 & 53 \\
\hline u & 16 & 24 & 6 & 13 & 20 & 4 \\
\hline $\mathrm{Cs}$ & 6 & 6 & 9 & 3 & 7 & 6 \\
\hline TI & 3 & 2 & 4 & 2. & 4 & 2 \\
\hline $\mathrm{Bi}$ & 2 & 1 & 17 & 0 & 7 & 8 \\
\hline$F^{1}$ & 1,06 & 1,10 & 1,14 & 0,37 & 1,15 & 0,71 \\
\hline La & 100,00 & 65,10 & 49,50 & 102,00 & 2010,00 & 51,20 \\
\hline $\mathrm{Ce}$ & 181,00 & 138,00 & 90,00 & 207,00 & 331.00 & 90,70 \\
\hline $\mathrm{Pr}$ & 19.80 & 15,40 & 12,40 & 24,90 & 567,00 & 12,10 \\
\hline $\mathrm{Nd}$ & 70.70 & 58,40 & 46,90 & 72,00 & 1960,00 & 44,60 \\
\hline $\mathrm{Sm}$ & 14,40 & 13,40 & 11,70 & 16,20 & 444,00 & 10,70 \\
\hline Eu & 0,58 & 0,38 & 0.16 & 0,07 & 10,60 & 0.14 \\
\hline $\mathrm{Gd}$ & 15.40 & 15,20 & 11,70 & 13,60 & 336,00 & 10,80 \\
\hline $\mathrm{Tb}$ & 3,17 & 3,30 & 2,49 & 2.97 & 49,10 & 2,33 \\
\hline Dy & 22,40 & 23,10 & 15,60 & 21,10 & 260,00 & 15,80 \\
\hline Ho & 5,54 & 5,42 & 3,56 & 4,50 & 39,60 & 3,53 \\
\hline Er & 19,90 & 19,20 & 13,30 & 15,90 & 115,00 & $+2,60$ \\
\hline $\mathrm{Tm}$ & 3,97 & 3,59 & 2,85 & 3,69 & 19.50 & 2,54 \\
\hline $\mathrm{Yb}$ & 26,90 & 24,30 & 21,30 & 26,00 & 124,00 & 19,10 \\
\hline Lu & 4.34 & 3,73 & 3,49 & 3,86 & 14,80 & 3,02 \\
\hline
\end{tabular}

\begin{tabular}{|c|c|c|c|c|c|c|}
\hline $\mathrm{Fe} 2 \mathrm{O} 3 \mathrm{TI}$ & 0,99 & 0,99 & & & & \\
\hline $\mathrm{Fe} 2 \mathrm{O} 3 \mathrm{~T}+\mathrm{MgO}$ & & & & & & \\
\hline AlCNK & 1,06 & 1,06 & 1,16 & 1,09 & 1,29 & 1,16 \\
\hline A/NK & 1,18 & 1,18 & 1,25 & 1,15 & 3,65 & 1,21 \\
\hline $10000 \mathrm{Ga} / \mathrm{Al}$ & 5,00 & 5.13 & 6,00 & 5,04 & 6,49 & 5,19 \\
\hline $\mathrm{K} / \mathrm{Na}$ & 1,07 & 0,89 & 0,89 & 0,69 & 0,88 & 0,78 \\
\hline $\mathrm{K} / \mathrm{Rb}$ & 57.09 & 55,95 & 34,30 & 74.75 & 34,53 & 42,43 \\
\hline $\mathrm{Rb} / \mathrm{Sr}$ & 56,15 & 52,62 & 265,00 & 154,00 & & 285,00 \\
\hline $\mathrm{Rb} / \mathrm{Ba}$ & 12,37 & 22,06 & 35,33 & 92,40 & & 71,25 \\
\hline SOMA ETR & 488,10 & 388,52 & 284,95 & 513,79 & 6280,60 & 279,16 \\
\hline $\mathrm{LaN} / \mathrm{YbN}{ }^{2}$ & 2,51 & 1,81 & 1,57 & 2,64 & 10,93 & 1,81 \\
\hline EuN/Eu ${ }^{\star^{2}}$ & 0,12 & 0,08 & 0,04 & 0,02 & 0,08 & 0,04 \\
\hline Q & 37.75 & 37,77 & 39.81 & 37,32 & 37,91 & 39,54 \\
\hline Or & 30,00 & 27,50 & 26,52 & 24,89 & 26,05 & 26,95 \\
\hline $\mathrm{Ab}$ & 26,47 & 28,98 & 27,95 & 34,02 & $31,5 \pm$ & 28,65 \\
\hline An & 3,56 & 3.30 & 2,34 & 1,76 & 1,40 & 0,25 \\
\hline C & 0,65 & 0,72 & 1,73 & 1,06 & 1,78 & 3,10 \\
\hline
\end{tabular}




\section{QUIMICA MINERAL}

\subsection{Química das Micas}

\subsubsection{Introdução}

As fórmulas estruturais das micas aqui estudadas foratn calculadas em base anidra considerando 22 átomos de oxigênio na meia cela unitária e corrigindo o total de oxigênio em função dos teores de flúor e cloro medidos, conforme o método descrito por Deer et al. (1992).

É possível separá-las em dois grupos: a) micas dioctaédricas, cujos conteúdos de Si são altos (/6,0 átomos p.f.u.) e os de $\mathrm{Al}^{\mathrm{IV}}$ baixos ( $\leq 2,0$ átomos p.f.u.), e cuja ocupação octaédrica é aproximada a 4,0 átomos p.f.u.; e b) micas trioctaédricas. As primeiras ocorrem unicamente naquelas rochas afetadas pela alteração pós-magmática denominada muscovitização.

Dada a importância das trioctaédricas no maciço estudado, haja vista predominarem amplamente e estarem representadas desde o estágio magmático até o pós-magmático, serão abordadas primeiramente.

\subsubsection{Micas trioctaédricas}

As composições médias das micas trioctaédricas do Maciço Granítico Santa Bárbara medidas com Microssonda Eletrônica (EPMA), incluindo teores de lítio obtidos via química analítica, estão ilustrados na Tabela 7.I. O conjunto completo das análises encontra-se no Anexo II. Podem ser classificadas como annita $\left(\mathrm{K}_{2} \mathrm{Fe}_{6}\left[\mathrm{Al}_{2} \mathrm{Si}_{6} \mathrm{O}_{20}(\mathrm{OH}, \mathrm{F})_{4}\right)\right.$ e siderofilita $\left(\mathrm{K}_{2}\left(\mathrm{Fe}^{2+}{ }_{4} \mathrm{Al}_{2}\right)\left[\mathrm{Al}_{4} \mathrm{Si}_{4}\right] \mathrm{O}_{20}(\mathrm{OH}, \mathrm{F})_{4}\right)$ no diagrama $\mathrm{Al}^{\mathrm{IV}} \times \mathrm{Fe} /\left(\mathrm{Fe}+\mathrm{Mg}\right.$ ) (Fig. 7.1.a), e como siderofilita no diagrama $\mathrm{Al}^{\mathrm{VI}} \times \mathrm{Fe} /(\mathrm{Fe}+\mathrm{Mg}$ ) (Fig. 7.1.b). 
Tabela 7.I - Médias das composições das micas do Maciço Granítico Santa Bárbara obtidas com EPMA (Li 20 determinado por química analítica)

\begin{tabular}{|c|c|c|c|c|c|c|c|c|c|c|}
\hline FÁCIES & $\begin{array}{c}\text { fSC } \\
\text { (AM-52B) }\end{array}$ & fSA $53 B)(A M$ & $\begin{array}{c}\text { fSBf } \\
(A M-145)\end{array}$ & $\begin{array}{c}\text { fSBm } \\
(\mathrm{AM}-2248)\end{array}$ & $\mathrm{fSBfb}_{134)}$ & pegmatóide & $\begin{array}{c}\text { greisen tabular } \\
\text { (AM-35) }\end{array}$ & $\begin{array}{c}\text { granito } \\
\text { greisenizado } \\
\text { (AM-19) }\end{array}$ & $\begin{array}{l}\text { gr. albitizado } \\
\text { salmāo } \\
(\mathrm{AM}-14 \mathrm{~B})^{\star}\end{array}$ & $\begin{array}{c}\text { velo de } \\
\text { greisen } \\
41 \mathrm{~B})^{\star \star}\end{array}$ \\
\hline $\mathrm{SiO}_{2}$ & 35,217 & 38,503 & 36,667 & 37,851 & 38,893 & 38,462 & 40,245 & 40,726 & 40,849 & 39,880 \\
\hline $\mathrm{TiO}_{2}$ & 2,802 & 0,426 & 1,110 & 1,032 & 0,206 & 0,082 & 0,045 & 0,312 & 0,095 & 0,021 \\
\hline $\mathrm{Al}_{2} \mathrm{O}_{3}$ & 20,530 & 20,603 & 19,737 & 19,981 & 21,875 & 21,174 & 22,215 & 22,854 & 23,104 & 21,130 \\
\hline $\mathrm{FeO}$ & 27,270 & 22,857 & 27,811 & 23,179 & 22,177 & 23,530 & 19,422 & 18,304 & 17,830 & 21,388 \\
\hline $\mathrm{MnO}$ & 0,349 & 1,190 & 0,722 & 0,906 & 0,880 & 1,473 & 1,178 & 1,456 & 1,297 & 0,857 \\
\hline $\mathrm{MgO}$ & 1,400 & 0,306 & 0,271 & 0,244 & 0,048 & 0,009 & 0,008 & 0,052 & 0,055 & 0,014 \\
\hline $\mathrm{H}_{2} \mathrm{O}$ & 0,084 & 0,279 & 0,301 & n.d. & 0,598 & n.d. & 0,504 & n.d. & 0,755 & 0,693 \\
\hline $\mathrm{BaO}$ & 0,052 & 0,088 & 0,034 & 0,009 & 0,037 & n.d. & 0,032 & 0,060 & 0,000 & n.d. \\
\hline $\mathrm{CaO}$ & n.d. & n.d. & 0,003 & n.d. & n.d. & 0,000 & 0,002 & 0,002 & n.d. & 0,000 \\
\hline $\mathrm{Na}_{2} \mathrm{O}$ & 0,121 & 0,101 & 0,163 & 0,182 & 0,206 & 0,259 & 0,121 & 0,229 & 0,157 & 0,233 \\
\hline $\mathrm{K}_{2} \mathrm{O}$ & 9,335 & 9,292 & 9,274 & 9,140 & 9,198 & 9,136 & 9,475 & 9,290 & 9,656 & 9,615 \\
\hline$F$ & 1,985 & 4,594 & 4,173 & 4,600 & 5,010 & 4,610 & 5,202 & 5,350 & 5,342 & 5,571 \\
\hline $\mathrm{Cl}$ & 0,339 & 0,031 & 0,099 & 0,021 & 0,038 & 0,020 & 0,018 & 0,009 & 0,007 & 0,030 \\
\hline $\mathrm{Nb}_{2} \mathrm{O}_{5}$ & 0,073 & 0,012 & n.d. & 0,030 & 0,014 & n.d. & n.d. & n.d. & 0,001 & n.d. \\
\hline TOTAL & 99,556 & 98,281 & 100,363 & 97,173 & 99,178 & 98,754 & 98,468 & 98,644 & 99,146 & 99,429 \\
\hline $\mathrm{O}=\mathrm{F}, \mathrm{Cl}$ & 0,912 & 1,941 & 1,779 & 1,941 & 2,118 & 1,945 & 2,194 & 2,255 & 2,251 & 2,352 \\
\hline T. corrigido & 98,643 & 96,339 & 98,584 & 95,232 & 97,060 & 96,809 & 96,273 & 96,389 & 96,895 & 97,077 \\
\hline $\mathrm{Si}$ & 5,3106 & 5,7016 & 5,4675 & 5,6871 & 5,6524 & 5,6867 & 5,8061 & 5,8341 & 5,7959 & 5,7585 \\
\hline $\mathrm{Ti}$ & 0,3178 & 0,0474 & 0,1245 & 0,1167 & 0,0225 & 0,0091 & 0,0048 & 0,0336 & 0,0101 & 0,0023 \\
\hline $\mathrm{Al}^{\mathrm{IV}}$ & 2,6894 & 2,2984 & 2,5325 & 2,3129 & 2,3476 & 2,3133 & 2,1939 & 2,1659 & 2,2041 & 2,2415 \\
\hline $\mathrm{Al}^{\mathrm{N}}$ & 0,9590 & 1,2971 & 0,9358 & 1,2251 & 1,3991 & 1,3762 & 1,5831 & 1,6923 & 1,6592 & 1,3542 \\
\hline $\mathrm{Fe}^{2+}$ & 3,4385 & 2,8303 & 3,4677 & 2,9122 & 2,6951 & 2,9090 & 2,3430 & 2,1926 & 2,1154 & 2,5825 \\
\hline $\mathrm{Mn}$ & 0,0446 & 0,1492 & 0,0912 & 0,1153 & 0,1083 & 0,1844 & 0,1439 & 0,1766 & 0,1559 & 0,1047 \\
\hline $\mathrm{Mg}$ & 0,3147 & 0,0676 & 0,0603 & 0,0546 & 0,0103 & 0,0019 & 0,0016 & 0,0110 & 0,0116 & 0,0029 \\
\hline 4 & 0,0509 & 0,1661 & 0,1805 & n.d. & 0,3495 & n.d. & 0,2924 & n.d. & 0,4308 & 0,4024 \\
\hline $8 a$ & 0,0030 & 0,0051 & 0,0020 & 0,0005 & 0,0021 & n.d. & 0,0018 & 0,0034 & 0,0000 & n.d. \\
\hline $\mathrm{Ca}$ & n.d. & n.d. & 0,0004 & n.d. & n.d. & 0,0000 & 0,0003 & 0,0003 & n.d. & 0,0000 \\
\hline $\mathrm{Na}$ & 0,0354 & 0,0290 & 0,0470 & 0,0530 & 0,0579 & 0,0742 & 0,0339 & 0,0637 & 0,0431 & 0,0651 \\
\hline $\mathrm{K}$ & 1,7955 & 1,7552 & 1,7639 & 1,7517 & 1,7051 & 1,7230 & 1,7437 & 1,6976 & 1,7476 & 1,7710 \\
\hline$F$ & 0,9464 & 2,1512 & 1,9677 & 2,1853 & 2,3023 & 2,1552 & 2,3731 & 2,4233 & 2,3968 & 2,5437 \\
\hline $\mathrm{Cl}$ & 0,0865 & 0,0077 & 0,0250 & 0,0054 & 0,0093 & 0,0050 & 0,0005 & 0,0022 & 0,0016 & 0,0072 \\
\hline $\mathrm{Nb}$ & 0,0124 & 0,0019 & n.d. & 0,0051 & 0,0023 & n.d. & n.d. & n.d. & 0,0001 & n.d. \\
\hline TOTAL & 16,0048 & 16,5078 & 16,6659 & 16,4249 & 16,6638 & 16,4382 & 16,5224 & 16,2966 & 16,5722 & 16,8360 \\
\hline$x$ & 1,8340 & 1,7893 & 1,8129 & 1,8052 & 1,7651 & 1,7973 & 1,7798 & 1,7649 & 1,7907 & 1,8360 \\
\hline$Y$ & 5,1379 & 4,5597 & 4,8600 & 4,4290 & 4,5871 & 4,4807 & 4,3690 & 4,1062 & 4,3832 & 4,0466 \\
\hline
\end{tabular}



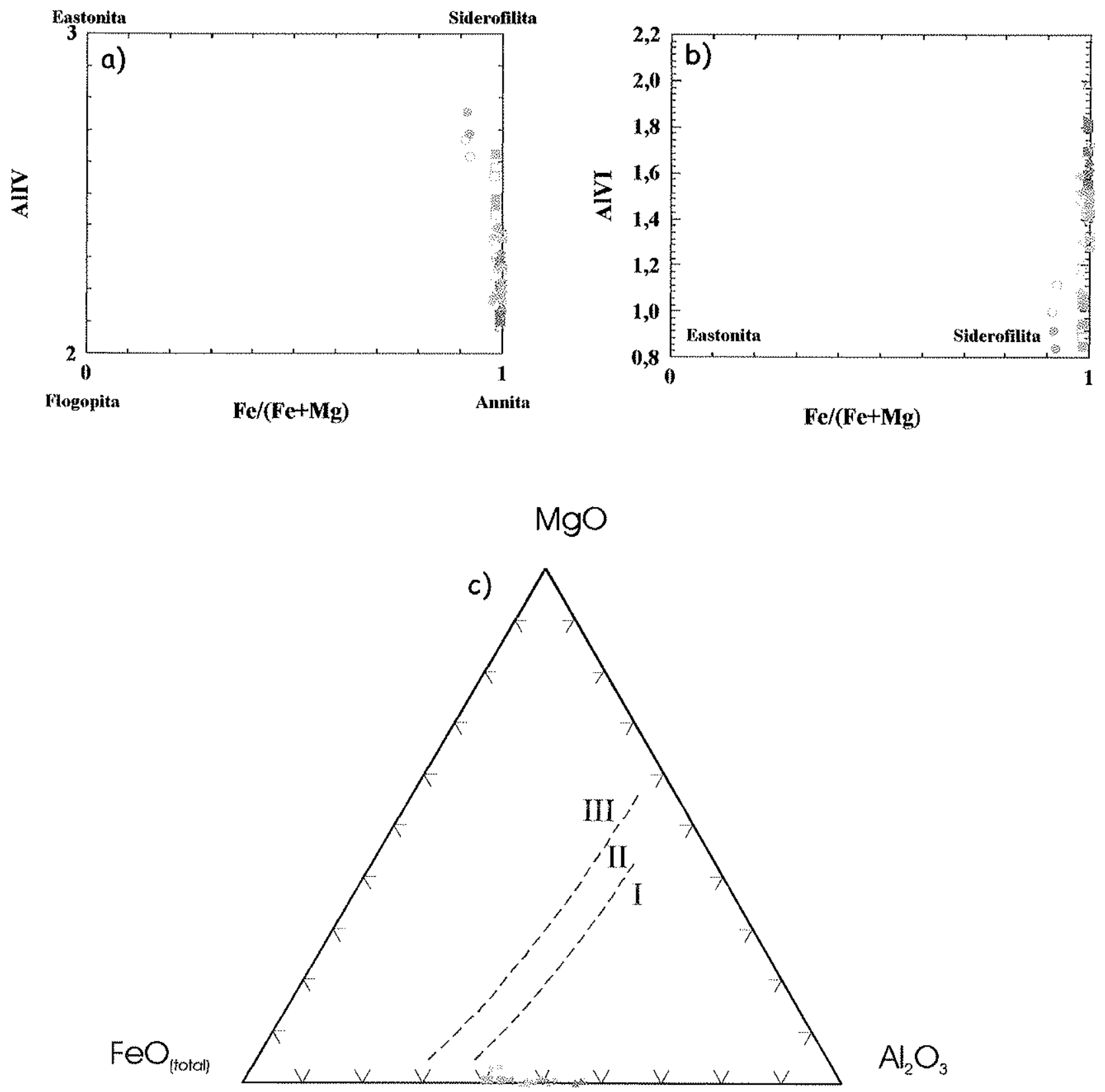

Figura 7.1 - Classificação das micas estudadas conforme os diagramas de a) $\mathrm{Al}^{\mathrm{N}} \times \mathrm{Fe} /(\mathrm{Fe}+\mathrm{Mg})$ e b) $\left.\mathrm{Al}^{\mathrm{v}} \times \mathrm{Fe} /(\mathrm{Fe}+\mathrm{Mg}) ; \mathrm{c}\right)$ diagrama de Nockolds (1947) ilustrando a paragênese máfica associada com a biotita esperada em função dos seus conteúdos de $\mathrm{MgO}, \mathrm{FeO}_{\text {(tdal) }} \mathrm{e}$ $\mathrm{Al}_{2} \mathrm{O}_{3}$. Campos: I) muscovita, topázio, espodumênio e outros minerais aluminosos; II) biotita ocorrendo como única fase máfica; III) hornblenda, piroxênio ou olivina. Símbolos para os pontos analíticos das composições das mica obtidos com EPMA e química analítica - facies Serra do Cícero (AM-52): " núcleo, borda; facies Serra Azul (AM-53): mica primária (?), mica secundária; facies Santa Bárbara fina (AM-145): " núcleo, borda; facies Santa Bárbara média (AM-224B): núcleo, borda; albita-microclínio granito branco (AM-134): núcleo, - borda; granito pegmatóide (AM-211A): núcleo, borda; granito albitizado salmão (AM-14A): anúcleo, borda. 
Os intervalos composicionais abrangidos pelas micas trioctaédricas de cada uma das fácies estudadas são exemplificados pelas seguintes fórmulas estruturais:

\section{$\checkmark$ fácies Serra do Cícero (fSC)}

$\mathrm{K}_{1,75-1,84} \mathrm{Na}_{0,01-0,02}\left(\mathrm{Mg}_{0,27-0,34} \mathrm{Fe}_{3,27-3,60} \mathrm{Ti}_{0,29-0,33} \mathrm{Al}_{0,83-1,22} \mathrm{Li}_{0,05} \mathrm{Mn}_{0,04-0,05}\right)\left(\mathrm{Si}_{5,24-5,38} \mathrm{Al}_{3,52-3,73}\right) \mathrm{O}_{20}\left(\mathrm{OH}_{\mathrm{x}_{1}} \mathrm{~F}_{0,76-1,15,} \mathrm{Cl}_{0,08-0,00}\right)$

$\checkmark$ fácies Serra Azul ( $S S A)$

$\mathrm{K}_{1,74-1,76} \mathrm{Na}_{0,01-0,02}\left(\mathrm{Mg}_{0,06-0,07} \mathrm{Fe}_{2,43-3,12} \mathrm{Ti}_{0,02-0,08} \mathrm{Al}_{1,05-1,55} \mathrm{Li}_{0,16-0,17} \mathrm{Mn}_{0,11-0,20}\right)\left(\mathrm{Si}_{5,61-5,81} \mathrm{Al}_{3,44-3,74}\right) \mathrm{O}_{20}\left(\mathrm{OH}_{\mathrm{x},} \mathrm{F}_{2,02-2,36,} \mathrm{Cl}_{0,00-0,01}\right)$

$\checkmark$ fácies Santa Bárbara média (fSBm)

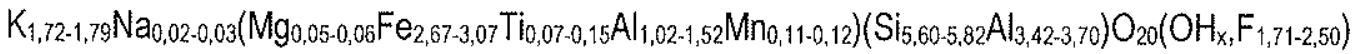

\section{$\checkmark$ fácies Santa Bárbara fina ( $(S B)$}

$\mathrm{K}_{1,73-1,77} \mathrm{Na}_{0,04-0,05}\left(\mathrm{Mg}_{0,05-0,07} \mathrm{Fe}_{3,243,62} \mathrm{Ti}_{0,09-0,16} \mathrm{Al}_{0,81-1,03} \mathrm{Li}_{0,18} \mathrm{Mn}_{0,08-0,10}\right)\left(\mathrm{Si}_{5,35-5,54} \mathrm{Al}_{3,42-3,48}\right) \mathrm{O}_{20}\left(\mathrm{OH}_{x_{1}} \mathrm{~F}_{1,74-2,09}, \mathrm{Cl}_{0,08-0,21}\right)$

\section{$\checkmark$ albita-mictoclínio granito branco}

$\mathrm{K}_{1,64-1,76} \mathrm{Na}_{0,02-0,04}\left(\mathrm{Mg}_{0,00-0,01} \mathrm{Fe}_{2,58-2,99} \mathrm{Ti}_{0,01-0,05} \mathrm{Al}_{1,32-1,54} \mathrm{Li}_{0,35-0,36} \mathrm{Mn}_{0,10-0,11}\right)\left(\mathrm{Si}_{5,57-5,73} \mathrm{Al}_{3,66-3,81}\right) \mathrm{O}_{20}\left(\mathrm{OH}_{\mathrm{x}}, \mathrm{F}_{1,99-1,66}\right)$

\section{$\checkmark$ topázio-siderofilita-quattzo greisen tabulat}

$\mathrm{K}_{1,73-1,76} \mathrm{Na}_{0,01-0,04}\left(\mathrm{Fe}_{2,24-2,42} \mathrm{Al}_{2,16-2,24} \mathrm{Li}_{0,29} \mathrm{Mn}_{0,13-0,15}\right)\left(\mathrm{Si}_{5,76-5,84} \mathrm{Al}_{3,68-3,83}\right) \mathrm{O}_{20}\left(\mathrm{OH}_{x}, \mathrm{~F}_{1,92-3,01}, \mathrm{Cl}_{0,00-0,04}\right)$

\section{$\checkmark$ granito greisenizado}

$\mathrm{K}_{1,67-1,72} \mathrm{Na}_{0,04-0,09}\left(\mathrm{Mg}_{0,01} \mathrm{Fe}_{2,08-2,32} \mathrm{Ti}_{0,00-0,08} \mathrm{Al}_{1,56-1,83} \mathrm{Mn}_{0,16-0,20}\right)\left(\mathrm{Si}_{5,71-5,90} \mathrm{Al}_{3,76-3,93}\right) \mathrm{O}_{20}\left(\mathrm{OH}_{x}, \mathrm{~F}_{2,06-2,69}, \mathrm{Cl}_{0,00-0,02}\right)$

\section{$\checkmark$ granito albitizado salmão}

$\mathrm{K}_{1,72-1,78} \mathrm{Na}_{0,02-0,06}\left(\mathrm{Mg}_{0,01} \mathrm{Fe}_{2,06-2,16} \mathrm{Ti}_{0,01-0,02} \mathrm{Al}_{1,56-1,88} \mathrm{Li}_{0,43} \mathrm{Mn}_{0,15-0,16}\right)\left(\mathrm{Si}_{5,72-5,85} \mathrm{Al}_{3,77-4,03}\right) \mathrm{O}_{20}\left(\mathrm{OH}_{1}, \mathrm{~F}_{1,58-2,78}\right)$

\section{$\checkmark$ pegmatóide}

$\mathrm{K}_{1,71-1,75} \mathrm{Na}_{0,03-0,04}\left(\mathrm{Fe}_{2,86-2,98} \mathrm{Ti}_{0,00 \cdot 0,02} \mathrm{Al}_{2,26-2,37} \mathrm{Mn}_{0,18-0,19}\right)\left(\mathrm{Si}_{5,63-5,74} \mathrm{Al}_{3,64-3,73}\right) \mathrm{O}_{20}\left(\mathrm{OH}_{\mathrm{x},} \mathrm{F}_{1,85-2,39}\right)$

$\checkmark$ veio de topázio-siderofilita-quartzo greisen

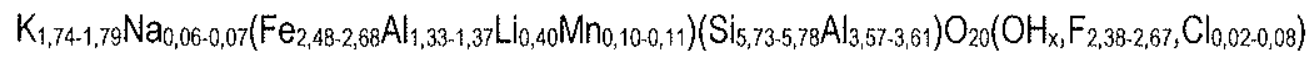

A maioria dessas micas apresenta conteúdo de $\mathrm{Al}^{\mathrm{IV}}$ entre 2,1 e 2,7 p.f.u., compatível com a siderofilita de Foster (1960a). Seu conteúdo de ferro, é pelo menos metade daquele esperado para a annita, e os teores muito baixos de $\mathrm{Mg}$ no sítio octaédrico dificultam sua classificação como biotita. Com efeito, a composição das micas classificadas como annita nos referidos diagratmas, 
especialmente aquelas de origem nos estágios transicional e hidrotermal, seria melhor representada pela fórmula ideal da zinnwaldita $\left(\mathrm{K}_{2}\left(\mathrm{Li}_{2} \mathrm{Fe}^{2}{ }^{2 \cdot+}{ }_{2} \mathrm{Al}_{2}\right)\left[\mathrm{Al}_{2} \mathrm{Si}_{6}\right\} \mathrm{O}_{20}(\mathrm{OH}, \mathrm{F})_{4}\right)$, dado seu conteúdo de ferro, no sítio octaédrico, menor do que 3,0 átomos p.f.u..

A caracterização do tipo de rocha ígnea portadora de biotita a partir da composição dessa fase mineral foi inicialmente explorada por Nockolds (1947), que construiu um diagrama ternário capaz de separar aquelas onde a mica ocorre em paragênese com muscovita, topázio, espodumênio ou outros minerais aluminosos (campo I) das que ocorrem sozinhas (campo II, ou ainda em associação com hornblenda, piroxênio ou olivina (campo III) (Fig. 7.1.c).

A presença de topázio magmático é confirmada pela petrografia. A colocação dos pontos analíticos relativos à composição dessas micas no campo I do gráfico pode ser entendida como indício de peraluminosidade das tochas. Progressivamente mais aluminosas são as micas da fácies Santa Bárbata média, o albita-microclínio branco da fácies Santa Bárbara fina e o granito albitizado salmão classificadas, segundo o diagrama de Gokhale (1968, Fig. 7.2), como pós-magmáticas.

Frank (1990) chamou atenção para a presença de teores de lítio entre 0,22 e 0,95\% nas micas da zona mineralizada do Maciço Granítico Santa Bárbara. As características óticas das micas do maciço, conforme determinadas no presente estudo, permitem classificá-las como micas de Fe-Li. Adicione-se a isso o fechamento sistemático do seu sítio octaédrico em menos de 4,6 átomos p.f.u., excetuadas as micas das fácies primárias, e o seu alto teor de flúor, elemento que apresenta correlação positiva com o lítio nas micas trioctaédricas (Foster 1960b). No presente estudo, os teores medidos de lítio em dez concentrados de micas trioctaédricas das fácies magmáticas, transicionais e hidrotermais ocorrem no intervalo de 0,084 a $0,755 \%$ em peso.

Foster (1960b) reconheceu a existência de uma série de micas de ferro e lítio, representada pela siderofilita e pela lepidolita nos extremos ticos em ferro e em lítio, respectivamente, onde a segunda derivaria da primeira pela substituição do ferro pelo lítio acompanhada pelo decréscimo de $\mathrm{Al}^{\mathrm{lV}}$ e aumento de silício. Os membros intermediários seriam a siderofilita com lítio, a protolitionita e a zinnwaldita.

Rieder (1970) argumentou que a protolitionita de Winchell (1942) não pertence à série siderofilita-polilitionita, e questionou inclusive sua existência. Também as Associação Mineralógica Internacional não reconhece essa fase mineral. Desde então, tem-se preferido utilizar os nomes zinnwaldita com ferto e siderofilita com lítio para micas de composição semelhante (e.g. Stone et al. 1988, Tindle \& Webb 1990). 


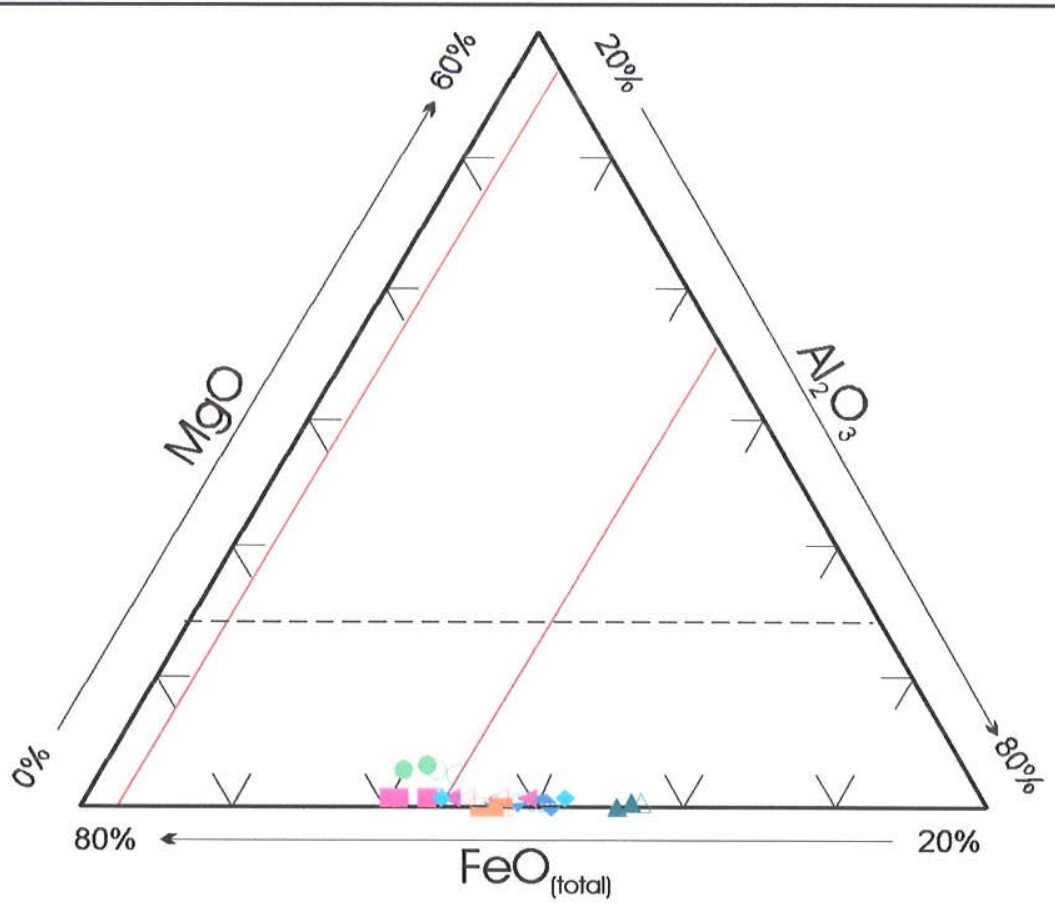

Figura 7.2 - Diagrama de Gokhale (1968) para distinção entre biotitas de origem ígnea daquelas metamórfico-metassomáticas. Em cinza - campo das micas ígneas. Símbolos conforme Fig. 7.1.

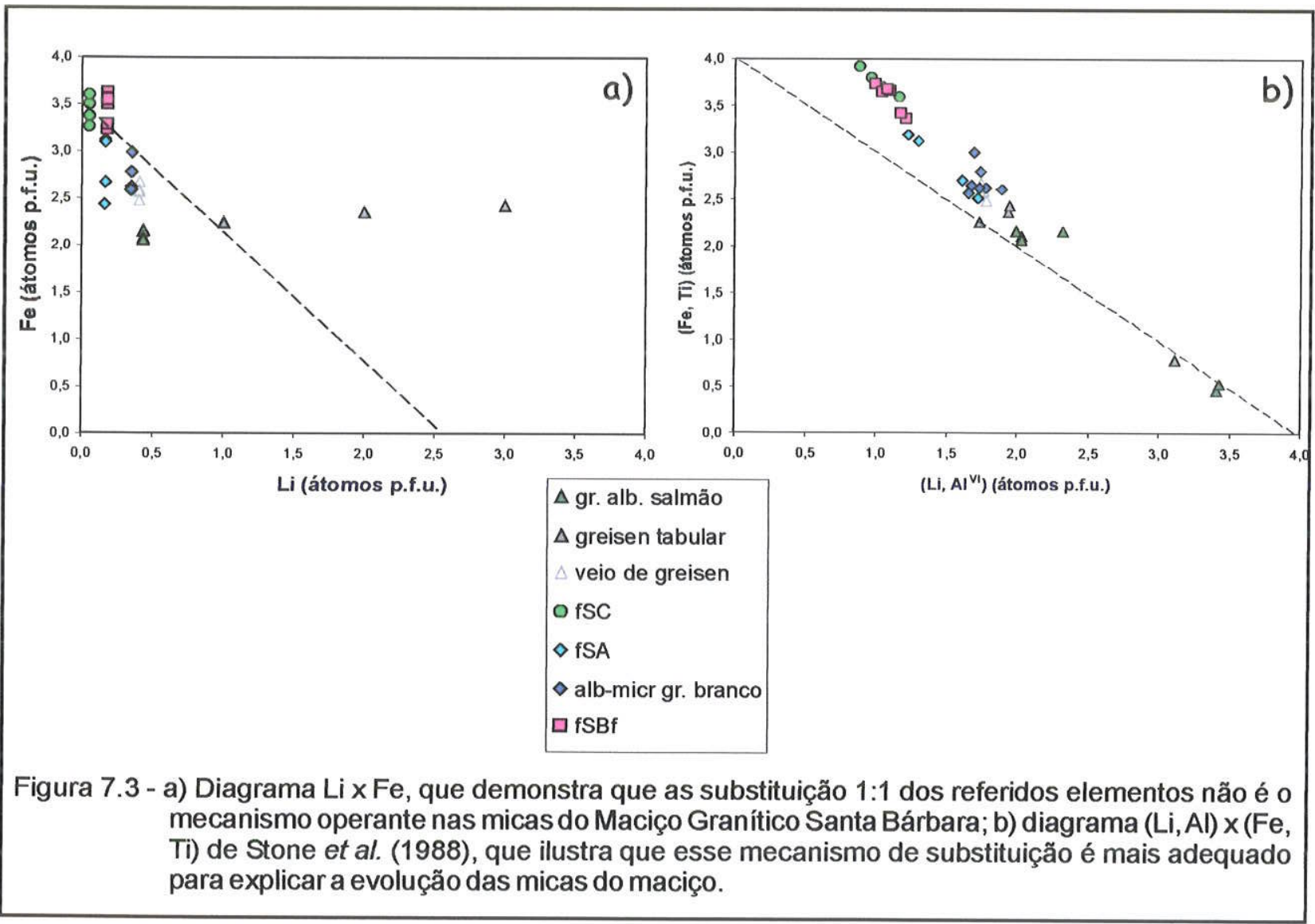


Para Foster (1960a), a siderofilita não ocorre em rochas ígneas como granitos, dioritos e sienitos, mas somente em litotipos extremos, como pegmatitos e greisens. Da mesma forma, todas as demais micas integrantes da série $\mathrm{Fe}-\mathrm{Li}$, presentes unicamente em álcali-feldspato granitos altamente evoluídos, pegmatitos graníticos, greisens associados com depósitos de metais raros, além de veios hidrotermais relacionados à formação de estanho-tungstênio-molibdênio (Henderson et al. 1989, du Bray 1994). Rochas graníticas que contêm micas com Li quase invariavelmente mostram efeitos de alteração hidrotermal subsolvus, algumas vezes pervasiva. Alguns autores acreditam que gerações de micas com Li de cristalização tardia podem ser hidrotermais ao invés de primárias (Stone 1984, Manning \& Exley 1984).

Segundo Deer et al. (1992), a ocupação octaédrica pode variar entre 6,0 e 5,6 átomos p.f.u. nas micas trioctaédricas, sendo freqüentemente significativamente menor na zinnwaldita. Já Tischendorf et al. (1997) defendem que 4,4 átomos p.f.u. seria o limite entre as micas di e trioctaédricas. Stone et al. (1988) obtiveram valores de ocupação octaédrica da ordem de 5,5 p.f.u. ao pesquisar micas trioctaédricas do Batólito Cornubiano. Observaram uma correlação linear bem marcada entre lítio e silício acompanhada do decréscimo de $\mathrm{Al}^{\mathrm{IV}}$ e de $\mathrm{F} \mathrm{e}^{2+}$ e do incremento do teor de $\mathrm{Al}^{\mathrm{V}}$, com pouca mudança nos valores de ocupação octaédrica. Isso lhes permitiu modificar o esquema de substituição elementar proposto por Foster (1960b), segundo o qual a lepidolita deriva da siderofilita pela substituição simples de $\mathrm{Fe}^{2+}$ por lítio no sítio octaédrico, e propor uma substituição $(\mathrm{Li}, \mathrm{Al}) \Rightarrow\left(\mathrm{Fe}^{2+1}, \mathrm{Fe}^{3+1}, \mathrm{Ti}\right)$.

Pata Henderson et al. (1989), o mecanismo de substituição na série siderofilita-polilitionita pode ser resumido pela equação $\mathrm{Li}^{\mathrm{VI}}+\mathrm{Si}^{\mathrm{lV}} \Rightarrow\left(\mathrm{Fe}^{2+\mathrm{V}}\right)^{\mathrm{VI}}+\mathrm{Al}^{\mathrm{IV}}$, onde a ocupação do sítio octaédrico é mantida em cerca de 6,0 átomos p.f.u.. Para os autores, embora essa relação tesulte numa tendência evolutiva semelhante àquela postulada por Stone et al. (1988), o lítio substitui unicamente os f́ons do tipo $\mathrm{R}^{2+*}$ no sítio octaédrico numa proporção de $1: 1$, sem envolvimento do $A 1$, ao contrário do que acreditam os últimos. Mais do que isso, Henderson et al. (1989) defendem que o membro final da série seria de composição intermediária entre a annita e a siderofilita, e não siderofilita sensu stricto.

Rieder (1970) ressaltou que as micas cuja ocupação octaédrica é inferior a 5,5 cátions não apresentam substituição 4:4 de ferro por lítio, o que se verifica naquelas aqui estudadas (Fig. 7.3.a). O diagrama ( $\mathrm{Li}, \mathrm{Al}) \times(\mathrm{Fe}, \mathrm{Ti})$ de Stone et al. (1988) (Fig. 7.3.b) ilustra melhor o mecanismo de substituição operante nas micas do Maciço Granítico Santa Bárbara.

Henderson et al. (1989) mencionam um enriquecimento das bordas dos cristais de mica em Li, F, Rb e Cs e um empobrecimento em ferro relativamente aos núcleos. Descrevem também as 
correlações positivas entre os teores de $\mathrm{SiO}_{2}$ e $\mathrm{Li}_{2} \mathrm{O}$ e entre $\mathrm{F}$ e $\mathrm{Li}_{2} \mathrm{O}$, amplamente reconhecidas na literatura, e a correlação negativa entre $\mathrm{Al} 2 \mathrm{O} 3$ e $\mathrm{Li}_{2} \mathrm{O}$ em micas primárias, utilizando-as conjuntamente para a estimativa dos teores de $\mathrm{Li}_{2} \mathrm{O}$ para aquelas em que o teor desse elemento não foi determinado.

Por analogia, deve-se esperar uma cortelação negativa entre $\mathrm{Al}_{2} \mathrm{O}_{3}$ e $\mathrm{SiO}_{2}$. No caso das micas aqui estudadas, essa relação separa bem o estágio magmático, onde ocorre diminuição do conteúdo de $\mathrm{Al}_{2} \mathrm{O}_{3}$ e suposto aumento de $\mathrm{Li}_{2} \mathrm{O}$, dos estágios transicional e pós-magmático, onde o aumento do $\mathrm{Al}_{2} \mathrm{O}_{3}$ é acompanhado pelo aumento de $\mathrm{Li}_{2} \mathrm{O}$ (Fig. 7.4.a). A trajetória, para ambos os casos, é a de perda de FeO (Fig. 7.4.b). Claro está também, a partir dos gráficos, que toda a alteração hidrotermal se dá sobre a associação de fácies Santa Bárbara.

Estimativas dos teores de lítio das micas trioctaédricas a partir de correlações empíricas com $\mathrm{SiO}_{2}, \mathrm{MgO}, \mathrm{F}, \mathrm{FeO}$ e $\mathrm{Al}^{\mathrm{VI}}$ têm sido propostas por diversos pesquisadores, entre eles Stone et al. (1988), Tindle \& Webb (1990) e Tischendorf et al. (1997, 1999). As micas estudadas apresentam ocupação octaédrica geralmente inferior a 5,0 cátions p.f.u., o que desaconselha a utilização das equações de correlação com $\mathrm{MgO}$ (Tischendorf et al. 1999). A correlação Li-F na zinnwaldita não é tão bem definida quanto no grupo muscovita-lepidolita, verificando-se não só excesso do halógeno relativamente ao metal alcalino, mas também excesso de $(\mathrm{OH}, \mathrm{F})$ nas micas da série siderofilitazinnwadita (Levillain 1980, Cerný \& Burt 1984), o que desencoraja o emprego do flúor nas estimativas. Tindle \& Webb (1990) reconhecem que a equação de regressão entre $\mathrm{Li}_{2} \mathrm{O}$ e $\mathrm{FeO}$ tem um ajuste pobre ou, ainda, a correlação entre os dois elementos só é bem definida em determinados intervalos de teores de $\mathrm{Li}_{2} \mathrm{O}$ (Tischendorf et al. 1997). Por fim, a participação do $\mathrm{Al}^{\mathrm{VI}}$ no mecanismo de substituição operante na série siderofilita-lepidolita não é confirmada por: alguns autores (Foster 1960b, Henderson et al. 1989). Diante desse fatores, $\mathrm{S} \mathrm{SiO}_{2}$ parece mais adequado.

Os teores de lítio das micas do Maciço Granítico Santa Bárbara, calculados por meio das diversas equações de correlação com a sílica disponíveis na literatura, são muito semelhantes. Optou-se, então, por utilizar os valores gerados conforme a equação de Tischendorf $e t$ al. (1997) por terem os autores obtido uma reta de regressão com ajuste ligeiramente melhor. Seu emprego é recomendado somente para rochas com percentual em peso de $\mathrm{SiO}_{2}$ maior do que 36, e funciona somente no caso de micas com mais de $0,6 \%$ em peso de $\mathrm{Li}_{2} \mathrm{O}$. 


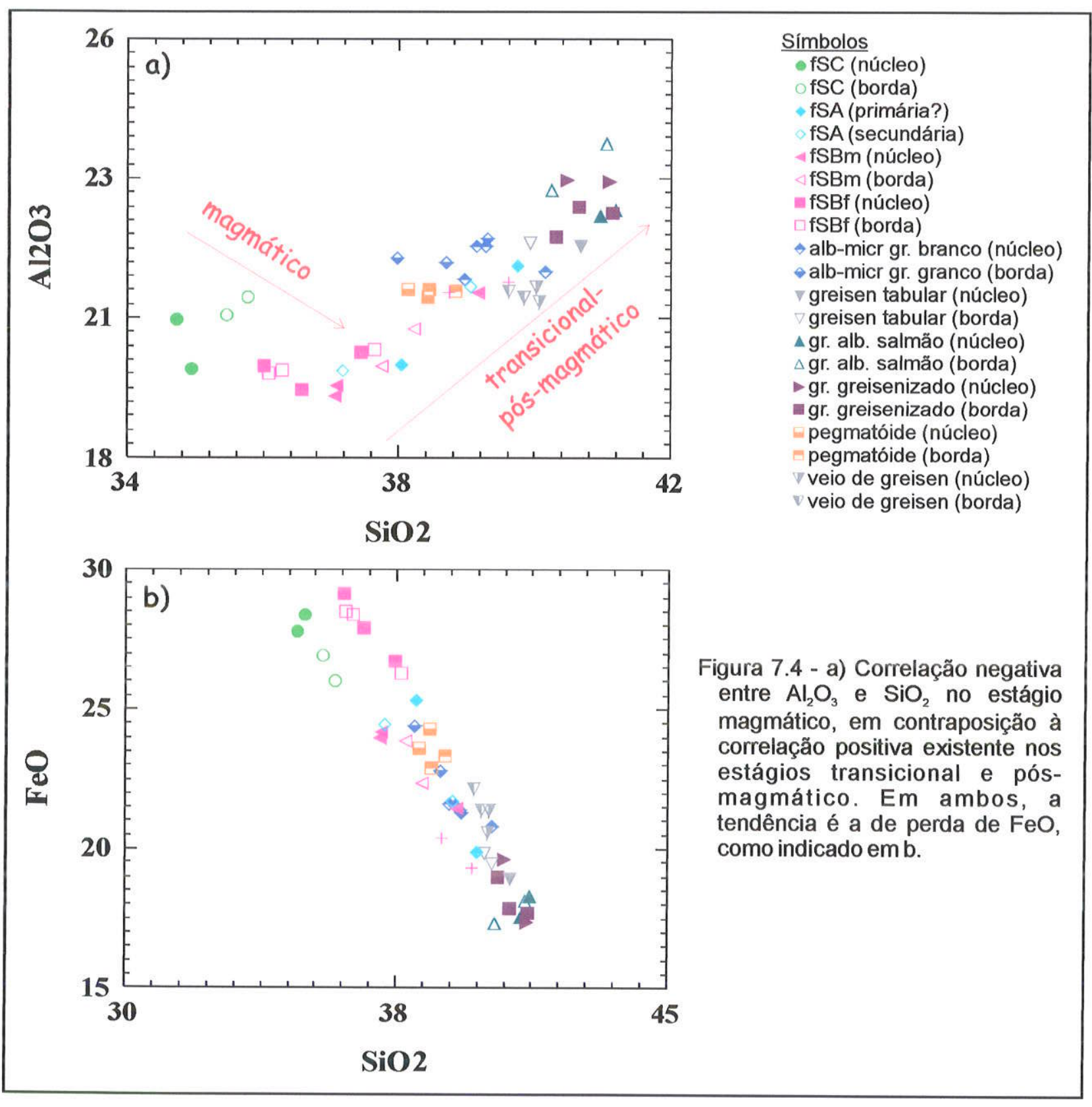


Esses conteúdos de lítio calculados variam entre 0,37 e 1,22\% nas micas primárias, sendo menores na fácies Serra do Cícero em comparação à associação de fácies Santa Bárbara, e entre 1,05 e 2,24\% nas dos estágios transicional e hidrotermal, atingindo seus maiores valores médios no granito albitizado salmão. De maneira geral, excedem os valores reais em 1 a 5 vezes. As composições médias estão ilustradas na Tabela 7.II.

Utilizando-se o gráfico mgli-feal (Tischendorf et al. 1997, Fig. 7.5), modificado pela exclusão do campo da protolitionita e extensão do campos da siderofilita até o limite de 1,0 átomo de lítio p.f.u. ( $f$. Rieder 1970 e Stone et al. 1988), todas as micas trioctaédricas do Maciço Granítico Santa Bárbara, incluindo aquelas das fácies dos estágios transicional e hidrotermal, podem ser classificadas como siderofilita.

Se aplicado o critério de Stone et al. (1988), que preconiza a proporção $\mathrm{Li}_{30} \mathrm{R}^{2+}{ }_{70}$ como limite entre siderofilita (quando $\mathrm{Li}<30$ ) e zinnwaldita, as micas do Maciço Granítico Santa Bárbatá também são todas classificáveis como siderofilita. Ressalte-se que as micas estudadas nem sempre atingem a ocupação octaédrica de 5,0 átomo p.f.u. recomendada pelos autores para o emprego dessa relação, mesmo com a inclusão do lítio. Os autores advertem, ainda, que esse não é um limite preciso e que zonas de transição devem ocorrex.

No que diz respeito à forte zonação exibida pelas micas dos greisents em lâmina delgada, as únicas tendências consistentes em termos de variação elementar que puderam ser observadas foram aumento nos teores de $\mathrm{Al}^{\mathrm{Vl}}$ e $\mathrm{Mn}$ e diminuição dos conteúdos de $\mathrm{Al}^{\mathrm{VV}}$, Fe, Ti, F e li do núcleo para a borda dos cristais. Somente a relação $\mathrm{Fe}^{3+/} \mathrm{T}$ i parece influir nas propriedades óticas das micas: altas $\mathrm{e}$ baixas tazões são responsáveis por pleocroísmo em tons de verde e marrom (Deer et al. 1966), que é a variação de cor observada nas micas estudadas. 
Tabela 7.ll. Médias das composiçōes das micas do Maciço Santa Bárbara obtidas com EPMA com Li 2 O calculado cfischendorf et al. (1997)

\begin{tabular}{|c|c|c|c|c|c|c|c|c|c|c|}
\hline FÁCIES & fSC $(A M-52 B)$ & $\mathrm{fSA}(\mathrm{AM}-53 \mathrm{~B})$ & fSBf $(A M-145)$ & $\begin{array}{c}\text { fSBm (AM- } \\
224 B)\end{array}$ & fSBfb $(A M-134)$ & pegmatóide & $\begin{array}{c}\text { greisen tabular } \\
\text { (AM-35) }\end{array}$ & $\begin{array}{c}\text { granito } \\
\text { greisenizado } \\
\text { (AM-19) }\end{array}$ & $\begin{array}{c}\text { gr. albitizado } \\
\text { salmão (AM- } \\
14 \mathrm{~B})^{*}\end{array}$ & $\begin{array}{l}\text { veio de greisen } \\
(\mathrm{AM}-41 \mathrm{~B})^{* *}\end{array}$ \\
\hline $\mathrm{SiO}_{2}$ & 35,217 & 38,503 & 36,667 & 37,851 & 38,893 & 38,462 & 40,245 & 40,726 & 40,849 & 39,880 \\
\hline $\mathrm{TiO}_{2}$ & 2,802 & 0,426 & 1,110 & 1,032 & 0,206 & 0,082 & 0,045 & 0,312 & 0,095 & 0,021 \\
\hline $\mathrm{Al}_{2} \mathrm{O}_{3}$ & 20,530 & 20,603 & 19,737 & 19,981 & 21,875 & 21,174 & 22,215 & 22,854 & 23,104 & 21,130 \\
\hline $\mathrm{FeO}$ & 27,270 & 22,857 & 27,811 & 23,179 & 22,177 & 23,530 & 19,422 & 18,304 & 17,830 & 21,388 \\
\hline $\mathrm{MnO}$ & 0,349 & 1,190 & 0,722 & 0,906 & 0,880 & 1,473 & 1,178 & 1,456 & 1,297 & 0,857 \\
\hline $\mathrm{MgO}$ & 1,400 & 0,306 & 0,271 & 0,246 & 0,048 & 0,009 & 0,008 & 0,056 & 0,055 & 0,014 \\
\hline $\mathrm{Li}_{2} \mathrm{O}$ & 0,520 & 1,469 & 0,939 & 1,281 & 1,582 & 1,458 & 1,973 & 2,112 & 2,147 & 1,867 \\
\hline $\mathrm{BaO}$ & 0,052 & 0,088 & 0,034 & 0,009 & 0,037 & n.d. & 0,032 & 0,060 & 0,000 & n.d. \\
\hline $\mathrm{CaO}$ & n.d. & n.d. & 0,003 & n.d. & n.d. & 0,000 & 0,002 & 0,002 & n.d. & 0,000 \\
\hline $\mathrm{Na}_{2} \mathrm{O}$ & 0,121 & 0,101 & 0,163 & 0,182 & 0,206 & 0,259 & 0,121 & 0,229 & 0,157 & 0,233 \\
\hline $\mathrm{K}_{2} \mathrm{O}$ & 9,335 & 9,292 & 9,274 & 9,140 & 9,198 & 9,136 & 9,475 & 9,290 & 9,656 & 9,615 \\
\hline$F$ & 1,985 & 4,594 & 4,373 & 4,600 & 5,010 & 4,610 & 5,202 & 5,350 & 5,342 & 5,571 \\
\hline $\mathrm{Cl}$ & 0,339 & 0,031 & 0,099 & 0,021 & 0,038 & 0,020 & 0,018 & 0,009 & 0,007 & 0,030 \\
\hline $\mathrm{Nb}_{2} \mathrm{O}_{5}$ & 0,073 & 0,012 & n.d. & 0,030 & 0,014 & n.d. & n.d. & n.d. & 0,001 & n.d. \\
\hline TOTAL & 99,991 & 99,471 & 101,001 & 98,456 & 100,162 & 100,212 & 99,936 & 100,760 & 100,539 & 100,603 \\
\hline $\mathrm{O}=\mathrm{F}, \mathrm{Cl}$ & 0,912 & 1,941 & 1,779 & 1,941 & 2,118 & 1,945 & 2,194 & 2,255 & 2,251 & 2,352 \\
\hline T. corrigido & 99,079 & 97,530 & 99,221 & 96,515 & 98,044 & 98,266 & 97,742 & 98,505 & 98,288 & 98,251 \\
\hline $\mathrm{Si}$ & 5,2789 & 5,6112 & 5,4204 & 5,5887 & 5,5795 & 5,5769 & 5,6958 & 5,6769 & 5,6931 & 5,6706 \\
\hline $\mathrm{Ti}$ & 0,3159 & 0,0466 & 0,1234 & 0,1147 & 0,0222 & 0,0089 & 0,0048 & 0,0327 & 0,0100 & 0,0022 \\
\hline $\mathrm{Al}^{\mathrm{N}}$ & 2,7211 & 2,3888 & 2,5796 & 2,4113 & 2,4205 & 2,4231 & 2,3042 & 2,3231 & 2,3069 & 2,3294 \\
\hline $\mathrm{Al}^{\mathrm{V}}$ & 0,9055 & 1,1497 & 0,8588 & 1,0655 & 1,2778 & 1,1951 & 1,4011 & 1,4312 & 1,4879 & 1,2115 \\
\hline $\mathrm{Fe}^{2+}$ & 3,4179 & 2,7854 & 3,4378 & 2,8618 & 2,6603 & 2,8529 & 2,2985 & 2,1335 & 2,0779 & 2,5431 \\
\hline Mn & 0,0443 & 0,1469 & 0,0904 & 0,1133 & 0,1069 & 0,1809 & 0,1412 & 0,1719 & 0,1531 & 0,1031 \\
\hline $\mathrm{Mg}$ & 0,3128 & 0,0665 & 0,0598 & 0,0541 & 0,0102 & 0,0019 & 0,0016 & 0,0116 & 0,0114 & 0,0029 \\
\hline $\mathrm{Li}$ & 0,3133 & 0,8611 & 0,5580 & 0,7605 & 0,9127 & 0,8499 & 1,1228 & 1,1838 & 1,2035 & 1,0677 \\
\hline $\mathrm{Ba}$ & 0,0030 & 0,0050 & 0,0019 & 0,0005 & 0,0021 & n.d. & 0,0018 & 0,0033 & 0,0000 & n.d. \\
\hline $\mathrm{Ca}$ & n.d. & n.d. & 0,0004 & n.d. & n.d. & 0,0000 & 0,0003 & 0,0003 & n.d. & 0,0000 \\
\hline $\mathrm{Na}$ & 0,0352 & 0,0285 & 0,0466 & 0,0521 & 0,0572 & 0,0728 & 0,0333 & 0,0619 & 0,0424 & 0,0641 \\
\hline$K$ & 1,7848 & 1,7274 & 1,7487 & 1,7214 & 1,6831 & 1,6898 & 1,7106 & 1,6519 & 1,7166 & 1,7439 \\
\hline$F$ & 0,9407 & 2,1170 & 1,9507 & 2,1475 & 2,2726 & 2,1136 & 2,3280 & 2,3580 & 2,3543 & 2,5049 \\
\hline $\mathrm{CI}$ & 0,0860 & 0,0076 & 0,0248 & 0,0053 & 0,0092 & 0,0049 & 0,0005 & 0,0022 & 0,0016 & 0,0071 \\
\hline $\mathrm{Nb}$ & 0,0123 & 0,0019 & n.d. & 0,0050 & 0,0023 & n.d. & n.d. & n.d. & 0,0001 & n.d. \\
\hline TOTAL & 16,1720 & 16,9437 & 16,9014 & 16,9016 & 17,0165 & 16,9705 & 17,0444 & 17,0421 & 17,0587 & 17,2506 \\
\hline$x$ & 1,8231 & 1,7609 & 1,7972 & 1,7740 & 1,7423 & 1,7626 & 1,7460 & 1,7174 & 1,7590 & 1,8080 \\
\hline$Y$ & 5,3221 & 5,0582 & 5,1282 & 4,9749 & 4,9924 & 5,0895 & 4,9699 & 4,9646 & 4,9439 & 4,9305 \\
\hline
\end{tabular}




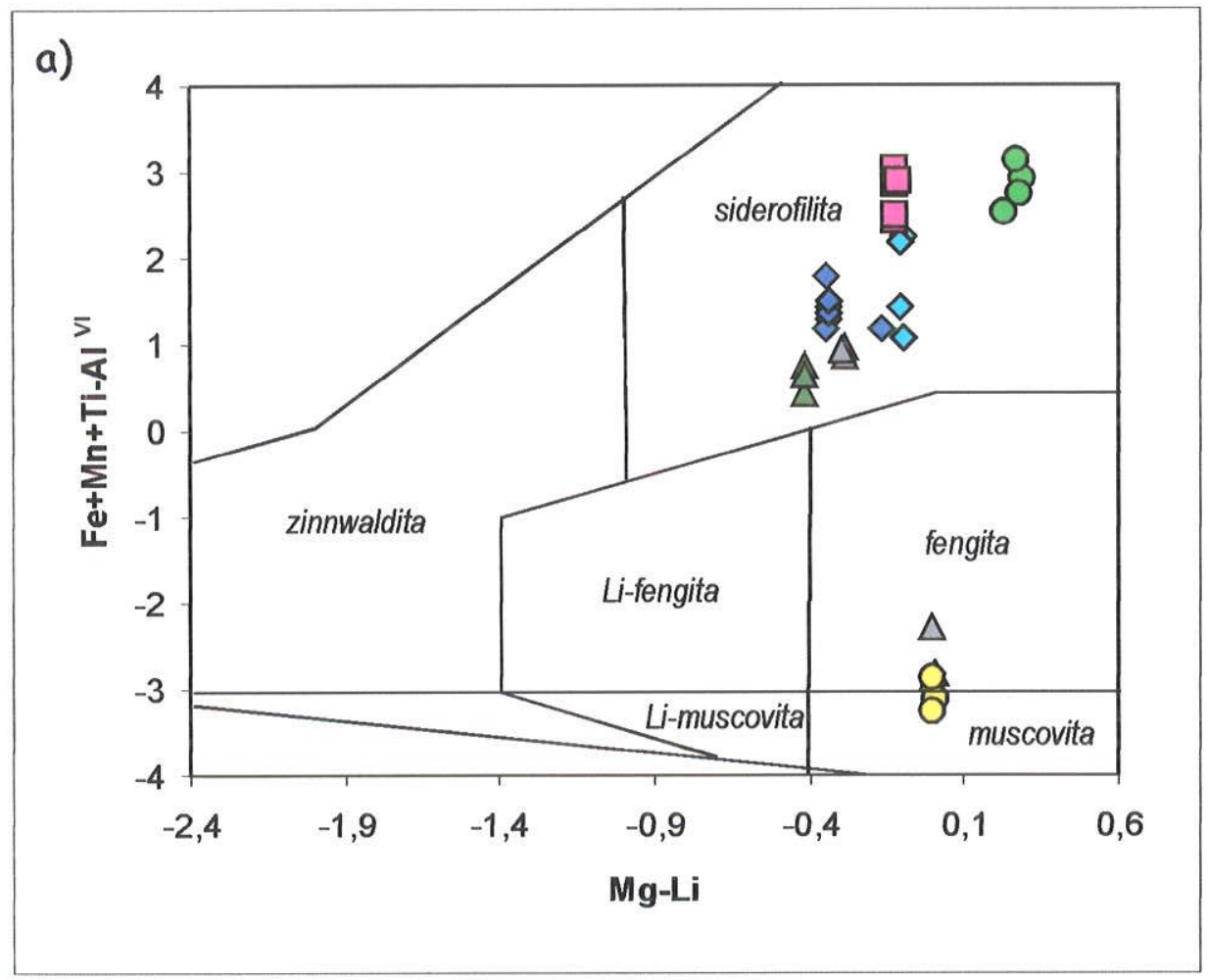

b)

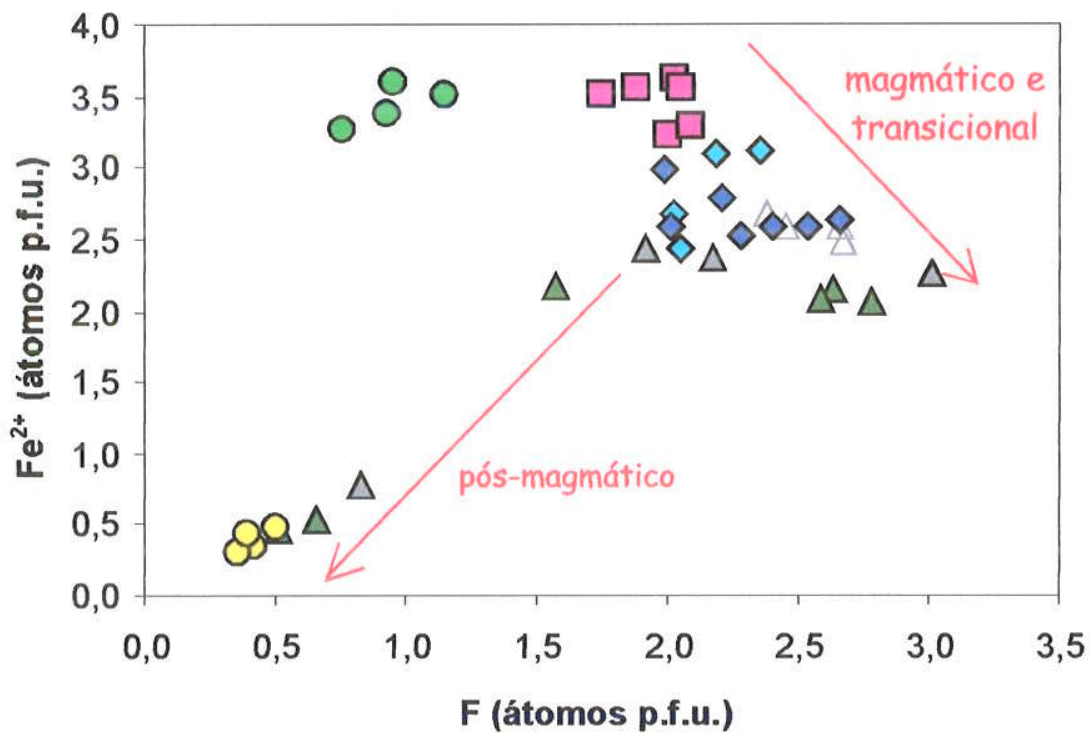

Figura 7.5 - a) Diagrama mgli-feal modificado de Tischendorf et al. (1997) pela exclusão do campo da protolitionita e inclusão de outro limite entre zinnwaldita e siderofilita, conforme parâmetros de Rieder (1970) e Stone et al. (1988); b) diagrama F x Fe (Henderson et al. 1989) ilustrando a substituição das micas do estágio transicional, predominantemente, pela muscovita, com pronunciada perda de Fe e F. Símbolos conforme Fig. 7.3 acrescidos do círculo amarelo, representativo das micas dioctaédricas. 


\subsubsection{Micas dioctaédricas}

A composição média dessas micas, obtida a partir das medidas de Microssonda Eletrônica nas duas amostras onde estão presentes, está ilustrada na Tabela 7.III, bem como o teor de lítio medido via química analítica para uma delas. O conjunto completo das análises encontra-se no Anexo II. Tratam-se de micas presentes em topázio-mica greisens afetados em intensidades diferentes pela alteração pós-magmática denominada muscovitização.

Os intervalos composicionais abrangidos pelas micas dioctaédricas de cada uma das fácies estudadas são exemplificados pelas seguintes fórmulas estruturais:

\section{topázio-siderofilita-quartzo greisen muscovitizado \\ $\mathrm{K}_{1,65-1,85} \mathrm{Na}_{0,01-0,03}\left(\mathrm{Fe}_{0,34-0,48} \mathrm{Al}_{3,35-3,32} \mathrm{Mn}_{0,04-0,06}\right)\left(\mathrm{Si}_{6,11-6,32} \mathrm{Al}_{5,03-5,81}\right) \mathrm{O}_{20}\left(\mathrm{OH}_{x}, \mathrm{~F}_{0,14-0,67}\right)$ \\ $\checkmark$ muscovita-cassiterita greisen \\ $\mathrm{K}_{1,79-1,92 .} \mathrm{Na}_{0,01}\left(\mathrm{Fe}_{0,30-0,45} \mathrm{Al}_{3,40-3,60} \mathrm{Mn}_{0,06-0,10}\right)\left(\mathrm{Si}_{6,26-6,32} \mathrm{Al}_{5,08-5,32}\right) \mathrm{O}_{20}\left(\mathrm{OH}_{\mathrm{x}}, \mathrm{F}_{0,39 \cdot 0,50)}\right.$}

A amostra AM-3B consiste de greisen onde a referida alteração se manifesta meramente pela substituição da mica original da rocha pela mica dioctaédrica. Já na amostra AM-89 o grau de alteração foi tão intenso que eliminou completamente o quartzo, deixando uma rocha biminerálica à base de cassiterita e muscovita.

As proporções de Si: $\mathrm{Al}^{\mathrm{V}}$ maiores do que 3:1 e os teores significativos de $\mathrm{FeO}$ dessas micas dioctaédricas sugerem composição fengítica (Deer et al. 1992), porém trata-se de muscovita com até $12 \%$ da molécula da fengita. Sua classificação conforme o diagrama mgli-feal de Tischendorf et al. (1997) pode ser observada na Fig. 7.5.a.

Apesar de problemáticas, as estimativas de seus teores de lítio foram efetuadas com base na equação de Tischendorf et al. (1997), que correlaciona lítio e flúor, e situaram-se no intervalo de 0,10 até $0,72 \%$, excedendo os valores reais em algumas dezenas de vezes.

As micas mais alteradas tendem a ter baixos teores de Li, Rb e Cs, altos conteúdos de $\mathrm{Al}$ e baixa ocupação octaédrica (Henderson et al. 1989). Os autores referem-se à muscovita cristalizada em condições subsolidus e que apresenta fluorita precipitada nas suas clivagens como "micas alteradas", pois acreditam que lítio e flúor são provavelmente muito suscetíveis à alteração, mesmo que incipiente.

Neste sentido, Henderson et al. (1989) propuseram o diagrama Fe x F como uma poderosa 
ferramenta na identificação desse tipo de alteração. Com efeito, mostra claramente a incidencia do fenômeno no caso das micas estudadas na presente pesquisa (Fig. 7.5.b).

\subsubsection{Implicações metalogenéticas da composição das micas trioctaédricas}

Micas de lítio são fases minerais típicas de greisens, granitos diferenciados e pegmatitos, além de veios hidrotermais em depósitos de Sn-W-Mo (Cissarz 1927 in Rieder 1970, Henderson et al. 1989). São comuns também nos topázio granitos que hospedam a mineralização estanífera nos granitos rapakivi (Haapala \& Rämö 1990).

Na qualidade de fases minerais hidratadas, as micas são sensíveis às condições de fugacidade de água, oxigênio, flúor e outras espécies voláteis e, portanto, são indicadores úteis das condições físico-químicas em que se cristalizaram (Bailey 1984). A presença de micas de Fe-Li em granitos mineralizados com elementos raros resulta do papel crescente dos voláteis nos estágios finais de diferenciação dessas rochas (Pollard 1983).

A substituição de protolitionita por zinnwaldita devida à interação com fluidos ricos em flúor tem sido apontada como um importante mecanismo de transferência do 'Ti, Sn, Nb, Ta e W da estrutura da mica para a fase fluida, na forma de fluoretos, com posterior precipitação dos metais por hidrólise desses compostos (Johan \& Johan 2001).

No caso do Maciço Granítico Santa Bárbara, o aumento dos conteúdos de Li e de Fi das micas das fácies mais precoces rumo às mais evoluídas, bem como a correlação positiva do Sn com o F (Fig. 6.12.b), comprovam a importância da composição dessas micas como indicador da potencialidade metalogenética desses granitos. 
Tabela 7.llI. Médias das composições das micas dioctaédricas do Maciço Santa Bárbara obtidas com EPMA incluindo $\mathrm{Li}, \mathrm{O}$ medido por química analítica.

\begin{tabular}{|c|c|c|}
\hline FÁCIES & $\begin{array}{c}\text { greisen } \\
\text { muscovitizado } \\
\text { (AM-3B) }\end{array}$ & $\begin{array}{c}\text { cassit.-musc. } \\
\text { greisen (AM- } \\
89)^{\star}\end{array}$ \\
\hline $\mathrm{SiO}_{2}$ & 46,815 & 46,009 \\
\hline $\mathrm{TiO}_{2}$ & 0,018 & 0,000 \\
\hline $\mathrm{Al}_{2} \mathrm{O}_{3}$ & 33,801 & 32,290 \\
\hline $\mathrm{FeO}$ & 3,046 & 3,487 \\
\hline $\mathrm{MnO}$ & 0,463 & 0,626 \\
\hline $\mathrm{MgO}$ & 0,011 & 0,012 \\
\hline $\mathrm{Li}_{2} \mathrm{O}$ & n.d. & 0,007 \\
\hline $\mathrm{BaO}$ & n.d. & n.d. \\
\hline $\mathrm{CaO}$ & 0,018 & 0,006 \\
\hline $\mathrm{Na}_{2} \mathrm{O}$ & 0,088 & 0,101 \\
\hline $\mathrm{K}_{2} \mathrm{O}$ & 10,534 & 10,519 \\
\hline$F$ & 1,118 & 0,966 \\
\hline $\mathrm{Cl}$ & 0,005 & 0,002 \\
\hline $\mathrm{Nb}_{2} \mathrm{O}_{5}$ & n.d. & n.d. \\
\hline TOTAL & 95,916 & 94,023 \\
\hline $\mathrm{O}=\mathrm{F}, \mathrm{Cl}$ & 0,472 & 0,407 \\
\hline T. corrigido & 95,444 & 93,616 \\
\hline $\mathrm{Si}$ & 6,2436 & 6,2902 \\
\hline $\mathrm{Ti}$ & 0,0018 & 0,0000 \\
\hline $\mathrm{A}^{\mathrm{iN}}$ & 1,7564 & 1,7098 \\
\hline $\mathrm{Al}^{\mathrm{V}^{\mathrm{V}}}$ & 3,5561 & 3,4928 \\
\hline $\mathrm{Fe}^{2+}$ & 0,3396 & 0,3986 \\
\hline $\mathrm{Mn}$ & 0,0523 & 0,0724 \\
\hline $\mathrm{Mg}$ & 0,0023 & 0,0024 \\
\hline Li & n.d. & 0,0038 \\
\hline $\mathrm{Ba}$ & n.d. & n.d. \\
\hline $\mathrm{Ca}$ & 0,0025 & 0,0008 \\
\hline $\mathrm{Na}$ & 0,0227 & 0,0267 \\
\hline $\mathrm{K}$ & 1,7920 & 1,8344 \\
\hline$F$ & 0,4715 & 0,4176 \\
\hline $\mathrm{Cl}$ & 0,0011 & 0,0005 \\
\hline $\mathrm{Nb}$ & n.d. & n.d. \\
\hline TOTAL & 14,2419 & 14,2500 \\
\hline$x$ & 1,8172 & 1,8619 \\
\hline$Y$ & 3,9521 & 3,9701 \\
\hline
\end{tabular}

* Teor de lítio medido na amostra AM-307, que pertence à mesma fácies. 


$$
\text { VIII. GEOCRONOLOGIA }
$$

Este capítulo é constituído, na íntegra, por artigo publicado da revista Geologia USP, Série Científica, Volume 2 (2002). 


\title{
Datações U-Pb Convencional Versus SHRIMP do Maciço Estanífero Santa Bárbara, Suíte Granitos Últimos de Rondônia, Brasil
}

\author{
Irena Sparrenberger ${ }^{1}$, Jorge Silva Bettencourt ${ }^{2}$, Richard M. Tosdal ${ }^{3}$, Joseph L. Wooden ${ }^{4}$ \\ 'Programa de Pós-Graduação em Recursos Minerais e Hidrogeologia - Instituto de Geociências - USP \\ Rua do Lago 562, CEP 05508-080, São Paulo, SP, BRA \\ 2Departamento de Mineralogia e Geotectônica - Instituto de Geociências - USP, São Paulo, SP, BRA \\ ${ }^{3}$ Department of Earth \& Ocean Sciences - University of British Columbia, Vancouver, CAN \\ ${ }^{4}$ USGS-SUMAC, lon Probe Lab.- Stanford University, Stanford, USA
}

Palavras-chave: SHRIMP, granitos estaníferos, Província Estanífera de Rondônia, Cráton Amazônico.

\section{RESUMO}

O Maciço Granítico Santa Bárbara é parte da Suíte Granitos Últimos de Rondônia (998 - 974 Ma), e integra a Província Estanífera de Rondônia (SW do Cráton Amazônico). Compreende três unidades de granitos altamente fracionados, metaluminosos a peraluminosos, de afinidade geoquímica com granitos do tipo $A$ e intraplaca. A mineralização estanífera está associada com a unidade tardia. As unidades facies Serra do Cícero, precoce, e facies Serra Azul, tardia, foram datadas por U-Pb em monazita em $993 \pm 5 \mathrm{Ma}$ e $989 \pm 13 \mathrm{Ma}$, respectivamente. A datação U-Pb convencional de zircão, entretanto, demonstrou perturbação isotópica e revelou importantes componentes herdados das unidades em questão, sendo inadequada para a definição da idade de cristalização desses granitos. Datações via SHRIMP do zircão da unidade associação de facies Santa Bärbara forneceram média ponderada das idades ${ }^{207} \mathrm{~Pb}{ }^{206} \mathrm{~Pb}$ de $978 \pm 13 \mathrm{Ma}$. A alta complexidade textural dos cristais de zircão da associação de facies Santa Bárbara, seus teores variáveis de $\mathrm{U}$, Th e $\mathrm{Pb}$, além da presença comum de populações de zircão com núcleos herdados, desencorajam o uso da datą̧ão U-Pb convencional em multigrão em granitos similares. As idades-modelo Sm-Nd e os valores de $\varepsilon_{\mathrm{Nd}}(\mathrm{T})$ revelam dados isotópicos anômalos, confirmando a complexidade do comportamento dos sistemas isotópicos nestes granitos altamente fracionados. Diante desse cenário, os autores consideram os métodos U-Pb em zircão via SHRIMP e U-Pb convencional em monazita como mais adequados para a estimativa da idade de cristalização em sistemas graníticos mineralizados na Província Estanífera de Rondônia.

Keywords: SHRIMP, tin granites, Rondônia Tin Province, Amazonian Craton.

\begin{abstract}
The Santa Bárbara Granite Massif is part of the Younger Granites of Rondônia (998 - $974 \mathrm{Ma}$ ) and is included in the Rondônia Tin Province (SW Amazonian Craton). It comprises three highly fractionated metaluminous to peraluminous within-plate A-type granite units emplaced in older medium-grade metamorphic rocks. Sn-mineralization is closely associated with the late-stage unit. U-Pb monazite conventional dating of the early-stage Serra do Cícero facies and late-stage Serra Azul facies yielded ages of $993 \pm 5 \mathrm{Ma}$ and $989 \pm 13 \mathrm{Ma}$, respectively. Conventional multigrain U-Pb isotope analyses of zircon demonstrate isotopic disturbance (discordance) and the preservation of inherited older zircons of several different ages and thus yield little about the ages of Sn-granite magmatism. SHRIMP U-Pb ages for the Santa Bárbara facies association yielded $\mathrm{a}^{207} \mathrm{~Pb} /{ }^{206} \mathrm{~Pb}$ weighted-mean age of $978 \pm 13 \mathrm{Ma}$. The textural complexity of the zircon crystals of the Santa Bárbara facies association, the variable concentrations of $\mathrm{U}$, Th and $\mathrm{Pb}$, as well as the mixed inheritance of zircon populations are major obstacles to using conventional multigrain U-Pb isotopic analyses. Sm-Nd model ages and $\varepsilon_{\mathrm{Nd}}(\mathrm{T})$ values reveal anomalous isotopic data, attesting to the complex isotopic behaviour within these highly fractionated granites. Thus, SHRIMP U-Pb zircon and conventional U-Pb monazite dating methods are the most appropriate to constrain the crystallization age of the Sn-bearing granite systems in the Rondonia Tin Province.
\end{abstract}




\section{INTRODUÇÃO}

O zircão é uma fase mineral acessória tradicionalmente usada na datação U-Pb de granitos. Sua utilidade reside na alta estabilidade química observada frente a processos geológicos em estágio subsolidhs' e ao intemperismo.

No caso estudado, as rochas portadoras de zircão são granitos altamente fracionados, ricos em voláteis e, em alguns casos, hospedeiros de minério de elementos raros. Boa parte dos cristais do mineral são turvos, com feições morfológicas internas complexas e teores de $\mathrm{U}$, Th e Pb altamente variáveis.

O método convencional de datação U-Pb em zircão, utilizado em duas das três unidades do Maciço Granítico Santa Bárbara, mostrou-se inadequado para a definição da idade de cristalização dos granitos em virtude do alto grau de discordância das análises, que pode ser atribuído a distúrbios do sistema U-Th-Pb causados por interação rocha-fluido em estágio tardi à pós-magmático, e da freqüência de zircão herdado.

Diante desse cenário, a intenção dos autores é de confrontar os métodos clássicos de datação U-Pb em zircão (espectrometria de massa por ionização térmica em multigrão) com o SHRIMP neste granito estanifero, bus. cando a definição da abordagem mais adequada à problemática da datação de rochas similares.

\section{CONTEXTO GEOLÓGICO}

O Maciço Granítico Santa Bárbara localiza-se no norte do estado de Rondônia, margem sudoeste do Cráton Amazônico, alojado em rochas da Provincia Geocronológica Rio Negro-Juruena (Cordani et al., 1979; Teixeira et al., 1989; Tassinari, 1996) (Fig. 1a). Integra a Província Estanifera de Rondônia, cujo embasamento é constituído predominantemente pelos granitóides metamorfizados nas facies anfibolito e granulito do Complexo Jamari (Isotta et al., 1978).

Cinco associações litológicas ocorrem no embasamento da porção centro-leste da Província Estanifera de Rondônia (Payolla et al., 2001b; 2002):

1. gnaisses tonalíticos $\left(1,75 \mathrm{Ga} ; \mathcal{E}_{\mathrm{Nd}}(\mathrm{T})-1,5 \mathrm{a}+0,1\right.$; $\left.\mathrm{T}_{\mathrm{DM}} 2,2 \mathrm{a} 2,1 \mathrm{Ga}\right)$

2. granulitos enderbíticos $\left(1,73 \mathrm{Ga} ; \varepsilon_{\mathrm{Nd}}(\mathrm{T})\right.$ $\left.-0,6 \mathrm{a}+0,1 ; \mathrm{T}_{\mathrm{DM}} 2,1 \mathrm{Ga}\right)$;

3. paragnaisses (idade incerta; $\mathrm{T}_{\mathrm{DM}} 2,2$ a $2,1 \mathrm{Ga}$ );
4. augen-gnaisses graníticos e charnockíticos $(1,57$ a $\left.1,53 \mathrm{Ga} ; \mathcal{E}_{\mathrm{Nd}}(\mathrm{T})+0,6 \mathrm{a}+2,0 ; \mathrm{T}_{\mathrm{DM}} 1,9 \mathrm{a} 1,8 \mathrm{Ga}\right)$;

5. gnaisses graníticos e granulitos chamockíticos fi$\operatorname{nos}\left(1,43-1,42 \mathrm{Ga} ; \mathcal{E}_{\mathrm{Nd}}(\mathrm{T})+0,7 \mathrm{a}+1,2 ; \mathrm{T}_{\mathrm{DM}} 1,8 \mathrm{a} 1,7 \mathrm{Ga}\right)$ (Fig. 1b).

As duas primeiras associações apresentam afinidade geoquímica cálcio-alcalina e constituem produtos de ambiente de margem continental do tipo andino. A associação de paragnaisses tem seu intervalo de deposição limitado entre 1,67 e 1,57 Ga, com contribuição significativa da crosta da Província Geocronológica Ventuari-Tapajós, definida por Tassinari (1996). Essas três associações estão relacionadas ao desenvolvimento da Província Rio Negro-Juruena, e representam a crosta mais antiga da re. gião (Payolla et al., 2002).

Os augen-gnaisses graníticos e chamockíticos têm afinidades geoquímicas com granitos do tipo $A$, intraplaca. São derivados de mistura de magma do manto empobrecido com crosta mais antiga (Payolla et al., 2001) e correlacionados à Suite Intrusiva Serra da Providência (Bettencourt et al, 1999), uma associação MCG (de AMCG: anortosito-mangerito-charnockito-granito rapakivi; Emslie, 1991) (Rizzotto et al., 1996) contemporànea ao Orógeno Cachocirinha, reconhecido no estado do Mato Grosso (Tassinari et al, 2000; Geraldes et al., 2001).

Os gnaisses graníticos e granulitos charnockíticos finos da Suite Intrusiva Rio Crespo (Payolla et al., 2001 a, b), săo o primeiro registro de magmatismo do tipo $A$, intraplaca, no norte de Rondônia no intervalo de 1,43 - 1,42 Ga. Constituem expressões reflexas distais (inboarc) dos proces. sos acrescionários de margem continental reconhecidos por Geraldes et al. (2001) no Mato Grosso, e seus protólitos ter-se-iam originado da mistura de material juvenil e crosta antiga (Payolla et al., 2002).

A Província Estanifera de Rondônia compreende ainda sete suítes de granitos rapakivi e rochas máficas associadas, geradas durante seis episódios magmáticos entre 1,6 e $0,9 \mathrm{Ga}$ (Bettencourt et al., 1997; 1999). Na sua porção centro-leste, ocorrem rochas da Suite Intrusiva Santa Clara e da Suíte Granitos Últimos de Rondônia. A primeira tem como encaixantes as rochas das associações dos gnaisses tonalíticos, dos paragnaisses, dos augen-gnaisses graníticos e charnockíticos, e dos gnaisses graníticos e granulitos charnockíticos finos. A Suíte Granitos Últimos de Rondônia é intrusiva em todas as associações litológicas presentes na porção centro-leste da Província Estanífera de Rondônia com exceção daquela dos paragnaisses (Payolla et al., 2002). Ambas suítes constituem magmatismo inboard relacionado ao estágio colisional 


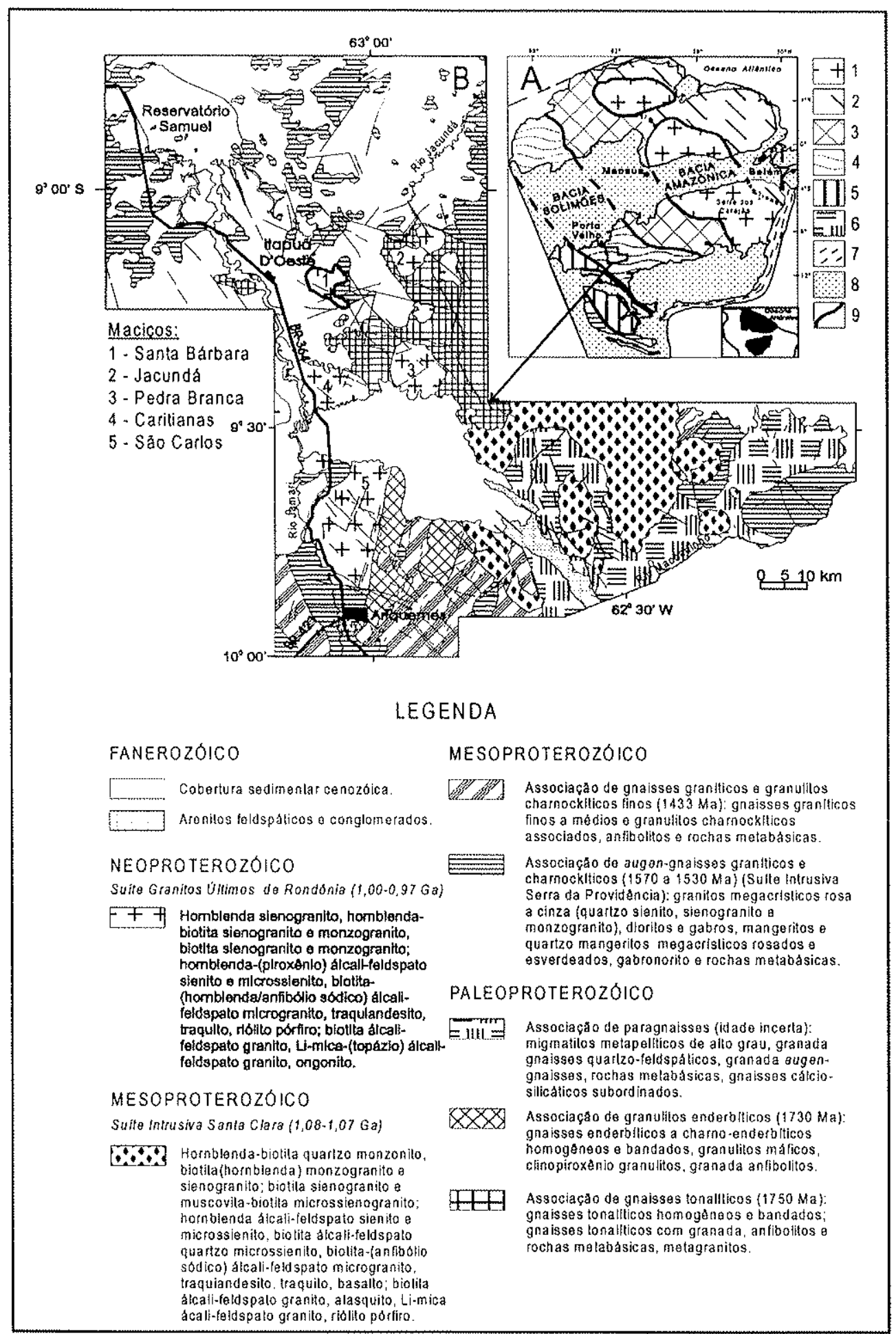

Figura 1. A) Mapa geológico esquemático do Cráton Amazônico. 1) Província Amazônia Central (> 2,3 Ga); 2) Província Maroni-ltacaiúnas $(2,2$ - 1,95 Ga); 3) Província Ventuari-Tapaiós $(1,95$ - 1,8 Ga); 4) Província Rio Negro-Juruena (1,8 $1,55 \mathrm{Ga})$; 5) Província Rondoniana-San Ignacio $(1,5-1,3 \mathrm{Ga})$; 6) Província Sunsás $(1,25-1,0 \mathrm{Ga}) ; 7)$ Cinturão móvel neoproterozóico; 8) Rochas sedimentares fanerozóicas; 9) Limites de província. Simplificado de Tassinari et al. (2000). B) Mapa de associaçōes litológicas da porção centro-leste da Província Estanífera de Rondônia. Simplificado de Payolla et al. $(2002)$. 
da Orogênese Sunsás, de Tassinari et al. (2000), e hospedam minério primário de estanho (Bettencourt et al., 1999).

As rochas dessas duas suítes apresentam características geoquímicas de granitos do tipo $A$, intraplaca. Recentemente, foram subdivididas em dois subgrupos (Leite Júnior et al., 2000; 2001), a saber: subgrupo precoce, de caráter metaluminoso a levemente peraluminoso; e tardio, compreendendo rochas metaluminosas, peralcalinas e peraluminosas. $O$ subgrupo tardio peraluminoso hospeda a mineralização primária de $\mathrm{Sn}, \mathrm{W}, \mathrm{Ta}, \mathrm{Nb}, \mathrm{Zn}, \mathrm{Cu}$ e $\mathrm{Pb}$.

\section{GEOLOGIA DO MACIÇO GRANÍTICO SANTA BÁRB ARA}

O Maciço Granítico Santa Bárbara está encaixado em granitos cinza que, juntamente com granitóides rosas e charnockitóides, compõem a associação dos augen-gnaisses graníticos e charnockíticos (Fig. 1b). Os granitos cinza predominam no setor norte da região centro-leste da Província Estanífera de Rondônia, e compreendem hornblenda e/ou biotita sienogranitos e monzogranitos com megacristais que apresentam, localmente, encraves ou enxames de diques máficos e de rochas híbridas. Geralmente indeformados, podem exibir foliação magmática ou estrutura S-C desenvolvida em zonas de cisalhamento. Sua idade de cristalização é estimada em 1550 - 1540 Ma (Payolla et al., 2002).

O maciço consiste de stock semicircular com cerca de $7 \mathrm{~km}$ de diâmetro, localizado no Distrito Mineiro de Santa Bárbara. Apresenta três unidades magmáticas subsolvus: facies Serra do Cícero, facies Serra Azul e associação de facies Santa Bárbara (Fig. 2). A facies Serra do Cícero faz parte do subgrupo precoce e compreende sienogranito rosa porfirítico de matriz fina ou média, com textura wiborgitica e caráter metaluminoso. A facies Serra Azul é composta por albita-microclínio granito rosa inequigranular de granulação média e natureza peraluminosa. Duas facies de albita-microclínio granito de contato transicional fazem parte da associação de facies Santa Bárbara: uma rosa porfirítica de matriz média com textura piterlítica (facies Santa Bárbara média); e outra, restrita à porção superior (cúpula) da unidade, de granito equigranular ou microporfirítico rosa-esbranquiçado a branco, de matriz fina (facies Santa Bárbara fina), todos peraluminosos. As facies Serra Azul e Santa Bárbara são enquadradas no subgrupo tardio peraluminoso (Sparrenberger \& Bettencourt, 2002a).

$\mathrm{Na}$ facies Serra do Cícero é reconhecido, raramente, oligoclásio, enquanto que nas demais unidades o plagioclásio é de composição albítica. Em todas elas, o mineral máfico presente é a siderofilita com teores decrescentes de ferro e crescentes de lítio e flúor da facies Serra do Cícero para a associação de facies Santa Bárbara, e ocorrem fluorita e topázio magmáticos como minerais acessórios. A monazita, mais abundante na facies Serra do Cícero, o zircão, a xenotima (rara, na facies Serra do Cícero), e a cassiterita (rara, na facies Santa Bárbara média) são outras fases acessórias (Sparrenberger \& Bettencourt, 2002a).

Alteração hidrotermal pervasiva e pervasiva fissural afeta as rochas da associação de facies Santa Bárbara. A primeira compreende metassomatismo ácido (greisenização) e metassomatismo alcalino (feldspatização sódica). Corpos de topázio-siderofilita-quartzo greisens horizontais ou de baixo mergulho, com grande extensão lateral, ocorrem como produtos do metassomatismo ácido, e configuram modelo de greisens acamadados. Granitos albitizados, espacialmente associados aos greisens, são produtos do metassomatismo alcalino.

A alteração pervasiva fissural, representada por greisenização, silicificação, fengitização e argilização compreende stockwork de topázio-siderofilita-quartzo greisen e de caulinita, além de veios de quartzo-cassiterita, veios de fengita e veios de quartzo estéreis, alojados principalmente na facies Santa Bárbara fina.

O minério estanífero está restrito à região de cerca de $500 \mathrm{~m} \times 150 \mathrm{~m}$ em planta, e ocorre principalmente em corpos de topázio-siderofilita-quartzo greisen, mas também em veios de greisen e de quartzo-cassiterita. Formou-se no intervalo de 500 a $400^{\circ} \mathrm{C}$, conforme indicam dados isotópicos de oxigênio em quartzo e cassiterita (Sparrenberger \& Bettencourt, 2000; 2002a, b).

As primeiras datações dos granitos estaníferos de Rondônia definiram a idade de cristalização do Granito Jacundá como $940 \pm 20 \mathrm{Ma}$ (Priem et al., 1966), e estabeleceram a época da intrusão de três corpos graníticos em $980 \pm 20 \mathrm{Ma}$ por meio de isócrona de referência $\mathrm{Rb}-\mathrm{Sr} \mathrm{e}$ datações K-Ar em mica (Priem etal., 1971). Ainda utilizando isócrona de referência $\mathrm{Rb}-\mathrm{Sr}$, Priem et al. (1989) obtiveram uma idade de $956 \pm 9$ Ma para cinco intrusões graníticas que integram a Suite Granitos Últimos de Rondônia.

Os maciços Pedra Branca, Caritianas e São Carlos (isócrona de referência), e Massangana têm idades isocrônicas $\mathrm{Rb}-\mathrm{Sr}$ de $954 \pm 20,960 \pm 6$ e $960 \pm 27 \mathrm{Ma}$ (Bettencourt, dados inéditos), respectivamente, porém a definição mais precisa do episódio de intrusão dos Granitos Últimos de Rondônia, entre 998 e $974 \mathrm{Ma}$, foi obtida via datações U-Pb em zircão para os maciços Pedra Branca 


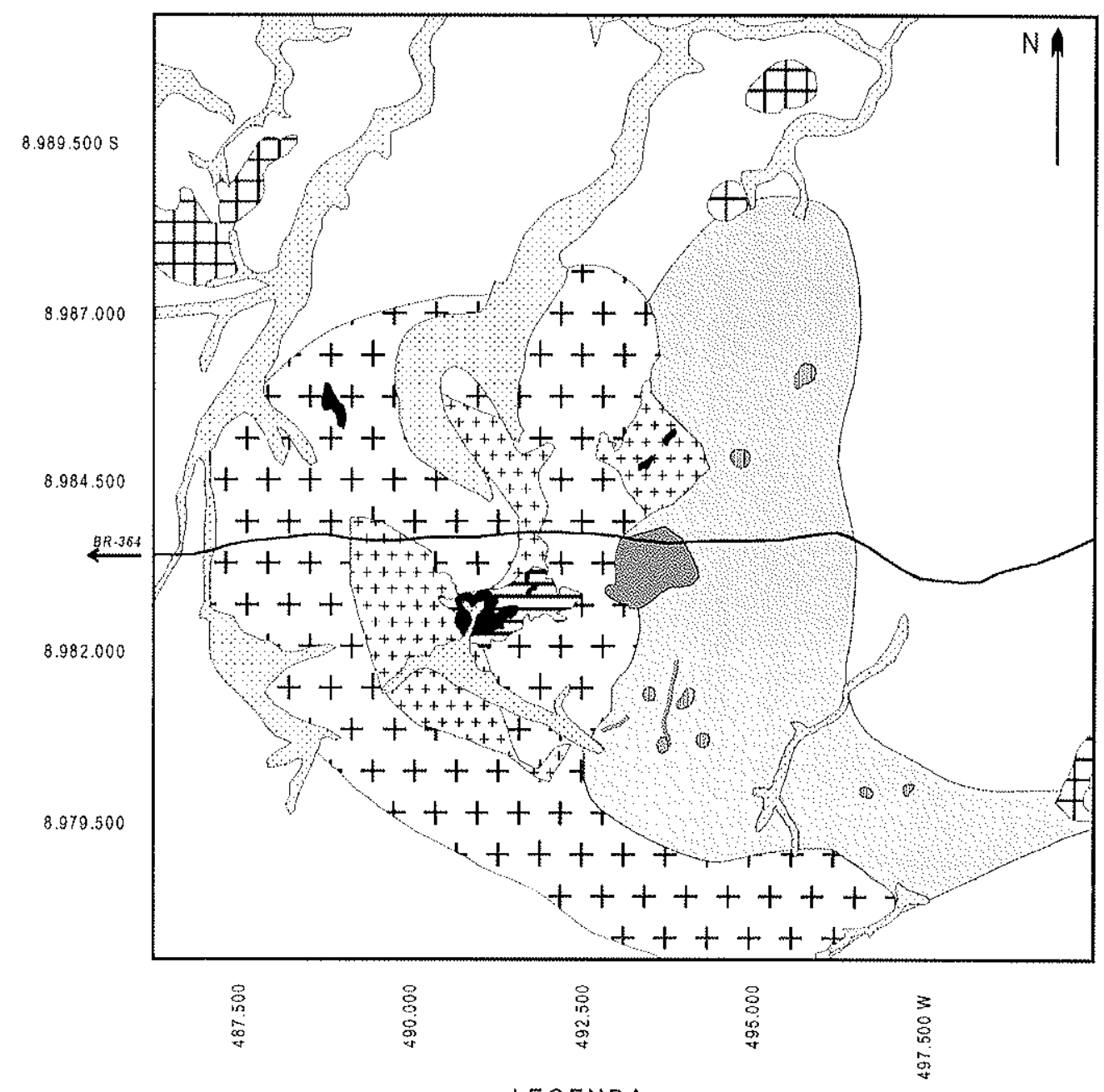

LEGENDA

FANEROZÓICO

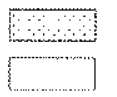

Aluviåo.

Cobertura sedimentar cenozólca.

\section{NEOPROTEROZOICO}

Sulte Grantitos Ultimos de Rondonia $(1,00-0,97 \mathrm{Ga}$ Maciço Grantilico Santa Bárbara

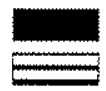

Topázlo-siderofillta-quartzo greisen.

Associaçăo de fácles Santa Bárbara (afSB): aibita-microclínlo granito rosa porfiritico, médlo; albita-mircrocilinlo granlto rosa a branco, equigranular ou microporfirttico, firo. Pereluminosos.

\section{NEOPROTEROZOICO}

TT Granitos indterenciados.

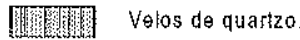

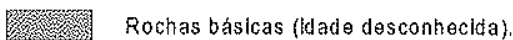

MESOPROTEROZOICO

Assoclaçăo de augen-gnalsses granticos $\theta$ charnocklticos (1570 a $\$ 530 \mathrm{Ma}$ ) (Sulte Intrusiva Serra da Providencla): granllos megacrlsticos rosa a clnza (quartzo slenito, slenograntlo $\theta$

monzogranilo), dtorttos $\theta$ gabros, mangeritos $\theta$

quartzo mangeritos megacristicos rosados $\theta$

өsverdeados, gabronorito $\theta$ rochas metabásicas.

F+f Facles Serra Azul (FA): albita-microclinio granito rosa inequigranular, médio. peraluminoso.

++++ Fácles Serra do Cicero (fSC): slenogranlto rose, porflítico, médlo ou fino, metalumlnoso.

Figura 2. Mapa geológico do Maciço Granítico Santa Bárbara. Modificado de Frank (1990), CESBRA (1994) e Payolla et al. (2002). 


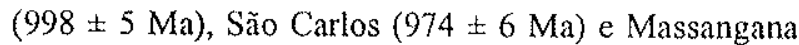
(991 土14 Ma)(Bettencourt et al, 1999).

A idade da mineralização estanífera no Maciço Granítico Santa Bárbara, estimada por datação K-Ar de mica de greisen, é de $961 \pm 19 \mathrm{Ma}$ (Leite Júnior et al., 2001). A datação da mineralização de Bom Futuro em $969 \pm 27 \mathrm{Ma}$ pelo mesmo método levou Leite Júnior et al. (2001) a concluir que esta ocorreu imediatamente após a cristalização dos granitos tardios peraluminosos da Suíte Granitos Últimos de Rondônia (974 Ma).

\section{MÉTODOS ANALÍTICOS}

\section{Sistema U.Pb}

\section{Separação mineral}

A separação prévia de zircão das três amostras data das nesta pesquisa foi feita no Laboratório de Preparação de Amostras Geológicas e Pedológicas (LAPEGE) do Instituto de Geociências e Ciências Exatas da Universidade Estadual Paulista (IGCE-UNESP), Campus Rio Claro, conforme procedimentos descritos em Galembeck (1997), que envolvem: britagem, peneiramento, separação gravimétrica em bateador mecânico, separação de minerais magnéticos com auxílio de ímã e de minerais paramagnéticos com Separador Isodinâmico de Frantz, separação das frações leve e pesada com bromofórmio e nova classificação granulométrica, com minipeneiras.

A separação foi concluída no Centro de Pesquisas Geocronológicas (CPGeo) do Instituto de Geociências da Universidade de São Paulo (IGcuUSP). Constou de uma etapa adicional de separação gravimétrica com líquidos densos e da separação do concentrado em frações magnéticas no Separador Isodinâmico de Frantz, que compreendeu uma purificação inicial para separação de xenotima $\mathrm{e}$ monazita conforme Hutchinson (1974, pg. 119), seguida da separação em frações conforme o método de Krogh (1982). Finalmente, selecionaram -se os melhores cristais com lupa binocular.

A escassez de zircão na facies Santa Bárbara fina foi fator proibitivo da utilização do método da espectrometria de massa por ionização térmica para sua datação U Pb. Procedeu-se então à catação, com lupa binocular, de todos os cristais de zircão presentes no concentrado, num total de cerca de 90, para datação pelo método SHRIMP-RG.

Adicionalmente, selecionou-se monazita das três unidades do maciço.

\section{Análises por Espectrometria de Massa por Ionização Térmica}

Executaram-se as análises U-Pb em zircão e monazita por espectrometria de massa por ionização térmica (TIMS) no CPGeo, conforme os procedimentos de Krogh (1973) e Corfu \& Stott (1986), sintetizados em Basei et al. (1995).

A determinação das composições isotópicas foi feita em espectrômetro de massa de fonte sólida Finnigan MAT 262.

Os resultados finais das análises foram calculados e lançados nos diagramas com auxílio do programa ISOPLOT/ Ex, versão 2.10, de Ludwig (1999), observando-se as constantes recomendadas pela IUGS (Steiger \& Jäger, 1977). Os erros das contagens e dos interceptos com a concórdia são dados em $2 \sigma$.

\section{Análises por SHRIMP.RG}

As datações U-Pb em zircão da facies Santa Bárbara fina pelo método SHRIMP-RG foram executadas no Stanford USGSMicro Analysis Center(SUMAC), na Universidade de Stanford, Califómia, Estados Unidos da América, por Jorge Silva Bettencourt, Richard. M. Tosdal e Joseph L. Wooden.

Os cristais de zircão foram montados em seções circulares de epóxi com $2,54 \mathrm{~cm}$ de diâmetro e 6 mm de espessu$\mathrm{ra}$, polidas em ambas as faces e metalizadas com $10 \mathrm{~nm}$ de ouro naquela onde é feita a leitura. Obtiveram-se imagens de catodoluminescência e de microscópio petrográ fico em luz transmitida e refletida, previamente à cobertura, para a caracterização dos cristais e escolha dos pontos adequados para análises.

O equipamento utilizado foi o SHRIMP-RG (Sensitive High Resolution lon Micro Probe-Reverse Geometry) $\mathrm{e}$ os procedimentos seguiram os mesmos preconizados em Compston et al. (1984) e Williams (1997). Os padrões de zircão usados para a medição das concentrações e das razões isotópicas foram o SL-13 e o AS-57. Os erros das contagens são absolutos e dados em $1 \sigma$, enquanto que aqueles das idades calculadas são em $2 \sigma$. 
Os resultados finais das análises foram calculados e lançados em diagramas com auxílio do programa ISOPLOT/ Ex, versão 2.10, de Ludwig (1999), observando-se as constantes recomendadas pela IUGS (Steiger \& Jäger, 1977).

\section{Sistema Sm-Nd}

Efetuaram-se análises $\mathrm{Sm}-\mathrm{Nd}$ em rocha total no Laboratório de Geocronologia do Instituto de Geociências da Universidade de Brasília, segundo os procedimentos descritos em Gioia \& Pimentel (2000). Os materiais utilizados foram as mesmas aliquotas de rochas preparadas para análises litogeoquímicas, na granulação $\leq 0,105 \mathrm{~mm}$ (150\#, Tyler).

As razões isotópicas foram medidas em espectrômetro de massa Finnigan MAT 262 com multicoletor no modo estático. As reprodutibilidades das razões $\mathrm{Sm} / \mathrm{Nd}$ e ${ }^{143} \mathrm{Nd} /{ }^{144} \mathrm{Nd}$ são melhores do que $\pm 0,05 \%(7 \sigma)$ e $\pm 0,000005$ ( $1 \sigma$ ), respectivamente, com base em análises repetidas dos padrões internacionais de rochas BCR-1 e BHVO-1. As razões ${ }^{143} \mathrm{Nd} /{ }^{144} \mathrm{Nd}$ foram normalizadas para ${ }^{146} \mathrm{Nd} /{ }^{144} \mathrm{Nd}$ de 0,7219 (O'Nions et al., 1977). Os valores atuais do CHUR usados nos cálculos de $\varepsilon_{\mathrm{Nd}}$ foram ${ }^{147} \mathrm{Sm} /{ }^{144} \mathrm{Nd}$ de 0,1967 $\mathrm{e}^{143} \mathrm{Nd} /{ }^{44} \mathrm{Nd}$ de 0,512638 (Wasserburg et al., 1981). Os valores do MORB utilizados no cálculo das idades-modelo foram ${ }^{147} \mathrm{Sm} /{ }^{144} \mathrm{Nd}$ de $0,513114 \mathrm{e}^{143} \mathrm{Nd} /{ }^{144} \mathrm{Nd}$ de 0,222 (Michard et al., 1985).

A constante de decaimento do ${ }^{147} \mathrm{Sm}$ empregada é aquela recomendada por Lugmair \& Marti (1978). O cálculo das idades foi efetuado conforme o modelo do Manto Empobrecido de DePaolo (1981).

\section{RESULTADOS}

\section{Método U-Pb Convencional}

Obtiveram -se datações inéditas das facies Serra do Cícero (AM - 52B), 993 上 5 Ma, e Serra Azul (AM - 53B), $989 \pm 13 \mathrm{Ma}$, por U-Pb convencional em monazita (Fig. 3a e b). Os resultados analíticos estão ilustrados na Tabela 1 .

Inicialmente, dataram-se as mesmas facies por $\mathrm{U}-\mathrm{Pb}$ em zircão (Tabela 2). No primeiro caso, obtiveram-se três pontos analíticos discordantes (Fig. 3a). Um deles, que ocorre isolado, é interpretado como zircão que perdeu chumbo radiogênico, sendo sua idade mínima ${ }^{207} \mathrm{~Pb} / 206 \mathrm{~Pb}$ cerca de 150 m.a. mais jovem do que o dado fornecido pela datação da monazita da mesma rocha. Os outros dois pontos, entretanto, ocorrem à direita do primeiro, e indicam um componente herdado significativo nas duas frações em questão. Com efeito, suas idades mínimas ${ }^{207} \mathrm{~Pb} /{ }^{206} \mathrm{~Pb}$ são de 1979 e $1993 \mathrm{Ma}$.

Para a facies Serra Azul, ambos os pontos analíticos são discordantes e desalinhados. Um deles localiza-se próximo ao ponto da monazita e tem idade mínima ${ }^{207} \mathrm{~Pb} /{ }^{206} \mathrm{~Pb}$ razoavelmente compatível ( $958 \mathrm{Ma}$ ), enquanto que o outro ocorre deslocado para a direita, o que sugere herança a partir de um protólito cuja idade mínima ${ }^{207} \mathrm{~Pb} /{ }^{206} \mathrm{~Pb}$ é de cerca de $1617 \mathrm{Ma}$ (Fig. 3b).

\section{Método SHRIMP-RG}

Analisaram-se 24 pontos em diferentes cristais de zircão da facies Santa Bárbara fina (AM - 145) por SHRIMP-RG (Tabela 3). A curva de probabilidade acumulada desses dados indica a existência de pelo menos quatro populações de idades da ordem de $1660,1045,970$ e 735 $\mathrm{Ma}$ (Fig. 3c).

Dezesseis análises foram descartadas para efeito da definição da idade dessas populações com base em uma ou mais das seguintes razões:

a. discordância inversa nos diagramas Concórdia (Wetherill, 1956) e de Tera \& Wasserburg (1972) (pontos 3 , $6,8,10,12,19$ e 23 );

b. conteúdos de U maiores que 1000 ppm (pontos 2, 3, 4, 610,11, 12, 17, 19e 23);

c. altos conteúdos de ${ }^{204} \mathrm{~Pb}$;

d. erros elevados das idades ${ }^{207} \mathrm{~Pb} /{ }^{206} \mathrm{~Pb}$.

Das oito análises restantes, quatro são representativas da idade da facies Santa Bárbara fina (Fig. 3d), e correspondem ao pico próximo dos $970 \mathrm{Ma}$ na curva de probabilidade acumulada. A média das idades ${ }^{207} \mathrm{~Pb} /{ }^{206} \mathrm{~Pb}$ dessas quatro análises, ponderada pelos seus respectivos erros, é de $978 \pm 13 \mathrm{Ma}$, e concorda, dentro dos intervalos dos erros, com as idades U-Pb em zircăo (TIMS) para as facies Serra do Cícero e Serra Azul.

Das outras três populações identificadas, a mais antiga é representada pelos pontos 1 e 15 , para os quais são admitidas as idades mínimas de $1651 \pm 28$ e $2067 \pm 227 \mathrm{Ma}$, respectivamente. $O$ ponto 20 trata-se de núcleo herdado 

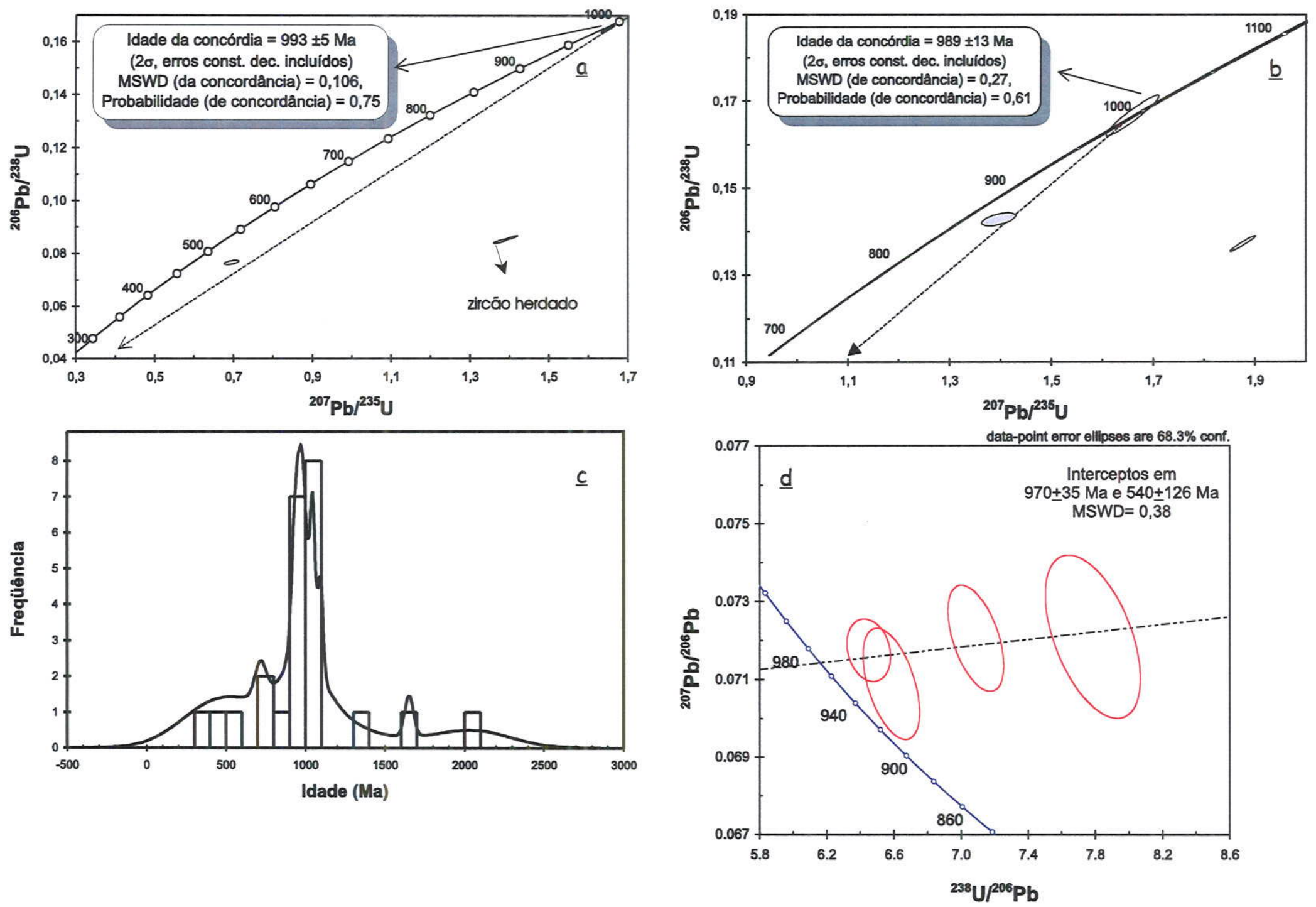

Figura 3. a) Diagrama Concórdia para a amostra AM - 52B (facies Serra do Cícero) mostrando o ponto analítico relativo à datação U-Pb da monazita (elipse incolor) e os pontos analíticos relativos à datação U.Pb de três alíquotas de zircão (elipses cinza). A idade exibida refere-se à datação da monazita. b) Diagrama Concórdia para a amostra AM - 53B (facies Serra Azul) mostrando o ponto analítico relativo à datação U-Pb da monazita (elipse incolor) e os pontos analíticos relativos à dałação U-Pb de duas alíquotas de zircão (elipses cinza). A idade exibida refere-se à dałação da monazita. c) Histograma de freqüência e curva de probabilidade acumulada das idades ${ }^{207} \mathrm{~Pb} / 206 \mathrm{~Pb}$ de 24 análises SHRIMP em zircão da amostra AM - 145 (facies Santa Bárbara fina). d) Diagrama de Tera \& Wasserburg (1972) de quatro análises selecionadas do zircão tipo do Maciço Santa Bárbara. 
Dataçes U-Pb Convencional Versws Shrimp do Mactco... $\quad$ U

Tabela 1. Resultados analíticos das datações U-Pb em monazita por espectrometria de massa por ionização térmica.

\begin{tabular}{|c|c|c|c|c|c|c|c|c|c|c|}
\hline $\begin{array}{l}\text { No. da amostra } \\
\text { (fração magnétlca) }\end{array}$ & $\begin{array}{c}\text { Peso } \\
\text { (miligramas) }\end{array}$ & $\begin{array}{c}\mathrm{Pb} \\
(\mathrm{ppm})\end{array}$ & $\begin{array}{c}\mathrm{U} \\
(\mathrm{ppm})\end{array}$ & ${ }^{200} \mathrm{~Pb} /{ }^{204} \mathrm{~Pb}$ & ${ }^{206} \mathrm{~Pb} /{ }^{238} \mathrm{U}^{*}$ & $\left.{ }^{207} \mathrm{~Pb}\right|^{235} \mathrm{U}^{*}$ & ${ }^{207} \mathrm{~Pb} /{ }^{206} \mathrm{~Pb}^{*}$ & $\begin{array}{c}\text { Idade } \\
{ }^{208} \mathrm{~Pb} /{ }^{238} \mathrm{~Pb}\end{array}$ & $\begin{array}{l}\mid d a d \theta^{\star x} \\
\left.{ }^{207} \mathrm{~Pb}\right|^{235} \mathrm{U}\end{array}$ & $\begin{array}{l}\text { Idade } \\
{ }^{207} \mathrm{~Pb} /{ }^{208} \mathrm{~Pb}\end{array}$ \\
\hline$A M-52 B$ & 0.005650 & 2258 & 1847 & 200 & $0,16674(0,74)$ & $1,6606(0,77)$ & $0,072234(0,20)$ & 994 & 994 & $993+4$ \\
\hline$A M-53 B$ & 0,003390 & 636 & 744 & 182 & $0,16670(2,39)$ & $1,6556(2,53)$ & $0,072029(0,79)$ & 994 & 992 & $987 \pm 16$ \\
\hline
\end{tabular}

Tabela 2. Resultados analíticos das datações U-Pb em zircão por espectrometria de massa por ionização térmica.

\begin{tabular}{|c|c|c|c|c|c|c|c|c|c|c|}
\hline $\begin{array}{l}\text { No. da amostra } \\
\text { (fraçäo magnética) }\end{array}$ & $\begin{array}{c}\text { Peso } \\
\text { (miligramas) }\end{array}$ & $\begin{array}{c}\mathrm{Pb} \\
(\mathrm{ppm})\end{array}$ & $\begin{array}{c}\mathrm{U} \\
(\mathrm{ppm})\end{array}$ & ${ }^{206} \mathrm{~Pb} /{ }^{204} \mathrm{~Pb}$ & ${ }^{206} \mathrm{~Pb} /{ }^{238} \mathrm{U}^{*}$ & ${ }^{207} \mathrm{~Pb} /{ }^{235} \mathrm{U}^{*}$ & ${ }^{207} \mathrm{~Pb} /{ }^{206} \mathrm{~Pb}^{*}$ & $\begin{array}{c}\text { Idade } \\
{ }^{206} \mathrm{~Pb} /{ }^{23 \theta} \mathrm{Pb}\end{array}$ & $\begin{array}{l}\text { Idadent } \\
{ }^{207} \mathrm{~Pb} /{ }^{235} \mathrm{U}\end{array}$ & $\begin{array}{c}\text { Idade** } \\
{ }^{207} \mathrm{~Pb} /{ }^{206} \mathrm{~Pb}\end{array}$ \\
\hline$A M-52 B M(-3)$ & 0,096018 & 33 & 286 & 296 & $0,08246(0,77)$ & $1,3818(0,95)$ & $0,121534(0,56)$ & 511. & 881. & $1979 \pm 10$ \\
\hline $\mathrm{AM}-52 \mathrm{~B} M(-1)$ & 0,086138 & 40 & 321 & 239 & $0,08343(0,80)$ & $1,4092(0,87)$ & $0,122501(0,33)$ & 517 & 893 & $1993 \pm 6$ \\
\hline AM-52B NM(-3) & 0,061315 & 30 & 224 & 100 & $0,07410(1,06)$ & $0,6859(2,15)$ & $0,067131(1,76)$ & 461 & 530 & $842 \pm 37$ \\
\hline$A M-53 B$ & 0,113470 & 318 & 1858 & 455 & $0,13638(1,07)$ & $1,8732(1,11)$ & $0,099619(0,28)$ & 824 & 1072 & $1617 \pm 5$ \\
\hline AM-53B & 0,068440 & 406 & 1470 & 84 & $0,14209(0,88)$ & $1,3917(1,97)$ & $0,071034(1,65)$ & 856 & 885 & $958:+34$ \\
\hline
\end{tabular}

Tabelas 1 e 2: M, NM - frações magnética e não-magnética obtidas com Separador Isodinâmico de Frantz, com corrente elétrica de 1,5 ampère e inclinaçäo frontal de $20^{\circ}$; inclinaçäo lateral dada entre parênteses. * Razões corrigidas pelo branco analítico e pelo chumbo inicial (Stacey \& Kramers, 1975). Erros, entre parênteses, säo dados em percentual e $2 \sigma .{ }^{* *}$ Idades calculadas com base nas constantes de decaimento recomendadas por Steiger \& Jäger (1977).

Tabela 3. Resultados analíticos das datações U-Pb em zircão por SHRIMP-RG.

\begin{tabular}{|c|c|c|c|c|c|c|c|c|c|c|}
\hline $\begin{array}{l}\text { No. da amostra } \\
\text { (No. do ponto) }\end{array}$ & $\begin{array}{c}\mathrm{U} \\
(\mathrm{ppm})\end{array}$ & $\begin{array}{c}\text { Th } \\
\text { (ppm) }\end{array}$ & $\begin{array}{c}\mathrm{Pb} \\
(\mathrm{ppm})\end{array}$ & $\begin{array}{l}{ }^{204} \mathrm{~Pb} \\
(\mathrm{ppb})\end{array}$ & ${ }^{206} \mathrm{~Pb} /{ }^{238} \mathrm{U}^{*}$ & ${ }^{207} \mathrm{~Pb} /\left.\right|^{235} \mathrm{U}^{*}$ & ${ }^{207} \mathrm{~Pb} / /^{206} \mathrm{~Pb}^{*}$ & $\begin{array}{l}\text { Idade } \\
\left.{ }^{206} \mathrm{~Pb}\right|^{238} \mathrm{~Pb}\end{array}$ & $\begin{array}{l}\text { Idade }{ }^{k+k} \\
{ }^{207} \mathrm{~Pb} /{ }^{235} \mathrm{U}\end{array}$ & $\begin{array}{c}\text { Idade }{ }^{\star \star \hbar} \\
{ }^{207} \mathrm{~Pb} /{ }^{206} \mathrm{~Pb}\end{array}$ \\
\hline AM-145(1) & 141 & 77 & 42 & 2 & $0,2745(0038)$ & $3,8389(0834)$ & $0.1014(0015)$ & $1563(19)$ & $1601(18)$ & $1651(28)$ \\
\hline$A M-145$ (15) & 48 & 31 & 11 & 33 & $0.1754(0061)$ & $3,0885(3971)$ & $0,1277(0153)$ & $1042(34)$ & $1430(104)$ & $2067(227)$ \\
\hline AM-145 (18) & 6496 & 3648 & 1131 & 38 & $0.1623(0039)$ & $1,6567(0433)$ & $0,0740(0005)$ & $970(22)$ & $992(17)$ & $1042(14)$ \\
\hline$A M-145(20)$ & 3103 & 1698 & 591 & 72 & $0,1777(0052)$ & $1,8626(0577)$ & $0,0760(0006)$ & $1054(28)$ & $1068(21)$ & $1096\langle 15\rangle$ \\
\hline AM-145 (9) & 959 & 581 & 161 & 1 & $0.1550(0021)$ & $1,5337(0254)$ & $0,0718(0006)$ & $929(12)$ & $944(10)$ & $979(17)$ \\
\hline AM-145 (16) & 357 & 412 & 63 & 35 & $0,1519(0026)$ & $1,4843(0390)$ & $0,0709(0013)$ & $911(14)$ & $924(16)$ & $954(38)$ \\
\hline$A M-145(21)$ & 762 & 378 & 101 & 100 & $0,1284(0031)$ & $1,2768(0481)$ & $0,0721(0019)$ & $779(18)$ & $835(22)$ & $989(54)$ \\
\hline AM-145 (24) & 318 & 312 & 48 & 12 & $0,1411(0022)$ & $1,4017(0343)$ & $0,0721(0012)$ & $851(12)$ & $890(15)$ & $988(35)$ \\
\hline$A M-145(2)$ & 1725 & 764 & 166 & 45 & $0,0917(0017)$ & $0,8000(0213)$ & $0,0633(0011)$ & $566(10)$ & $597(12)$ & $717(36)$ \\
\hline AM-145 (3) & 1827 & 34 & 408 & 1100 & $0,2414(0023)$ & $2,4892(1189)$ & $0,0748(0034)$ & $1394(12)$ & $1269(35)$ & $1063(95)$ \\
\hline$A M-145(4)$ & 5584 & 3030 & 551 & 4784 & $0,0944(0013)$ & $0,7339(0690)$ & $0,0564(0052)$ & $582(8)$ & $559(41)$ & $467(216)$ \\
\hline$A M-145(5)$ & $\$ 19$ & 264 & 18 & 30 & $0,1351(0045)$ & $1,3896(1322)$ & $0,0746(0064)$ & $817(26)$ & $885(58)$ & $1058(181)$ \\
\hline$A M-145(6)$ & 3490 & 1475 & 759 & 608 & $0,2130(0049)$ & $2,1391(0645)$ & $0,0728(0012)$ & $1245(26)$ & $1162(21)$ & $1009(35)$ \\
\hline$A M-145(7)$ & 35 & 30 & 6 & - & $0,1581(0048)$ & $1,6161(2017)$ & $0.0741(0087)$ & $946(27)$ & $976(81)$ & $1045(257)$ \\
\hline$A M-145(8)$ & 34 & 28 & 6 & 3 & $0,1573(0042)$ & $1,4158(1845)$ & $0,0653(0081)$ & $942(24)$ & $896(81)$ & $784(285)$ \\
\hline$A M-145(10)$ & 1182 & 463 & 205 & 341 & $0,1695(0018)$ & $1,6001(0696)$ & $0,0685(0028)$ & $1010(10)$ & $970(28)$ & $882(87)$ \\
\hline AM-145 (11) & 16966 & 7900 & 2670 & 2625 & $0.1592(0043)$ & $1,5460(0473)$ & $0,0705(0008)$ & $952(24)$ & $949(19)$ & $941(23)$ \\
\hline$A M-145(12)$ & 4580 & 7454 & 848 & 8047 & $0,1543(0055)$ & $1,2507(1389)$ & $0,0588(0059)$ & $925(31)$ & $824(65)$ & $560(236)$ \\
\hline AM-145 (13) & 577 & 6916 & 36 & 34 & $0,0302(0030)$ & $0,2219(0309)$ & $0,0533(0046)$ & $192(19)$ & $203(26)$ & $340(210)$ \\
\hline AM-145 (14) & 438 & 358 & 75 & 38 & $0,7593(0015)$ & $1,5645(0369)$ & $0,0712(0015)$ & $953(9)$ & $956(15)$ & $964(42)$ \\
\hline AM-145 (17) & 11367 & 2682 & 1809 & 821 & $0.1590(0026)$ & $1,5417(0322)$ & $0,0703(0008)$ & $951(15)$ & $947(13)$ & $938(22)$ \\
\hline$A M-145(19)$ & 5130 & 2939 & 1132 & 432 & $0,2026(0079)$ & $2 . \uparrow 119(0886)$ & $0,0756(0008)$ & $1189(43)$ & $1153(29)$ & $1085(22)$ \\
\hline AM-145 (22) & 556 & 481 & 95 & 1467 & $0.1419(0055)$ & $1,6797(4007)$ & $0,0859(0198)$ & $855(31)$ & $1001(164)$ & $1335(526)$ \\
\hline$A M-145(23)$ & 5916 & 3353 & 1250 & 35 & $0,1995(0061)$ & $2.0414(0651)$ & $0,0742(0005)$ & $1173(33)$ & $1129(22)$ & $1047(13)$ \\
\hline
\end{tabular}

* Erros de contagem, entre parênteses, são absolutos, em $l \sigma$, e referemnse às úllimas casas decimais.** Erros das ida. des, entre parênteses, são dados em $2 \sigma$, em milhões de anos. 
de zircão da Suíte Intrusiva Santa Clara, enquanto que o 18 é de difícil enquadramento em funçăo da variabilidade das idades, porém agrupado ao $20 \mathrm{com}$ base na sua idade ${ }^{207} \mathrm{~Pb} /{ }^{266} \mathrm{~Pb}$. $\mathrm{O}$ valor de $735 \mathrm{Ma}$ é identificado unicamente nas análises descartadas, e interpretado como fruto de perturbações do sistema isotópico.

Do ponto de vista morfológico, observa-se que o zircão da facies Santa Bárbara fina pertence a dois tipos bem distintos. Um deles é prismático curto e tem zoneamento oscilatório largo, que indica condições de subsaturação em zircão durante a cristalização do magma (cf. Vavra, 1990; cristais $8,9,11,17$ e 21; Fig. 4). O outro tipo é prismático longo e ocorre como sobrecrescimentos, em cristais nos quais a presença de núcleos herdados é denunciada por superficies de dissolução (cristais 5, 7, 14, 16 e 24; Fig. 4).

O zircão de $1651 \pm 28 \mathrm{Ma}$ apresenta zoneamento oscilatório bem desenvolvido e ocorre como sobrecrescimento sobre núcleo com a mesma estrutura, o que aponta para condições de cristalização ígnea e para a existência de evento geológico ainda mais antigo (Fig. 4).

O zircão de idade compatível com o magmatismo Santa Clara (pontos 18 e 20) tem características muito semelhantes àquelas do zircão do tipo 1 do Maciço Granítico Santa Bárbara, sendo bastante expressivas as feições de recristalização (c). Pidgeon, 1992; Fig. 4).

Comum à maioria dos cristais cujas análises foram descartadas é o zoneamento oscilatório alargado e/ou modificado em conseqüência de reações secundárias, que culminam com o desenvolvimento de regiões centrais escuras e convolutas onde se observam altas concentrações de $U$ e Th (cristais 4, 6, 8, 10, 11, 19, 22 e 23) (Fig. 4). Tais feições foram descritas e interpretadas por Pidgeon et al. (1998) como devidas à reconstituição do zircão em sistema fechado clurante o resfriamento do granito a partir de altas temperaturas, e resultam geralmente em discordância inversa. No Maciço Granítico Santa Bárbara, entretanto, não se pode descartar que tais feições resultem também de reações pós-magmáticas, dadas as intensas interações rocha-fluido que acompanharam a mineralização. Feições de recristalização (cf. Pidgeon, 1992), na forma de manchas difusas que obliteram o zoneamento magmático, também são observadas (cristais 11 e 21 ; Fig. 4).

A metamictização provavelmente concorreu para a perturbação do sistema isotópico U-Pb, especialmente no caso dos cristais fortemente discordantes, como o 2 e o 13, haja vista as altas concentrações de U e Th observadas em boa parte das análises.

\section{Método Sm-Nd}

As mesmas amostras que tiveram zircão e monazita datados via $\mathrm{U}-\mathrm{Pb}$ foram submetidas a análises $\mathrm{Sm}-\mathrm{Nd}$ em rocha total. As idades-modelo $T_{D M}$ resultaram em valores crescentes da facies Serra do Cícero (1711 Ma) para a associação de facies Santa Bárbara (2221 Ma), passando pela facies Serra Azul (1846 Ma), com $\mathcal{E}_{\mathrm{Nd}}(\mathrm{T})$ de $-2,95,-4,58$, e $-3,69$, respectivamente (Tabela 4).

Dados litogeoquímicos e de química mineral apontam para a geração dos granitos do Maciço Granítico Santa Bárbara a partir da diferenciação do mesmo magma. Fracionamento dos ETRL é observado da facies Serra do Cícero para a Serra Azul e, finalmente, para a Santa Bárbara fina, e expresso pelos valores de $(\mathrm{La} / \mathrm{Yb})_{\mathrm{N}}$ de $4,67,3,91 \mathrm{e}$ 1,81 , respectivamente (Sparrenberger, dados inéditos).

Noventa a noventa e cinco por cento em peso do conteúdo de ETRL dos granitos peraluminosos estão contidos nas fases minerais acessorias concentradoras desses elementos, enquanto que os feldspatos respondem por $5-10 \%$ em peso do total de ETRL nessas rochas (Bea, 1996). No Maciço Granítico Santa Bárbara, a monazita é freqüente na facies Serra do Cícero, mas escassa nas facies Serra Azul e Santa Bárbara fina. Com uma porcentagem mínima de $62 \%$ de $\mathrm{ETR}_{2} \mathrm{O}_{3}$ (Sparrenberger, dados inéditos), a fase mineral constitui o principal carreador dos ETRL. nesses granitos, acompanhada, subordinadamente, pelos feldspatos, e reflete o fracionamento dos ETRL identificado.

Dada a cogeneticidade das rochas estudadas, a variação de aproximadamente 500 m.a. nas idades-modelo $T_{D M}$ é entendida como anômala. Valores de $\mathrm{T}_{D M}$ errôneos para granitos altamente silicosos com razões $(\mathrm{La} / \mathrm{Yb})_{\mathbb{N}} \leq 3,0$ também foram observados por Pimentel \& Charnley (1991).

Contrariamente ao observado nas amostras do Maciço Granítico Santa Bárbara, foi reconhecido aumento de até uma ou duas unidades no valor do $\varepsilon_{N d}(T)$ dos topázios granitos tardios mineralizados em relação àqueles estéreis mais precoces nos maciços rapakivi da Finlândia, Rússia e China, fenômeno atribuido a processos pós-magmáticos (Rämö etal., 1997).

A reconhecida mobilidade do ETR durante processos pós-magmáticos (Bea, 1996), bem como a partição desses elementos para fluidos ricos em flúor, na forma de complexos do elemento (Muecke \& Clarke, 1981), também podem ter concorrido para o fracionamento observado. 


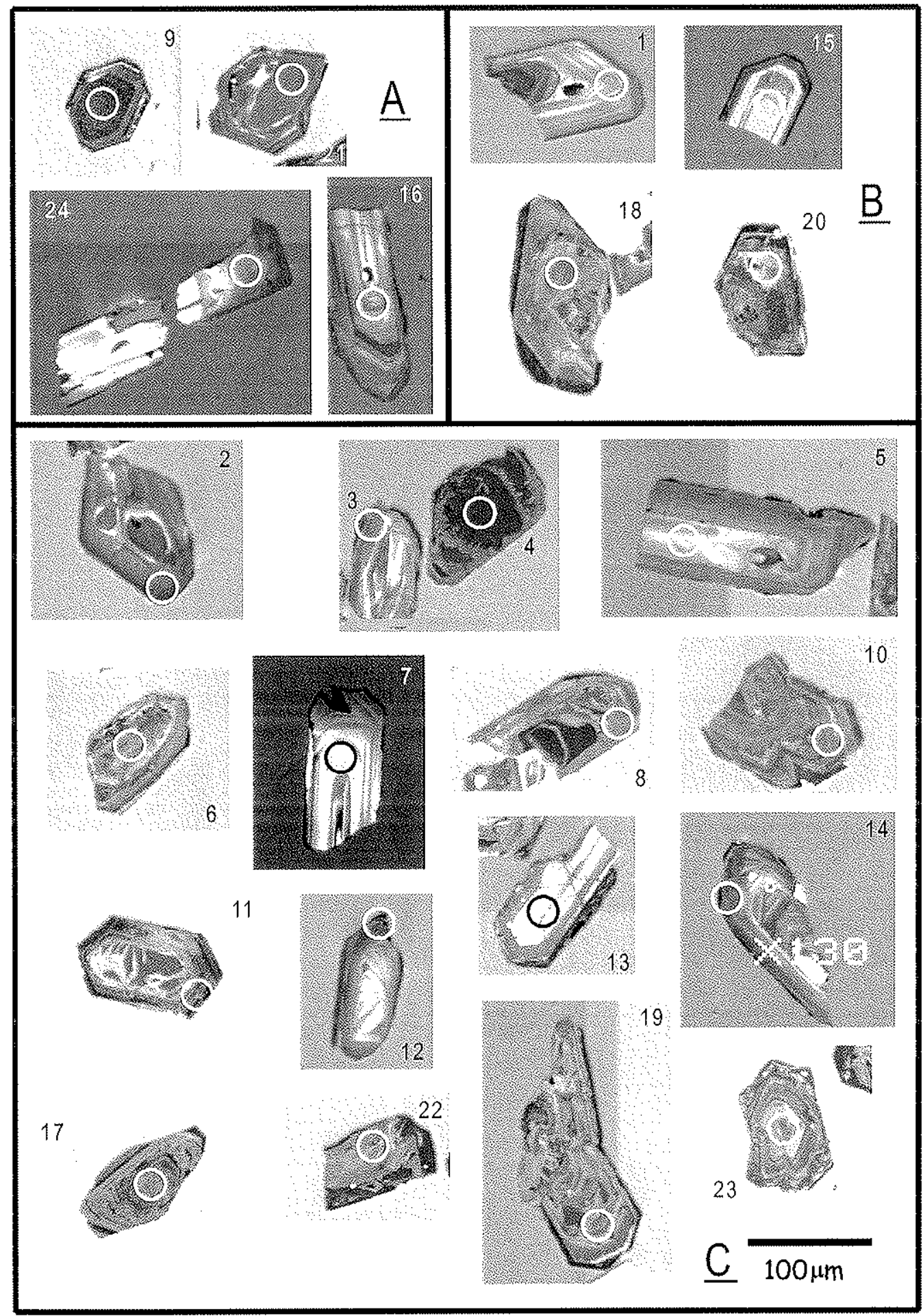

Figura 4. Imagens de catodoluminescência do zircão da AM-145 (facies Santa Bárbara fina) datado via SHRIMP-RG. Grupo A: cristais cujos pontos datados säo representativos da cristalização da facies. Grupo B: cristais cujos pontos datados representam herança. Grupo C: cristais cujas análises foram desconsideradas. Ponto analisado representado por círculo, com o respectivo número grafado na imagem. A escala é a mesma para todos os grãos. 
Tabela 4. Resultados analíticos Sm-Nd em rocha total.

\begin{tabular}{|c|c|c|c|c|c|c|c|c|c|}
\hline Amostra & $\begin{array}{l}\text { Idade } \\
\text { (Ma) }\end{array}$ & Sm (ppm) & Nd (ppm) & ${ }^{147} \mathrm{Sm} /{ }^{144} \mathrm{Nd}$ & ${ }^{143} \mathrm{Nd} /{ }^{144} \mathrm{Nd}$ & $\varepsilon_{N d}(0)$ & $f_{\mathrm{Sm} / \mathrm{Nd}}$ & $\varepsilon_{N d}(T)$ & $T_{\text {DMr: }}$ \\
\hline$A M-52 B$ & 993 & 16,54 & 83,43 & 0,11987 & $0,511988(13)$ & $-12,68$ & $-0,39$ & $-2,95$ & 1711 \\
\hline$A M-53 B$ & 989 & 17,77 & 83,86 & 0,12810 & $0,512005(13)$ & $-12,35$ & $-0,35$ & $-3,69$ & 1846 \\
\hline AM- 145 & 978 & 14,18 & 57,75 & 0,14849 & $0,512095(18)$ & $-10,59$ & $-0,25$ & $-4,58$ & 2221 \\
\hline
\end{tabular}

* Erro absoluto dado em lo. Refere-se às últimas casas decimais. ** Idade-modelo de acordo com DePaolo (1981).

\section{DISCUSSÃO E CONCLUSÕES}

A monazita é um mineral particularmente apropriado para a datação U-Pb de granitos em que a herança de zircão é comum (Parrish, 1990). Embora possa ocorrer como restito em líquidos graníticos gerados por anatexia a temperaturas da ordem de 700 a $800^{\circ} \mathrm{C}$ (Rapp et al., 1987), sua temperatura de bloqueio para a difusão de $\mathrm{Pb}\left(725 \pm 25^{\circ} \mathrm{C}\right.$; Copeland $e t a l ., 1988$ ) menor do que a do zitrão coincide com o intervalo de temperaturas magmáticas de líquidos graníticos, tornando a herança do sistema U-Pb rara. A fase também traz a vantagem de raramente tornar-se metamíctica, apresentando perda de $\mathrm{Pb}$ em baixas temperaturas muito menos comum do que o zitcão (Parrish, 1990). Assim, os dados de $993 \pm 5 \mathrm{Ma}$ e $989 \pm 13 \mathrm{Ma}$ obtidos pela datação U-Pb de monazita para as facies Serra do Cícero e Serra Azul, respectivamente, são admitidos como as idam des da cristalização magmática desses granitos.

A idade U-Pb SHRIMP em zircão de $978 \pm 13$ Ma para a facies Santa Bárbara fina é interpretada como idade da cristalização magmática do granito, e concorda, dentro do intervalo dos erros, com as idades das demais facies do Maciço Granítico Santa Bárbara, apontando para a possível contemporaneidade das mesmas.

Segundo Pidgeon (1992), a recristalização progressiva do zircão resulta da instabilidade do mineral provocada pela incorporação de altas concentrações de elementos contaminantes em solução sólida, como TR, U e Th, que distorcem seu retículo cristalino. Ela pode se dar logo após o término da cristalizaçăo primária ou em evento posterior, e constitui um mecanismo de zeragem do geocronômetro $\mathrm{U}-\mathrm{Pb}$. Portanto, a datação de zircão recristalizado, que tende a ser concordante ou pouco discordante, fornece uma idade mínima para a cristalização primária do mineral. Idades mistas, resultantes da recristalização parcial e remoção incompleta do $\mathrm{Pb}$ radiogênico, são possíveis.
As reações secundárias (c.f. Pidgeon et al., 1998) que afetaram boa parte dos cristais de zircão do Maciço Granítico Santa Bárbara, tidas como ocorridas em regime magmático, provavelmente foram favorecidas ou intensificadas pela permanência do magma granítico original, rico em flúor, em estado liquido por tempo mais longo do que o usual para magmas desprovidos do referido elemento, em conseqüência da diminuição da temperatura da liquidus (Manning, 1981).

A circulação dos fluidos ácidos responsáveis pela greisenização observada na associação de facies Santa Bárbara, datada em $961 \pm 19 \mathrm{Ma}$ (K-Ar em mica de greisen; Leite Júnior et al., 2001), é admitida como possível causa da recristalização do zirč̃o da AM-145.

Componentes herdados com idades mínimas ${ }^{207} \mathrm{~Pb} / 206 \mathrm{~Pb}$ de $1617,1651,1979,1993$ e $2067 \mathrm{Ma}$, além daquele representativo do magmatismo Santa Clara, ocorrem nas três unidades do Maciço Granítico Santa Bárbara. Dentre as associações litológicas que constituem o embasamento da porção centro-leste da Província Estanífera de Rondônia, a dos paragnaisses possui zircão com idades mínimas entre 1673 e $1808 \mathrm{Ma}$, e a possibilidade de que essas rochas derivem de uma tonte com idade entre $1,8 \mathrm{e}$ 2,0 Ga é aventada por Payolla et al. (2002). Logo, a herança de zircão a partir de rochas das associações dos paragnaisses e/ou dos augen-gnaisses graníticos e charnockíticos e dos gnaisses graníticos e granulitos charnockíticos finos, ainda que subordinada, é sugerida pelos dados.

Os valores de $\varepsilon_{\mathrm{Nd}}(\mathrm{T})(-2,95)$ e $\mathrm{T}_{\mathrm{DM}}(1,7 \mathrm{Ga})$ da facies Serra do Cícero são admitidos como representativos para o Maciço Granítico Santa Bárbara. Indicam fonte crustal para o protólito, diferenciado do manto em 1,7 Ga.

Os componentes herdados presentes no maciço indicam a existência de rochas mais antigas do que 1,8 Ga no setor sul da Província Rio Negro-Juruena. 
A herança comum de zircão no Maciço Granítico Santa Bárbara, bem como a complexidade textural observada no mineral, que reflete importantes perturbaçōes do sistema isotópico $\mathrm{U}-\mathrm{Pb}$, documentam amplamente as dificuldades envolvidas na datação U.Pb convencional dos granitos estudados. A datação U-Pb pelo método SHRIMP, ou mesmo a datação $\mathrm{U}-\mathrm{Pb}$ convencional de monazita, quando a fase está presente, são alternativas muito mais apropriadas para o estudo geocronológico desse tipo de rocha.

\section{AGRADECIMENTOS}

Esta pesquisa é parte da Tese de Doutoramento de Irena Sparrenberger e decorre de projetos com recursos de agências às quais os autores agradecem: FAPESP (processo 2.000/08033 5), outorgado a Jorge S. Bettencourt; bolsa de Doutoramento FAPESP para Irena Sparrenberger (processo 1.998/04469-1); PADCT/FINEP (Convênio 64.99.0276.00/GTM/PADCT).

Este trabalho é uma contribuição ao projeto IGCP/ UNESCO 426 - Granite Systems and Proterozoic Lithospheric Processes.

\section{REFERÊNCIAS BIBLIOGRÁFICAS}

BASEI, M.A. S.; SIGAJR., O.; SATO, K.; SPROESSER, W. M. (1995) A metodologia Urânio-Chumbo na Universidade de São Paulo. Princípios Metodológicos, Aplicações e Resultados Obtidos. Anats Academia Brasileira de Ciências, v. 67, n. 2, p. 221-237.

BEA, F. (1996) Residence of REE, Y, Th and U in Granites and Crustal Protoliths; Implications for the Chemistry of Crustal Melts. Journal of Petrology, v. 37, n. 3, p. $521-552$.

BETTENCOURT, J. S.; DALL'AGNOL, R.; YOKOI, O. Y.; VIGLIO,E.P.; PINHO,O.G.; SILVA, R. F; CARNEIRO Fo, L. (1987) The Rondonian tin-bearing anorogenic granites and associated mineralization. In: INTERNATIONAL SYMPOSIUM ON GRANITES AND ASSOCIATED MINERALIZATIONS, 1., Salvador, 1987. Exctursions Guide. Salvador, 1987, Superintendência de Geologia e Recursos Minerais, p. 49.87.

BETTENCOURT, J. S.; LEITE JR., W. B.; PAYOLLA, B. L.; SCANDOLARA, J. E.; MUZZOLON, R.; VIAN, J.A. J. (1997) The rapakivi granites of the Rondônia Tin
Province, northern Brazil. In: INTERNATIONAL SYMPOSIUM ON GRANITES AND ASSOCIATED MINERALIZATIONS, 2., Salvador, 1997. Excursions Guide. Salvador, 1997, Companhia Baiana de Pesquisa Mineral/Superintendência de Geologia e Recursos Minerais do Estado da Bahia, p. 3-31.

BETTENCOURT, J. S.; TOSDAL, R. M.; LEITE JR., W. B.; PAYOLLA, B. L. (1999) Mesoproterozoic rapakivi granites of the Rondônia Tin Province, southwestern border of the Amazonian Craton, Brazil: I. Reconnaissance $\mathrm{U}-\mathrm{Pb}$ geochronology and regional implications. Precambrian Research, v. 95, n.1-2, p. 41-67.

COMPANHIAESTANIFERA DO BRASIL (1994) Projeto Integração: Mapa Geológico - Folha 2C. (inédito).

COMPSTON, W.; WILLIAMS, I. S.; MYER, C. (1984) U-Pb geochronology of zircons from Lunar Breccia 73217 using a sensitive high massuresolution ion microprobe. Journal of Geophyical Research, v. 89, suppl.B, p. 525-534.

COPELAND, P; PARRISH, R. R.; HARRISON,T.M. (1988) Identification of inherited radiogenic $\mathrm{Pb}$ in monazite and its applications for U-Pb systematics. Nature, v. 333 , n. 6175 , p. $760-763$.

CORDANI, U. G.; TASSINARI, C. C. G.; TEIXEIRA, W; BASEI, M. A. S.; KAWASHITA, K. (1979) Evolução tectônica da Amazônia com base nos dados geocronológicos. In: CONGRESSO GEOLOGICOCHILENO, 2., Arica, 1979. Actas. Arica, v. 4, p.137-148.

CORFU, F.; STOTT, G. M. (1986) U/Pb ages for late magmatism and regional deformation in the Shebandowan Belt, Superior Province, Canada. Canadian Journal of Earth Saiences, v. 23, n. 8, p. 1075 1082.

DePAOLO, D. J. (1981) A neodymium and strontium isotopic study of the Mesozoic calc-alkaline granitic batholiths of the Sierra Nevada and Peninsular Ranges, California. Journal of Geophysical Research. v. 86, n. B11, p. 10470-10488.

EMSLIE, R. F. (1991) Granitoids of rapakivi granite-anorthosite and related associations. Precam brian Research, v. 51, n. 1-4, p. 173-192.

FRANK, R. E. (1990) Geologia, petrologia e mineralizaşöes estaniferas do Complexo Granitico de Santa Bárbara, Rondonia, Brasil. Rio de Janeiro, 244p. Dissertação (Mestrado) - Instituto de Geociências, Universidade Federal do Rio de Janeiro.

GALEMBECK, T. M. B. (1997) O complero miltiplo, centracto e plurissertial Itu -... SP. Rio Claro, $374 \mathrm{p}$. Tese (Doutorado) - Instituto de Geociências e Ciências Exatas, Universidade Estadual Paulista. 
GERALDES, M. C.; VAN SCHMUS, W. R.; CONDIE, K.C.; BELL, S.; TEIXEIRA, W.; BABINSKI, M. (2001) Proterozoic geologic evolution of the SW part of the Amazonian Craton. Precambrian Research, v. 111, n. 1-4, p. 91-128.

GIOIA, S. M. C. L.; PIMENTEL, M. M. (2000) The Sm-Nd Isotopic Method in the Geochronology Laboratory of the University of Brasilia. Anais Academia Brasileira de Ciências, v. 72, n. 2, p. 219-245.

HUTCHINSON, C. S. (1974) Laboratory handbook of petrographic techniques. New York, John Wiley \& Sons. $527 \mathrm{p}$.

ISOTTA, C. A. L.; CARNEIRO, J. M.; KATO, H. T.; BARROS, R. J. L. (1978) Projeto Provincia Estanifera de Rondónia. Porto Velho. DNPM/CPRM. Vols. 1-3. (Relatório final).

KROGH, T. E. (1973) A low-contamination method for hidrothermal decomposition of zircon and extraction of $\mathrm{U}$ and $\mathrm{Pb}$ for isotopic age determinations. Geochimica et Cosmochimica Acta, v. 37, n. 3, p. 485-494.

KROGH, T. E. (1982) Improved accuracy of U/Pb dating by selection of more concordant fractions using a high gradient magnetic separation technique. Geochimica et Cosmochimica Acta, v. 46, n. 4, p. 631-636.

LEITE JR., W. B.; PAYOLLA, B. L.; BETTENCOURT, J. S. (2000) Petrogenesis of two Grenvillian tin-bearing rapakivi granite suites, southwestern Amazonian craton, Rondônia, Brazil. In: INTERNATIONAL GEOLOGICAL CONGRESS, 31., Rio de Janeiro, 2000. Abstracts Rio de Janeiro, CPRM. (CD-ROM)

LEITE JR., W. B.; PAYOLLA, B. L.; BETTENCOURT, J. S.; TASSINARI, C. C. G. (2001) New K-Ar ages of the primary tin mineralization in the Rondonia Tin Province, Brazil. In: SOUTH AMERICAN SYMPOSIUM ON ISOTOPE GEOLOGY, 3., Pucón, 2001. Extended Abstracts Vohume. Pucón, Serviço Nacional de Geología y Minería de Chile/Departamen. to de Geología de la Universidad de Chile, p. 484-487.

LUDWIG, K. R. (1999) User's Manual for IsoplotEx version 2.10: a Geochronological Toolkit for Microsoft Excel. Berkeley Geochronology Center Special Publication No. la.

LUGMAIR, G. W.; MARTI, K. (1978) Lunar initial ${ }^{143} \mathrm{Nd} /$ ${ }^{144} \mathrm{Nd}$ : Differential evolution of the lunar crust and mantle. Earth and Planettary Science Letters, v. 39, n. 3, p. 349.357.

MANNING, D. A. C. (1981) The effect of fluorine on liquidus phase relationships in the system $\mathrm{Q} z$-Ab-Or with excess water at $1 \mathrm{~kb}$. Contributions to Mineralogy and Petrology, v. 76, n. 2, p. 206-215.

MICHARD, A.; GURRIET, P.; SOUNDANT, M.; ALBARÉDE, F. (1985) Nd isotopes in French Phanerozoic shales: external vs. internal aspects of crustal evolution. Geochimica et Cosmochimica Acta, v. 49, n. 2, p. $601-610$.

MUECKE, G. K.; CLARKE, D. B. (1981) Geochemical evolution of the South Mountain batholith, Nova Scotia: rare-earth-element evidence. Canadian Mineralogist, v. 19, n. 1, p. 133-145.

O'NIONS, R. K.; HAMILTON, P. J.;EVENSON, N. M.(1977) Variations in ${ }^{143} \mathrm{Nd} /{ }^{144} \mathrm{Nd}$ and ${ }^{87} \mathrm{Sr} /{ }^{86} \mathrm{Sr}$ in oceanic basalts. Earth and Planettary Science Letters, v. 34, p. 13-22.

PARRISH, R. R. (1990) U-Pb dating of monazite and its application to geological problems. Canadian Journal of Earth Sciences, v. 27, n. 11, p. 1431-1450.

PAYOLLA, B. L.; BETTENCOURT, J. S.; LEITE JR.; W. B.; BASEI, M. A. S. (2001a) The Rio Crespo Intrusive Suite: geological U-Pb and Sm-Nd isotopic evidence for a major $1.43 \mathrm{Ga}$ arc-related magmatism in the Rondônia State, SW Amazonian Craton, Brazil. In: SOUTH AMERICAN SYMPOSIUM ON ISOTOPE GEOLOGY, 3., Pucón, 2001. Extended Abstracts Volume. Pucón, Serviço Nacional de Geología y Minería de Chile/Departamento de Geología de la Universidad de Chile, p. 199-202.

PAYOLLA, B. L.; BETTENCOURT, J. S.; LEITE JR., W. B.; BASEI, M. A. S. (2001b) The Rio Crespo Intrusive Suite: geological U.Pb and $\mathrm{Sm} \cdot \mathrm{Nd}$ isotopic evidence for a major $1.43 \mathrm{Ga}$ arc-related magmatism in the Rondônia State, SW Amazonia Craton, Brazil. In: BETTENCOURT, J. S.; TEIXEIRA, W, PACCA, I. I. G.; GERALDES, M. C.; SPARRENBERGER, I. (eds.) WORKSHOP ON GEOLOGY OF THE SW AMAZONIAN CRATON: STATE-OF-THE-ART. São Paulo, 2001. Extended Abstract Volume. São Paulo, p. 96-99.

PAYOLLA, B. L.; BETTENCOURT, J. S.; KOZUCH, M.; LEITE JR., W. B.; FETTER, A. H.; VAN SCHMUS, W. R. (2002) Geological evolution of the basement rocks in the central-eastern part of the Rondônia Tin Province, SW Amazonian Craton, Brazil: U-Pb and Sm-Nd isotopic constraints. Precambrian Research, v. 119, n. 1-4, p. 1-29.

PIDGEON, R. T. (1992) Recrystallisation of oscillatory zoned zircon: some geochronological and petrological implications. Contributions to Mineralogy and 
Petrology, v. 110, n. 4, p. 463.472.

PIDGEON, R. T.; NEMCHIN, A. A.; HITCHEN, G. J. (1998) Internal structures of zircons from Archaean granites from the Darling Range batholith: implications for zircon stability and the interpretation of zircon $\mathrm{U}-\mathrm{Pb}$ ages. Contributions to Mineralogy and Petrology, v. 132, n. 3, p. 288-299.

PIMENTEL, M. M.; CHARNLEY, N. (1991) Intracrustal REE fractionation and implications for $\mathrm{Sm}-\mathrm{Nd}$ model age calculations in late-stage granitic rocks: An example from central Brazil. Chemical Geology, v. 86, n. 2, p. 123-138.

PRIEM, H. N. A.; BOELRIJK, N. A. I. M.; HEBEDA, E. H.; VERDUMEN, E.A. T.; VERSCHURE, R. H.;BON, E. H. (1971) Granitic complexes and associated tin mineralization of Grenville age in Rondônia, western Brazil. Geological Society of America Bulletin, v. 82, n. 4, p. 1095-1102.

PRIEM, H. N.A.; BOELRIJK, N.A. I. M.; HEBEDA, E. H.; VERSCHURE, R. H.; BON, E. H. (1966) Isotopic age of tin granites in Rondônia, N.W. Brazil. Geologie en Mijnbouw, v. 45, n. 6, p. 191.192.

PRIEM, H. N. A.; BON, E. H.; VERDUMEN, E. A. T.; BETTENCOURT, J. S. (1989) Rb-Sr chronology of precambrian crustal evolution in Rondônia (western margin Brazilian craton). Joumal of South American Earth Sciences, v. 2, n. 2, p. 163-170.

RÄMÖ, O. T.; VAASJOKI, M.; HAAPALA, I. (1997) Isotopic insights into the origin of tin-mineralized and barren granites in selected Proterozoic rapakivi granite complexes. In: INTERNATIONAL SYMPOSIUM ON GRANITES AND ASSOCIATED MINERALIZATIONS, 2., Salvador, 1997. Abstracts. Salvador, 1997, Companhia Baiana de Pesquisa Mineral/Superintendência de Geologia e Recursos Minerais do Estado da Bahia, p. 286 287.

RAPP, R. P.; RYERSON, F. J.; MLLER, C. F. (1987) Experimental evidence bearing on the stability of monazite during crustal anatexis. Geophysical Research Letters, v. 14, n. 3, p. 307-310.

RIZZOTTO, G. J.; SCANDOLARA, J. E.; QUADROS, M. L. do E. S. (1996) Aspectos gerais da associação mangerito-charnockito-granito (MCG) da porção oriental do sul de Rondônia. In: CONGRESSO BRASILEIRO DE GEOLOGIA, 39., Salvador, SBG/Núcleo Bahia-Sergipe, 1996, v. 1, p. 35-37.

SPARRENBERGER, I.; BETTENCOURT, J. S. (2000) The tin mineralization at the Santa Bárbara Massif, Rondônia Tin Province, Brazil. In. INTERNATIONAL
GEOLOGICAL CONGRESS, 31., Rio de Janeiro, 2000. Abstracts. Rio de Janeiro, CPRM.. (CD-ROM)

SPARRENBERGER, I.; BETTENCOURT, J. S. (2002a) O Maciço Granítico Santa Bárbara, Província Estanifera de Rondônia - Parte I. Caracterização petrográfica e geoquímica. In: CONGRESSO BRASILEIRO DE GEOLOGIA, 41., João Pessoa, 2002. Resumos. João Pessoa, SBG-Núcleo Nordeste, p. 475.

SPARRENBERGER, I.; BETTENCOURT, J. S. (2002b) O Maciço Granítico Santa Bárbara, Província Estanífera de Rondônia - Parte II. A mineralização estanífera em greisens acamados. In: CONGRESSO BRASILEIRO DE GEOLOGIA, 41, João Pessoa, 2002. Resumos. João Pessoa, SBG - Núcleo Nordeste, p. 475.

STACEY, J. S.; KRAMERS, J. D. (1975) Approximation of terrestrial lead isotope evolution by a two-stage model. Earth and Planettary Science Letters, v. 26, n. 2, p. 207-221.

STEIGER, R. H.; JÄGER, E. (1977) Subcommission on geochronology: Convention on the use of decay constants in geo- and cosmochronology. Earth and Planettary Science Letters, v. 36, n. 3, p. 359-362.

TASSINARI, C. C. G. (1996) O mapa geocronológico do cráton Amazónico no Brasil: revisão dos dados isotópicos. São Paulo, 139 p. Tese (Livre Docência) Instituto de Geociências, Universidade de São Paulo.

TASSINARI, C. C. G.; BETTENCOURT, J. S.; GERALDES, M. C.; MACAMBIRA, M. J .B.; LAFON, J. M. (2000) The Amazonia Craton. In: CORDANI, U.G.; MILANI, E.J.; THOMAZ FLLHO, A.; CAMPOS, D.A. (eds.) Tectonic Evolution of South America, p. 41-95.

TEIXEIRA, W.; TASSINARI, C. C. G.; CORDANI, U. G; KAWASHITA, K. (1989) A review of the geochronology of the Amazonian craton: tectonic implications. Precambrian Research, v. 42, n. 3.4, p. 213-227.

TERA, F.; WASSERBURG, G. J. (1972) U-Th-Pb systematics in three Apolto 14 basalts and the problem of initial $\mathrm{Pb}$ in lunar rocks. Earth and Planettary Science Letters, v. 14, n. 3, p. $281-304$.

VAVRA, G. (1990) On the kinematics of zircon growth and its petrogenetic significance: a cathodoluminescence study. Contributions' to Mineralogy and Petrology, v. 106, p. 90-99.

WASSERBURG, G. J.; JACOBSEN, S. B.; DePAOLO, D. J.; McCULLOCH, M. T.; WEN, T. (1981) Precise determination of $\mathrm{Sm} / \mathrm{Nd}$ ratios, $\mathrm{Sm}$ and $\mathrm{Nd}$ isotopic abundances in standard solutions. Geochimica et Cosmochimica Acta, v. 45, n. 12, p. 2311-2323. 
WETHERIL L, G. W. (1956) Discordant uranium-lead ages.

Transactions American Geophysical Union, v. 37, n. 3,p. 320-326.

WILLIAMS, I. S. (1997) U-Th-Pb geochronology by ion microprobe: not just ages but histories. Reviews in Economic Geology, v. 7, p. 1-35. 


\section{INCLUSOOES FLUIDAS}

\subsection{Introdução}

A microtermometria das inclusões fluidas efetuada nesta pesquisa contemplou oito litotipos dos estágios magnático, transicional e pós-magmático (hidrotermal), a partir dos quais foram preparadas nove seções polidas em ambas as faces. Em todos eles analisatam-se as inclusões hospedadas em quartzo e em quatro deles as medidas foram executadas também em topázio.

\subsection{Classificação}

Os critérios de classificação e descrição petrográfica das inclusões fluidas adotados neste capítulo seguem Roedder (1984) e Van Den Kerkhof \& Hein (2001).

Tendo como base os critétios de Roedder (1984; pg. 2), que levam em consideração o estado do material incorporado na inclusão na época do aprisionamento, as inclusões fluidas presentes nas rochas do depósito estanífero Santa Bárbara durante os estágios magmático, transicional e hidrotermal podem ser subdivididas em melt inclusions, inclusões fluidas (aquosas e aquo-carbônicas) propriamente ditas e inclusões compostas. Pelas características intrínsecas ao seu processo de aprisionamento e pela sua distribuição no mineral hospedeiro, as melt inclusions e as inclusões compostas são primárias, enquanto que as fluidas podem ter qualquer origem.

a) Melt inclusions - ocorrem principalmente em topázio, mas são observadas também no quartzo;

b) Inclusões compostas - ocorrem no topázio e no quartzo. Compreendem sólidos capturados juntamente com porções variáveis de vapor/gás ou de líquido;

c) Aquosas - presentes nos dois minerais em todas as amostras. $O$ número de fases existentes nessas inclusões, em temperatura ambiente, permite agrupá-las em monofásicas (L), bifásicas $(\mathrm{L}+\mathrm{V})$ e multifásicas $\left(\mathrm{I}+\mathrm{V}+\mathrm{S}_{1 \ldots \mathrm{n}}\right)$; 
d) Aquo-carbônicas - ocorrem predominantemente no topázio. São bifásicas $\left(\mathrm{H}_{2} \mathrm{Ol}+\right.$ $\left.\mathrm{CO}_{2} \mathrm{~g}\right)$, trif́́sicas $\left(\mathrm{H}_{2} \mathrm{Ol}+\mathrm{CO}_{2} \mathrm{I}+\mathrm{CO}_{2} \mathrm{~g}\right)$ e multifásicas $\left(\mathrm{H}_{2} \mathrm{Ol} \pm \mathrm{CO}_{2} \mathrm{I}+\mathrm{CO}_{2} \mathrm{~g}+\mathrm{S}_{1 \ldots \mathrm{D}}\right)$. Contêm quantidades variáveis de $\mathrm{CH}_{4}$ e incluem os subtipos ' $\mathrm{X}_{\mathrm{F} 2 \mathrm{O}}$ muito alta' e ' $\mathrm{X}_{\mathrm{H} 20}$ alta' (Diamond, 1994, 2001).

\subsection{Litotipos e gerações de inclusões fluidas associadas}

As características microtermométricas gerais das amostras estão sumariadas no Quadro 9.I. A íntegra dos dados microtermométricos encontra-se no Anexo II.

\subsubsection{Estágio magmático}

\section{a) Albita-microclínio granito fino branco}

Inclusões fluidas são escassas no albita-microclínio granito fino branco. Efetuaram-se medidas em dois cristais de quartzo e um de topázio, perfazendo cerca de 50 inclusões.

A geração mais precoce de inclusões no quartzo compreende melt inclusions com propotções variáveis de fase vapor. Suas porções cristalinas não fundiram até os $600^{\circ} \mathrm{C}$, indicando que o cristal hospedeiro gerou-se em temperaturas superiores.

As inclusões fluidas com feições de primárias no quartzo compreendem populações de inclusões aquosas e aquo-carbônicas. As inclusões aquosas subdividem-se nos tipos 1 , 2 e 3 . As inclusões do tipo 1 são bifásicas ou multifásicas, com proporção volumétrica da fase vapor $\left(\mathrm{V}_{\mathrm{v}} / \mathrm{V}_{\mathrm{IV}}\right)$ variável de 0,05 a 0,70 . Entre as multifásicas, a ocorrência de sólidos não é regra, e o número deles é variável (Prancha 9.1.a), o que sugere que foram aprisionados ocasionalmente (Roedder 1984, pg. 55; Higgins 1985). As aquosas do tipo 2 são escassas, ocorrem isoladas ou em pequenos grupos, e têm como característica marcante a presença de dois ou mais sólidos, via de regra grandes, e bolhas pequenas. A presença de inclusões aquosas do tipo 3, altamente salinas, com tamanhos desde pequenos até grandes, com ou sem bolha de vapor, é sugerida pelo comportamento de algumas durante o aquecimento. Em temperaturas ao redor dos $100^{\circ} \mathrm{C}$, mostram separação de uma fase com índice de refração elevado e comportamento viscoso de outra fase, aquosa. Permanecem sem transformações posteriores significativas até os $600^{\circ} \mathrm{C}$, além da homogeneização da fase vapor para o líquido, assemelhando-se às inclusões altamente salinas descritas por Roedder (1984, pg. 51-52). 
Quadro 9.1 - Caracteristicas microtermométricas das inclusōes fluidas estudadas no Maciço Granítico Santa Bárbara.

\begin{tabular}{|c|c|c|c|c|c|c|c|c|c|c|c|c|c|}
\hline Estágio & $\begin{array}{l}\text { Litotipo (no. } \\
\text { amostra) }\end{array}$ & $\begin{array}{c}\text { Mineral } \\
\text { analisado }\end{array}$ & $\begin{array}{c}\text { Origem } \\
\text { (geraçāo) }\end{array}$ & $\begin{array}{l}\operatorname{TE}\left({ }^{\circ} \mathrm{C}\right) \\
\text { (moda) }\end{array}$ & $\operatorname{TfCO}_{2}\left({ }^{\circ} \mathrm{C}\right)$ & $\begin{array}{l}\text { Th }\left({ }^{\circ} \mathrm{C}\right) \\
\text { (moda) }\end{array}$ & $\mathbf{X}_{\mathrm{H} 2 \mathrm{O}}$ & $X_{\mathrm{CO} 2}$ & $\mathbf{X}_{\mathrm{NaCl}}$ & $\begin{array}{c}\text { Salinidade } \\
\text { (\% peso } \\
\text { NaCl eq.) } \\
\text { (moda) }\end{array}$ & $\begin{array}{c}\text { Densidade } \\
\left(\mathrm{g} / \mathrm{cm}^{3}\right)\end{array}$ & $\mathrm{V}_{\mathrm{V} / \mathrm{g}} / N_{\mathrm{IF}}$ & $\begin{array}{c}\mathrm{P} \\
\text { (kbar) } \\
\mathrm{e} \\
\mathrm{T}\left({ }^{\circ} \mathrm{C}\right) \\
\end{array}$ \\
\hline \multirow{9}{*}{ 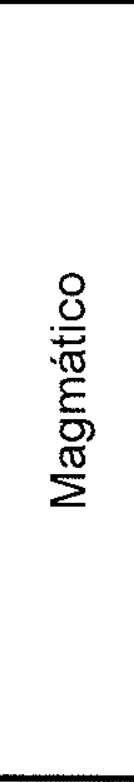 } & \multirow{6}{*}{$\begin{array}{c}\text { albita- } \\
\text { microclínio } \\
\text { granito fino } \\
\text { branco (AM- } \\
134 \text { ) }\end{array}$} & \multirow{5}{*}{ quartzo } & $\begin{array}{c}\text { aquosas } \\
\text { primárias tipo } 1\end{array}$ & $\begin{array}{c}-50,0 \mathrm{a} \\
-22,5(-39 \mathrm{a} \\
-35) \\
\end{array}$ & - & $\begin{array}{c}123,0 a \\
451,8\end{array}$ & $\begin{array}{c}0,983 a \\
0,962\end{array}$ & - & $\begin{array}{c}0,017 \mathrm{a} \\
0,038\end{array}$ & $\begin{array}{c}5,2 \text { a } 11,5(6 \mathrm{e} \\
7)\end{array}$ & 0,509 a 0,996 & $\begin{array}{c}0,05 a \\
0,70\end{array}$ & \\
\hline & & & $\begin{array}{c}\text { aquosas } \\
\text { primárias tipo } 2\end{array}$ & $\begin{array}{c}-53,7 a \\
-44,3 \\
\end{array}$ & - & 88,7 a 215,5 & $\begin{array}{c}0,952 a \\
0,919 \\
\end{array}$ & - & $\begin{array}{c}0,048 \mathrm{a} \\
0,081 \\
\end{array}$ & $\begin{array}{c}14,1 \text { a }-42,0 \\
(14 \text { a } 18) \\
\end{array}$ & 0,988 a 1,129 & $<0,10$ & \\
\hline & & & $\begin{array}{c}\text { aquosas } \\
\text { primárias tipo } 3\end{array}$ & $-42,3$ & - & 329,3 & 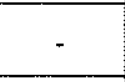 & * & 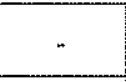 & 34 & - & 0,10 & \\
\hline & & & aquo-carbônicas & - & $-58,2$ & 397,3 & - & - & - & 6,1 a 11,7 & - & $\begin{array}{c}0,60 \mathrm{a} \\
0,90\end{array}$ & \\
\hline & & & $\begin{array}{c}\text { aquosas } \\
\text { secundárias }\end{array}$ & $\begin{array}{c}-40,4 \mathrm{a}- \\
21,1 \\
\end{array}$ & - & $\begin{array}{c}163,7 \mathrm{a} \\
380,0 \\
\end{array}$ & $\begin{array}{c}0,997 a \\
0,991 \\
\end{array}$ & - & $\begin{array}{c}0,003 a \\
0,009\end{array}$ & $\begin{array}{c}0,3 \text { e } 3,0(0 \mathrm{a} \\
1)\end{array}$ & 0,755 a 0,926 & $\begin{array}{c}0,10 \mathrm{a} \\
0,50\end{array}$ & \\
\hline & & topázio & aquo-carbônicas & $\begin{array}{c}-42,1 e \\
-24,6\end{array}$ & $\begin{array}{c}-57,0 a \\
-56,8\end{array}$ & $\begin{array}{c}356,3 \mathrm{a} \\
553,0 \\
(<390) \\
\end{array}$ & 0,902 & 0,079 & 0,019 & 3,4 a 25,7 & 0,499 & $\begin{array}{l}0,25 a \\
>0,90\end{array}$ & \\
\hline & \multirow{3}{*}{$\begin{array}{c}\text { pegmatito (AM- } \\
213)\end{array}$} & \multirow{3}{*}{ quarzzo } & $\begin{array}{c}\text { aquosas } \\
\text { secundárias } 1\end{array}$ & - & - & $\begin{array}{c}327,7 \mathrm{a} \\
369,6\end{array}$ & - & - & - & - & - & $\sim 0,10$ & \\
\hline & & & $\begin{array}{c}\text { aquosas } \\
\text { secundárias } 2\end{array}$ & $\begin{array}{c}-40,2 a \\
-38,6\end{array}$ & - & $\begin{array}{c}114,2 \text { e } \\
302,0 \\
(>230) \\
\end{array}$ & $\begin{array}{c}0,999 a \\
0,996\end{array}$ & - & $\begin{array}{c}0,001 \mathrm{a} \\
0,004\end{array}$ & $\begin{array}{c}0,2 \text { a } 1,3(0 a \\
1)\end{array}$ & 0,762 a 0,811 & 0,15 & \\
\hline & & & $\begin{array}{l}\text { aquo-carbônicas } \\
\text { secundárias }\end{array}$ & $\begin{array}{l}-31,9 a \\
-27,7\end{array}$ & - & $\begin{array}{c}128,0 \text { a } \\
304,4(240 \\
\text { a } 250) \\
\end{array}$ & - & - & - & 3,0 a 5,8 & - & $\begin{array}{c}0,10 \mathrm{a} \\
0,55\end{array}$ & \\
\hline \multirow{6}{*}{ 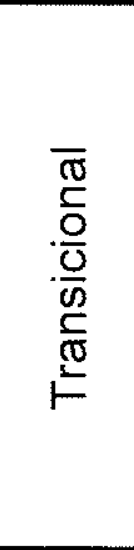 } & \multirow{3}{*}{$\begin{array}{c}\text { bucho de } \\
\text { quartzo (AM- } \\
168 \mathrm{~A} \text { ) }\end{array}$} & \multirow{3}{*}{ topázio } & $\begin{array}{l}\text { aquosas } \\
\text { primárias }\end{array}$ & $\begin{array}{c}-51,0 a \\
-26,8(-49 a \\
-45 e-37) \\
\end{array}$ & - & $\mid \begin{array}{c}400 \text { a } 506 \\
(450 \text { a } 490)\end{array}$ & $\begin{array}{c}0,970 \mathrm{a} \\
0,949\end{array}$ & - & $\begin{array}{c}0,030 \mathrm{a} \\
0,051\end{array}$ & $\begin{array}{c}9,1 \text { a } 14,9\langle 10 \\
\text { a } 12\rangle\end{array}$ & 0,472 a 0,621 & $\begin{array}{c}0,30 \mathrm{a} \\
0,40\end{array}$ & \\
\hline & & & $\begin{array}{l}\text { aquosas pseudo- } \\
\text { sedundárias }\end{array}$ & $\begin{array}{c}-48,9 a \\
-23,5(-37)\end{array}$ & - & $\begin{array}{c}374,9 \text { a } \\
572,7(400 \\
\text { a 490) }\end{array}$ & $\begin{array}{c}0,970 a \\
0,959\end{array}$ & - & $\begin{array}{c}0,030 \text { a } \\
0,041\end{array}$ & $\begin{array}{c}7,1 \text { a } 12,2(10 \\
\text { a } 12)\end{array}$ & 0,472 a 0,681 & $\begin{array}{c}0,30 a \\
0,40\end{array}$ & \\
\hline & & & $\begin{array}{l}\text { aquosas } \\
\text { secundárias }\end{array}$ & $\begin{array}{c}-47,1 \mathrm{e} \\
-25,8(-38 \mathrm{a} \\
-34) \\
\end{array}$ & - & $\begin{array}{c}446,1 \mathrm{a} \\
484,2(460 \\
\mathrm{a} 470) \\
\end{array}$ & $\begin{array}{c}0,967 \mathrm{a} \\
0,916\end{array}$ & - & $\begin{array}{c}0,033 a \\
0,084\end{array}$ & 10,7 a 22,9 & 0,578 & $\begin{array}{c}0,30 \mathrm{a} \\
0,40\end{array}$ & \\
\hline & \multirow{3}{*}{$\begin{array}{c}\text { bucho de } \\
\text { quartzo (AM- } \\
168 \mathrm{C} \text { ) }\end{array}$} & \multirow{3}{*}{ quartzo } & $\begin{array}{c}\text { aquo-carbônicas } \\
\text { primárias }\end{array}$ & $\begin{array}{c}-48,3 \mathrm{a} \\
-24,8 \\
\end{array}$ & $\begin{array}{l}-58,4 a \\
-58,1 \\
\end{array}$ & $\begin{array}{c}206,4 \text { a } \\
524,0\end{array}$ & $\begin{array}{c}0,852 \mathrm{a} \\
0,897 \\
\end{array}$ & $\begin{array}{c}0,089 \mathrm{a} \\
0,116 \\
\end{array}$ & $\begin{array}{c}0,014 \mathrm{a} \\
0,076 \\
\end{array}$ & $\begin{array}{c}4,7 \text { a } 11(10 \mathrm{a} \\
11)\end{array}$ & 0,736 a 0,906 & $\begin{array}{c}0,35 \mathrm{a} \\
0,70\end{array}$ & \\
\hline & & & $\begin{array}{l}\text { aquosas } \\
\text { primárias }\end{array}$ & $\begin{array}{c}-41,3 a \\
-31,9(-41 \text { a } \\
-38) \\
\end{array}$ & -2 & $\begin{array}{c}97,6 \text { a } 417,5 \\
(100 \text { a } 140) \\
\end{array}$ & $\begin{array}{c}0,985 a \\
0,952\end{array}$ & - & $\begin{array}{c}0,015 a \\
0,048\end{array}$ & $\begin{array}{c}4,9 \text { a } 14,1(13 \\
\text { a } 14)\end{array}$ & 0,776 a 1,050 & $\begin{array}{c}0,10 \mathrm{a} \\
0,70\end{array}$ & \\
\hline & & & $\begin{array}{c}\text { aquo-carbônicas } \\
\text { secundárias }\end{array}$ & $\begin{array}{c}-37,6 \mathrm{a} \\
-27,0 \\
\end{array}$ & $\begin{array}{c}-58,6 a \\
-57,8 \\
\end{array}$ & $\begin{array}{c}234,4 a \\
409,8 \\
\end{array}$ & $\begin{array}{c}0,889 \mathrm{a} \\
0,927 \\
\end{array}$ & $\begin{array}{c}0,054 \mathrm{a} \\
0,093 \\
\end{array}$ & $\begin{array}{c}0,018 a \\
0,043 \\
\end{array}$ & 8,1 a 15,4 & 0,514 a 0,765 & $\begin{array}{c}0,35 \mathrm{a} \\
0,90\end{array}$ & \\
\hline
\end{tabular}


Quadro 9.1 - Características microtermométricas das inclusões fluidas estudadas no Maciço Granítico Santa Bárbara (continuação).

\begin{tabular}{|c|c|c|c|c|c|c|c|c|c|c|c|c|c|}
\hline Estágio & $\begin{array}{l}\text { Litotipo (no. } \\
\text { amostra) }\end{array}$ & $\begin{array}{c}\text { Mineral } \\
\text { analisado }\end{array}$ & $\begin{array}{l}\text { Origem } \\
\text { (geração) }\end{array}$ & $\begin{array}{l}\text { TE }\left({ }^{\circ} \mathrm{C}\right) \\
\text { (moda) }\end{array}$ & $\mathrm{TfCO}_{2}\left({ }^{\circ} \mathrm{C}\right)$ & $\begin{array}{l}\text { Th }\left({ }^{\circ} \mathrm{C}\right) \\
\text { (moda) }\end{array}$ & $X_{\mathrm{H} 2 \mathrm{O}}$ & $\mathrm{X}_{\mathrm{CO} 2}$ & $\mathbf{X}_{\mathrm{NaCl}}$ & $\begin{array}{c}\text { Salinidade } \\
\text { (\% peso } \\
\text { NaCl eq.) } \\
\text { (moda) }\end{array}$ & $\begin{array}{l}\text { Densidade } \\
\left(\mathrm{g} / \mathrm{cm}^{3}\right)\end{array}$ & $\mathrm{V}_{\mathrm{vig}} / \mathrm{V}_{\mathrm{IF}}$ & $\begin{array}{c}\mathrm{P} \\
\text { (kbar) } \\
e \\
\mathrm{~T}\left({ }^{\circ} \mathrm{C}\right)\end{array}$ \\
\hline \multirow{14}{*}{ 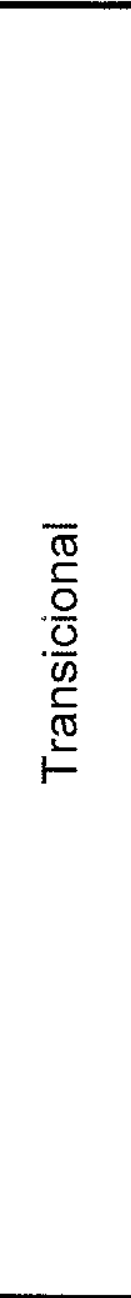 } & $\begin{array}{c}\text { bucho de } \\
\text { quartzo (AM } \\
168 \mathrm{C} \text { ) }\end{array}$ & quartzo & $\begin{array}{l}\text { aquosas } \\
\text { secundárias }\end{array}$ & $\begin{array}{c}-49,9 a \\
-21,8(-46 a \\
-38)\end{array}$ & - & $\begin{array}{c}102,2 a \\
388,5(130 \\
a 160) \\
\end{array}$ & $\begin{array}{c}0,978 \text { a } \\
0,942\end{array}$ & - & $\begin{array}{c}0,022 \mathrm{a} \\
0,058\end{array}$ & $\begin{array}{c}6,7 \text { a } 16,7(12 \\
\text { a } 16)\end{array}$ & 0,808 a 1,071 & $\begin{array}{c}0,10 \mathrm{a} \\
0,50\end{array}$ & \\
\hline & & & $\begin{array}{l}\text { melt inclusions } \\
\text { aquo-carbônicas }\end{array}$ & - & $\begin{array}{l}-57,2 \mathrm{a} \\
-56,7\end{array}$ & - & - & - & - & 10,0 a 15,2 & - & $\begin{array}{c}0,10 a \\
0,20\end{array}$ & $>600$ \\
\hline & & & $\begin{array}{c}\text { melt inclusions } \\
\text { aquosas }\end{array}$ & $-27,1$ & - & - & - & - & - & $\sim 1$ & - & 0,10 & $>600$ \\
\hline & & & $\begin{array}{c}\text { aquo-carbônicas } \\
\text { primárias }\end{array}$ & $\begin{array}{c}-32,6 \mathrm{a} \\
-24,8(-27 \text { a } \\
-25)\end{array}$ & $\begin{array}{l}-57,0 a \\
-56,7\end{array}$ & $\begin{array}{c}336,6 \text { a } \\
423,8(340 \\
\text { a } 370)\end{array}$ & - & - & - & $\begin{array}{c}2,2 \text { a } 13,2(5 a) \\
11)\end{array}$ & - & $\begin{array}{l}0,10 a \\
>0,90\end{array}$ & \\
\hline & & & $\begin{array}{l}\text { aquosas } \\
\text { primárias }\end{array}$ & $-42,6$ & - & $\begin{array}{c}211,3 \mathrm{a} \\
352,8\end{array}$ & - & - & - & 0,5 a 1,8 & - & $\begin{array}{c}0,05 a \\
0,40\end{array}$ & \\
\hline & & \multirow{6}{*}{ quartzo } & $\begin{array}{c}\text { aquo-carbônicas } \\
\text { primárias }\end{array}$ & $-28,1$ & $\begin{array}{l}-57,5 a \\
-57,2 \\
\end{array}$ & $\begin{array}{c}355,2 \mathrm{a} \\
378,6\end{array}$ & - & - & - & $\begin{array}{c}5,1 \text { a } 8,5(5 \text { a } \\
6)\end{array}$ & - & $\begin{array}{c}0,30 a \\
0,90\end{array}$ & \\
\hline & & & $\begin{array}{l}\text { aquosas } \\
\text { primárias } 1\end{array}$ & $\begin{array}{c}-40,3 a \\
-33,6 \\
\end{array}$ & " & - & $\begin{array}{c}0,999 a \\
0,973\end{array}$ & - & $\begin{array}{c}0,001 \mathrm{a} \\
0,027\end{array}$ & $\begin{array}{c}3,6 \text { e } 8,2(5 \mathrm{a} \\
8\}\end{array}$ & - & $\begin{array}{c}0,10 a \\
0,30\end{array}$ & \\
\hline & & & $\begin{array}{l}\text { aquosas } \\
\text { primárias } 2\end{array}$ & $\begin{array}{l}-52,4 a \\
-26,5\end{array}$ & - & $\begin{array}{c}111,8 \mathrm{a} \\
331,9(310 \\
\text { a } 320)\end{array}$ & $\begin{array}{c}0,999 \mathrm{a} \\
0,972\end{array}$ & - & $\begin{array}{c}0,001 a \\
0,028\end{array}$ & $\begin{array}{c}0,3 \text { até os } 22,0 \\
(0 \mathrm{a} 2)\end{array}$ & 0,661 a 1,106 & $\begin{array}{c}0,10 a \\
0,90\end{array}$ & \\
\hline & & & $\begin{array}{l}\text { aquosas pseudo } \\
\text { secundárias } \\
\text { (campo 3) }\end{array}$ & $\begin{array}{c}-53,3 a \\
-28,1(-42 a \\
-40) \\
\end{array}$ & - & $\begin{array}{c}127,2 \mathrm{e} \\
423,6(330 \\
\text { a } 370) \\
\end{array}$ & $\begin{array}{c}0,995 \text { a } \\
0,957\end{array}$ & - & $\begin{array}{l}0,005 a \\
0,043\end{array}$ & $\begin{array}{c}1,7 \text { a } 12,9(10 \\
\text { e } 11)\end{array}$ & 0,652 a 1,000 & $\begin{array}{c}0,05 a \\
0,40\end{array}$ & \\
\hline & & & $\begin{array}{c}\text { aquosas } \\
\text { secundárias } \\
\text { (campo } 3 \text { ) }\end{array}$ & $\begin{array}{c}-42,8 a \\
-23,1\end{array}$ & - & $\begin{array}{c}141,7 \mathrm{a} \\
237,7(140 \\
\text { a } 150) \\
\end{array}$ & $\begin{array}{c}0,997 \mathrm{a} \\
0,958\end{array}$ & - & $\begin{array}{l}0,003 a \\
0,042\end{array}$ & 0,8 a 12,5 & 0,870 a 1,004 & 0,15 & \\
\hline & & & $\begin{array}{l}\text { aquosas } \\
\text { secundárias } \\
\text { (campo 5) }\end{array}$ & $-36,0$ & - & $\begin{array}{c}102,5 \mathrm{a} \\
285,7(130 \\
\text { a } 140) \\
\end{array}$ & $\begin{array}{c}0,999 a \\
0,993\end{array}$ & - & $\begin{array}{l}0,001 \mathrm{a} \\
0,007\end{array}$ & $\begin{array}{c}0,2 \text { a } 2,1(1 \text { a } \\
2)\end{array}$ & 0,736 a 0,916 & $\begin{array}{l}0,10 \mathrm{a} \\
0,20\end{array}$ & \\
\hline & \multirow{3}{*}{$\begin{array}{c}\text { granito } \\
\text { albitizado } \\
\text { saimão (AM- } \\
14 B)\end{array}$} & \multirow{3}{*}{ quartzo } & melt inclusions & - & - & - & $\begin{array}{c}0,968 \text { a } \\
0,962\end{array}$ & - & $\begin{array}{c}0,032 \mathrm{a} \\
0,038\end{array}$ & 9,7 a 11,7 & - & & $>600$ \\
\hline & & & $\begin{array}{l}\text { aquosas } \\
\text { primárias }\end{array}$ & $\begin{array}{l}-46,6 a \\
-32,0\end{array}$ & - & $\begin{array}{c}232,7 \text { a } \\
404,0(150 \\
\text { a } 220 \& 370 \\
\text { a } 410) \\
\end{array}$ & $\begin{array}{c}0,994 \mathrm{a} \\
0,981\end{array}$ & - & $\begin{array}{c}0,006 \mathrm{a} \\
0,019\end{array}$ & $\begin{array}{c}2,0 \text { a } 5,8(2 a \\
4)\end{array}$ & 0,476 a 0,839 & $\begin{array}{c}0,10 a \\
0,90\end{array}$ & \\
\hline & & & $\begin{array}{l}\text { aquosas pseudo- } \\
\text { secundárias }\end{array}$ & $\begin{array}{l}-44,6 a \\
-31,3\end{array}$ & - & $\begin{array}{c}153,0 \mathrm{a} \\
485,8(150- \\
220 \mathrm{e} 370 \mathrm{a} \\
410)\end{array}$ & $\begin{array}{l}0,996 \mathrm{a} \\
0,975\end{array}$ & - & $\begin{array}{l}0,004 a \\
0,025\end{array}$ & $\begin{array}{c}1,3 \text { a } 7,5(1 \mathrm{a} \\
3)\end{array}$ & 0,505 a 0,941 & $\begin{array}{c}0,10 a \\
0,90\end{array}$ & \\
\hline
\end{tabular}


Quadro 9.1-Características microtermométricas das inclusōes fluidas estudadas no Maciço Granitico Santa Bárbara (continuação).

\begin{tabular}{|c|c|c|c|c|c|c|c|c|c|c|c|c|c|}
\hline Estágio & $\begin{array}{c}\text { Litotipo (no. } \\
\text { amostra) }\end{array}$ & $\begin{array}{l}\text { Mineral } \\
\text { analisado }\end{array}$ & $\begin{array}{c}\text { Origem } \\
\text { (geração) }\end{array}$ & $\begin{array}{l}\mathrm{TE}\left({ }^{\circ} \mathrm{C}\right) \\
\text { (moda) }\end{array}$ & $\mathrm{TfCO}_{2}\left({ }^{\circ} \mathrm{C}\right)$ & $\begin{array}{l}\mathrm{Th}\left({ }^{\circ} \mathrm{C}\right) \\
\text { (moda) }\end{array}$ & $X_{\mathrm{H} 2 \mathrm{O}}$ & $X_{\mathrm{cO} 2}$ & $\mathbf{X}_{\mathrm{NaCl}}$ & $\begin{array}{c}\text { Salinidade } \\
\text { (\% peso } \\
\text { NaCl eq.) } \\
\text { (moda) }\end{array}$ & $\begin{array}{c}\text { Densidade } \\
\left(\mathrm{g} / \mathrm{cm}^{3}\right)\end{array}$ & $\mathrm{V}_{\mathrm{v} / \mathrm{g}} / \mathrm{V}_{\mathrm{IF}}$ & $\begin{array}{c}\mathrm{P} \\
\text { (kbar) } \\
\mathrm{e} \\
\mathrm{T}\left({ }^{\circ} \mathrm{C}\right) \\
\end{array}$ \\
\hline \multirow{9}{*}{ 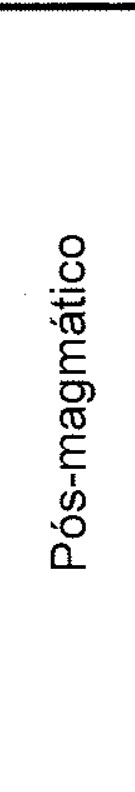 } & \multirow{5}{*}{$\begin{array}{l}\text { veio de greisen } \\
\qquad(A M-130)\end{array}$} & \multirow{3}{*}{ topázio } & $\begin{array}{l}\text { aquo-carbônicas } \\
\text { primárias }\end{array}$ & $\begin{array}{c}-36,5 a \\
-32,6(-35 a \\
-34)\end{array}$ & $\begin{array}{l}-57,8 a \\
-56,6\end{array}$ & $\begin{array}{c}364,8 a \\
445,2\end{array}$ & $\begin{array}{c}0,894 a \\
0,920\end{array}$ & $\begin{array}{c}0,061 \mathrm{a} \\
0,087\end{array}$ & $\begin{array}{c}0,018 \mathrm{a} \\
0,027\end{array}$ & $\begin{array}{c}1,8 \text { a } 11,8(4 a \\
7)\end{array}$ & 0,570 a 0,657 & $\begin{array}{c}0,20 a \\
0,55\end{array}$ & \\
\hline & & & $\begin{array}{l}\text { aquosas } \\
\text { primárias } 1\end{array}$ & $\begin{array}{c}-48,0 \text { a } \\
-42,3\end{array}$ & - & $\begin{array}{c}360,3 a \\
461,5(360 \\
\text { a } 410)\end{array}$ & $\begin{array}{c}0,981 \mathrm{a} \\
0,922\end{array}$ & - & $\begin{array}{c}0,019 \mathrm{a} \\
0,078\end{array}$ & $\begin{array}{c}5,8 \text { a } 21,6(5 a) \\
12)\end{array}$ & 0,486 a 0,873 & 0,15 & \\
\hline & & & $\begin{array}{l}\text { aquosas } \\
\text { primárias } 2\end{array}$ & $\begin{array}{c}-47,5 a \\
-42,1 \\
\end{array}$ & - & $\begin{array}{c}272,4 a \\
422,9 \\
\end{array}$ & $\begin{array}{c}0,978 \mathrm{a} \\
0,960\end{array}$ & - & $\begin{array}{c}0,022 \mathrm{a} \\
0,040\end{array}$ & $\begin{array}{c}6,8 \text { a } 11,9(6 a \\
8)\end{array}$ & 0,536 a 0,691 & $\begin{array}{c}0,15 a \\
0,25\end{array}$ & \\
\hline & & \multirow{2}{*}{ quartzo } & $\begin{array}{l}\text { aquosas } \\
\text { primárias }\end{array}$ & $\begin{array}{c}-51,3 \mathrm{a} \\
-11,7(-34 \mathrm{a} \\
-33)\end{array}$ & $\sim$ & $\begin{array}{c}134,0 \mathrm{a} \\
435,0 \\
(>320) \\
\end{array}$ & $\begin{array}{c}0,998 a \\
0,938 \\
\end{array}$ & - & $\begin{array}{c}0,002 a \\
0,062\end{array}$ & $\begin{array}{c}2,3 \text { a } 17,7<6 \text { a } \\
9) \\
\end{array}$ & 0,487 a 0,994 & $\begin{array}{c}0,10 a \\
0,70 \\
\end{array}$ & \\
\hline & & & $\begin{array}{l}\text { aquosas } \\
\text { secundárias }\end{array}$ & $\begin{array}{c}-47,2 \mathrm{a} \\
-28,4 \\
\end{array}$ & - & $\begin{array}{c}124,2 \mathrm{a} \\
415,1 \\
(>290) \\
\end{array}$ & $\begin{array}{c}0,998 \mathrm{a} \\
0,980\end{array}$ & - & $\begin{array}{c}0,002 \mathrm{a} \\
0,020\end{array}$ & $\begin{array}{c}0,7 \text { a } 6,1<0 \mathrm{e} \\
1)\end{array}$ & 0,482 a 0,917 & $\begin{array}{c}0,10 \mathrm{a} \\
0,90\end{array}$ & \\
\hline & \multirow{2}{*}{$\begin{array}{l}\text { veio de quartzo } \\
\text { e cassiterita } \\
\text { (AM-131) }\end{array}$} & \multirow[t]{2}{*}{ quartzo } & $\begin{array}{l}\text { aquosas } \\
\text { primárias } 1\end{array}$ & $\begin{array}{c}-41,9 a \\
-26,4(-31 a \\
-26) \\
\end{array}$ & - & $\begin{array}{c}153,4 a \\
375,4(320 \\
a 380) \\
\end{array}$ & $\begin{array}{c}0,999 \mathrm{a} \\
0,977\end{array}$ & - & $\begin{array}{c}0,001 \mathrm{a} \\
0,023\end{array}$ & $\begin{array}{c}0,3 \text { a } 7,0<0 a \\
3)\end{array}$ & 0,494 a 0,863 & $\begin{array}{c}0,10 \mathrm{a} \\
0,90\end{array}$ & \\
\hline & & & $\begin{array}{l}\text { aquosas } \\
\text { primárias } 2\end{array}$ & $\begin{array}{l}-47,4 a \\
-28,0 \\
\end{array}$ & - & $\begin{array}{c}110,3 a \\
176,7 \\
\end{array}$ & $\begin{array}{c}0,994 \text { a } \\
0,951\end{array}$ & - & $\begin{array}{c}0,006 a \\
0,049\end{array}$ & 2,0 a 14,4 & 0,935 a 1,053 & $\begin{array}{c}0,10 \mathrm{a} \\
0,20 \\
\end{array}$ & \\
\hline & \multirow{2}{*}{$\begin{array}{c}\text { veio de quartzo } \\
\text { estéril (AM- } \\
\text { 159) }\end{array}$} & \multirow{2}{*}{ quartzo } & $\begin{array}{l}\text { aquosas } \\
\text { primárias }\end{array}$ & $\begin{array}{l}-42,1 \mathrm{a} \\
-34,8 \\
\end{array}$ & - & $\begin{array}{c}145,6 \mathrm{a} \\
415,2\end{array}$ & $\begin{array}{c}0,997 a \\
0,982\end{array}$ & - & $\begin{array}{c}0,003 a \\
0,018 \\
\end{array}$ & $\begin{array}{c}1,7 \text { a } 5,5(1 \text { a } \\
3) \\
\end{array}$ & 0,495 a 0,932 & $\begin{array}{c}0,10 \mathrm{a} \\
0,70\end{array}$ & \\
\hline & & & $\begin{array}{c}\text { aquosas } \\
\text { secundárias }\end{array}$ & $\begin{array}{c}-57,9 \text { a } \\
-47,0 \\
\end{array}$ & - & 94,2 a 147,4 & $\begin{array}{c}0,949 \mathrm{a} \\
0,933\end{array}$ & - & $\begin{array}{c}0,051 \mathrm{a} \\
0,067\end{array}$ & 14,8 a 18,9 & 1,052 a 1,099 & 0,10 & \\
\hline
\end{tabular}


As salinidades das inclusões aquosas do tipo 1, obtidas a partir das temperaturas de fusão do gelo (Tfg), situam-se no intervalo de 5,2 a 11,5\% em peso $\mathrm{NaCl}$ equiv., com moda bem marcada entre 6 e $8 \%$ (Fig. 9.1.a). As temperaturas do ponto eutético (TE) variam de $-50,0$ a $-22,5^{\circ} \mathrm{C}$, com sugestão de pico ao redor de -39 a $-35^{\circ} \mathrm{C}$ (Fig. 9.1.b). Tão amplo espectro de TE's pressupõe grande variação composicional do fluido entre termos cálcicos, no extremo inferiot, e sódicos, no extremo superior, passando por fluidos com ferro, isentos de cálcio (Borisenko 1978, Crawford 1981, Davis et al. 1990). Em todos os casos, provavelmente está também presente o potássio. Temperaturas de homogeneização (Th), principalmente para o líquido, variáveis entre 123,0 e 451,8 $\mathrm{C}$, sem pico definido, caracterizam essa população de inclusões (Fïg. 9.1.c).

No caso das inclusões do tipo 2, sempre com $\mathrm{V}_{\mathrm{v}} / \mathrm{V}_{\mathrm{IF}}$ menores do que 0,10 , as salinidades, obtidas a partir das temperaturas de fusão do gelo e de hidratos, variam de 14,1 a cerca de $42 \%$ em peso $\mathrm{NaCl}$ equiv., predominando entre 14 e 18\%. As TE's estão restritas ao intervalo de $-53,7$ a $-44,3^{\circ} \mathrm{C}$, demonstrando composição predominantemente cálcica do sistema, sem descartar a presença de sódio, ferro e potássio, entre outros (Fig. 9.1.a e b). As Th's para o líquido são da ordem de 88,7 a $215,5^{\circ} \mathrm{C}$ (Fig. 9.1.c.). Fenômenos de meta-estabilidade são comuns.

Para as inclusões aquosas do tipo 3, obtiveram-se medidas em apenas uma delas, com salinidade de $29,6 \%$ em peso $\mathrm{NaCl}$ equiv., TE de $-42,3^{\circ} \mathrm{C}$ e Th de $329,0^{\circ} \mathrm{C}$.

Inclusões aquo-carbônicas primárias coexistem com as aquosas primárias do tipo 1 no quartzo. Raramente, observam-se monofásicas carbônicas gasosas. A proporção volumétrica da fase gasosa nas aquo-carbônicas é de 0,60 a 0,90 . Suas salinidades são dadas pela dissolução do clatrato ( $\mathrm{Tfcl}$ ), e situam-se no intervalo entre 6,1 a $11,7 \%$ em peso $\mathrm{NaCl}$ equiv. (Fig. 9.1.a). Uma única homogeneização total pela expansão da fase carbônica foi observada aos $397,3^{\circ} \mathrm{C}$ em uma inclusão $\operatorname{com} \mathrm{V}_{\mathrm{g}} / \mathrm{V}_{\mathrm{H}}$ de 0,80 (Fig. 9.1.c.). Análise por microespectrometria Raman indicou a presença de $\mathrm{CH}_{4}$ associado ao $\mathrm{CO}_{2}$, refletida na temperatura de fusão do $\mathrm{CO}_{2}\left(\mathrm{~T}^{\prime} \mathrm{CO} \mathrm{CO}_{2}\right) \mathrm{em}-58,2^{\circ} \mathrm{C}$ (Fig. 9.2.c e Fig. $9.3)$. 
a)

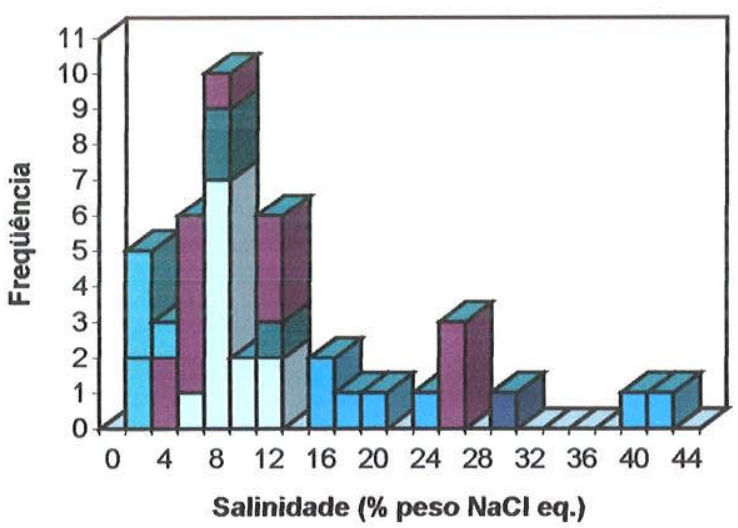

$\square$ campo 3, qtz, aq. sec. $\square$ campo 1, qtz, aq. sec. 口campo 2, top, aq-carb acampo 3, qtz, aq-carb. 口campo 1, qtz, aq-carb 口campo 3, qtz, aq. prim. 3 पcampo 3, qtz, aq. prim. 2 口campo 1, qtz, aq. prim. 2 $\square$ campo 1, qtz, aq. prim. 1

b)

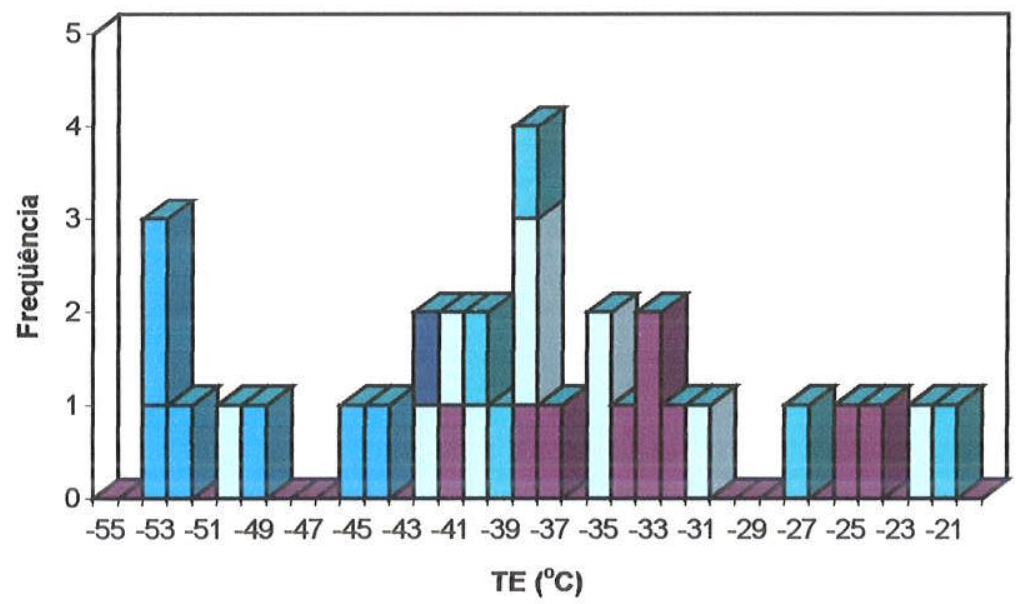

c)

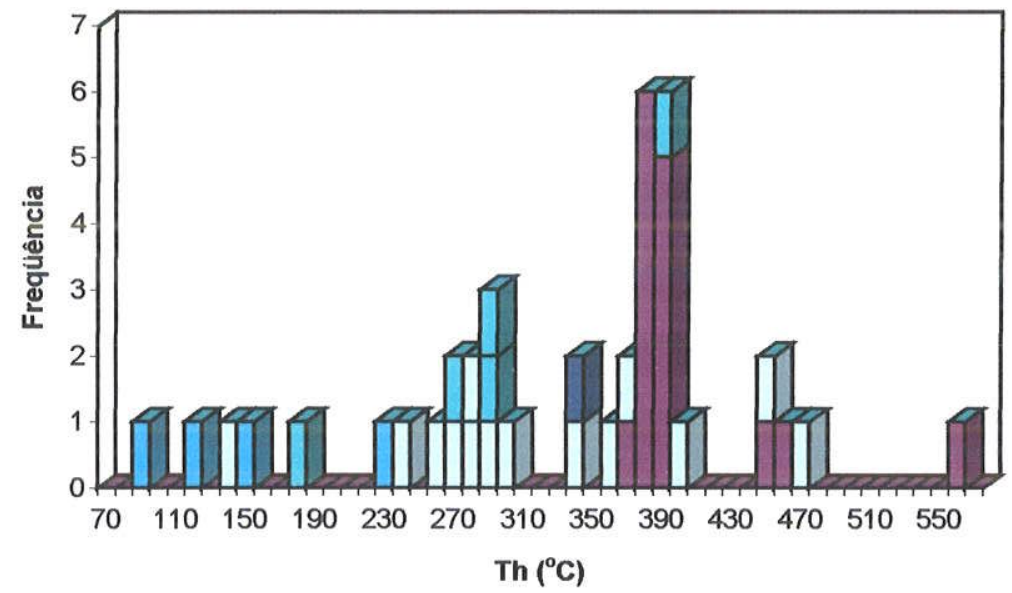

Figura 9.1 - Histogramas dos dados microtermométricos de a) salinidade, b) temperatura do ponto eutético, e c) temperatura de homogeneização para o líquido ou para o gás/vapor das inclusões aquosas e aquocarbônicas hospedadas em quartzo e topázio do albita-microclínio granito branco (AM-134). Legenda conforme Fig. 9.1.a. 

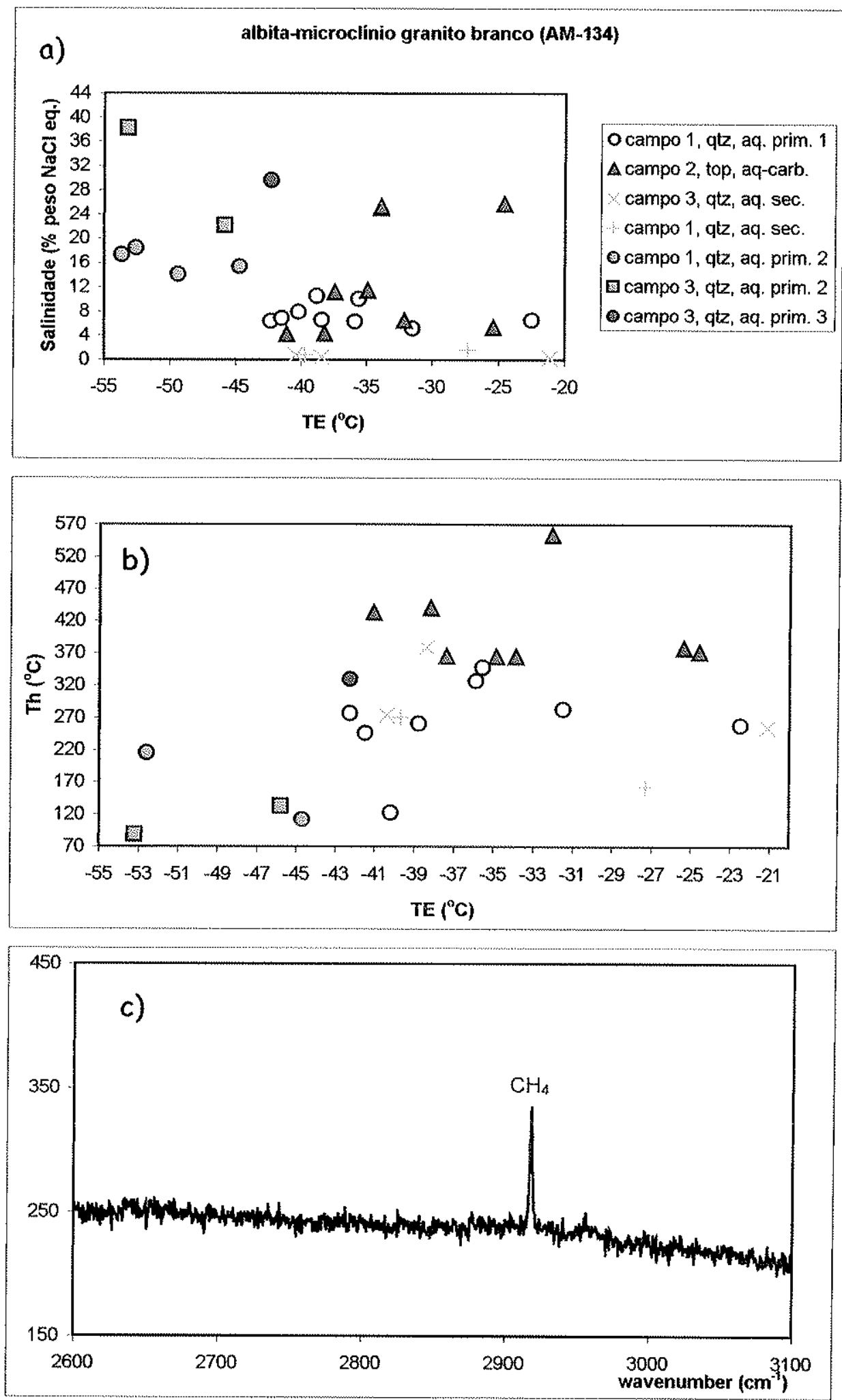

Figura 9.2 - Diagramas de correlação da TE versus a) salinidade; e b) Th. c) Espectro de efeito Raman da fase gasosa das inclusões aquocarbônicas primárias presentes no quartzo do albita-microclínio granito tino branco $(A M-134)$. 
Ainda no quartzo, observam-se trilhas intragranulares, radiais a partir de inclusões minerais, que são internas ao cristal ou atingem sua bordá. Dada a presença comum de feldspatos e mica, opacos, no entorno desses cristais de quartzo, raramente foi possível determinar a extensão dessas trilhas para além dos limites do cristal. Assim, as inclusões aquosas localizadas em ou espacialmente associadas a essas trilhas intragranulares foram, arbitrariamente, consideradas secundárias, ou tardias em relação àquelas descritas anteriormente. Podem ser pequenas e bemformadas, quadrangulares, ou ainda de formas irregulares, sempre com $V_{v} / V_{\text {II }}$ entre 0,10 e 0,50 . Suas salinidades são baixas, entre 0,3 e $3,0 \%$ em peso $\mathrm{NaCl}$ equiv., com pico entre 0 e $1 \%$. Há grande espalhamento das temperaturas do ponto eutético (TE), entre $-40,4$ e $-21,1^{\circ} \mathrm{C}$, sem pico definido, da mesma forma que as temperaturas de homogeneização (Th) para o líquido, obsetvadas entre os 163,7 e os $380,0^{\circ} \mathrm{C}$ (Fig. 9.1.a, b e c).

Os diagramas das Figs. 9.2.a e b mostram que as inclusões aquosas primárias de maior salinidade (tipo 2) são também as que apresentam os menores valores de TE (composições mais cálcicas), e as mais baixas 'Th's. Observa-se correlação negativa no diagrama salinidade versus TE, no que diz respeito às inclusões aquosas primárias, e também a algumas aquo-carbônicas, à despeito da imprecisão das medidas das 'TE's das aquo-carbônicas dada pela presença de clatratos.

No topázio são observadas melt inclusions além de inclusões aquo-carbônicas, as últimas de formas irregulares e tamanhos muito variáveis, com feições pronunciadas de necking down. A proporção volumétrica da fase vapor das inclusões aquo-carbônicas é de 0,25 a mais de 0,90 . Ocorrem em uma larga banda, que atravessa o cristal de borda a borda, e foram interpretadas como secundárias (Prancha 9.1.b).

Apresentam salinidades, calculaclas a partir da fusão de clatratos e de hidratos, vatiáveis dos 3,4 aos $25,7 \%$ em peso $\mathrm{NaCl}$ equiv.. As TE's situam-se no intervalo de $-42,1$ a $-24,6^{\circ} \mathrm{C}$, indicando soluções compostas provavelmente por $\mathrm{NaCl}+\mathrm{KCl} \pm \mathrm{CaCl}_{2} \pm \mathrm{FeCl}_{2}+\mathrm{H}_{2} \mathrm{O}$ (Borisenko 1978, Crawford 1981, Davis et al. 1990). As 'Th's, pela expansão da fase aquosa e da fase carbônica, ocorrem entre 356,3 e $553,0^{\circ} \mathrm{C}$ (Fig. 9.1.a, b e c), sendo que aquelas maiores do que $390^{\circ} \mathrm{C}$, observadas em inclusões homogeneizadas para o gás, são tidas como superestimadas (cf. Bodnar et al., 1985).

A composição do $\mathrm{CO}_{2}$ é quase pura, visto que suas temperaturas de fusão, consistentes entre $-57,0$ e $-56,8^{\circ} \mathrm{C}$ (Fig. 9.3), são pouco inferiores ao ponto triplo do $\mathrm{CO}_{2}\left(-56,6^{\circ} \mathrm{C}\right.$; Angus et al., 1976) 
nas inclusões onde foi possível observar essa mudança de fase. A presença de $\mathrm{CO}_{2} \mathrm{l}$ é rara e a temperatura de homogeneização do componente $\left(\mathrm{ThCO}_{2}\right)$ foi obtida em apenas uma inclusão. $\mathrm{Na}$ maioria dos casos, a existência de $\mathrm{CO}_{2}$ foi identificada unicamente pela formação de clatratos, demonstrando a pequena concentração do componente. $\mathrm{O}$ valor de $\mathrm{X}_{\mathrm{CO} 2}$ obtido permite classificar o sistema como de 'alta $\mathrm{X}_{\mathrm{H} 2 \mathrm{O}}$ ' (Diamond 1994, 2001). Diamond $(1994,2001$ ) relata que a homogeneização do $\mathrm{CO}_{2}$ pode não ser vista e que a determinação das Th's para o gás é muito difícil nesse tipo de inclusão quando aprisionada em baixa pressão.

Cabe ressaltar que a maioria das salinidades dessas inclusões fluidas foram calculadas à partir das Tfcl's, mesmo na ausência do $\mathrm{CO}_{2} \mathrm{l}$. A presença do $\mathrm{CO}_{2} \mathrm{l}$ é pré-requisito para a estimativa de salinidades pelo clatrato, conforme Collins (1979). Entretanto, Graupner et al. (1999) argumentam que a ausência da fase não causa maiores erros nessa estimativa.

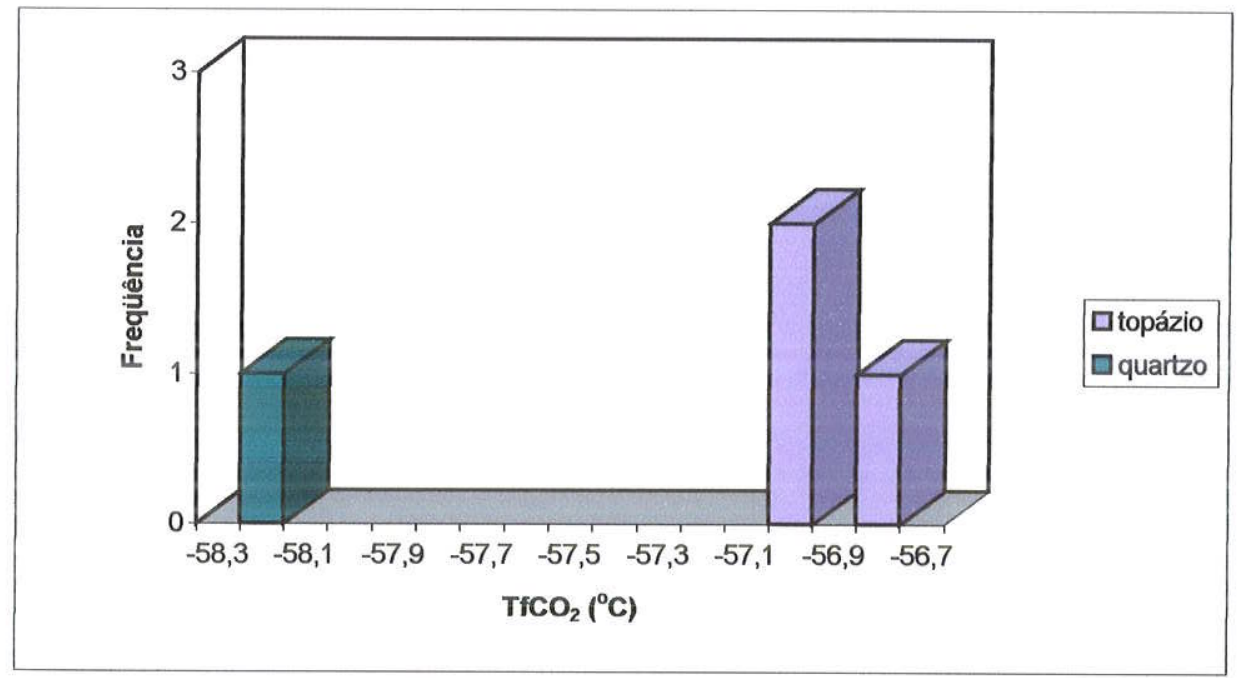

Figura. 9.3. Temperatura de fusão do $\mathrm{CO}_{2}$ nas inclusões aquo-carbônicas primárias em quartzo e aquo-carbônicas secundárias em topázio do albitamicroclínio granito branco (AM-134).

\section{b) Pegmatito}

Foram medidas cerca de 50 inclusões em um único campo, hospedadas em quartzo. Três populações de inclusões dispostas em trilhas foram identificadas. Como a seção compreende um único cristal de quartzo, não foi possível determinar se as trilhas são inter ou intragranulares, porém as feições são seguramente indicativas de origem secundária para a população 3.

A primeira população foi considerada a mais antiga com base nas Th's mais elevadas. Compreende discretas trilhas de pequenas inclusões aquosas, com volume da fase vapor constante, da ordem de 0,10. Suas Th's são de 327,7 a $369,6^{\circ} \mathrm{C}$ (Fig. 9.4.a). 
a)

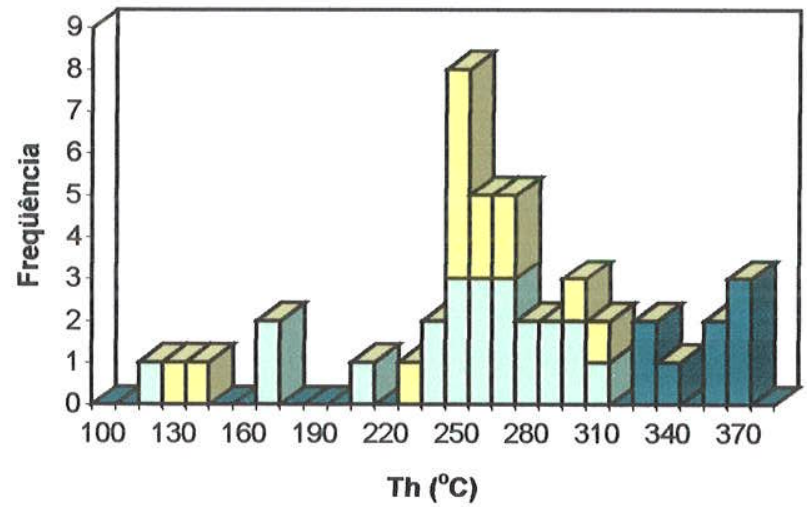

口aq-carb sec 3

口aq. sec. 2

口aq. sec. 1

b)

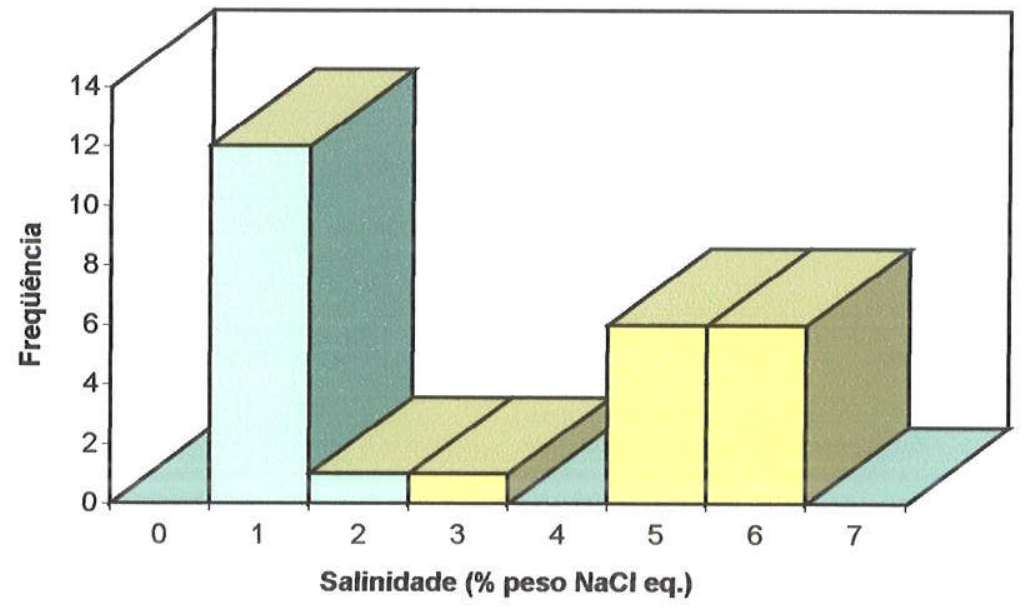

c)

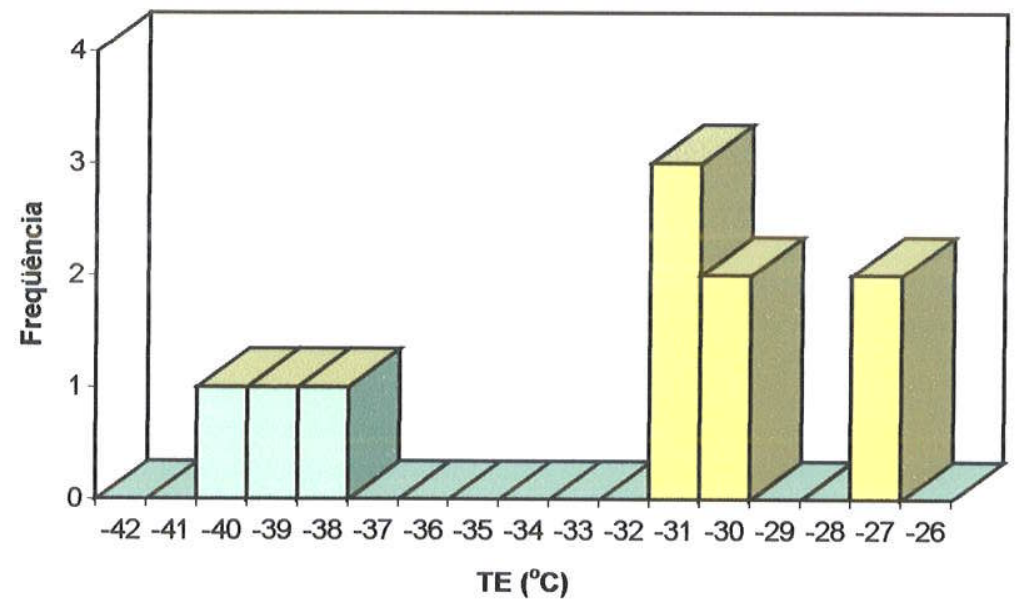

Figura 9.4 - Histogramas dos dados microtermométricos de a) temperatura de homogeneização para o líquido ou para o gás/vapor, b) temperatura do ponto eutético, e c) salinidade das inclusões aquosas e aquocarbônicas hospedadas em quartzo do pegmatito (AM-213). Legenda conforme Fig. 9.4.a. 
A segunda população compreende inclusões na forma de cristais negativos, pequenas e abundantes, dispostas em planos bem definidos. São aquosas, com fase vapor de volume constante de cerca de 0,15 (Prancha 9.1.c e d). Suas Th's para o líquido situam-se entre 114,2 e $302,0^{\circ} \mathrm{C}$, com concentração maior nas temperaturas superiores a $230^{\circ} \mathrm{C}$. As salinidades variam de 0,2 a $1,3 \% \mathrm{em}$ peso $\mathrm{NaCl}$ equiv. com pico entre 0 e $1 \%$. As 'TE's ocorrem na faixa dos $-40,2$ aos $-38,6^{\circ} \mathrm{C}$, que sugerem composição do fluido no sistema $\mathrm{CaCl}_{2} 6 \mathrm{FeCl}_{2}+\mathrm{NaCl}+\mathrm{H}_{2} \mathrm{O}$ (Fig. 9.4.a, b e c).

Inclusões maiores, quadrangulares ou irregulares, distribuídas ao longo de ramificações sinuosas de trilhas ortogonais aos planos da segunda população, constituem a população 3. São aquo-carbônicas, com volume da fase gasosa entre 0,10 e 0,55 do tamanho da inclusão (Prancha 9.1.c e e). Não foram observadas quaisquer mudanças de fase relacionadas à presença de $\mathrm{CO}_{2}$ e de $\mathrm{CH}_{4}$, que foram identificados somente por microespectrometria Raman (Fig. 9.5.a e b), indicando as densidades extremamente baixas desses componentes.

As 'Th's pela expansão da fase aquosa variam de 128,0 a $304,4^{\circ} \mathrm{C}$, com moda entre 240 e $250^{\circ} \mathrm{C}$. As 'TE's situam-se na faixa dos $-31,9$ aos $-27,7^{\circ} \mathrm{C}$, e indicam um sistema de composição predominantemente sódica.

As salinidades foram calculadas a partir da fusão do gelo, porque não houve deformação da bolha (indicativa da presença de clatrato) durante resfriamentos cíclicos. O rebaixamento do ponto triplo da água na presença do $\mathrm{CO}_{2}$ (Hedenquist \& Henley, 1985), entretanto, sugere que as temperaturas de fusão do gelo (Tfg's) medidas são menores do que as reais e, conseqüentemente, que as salinidades, entre 3,0 a $5,8 \%$ em peso $\mathrm{NaCl}$ equiv., estão superestimadas.

\subsubsection{Estágio transicional}

\section{a) Bolsão de quartzo com siderofilita e topázio}

Este litotipo foi extensivamente explorado na microtermometria em função do tamanho e quantidade das inclusões fluidas, que redundaram em grande facilidade de execução das medidas. Cinco campos em topázio e quatro em quartzo foram analisados, totalizando mais de 240 inclusões.

No topázio, as inclusões fluidas são aquosas bifásicas e multifásicas, com $V_{v} / V_{F F}$ vatiável de 0,30 a 0,55. A presença de sólidos birrefringentes é muito comum, e seu número é de cerca de 1 a 4 por inclusão. A microespectrometria Raman em um deles demonstrou tratar-se calcita (Fig. 9.5.c). 

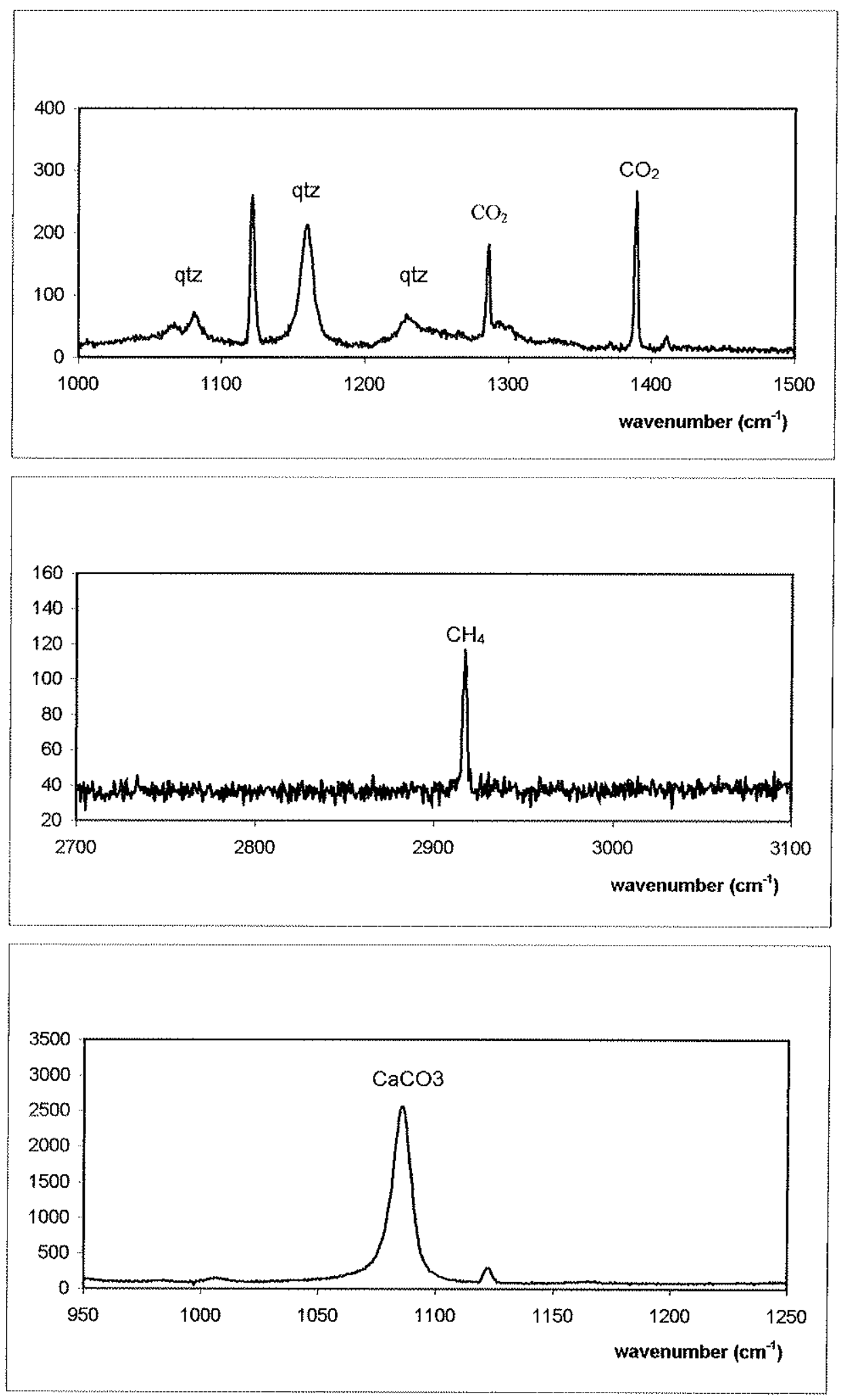

Figura 9.5 - Espectros de efeito Raman demonstrando a presença de a) $\mathrm{CO}_{2}$ e de b) $\mathrm{CH}_{4}$ nas inclusões aquo-carbônicas secundárias do tipo $3 \mathrm{em}$ quartzo do pegmatito (AM-213); c) de sólido presente em inclusão fluida aquosa multifásica no topázio do bucho de quartzo com siderofilita e topázio (AM-168A). 
Durante o aquecimento, houve dissolução de 1 ou 2 sólidos em algumas inclusões, muito raramente de um terceiro sólido, mas a maioria deles permaneceu, embora sofrendo diversas dissoluções parciais ou reações, até os $600^{\circ} \mathrm{C}$.

Com efeito, esse comportamento é esperado em vista da solubilidade retrógrada da calcita (ff. Holland 1967, Higgins 1985, Hedenquist \& Henley 1985, Rimstidt 1997). A precipitação do mineral é governada pela temperatura, $\mathrm{pH}$, pressão de $\mathrm{CO}_{2}$ e salinidade da solução, podendo resultar da degaseificação ou do aumento de pH, por exemplo, conforme ilustra a reação

$$
\mathrm{Ca}^{+2}+2 \mathrm{HCO}^{-3} \Leftrightarrow \mathrm{CaCO}_{3}+\mathrm{CO}_{2}(\mathrm{~g})+\mathrm{H}_{2} \mathrm{O}
$$

Segundo Ramboz et al. (1982), o boiling de soluções saturadas em um ou mais sólidos pode levar ao aprisionamento heterogêneo de quantidades variáveis desses sólidos, o que redundaria em acréscimo nas salinidades das inclusões com pouca mudança nas 'Th's. A ocorrência das menores temperaturas de fusão desses sólidos no mesmo intervalo das temperaturas de homogeneização da inclusão é um bom indício desse fenômeno (Ramboz et al. 1982).

A proporção variável de sólidos em inclusões fluidas distintas pode significar aprisionamento ocasional ou formação dos carbonatos como conseqüência da degaseificação de um sistema imiscível. Desse modo, as temperaturas de dissolução dos sólidos não representariam as salinidades reais do fluido original. Assim, as salinidades e as densidades calculadas a partir da fusão do gelo (Ifg) são tidas como mais apropriadas para a avaliação da evolução fluidal da amostra em apreço.

São identificadas três populações de inclusões aquosas no topázio, com base na sua distribuição espacial. As consideradas primárias, de ocorrência predominante em um dos cinco campos estudados, compreendem inclusões prismáticas longas orientadas paralelamente ao seu comprimento (Prancha 9.1.f). Possuem salinidades de 9,1 a 14,9\% em peso $\mathrm{NaCl}$ equiv., com forte concentração entre 10 e $12 \%$. O espectro TE's é amplo, dos $-51,0$ aos $-26,8^{\circ} \mathrm{C}$, com picos em -49 a $-45^{\circ} \mathrm{C}$ e $-37^{\circ} \mathrm{C}$, mostrando a influência do cálcio e do ferro no sistema. As Th's, para o líquido e para o vapor, ocorrem dos 400 aos $506^{\circ} \mathrm{C}$, com moda entre 450 e $490^{\circ} \mathrm{C}$ (Fig. 9.6.a, b e c).

A segunda população consiste da maioria das inclusões presentes no topázio. Compreende inclusões aquosas em cristais negativos, não orientadas, distribuídas em superfícies sinuosas (Prancha 9.1.g). Podem ser pseudo-secundárias ou secundárias, mas são sem dúvida posteriores às orientadas. Serão doravante tratadas como pseudo-secundárias. 


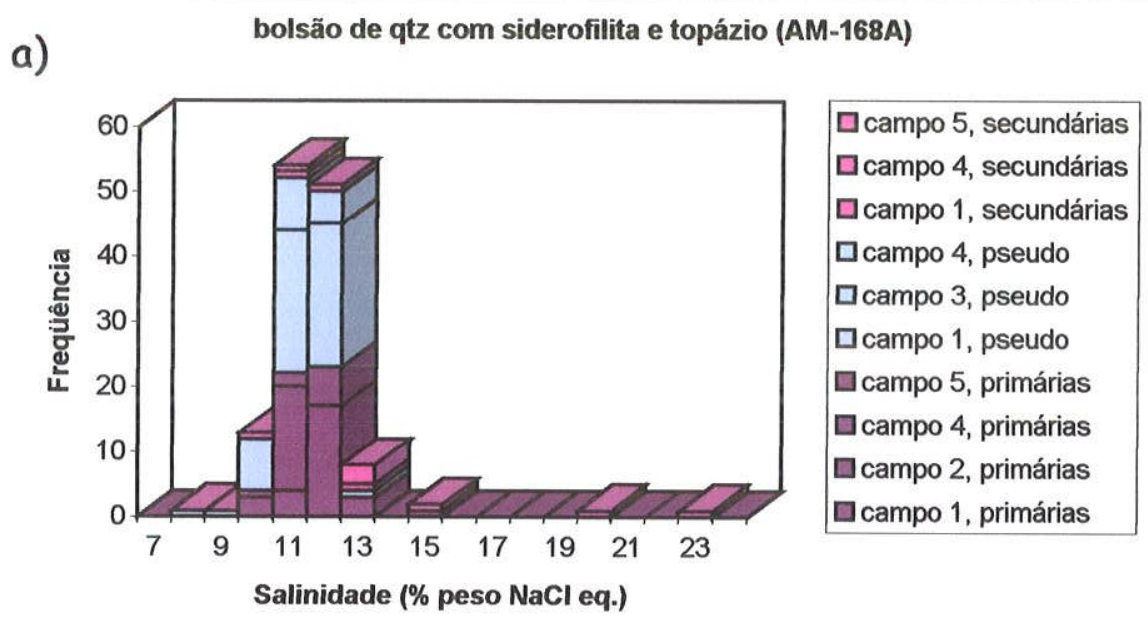

b)

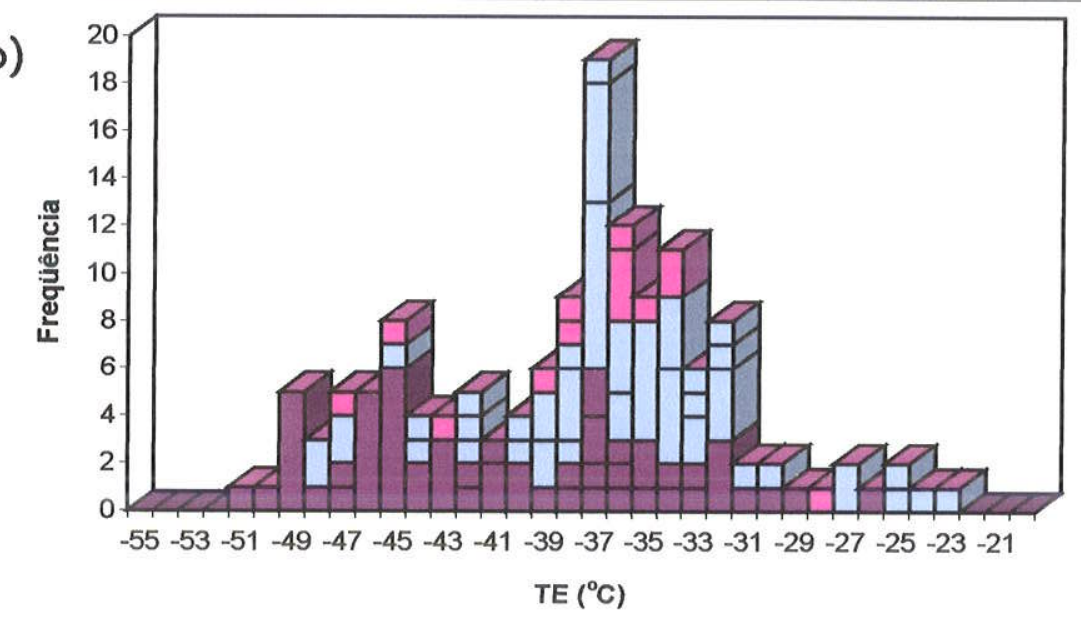

c)

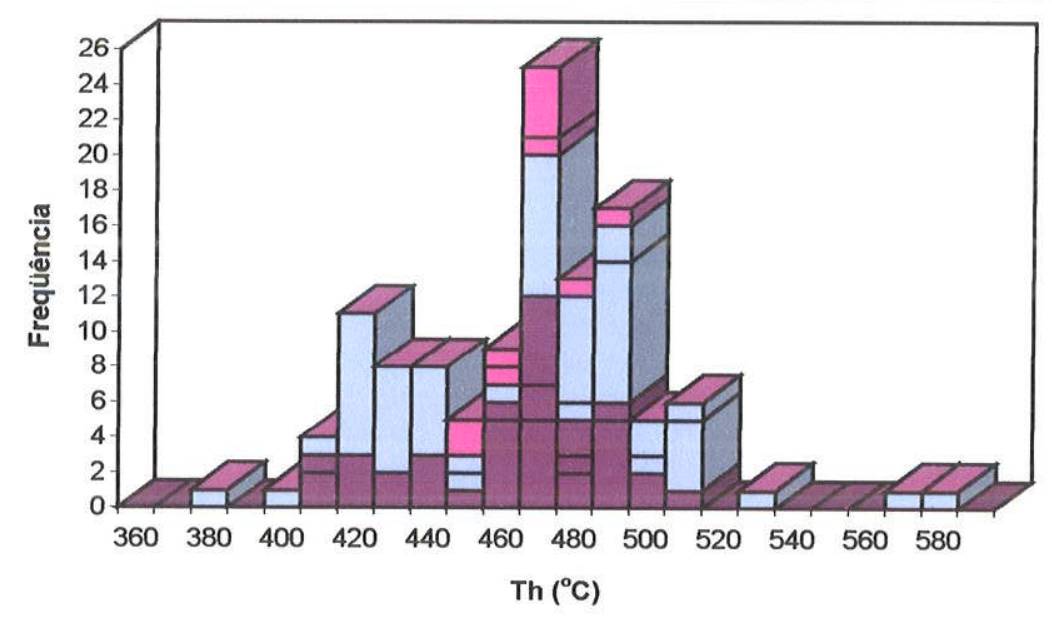

Figura 9.6 - Histogramas dos dados microtermométricos de a) salinidade, b) temperatura do ponto eutético, e c) temperatura de homogeneização para o líquido ou para o vapor das inclusões aquosas hospedadas em topázio (AM-168A) do bucho de quartzo com siderofilita e topázio. Legenda conforme Fig. 9.6.a. 
As salinidades dessa população estão na faixa dos 7,1 aos $12,2 \%$ em peso $\mathrm{NaCl}$ equiv., com pico bem definido entre 10 e $12 \%$. Diferentemente das inclusões primárias, as pseudosecundárias apresentam uma única faixa de predomínio para as TE's, entre -39 e $-32^{\circ} \mathrm{C}$, com moda em $-37^{\circ} \mathrm{C}$, embora seu espectro de variação seja igualmente amplo $\left(-48,9 \mathrm{a}-23,5^{\circ} \mathrm{C}\right)$. As Th's, para o líquido e para o vapor, ocorrem de 374,9 a $572,7^{\circ} \mathrm{C}$, mas predominantemente entre os 400 e os $490^{\circ} \mathrm{C}$, um espectro mais amplo que o da primeira população (Fig. 9.6.a, b e c).

Dentre as inclusões pseudo-secundárias foram identificadas apenas duas aquo-carbônicas (campo 4), com salinidades calculadas pela fusão do clatrato (Tfcl) em 7,1 e 8,1\% em peso $\mathrm{NaCl}$ equiv. e temperatura de fusão do $\mathrm{CO}_{2}\left(\mathrm{TfCO}_{2}\right)$ de $-61,3{ }^{\circ} \mathrm{C}$. Sua presença demonstra a possibilidade de que outras inclusões dessa população também possam ter $\mathrm{CO}_{2}$, em pequenas quantidades.

Inclusões aquosas secundárias, dispostas em planos, são menos freqüentes. Cobrem toda a faixa de salinidades observadas nas duas populações anteriores, sem pico definido. Suas TE's estão entre $-47,1$ e $-25,8^{\circ} \mathrm{C}$, com ligeira concentração entre -38 e $-34^{\circ} \mathrm{C}$. As Th's para o líquido são de 446,1 a $484,2^{\circ} \mathrm{C}$, predominando entre 460 e $470^{\circ} \mathrm{C}$ (Fig. 9.6.a, b e c).

Nas três populações descritas no topázio, a variação de TE's se dá em condições de salinidade quase constante, com leve correlação negativa (Fig. 9.7). Fogem da regra raras inclusões, na maioria secundárias, cujas salinidades são maiores do que $14 \%$ em peso $\mathrm{NaCl}$ equiv..

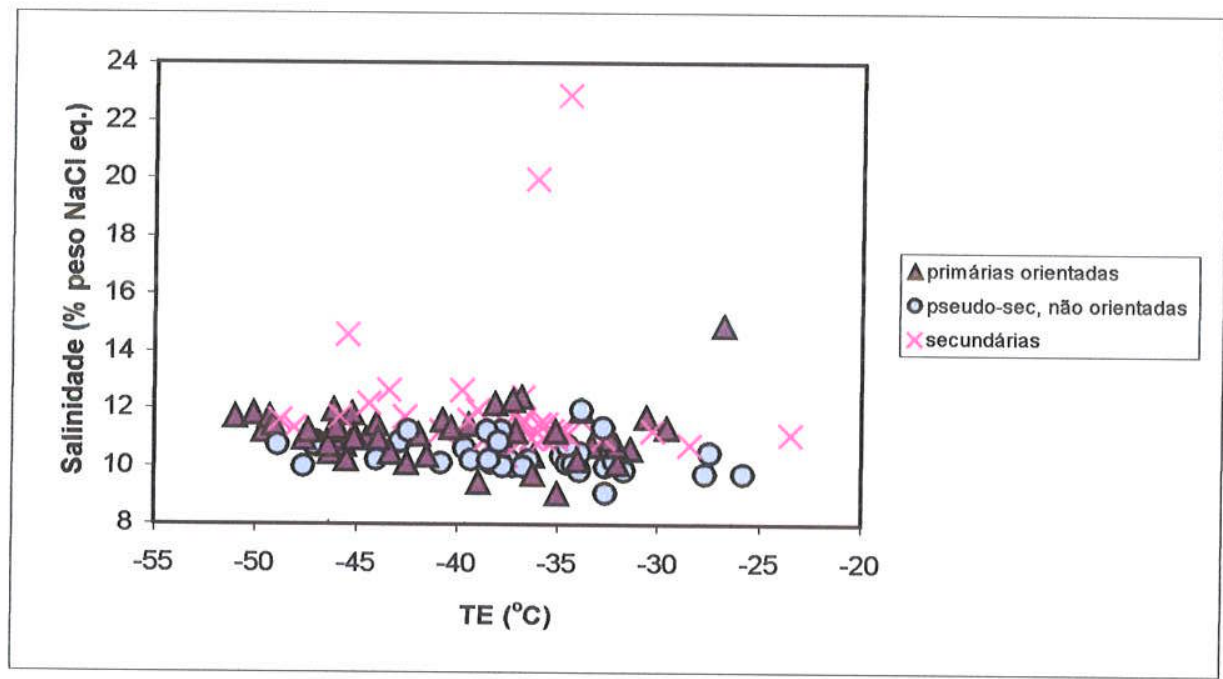

Figura 9.7 - Diagrama de covariação salinidade versus temperatura do ponto eutético (TE) para o topázio (AM-168A) do bolsão de quartzo com siderofilita e topázio.

As temperaturas do ponto crítico calculadas foram, algumas vezes, menores do que as temperaturas de homogeneização, para o líquido e para o vapor. Isso parece indicar que, em algumas 
inclusões, as salinidades foram subestimadas. Os poucos sólidos que dissolveram em temperaturas menores do que a 'Th líquido-vapor podem sinalizar que a salinidade real do fluido é maior do que a calculada pela T'fg.

O quartzo coexistente com o topázio no bolsão de quartzo com siderofilita e topázio apresenta abundantes pequenas inclusões bifásicas e monofásicas, secundárias (Prancha 9.1.h). Ainda que se tenha procurado trabalhar $\mathrm{cm}$ regiões intertrilhas, não é possível assegurar que quaisquer das populações estudadas sejam inequivocamente primárias.

A população com maior probabilidade de origem primária ocorre ao longo de planos que aparentam ser faces de crescimento do quartzo hospedeiro. Compreende inclusões aquosas e aquocarbônicas pequenas a grandes, com grande variação da fração volumétrica da fase vapor $(0,10$ a 0,70 ) e da forma das inclusões (Prancha 9.2.a e b).

As aquosas são bifásicas e, menos freqüentemente, multifásicas. Quando multifásicas, possuem um a três sólidos que, da mesma forma que aqueles presentes no topázio, não dissolveram até os $600^{\circ} \mathrm{C}$ durante o aquecimento. As $\mathrm{V}_{\mathrm{v}} / \mathrm{V}_{\mathrm{l}}$ variam de 0,10 a 0,40 . As salinidades são de 4,9 a $14,1 \%$ em peso $\mathrm{NaCl}$ equiv., com moda no intervalo de 13 a $14 \%$. As 'T'E's são de $-41,3$ a $-31,9^{\circ} \mathrm{C}$, concentrando-se na faixa dos -41 aos $-38^{\circ} \mathrm{C}$. As Th's para o líquido vão dos 97,6 aos $417,5^{\circ} \mathrm{C}$, com sugestão de concentração no intervalo de 100 a $140^{\circ} \mathrm{C}$ (Fig. 9.8.a, b e c).

As aquo-carbônicas são bifásicas, trifásicas e multifásicas. Quando multifásicas, contêm um ou dois cristais de calcita (Fig. 9.9.a), que também não dissolveram durante o aquecimento. As proporções volumétricas da fase gasosa são de 0,35 a 0,70 . As salinidades, calculadas a partir da Tfcl, são de 4,7 a $11 \%$ em peso de $\mathrm{NaCl}$ equiv., concentrando-se no intervalo de 10 a $11 \%$. As temperaturas do ponto eutético variam de $-48,3$ a $-24,8^{\circ} \mathrm{C}$, sem pico definido. As Th's, pela expansão da fase aquosa e da fase carbônica, vão de 206,4 a $524,0^{\circ} \mathrm{C}$, sem moda definida (Fig. 9.8.a, b e c).

A fase carbônica homogeneiza $\left(\mathrm{ThCO}_{2}\right)$, tanto para o líquido quanto para o vapor, entre 29,4 e $30,3^{\circ} \mathrm{C}$. Além do $\mathrm{CO}_{2}$, apresenta traços de $\mathrm{CH}_{4}$ (Fig. 9.9.b e c). A impureza da fase carbônica reflete-se nas $\mathrm{TfCO}_{2}$, no intervalo de $-58,4 \mathrm{e}-58,1^{\circ} \mathrm{C}$ (Fig. 9.10). 

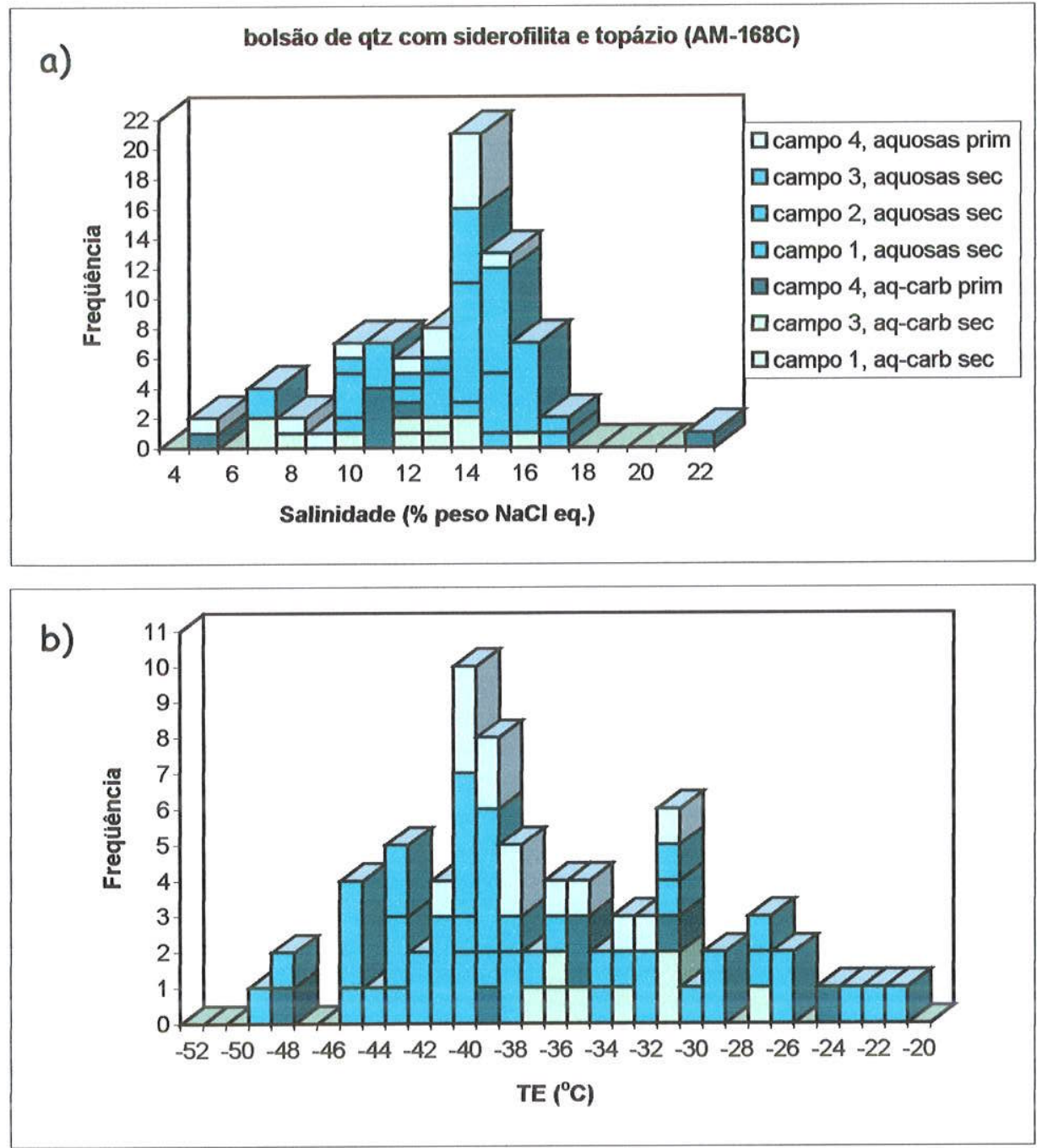

c)

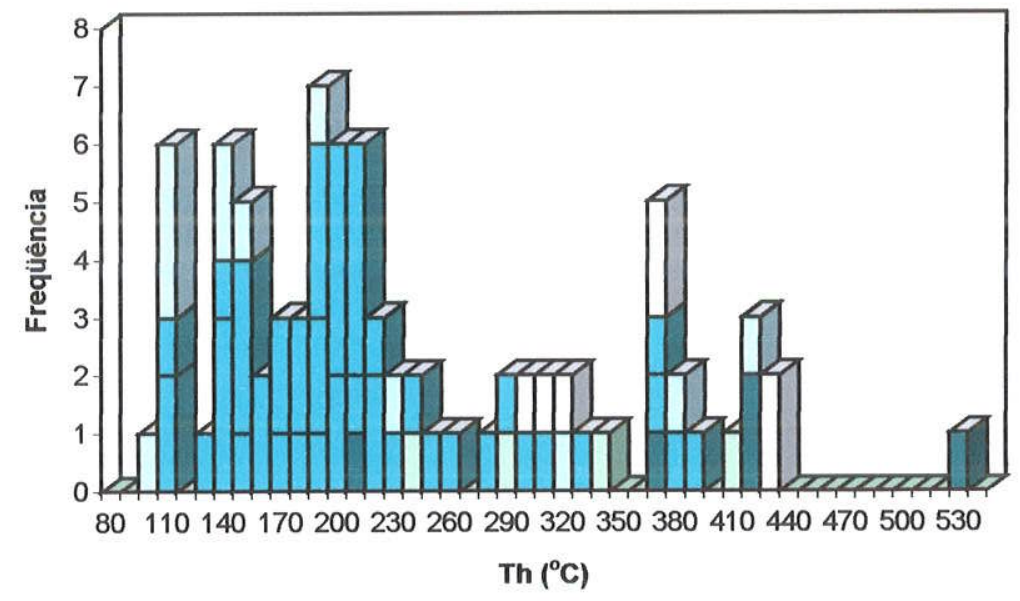

Figura 9.8 - Histogramas dos dados microtermométricos de a) salinidade, b) temperatura do ponto eutético, e c) temperatura de homogeneização para o líquido ou para o gás das inclusões aquosas e aquo-carbônicas hospedadas em quartzo (AM-168C) do bolsão de quartzo com siderofilita e topázio. Legenda conforme Fig. 9.8.a. Barras incolores inclusões sem classificação. 
a)
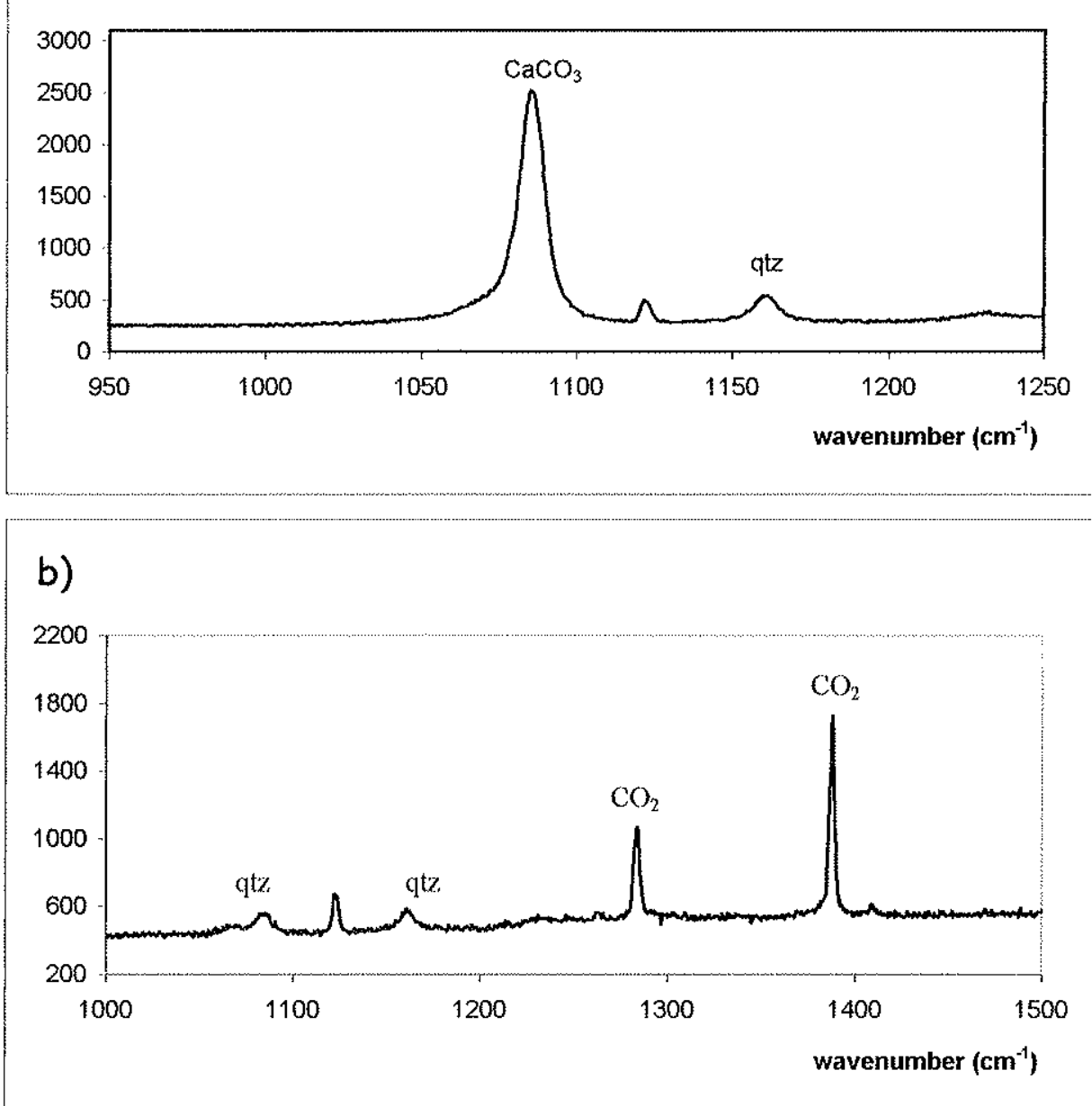

\section{c)}

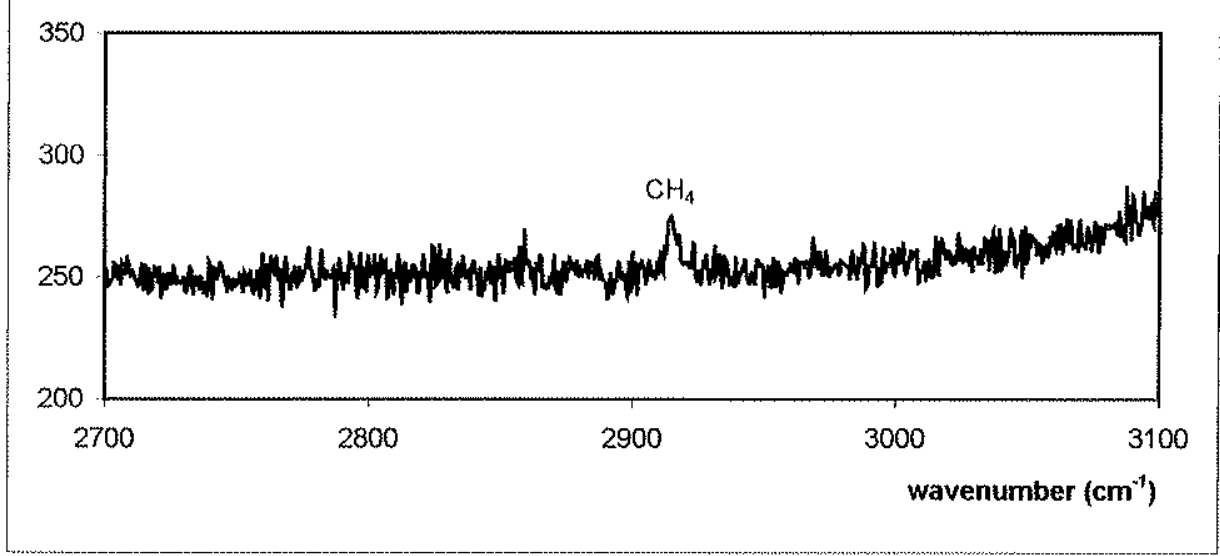

Figura 9.9 - Espectros de efeito Raman de a) sólido em inclusão aquo carbónica primária hospedada no quartzo do bolsão de quartzo com siderofilita e topázio ( $A M-168 C$ ); b) e c) dos gases presentes na fase gasosa das inclusöes aquo-carbônicas. 
Dos outros três campos estudados na amostra, dois consistem de inclusões aquosas e aquo-carbônicas coexistentes, enquanto que o terceiro possui apenas inclusões aquosas. São todas consideradas secundárias e tratadas conjuntamente. Os histogramas dos dados microtermométricos são apresentados para os três campos, na Fig. 9.8, como inclusões aquosas e aquo-carbônicas secundárias.

As inclusões aquosas dos dois campos em que elas coexistem com aquo-carbônicas são bifásicas e multifásicas com um a três sólidos. Em ambos as inclusões são de tamanhos e formas variados, bem como as bolhas, que ocupam 10 a 50\% das inclusões. As salinidades variam de 6,7 a 16,7\% em peso $\mathrm{NaCl}$ equiv., com pico dos 12 aos 16\%. As TE's são de $-49,9$ a $-21,8$, com predomínio no intervalo de $-46 \mathrm{a}-38^{\circ} \mathrm{C}$. Há grande espalhamento das Th's para o líquido, desde 102,2 a $388,5^{\circ} \mathrm{C}$, com sugestão de concentração entre os 130 e os $160^{\circ} \mathrm{C}$.

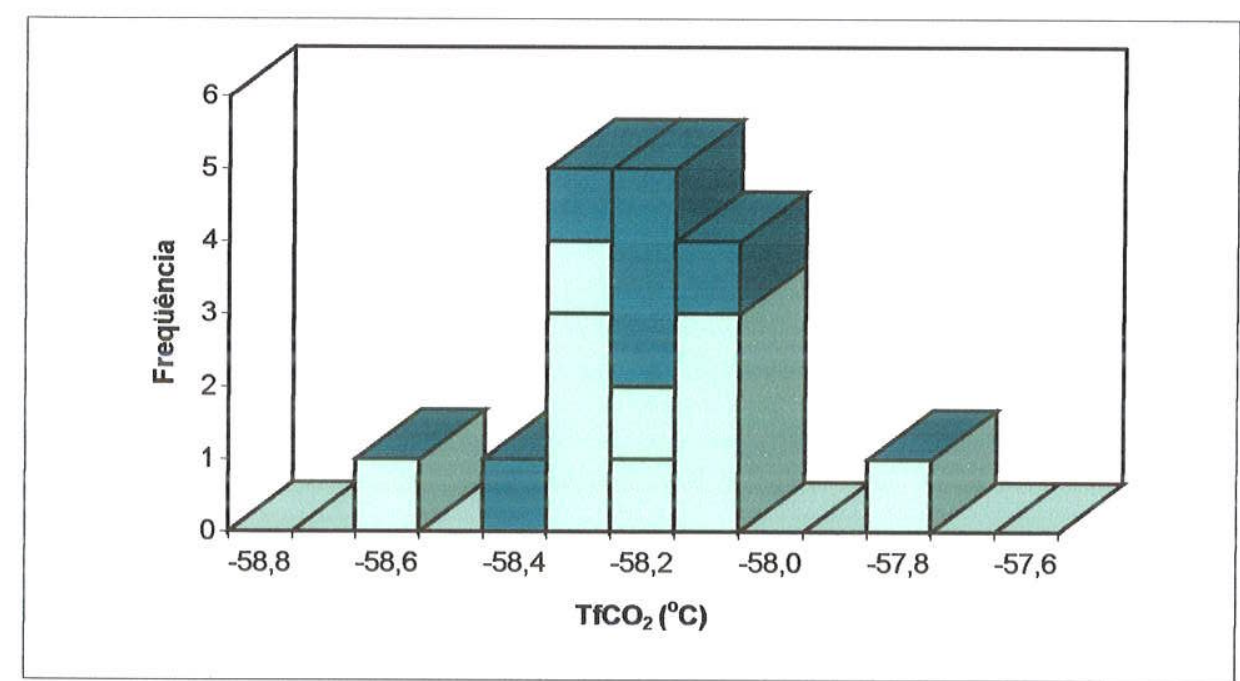

Figura 9.10 - Temperaturas de fusão do $\mathrm{CO}_{2}\left(\mathrm{TfCO}_{2}\right)$ das inclusões aquocarbônicas hospedadas no quartzo (AM-168C) do bolsão de quartzo com siderofilita e topázio. Barras: verde-escuras - aquocarbônicas primárias; verde-claras - aquo-carbônicas secundárias.

As aquo-carbônicas são bifásicas, muito raramente trifásicas e multifásicas, no último caso com apenas um sólido. A fração volumétrica da fase vapor varia de 0,35 a mais de 0,90 . As salinidades, estimadas pelas Tfcls, são de 6,1 a 15,4\% em peso $\mathrm{NaCl}$ equiv., sem moda definida, da mesma forma que as TE's e que as Th's, na maioria pela expansão da fase aquosa, que oscilam de $-37,6$ a $-27,0^{\circ} \mathrm{C}$ e de 234,4 a $409,8^{\circ} \mathrm{C}$, respectivamente. As Th's pela expansão da fase gasosa das inclusões com maiores proporções volumétricas da fase vapor não foram obtidas dadas as dificuldades de observação da temperatura exata em que a bolha atinge a parede da inclusão.

Uma discreta impureza da fase carbônica é denunciada pelas $\mathrm{TfCO}_{2}$, concentradas entre - 
58,6 e -57,8 $8^{\circ} \mathrm{C}$ (Fig. 9.10). Foram observadas homogeneizações do $\mathrm{CO}_{2}$ para o gás entre 15,9 e $26,0^{\circ} \mathrm{C}\left(\mathrm{ThCO}_{2}\right)$.

Tanto as aquo-carbônicas consideradas primárias quanto aquelas tidas como secundárias pertencem ao tipo 'alta $\mathrm{X}_{\mathrm{H} 2 \mathrm{O}}$ ', de Diamond $(1994,2001)$.

Por fim, as inclusões aquosas sem aquo-carbônicas associadas apresentam bolhas de tamanho menos variável (10 a 30\% da inclusão). Ocorrem como pequenas inclusões quadrangulares ou retangulares, bifásicas e multifásicas com até dois sólidos. Suas salinidades variam de 9,5 a 14,6\% em peso $\mathrm{NaCl}$ equiv., com moda entre 13 e 14\%. As TE's são espalhados dos $-48,8$ aos $-26,3^{\circ} \mathrm{C}$, sem pico definido, da mesma forma que as Th's para o líquido, observadas entre 104,7 e $305,1^{\circ} \mathrm{C}$.

O conjunto das inclusões estudadas no quartzo exibe boa correlação negativa dos seus valores de salinidade e de TE (Fig. 9.11).

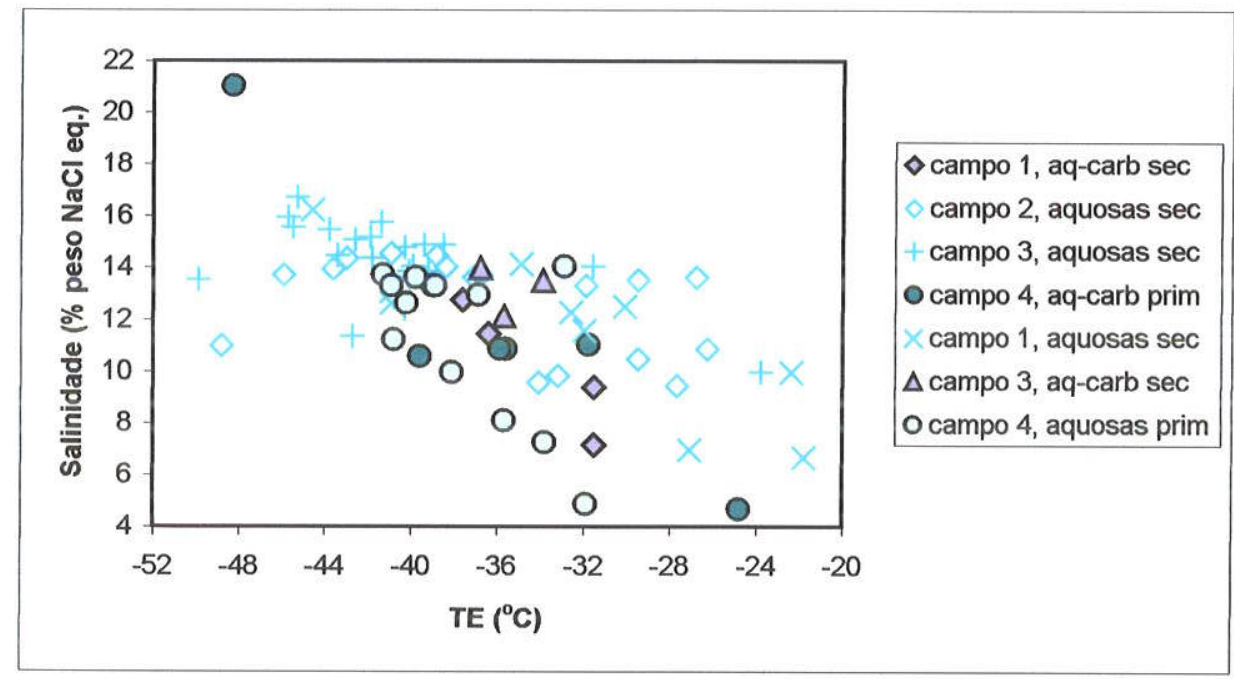

Figura 9.11 - Diagrama de covariação salinidade versus temperatura do ponto eutético (TE) para o conjunto das inclusões estudadas no quartzo (AM-168C) do bolsão de quartzo com siderofilita e topázio.

\section{b) Topázio-siderofilita-quartzo greisen tabular}

Foram analisados dois campos em topázio e quatro campos em quartzo, totalizando 40 e 155 inclusões fluidas, respectivamente.

O topázio possui abundantes silicate-melt inclusions. Caracterizam-se por formas equidimensionais quadrangulares a prismáticas longas, ou tubulares, desde pequenas até grandes, com bolhas de vapor/gás e/ou líquido de tamanhos variáveis (Prancha 9.2.c). Na fase sólida, a espectrometria Raman identificou picos em 407, 560, 937 e $985 \mathrm{~cm}^{-1}$, atribuíveis ao efeito Raman do 


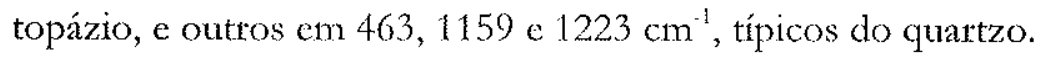

A fase fluida pode ser monofásica ou bifásica. Se monofásica, é de vapor ou gás. Quando bifásica, é constituída por uma fase líquida e uma pequena bolhas de gás/vapor.

Quanto à composição, podem ser: aquosas ou, predominantemente, aquo-carbônicas. As salinidades calculadas a partir das Tfg's ou das 'Ttel's, nos casos em que a fase fluida permitiu medidas microtermométricas, é de 10,0 a $15,2 \%$ em peso $\mathrm{NaCl}$ equiv., nas aquo-carbônicas, e de cerca de $1 \%$ nas aquosas, sempre coerentes com aquelas das inclusões fluidas aquosas e aquocarbônicas coexistentes. A TE foi estimada em apenas uma silicate-melt inclusion aquosa, em $-27,1^{\circ} \mathrm{C}$ (Fig. 9.12.a e b), indicando composição sódica para o fluido mais primitivo.

As $\mathrm{TfCO}_{2}$ nas silicate-melt inclusions aquo-carbônicas são de $-57,2 /-57,1^{\circ} \mathrm{C}$ a $-56,7^{\circ} \mathrm{C}$ (Fig. 9.13.a). $\mathrm{O} \mathrm{CH}_{4}$ acompanha o $\mathrm{CO}_{2}$.

Além das melt inclusions, o topázio hospeda inclusões fluidas aquo-carbônicas primárias, predominantemente, e aquosas. As aquo-carbônicas são bifásicas e multifásicas, podendo ter até dois sólidos que, na grande maioria, não dissolveram no aquecimento até $600^{\circ} \mathrm{C}$. Via de regra possuem formas prismáticas curtas, constituindo cristais negativos, mas feições de necking down são encontradas. As bolhas têm volumes desde 10 até $90 \%$ da inclusão, mas algumas com mais de $90 \%$ de gás, praticamente monofásicas, também estão presentes (Prancha 9.2,d).

As inclusões aquo-carbônicas ocorrem em um intervalo de salinidades de 2,2 a $13,2 \% \mathrm{em}$ peso $\mathrm{NaCl}$ equiv., predominando dos 5 aos $11 \%$. As TE's são de $-32,6$ a $-24,8^{\circ} \mathrm{C}$, concentrando-se entre -27 e $-25^{\circ} \mathrm{C}$. As 'Th's pela expansão da fase aquosa ou catbônica, vão de 336,6 a $423,8^{\circ} \mathrm{C}$, com pico entre 340 e $370^{\circ} \mathrm{C}$ (Fìg. 9.12.a, b e c). Suas 'TfeCO de $-57,0$ até $-56,7^{\circ} \mathrm{C}$ revelam a presença de quantidades variáveis e pequenas de $\mathrm{CH}_{4}$ (Fig. 9.13.a, b e c).

As poucas inclusões aquosas observadas no topázio possuem salinidades de 0,5 a $1,8 \% \mathrm{em}$ peso $\mathrm{NaCl}$ equiv., TE's da ordem de $-42^{\circ} \mathrm{C}$ e 'Th's pata o líquido de 211,3 a $352,8^{\circ} \mathrm{C}$. Dada a escassez de dados, não foi possível estabelecer as faixas de predomínio dessas grandezas. 

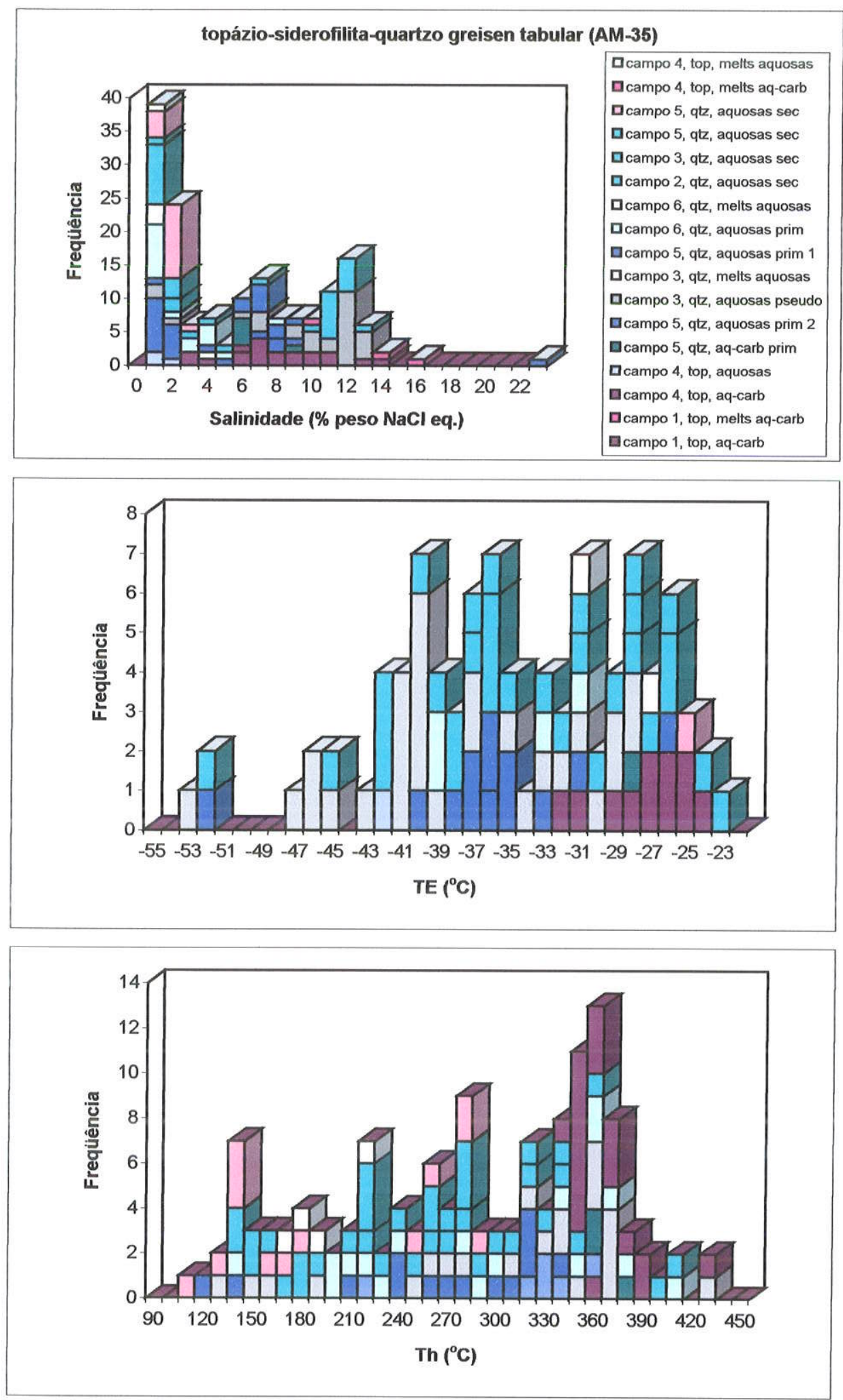

Figura 9.12 - Histogramas dos dados microtermométricos de a) salinidade, b) temperatura do ponto eutético, e c) temperatura de homogeneização para o líquido ou para o vapor/gás das inclusões aquosas e aquocarbônicas hospedadas em topázio e quartzo do topázio-siderofilitaquartzo greisen tabular (AM-35). Legenda conforme Fig. 9.12.a. 
a)

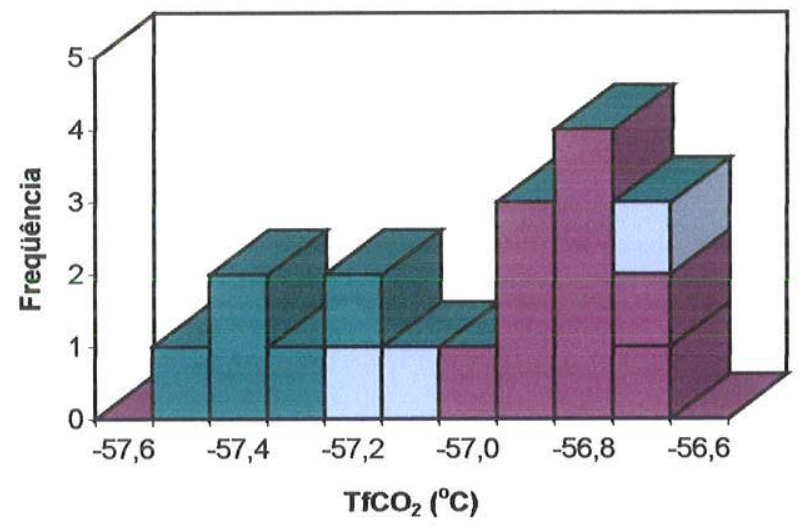

Qcampo 5, qtz

पampo 4, top, melts

口campo 4, topázio

口campo 1, top, melts

G campo 1, topázio

b)

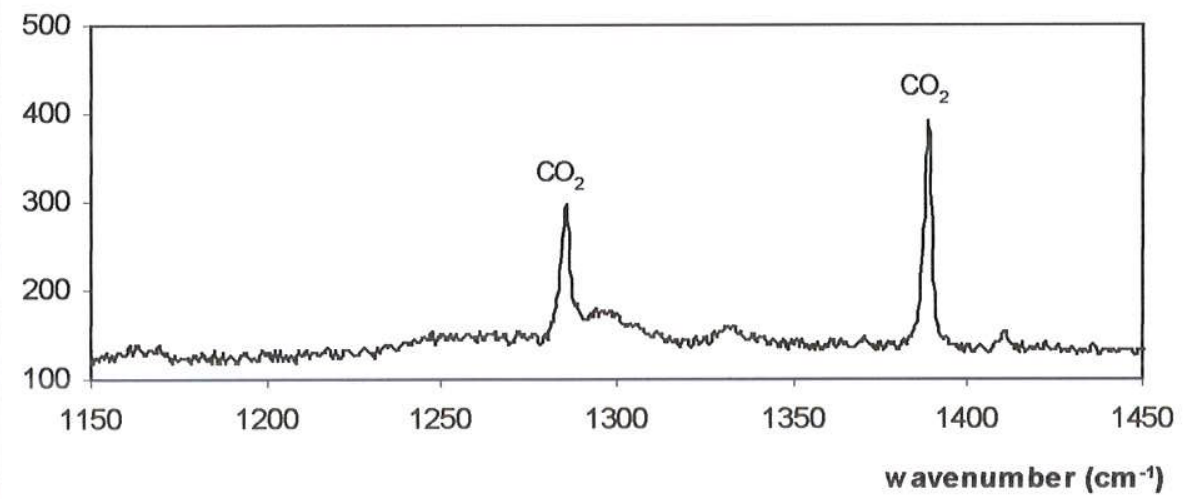

c)

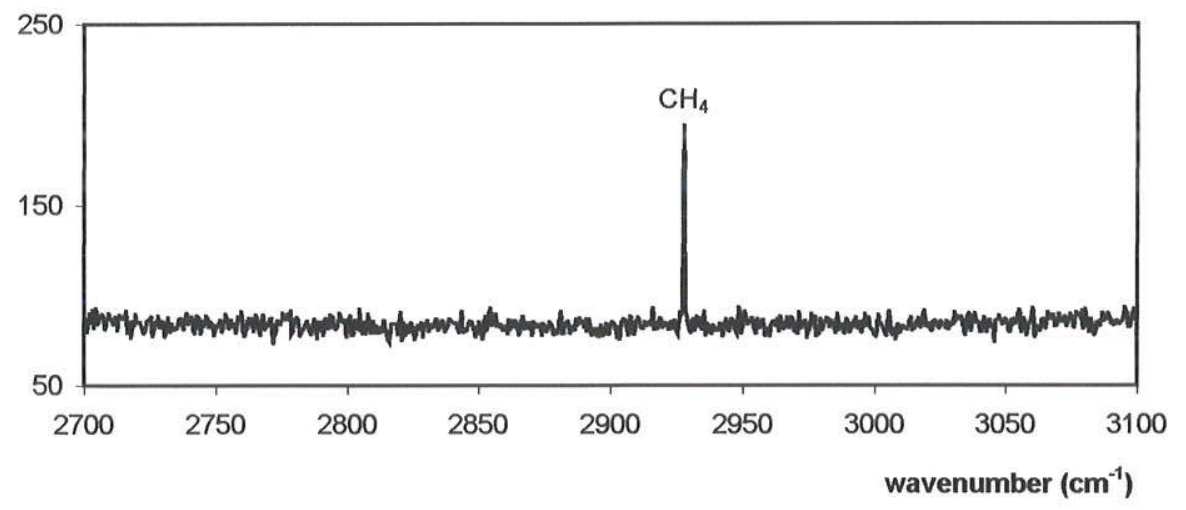

Figura 9.13 - a) Histograma das temperaturas de fusão do $\mathrm{CO}_{2}\left(\mathrm{TfCO}_{2}\right)$ das inclusões aquo-carbônicas hospedadas em topázio e quartzo. Espectros de efeito Raman demonstrando a presença b) do $\mathrm{CO}_{2}$ e c) do $\mathrm{CH}_{4}$ nas inclusões aquo-carbônicas hospedadas em topázio. Dados relativos ao topázio-siderofilita-quartzo greisen tabular (AM-35). 
Dos quatro campos estudados no quattzo, um único contém inclusões aquo-carbônicas e aquosas coexistentes (campo 5). Observam-se nesse campo pelo menos três populações de inclusões. A primeira delas, considerada primária, compreende uma latga faixa que atravessa o cristal de uma borda a outta e possui inclusões aquosas, denominadas populações aquosas 1 e 2 , e aquocarbônicas, coexistentes (Prancha 9.2.c).

A população aquosa 1 consiste de um pequeno grupo de inclusões, ocasionalmente com pequenas quantidades de $\mathrm{CO}_{2}$ identificado por microespectrometria Raman, de distribuição localizada. Essas inclusões possuem $V_{\mathrm{v} / \mathrm{s}} / \mathrm{V}_{\mid: i}$ variável de 0,10 a 0,30 . As salinidades consistentes entre 3,6 e 8,2\% em peso $\mathrm{NaCl}$ equiv., concentram-se discretamente dos 5 aos $8 \%$. As TE's variam de $-40,3$ a $-33,6^{\circ} \mathrm{C}$, sem moda significativa (Fig. 9.12 a e b). Infelizmente, não foram obtidos dados de Th para essa população.

A população aquosa 2 é tida como cogenética à 1 , porém aparenta ter sofrido modificação pela superposição de um trilhá Compreende inclusões bem formadas, quadrangulares ou retangulares, com bolhas de volumes extremamente variáveis (10 a mais de $90 \%$ da inclusão). As salinidades da população aquosa 2 ocortem desde os 0,3 até os $22,0 \%$ em peso $\mathrm{NaCl}$ equiv., com predomínio entre 0 e $2 \%$. Os valores de $\mathrm{TE}$ são espalhados desde os $-52,4$ até os $-26,5^{\circ} \mathrm{C}$, não permitindo a identificação de qualquer concentração. As 'Th's para o líquido, ocasionalmente para o vapor, vão de 111,8 a $331,9^{\circ} \mathrm{C}$, com sugestão de pico entre $310-320^{\circ} \mathrm{C}$. As duas populações são consideradas primárias e contemporâneas à população de inclusões aquo-carbônicas, descrita a seguir.

As inclusões aquo-carbônicas hospedadas no quartzo também são quadrangulares ou retangulates, bem formadas, e têm bothas com 30 a $90 \%$ do volume da inclusão (Prancha 9.2.e). As salinidades, estimadas pelas T'fel's, são de 5,1 a 8,5\% em peso $\mathrm{NaCl}$ equiv., e as Th's, quando possível a medida, são de 355,2 a $378,6^{\circ} \mathrm{C}$, para o líquido. Mediu-se uma única TE em $-28,1^{\circ} \mathrm{C}$ (Fig. 9.12.a, b e c). Dióxido de carbono e traços de $\mathrm{CH}_{4}$ (Fig. 9.14.a e b) foram identificados por microespectrometria Raman nessa população, em que os valores de $\mathrm{TfCO}_{2}$ ocorrem entre $-57,5$ e $-57,2^{\circ} \mathrm{C}$ (Fig. 9.13.a). 

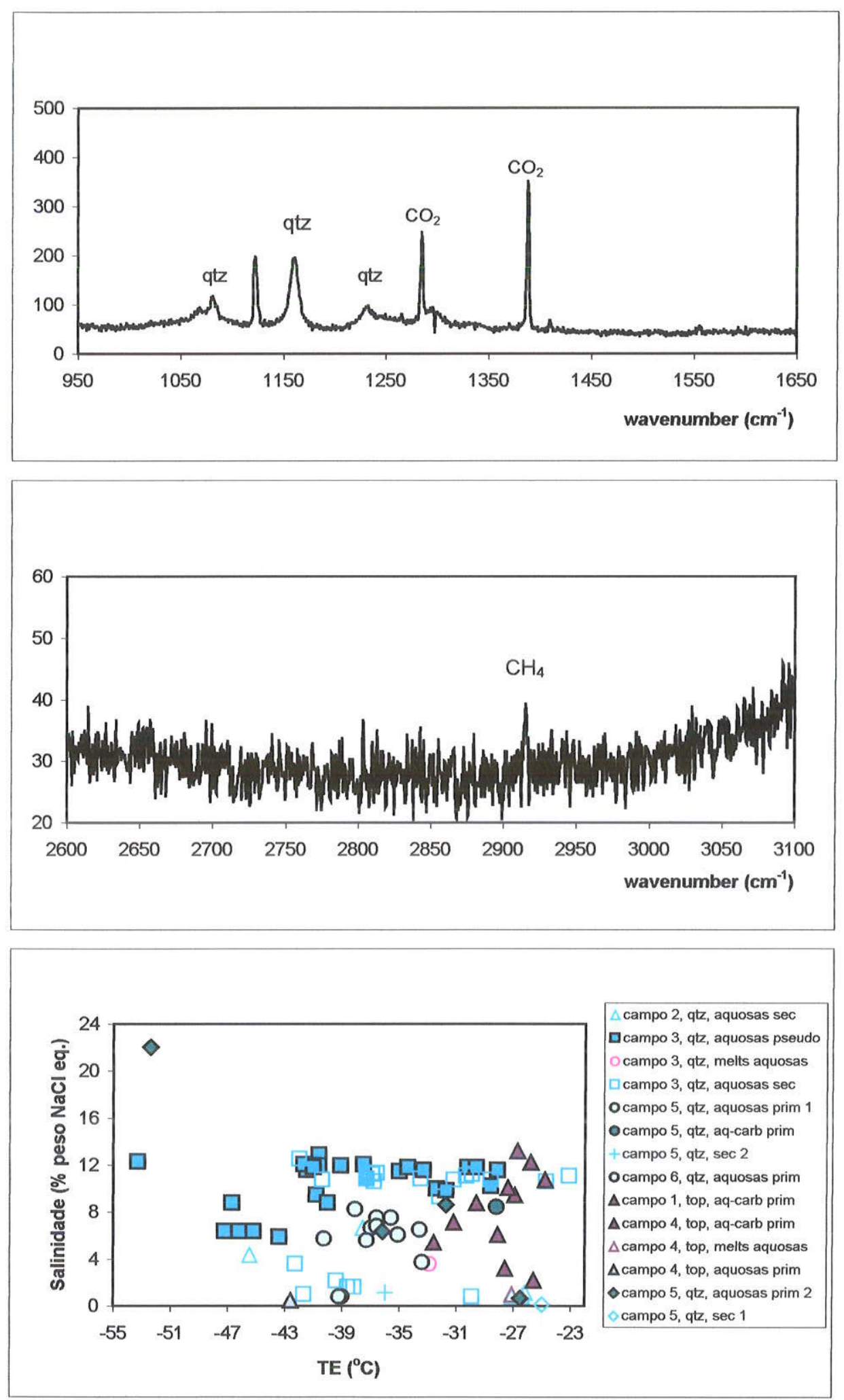

Figura 9.14 - Espectros de efeito Raman da fase gasosa das inclusões aquocarbônicas hospedadas no quartzo mostrando a presença de a) $\mathrm{CO}_{2}$ e b) de $\mathrm{CH}_{4}$. c) Diagrama de co-variação da salinidade versus a temperatura do ponto eutético (TE) da totalidade das inclusöes analisadas na amostra. Dados relativos ao topázio-siderofilita-quartzo greisen acamadado (AM-35). 
As inclusões aquosas secundárias identificadas no campo 5 distribuem-se em trilha intragranular do centro à borda do quartzo. Diferenciam-se das demais pelo tamanho diminuto, formas retangulares ou semi-retangulares, constância do volume da bolha em cerca de 10 a $20 \%$ da inclusão. Suas salinidades variam de 0,2 a $2,1 \% \mathrm{~cm}$ peso $\mathrm{NaCl}$ equiv., concentradas entre 1 e $2 \%$, e suas temperaturas de aprisionamento, que estão entre as mais baixas encontradas no quartzo, variam de 102,5 a $285,7^{\circ} \mathrm{C}$, com moda dos 130 aos $140^{\circ} \mathrm{C}$ (Fig. 9.12.a e c).

Outra população de inclusões aquosass, possivelmente pseudo-secundárias, ocorte como cristais negativos em um plano intragranualat, no campo 3 (Prancha 9.2.f). São bifásicas e multifásicas, com até dois sólidos, e $V_{v} / V_{\|:}$vartiável de 0,05 a 0,40 . Suas salinidades são de 1,7 a $12,9 \% \mathrm{em}$ peso $\mathrm{NaCl}$ equiv, mas concentram-se fortemente entre 10 e 11\%. As TE's variam de $-53,3$ a $-28,1^{\circ} \mathrm{C}$, com faixa de predomínio dos -42 aos $-40^{\circ} \mathrm{C}$. As homogeneizações são para o líquido, entre 127,2 e $423,6^{\circ} \mathrm{C}$, mas peferencialmente dos 330 aos $370^{\circ} \mathrm{C}$. Aquosas secundárias ocorrem nesse campo, com a mesma faixa de salinidades, mas com valores de TE entre $-42,8$ e $-23,1^{\circ} \mathrm{C}$. As 'Th's para o líquido são significativamente menores, com moda em $140-150^{\circ} \mathrm{C}$ (Fig. 9.12.a, b e c). Apresentam $V_{v} / V_{H:}$ constante cm 0,15.

Cabe ressaltar que inclusões monofásicas aquosas são comuns $\mathrm{em}$ todos os campos do quartzo nessa amostra.

Na totalidade das inclusǒes estudadas no topázio-siderofilita-quartzo greisen tabular, observase que as TE's das aquo-carbônicas, especialmente aquelas hospedadas em topázio, exibem, grosso modo, correlação positiva com os valores de salinidade, enquanto que as aquosas, predominantes no quartzo, mostram variação do eutético em condições de salinidade razoavelmente estável, havendo leve correlação negativa se consideradas as primátias (Fig. 9.14.c).

\section{c) Granito albitizado salmão}

Dois campos em cristais distintos de quartzo foram analisados nesta amostra, totalizando cerca de 80 inclusões. São essencialmente aquosas bifásicas, com tarússimos casos de ocorrência de sólidos. Monofásicas aquosas são comuns, ben como melt inclusions.

As melt inclusions são as mais antigas. Medidas de T'fg em inclusões aquosas bifásicas inclusas nessas melts revelaram salinidades altas em relação às demais inclusões presentes no campo, de 9,7 e $11,3 \% \mathrm{~cm}$ peso $\mathrm{NaCl}$ equiv., c podem representar os fluidos aquosos mais precoces que coexistiram 
com o quartzo.

As inclusões aquosas bifásicas possuem traços de $\mathrm{CO}_{2}$ detectados por microespectrometria Raman (Fig. 9.15). O tamanho extremamente reduzido dos picos do $\mathrm{CO}_{2}$ nessas inclusões, que não chegam a diferir por 30 unidades de contagem em relação ao background, constitui forte indício de que as mesmas pertencem ao tipo composicional ' $\mathrm{X}_{\mathrm{H} 2 \mathrm{C}}$, muito alta' de Diamond (2001), tendo-se como critério de comparação os picos do mesmo gás obtidos nas populações de inclusões aquocarbônicas das amostras previamente descritas e suas respectivas concentrações de $\mathrm{CO}_{2}$. Embora o clatrato possa formar-se, o gelo é sempre a última fase a fundir no sistema (Diamond, 2001), e essa mudança de fase ( $\mathrm{f} f \mathrm{~g}$ ) foi utilizada para o cálculo da salinidade do fluido. Todavia, os valores das salinidades assim obtidos possivelmente estão superestimados, dada a influência da presença do $\mathrm{CO}_{2}$ no rebaixamento do ponto triplo da água (Hedenquist \& Henley, 1985).

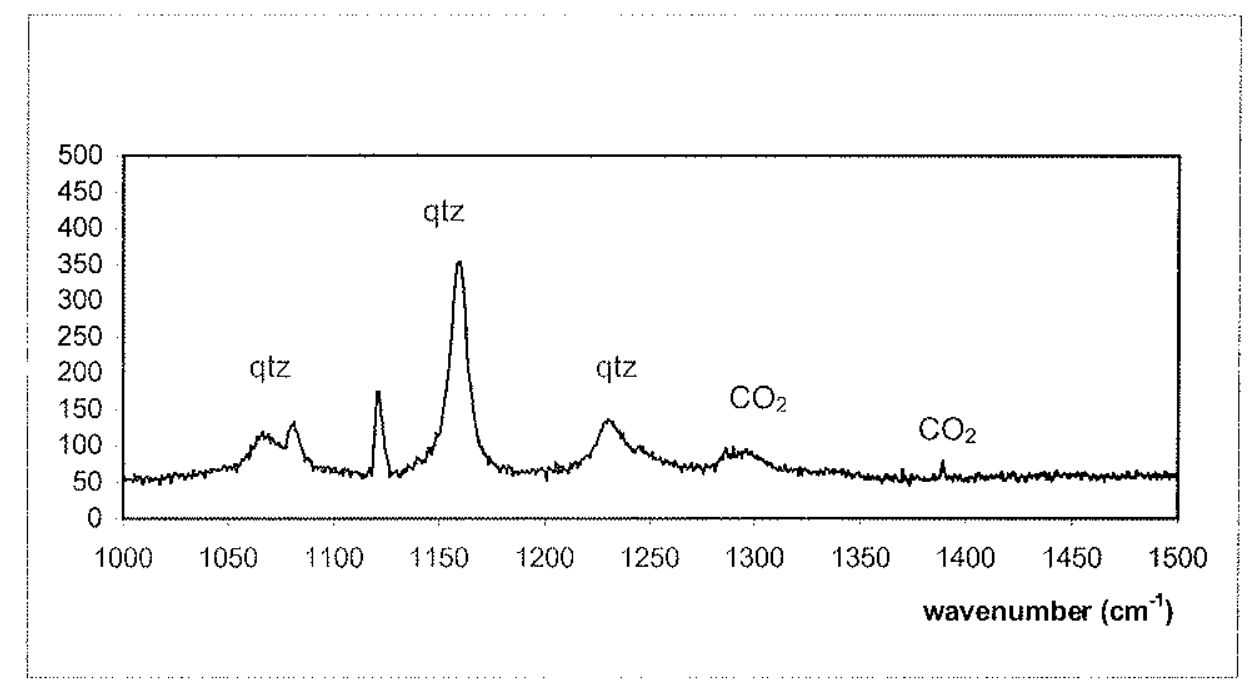

Figura 9.15 - Espectro de efeito Raman da fase gasosa de inclusão aquo-carbônica bifásica hospedada em quartzo do granito albitizado salmão (AM-14B).

Inclusões que constituem estruturas similares a bolsões (Prancha 9.2.g e h) foram consideradas primátias, enquanto que aquelas concentradas em trilhas ou faixas intragranulares são tidas como pseudo-secundárias. À parte essas características de distribuição e os valores de Th, ambas as populações assemelham-se no que diz respeito à grande variação da fração volumétrica da fase vapor, que é de 0,10 a mais de 0,90 , c nas faixas de predomínio de salinidades, que são de 2 a $4 \%$ em peso $\mathrm{NaCl}$ cquiv. para as primárias e de 1 a $3 \%$ para as pseudo-secundárias (Fig. 9.16.a).

A faixa de 'TE's observadas é de $-46,6$ a $-31,3^{\circ} \mathrm{C}$, com concentração de -38 a $-31^{\circ} \mathrm{C}$, o que indica composição do fluido no sistema $\mathrm{NaCl} \mathrm{CaCl}_{2} 6 \mathrm{FeCl}_{2}$ (Fig. 9.16.b). Observa-se, de modo geral, correlação negativa dos valores de salinidade com os de TE (Fig. 9.17). 

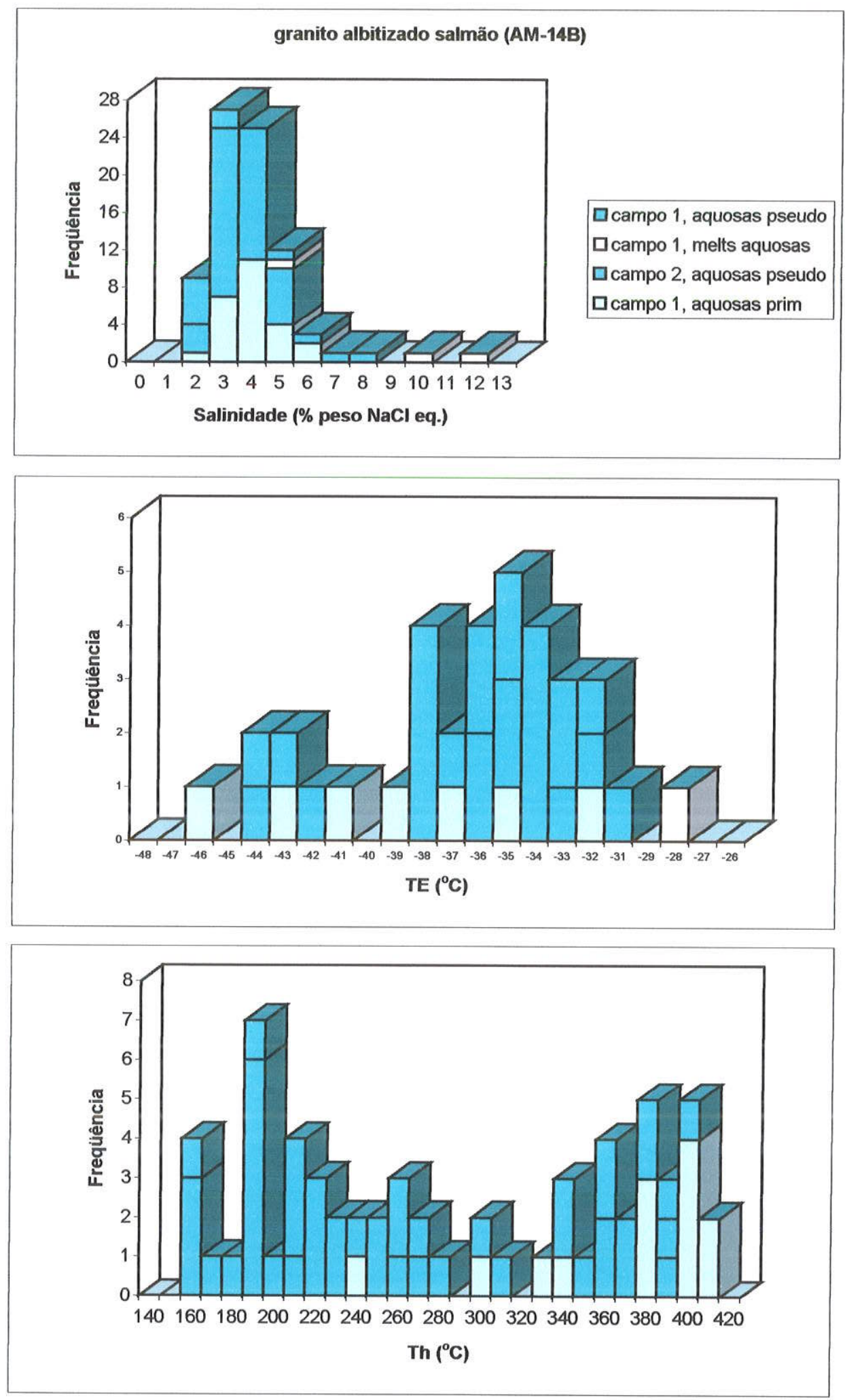

Figura 9.16 - Histogramas dos dados microtermométricos de a) salinidade, b) temperatura do ponto eutético, e c) temperatura de homogeneização para o líquido ou para o gás/vapor das inclusões aquosas hospedadas em quartzo do granito albitizado salmão ( $A M-14 B$ ). Legenda conforme Fig. 9.16.a. 


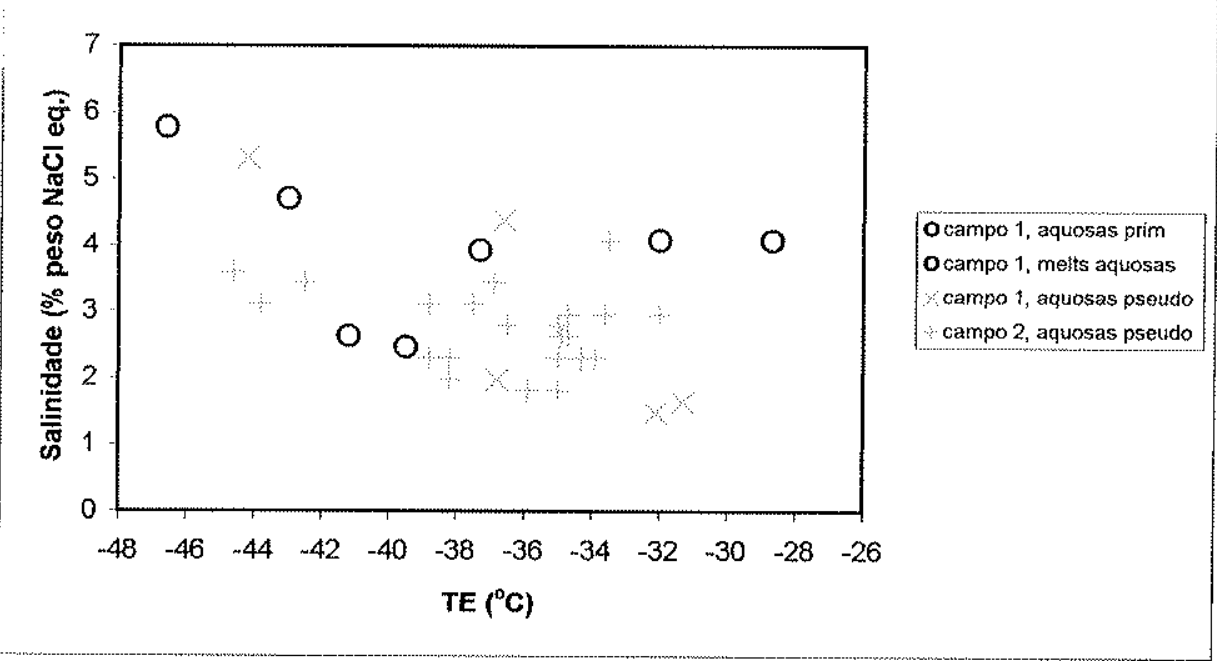

Figura 9.17 - Diagrama de covariação da salinidade versus a temperatura do ponto eutético (TE) para as inclusões aquosas primárias e pseudosecundárias hospedadas em quartzo do granito albitizado salmão (AM-14B).

\subsubsection{Estágio pós-magmático}

Ao estágio pós-magmático foi atribuída a gênese de todos os sistemas stockmork e de veios analisados neste estudo.

\section{a) Stockwork de topázio-siderofilita-quartzo greisen}

Um campo em topázio e dois em quartzo foram estudados nesta amostra, perfazendo 38 e 53 inclusões medidas, respectivamente.

No topázio, há uma população de inclusões aquo-carbônicas, além de inclusões aquosas e de melt inclusions.

As aquo-carbônicas têm formas de cristais negativos de seção prismática curta ou semitriangular e distribuição aleatória no topázio hospedeiro, porém são comuns feições pronunciadas de necking down (Prancha 9.3.a e b). Os conteúdos de gases contaminantes do $\mathrm{CO}_{2}$ são variáveis, conforme demonstram os valores de $\mathrm{TfCO}_{2}$ no intervalo de $-57,8$ e $-56,6^{\circ} \mathrm{C}$ (Fig. 9.18). As frações molares do $\mathrm{CO}_{2}$ presentes nessas inclusões, quando foi possivel sua determinação, permitem incluilas no sistema do tipo 'alta $\mathrm{X}_{\mathrm{H} 20}$ ' de Diamond $(1994,2001)$. 


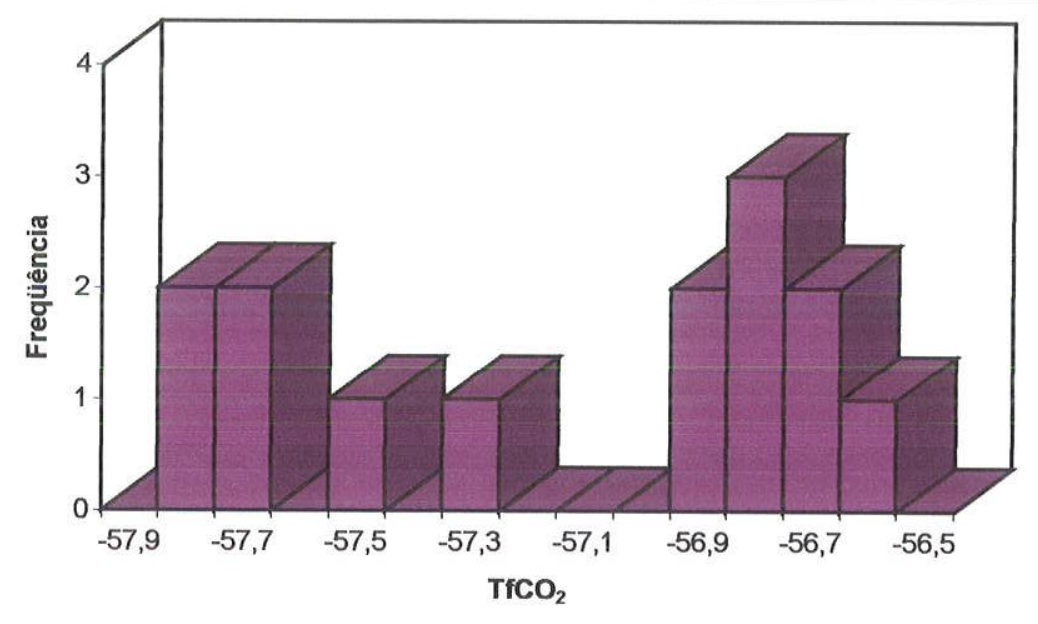

Figura 9.18 - Histograma das temperaturas de fusão do $\mathrm{CO}_{2}\left(\mathrm{TfCO}_{2}\right)$ nas inclusões aquo-carbônicas hospedadas no topázio do stockwork de topáziosiderofilita-quartzo greisen (AM-130).

As inclusões aquo-carbônicas são principalmente bifásicas e possuem $\mathrm{V}_{\mathrm{g}} / \mathrm{V}_{\mathrm{IF}}$ de $0,20 \mathrm{a} 0,55$. As salinidades, calculadas pela Tfcl, ocorrem desde 1,8 até 11,8\% em peso $\mathrm{NaCl}$ equiv., com moda entre 4 e $7 \%$. As TE's situam-se em um intervalo restrito $\left(-36,5\right.$ e $-32,8^{\circ} \mathrm{C}$, com pico entre -35 e $-34^{\circ} \mathrm{C}$ ) diferentemente de todas as populações de inclusões descritas até o momento. As Th's, pela contração e expansão da fase carbônica, foram observadas entre 364,8 e 445,2 ${ }^{\circ} \mathrm{C}$ (Fig. 9.19.a, b e c).

As inclusões aquosas coexistentes com as aquo-carbônicas foram subdivididas em dois tipos. O primeiro compreende um pequeno grupo de cerca de oito inclusões, de distribuição localizada, ovaladas a retangulares, pequenas e bem formadas, com $\mathrm{V}_{\mathrm{v}} / \mathrm{V}_{\mathrm{IF}}$ constante $(0,15)$, cuja característica típica é a presença de mais de um sólido (multifásicas), que não dissolveram até $600^{\circ} \mathrm{C}$ (Prancha 9.3.c). Suas salinidades são de 5,8 a $21,6 \%$ em peso de $\mathrm{NaCl}$ equiv., mais comumente de 5 a $12 \%$, seus TE's de $-48,0$ a $-42,3^{\circ} \mathrm{C}$ e os Th's de 360,3 a $431,5^{\circ} \mathrm{C}$, com sugestão de predomínio entre 360 e $410^{\circ} \mathrm{C}$ (Fig. 9.19.a, b e c).

As aquosas do tipo 2 diferem das primeiras pela distribuição aleatória, pelo tamanho maior e pela menor freqüência de sólidos, sendo na maior parte bifásicas com pequena variação da $V_{v} / V_{I F}$ $(0,15$ a 0,25$)$. Seu espectro de salinidades é mais restrito $(6,8$ a $11,9 \%$ em peso $\mathrm{NaCl}$ equiv.), com predomínio entre 6 a 8\%. As TE's pertencem à mesma faixa de variação observada para o tipo 1 , enquanto que as Th's para o líquido exibem espalhamento em direção a temperaturas menores $\left(272,4\right.$ a $\left.422,9^{\circ} \mathrm{C}\right)$ (Fig. 9.19. a, b e c). 

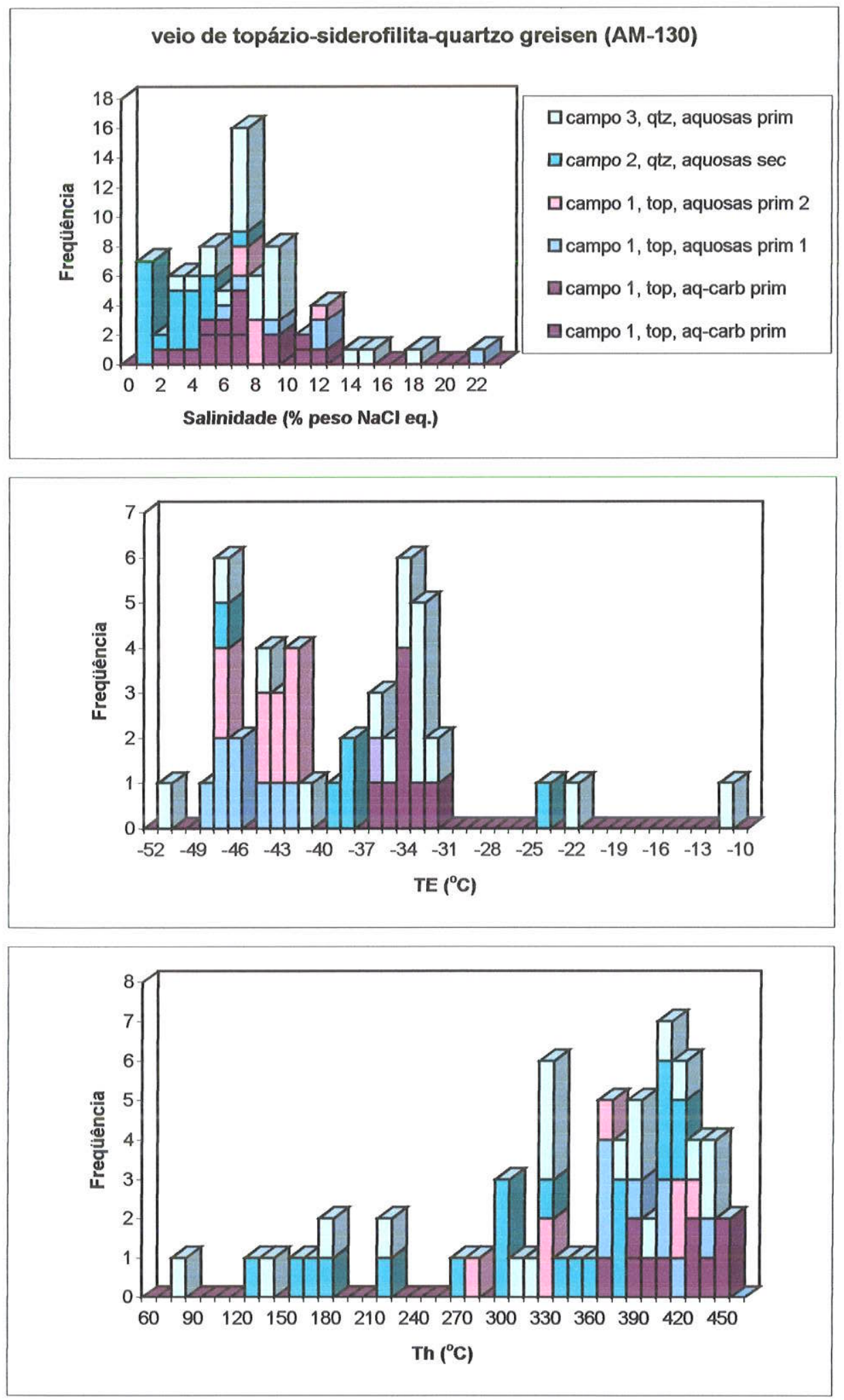

Figura 9.19 - Histogramas dos dados microtermométricos de a) salinidade, b) temperatura do ponto eutético (TE), e c) temperatura de homogeneização (Th) para o líquido ou para o vapor/gás das inclusões aquosas e aquo-carbônicas hospedadas em topázio e quartzo do veio de topázio-siderofilita-quartzo greisen (AM-130). Legenda conforme Fig. 9.19.a. 
Cabe ressaltar: a nítida diferença dos valores de TE das inclusões aquo-carbônicas em relação às aquosas (Fig. 9.19.b). Nas últimas, esses valores apontam fortemente a presença constante do $\mathrm{Ca}^{+2}$ no sistema, enquanto que para as aquo-carbônicas os valores de TE podem estar sendo influenciados pela presença de clatratos.

No quartzo, é marcante a abundância de inclusões compostas. Essas compreendem um ou mais sólidos aprisionados conjuntamente com bolhas gasosas, localizadas na superfície do conjunto em posição que sugere o escape iminente dessa fase durante o aprisionamento (Prancha 9.3.d), ou ainda com porções de líquido. Se líquida, a fase fluida tem as mesmas características microtermométricas das inclusòes aquosas coexistentes.

As inclusões aquosas primárias são cogenéticas às inclusões compostas. São bifásicas e multifásicas, pequenas e retangulares, com $V_{v} / V_{1 F}$ vartiáveis dos 0,10 ao 0,70 , predominando as de 0,10. Monofásicas são comuns, sugerindo a presença de necking down $\mathrm{cm}$ alguns casos. As salinidades variam de 2,3 a $17,7 \% \mathrm{~cm}$ peso $\mathrm{NaCl}$ equiv., com moda entre 6 e $9 \%$. As 'TE's cobrem um espectro de $-51,3$ a $-11,7$, com pico em -34 a $-33^{\circ} \mathrm{C}$, demonstrando variações de composição do fluido no sistema $\mathrm{NaCl}-\mathrm{CaCl}_{2}-\mathrm{FeCl}_{2}$. $\mathrm{KCl}$. Th's, para o vapor e para o líquido, foram observadas desde 134,0 até $435,0^{\circ} \mathrm{C}$, mas são predominantemente maiores do que $320^{\circ} \mathrm{C}$ (Fig. 9.19.a, b e c).

T'ambém existem inclusões aquosas secundárias, cuja fase vapor ocupa até $90 \%$ do volume da inclusão. As salinidades são mais baixas, variando entre 0,7 e $6,1 \%$ em peso $\mathrm{NaCl}$ equiv., com predomínio entre 0 e 1\%. As 'Tle's e as 'Th's sĩo espalhadas dos $-47,2$ aos $-24,8^{\circ} \mathrm{C}$ e dos 124,2 aos $415,1^{\circ} \mathrm{C}$, respectivamente, sendo mais comuns homogeneizações acima dos $300^{\circ} \mathrm{C}$, algumas para o vapor (Fig. 9.19.a, b e c).

\section{b) Veio de quartzo e cassiterita}

Esta amostra consiste de quartzo leitoso com profusão de inclusões monofásicas e bifásicas aquosas, que configuram verdadeiras nuvens turvas. Dada a dificuldade de seleção de uma região apropriada, foi possivel analisar apenas um campo, em que 38 inclusöes foram medidas.

Estão presentes duas populações de inclusooes aquosas bifásicas. A primeira, considerada primária (tipo 1), compreende a maioria das inclusões, caracterizadas pela morfologia de cristais negativos, bem como pela variaçào $V_{v} / V_{u:}$ entre 0,10 e mas de 0,90 (Prancha 9.3.e e f). As salinidades calculadas pelos ' $\mathrm{C} f \mathrm{~g}$ 's situam-se no intervalo de 0,3 a $7,0 \% \mathrm{em}$ peso $\mathrm{NaCl}$ equiv., 
predominando na faixa de 0 a $3 \%$. As 'TE's são consistentes entre -31 e $-26^{\circ} \mathrm{C}$, com raros valores matores. Embora ocorram em um espectro espalhado de 153,4 a 375,4"C, as 'Th's tamberm possuem moda matcada, entre 320 e $380^{\circ} \mathrm{C}$ (Fig. 9.20.a, b e c). As homogeneizaçoes ocorrem parao líquido e para o vapor.

A outra população, também primária (tipo 2), consiste de pequenas inclusòes aquosas multifásicas, quadrangulares, esparsas, com $V_{v} / V_{n}$ constante entre 0,10 e 0,20 e pelo menos 2 a 3 sólidos por inclusào. Caracterizam-se por salinidades mais elevadas $(2,0$ a $14,4 \%$ em peso $\mathrm{NaCl}$ equiv.), e tanto 'TE's $\left(-47,4\right.$ a $\left.-28,0^{\circ} \mathrm{C}\right)$ quanto 'Th's $\left(110,3\right.$ a $\left.176,7^{\circ} \mathrm{C}\right)$ mais baixas do que a populaçào anterior (Fig. 9.20.a, b e c). A composição do fluido é tidá como variável, nos sistemas $\mathrm{CaCl}_{2} \pm \mathrm{NaCl}$ c $\mathrm{NaCl}+\mathrm{KCl}$.

\section{c) Veio de quartzo estéril}

Duas populações hospedadas em quartzo, totalizando 33 inclusões medidas, foram analisadas em um único campo nesta amosta.

A população de inclusóes aquosas primárias ocotre segundo as faces de crescimento do quartzo, em suas terminações piramidais (Prancha 9.3.g). Consiste de inclusòes predominantemente bifásicas, mas também multifásicas, com proporções volumétricas da fase vapor variáveis de 0,10 a 0,70, mas predominantemente menores do que 0,40 (Prancha 9.3.h). Suas salinidades variam de 1,7 a $5,5 \% \mathrm{~cm}$ peso $\mathrm{NaCl}$ equiv., concentrando-se fortemente entre 1 e $3 \%$. Os valores de TE situam-se na faixa de $-42,1$ a $-34,8^{\circ} \mathrm{C}$, preferencialmente entre -40 e $-35^{\circ} \mathrm{C}$, indicando variaçóes composicionais no sistema $\mathrm{CaCl}_{2}+\mathrm{FeCl}_{2}+\mathrm{NaCl}$, enquanto que os de Th, para o líçuido e para o vapor, oscilam de 145,6 a $415,2^{\circ} \mathrm{C}$ (Fig. 9.21 a, b e c).

A população de aquosas secundárias, situadas ao longo de discretas trilhas, compreende inclusões bifásicas com bolhas de, no máximo, $10 \%$ do volume da inclusão, freqüentemente meta-estáveis. Suas salinidades estão restritas ao intervalo de 14,8 a $18,9 \%$ em peso $\mathrm{NaCl}$ equiv. e suas TE's são todas do sistema cálcico $\left(-57,9\right.$ a $\left.-47,0^{\circ} \mathrm{C}\right)$. Também as 'Th's, para o líquido, ocorrem numa faixa estreita (94,2 a 147,4) (Fig. 9.21.a, b e c). 

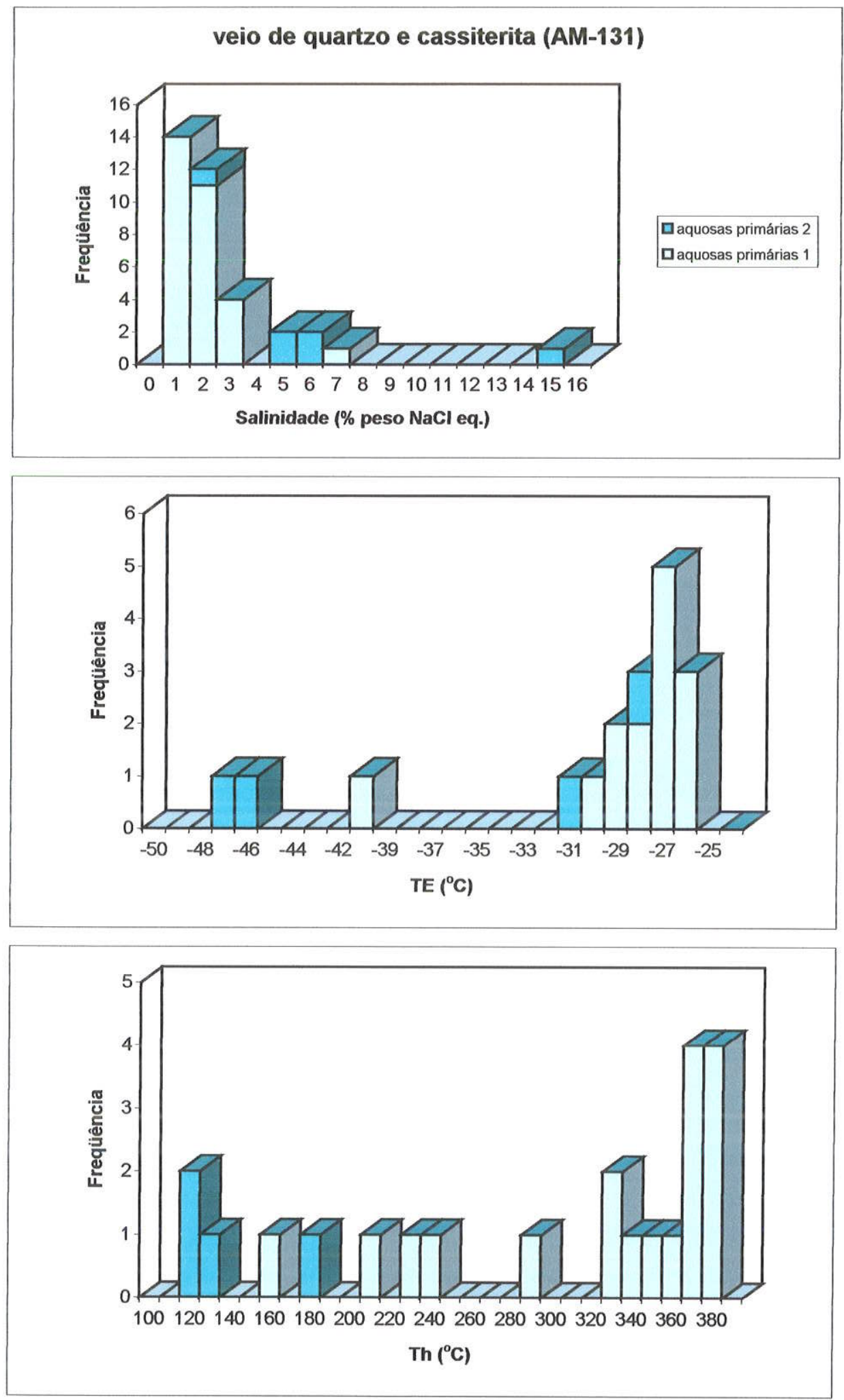

Figura 9.20 - Histogramas dos dados microtermométricos de a) salinidade, b) temperatura do ponto eutético (TE), e c) temperatura de homogeneização (Th) para o líquido ou para o vapor das inclusões aquosas hospedadas em quartzo do veio de quartzo e cassiterita (AM-131). Legenda conforme Fig. 9.20.a. 

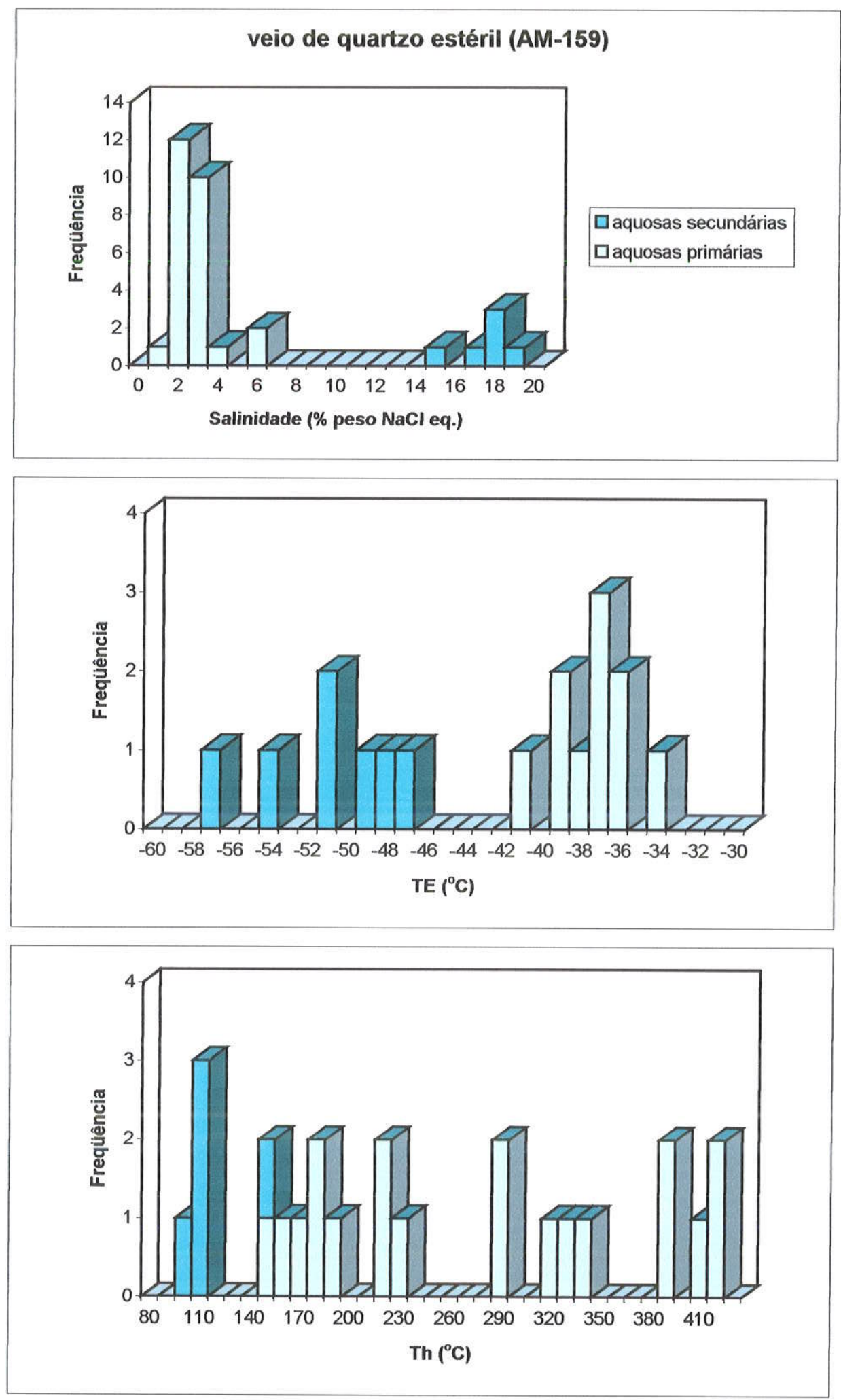

Figura 9.21 - Histogramas dos dados microtermométricos de a) salinidade, b) temperatura do ponto eutético (TE), e c) temperatura de homogeneização (Th) para o líquido ou para o vapor das inclusões aquosas hospedadas em quartzo do veio de quartzo estéril (AM159). Legenda conforme Fig. 9.21.a. 


\subsection{A evolução dos fluidos no sistema greisen do Maciço Granítico Santa Bárbara}

\subsubsection{Estágio magmático}

\section{a) Albita-microclínio granito branco}

No topázio do albita-microclínio granito branco foram observadas inclusoes aquo-. carbônicas secundátias com grandes variações nas proporções volumétricas da fase gasosa. lessas inclusões ocorrem associadas nas mesmas regiòes (trilhas) da amostra, o que indica aprisionamento contemporâneo, um dos criterios apontados por Rambo\% at al. (1982) como indicativo de imiscibilidade.

Outro critério importante, relativo às inclusões que aprisionaram os termos extremos representativos das fases imisciveis, é que esses dois tipos de inclusoes devem sofre: homogeneizaçăo no mesmo intervalo de temperaturas, em um dos tipos para o líquido (ou expansào da fase aquosa) e, no outro, para o vapor (ou expansão da fase gasosa) (Ramboz of al. 1982). Adicionamente, Roedder (1984) mostra que essas temperaturas seriam as mínimas obtidas a partir: de um grande número de medidas, e representariam as condiçoes reais de aprisionamento. lisse critério é obedecido pelas inclusões presentes no topázio, cmbora a homogeneização pela expansão da fase carbônica, quando pôde ser observada, apresente algumas incertezas, sendo muitas vezes superestimada.

Vários autores (Ramboz ot al. 1982, Pichavant et al. 1982, Bowers \& Helgeson 1983, Bodnar \& Vityk 1993, Wilkinson 2001, entre outros) também mostram que a imiscibilidade de um sistema composto por $\mathrm{H}_{2} \mathrm{O}-\mathrm{CO}_{2} \cdot \mathrm{NaCl}$ daria origem a fluidos com densidades e composiçoes contrastantes, em virtude da partição dos solutos para a fase líquida durante o processo de imiscibilidade: fases essencialmente aquosas, pobres em voláteis e enriquecidas em sais dissolvidos, e fases ricas em $\mathrm{CO}_{2}$ de baixa salinidade. Essas relaçòes, de um modo geral, também são observadas nas inclusôes fluidas do topázio (lig. 9.22.c). 

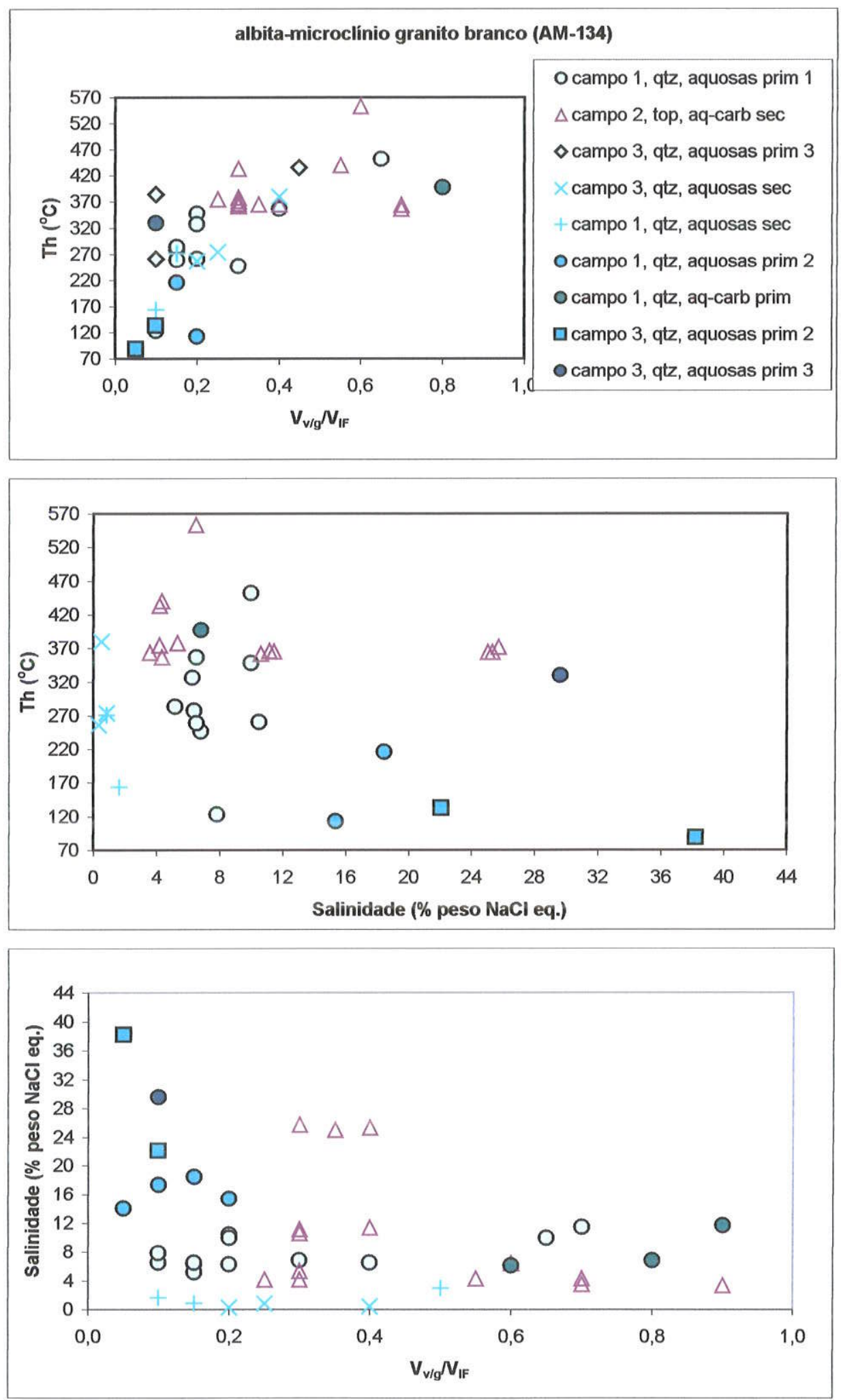

Figura 9.22 - a) $\mathrm{V}_{\mathrm{V} / g} / \mathrm{V}_{\mathrm{IF}}$ versus $\mathrm{Th}$, b) salinidade versus $\left.\mathrm{Th}, \mathrm{c}\right) \mathrm{V}_{\mathrm{V} / \mathrm{g}} / \mathrm{V}_{\mathrm{IF}}$ versus salinidade do albita-microclínio branco (AM-134). 
Higgins (1985) enfatiza que as inclusões aprisionadas a partir de sistemas imiscíveis devem homogeneizar sobre a curva soluts definida para a composiçào específica do fluido, nas condiçòes de aprisionamento, representada no diagrama 'I'h uersus $\mathrm{XCO}_{2}$. No caso das inclusoes presentes no topázio, poucos dados de $\mathrm{XCO}_{2}$ puderam ser obtidos, uma vez que elas pertencem ao sistema classificado como alta $\mathrm{XH}_{2} \mathrm{O}$ (Diamond 1994, 2001). Desse modo, ao invés de $\mathrm{XCO}_{2}$, foi utilizada, como uma aproximação, a variaçào da proporção volumétrica da fase gasosa na confecção do diagrama representativo da solmus (Fig. 9.22.a). Mesmo considerando-se as imprecisóes existentes na determinação dessas proporções volumétricas, dadas, entre outros fatotes, pela sua observação

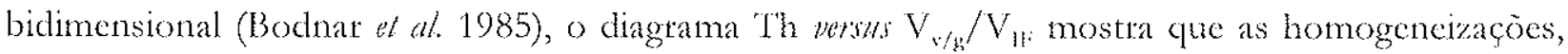
tanto pela contração como pela expansão da fase carbônica, delimitam uma curva de imiscibilidade.

$\Lambda$ partir de todas as consideraçòes acima, pode-se concluir que as inclusoes aquo-carbônicas secundárias presentes no topázio foram aprisionadas a partir de um sistema imiscivel $\left(\mathrm{H}_{2} \mathrm{O}+\mathrm{CO}_{2}+\right.$ sais $)$ em temperaturas da ordem de $350 / 370^{\circ} \mathrm{C}$ (temperaturas mínimas de homogeneização).

No quartzo do albita-microclínio granito branco, as inclusoes primátias (tipo 1) e aquocarbônicas coexistentes também situam-se sobte a mesma curva solmus delimitada pelas do topázio, sugerindo também a presença de imiscibilidade ao tedor de $350 / 370^{\circ} \mathrm{C}$. No entanto, no que diz respeito às salinidades, a premissa indicativa de imiscibilidade nào é obedecida, mostrando que outros processos podem estar associados, tais como modificaçōes, misturas e recquilíbrios posteriores.

Esses dados parecem sugerir que, durante algum episódio de reequilibrio do quartzo, suas inclusòes primárias tenham sido modificadas pelos fludos imiscíveis secundarios aprisionados no topázio. Desse modo, pode ter sido eliminado qualquer registro do fluido primário original.

A tendência evolutiva em direçăo a temperaturas baixas $\left(<230^{\circ} \mathrm{C}\right)$ indica o aumento da salinidade (Fig. 9.22.b) Esses fluidos tardios apresentam sempre salinidades superiores a $14 \% \mathrm{~cm}$ peso $\mathrm{NaCl}$ equiv. e TE's indicativas da presença do cálcio (Fig. 9.2.a e b).

A incidência de processos posteriores de mistura desses fluidos com outros aquosos, menos salinos, abaixo da curva solvus do sistema $\mathrm{H}_{2} \mathrm{O}_{-} \mathrm{CO}_{2}$-sais, nào pode ser descartada. Esses fluidos aquosos pouco salinos estão representados nas inclusões aquosas secundárias preservadas no quartzo. 
Haja vista a morfologia das inclusões presentes no topázio, sugestivas de origem secundária, toda a evolução fluidal discutida acima ć tida como secundária, desenvolvida cm condições subsolidus. Como as inclusòes aquosas primátras dos tipos 1 e 2 , bem como as secundárias c as aquo-carbônicas primátias no quartzo, distribuem-se primordialmente no entorno de inclusões sólidas, freqüentemente de mica, parece provável que a alteração desses minerais pela circulação de fluidos hidrotermais seja responsável também pelo reequilibrio ou mesno geração dessas inclusoes espacialmente associadas.

\section{b) Pegmatito}

Todas as populações de inclusòes preservadas no quartzo desta amostra são aparentemente secundárias. A presençá comum de fraturas preenchidas com muscovita no feldspato alcalino coexistente com o quartzo analisado constitui forte evidência de que o fluido trapeado nessas inclusòes está relacionado a estáa âteração pós-magmática.

Com exceção da população 3, esse fluido é essencialmente aquoso, de baixa salinidade (população 2; Fïg. 9.4.b), com temperaturas de homogeneização no intervalo de 330 a $370^{\circ} \mathrm{C}$ (população 1) e de 230 a $300^{\circ} \mathrm{C}$ (populaçào 2 ; Figg. 9.4.a).

A população 3, de aquo-carbònicas, tem temperaturas de homogencizaçào de 230 a $310^{\circ} \mathrm{C}$, em grande parte coincidentes com aquelas da população 2. Suas inclusòcs possuem proporçòes variáveis da fase gasosa, o que seria indicativo de imiscibilidacle.

A distribuição dos scus pontos no diagrama the versus salinidade (Fig. 9.23.b), onde observase diminuição da salinidade com a temperatura, indica aprisionamento de uma soluçăo de baixíssima salinidade e baixa pressão de $\mathrm{CO}_{2} \mathrm{~cm}$ itniscibilidade, conforme exemplificado por Hedenquist \& Henley (1985) e Wilkinson (2001). Nesses casos, a perda preferencial do $\mathrm{CO}_{2}$ para a fase gasosa com a continuidade do processo de imiscibilidade elimina a influência do $\mathrm{CO}_{2}$ na depressão das 'Tfg's, resultando num aparente decréscimo de salinidade.

Assim, a muscovitização pós-magmática parece ser devida principalmente à presença de fluidos aquosos pouco salinos, com influência meteórica, tapeados no intervalo de $370-230^{\circ} \mathrm{C}$, cmbora não possa ser descartada a influência dos fluidos aquo-carbônicos, em boiling, de provável origem magnática, aptisionados em temperaturas ao redor de $230 / 250^{\circ} \mathrm{C}$. 

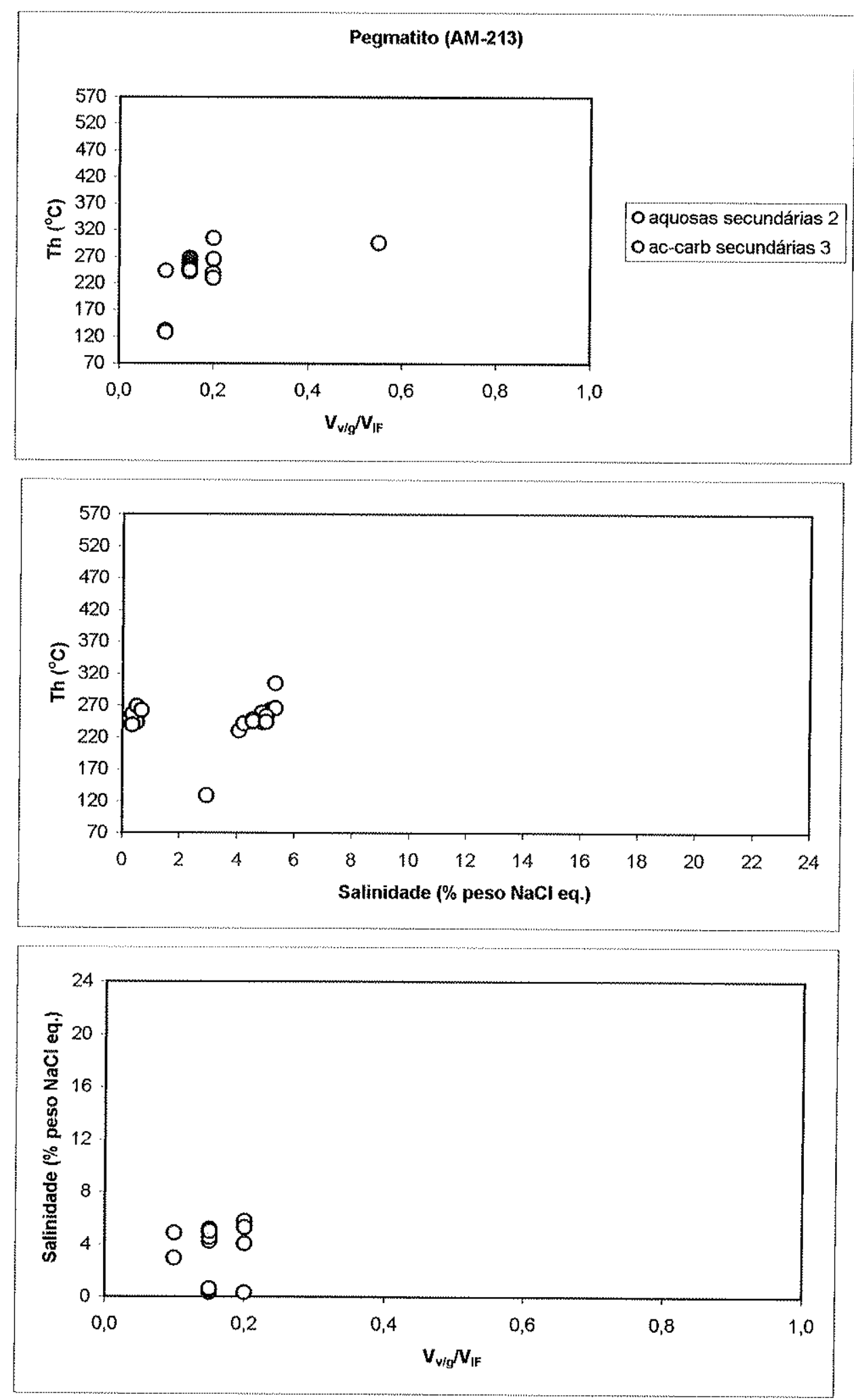

Figura 9.23 - a) $V_{\mathrm{V} / g} / V_{\mathrm{FF}}$ versus Th, b) salinidade versus $T$, c) $V_{\mathrm{V} / \mathrm{g}} / \mathrm{N}_{\mathrm{IF}}$ versus salinidade do pegmatito (AM-213). 


\subsubsection{Estágio transicional}

\section{a) Bolsão de quartzo com siderofilita e topázio}

As inclusões aquosas primárias e pscudo-secundárias no topázio desta amostra aptesentam um intervalo de temperaturas de homogeneização entre 400 e $510^{\prime \prime} \mathrm{C}$ (Fìg. 9.6.c).

A presença abundante de calcita indica a existência pregressa de quantidades variáveis de $\mathrm{CO}_{2}$ dissolvido no fluido. Processos como a degaseificaçào desse $\mathrm{CO}_{2}$, a mudança do pH ou o decréscimo dá salinidade podem ter sido responsáveis pela significativa precipitação de calcita (Holland 1967, Higgins 1985, Hedenquist \& Henley 1985, Rimstidt 1997).

A evolução por degaseificação (desmistura) do $\mathrm{CO}_{2}$ é favorecida por diversos fatores: 1) as salinidades de ambas geraçōes de inclusòes no topázio sào pouco variáveis (Fig. 9.1.a); 2) a presença de raras inclusoes pseudo-secundárias com $\mathrm{CO}_{2}$ gasoso, identificado por meio da formação de clatratos durante o resfriamento; 3) fluidos aquosos e aquo-carbônicos desmisturados estão presentes no quartzo coexistente com o topázio.

Essa imiscibilidade, próxima ao ponto crítico, explicá a variação restrita da $V_{v} / V_{11}$ e da salinidade. O trend observado no diagrama salinidade mersus 'Th (Fig. 9.24.a) é dado pelá diminuiçăo irreal da salinidade com a temperatuma pela remoção do $\mathrm{CO}_{2}$ da fase fluida, posto que ele deixa de rebaixar o ponto triplo da água (Hedenquist \& Henley 1985, Wilkinson 2001).

No quartzo coexistente com o topázio, as poucas inclusões aquo-carbônicas predominam no intervalo térmico entre cerca de 370 e $520^{\circ} \mathrm{C}$ (Fig. 9.8.c). Apesar da grande variaçăo de $V_{\mathrm{v} / \mathrm{k}} / \mathrm{V}_{1:}$ entre elas $c$ as aquosas coexistentes, não pode-se assegurar que tenha havido indubitavelmente a imiscibilidade com base no diagrama 'th versus $\mathrm{V}_{\mathrm{v} / \mathrm{g}} / \mathrm{V}_{11}$ ( $\mathrm{Hig}$. 9.25), dado o provável mascaramento do trend devido à evoluçăo posterior do fluido.

Predominam no quartzo inclusòes aquosas secundárias. A maior parte dessas inclusòes têm salinidades maiores do que as do topázio (compare Figs. 9.6.a e 9.8.a) e temperaturas de homogeneização relativamente baixas (Fig. 9.8.c). No diagrama salinidade wersus Th (Fig. 9.24.b) há uma grande dispersão de pontos. A mistua de fluidos é sugerida pela correlaçào negativa no diagrama salinidade verus TE (Fig. 9.11). 

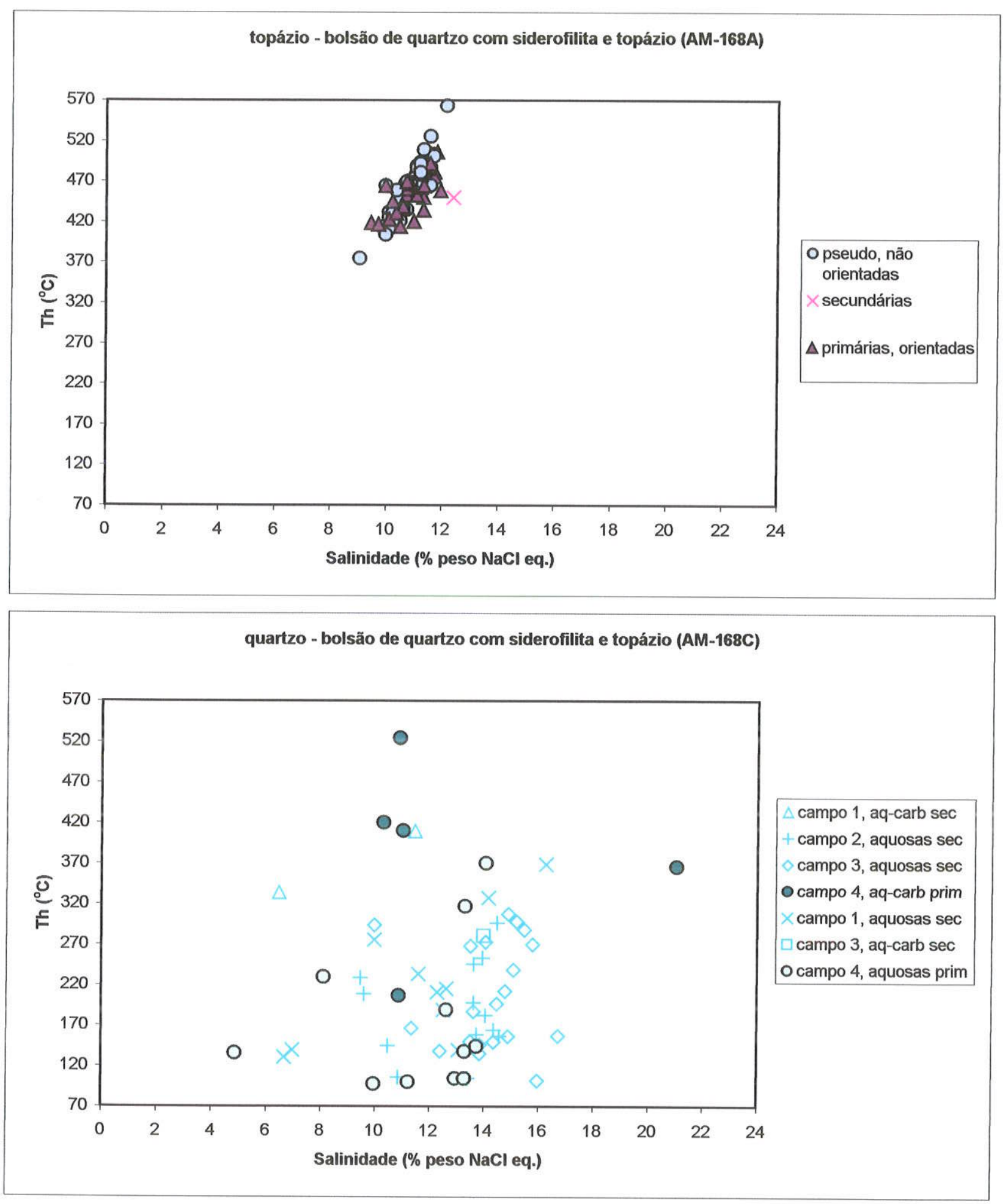

Figura 9.24 - Diagrama salinidade versus Th das inclusões fluidas aquosas e aquo-carbônicas presentes no a) topázio e b) no quartzo do bolsão de quartzo com siderofilita e topázio (AM-168A e AM168C, respectivamente). 


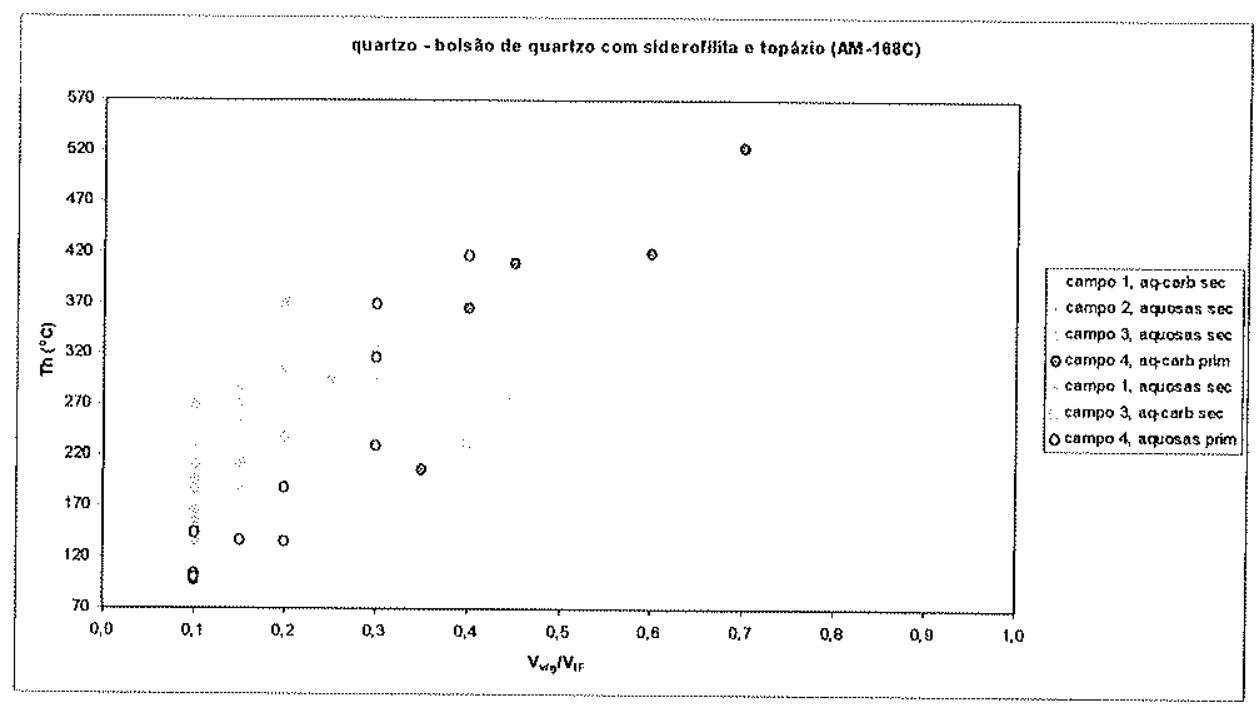

Figura 9.25 - Diagrama Th versus VV/g/VIF para as inclusões aquosas e aquocarbônicas presentes no quartzo (AM-168C) do bolsão de quartzo com siderofilita e topázio.

No conjunto, o bolsão de quartzo com siderofilita e topázio parece refletir a evolução de fluido aquo-carbônico via imiscibilidade, com posterior abertura do sistema, possivelmente em diversos pulsos, e entrada de fluidos menos salinos, possibilitando mistura de fluidos abaixo da curva solums do sistema $\mathrm{H}_{2} \mathrm{O}-\mathrm{CO}_{2}$-sais, responsável pela extrema dispersão dos pontos analíticos no diagrama Th versus salinidade (Fig. 9.24.b).

\section{b) Topázio-siderofilita-quartzo greisen tabular}

No topázio do greisen tabular são comuns as silicate-melt inclusions. Aquo-carbôtnicas primárias também são abundantes e, subordinadamente, existem as inclusôes aquosas. Essa associação marca uma evolução desde temperaturas magmáticas, com coexistência de fundido e fluido magmáticos, até condições subsolidus.

Há grande variação volumétrica da fase gasosa presente nas inclusões no topázio. Porém, as salinidades das inclusões aquosas, muito inferiores às das aquo-carbônicas coexistentes, não satisfaz a premissa de partição de solutos para a fase aquosa durante a imiscibilidade ( $f$. Pichavant el al. 1982, entre outros). Da mesma forma, a distribuição dos pontos relativos às inclusões aquo-carbônicas no diagrama The versus $\mathrm{V}_{\mathrm{v} / \mathrm{g}} / \mathrm{V}_{\mathrm{IF}}$ rião delineia uma curva soluus (Fig. 9.26.b). 

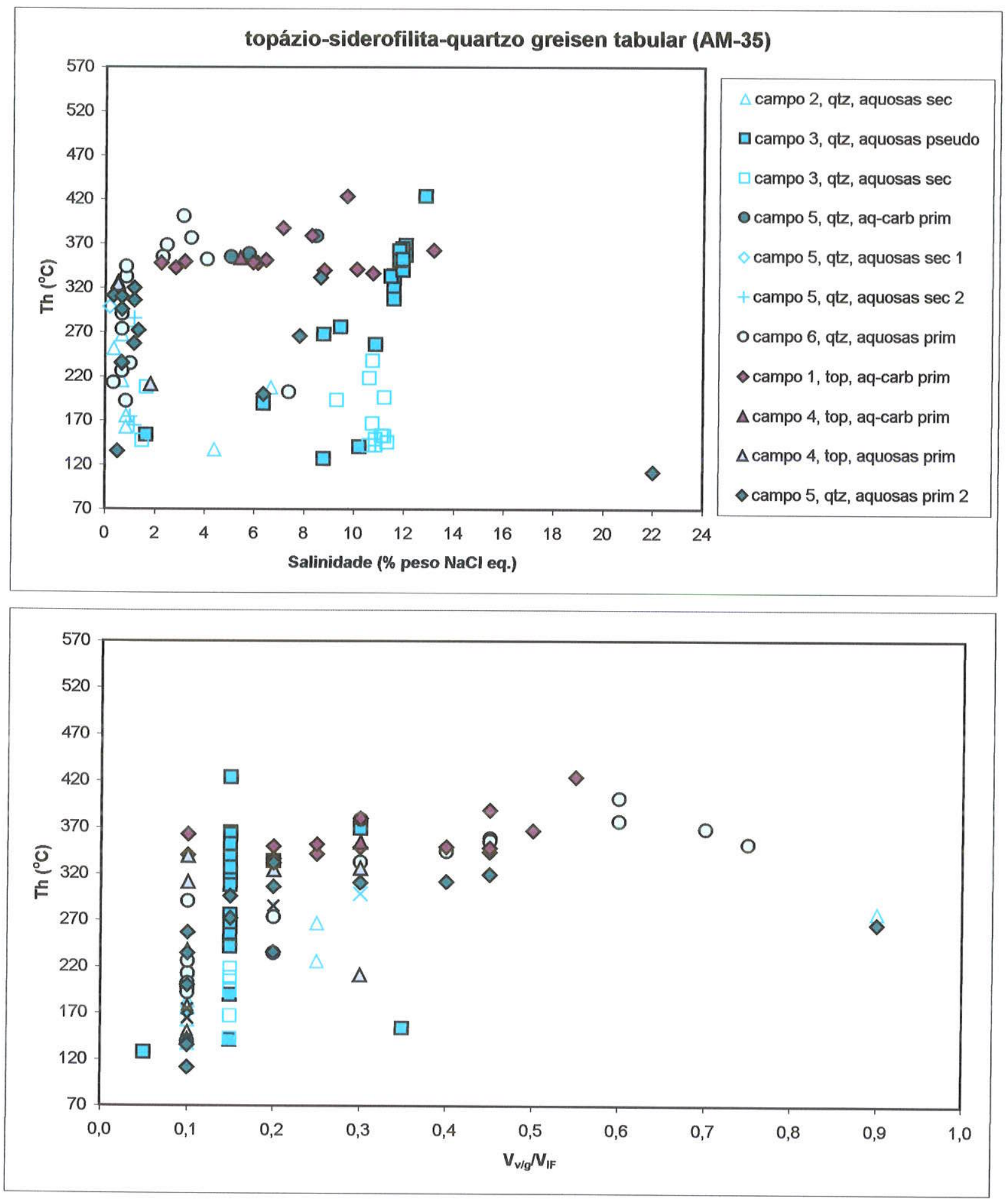

Figura 9.26 - Diagramas de a) salinidade e b) $V_{\mathrm{V} / g} / \mathrm{V}_{\mathrm{IF}}$ versus Th das inclusões aquosas e aquocarbônicas, primárias e secundárias, do topázio-siderofilita-quartzo greisen tabular (AM35). 
Todavia, as tendências obscrvadas no diagrama Th versus salinidade (Fig. 9.26.a) são análogas àquela definida por Hedenquist \& Henley (1985) para a imiscibilidade seguida de mistura em sistemas de alto conteúdo de gases, em que a diminuição da salinidade no intervalo entre $420 \mathrm{e}$ $330^{\circ} \mathrm{C}$, nessa amostra, representaria a imiscibilidade, e o lend vertical na extrema esquerda do diagrama representa a mistura, ou mesmo o próprio extremo final, aquoso, de origem meteórica, de baixa salinidade, envolvido no processo.

O fluido aquoso da população pseudo-secundátia do campo 3, aprisionado no quartzo, parece ser representativo do extremo aquoso salino resultante do processo de imiscibilidade. Sua dispersão rumo às temperaturas e salinidades mais baixas representa a diluição desse fluido.

A coexistência de dois fluidos, de densidades diferentes, à mesma temperatura, é comprovada no diagrama da Fig. 9.27.b.

\section{C) Granito albitizado salmão}

No granito albitizado salmão estão representados fluidos aquosos, com concentrações taço de $\mathrm{CO}_{2}$, de baixa salinidade. A presença do $\mathrm{CO}_{2}$, bem como a superposição das maiores 'Th's dessas inclusoes com aquelas que definem o lrend de imiscibilidade identificado no topázio-siderofilitaquartzo greisen tabular, permitem supor uma vinculação com a crolução dos fluidos aprisionados nesse greisen. As inclusòes aquosas aprisionadas no granto albitizado salmào podem corresponder aos fluidos aquo-carbônicos de origem magmática, identificados no topázio-siderofilita-çuartzo greisen tabular, diluídos pela mistura com fluidos metéricos, conforme sugerido pela evolução identificada na amostra AM-35.

Os pontos analíticos das inclusòes dessa amostra definem belamente a curva de imiscibilidade no diagrama the trsus $V_{v} / V_{11}$ (Fig. 9.28.b), e o trend no diagtama de th versus salinidade (Fig. 9.28.a) é coerente com diminuiçăo da salinidade com a temperatua paxa sistemas de baixas salinidade concentração de $\mathrm{CO}_{2}(\%$ Wilkinson 2001). O discreto aumento da salinidade com o volume da fase vapor (Fig. 9.28.c) reforça essa hipótese, pois inclusooes com maior $V_{v} / V_{H 1}$ e, provavelmente, maior quantidade de $\mathrm{CO}_{2}$, são levemente mais salinas. 

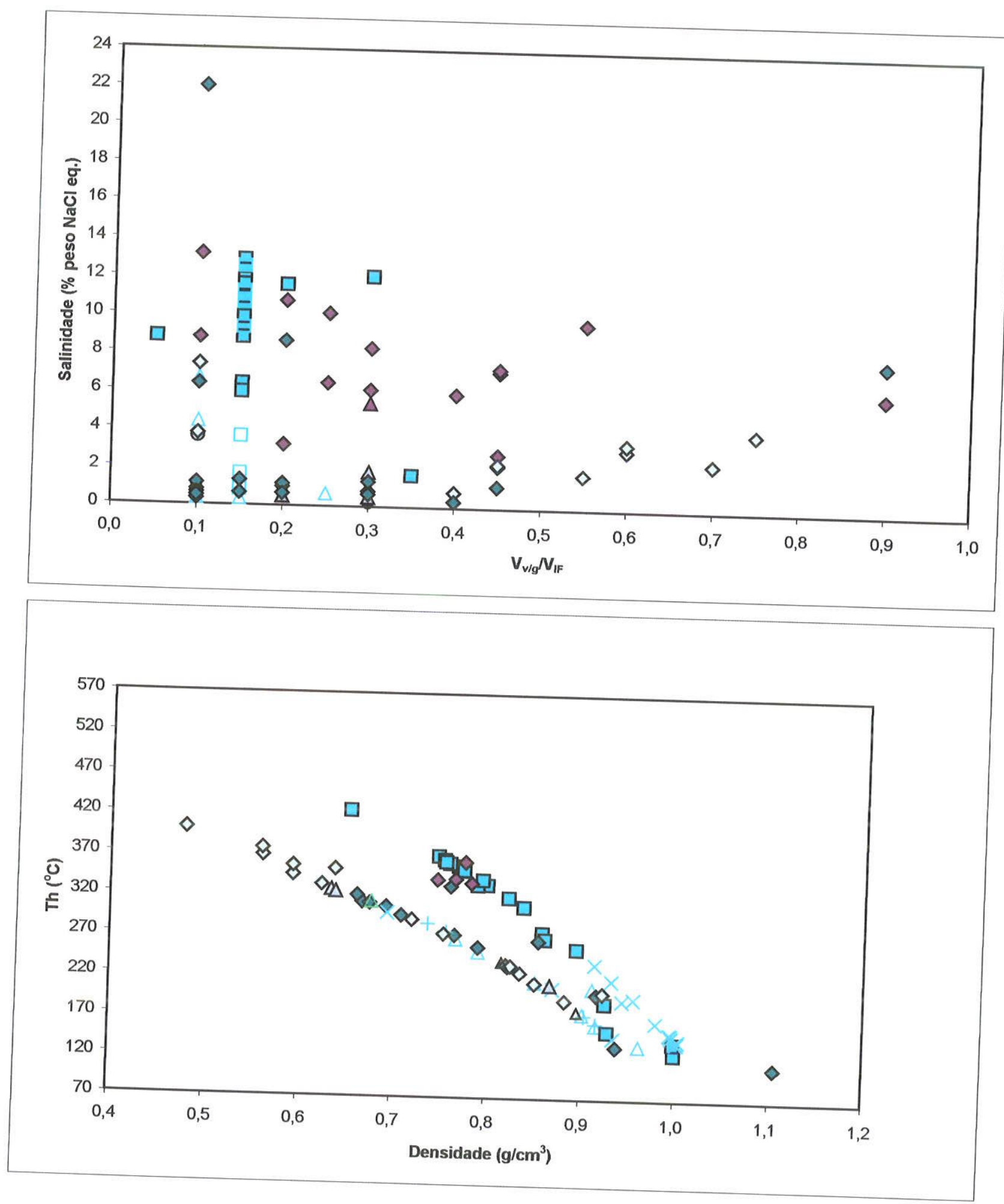

Figura 9.27 - a) Diagrama Vv/g/VIF versus salinidade e b) densidade versus Th das inclusões aquosas
e aquo-carbônicas, primárias e tabular (AM-35). Legenda conforme Fig. 9.26.a do topázio-siderofilita-quartzo greisen 

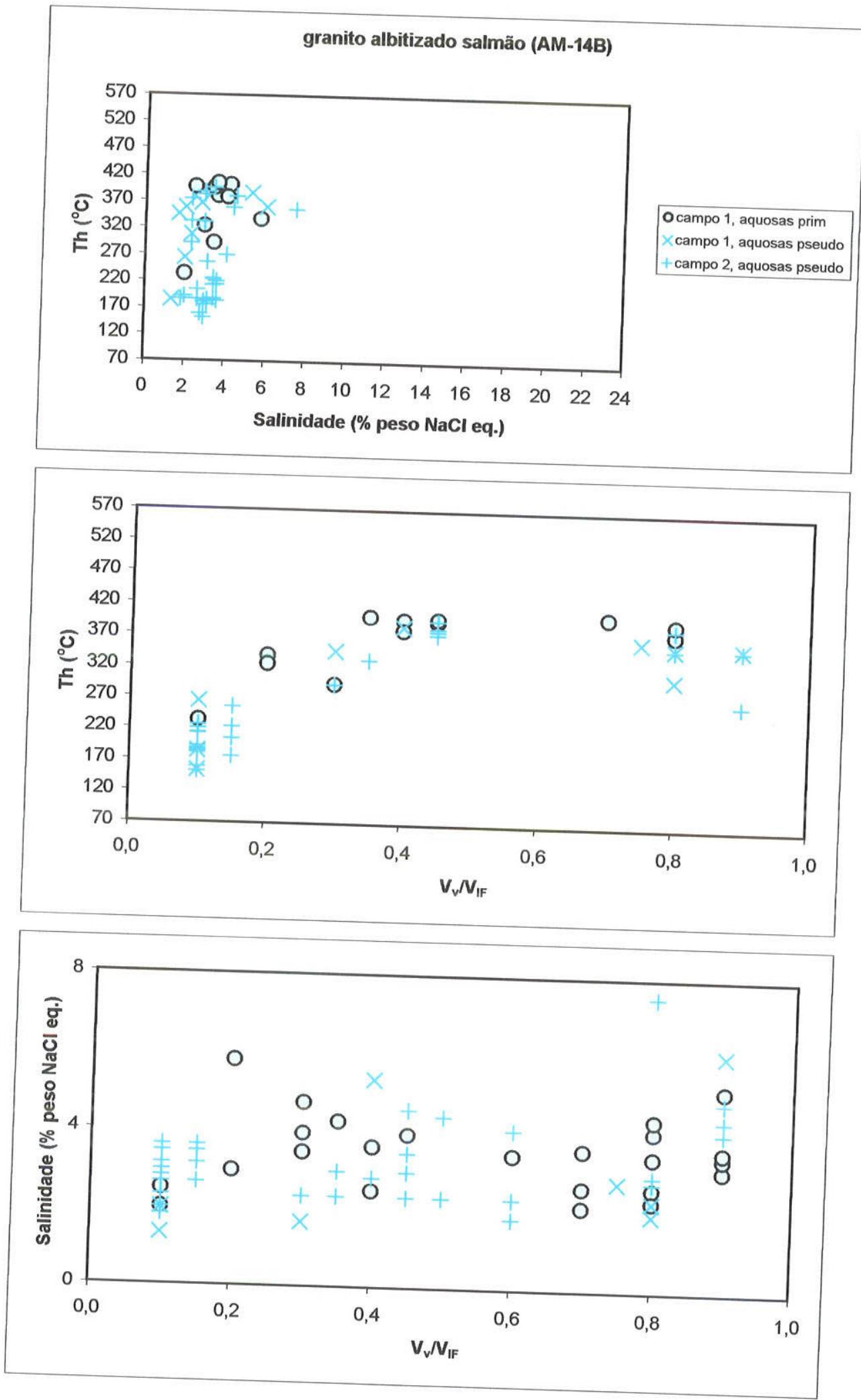

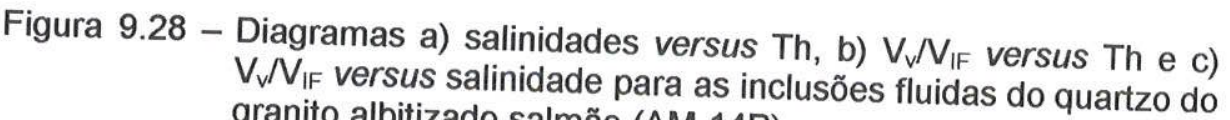
granito albitizado salmão (AM-14B). 


\subsubsection{Estágio pós-magmático}

\section{a) Stockwork de topázio-siderofilita-quartzo greisen}

No topázio dessa amostra, inclusòes fluidas aquo-carbônicas, com proporções volamétricas da fase vapor variaves, coexistem, na mesma região da mesma amostra, com aquosas primátias, sugerindo imiscibiliclade.

No quartzo, ocorrem apenas inclusòes aquosas, também caracterizadas por proporçoes volumétricas da fase vapor variáveis, distribuídas nas mesmas regiòes das mesmas amostras.

A análise conjunta das inclusões presentes em topázio e quartzo mostra cvolução extremamente semelhante àquela delineada para o topázio-siderofilita-quartzo greisen tabular, porém com menor contribuiçăo de fluidos meteóricos. Para os dois minerais analisados, a existência de imiscibilidade é, ainda, corroborada pela distribuição dos pontos no diagrama Th versus $\mathrm{V}_{\mathrm{s} / \mathrm{v}} / \mathrm{V}_{\mathrm{HI}}$ ( Fìg. 9.29.b), em que os mesmos configuram uma curva solmus, melhor definida para o topázio, sugestiva de trapeamento ao redor de $350^{\circ} \mathrm{C}$.

Observa-se, de modo geral, diminuição da salinidade com o aumento da proporçăo volumétrica da fase gasosa ou vapor nas inclusòes primárias aquo-carbonicas e aquosas coexistentes, presentes tanto no quartzo quanto no topázio (Fig. 9.29.c), o que constitui mais um indício de imiscibilidade.

As inclusoes fluidas secundárias apresentam, freqüentemente, as mais baxas salinidades, sendo possivelmente representativas de fluidos meteóricos aquecidos.

\section{b) Veio de quartzo-cassiterita}

Os fluidos envolvidos na gênese desse veio parecem constituir o extremo de baixa salinidade do processo de imiscibilidade e diluição reconhecido nos greisens. A tenclência, com o rebaixamento da temperatura, é de aumento da salinidade (lig. 9.30.a, b e c). A composição do sistema é essencialmente sódica, nas maiores temperaturas, e evolui para a cálcica nas mais baixas (Fig. 9.20.b). O boiling dessa solução é sugerido pela variaçào volumétrica da fase vapor, em inclusões fluidas coexistentes nas mesmas regiòes das mesmas amostras, e pela distribuição dos pontos no diagrama Th wersus $\mathrm{V}_{\mathrm{s}} / \mathrm{V}_{\mathrm{IF}}$ (Fig. 9.30.b), que indicam temperatura de aprisionamento da ordem de $320 / 370^{\circ} \mathrm{C}$. 

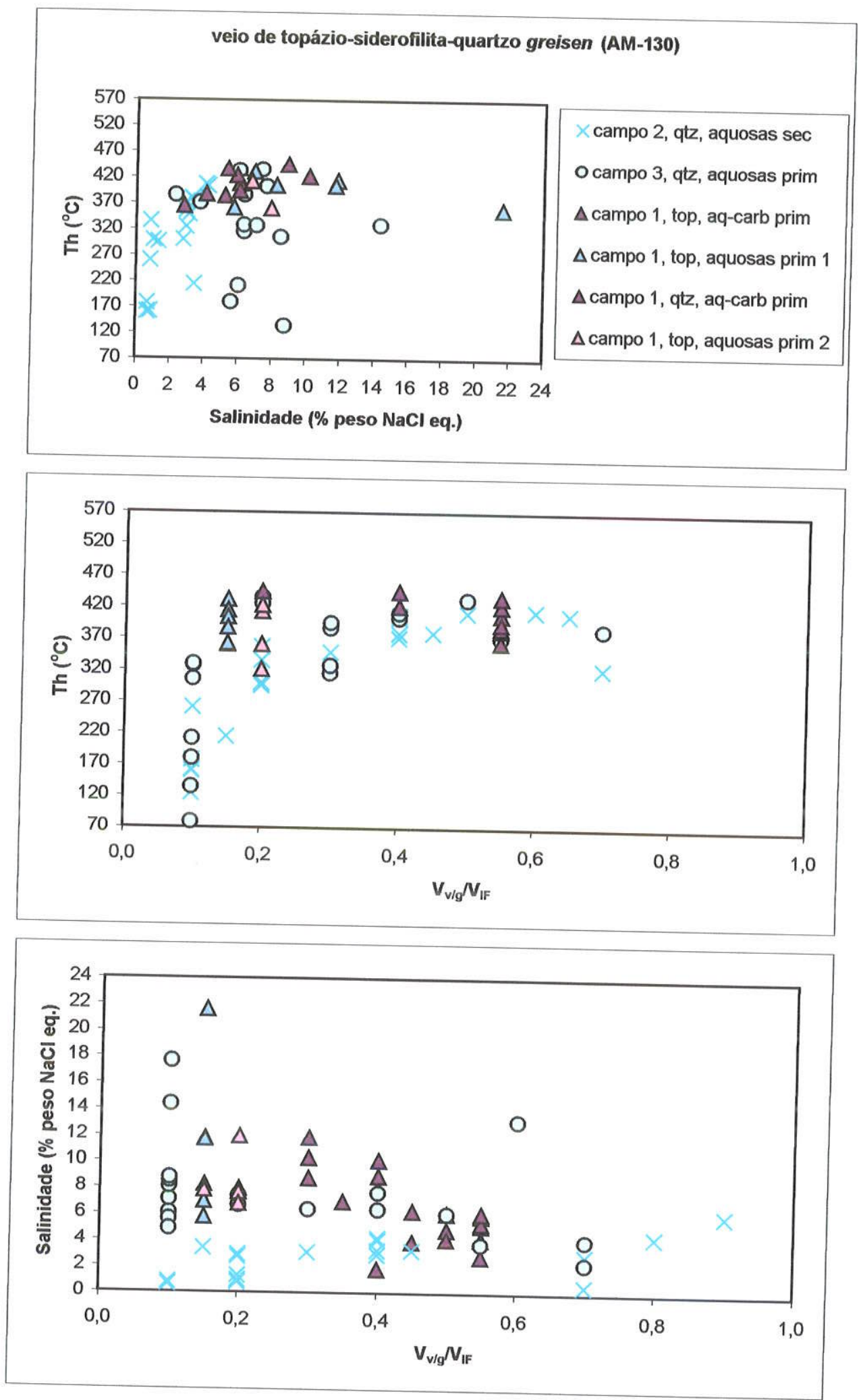

Figura 9.29 - Diagramas a) salinidade versus $T h$, b) $\mathrm{V}_{\mathrm{v} / \mathrm{g}} / \mathrm{V}_{\mathrm{IF}}$ versus $\mathrm{Th}$ e c) $\mathrm{V}_{\mathrm{V} / \mathrm{g}} / \mathrm{V}_{\mathrm{IF}}$ versus salinidade para as inclusões em quartzo e topázio do veio de topázio-siderofilita-quartzo greisen (AM130). 

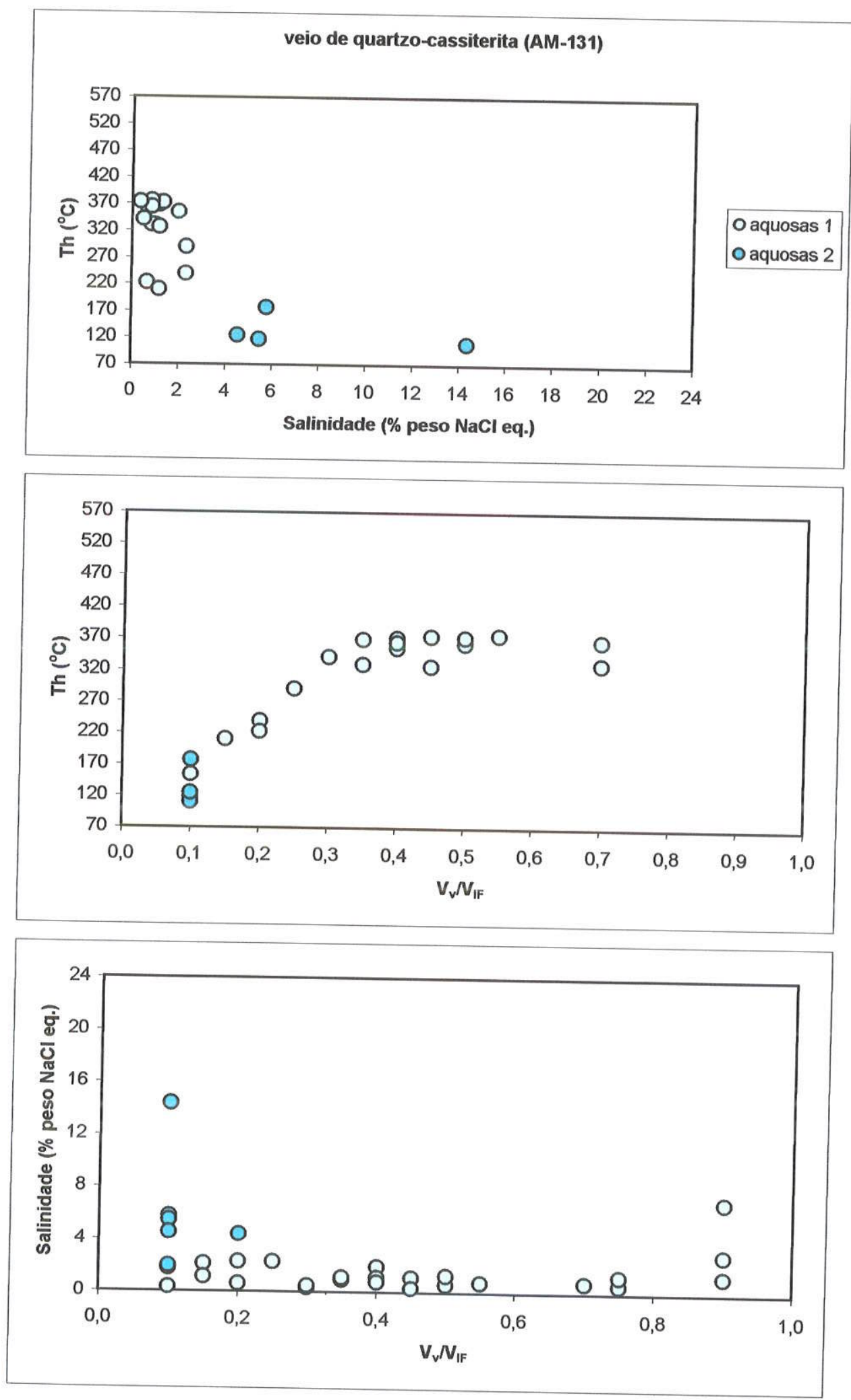

Figura 9.30 - Diagramas a) salinidade versus $T h, b) V_{V} / V_{I F}$ versus $T$ e e c) $\mathrm{V}_{\mathrm{V}} / \mathrm{V}_{\mathrm{IF}}$ versus salinidade para as inclusões em quartzo do veio de quartzo-cassiterita (AM-131). 


\section{c) Veio de quartzo estéril}

O fluido tapeado nas inclusòes dessa amostra representa, provavelmente, o extremo aquoso meteórico, de baixa salinidade, envolvido no processo de diluição discutido anteriormente, conforme corroboram os dados de isótopos estáveis a seren discutidos no Capítulo XI. Sua presença está registrada na maioria das amostras dos estágios evolutivos precedentes, na forma de inclusoes acuosas secundárias. Sua evolução provavelmente resultou do simples aquecimento/resfriamento do fluido meteótico, que promoveu o boiling da soluçáo, conforme sugere a grande variaçào volumétrica da fase vapor nas inclusões primárias, ou aincla por necking doum.

As inclusòes primátias têm composição variável no sistema $\mathrm{CaCl}_{2}+\mathrm{FeCl}_{2}+\mathrm{NaCl} \pm \mathrm{KCl}$. As secundárias, que ocorrem em trilhas discordantes, são essencialmente cálcicas, mais salinas e de menor temperatura, muitas vezes meta-estáveis (lïg. 9.21 a, b e c e 9.31.a, b e c).

\subsubsection{Evolucão geral do sistema greisen}

Em termos composicionais, os fluidos magmáticos e meteóricos envolvidos na gênese do depósito estanífero do Maciço Granítico Santa Bárbara sĩo variáveis dentro do sistema $\mathrm{CaCl}_{2}-\mathrm{FeCl}_{2}$ $\mathrm{NaCl}-\mathrm{KCl}-\mathrm{H}_{2} \mathrm{O}_{6} \mathrm{CO}_{2}$. Temperaturas do ponto eutético representativas de sistemas sódicos são menos comuns, ou ainda identificadas em uma melt inclusion aquosa e entre as inclusões aquocarbônicas. As últimas são descartadas para cfeito da definição da composição em virtude da influência do $\mathrm{CO}_{2}$ no ponto eutético de sistemas $\mathrm{H}_{2} \mathrm{O}-\mathrm{CO}_{2}$-sais (Chen 1972 e Bozzo do al. 1975 in Collins 1979). De qualquer mancira, os dados sugerem que os fluidos magmáticos iniciais seriam mais sódicos, havendo evoluçào para fluidos salinos mais cálcicos rumo às baixas temperaturas c/ou diluição por fluidos de baixa salinidade de provável origen meteórica.

Algumas condiçòes para a caracterização do processo de imiscibilidade no sistema ( 6 . Ramboz et al. 1982), como a ocorrência de inclusões de tipos distintos nas mesmas regiòes das mesmas amostras, a homogeneizaçăo desses tipos no mesmo intervalo de temperaturas, sendo um para o líquido e outro para o vapor:/gás, a ctepitaçào antes ou depois da homogenerzaçào coerente entre os dois tipos de inclusòes, a dispersão dos dados de $V_{v / g} / V_{1 l}$, de temperaturas de homogeneizaçào e de composição, săo satisfeitas na maior parte das amostras analisadas. No entanto, a ausência de vazamento ou necking down e a assimetria dos histogramas de Th's, que seriam outros critérios para a identificação de aprisionamento heterogêneo, não puderam ser inequivocamente assegurados. 

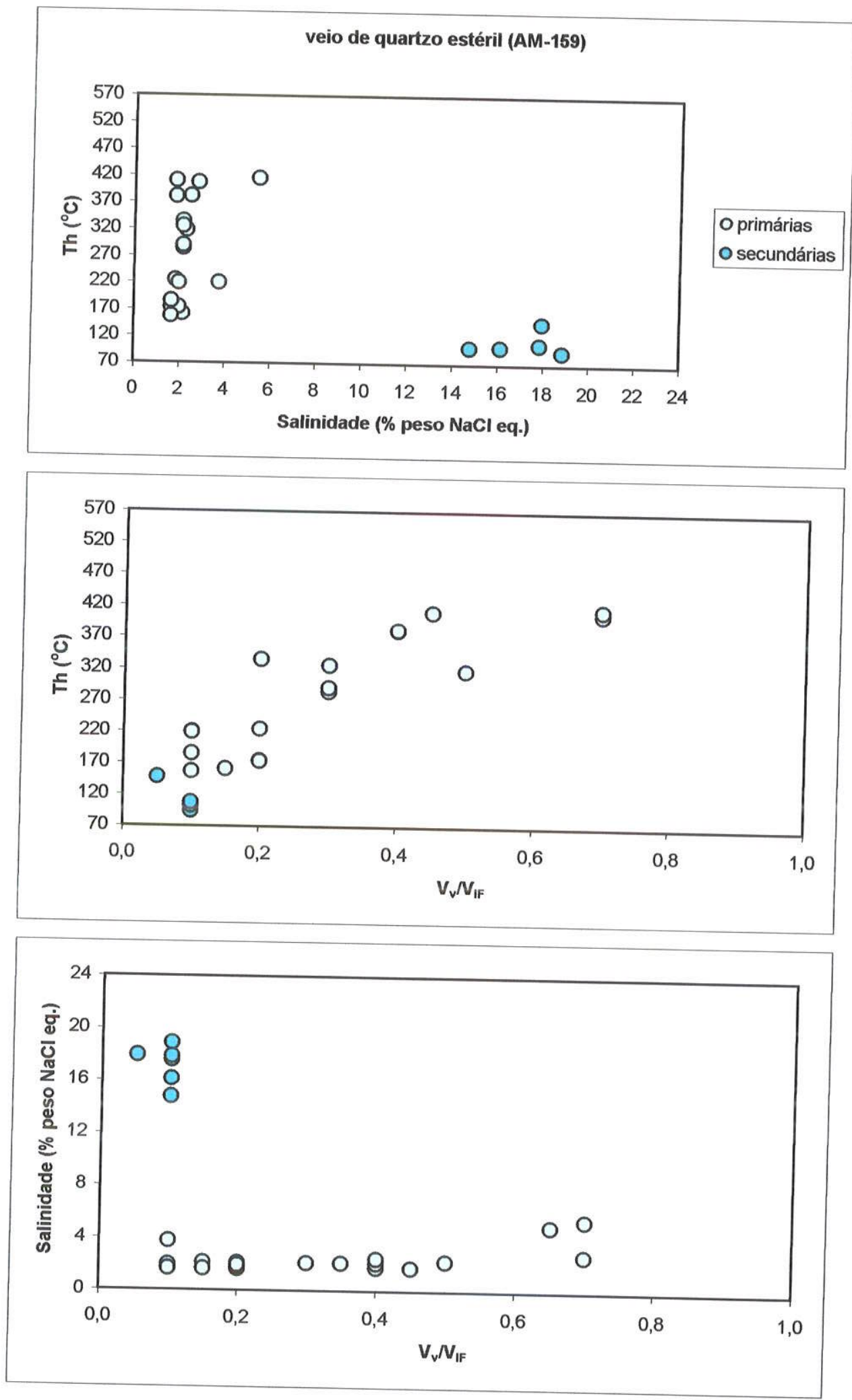

Figura 9.31 - Diagramas a) salinidade versus $T h, b) V_{\mathrm{V}} / \mathrm{V}_{\mathrm{IF}}$ versus $\mathrm{Th}$ e c) $V_{V} / V_{\text {IF }}$ versus salinidade para as inclusões em quartzo do veio de quartzo estéril (AM-159). 
Também o decréscimo da salinidade com o aumento do volume da fase vapor/gás, esperado em sistemas imisciveis, é muitas vezes razoavelmente definido nos diagramas nos intervalos de $V_{v / g} / V_{11}$ menor do que 0,5 , sendo duridosa a partir desse ponto.

$\Delta$ pequena representatividade de inclusòes com fração volumétrica da fase vapor ou gás maior do que 0,5 é comum em sistemas imisciveis, sendo decorrente dos comportamentos distintos das fases em relação às propriedades de umedecimento (metting properties, Watson \& Brenan 1987).

O predomínio de condições de baixa pressão durante a evolução do depósito é indicado pela

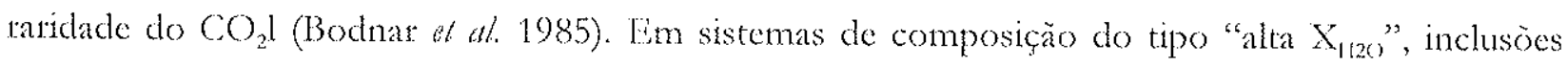
aprisionadas sob pressòes menores do que o ponto crítico do $\mathrm{CO}_{2}$ nào apresentam $\mathrm{CO}_{2} 1$ ( Diamond 1994, 2001). Esse empobrecimento em $\mathrm{CO}_{2}$ também pode ser devido ao escape de voláteis (degaseificação).

Finalmente, a evolução do depósito como um todo se deu num contínuo, em que sistemas fechados imiscíveis $\left(T=390 / 400^{\circ} \mathrm{C}\right)$ deram lugar à imiscibilidade me sistema aberto, via fraturamento, a $350 / 370^{\circ} \mathrm{C}$, evoluindo, ainda, para temperaturas mais baxas $\left(220 / 250^{\circ} \mathrm{C}\right)$. Esse fraturamento permitiu o alojamento dos sistema stockwork de greisen e marca o ponto inicial da mistura dos fluidos de origem magmática, aquo-carbônicos, com salinidades da ordem de $10 \ldots 14 \%$ em peso $\mathrm{NaCl}$ equiv.), definindo belos trends de mistura abaixo da curva soluus do sistema, análogos aos discutidos por Hedenquist \& Henley (1985).

O fluido magmático original é representado apenas pelas inclusões de melts silicáticos (mell inclusions), cuja fase aquosa, de salinidade entre 10 e $15 \% \mathrm{NaCl}$ equiv, revelou, principalmente, a presença de sódio. As fáses cristalinas dessas inclusòes não sofretam fusão até $600^{\circ} \mathrm{C}$, indicando temperaturas superiores de aprisionamento e de cristalização dos minerais hospedeiros. Essas inclusóes encontram-se preservadas no albita-microclínio granito branco do estácio magmático, bem como no granito albitizado salmão e no topázio-siderofilita-quartzo greisen tabular do estágio transicional.

A evidência mais precoce de imiscibilidade dos fluidos aquo-carbônicos, que cvoluíram a partir do sistema magmático, foi obtida por meio das inclusões primárias preservadas no topázio do bolsào de quartzo com siderofilita e topázio, do estágio transicional, que indicaram temperaturas de aprisionamento de $390 / 4000^{\circ} \mathrm{C}$ e pressòes da ordem de 300 bar (Fig. 9.32). Essas temperaturas e suas salinidades (10 a $14 \%$ em peso $\mathrm{NaCl}$ equiv.) são característicos de fluidos tipicamente magmáticos 
(Roedder 1992).

A evoluçào do sistema, com imiscibilidade em temperaturas mais baixas $\left(350 / 370^{\circ} \mathrm{C}\right)$, é representada principalmente pelas inclusòes primátras em minerais do topázio-siderofilita-quartzo greisen tabular do estágio transicional e do stockzork de topázio-siderofilita-quartzo greisen, estágio pósmagmático, sob condições de pressão da ordem de 200 e 200-250 bar, respectivamente (fig. 10.32). Esses fluidos afetaram, ainda, as rochas do estágio magmático, encontrando-se registrados nas inclusòes secundárias em quarto do pegmatito e topázio do albita-microclínio granito branco, sendo responsáveis por modificações das inclusões primárias do quartzo desse granito.

A contribuição dos fluidos meteóricos de baixa salinidade (0 a $3 \% \mathrm{~cm}$ peso $\mathrm{NaCl}$ equiv.), representados em inclusòes secundárias, é verificada na maior parte dos litotipos estudados. Esses fluidos constituem inclusòes primárias unicamente nos veios de quartzo estéreis, os mais tardios do sistema.

A presença de abundantes inclusòes fluidas monofásicas em algumas amostras demonstra a provável incidência do processo de necking down das inclusòes até temperaturas $\leq 100^{\circ} \mathrm{C}$ (Bodnar et al. 1985), embora não haja maiores incoerências em termos de temperaturas de homogencização nessas inclusoes.

Em muitas amostras ainda é evidente a presença de fluidos posteriores de salinidades elevadas e enriquecidos em cálcio. Esses fluidos podem representar a própria evolução do fluido magmático original, que teria sua salinidade aumentada pela hidratação de minetais das rochas encaixantes adjacentes. Os processos de albitizaçăo dos feldspatos liberam cálcio mais facilmente que sódio, com o decréscimo da temperatura (Schwartz \& Askury 1989 in Grapner at al. 1999), constituíndo um mecanismo plausivel para o enriquecimento em cálcio observado nas amostras estudadas.

Minérios de cassitcrita em veios, brechas e greisens mesotermais são formados a pastir de fluidos salinos inicialmente equilibrados com uma fonte granítica de alta temperatura $\left(>400^{\circ} \mathrm{C}\right)$, que reagem, posteriormente e de maneira irreversivel, com rochas e com outras soluçòes no ambiente deposicional mais frio (Heinrich 1990).

Os processos de imiscibilidade são responsáveis por mudanças na acidez e no pH das soluçòes. Um fluido em boiling tem efeito oxidante, e pode ocasionar a precipitação de minerais que envolvem oxidação (Drummond \& Ohmoto 1985, Heintich 1990). 
Heinrich (1990) discute que a precipitação da cassiterita da partir de complexos de Sn bivalente presentes em soluçòes redutoras e ácidas é favorecida pela oxidação e neutralização ácida. No entanto, no caso dos fluidos magmáticos de alta temperatura, tipicamente mais salinos, a perda do $\mathrm{CO}_{2}$ para a fase gasosa com a imiscibilidade nào afeta significativamente a acidez da solução, pois o ácido dominante (HC) nào sofre partição para aquela fase (Heinrich 1990). Mesmo a partir de um fluido em boiling, a precipitação efetiva de cassiterita num amplo intervalo de temperaturas requet reações concomitantes com as rochas encaixantes, que ocasionam neutralização dos ácidos c diminuição das concentrações iniciais de espécies redutoras (Heintich 1990).

A imiscibilidade em sistema aberto é mais efetiva nas modificações dos conteúdos de gases sendo, portanto, associada com maiores mudanças de $\mathrm{pH}, f_{2}$, eH e outros fatores, do que o sistema fechado, resultando em deposiçào mineral mais efetiva (Drummond \& Ohmoto 1985).

A diluição dos fluidos magmáticos por água pua promove precipitação de pequenas quantidades de cassiterita. Se os fluidos meteóricos, frios, forem misturados com pequenas proporçòes de fluidos magmáticos, entretanto, a precipitação de cassiterita é eficiente (Heinrich $1990)$.

Logo, o controle da deposiçáo da cassiterita no sistema estudado tem três vias: 1) o processo de imiscibilidade, com alto grau de interação rocha/fluido, no caso dos corpos de greisen tabulares e no sistema stockmork de greisen, 2) o boiling de fluidos aquosos sódicos nos veios de quartzocassiterita, e 3) a mistura dos fluido magmáticos de alta temperatura, mais salinos, com grandes proporções de fluidos meteóricos, frios, de baixa salinidade, nos veios de muscovita. 

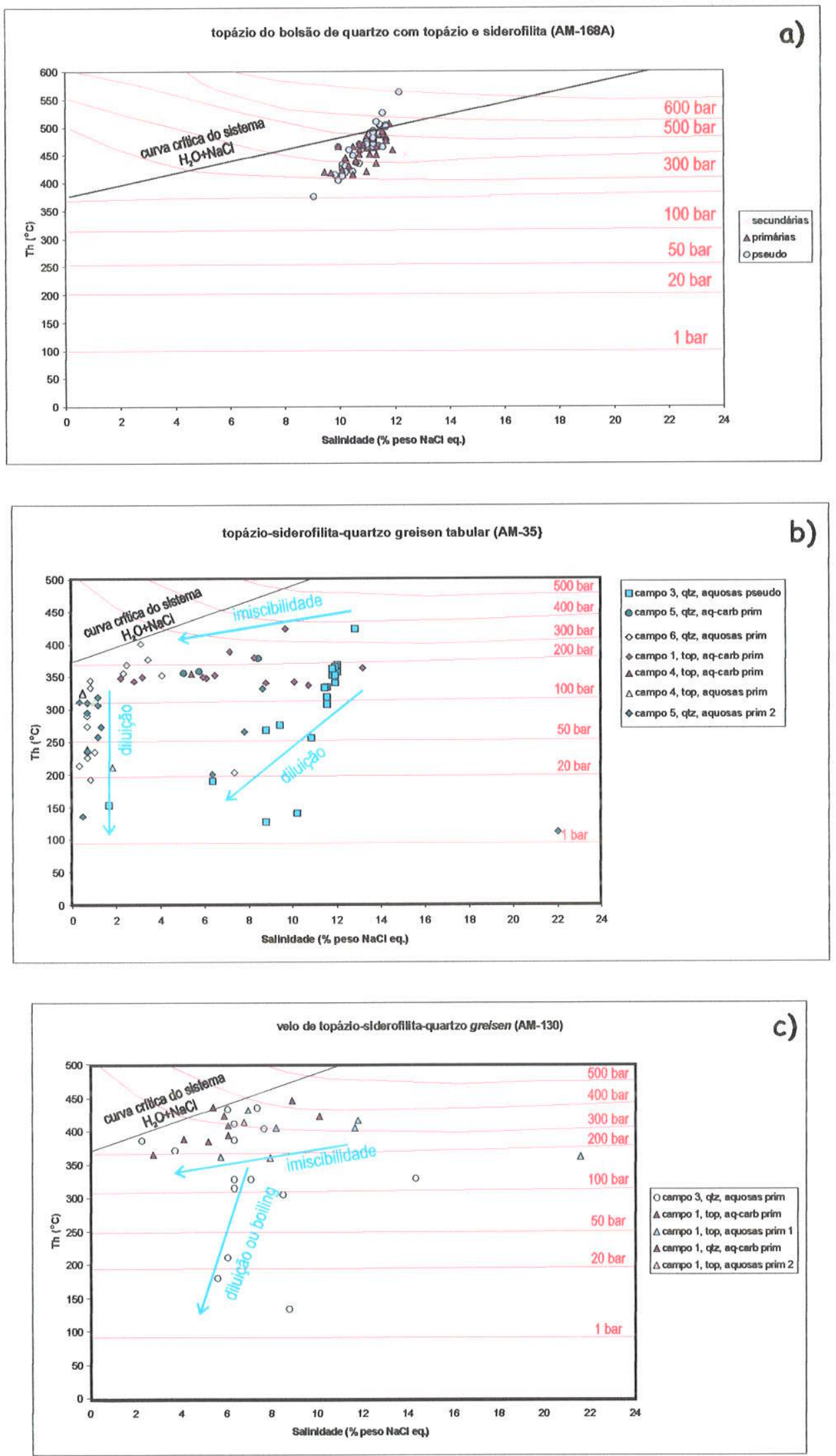

Figura 9.32 - Diagramas Th versus paraas inclusões primárias aquosas e aquo-carbônicas a) no topázio do bolsão de quarto com siderofilita e topázio, b) no quartzo e no topázio do greisen tabular e, c) no quartzo e no topázio do stockwork de greisen. As isóbaras são de Bodnar et al. 1985). 
Prancha 9.1 - a) Inclusões primárias aquosas e aquo-carbônicas em quartzo do albita-microclínio granito branco (AM-134); b) inclusões aquo-carbônicas secundárias no topázio do albitamicroclínio granito branco; c) plano de pequenas inclusões aquosas secundárias da população 2 (porção direita da foto) no quartzo do pegmatito (AM-213) e grupo de inclusões secundárias aquo-carbônicas da população 3 (maiores, de forma irregular, no centro da foto); d) detalhe das inclusões aquosas secundárias da população 2 da foto anterior; e) detalhe da inclusões aquo-carbônicas secundárias da população 3 da foto c; f) inclusões aquosas primárias, orientadas, presentes no topázio do bolsão de quartzo com siderofilita e topázio (AM-168A); g) inclusões aquosas pseudo-secundárias, não orientadas, presentes no topázio do bolsão de quartzo com siderofilita e topázio (AM$168 \mathrm{~A}) ; \mathrm{h}$ ) inclusões aquosas secundárias presentes no quartzo do bolsão de quartzo com siderofilita e topázio (AM-168C). 
a)
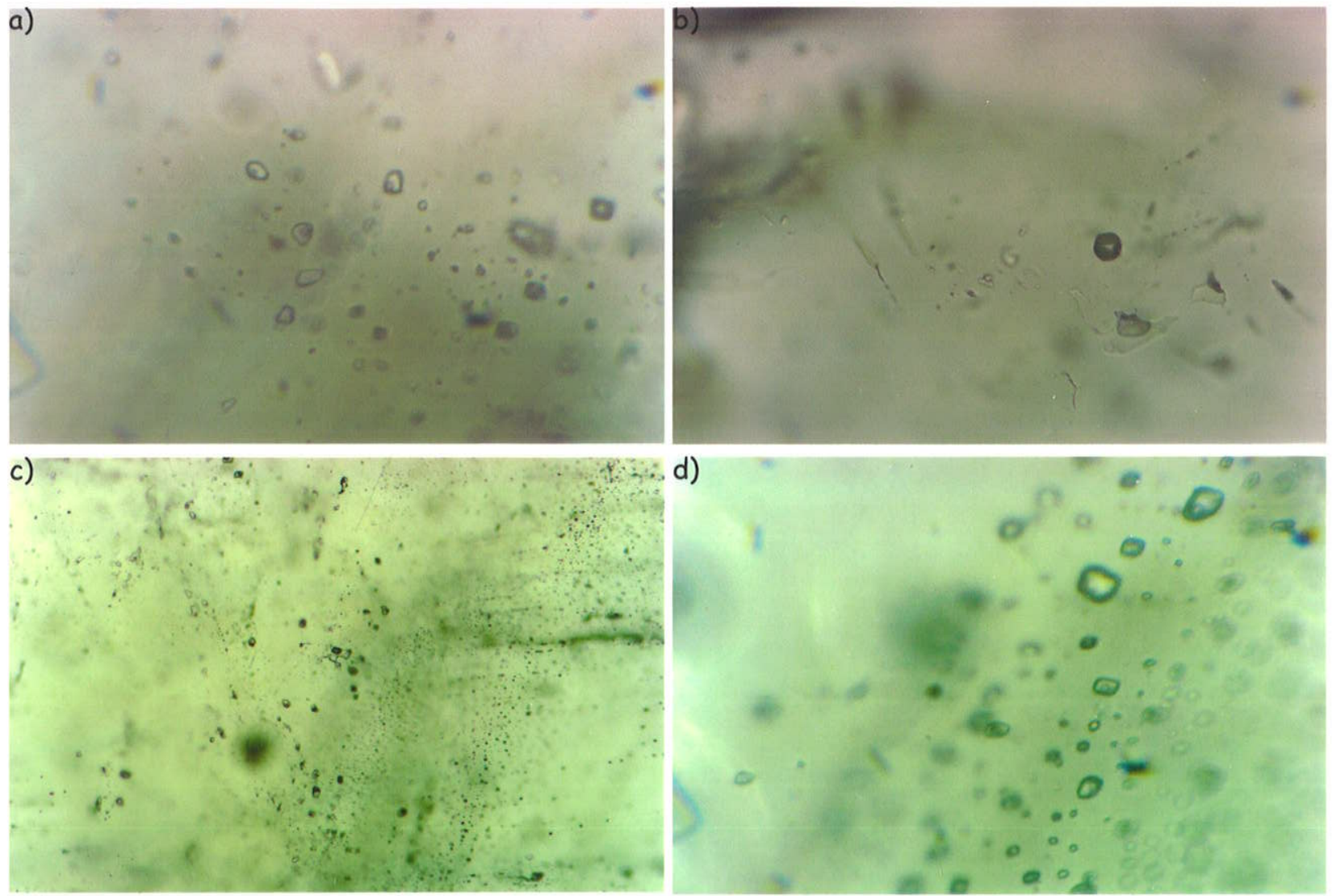

e)
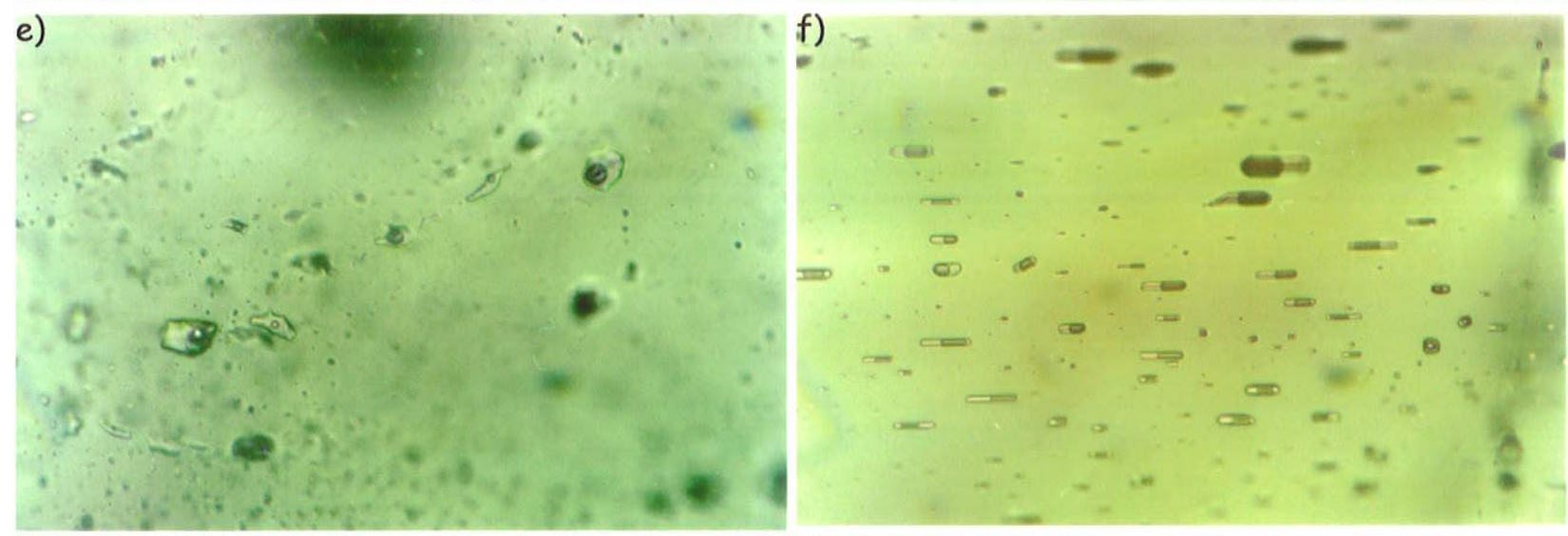

g)

tit

h)
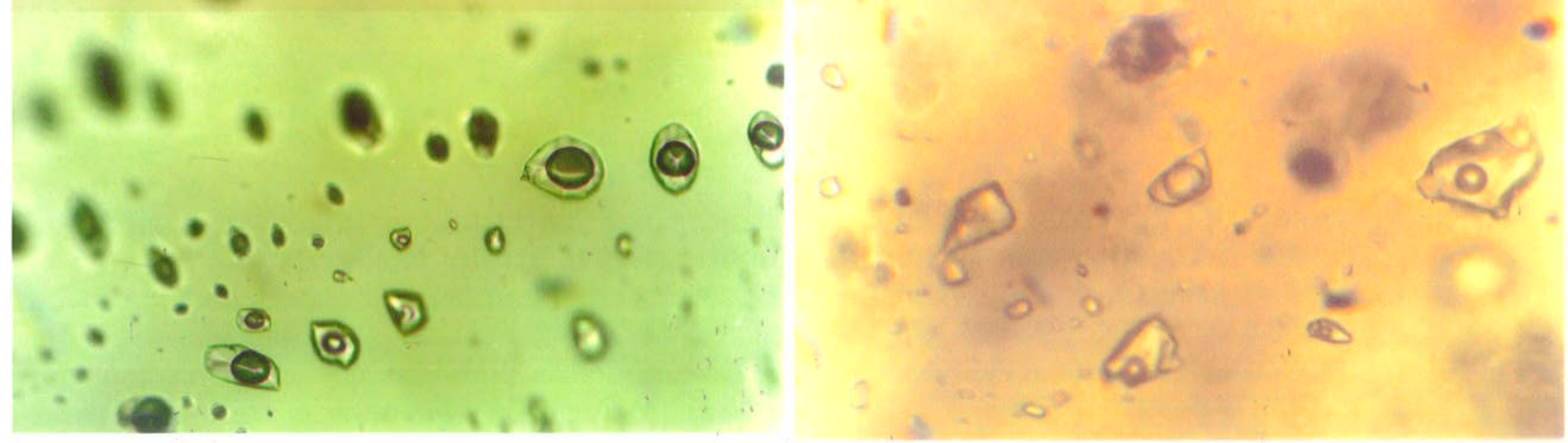

Prancha 9.1. 
Prancha 9.2 - a) Inclusões aquosas "primárias" localizadas nas faces de crescimento do quartzo do bolsão de quartzo com siderofilita e topázio (AM-168C); b) detalhe da foto anterior; c) melt inclusion com fase vapor de composição aquo-carbônica presente no topázio do topázio-siderofilita-quartzo greisen tabular (AM-35); d) aspecto geral da distribuição de melt inclusions, inclusões aquosas e aquo-carbônicas primárias no topázio do topáziosiderofilita-quartzo greisen tabular (AM-35); e) inclusões aquosas e aquo-carbônicas primárias presentes no quartzo (campo 5) do topázio-siderofilita-quartzo greisen tabular $(A M-35) ; f$ inclusões aquosas pseudo-secundárias presentes no quartzo (campo 3) do topázio-siderofilita-quartzo greisen tabular (AM-35); g) inclusões aquosas primárias e melt inclusions em quartzo do granito albitizado salmão (AM-14B); h) detalhe da foto anterior. 
a)

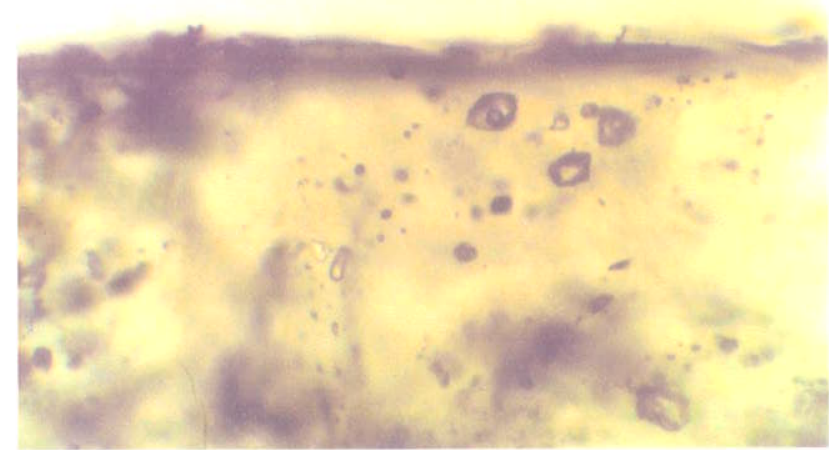

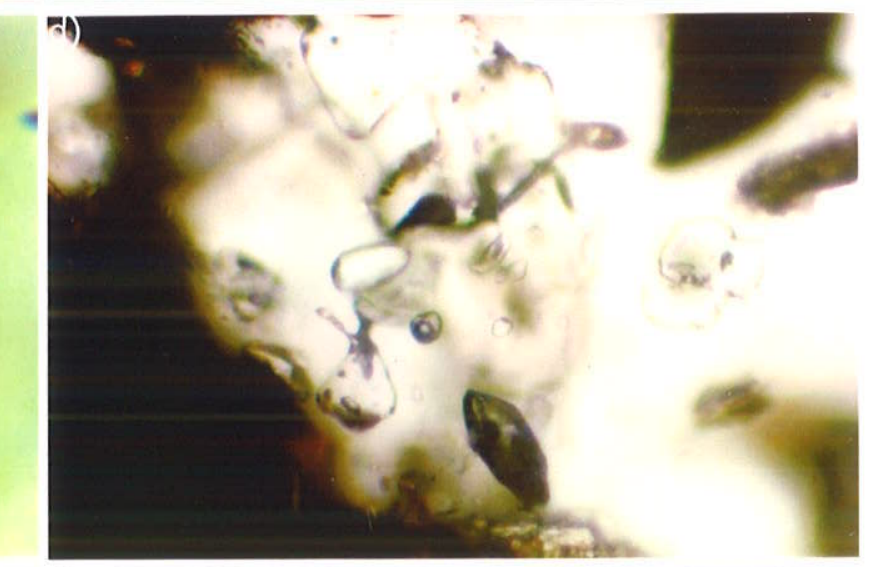

e)

c) $46,2 \mathrm{x}$ 6
+4
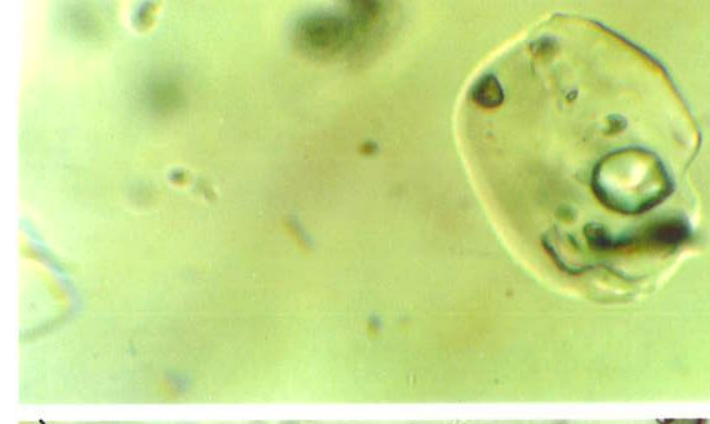

5

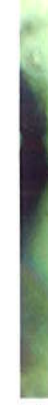

g)

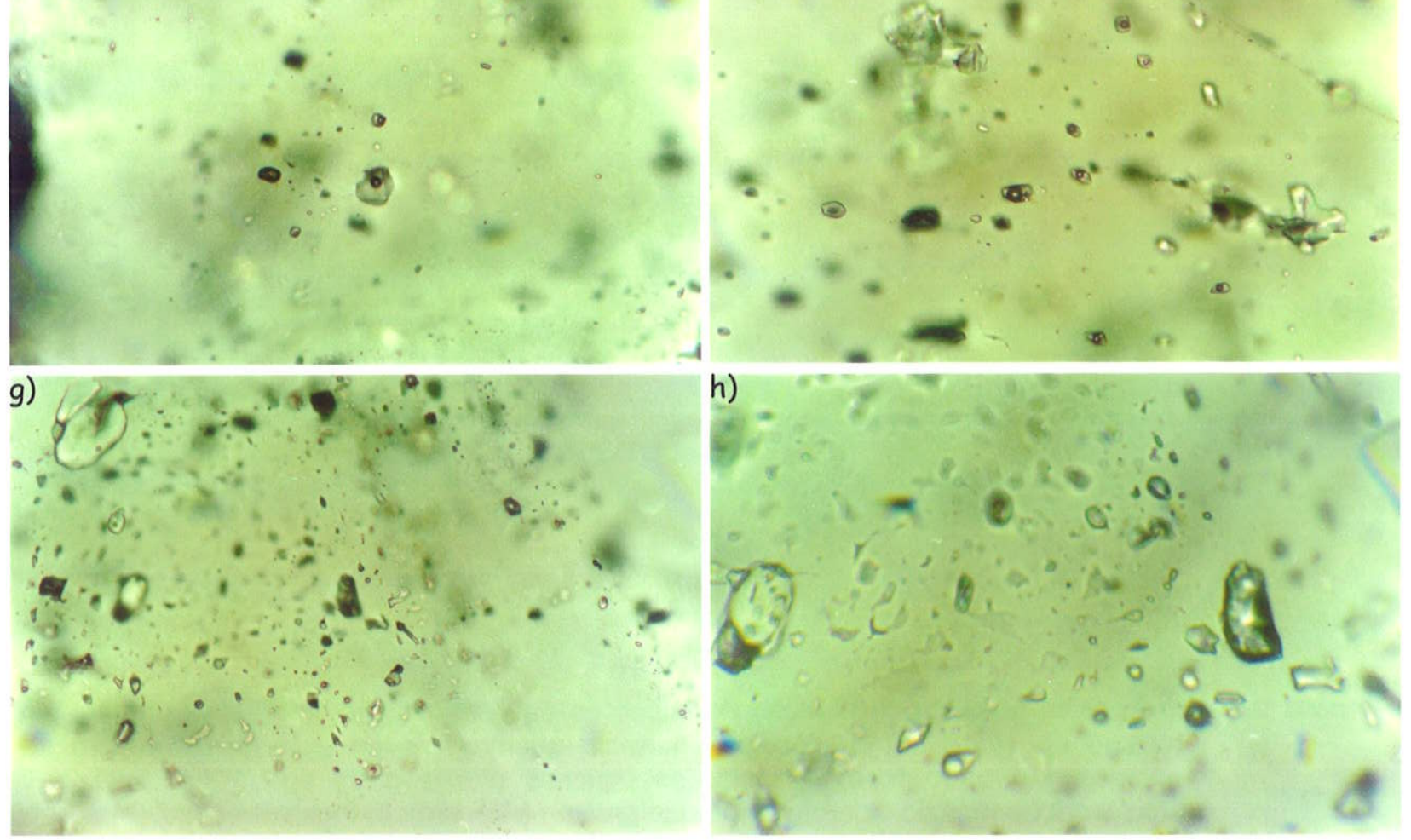

b)

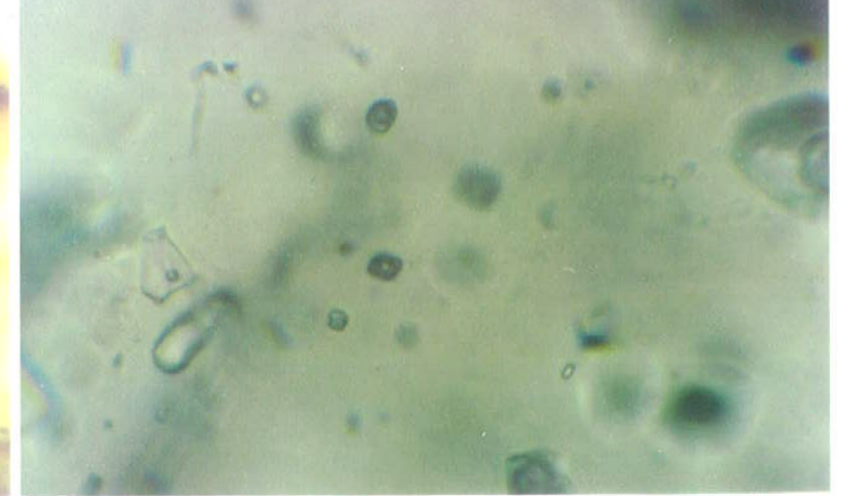

f)

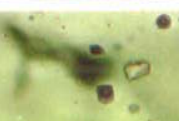

Prancha 9.2. 
Pfancha 9.3 - a) Aspecto geral da distribuição de inclusões aquosas e aquo carbônicas primárias no topázio do stockwork de topázio-siderofilita-quartzo greisen (AM-130); b) idem foto anterior, em outro foco; c) inclusões aquosas primárias do tipo 1 em topázio do stockwork de topázio-siderofilita-quartzo greisen (AM-130); d) inclusões compostas cujas fase vapor aparenta escape iminente durante o trapeamento - quartzo do stockwork de topázio-siderofilita-quartzo greisen (AM-130); e) inclusões aquosas primárias em quartzo do veio de quartzo-cassiterita (AM-131); $)$ detalhe da porção direita da foto anterior; 9 ) inclusões aquosas primárias distribuídas ao longo das faces de crescimento de quartzo do veio de quartzo esteril (AMw159); h) detalhe da foto anterior. 

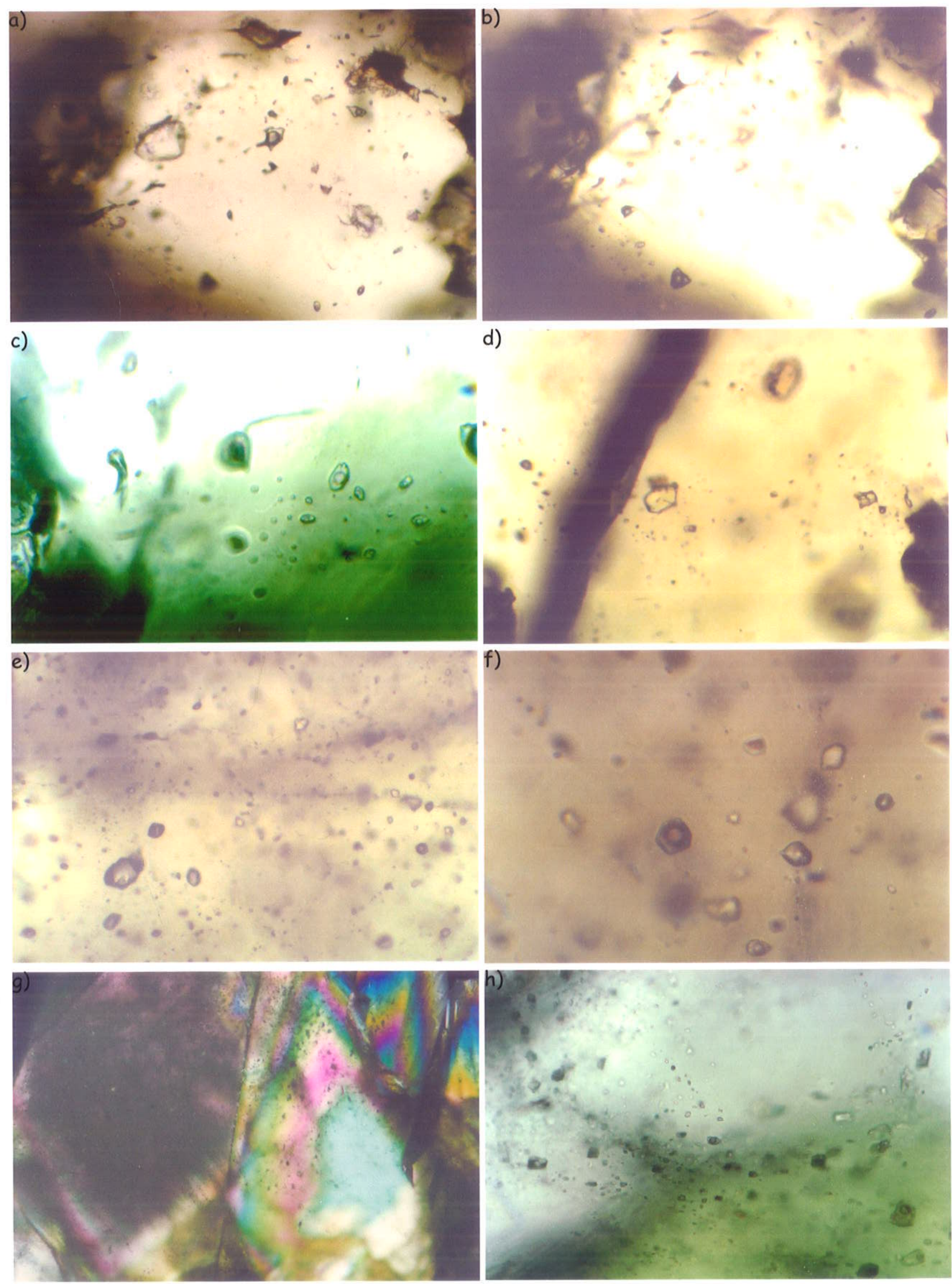

Prancha 9.3. 


\section{GEOQUIMICA ISOTÓPICA DE OXIGENNIO E HIDROGÊNIO}

\subsection{Introdução}

Os isótopos estáveis constituem uma feramenta em estudos petrológicos. O equilíbrio isotópico de oxigênio entre os minerais de uma rocha, por exemplo, é forte evidência de que a rocha está em equilíbrio quámico (O’Ncil 1986; Hoefs 1997).

As constantes de equilibrio para reaçòes de troca isotópica são dependentes da temperatuara, e essa é a base do seu uso na termometria (O’Neil 1986), com a vantagem de que sua dependência em relação à pressão é menor do que o limite analítico de detecção para o sistema do oxigênio a pressòes menores do que $20 \mathrm{kbar}$ (Clayton et al. 1975; Hoefs 1997).

Já os fracionamentos isotópicos de hidrogênio entre minerais são insensíveis à temperatura (Suzuoki e lepstein 1976; Graham et al. 1984). As reaçòes de troca isotópica de hidrogènio, entretanto, são importantes matcadores de transição de fase da água entre os estados vapor, líquido, e sólido (Hoefs 1997). O uso dos isótopos de hidrogênio também se aplica à investigaçăo do tipo de fluido presente em diversos processos geológicos.

A maior parte dos pares isotópicos apresentam o inconveniente de terem sido calibtados para temperaturas no intervalo de 500 a $800^{\circ} \mathrm{C}$ (e.g., Bottingal e Javoy 1973, 1974; Blatner e Bird 1974), de 200 a $750^{\circ} \mathrm{C}$ (Clayton ot al. 1972) ou, anda, de 350 a $800^{\circ} \mathrm{C}$ (O’Neil c Taylor 1967). Essa limitação tem sido superada, especialmente para o sistema oxigênio, com os trabalhos de Zheng (1991; 1993a,b), que propôs equaçòes de fracionamento válidas para temperatuas entre 0'C e $1200^{\circ} \mathrm{C}$. 


\subsection{Isótopos Estáveis no Estudo de Granitóides e Mineralizações Associadas}

\subsubsection{Comportamento isotópico do magma}

A maior parte das rochas igneas apresenta um intervalo de variação de $8 \mathrm{D}$ entre -50 e $-95 \%$ e de $\delta^{18} \mathrm{O}$ cntre $+5,5 \mathrm{e}+11,0 \%$. As composições isotópicas de rochas ígneas nào alteradas provavelmente refletem, em grande parte, as razões isotópicas da regiào fonte do magma $\mathrm{c}$ modificaçòes resultantes de processos de assimilação e/ou interação do magma com as encaixantes, além de processos tardios de unmixing (Taylor e Sheppard 1986).

\section{a) Sistema Oxigênio}

No estudo de rochas graníticas, podem-se usar pares de oxigênio quartzo-feldspato (Bottinga e Javoy 1973, 1974; Blattner e Bird 1974; Zheng 1993a), quartzo-magnetita (Becker 1971), quartzo-biotita (Bottinga e Javoy 1975; Zheng 1993b), biotita-feldspato (Bottinga e Javoy 1974) e feldspato-magnetita (Bottinga e Javoy 1973, 1974).

Quartzo e feldspato, no cntanto, não compòem um par confiável para a termometria de isótopos de oxigênio potque os valores de $\Delta^{18} \mathrm{O}$ são pequenos, variam pouco com a temperatura $\mathrm{e}$ porque o feldspato é particularmente suscetivel a troca isotópica com fluidos pós-formacionais (O’Neil 1986). Na termometria isotópica de rochas metamórficas e magmáticas, as estimativas de temperatura são freqücntemente significativamente menores do que aquelas de outros geotermômetros em função dessas trocas isotópicas retrógradas entre fases coexistentes ou fluidos (Hoets 1997).

Da mesma forma, a biotita apresenta taxas de difusão de oxigênio iguais às do feldspato e maiores do que as dos outros minerais formadores de rocha comuns, o que pode resultar em temperaturas de fechamento menores para o sistema oxigênio (Fortier e Giletti 1091). Iogo, o geotermômetro do par isotópico de oxigênio quartzo-biotita tende a fornecer baixas temperaturas, que refletem reequilíbrio retrógrado disseminado em rochas ígneas e metamórficas, especialmente quando essas temperaturas são menores do que $700^{\circ} \mathrm{C}$ (Zheng 1993b). Adicione-se a isso a "necessidade de informaçăo detalhada sobre o quimistmo e a estrutura da mica a fim de se deduzir. uma curva de fracionamento realística para o mineral", tendo cm vista a significativa dependência que os fatores de cnriquecimento em ${ }^{18} \mathrm{O}$ apresentam em relação à composição química e estado 
estrutural dos minerais, conforme preconizado no método de cálculo de curvas de fracionamento de Schütze (1980), modificado por theng (1991; 1993a, b).

Depois do quartzo, os feldspatos alcalinos e o plagioclásio são os minerais mais ricos $\mathrm{em}^{18} \mathrm{O}$ nas rochas ígneas e metamórficas em que coexistem (Taylor e Epstein 1962; Garlick e Epstein 1967). No caso específico dos granitos, depois desses minerais ocorrem biotita e magnetita em ordem decrescente de enriquecimento em ${ }^{18} \mathrm{O}$ (O'Neil 1986).

A cristalizaçào de quartzo empobrece a fusào silicática em ${ }^{18} \mathrm{O}$ enquanto que a cristalização de magnetita, ilmenita, homblenda, biotita, piroxênio e olivina causa aumento do $\delta^{18} \mathrm{O}$ da fusão coexistente. Como os materiais ricos em $\mathrm{SiO}_{2}$ tendem a concentrat: ${ }^{18} \mathrm{O}$, a fusão riolítica deve set: mais rica em ${ }^{18} \mathrm{O}$ do que a basáltica a partir da qual ela foi derivada, se mantidas temperaturas maiores do que $900^{\circ} \mathrm{C}$. Entretanto, esse efeito é menor do que $1 \%$, mesmo para magmas que diferem em até $30 \%$ em peso em conteúdo de $\mathrm{SiO}_{2}$. Efeitos isotópicos maiores somente podem ser esperados em estágios tardios de cristalização ou onde a cristalização de quartzo, biotita ou magnetita teve um papel preponderante (Taylor e Sheppard 1986).

\section{b) Sistema Hidrogênio}

A ocupaçào do sítio octaédrico nos minerais hidatados é o fator dominante no controle das composiçoes isotópicas telativas de hidrogênio. De maneira geral, quanto maior é a tazão $\mathrm{Fe} / \mathrm{Mg}$ de um mineral hidratado, menor é o seu conteúdo de deutério (Suzuoki e Epstein 1976). Os autores criaram uma equação para o fracionamento mineral-água aplicável a micás e anfibólios no intervalo de 450 a $800^{\circ} \mathrm{C}$, cujos resultados revelaram-se discordantes, particularmente para anfibólios, cm relaçào aos de Graham e Sheppard (1978) e Graham et al. (1984), que obtiveram fatores de fracionamento distintos em temperaturas inferiores a $600^{\circ} \mathrm{C}$.

Fracionamentos de D/H entre mineral-fusão comumente são da ordetn de $0 \pm 15$ per mil, e não são fortemente controlados pela composição. logo, se as variaçoes isotópicas de hiclrogênio são maiores do que 10 ou $20 \%$ cm um único plutào, outros processos além da cristalização fracionada estão cnvolvidos. Efeitos isotópicos maiores sào esperados em estágios muito tardios de cristalizaçăo (Taylor e Sheppard 1986).

\subsubsection{Comportamento isotópico dos fluidos magmáticos}

As composiçōes isotópicas de hidrogênio e de oxigênio das águas magmáticas são calculadas indiretamente, a partir das composiçoes isotópicas medidas de rochas ou minerais ígneos frescos não 
alterados, através da aplicação dos fatores de fracionamento mineral-água a temperaturas entre $700^{\circ}$ e $1200^{\circ} \mathrm{C} . \mathrm{A} \mathrm{H}_{2} \mathrm{O}$ magmáticá apresenta valores de $\delta \mathrm{D}$ no intervalo de -40 a $-80 \%$ e de $\delta^{18} \mathrm{O}$ entre $+5,5$ e $+9,5 \%$ (Sheppard 1986). Entende-se por água magmática, no contexto isotópico, conforme definida originalmente por Sheppard et al. (1969), aquela que está em equilíbrio químico com líquidos silicáticos (magmas) ou que tenha exsolvido deles. A palava "primátra" é adicionada pata descrever água dissolvida trazida no magma a partir da regiào fonte (Sheppard 1986; Taylor 1986; Taylor e Sheppard 1986).

O fluido magmático-hidrotermal retém sua assinatura isotópica original de hidrogênio e oxigênio somente enquanto sua composiçào é controlada pela troca com o magma ou silicatos ígneos em temperaturas magmáticas. Processos pós-magmáticos podem modificar os valotes de $\delta \mathrm{D}$ e de $\delta^{18} \mathrm{O}$ da água magmática (Sheppard 1986).

Águas magmáticas com outras composiçòes isotópicas podem ser geradas, por exemplo, a partir de magmas que tenham sofrido devolatilização (Nabelek et al. 1983; Taylor et al. 1983; Sheppard 1986). Acima de $220-230^{\circ} \mathrm{C}$, o vapor de água concentra deutério em relação à água lícuida. Os facionamentos se aproximam do zero novamente na temperatuta crítica da água (Horita e Wesolowski 1994). A desgascificação magmática gera uma cortelação entre $\delta \mathrm{D}$ e couteúdo de água, ambos decrescentes, efeito esse observado pela primeira vez em estudos de rochas graníticas dos tipos I e S por O'Neil c Chappell (1977) e O'Neil of al. (1977) e denominado "efeito O'Ncil" por: (Taylor 1986).

Os "sistemas dominados por vapor" podem ser encontrados em áreas de fluxo témico muito alto e permeabilidade telativamente baixa, e foram discutidos em detalhe por White at a (1971) e Truesdell e White (1973) (Criss e Taylor 1986).

Além da desgascificação magmática, dois outros processos podom alterar a composição isotópica dos voláteis magmáticos: 1) assimilaçào-contaminação; 2) assimilação-troca. A assimilação-contaminação e a desgascificação parecem ser os mais comuns (Taylor 1986).

Fracionamentos de D/H para fundido- $\mathrm{H}_{2} \mathrm{O}$ estimadas a partir de sistemas naturais desmisturados a baixá pressão são da ordem de $-15 \%$ (T'aylor et al. 1983; Nabelek el al. 1983; Sheppard e Harris 1985; Taylor e Sheppard 1986).

Fatores de fracionamento isotópico entre fluidos geologicamente importantes săo bem conhecidos, e foram compilados por Henley et al. (1984), que construíram curvas de fracionamento para sistemas de uso potencial como geotermômetros para sistemas hidtrotermais (O'Neil 1986). 
Casos extremos de desequilíbrio isotópico são observados onde fluidos hidrotermats convectivos interagem com corpos intrusivos rasos (Taylor e forester 1971, 1979). Enquanto os feldspatos sofrem troca isotópica contínua de oxigênio $\mathrm{em}$ estágio subsólido, o quartzo e o piroxênio retêm sua assinatura isotópica magmática (Criss e T'aylor 1983; T'aylor e Forester 1979; Cole e Ohmoto 1986). Nesses sistemas, as trocas isotópicas podem ser controladas amplamente por reaçòes superficiais, conforme definidas por Cole et al. (1983), ou seja, reaçóes de solução-precipitação e reações químicas envolvendo a geração de novas fases (O'Neil e Taylor 1967; Cole of at 1983; Giletti 1985; Cole e Ohmoto 1986).

\subsubsection{Interaçôes rocha/fluido}

"É conveniente tratar as interaçoes fluido/tocha através de modelos matemáticos simples de quatro tipos diferentes de sistemas: (1) Sistemas fechados verdadeiros, sem fluidos, onde as trocas isotópicas e os efeitos de balanço de massa ocorrem somente cutre fases minetais coexistentes presentes em proporçöes fixas; (2) Sistemas fechados onde as interações podem ocorter entre fases minerais e um fluido coexistente, todos presentes em proporçòes relativas constantes; (3) Sistemas abertos, em que interaçoes isotópicas complexas se dão entre uma matriz de fases minerais e fluidos extemos infiltrados progressivamente, de maneita que a razo fluido/rocha aumenta com o tempo; (4) Sistemas abertos tamponados, ou sistemas controlados pelo reservatório, em que o fluxo de fluidos é grande em comparaçăo às taxas de troca isotópica mineral-fuido" (Gregory e Criss 1986).

"Trocas isotópicas em sistemas naturais complexos podem ser aproximadas pelos casos extremos do sistemá aberto tamponado e do sistema fechado. Ambos convergem para os modelos simples de sistema aberto verdadeiro com duas fases, nos limites do qual a fraçào molar de fluido é pequena, no sistema fechado, ou a razão entre o fluxo de fluido c a taxa de troca isotópica ć próxima a zero, no sistema aberto. No caso do sistema aberto tamponado, onde o fluxo de fluido é muito maior do que a taxa de troca isotópica, é possível estimar a tazão fluido/rocha" (Gregory c Criss 1986).

"Em sistemas em que a água é de origem externa, ela geralmente é o reservatório dominante de hidrogênio e, portanto, controlará a razào D/H do sistema. Sua azão ${ }^{18} \mathrm{O} /{ }^{16} \mathrm{O}$, entretanto, pode ser determinada pelo oxigênio do mineral passivel de sofrer troca isotópica e pela temperatura da troca, com exceção dos casos em que a razão água/rocha (w/ i) é muito grande ou as reaçòes săo ineficientes por razões cinéticas ou outras. Logo, em sistemas hidrotermais de água oceânica ou meteórica, os valores de $\delta \mathrm{D}$ das águas são freqüentemente constantes a despeito das reaçoes de 
troca mineral-água, encuanto que a composição isotópica de oxigênio sofre um deslocamento $\left({ }^{18} O\right.$ shiff em relação ao seu valor incial, geralmente em direção a valotes maiores de $\delta^{18} O$ " (Sheppard 1986). "O entrquecimento das águas em ${ }^{18} \mathrm{O}$ requet, por balanço de massa, um empobrecimento em ${ }^{18} \mathrm{O}$ correspondente nas rochas afetadas. Assim, análises de ${ }^{18} \mathrm{O}$ de rochas formam a base do estudo de sistemas geotermais antigos e permitem a estimativa das temperaturas c razócs água/tocha (w/ $)$ prévias (T'aylor 1974)" (Criss c "laylor 1986).

\subsubsection{Uso dos isótopos de O e H na pesquisa metalogenética}

A geotermometria de isótopos estáveis e a microtermometria de inclusões fluidas são comumente utilizadas em conjunto na pesquisa de depósitos minerais. Einquanto a primeira dá a temperatura verdadeita da mineralização com uma margem de erro de $15 \%$, a segunda fornece a composição do fluido e suas propriedades de P-V-T, dados esses usados na construção da isócora. As verdadeiras condiçòes de P e T da mineralização situam-se em algum lugar sobre a isócona da inclusào fluida, na sua intersecçào com a temperatura fornecida pelos isótopos estáreis (Ohmoto 1986).

A origem dos fluidos formadores de minério e a natureza hidrológica dos sistemas de canalização (geometria, razóes água/rocha $(\mathrm{w} / \mathrm{r})$ ) também podem ser estimados através das composições isotópicas de $\mathrm{H}$ e $\mathrm{O}$ dos fluidos formadores de minério e de minerais e rochas que cescam os depósitos minerais (Ohmoto 1986). "Halos isotópicos de oxigènio podem estender"se em áreas muito mais amplas do que os halos de elementos químicos, além de serem menos variáveis em pequena escala e de poderem persistir durante o metamorfismo regional (Green et al. 1983)" (Ohmoto 1986).

A razào w/r estimada com o modelo do sistema fechado de Taylor (1979), cntretanto, é de valor mínimo e pode diferir consideravelmente do valor real (Ohmoto 1986).

\subsection{Resultados Parciais e Considerações Preliminares}

Os resultados das análises isotópicas de oxigênio e hidrogênio, expressos em valores de $\delta$, estão listados nas Tabelas 10.I e 10.II, respectivamente. Resultados dos cálculos de composiç̃o da água figuram na l'abela 10. III.

Os dados isotópicos de oxigênio para a fácies Serra $A z u l$ mostram que o valor de $\Delta^{18} \mathrm{O}_{\text {y. tedts }}$ é compatível com uma condição de equilíbrio isotópico, onde as reaçoes retrógradas do feldspato com 
fases coexistentes ou fluidos tardios, se existentes, não foram muito expressivas. Ainda assim, a temperatura de cristalização da tocha en $603^{\circ} \mathrm{C}$ será preferencialmente encarada como temperatura mínima.

As temperaturas de cristalizaçào estimadas pelo mesmo par para a fácies Santa Bárbara fita, entretanto, resultatam temperatura de $529^{\circ} \mathrm{C}$, registrando a interação tocha-fluido a que esteve sujeita essa rocha. No caso da fácies Serra do Cícero, os recquilíbrios do feldspato potássico com fluidos tardios, a baixas temperaturas $\left(\sim 298^{\circ} \mathrm{C}\right)$, invalidam o uso desse par para a estimativa da temperatura de cristalização da tocha, e a temperatura de $603^{\circ} \mathrm{C}$ foi preferida para o cálculo das composição isotópica do fluido magmático original em equilibrio com o quartzo, a mica e o próprio feldspato alcalino.

Cálculos termométricos para as amostras AM-168, AM-35 e AM-131 apontam para temperaturas de alteração hidrotermal da ordem de 500 a $570^{\circ} \mathrm{C}$ no caso das duas primeiras (bolsão de quartzo com siderofilita e topázio, e greisen tabular), ao passo que os veios de quartzo e cassiterita (AM-131) cristalizaram-se em temperaturas de cerca de $400^{\circ} \mathrm{C}$, em condições fancamente pós-magmáticas. As temperaturas de cristalização estimadas pata esses hidrotermalitos excedem em até $100^{\circ} \mathrm{C}$ as temperaturas de homogeneização de inclusoes fluidas presentes nas mesmas amostras.

A temperatura de cristalizaçào afericla pelo par isotópico muscovita-cassiterita resultou valor improvável, menor do que $100^{\circ} \mathrm{C}$, apontando para o descquilibrio isotópico entre as duas fases minerais e para a possibilidade de que năo pertençă à mesma paragênese.

Dentre as temperaturas obtidas pela geotermometria de isótopos de oxigênio, aquela relativa aos veios de cuartzo-cassiterita representa a mais confáarel em funçăo da grande variaçào dos valores de $\Delta^{18} \mathrm{O}_{\text {1yrass }}$ com a temperatura (Zheng 1991; Zhang at al. 1994). Além disso, o sistema provavelmente constitui um geotermómetro do tipo RAM (Refratory Awessory Minturali) (Eiler al al. 1993; Valley 2001), em que um mineral de pequena abundância resistente à temperatura, no caso a cassiterita, ocorre em uma rocha volumetricamente dominada por un mineral com alta taxa de difusào, como o quartzo. Enquanto que o mineval acessório preserva sua composição isotópica inicial devido a sua baixa difusão, a fase mineral predominante preserva sua razão isotópica inicial por balanço de massa, em virtude da ausência de outras fases suscetiveis à troca isotópica abundantes.

As composições isotópicas dá água, calculadas a partir de equações de equilíbrio mica-água, indicam contribuiçăo predominante de fluidos magmáticos ná formação dos granitos das fácies Serrá Azul e Santa Bárbara média, bem como nas fácies de alteraçào hidrotermal granito albitizado salmão 
e veios de greisen de granulaçào média e fina, estes alojacos na fácies Santa Bátbara fina. $A$ água em equilibrio com rochas de outas fácies magmáticas, como pegmatito e albitámicroclínio granito branco, e hidrotermais, como bolsão de quartzo com siderofilita e topázio, situa-se no intervalo composicional de $\delta \mathrm{D}$ das águas magmáticas, mas é ligeiramente enriquecida em $\delta^{18} \mathrm{O}$ (Fiig. 10.1).

As composições isotópicas do fluido para as rochas dos estágio magmático, transicional e parte do estágio pós-magtático, calculadas pelo par quartzo-água, são consistentes com as composiçôes de fluidos magmáticos na maior patte da história evolutiva do sistema. Decréscimos progressivos de temperatura e de $\delta^{18} \mathrm{O}$ do fluido hidrotermal são espetadas em sistemas magmáticos fechados, em que há reciclagem contínua desse fluido (f. Taylor 1979).

As amplas variaçoes de $\delta \mathrm{D}$, entretanto, sugerem que a composição isotópica de hidrogênio do sistema não foi governada unicamente pelo fluido magmático no que diz respeito aos topáziosiderofilitampuartzo greisens tabulares, aos mica greisens c aos veios de greisen grossos, bem como durante os processos tardios denominados muscovitização e caulinizaçào. A degarseificaçào magmática, responsável pelo empobrecimento dos fluidos em D ( $\%$. Nabelek of al. 1983), não pode ser descartada, com exceção do veio de muscovita, cuja composição é muito próxima àquela da água meteórica puta Porém, a posição dos pontos nos diagrama $\delta \mathrm{D}$ wersus $\delta \mathrm{O}$ sugerem a existência de mistura com fluidos meteóricos (Fìg. 10.1).

As alterações hidrotermais tardias identificadas no Maciço Granítico Santa Bárbara, a saber a muscovitização e a caulinização, podem ser atribuidas à citculação de fluidos meteóricos aquecidos, conforme a posição relativa à composição isotópica da água em equilíbrio com essas rochas na Figuia 10.1 .

A composição isotópica de oxigênio em rocha total dos granitos das fácies Serra do Cícero e da Santa Bárbara fina, aliada aos teores de $\mathrm{P}_{2} \mathrm{O}_{5}$ das mesmas rochas (inferiores a $0,04 \%$ em peso), permitem classificá-las como topázio granitos de baixo $\mathrm{P}_{2} \mathrm{O}_{5}$, um subtipo de topázio granitos inseridos no campo dos granitos do tipo I fracionados, conforme Taylor e Fallick (1997). 


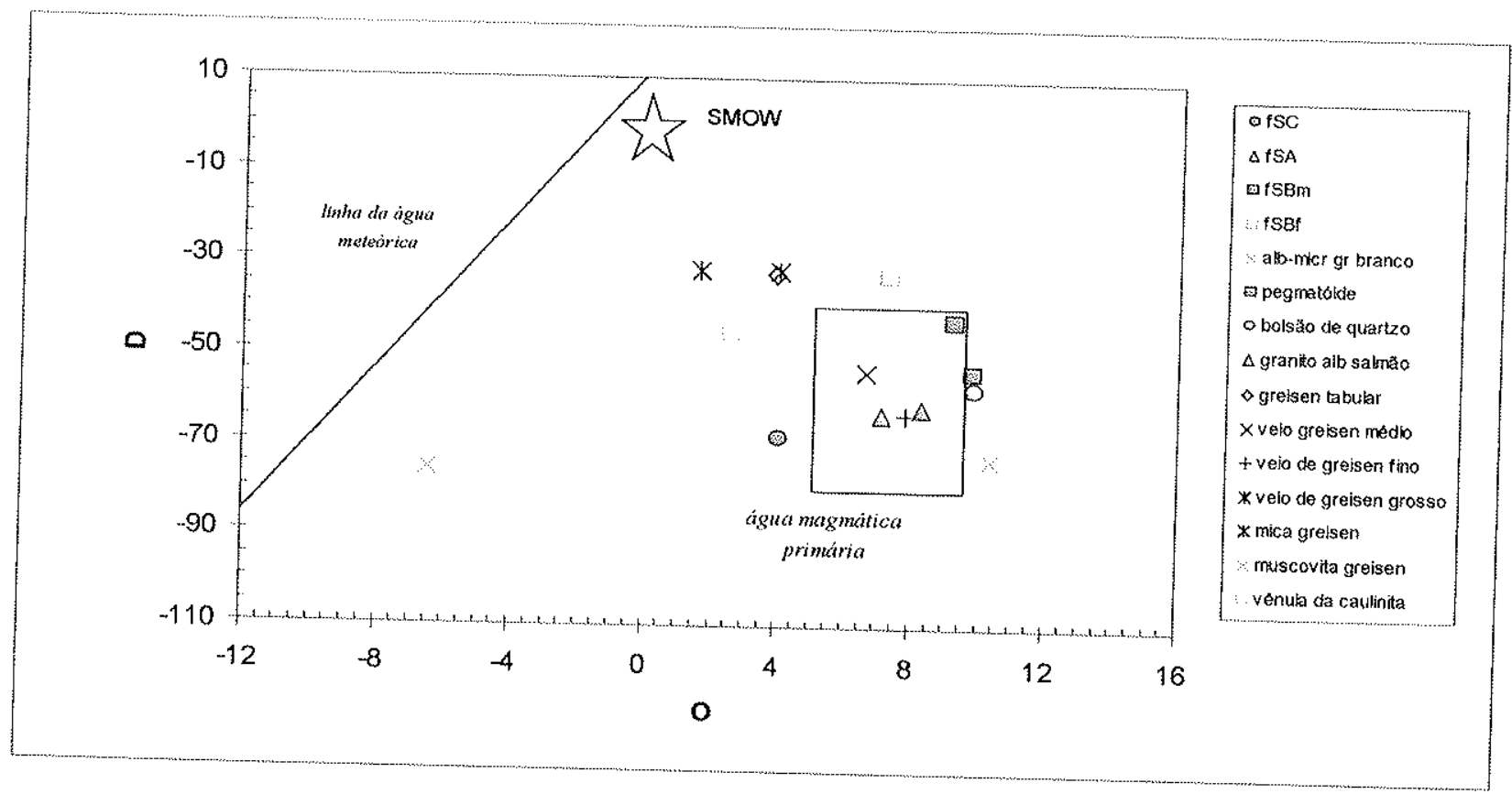

Figura 10.1 - Diagrama da composição isotópica da água em equilibrio com a mica nas diversas fácies do Maciço Granítico Santa Bárbara. Campo da composição isotópica da água magmática e linha da água
meteórica atual de Sheppard (1986). 
Tabela 10.1 - Dados de composição isotópica de oxigênio em minerais e rocha total.

\begin{tabular}{|c|c|c|c|c|c|c|c|c|c|}
\hline & & & \multicolumn{7}{|c|}{ Oxigênio } \\
\hline & Amostra & Rocha ou fácies & quartzo & feldspato & mica & cassit & top & rocha total & caul \\
\hline \multirow{6}{*}{$\begin{array}{l}M \\
A \\
G \\
M\end{array}$} & $A M-52 B$ & fSC (sienogranito) & 9,4 & 6,9 & 1,5 & & 3 & 7,3 & \\
\hline & AM 53 & fSA (albita-microclínio granito) & 10,3 & 90 & 5,8 & & & & \\
\hline & AM-108 & fSBm (alb-micr granito médio) & 10,4 & & 6,7 & & & & \\
\hline & $\mathrm{AM}-145$ & fSBf (albita-micr granito fino) & 9,3 & 7,8 & 4,8 & & & 8,7 & \\
\hline & $A M-134$ & fSBf (alb-micr granito branco) & 11,3 & & 7,9 & & 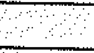 & & \\
\hline & $A M-213$ & pegmatóide & 10,0 & 4,5 & 7,3 & & & & \\
\hline \multirow{6}{*}{$\begin{array}{c}T \\
R \\
A \\
N \\
S\end{array}$} & AM-168a & \multirow{3}{*}{ bolsão de quartzo } & & & & & 7,5 & & \\
\hline & $A M-168 b$ & & & & 7,9 & & & & \\
\hline & $A M-168 \mathrm{C}$ & & 9,8 & & & & & & \\
\hline & AM-14A & granito albitizado salmão & 9,8 & 1,7 & 5,2 & & & & \\
\hline & & & & 1,5 & & & & & \\
\hline & AM-35 & top-sid-qtz greisen tabular & 10,0 & & 1,4 & \multirow{3}{*}{2,9} & & & \\
\hline \multirow{11}{*}{ 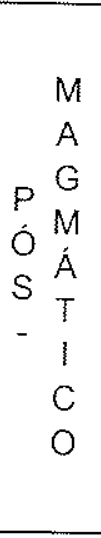 } & $A M-130$ & veio de greisen médio & & & 2,0 & & & & \\
\hline & $\mathrm{AM}-174 \mathrm{c}$ & $\begin{array}{l}\text { velo de greisen médio } \\
\text { velo de greisen fino }\end{array}$ & 11,8 & & 4,7 & & & & \\
\hline & $A M-131$ & $\begin{array}{l}\text { velo de greisen fino } \\
\text { veio de quartzo-cassiterita }\end{array}$ & 11,7 & & 5,9 & & & & \\
\hline & & velo de quartzo-cassiterita & 11,7 & & & 3,5 & & & \\
\hline & $A M-297$ & veio de grelsen grosso & 9,7 & & 2,1 & & 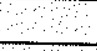 & & \\
\hline & & & & & 1,8 & & & & \\
\hline & $A M-159 a$ & velo de quartzo esteril & $\begin{array}{l}0,7 \\
0,6\end{array}$ & & & & & & \\
\hline & $A M-74 c$ & \multirow{2}{*}{ mica greisen } & & & & & & & \\
\hline & & & & & $\frac{-0,8}{-0,3}$ & & & & \\
\hline & $A M-307$ & velo de fengita & & & $-6,2$ & \multirow[t]{2}{*}{3,3} & & & \\
\hline & AM-298 & vênula de caulinita & & & $-6,1$ & & & $\ldots$ & \\
\hline & & venula de caulinita & & & & & & & 15,7 \\
\hline
\end{tabular}


Tabela 10.Jl - Dados de composição isotópica de hidrogênio em minerais.

\begin{tabular}{|c|c|c|c|c|c|c|c|c|c|}
\hline & & & & & & ogênio & & & \\
\hline & Amostra & Rocha ou fácies & K-feldsp & yield $(\%)$ & mica & yield $(\%)$ & top & kaol & yield $(\%)$ \\
\hline \multirow{6}{*}{$\begin{array}{l}M \\
A \\
G \\
M\end{array}$} & $A M-52 B$ & fSC (sienogranito) & -98 & 0,43 & -118 & 6,00 & 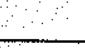 & & \\
\hline & $A M-53$ & fSA (albita-microclinio granito) & -74 & 0,31 & 110 & 3,17 & & & \\
\hline & $A M-108$ & fSBm (alb micr granito médio) & & & -92 & 1,82 & & & \\
\hline & $A M-145$ & fSBf (albita-micr granito fino) & -123 & 0,32 & -93 & 2,79 & 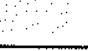 & & \\
\hline & AM-134 & fSBf (alb-micr granito branco) & & & -125 & 1,75 & $\cdots$ & & \\
\hline & AM-213 & pegmatóide & -68 & 0,22 & -106 & 2,23 & $\cdots$ & & \\
\hline \multirow{6}{*}{$\begin{array}{l}T \\
R \\
A \\
N \\
S\end{array}$} & AM-168a & \multirow{3}{*}{ bolsão de quartzo } & & & & & $x$ & & \\
\hline & $A M-168 \mathrm{~b}$ & & & & -124 & 2,03 & & & \\
\hline & $A M-168 c$ & & & & & & & & \\
\hline & \multirow{2}{*}{ AM-14A } & \multirow{2}{*}{ granito albitizado salmão } & -67 & 0,38 & -127 & 1,82 & & & \\
\hline & & & & & & & & & \\
\hline & AM-35 & top-sid-qtz greisen tabular & & & -99 & 2,77 & & & \\
\hline \multirow{11}{*}{ 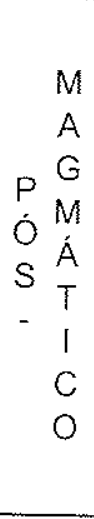 } & $A M-130$ & veio de greisen médio & & & -124 & 1,94 & $\cdots$ & & \\
\hline & $\mathrm{AM}-174 \mathrm{C}$ & veio de greisen fino & & & -133 & 1,62 & 6 & & \\
\hline & AM-131 & velo de quartzo-cassiterita & & & & & & & \\
\hline & \multirow{2}{*}{$A M-297$} & \multirow{2}{*}{ velo de greisen grosso } & & & -102 & 2,61 & : & & \\
\hline & & & & & & & & & \\
\hline & $A M-159 a$ & veio de quartzo esteril & & & & & & & \\
\hline & \multirow{2}{*}{$A M-74 c$} & \multirow{2}{*}{ mica greisen } & & & & & & & \\
\hline & & & & & -102 & 2,85 & & 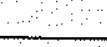 & \\
\hline & AM-307 & \multirow{2}{*}{ velo de fengita } & & & -107 & 4,53 & & & \\
\hline & & & & & & & & & \\
\hline & AM-298 & vênula de caulinita & & & & & & -69 & 14,40 \\
\hline
\end{tabular}


Tabela 10.114 - Composição isotópica do fluido calculada com base em equações de equilibrio mineral-água.

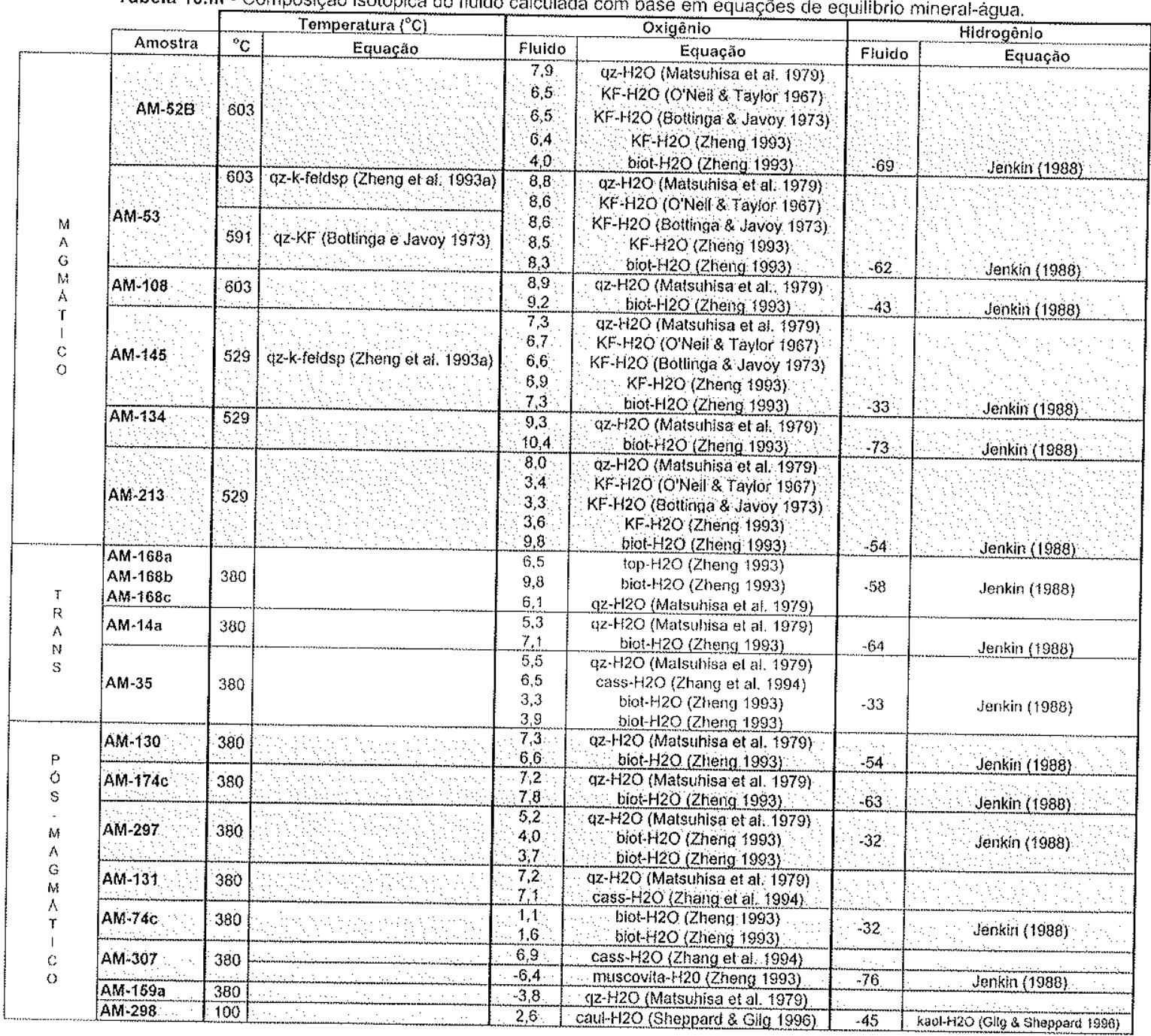




\section{DISCUSSÕESE CONSIDERAÇÕES FINAIS}

O Maciço Granítico Santa Bárbara possui características petrográficas, geoquímicas e metalogenéticas compatíveis com granitos rapakivi, conforme redefinidos por (Haapala \& Rämö 1992).

Compreende sienogranito e álcali-feldspato granitos, com texturas equigranular, porfirítica, wiborgítica e piterlítica, em que estão presentes duas gerações de feldspato alcalino e de quartzo. $O$ feldspato alcalino precoce, mesopertítico, está presente unicamente no sienogranito, dá fácies mais precoce, ao passo que a geração mais primitiva de quartzo, euédrico bipiramidal ou globular, de alta temperatura, ocorre em todas as três unidades que compõem o maciço, denominadas fácies Serma do Cícero, fácies Serra Azul, e associação de fácies Santa Bárbara..

Caracterítica de granitos rapakivi é, também, sua associação mineral, que inclui a siderofilita, com teores crescentes de Li e fi da fácies mais precoce para a mais tardia, além de monazita, anatásio, fluorita, topázio, cerianita e columbita-tantalita.

As unidades fácies Serra do Cícero e fácies Serra Azul foram datadas por U-Pb em monazita em 993 55 Ma e $989 \pm 13$ Ma, respectivamente. Datações via SHRIMP do zircão da associação de fácies Santa Bárbara forneceram média ponderada das idades ${ }^{2077} \mathrm{~Pb} /{ }^{216} \mathrm{~Pb}$ de $978 \pm 13 \mathrm{Ma}$. As três idades são concordantes no intervalo dos respectivos erros, refletindo a contempotaneidade das unidades magmáticas que constituem o maciço. A idade K-Ar cm mica de greisen kabulor $(961 \pm 19 \mathrm{Ma}$; Leite Júnior et al. 2001) se sobrepõe às das duas unidades mais evoluidas do Maciço Granítico Santa Bárbata, constituindo forte indício da vinculação genética da mineralização com a evolução magmática desse corpo granítico.

Do ponto de vista geoquímico, esses granitos são subalcalinos, metaluminosos a peraluminosos, com características de granitos do tipo $A \mathrm{e}$ intraplaca, anorogênicos, $\mathrm{cm}$ consonância com os granitos rapakivi (Rämö \& Haapala 1995).

As características acima apresentadas permitem enquadrar o Maciço Granítico Santa Bárbara na Suíte Granitos Últimos de Rondônia (sensu Bettencourt \% a. 1997, 1999b), que apresenta outros 
exemplos de importantes mineralizaçōes estaniferas primátias, como o depósito Bom fruturo.

As rochas do maciço possuem composição normativa CIPW próxima ao mínimo do sistema albita-ortoclásio-quartzo- $\mathrm{H}_{2} \mathrm{O}$ a 1 kbar e com 0 a $3 \%$ de anortita $(\%$. Tuttle \& Bowen 1958, James \& Hamilton 1969). As composiçoes normativas e as tendências continuas de evolução geoquímica, bem como de variação da composição das micas, sugerem a fusão parcial próxima ao mínimo seguida de cristalizaçăo fracionada de um mestno magma, com fracionamento de feldspato alcalino, plagioclásio, zircào e monazita, principalmente, para a origem dessas rochas. O progresso do fracionamento culminou com a cristalização de magmas sob condiçōes de saturação em $\mathrm{H}_{2} \mathrm{O}$ nas fases finais, conforme indicam a presença de cavidades miarolíticas e de textura granofírica na fácies Santa Bárbara fina. Sobre essas rochas operaram intensos processos de interação rocha/fluido, conforme sugerido pelas relações Sn mersus Rb/Sr. Esses fluidos, entretanto, são de origem intramagmática, conforme indica sua composição isotópica de oxigênio calculada a partir do par: quartzo-água.

Assim, a gènese das rochas apicais do sistema, representadas pela associação de fácies Santa Bárbara, é tida como resultado de diferenciação magmática de fundidos graníticos ticos em lítio e flúor, resultando em fases finais possivelmente cristalizadas a temperaturas da ordem de $550-600^{\circ} \mathrm{C}$, conforme proposto por Kovalenko ef at. (1970) para granitos similares. Os autores nào excluetm, entretanto, a possibilidade de recristalização dessas rochas no estado sólido, porém descartam o aporte de material, ou seja, o metassomatismo pós-magmático, implícito nos modelos de evolução de cúpulas do tipo apogranito (e.g., Serebryakov 1961, Beus c Zalashkova 1964, Beus 1982).

Evidências de cristalização magmática do produto extremo dessa diferenciação, representado, no Maciço Granítico Santa Bárbara, pelo albita-microclínio granito branco, compreendem a pequena representatividade de texturas do tipo albita chessboard, típica da albitização metassomática (\% Haapala 1997), a presença de texturas do tipo snowball, a presença de minerais primários de $\mathrm{Nb}-\mathrm{Ta}$, e o padrão de distribuição de ETR, semelhante ao dos granitos menos evoluídos porém enriquecido nos conteúdos desses elementos em mais de uma ordem de grandeza.

Essa composição normativa muito próxima à do sistema haplogranítico, bem como seus teores relativamente altos de $\mathrm{F}(0,37$ a $1,51 \% \mathrm{~cm}$ peso) e baixos de $\mathrm{CaO}(0,05$ a $1,05 \% \mathrm{em}$ peso), além da sua composição mineral (álcali-feldspato granitos com mica litinífera e topázio) são característicos de topázio granitos. Os conteúdos de $\mathrm{P}_{2} \mathrm{O}_{5}(\leq 0,04 \% \mathrm{em}$ peso) e as razòes isotópicas de oxigênio dessas rochas $\left(\delta^{18} \mathrm{O}=7,3\right.$ e $8,7 \%$ para as fácies Serra do Cícero e Santa Bárbara fina, respectivamente) permitem, ainda, classificá-los como topázio granitos do tipo I fracionados, 
conforme Taylor (1992) e Taylor \& Fallick (1997).

Dados isotópicos de $\mathrm{Nd}\left(\xi_{\mathrm{Nul}}(\mathrm{T})=-2,95\right.$ a $-4,58$; Sparrenberger er al. 2002) indicam protólito de natureza crustal, provavelmente representado pelos angen-gnaisses graníticos e charnockíticos encaixantes.

A mineralização estanífera primária está associada à zona de cúpula da fácies Santa Bárbata, a mais evoluída do maciço. Ocorre nos estilos disscminado, greisetus acamadados, stockenork e veios de quartzo. A mineralização mais expressiva está representada nos referidos greisens, cujas características de distribuição espacial e de relação com a hospedeira magmática, composição isotópica de oxigênio e de deutério, além da presença de melt inthusions, indicam gênese no estágio tardi-mágmático. A esses greisens estão espacialmente associados granitos de cor salmão enriquecidos em albita e micas da série Fe-li, com características de associação espacial consistente com os greisens, além de petrográficas e de composição isotópica de oxigênio e deutério também indicativas de origem magmática.

Sistemas similares têm sido descritos na República T'checa (Jarchovský et al. 1994; Seltmann et al. 1998, Breiter 1998 e Jarchovský 1998 in Breiter 1998, Breiter 2002), onde a presença de feldspatitos associados aos greisens tabulares é tida como resultante do acúmulo de elementos alcalinos oriundos dos feldspatos dissolvidos nos greisens, que provocaria a neutralização localizada dos fluidos ácidos responsáveis pela greisenização, em condições magmáticas.

A mincralização no Maciço Granítico Santa Bárbara ocorke ainda como sistemas stockeouorke c de veios de quartzo, pós-magmáticos. Assim como os greisens tabulares, o sistema shocknork conta com a contribuição primordial de fluidos magmáticos aquo-carbônicos, de salinidades entre 6 e $42 \%$ em peso $\mathrm{NaCl}$ equiv.

A incidência de mistura com fluidos meteóricos, aquosos, de salinidades entre 0 e $3 \% \mathrm{NaCl}$ equiv., em graus variáveis, é indicada pela microtermometria de inclusões fluidas e pela geoquímica de isótopos de oxigênio e deutério como um processo operante descle a greisenização pervasiva do estágio transicional, com circulação de fluidos provavelmente controlada pelos sistemas de fraturas que alojam o stockwork, de greisen e os veios de quartzo-cassiterita (Fig. 9.32.a, b e c).

As variações de composição isotópica de oxigênio e hidrogênio observadas nos litotipos magmáticos e hidrotermais do maciço, restritas a valores próximos ao campo das águas magmáticas primárias, sugerem contribuição predominante de líquidos magmáticos em todas as fases de evolução da mineralização, apesar da incidência de mistura com fluidos meteóricos já no estrígio transicional (Fig. 10.1). 
A temperatura de cristalização dos greisens tabulares é estimada em $495^{\circ} \mathrm{C}$ por termometria de isótopos de oxigênio, enquanto que os veios de quartzo-cassiterita têm temperaturas estimadas em torno de $415^{\circ} \mathrm{C}$. As temperaturas da imiscibilidade de fluidos entre $370-390^{\circ} \mathrm{C}$, entretanto, sugerem ser este o intervalo térmico abrangido pela precipitação de cassiterita.

O controle da deposição da cassiterita no sistema estudado tem três rias: 1) o processo de imiscibilidade, com alto grau de interação rocha/fluido, no caso dos corpos de greisen tabulares e no sistema stockwork de greisen, 2) o boiling de fluidos aquosos sódicos nos veios de quartzo-cassiterita, e 3) a mistura dos fluido magmáticos de alta temperatura, mais salinos, com grandes proporçòes de fluidos meteóricos, frios, de baixa salinidade, nos veios de muscovita.

Do ponto de vista da lavra deste depósito, há que ressaltar a presença de óxidos de ETR, columbita, thorita, monazita e ceranita nos granitos das fácies Santa Bátbara média, Santa Bárbara fina e nos greisens tabulares e granitos albitizados salmão, que são os litotipos explotados para a concentração do minétio. Dada a suá granulação extremamente fina, são perdidos para os rejeitos, que poderiam ser comercializados como importantes subpordutos, concentradores de ETR, Nb-Ta, The Ce.

\subsection{Conclusões}

$\checkmark$ O Maciço Granítico Santa Bátbara comprectade três unidades litológicas magmáticas subsolvus, de afinidade geoquímica com granitos rapakivi, do tipo A, intraplaca, subalcalinos;

$\checkmark$ As três unidades apresentam idades muito semelhantes, vatiáveis cntre 993 e 978 Ma;

$\checkmark$ A unidade litológica mais jovem é também a mais diferenciada, e hospeda mineralização descnvolvida nos estágios tardi a pós-magmático, nos estilos disseminado, acamadado (maciço), stockwork e sistemas de veios;

$\checkmark$ Os fluidos chvolvidos na alteração magmático-hidrotemal, ben como na precipitação metálica, são eminentemente magmáticos, aquo-carbônicos $e$ aprisionados sob condições de imiscibilidade no intevalo térmico de 350/400'C;

$\checkmark \quad O$ fiaturamento que possibilitou o alojamento dos sistemas stockwork e de veios provavelmente abriu caminho para a mistura com fluidos meteóricos frios, de baixíssima salinidade, com composição isotópica de fluidos meteóticos puros; 
$\checkmark$ A imiscibilidade, aliada a um alto grau de intetação rocha/fluido, constituiu o ptincipal mecanismo de deposição metálica, seguido da mistuta dos fluidos magxaáticos com grandes proporções de fluidos meteóticos;

$\checkmark$ Depósitos análogos são reconhecidos na República Tcheca e na Alemanha;

$\checkmark O$ depósito estudado não tem paralelos de interesse econômico descobertos no Brasil até o momento. Sua caracterização abre caminho para uma abordagem prospectiva focalizada nos controles litológicos das mineralizaçôes na Província Estanífera de Rondônia, exigitado campanhas de mapeamento de semi-detalhe c de perfuração de alvos potenciais. 


\section{REFERÊNCIAS BIBLIOGRÁFICAS}

ADAMY, A., ROMANINI, S.J. (1990) Geologia da Regiào Porto Velhom Abunà, Potto Velho (SC. 20-V-B.V), Mutumparaná (SC. 20-V-C-VI), Jaciparaná (SC. 20-V-D-I) e Abunà (SC. 20-V-C-V). Estados de Rondônia e Amazonas. Escala 1:100.000. Brasília, DNPM/CPRM. 273p.

ALMEID A, F.F.M. de (1974) Evoluçào tectôtica do cráton Guaporé comparada a do escudo Báltico. Revista Brasileira de Geociênncias, 4: 191-204.

ALMEIDA, F.F.M. de (1978) A evolıçào dos crátons Amazônico e do São Francisco comparada com homólogos do hemisfério norte. In: CONGRESSO BRASILEIRO DE GEOLOGIA, 30., Recife, 1978. Ancis: Recife, SBG, v. 6, p. 2393-2407.

ALMEID A FILIO, R, PAYOLIA, B.L., PINHO, O.G. de, BETTENCOURT, J.S. (1984) Utilzaçào de imagens digitais Landsat no estudo de corpos granitóides em Rondônia: caso exemplo do maciço Pedara Branca. In: SYMPOSIUM AMAZONNICO, 2., Manaus, 1984. Anuis: Manaus, DNPM, p. 409-415.

AMARAL, G. (1974) Geologia pré-cambriana da regiăo Amazônica. São Paulo, 212p. (T'ese - Livre Docência) Instituto de Geociências, Universidade de São Paulo.

AMARAL, G. (1984) Província Tapajós e Rio Branco. In: Almeida, F.F.M. de \& Hasui, Y. (eds.) O Pré-Cambriano do Brasil. São Paulo, Edgard Blücher. p. 6-35.

ANGUS, S., ARMSTRONG, B., de REUCK, KM., ALTUNIN, V.V., GADETSKII, O.G., CHAPEIA, G.A., ROWLINSON, J.S. (1976) International thermodynamic tables of the fluid state. Carbot Dioxide, vol. 3. Oxford, Pergamon. 385p.

BAHTA, R.B.C. (2002) petrogtafra dos litotipos da Formação palmeiral. In: CONGRESSO BRASILEIRO DE GEOLOGIA, 41., Joño Pessoa, 15 a 20/09/02. Anais. SBG/Núcleo Nordeste, p. 377.

BAHIA, R.B.C., 'TRUCKENBRODT, W., PEDREIRA, A.J. (1998) Sedimentologia, estratigrafía e tectônica da cobertura proterozóica do estado de Rondônia: Formaçào Palmeiral. In: CONGREsso BRASILEIRO DE GEOI.OGLA, 40, Belo Forizontc, 1998. Anais. Belo Forizonte, SBG, p. 8.

BAILEY, S.W. (1984) (ed.) Micas. Chelsea, Minetalogical Society of America. (Reviews in Mineralogy, 13)

BASEI, M.A.S., SIGA JUNIOR, O, SATO, K., SPROESSER, W.M. (1995) A Metodologia Urâtrio-Chumbo ta Universidade de São Paulo. Princípios Metodológicos, Aplicaçòes e Resultados Obtidos. An. Acat. Bras. Ci., 67(2): 221-237.

BATES, J. (1999) Rondônia, Quarenta anos de lavara de cassiterita. Brusil Mineral, 176: 20-22.

BECKER, R.H. (1971) Carbon and oxygen isotope ratios in iron-formation and associated tocks from the Mamersley Range of Western Australia and their implications. Ph.D. thesis, Chicago University, 138p.

BELIIZZIA, C.M. (1972) Paleotectônica del Escudo de Guyana, Boletin de Geologia, Publ. Espec., 6: 251-304.

BETTENCOURT, J.S. (1992) Pesquisas Geológica, Metalogenética e Mineral no Cráton Amazônico (Sistematizaçào crítica de parte da obra no período compreendido entre 1980 e 1992). São Paulo, 163p. (Tese - Livre Docência) - Instituto de Geociências, Universidade de São Paulo.

BEITENCOURT, J.S. \& DALL'AGNOL, R. (1987) The rondonian tin-bearing anorogenic granites and associated mineralization. In: INTERNATIONAL SYMPOSIUM ON GRANITES AND ASSOCIATED MINERALIZATIONS, Salvador, 1987. Exicursion Guide. Salvador, SME-BA, p. 49-87. 
BETTENCOUR'T, J.S, DALL'AGNOL, R, YOKOI, O.Y., VIGLIO, EP., PINHO, O.G, SLVA, R.F., CARNEIRO Fo, L. (1987) The Rondonian tin-bearing anorogenic granites and associated mineralization. In: INTERNATIONAL SYMPOSUUM ON GRANITES AND ASSOCLATED MINERALIZATIONS, 1., Salvador, 1987. Examrion Guides. Salvador, 1987, Superintendência de Geologia e Recursos Minerais, p. 49-87.

BETTENCOURT, J.S., KAEDEI, M. (1984) Reconhecimento dos granitos rapakivi (sensu stritu) da regiăo do ro Caripunas - Rondônia. In: SIMPÓSTUM AMAZONNICO, 2, 1984, Manaus. Anais. Manaus, DNPM, 1984. p. $271-286$.

BETTENCOURT, J.S, LETTE JÚNIOR, WB., PAYOLLA, B.L, MONTANFEIRO, T.J. (1991)

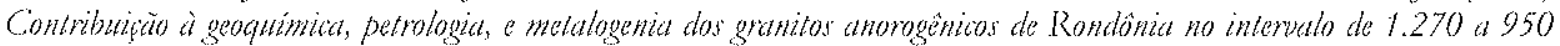
Ma. Relatório cientílico submetido à liAPESP. Processo Geologia 89/0305 4. 169p.

BETTENCOURT, JS, LETEE JÚNIOR, WB., PAYOLLA, B.L, SCANDOLARA, JE, MUZZOLON, R., VIAN, J.A.J. (1997) The rapakivi granites of the Rondonia Tin Province and acjacent region, nothern Brazil. In: INTERNATIONAL, SYMPOSIUM ON GRANITES AND ASSOCIATED MINERALIZA'TION, 2, Salvador, 1997. Exursions Guide. Belém, SGM, p. 2-31.

BETTENCOURT, J.S., ONSTOTT, T.C., DE JESUS, T., 'TEIXEIRA, W. (1995) Tectonic interpretation of 4I $\mathrm{Ar} /{ }^{39} \mathrm{Ar}$ ages on country rocks from the central sector of the Rio Negro-Jutuena Province, SW Amazon Craton. In: SYMPOSIUM ON RAPAKIVI GRANITES AND RELATED ROCKS, 6., Belém, 1995. Abstracts. Belém, URPA, p. 14.

BETTENCOURT, J.S., ONSTOTT, T.C., DE JESUS, T., TEIXEIRA, W. (1996) Tectonic Interpretation of ${ }^{40} \mathrm{Ar} /{ }^{39} \mathrm{Ar}$ Ages on Country Rocks from the Central Sector of the Rio Negro-Juruena Province, Southwest Amazon Craton. International Geology Review, 38(1): 42-56.

BETTENCOURT, J.S. PAYOLLA, B.L., LEITE JÚNIOR, W.B., TOSDAL, R.M., SPIRO, B. (1999a) Mesoproterozoic rapakivi granites of Rondônia Tin Province, SW Amazon Craton, Brazil: Nd, Sr, O, $\mathrm{Pb}$ isotopes and metallogenic implications. GEOLOGICAL, SOCIEIYY OF AMERICA, 1999 annual meeting, Boulder, 1999. Abstrats with Programs, Boulder, CO, p. 205.

BETIENCOURT', J.S, 'TEIXEIRA, W., PACCA, I.L.G., D'AGRELI FILIO, M.S.D., RTZZOTTO, G.J, VASCONCELOS, P.M.P. (2002) Perfil geocronológico ${ }^{4} \mathrm{Ar} /{ }^{39} \mathrm{Ar} \mathrm{cm}$ rochas paleo-mesoproterozóicas da regiào centro norte de Rondônia: Inferências tectônicas. In: CONGRESSO BRASILEIRO DE GEOLOGIA, 4l., Joào Pessoa, 15 a 20/09/02 Setembro, 2002. Anais. Joăo Pessoa, SBG -- Núdeo Nordeste, p. 296.

BETTENCOURT, J.S., TOSDAL, R.M., LETTE JÚNIOR, W.B., PAYOLLA, B.L. (1999b) Mesoproterozoic rapakivi granites of the Rondonia Tin Province, southwestern border of the Amazonian Craton, Brazil: I. Reconnaissance U.Pb geochronology and regional implications. Precantorian Researd, 95(1/2): 41-67.

BEUS, A.A. \& ZALASHKOVA, N.Ye. (1964) Post-magmatic high temperature metasomatic processes in granitic rocks. Inlemational Geology Revien, 6(4): 668-679.

BEUS, A.A. (1982) Metallogeny of Precambrian rare-metal granitoids. Revisk Brasileira de Geocièncius, 12(1-3): $410-413$.

BLAT'INNER, P., BIRD, G.W. (1974) Oxygen isotope fractionation between quartz and K-feldspar at $600{ }^{\circ} \mathrm{C}$. Earth Planelt. Sai. Lett., 23: 21-27.

BODNAR, R.J., BURNHAM, C.W., STERNER, S.M. (1985) Synthetic fluid inclusions in natural quartz. III. Determinations of phase equilibrium properties in the system $\mathrm{H}_{2} \mathrm{O}+\mathrm{NaCl}$ to $1000^{\circ} \mathrm{C}$ and 1500 bars. Geochimica et Cosmochimica Acta, 49: 1861-1873.

BODNAR, R.J., REYNOLDS, T.J., KUEHN, C.A. (1985) Fluid-inclusion systematics in epithermal systems. Reviews in Economic Geology, 2: 73-97.

BORISENKO, A.S. (1978) Study of the salt composition of solutions of gas-liquid inclusions in minerals by the cryometric method. Soviet Geology and Geophysics, 18: 11-19. 
BOTTINGA, Y., JAVOY, M. (1973) Comments on oxygen isotope geothermometry. Earth Planet. Sit. Leth., 20: $250-265$.

BOTTINGA, Y., JAVOY, M. (1974) Oxygen isotope geothermometry of igneous and metamorphic rocks. EOS, Am. Geophys. Union Trans., 55: 477.

BOWDEN, P., KINNAIRD, J.A., ABAA, S.I., IKE, E.C., TUREKI, U.M. (1984) Geology and mineralization of the Nigerian anorogenic ring complexes. Geol.Jb., 1356: 1-68.

BOWERS, T.S. \& FEIGESON, H.C. (1983) Calculation of the thermodynamic and geochemical consequences of nonideal mixing in the system $\mathrm{H} 2 \mathrm{O} \cdot \mathrm{CO} 2 \mathrm{NaCl}$ on pahse relations in geologic systems; metanorphic equilibria at high pressures and temperatures. American Mineralogist, 68(11-12): 1059-1075.

BRETTER, K. (1998) Granites of the Kunsné Hory/Erzgebrige Mts. - Slavkoský Les area. In: Breiter, K. (ed.) GENETIC SIGNIICANCE OF PHOSPHORUS IN FRACTIONATED GRANITES. Perslák, 1998. Examsion Guide. Prague, Czech Geological Survey, p. 21-31.

BREXTER, K. (2002) From explosive breccia to unidirectional solidification textures: magmatic evolution of phosphorus- and thorine-rich granite system (Podlesi, Krusté hory Mts., Czech Republic). Bulletin of the Cyech Geological Survey, 77(2): 67-92.

BROWN, P.E. (1989) FLINCOR: $A$ microcomputer program for the reduction and investigation of fluid inclusion data. American Mineralogist, 74: 1390-1393.

BROWN, P.E. \& LAMBB, W.M. (1989) P-V-T properties of fluids in the system $\mathrm{H}_{2} \mathrm{O} \pm \mathrm{CO}_{2} \pm \mathrm{NaCl}$ : $\mathrm{New}$ graphical presentations and implications for fluid inclusion studies. Geothimica et Cosmothimica Aita, 53: $1209-1221$.

BURNHAM, C.W., OHMOTO, H. (1980) Late-stage processes of felsic magnatism. In: Ishihara, S., Takenouchi, S. (eds.) Granitic mugmatism and related mineralization. p. 1-11.

CAPUTO, M.V., RODRIGUES, R., VASCONCELOS, D.N.N. de (1971) Litoestratigrafia da Bacia do Rio Amazonas. Belém, PETROBRAS-RENOR, 1971. (Relatório Interno, 641-A).

CERNÝ, P. \& BUR'T, D. (1984) Paragenesis, crystallochemical characteristics, and chemical evolution of micas in granite pegmatites. In: S.W. Bailey (ed.) Micas. Blacksburg, Mineralogical Society of America (Reviews In Mincralogy, 13), p. 257-297.

CLAYTON, R.N., GOLDSMTTH, J.R., KAREL, K.J., MAYEDA, 'T'K., NEW'ON, R.C. (1975) limits on the effect of pressure on isotopic fractionation. Geochim. Cosmochim. Akta, 39: 1197-1201.

CLAY'TON, R.N., O'NEIL, J.R., MAYEDA, 'T'.K. (1972) Oxygen isotope fractionation between quartz and water. J. Geophys. Res., 77: 3057-3067.

COLE, D.R., OHMOTO, H. (1986) Kinetics of Isotopic Exchange at Elevated Temperatures and Pressures. In: VALLEY, J.W., TAYLOR, H.P., O'NELL, J.R, eds. Stable liotopes in High Temperature Geological Processes. Blacksburgh, Mineralogical Society of America, p. 41-90. (Reviews in Mineralogy, 16).

COLE, D.R., OHMOTO, H., LASAGA, A.C. (1983) Isotopic exchange in mineral-fluid systems. I. Theoretical evaluation of oxygen isotopic exchange accompanying surface reactions and diffusion. Geochim. Cosmocbim. Acka, 47: 1681-1693.

COLLINS, P.L.F. (1979) Gas Hydrates in $\mathrm{CO}_{2}$-Bearing Fluid Inclusions and the Use of Freezing Data for Estimation of Salitity. Economic Geology, 74(6): 1435-1444.

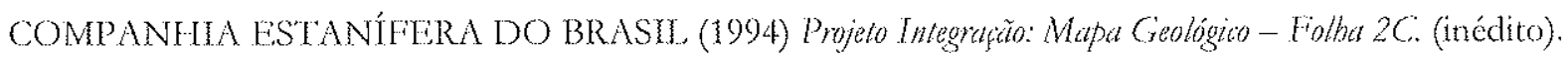

COMPSTON, W., WILLLAMS, I.S., MYER, C. (1984) U-Pb geochronology of zircons form lunar breccia 73217 using a sensitive high mass-resolution ion mictoprobe. Journal of Geoplysical Research, v.89, suppl. B, p. 525-534.

CORDANI, U.G. \& BRITO NEVES, B.B. de (1982) The geologic evolution of South America during the Archean and Eandy Proterozoic. Remista Brasileira de Geociêmicas, 12: 78-88. 
CORDANI, U.G., TASSINARI, C.C.G., TEIXEIRA, W., BASEI, M.A.S., KAWASHITA, K. (1979) Evoluçào tectônica da Amazônia com base nos dados geoctonológicos. In: CONGRESSO GEOLOGICO CHILENO, 2, Arica, 1979. Alas. Arian, v. 4, p.137-148.

CORFU, F., STOTT, G.M. (1986) U/Pb ages for late magmatism and regional deformation in the Shebandowan Belt, Superior Province, Canada. Canadian Journat of Earth Sizences, 23(8): 1075-1082.

COSTA, J.B.S. \& HASUI, Y. (1991) O quadro geral da evoluçăo tectônica da Amazônia. In: SIMPÓSIO NACIONAL DE ESTUDOS TECTONICOS, 3, Rio Clato, 1991. Boletim. Rio Claro, SBG/NSP, v. 1, p. 141.145 .

COSTA, J.B.S. \& HASUI, Y. (1997) Evolução geológica da Amazônia. In: Costa, M.L. \& Angélica, R.S. (coords.) Contribuiçöes à geologia da Amuvôniá. Belém, Finep/SBG-NO, 15-.90.

CRAWFORD, S.M. (1981) Phase equilibria in aqueous fluid inclusions. Mineralogical Assotiation of Canada. Short Coupre 6: 75-100.

CRISS, R.E, TAYLOR, H.P., Jr. (1986) Meteoric-Hydrothermal Systems. In: VALLEY, J.W., TAYLOR, H.P., O'NEIL, J.R, eds. Stable Isolopes in High Temperature Geological Processes. Blacksburgh, Mineralogical Society of America, p. 373-424. (Reviews in Mineralogy, 16).

DALL'IGNA, L.G. (1996) A mineraçào e o garimpo de cassiterita de Rondônia. A Terra em Revista, 1: 56-61.

DARBYSHIRE, D.P.F. (1979) Results of the age determination progtamme. Rep. E. Bolivia Miner. Explor. Proj. (Proyecto Precámbrico), Phase I, 9 (inédito).

DARBYSHIRE; D.P.F. (2000) The Precambrian of Eastern Bolivia … a Sm-Nd Isotope Study, In: INTERNATIONAL GEOLOGICAL CONGRESS, 31., Rio de Janeiro, 6-17 Agosto, 2000. Abstracts CD-ROM. Rio de Janeiro, IUGS/SBG/SBGF/MME/CPRM/PETROBRAS/DNPM/ANP/ ANEEI./ABC.

DARDENNE M.A., SCHOBBENHAUS, C. (2001a) Metalogênese do Brasil. Ed. UnB, Basillia, 394 p.

DARDENNE M.A., SCHOBBENHAUS, C. (2001b) Épocas Metalogenéticas no Cráton Amazônico. In: SIMPÓSTO DE GEOLOGIA DA AMAZONIA, 7, cidade?, 04 a 09/11/01. Anais CD ROM? cidade, SBG/Núcleo Norte.

DAVIS, D.W., LOWENSTEIN, T.K., SPENCER, R.S. (1990) Melting behavior o tuid inclusions in laboratory-grown halite crystals in the systems $\mathrm{NaCl}-\mathrm{H}_{2} \mathrm{O}, \mathrm{NaCl}-\mathrm{KCl}-\mathrm{H}_{2} \mathrm{O}, \mathrm{NaCl}-\mathrm{MgCl}_{2}-\mathrm{H}_{2} \mathrm{O}$ and $\mathrm{NaCl}-\mathrm{CaCl}_{2}-\mathrm{H} 2 \mathrm{O}$. Geochimuica el Cosmochimica Ata, 54: 591-601.

DEER, W.A., HOWIE, R.A., ZUSSMAN, J. (1960) Minerais constituintes das rochas. Lisboa, Fundaçio Calouste Gulbekian. $556 \mathrm{p}$.

DEER, W.A., HOWIE, R.A., ZUSSMAN, J. (1992) An introdution to the rock-forming minerals. 2 ed. Harlow, Longman Scientific \& T'echnical. 696p.

DePAOLO, D.J. (1981) A neodymium and strontium isotopic study of the Mesozoic calc-alkaline granitic batholiths of the Sierra Nevada and Peninsular Ranges, California. Journal of Geoplyssical Research, v.86, n. B11, p. 10470-10488.

DEPARTAMENTO NACIONAL DE PRODUCÃO MENERAL (1994) Plano plurianual para o desenwolvimento do setor mineral. Brasilia, MME/SMM. V. 1, 86 p.

DEPARTAMENTO NACIONAL DE PRODUÇÃO MINERAL (1996) Sumário Mineral. Brasilia, MME/SMM. 103 p.

DIAMOND, I..W. (1994) Introduction to phase relations of $\mathrm{CO}_{2}-\mathrm{H}_{2} \mathrm{O}$ fluid inclusions. In: De Vivo, B. \& Frezzotti, M.-L. (eds.) Fluid Indusions in Minerals, Methods and Applications. Short Course of the IMA Working Group 'Inclusions in Mincrals'. Virginia 'Tch., pp. 131-158.

DIAMOND, L. W. (2001) Review of the systematics of $\mathrm{CO}_{2}-\mathrm{H}_{2} \mathrm{O}$ fluid inclusions. Lithos, 55(1-4): 69-99. 
DONNELEY, T., WALDRON, S., TAIT, A., DOUGANS, J., BEARHOP, S. (2001) Hydtogen isotope analysis of natural abundance and deuterium-entiched waters by reduction over chromium on-line to a dynamic dual inlet isotope-ratio mass spectrometer. Rapid communications in mast spetromelry, $15: 1297$. 1303.

DRUMMOND, S.E. \& OHMOTO, H. (1985) Chemical evolution and mineral deposition in boiling hydrothermal systems. Economic Geology, 80:126-147.

DU BRAY, EA. (1994) Compositions of micas in peraluminous granitoids of the eastem Arabian Shickl. Contributions to Mineralogy and Petrology, 116(4): 381-397.

EBADI, A. \& JOHANNIS, W. (1991) Beginning of melting and composition of first melts it the system $\mathrm{Q} \%-\mathrm{Ab}-\mathrm{O}-\mathrm{H}_{2} \mathrm{O}-\mathrm{CO}_{2}$. Contributions to Mineralogy and Pelrology, 106: 286-295.

FMSIIE, R.F. (1991) Granitoids of tapakivi granite-anorthosite and related associations. Precumbrian Resumb, 51: $173-192$

FALLICK, A.E., MACAULAY, C.I, HASZEIDINe, R.S. (1993) Implications of linearly correlated oxygen and hydrogen isotopic compositions for kaolinite and illite in the Magnus Sandstone, North Sea. Clays and Clay Minerals, $41(2): 184-190$.

FIGUEIREDO, A.J., RODRIGUES, A.P., PIMENTEL, G. de B., REISCHI, J.L., REZENDE, FTLHO, S.'T., RIBEIRO FILIHO,W. (1974) Projeto Alto Guaporé. Goiânia, DNPM/CPRM. Relatório Final IV, 35 p.

FORTIER, S.M. \& GIIETTI, B.J. (1991) Volume self-diffusion of oxygen in biotite, muscovite, and phlogopite micas. Geochimia at Cosmochimiat Alta, 55: 1597-1607.

FOSTER, M.D. (1960) Interpretation of the composition of trioctahedral micas. U.S. Creologial Survey Professional Paper, 354-B: $11-49$.

FOSTER, M.D. (19606) Interpretation of the composition of lithiun micas. U.S. Geological Survey Profersional Paper, 354-E: 115-147.

FRANK, R.E (1990) Geologia, petrologia e mineralizazoes estaniferas do Complexo Grantico de Santa Bámbara, Rondônia, Brasil. Rio de Janeiro, 244p. (Dissertaçào - Mestrado) - Instituto de Geociências, Universidade Federal do Rio de Janciro.

FRANKF, N.D. (1994) Relatório Integraçäo - Bloco Santa Bárbara facundá. Relatório Interno teg. 004/96 da Companhia Fistanifera do Brasil. 19p.

FROST, B.R., BARNES, C.G., COLLINS, W.J, ARCULUS, R.J., EILLIS, D.J., FROST, C.D. (2001) A Geochemical Classification for Granitic Rocks. Joumal of Pelrology, 42(11): 2033-2048.

FROST, C.D. \& FROST, B.R. (1997) Reduced rapakivi-like ganites: The tholeite connection. Geology, 25(7): 647.650 .

GABRTEL, A., COX, E.F. (1929) A staining method for the quantitative deternination of certain rock minerals. Am. Minerth, $14(8): 290-292$.

GARLICK, GD., EPSTEIN, S. (1967) Oxygen isotope ratios in coexisting minerals of regionally metatnotphosed tocks. Geochim. Cosmockim. Acta, 31: 181-214.

GAUDETTE, H.E \& OLSZEWSKI Jr., W.R. (1985) Geochronology of the basement rocks, Amazonas territory, Venezucla and the tectonic evolution of the western Guiana shield. Crol. Mijnb., 64: 131-144.

GERAIDES, M.C. (2000) Geocronolgia e geoquímica do plutonismo mesoproterozóico do SW do estado de Mato Grosso (SW do Cráton Amazónico). Sào Paulo, 187p. (T'ese - Doutorado). Instituto de Geociências, Universidade de São Paulo. 
GERAIDES, M.C., MAIOS, J., RUT, A., FETTER, A.H., KOZUCH, M., VAN SCHMUS, W.R, TASSINARI, C.C.G., TRIXEIRA, W. (1999) U/Pb constraints on Proterozoic magmatic arcs in SW Amazonia Craton, Bazil. In: SOUTH AMERICAN SYMPOSIUM ON ISOTOPE GEOLOGY, 2, Cordoba, 1999. Anais. Cordoba, Secretaría de Minería de la Nación/Instituto de Geología y Recursos Minerales/Servicio Geológico Minero Argentino, p. 68-71.

GERALDES, M.C., TEIXEIRA, W., VAN SCHMUS, W.R. (2000) Isotopic and chemical evidence for three accretionary magmatic arcs (1.79-1.42 Ga) in the SW Amazon Craton, Mato Grosso State, Brazil. Revisla Brasileina de Geociências, 30(1):099-101.

GERAIDES, M.C., VAN SCHMUS, W.R., CONDTE, K.C., BHLI, S., 'TEIXEIRA, W., BABINSKI, M. (2001). Proterozoic Geologic Evolution of the SW Part of the Amazonian Caton in Mato Grosso State, Bazil. Precambrian Researh, 111(1-4): 91-128.

GERALDES, M.C., VAN SCHMUUS, W.R., TEIXEIRA, W. (2000b) Three parallel crustal accretionary arcs (1.79-1.43) in the SW Amazon Craton, state of Mato Grosso, Brazil. In: INTERNATIONAI, GEOLOGICAL CONGRESS, 31., Rio de Janeiro, August $6^{\text {th }}-17^{\text {th }}, 2000$. 4 bstrats CD-ROM. Rio de Janciro, IUGS/SBG/SBGF/MME/CPRM/PETROBRAS/DNPM/ANP/ANEEI/ABC.

GIBBS, A. \& BARRON, C.N. (1983) The Guyana shield reviewed. Eipisodes, 6: 7-14.

GILETLI, B.J. (1985) The nature of oxygen transport within minerals in the presence of hydrothermal water and the role of diffusion. Chom. Geol, 53; 197-206.

GILG, H.A. \& SHEPPARD, S.M.F. (1996) Hydrogen isotope fractionation between kaolinite and water revisited. Geochimita et Cosmoctimia Acta, $60(3): 529-533$.

GIOIA, S.M.C.L., PIMENTEL, M.M. (2000) The Sm-Nd Isotopic Method in the Geochronology Laboratory of the University of Brasilia. An. Acad. Bras. Ci., 72(2): 219-245.

GOKFAIF, N.W. (1968) Chemical composition of biotites as a guide to ascertain the origin of granites. Bulletin of The Crological Sociely of Tinland, 40: 107-111.

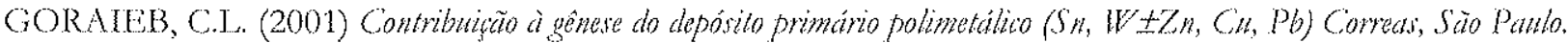
Sào Paulo, 215 p. (T'ese - Doutorado). Instituto de Geociências, Universidade de Sào Paulo.

GRAMAM, C.M. (1981) Experimental hydrogen isotope studies III: diffusion of hydrogen in hydrous minerals, and stable isotope exchange in metamorphic rocks. Contrib. Mineral. Petrol., 76: 216-228.

GRAHAM, C.M., IARMON, R.S., SHEPPARD, S.M.F. (1984) Experimental hydrogen isotope studies -... I. Systematics of hydrogen isotope exchange between amphibole and water. Am. Minewl, 69: 128-138.

GRAFAM, C.M., SHEPPARD, S.M.F. (1978) Hydrogen isotope fractionation between aluminous

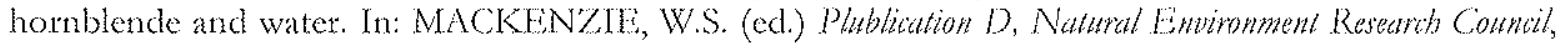
1, London. Natural Environment Research Council, p. 152-153.

GRAUPNIR, T., KEMPE, U., DOMBON, F., PÄTZOHD, O., LETDER, O., SPOONER, E.T.C. (1999) Fluid regime and ore formation in the tungsten (-ytrium) deposits of Kyryltau (Mongolian Altai): evidence for fluid variability in tungsten-tin ore systems. Chemial Geology, 154:21-58.

GREEN, GR, OHMOTO, H., DATE, J., WAKAFASHI, T. (1983) Whole-rock oxygen isotope distribution in the Fukuzawa-Kosaka area, Hokutoku district, Japan, and its potential application to mineral explonation. Ficon, Geol. Monograph, 5: 395-411.

GREGORY, R.T', CRISS, R.E. (1986) Isotopic Exchange in Open and Closed Systems. In: VALI.EY, J.W., TAYT.OR, M.P., O’NEII, J.R, eds. Stable Tsotopes in Tigh Temperature Geologial Processes. Blacksburgh, Mineralogical Society of America, p. 91-127. (Reviews in Mineralogy, 16).

HAAPALA, I. (1977) Petrography and geochemistry of the Eurajoki stock, a rapakivingranite complex with greisen-type mineralization in southwestern Finland. Geological survey of Finland Bulletin, 286, $128 \mathrm{p}$.

HAAPAIA, I. (1997) Magmatic and Postmagmatic Processes in Tin-mineralized Granites: Topaz-bearing Ieucogranite in the Eurajoki Rapakivi Granite Stock, Finland. Journal of Pelrology, 38(12): 1645.1659. 
HAAPALA, I. \& RÄMÖ, 'T. (1990) Petrogenesis of the Proterozoic rapakivi granites of Finland. In: Stein, H.J. \& Kannah, j.l. (eds.) Ore-bearing granite systems, Petrogenesis and mineralizing processes. Geological Society of America Special Paper 246: 275-286.

HAAPALA, I. \& RÄMÖ, T. (1992) Tectonic setting and origin of the proterozoic rapakivi granites of southeastern Fennoscandia. Trans. R. Soc. Edinbrugh, Eartb Sci., 83: 165-171.

HASUI, Y. \& ALMEIDA, F.F.M. de (1985) 'The central Brazil Stield reviewed. Episoder, 8(1): 29-37.

HASUI, Y., HARALYI, N.I.E., SCHOBBENHAUS, C. (1984) Elementos geolísicos e geológicos da região Amazonica: subsidio para o modelo geotectònico. In: SYMLPOSIUM AMAZONICO, 2, Mataus, 1984. Atas. Manaus, DNIM/MME, p. 129-147.

HEDENQUIST, J.W. \& HENIEY, R.W. (1985) The Importance of $\mathrm{CO}_{2}$ on Freering Point Measurements of Fluid Inclusions: Evidence from Active Geothermal Systems and Implications for Epithermal Ore Deposition. Eiconomic Geology, 80(5): 1379-1406.

FEINRICH, C.A. (1990) The geochemistry of hydrothermal tin (tungsten) ore deposition. Eionomic Geology, 85: 457-481.

HEINRICH, E.W.M. (1972) Microscopic identification of minerals. New York, McGraw-Hill. 414p.

HENDERSON, C.M.B., MARTIN, J.S., MASON, R.A. (1989) Compositional relations in Li-micas from S.W. England and France: tha ion- and electron-microprobe study. Mineralogical Magazine, 53: 427-449.

HENI.EY, R.W., 'TRUESDELL, A.H., BARTON, P.B., Jr. (1984) Fluid-mineral equilibria in hydrothermal systems. Reviews in Economic Cerology, 1, 267p.

HIGGINS, N.C. (1985) Wolframite Deposition in a Hyctrothermal Vein System: The Grey River Tungsten Porspect, Newfoundland, Canada. Economic Geology, 80(5): 1297-1327.

HOEFS, J. (1997) Stable Isotope Geochemistry. 4.ed. Berlim, Springer-Verlag. $201 \mathrm{p}$.

HOLLAND, M.D. (1967) Gatgue minerals in hydrothermal deposits. In: Batnes, H.L. (ed.) Geochemistry of Hydrothermul Ore Deposits. New York, Holt, Rinehart and Winston, p. 382-436.

FORITA, J., WESOLOWSKI, D.J. (1994) Liquid-vapor fractionation of oxygen and hydrogen isotopes of water: from the freezing to the critical temperature. Geochim. Cosmoctsim. Atu, 58: 3425-3437.

ISO'T'TA, C.A.L., CARNEIRO, J.M., KATO, H.T., BARROS, R.J.L. (1978) Projelo Província Eskanifera de Rondônia. Porto Velho. DNP'M/CPRM. Vols. 1, 2 e 3. (Relatório final).

ISSLER, R.S. (1977) Esboço Geológico Geotectônico do Cráton do Guaporé. Revista Brasileira de Geociênuiur, $7(3): 177-211$.

JAMES, R.S. \& HAMILTON, D.L. (1969) Phase relations in the system $\mathrm{NaAlSi}_{3} \mathrm{O}_{8}-\mathrm{KAISi} O 8-\mathrm{CaAl}_{2} \mathrm{Si}_{2} \mathrm{O}_{8}$ $\mathrm{SiO}_{2}$. Contributions to Mineralogy and Petrology, 21: 111-141.

JARCHOVSKÝ, T. (1998) Sn-IW mineralization in the Krasno district. In: Breiter, K. (ed.) GENETIC SIGNIFICANCE OF PHOSPHORUS IN FRACTIONATED GRANITES. Perslák, 1998. Excursion Guide. Prague, Czech Geological Survey, p. 77-92.

JARCHOVSKÝ, T., PAVLÚ, D., MORYSEK, J., NAJMAN, K., KOZUBEK, P. (1994) Li-F granite cupolas and Sn-W mineralization in the Slavkovský les Mts., Czech Republic. Monograph Series on Mineral Deposits, 31: 131-148.

JENKIN, G.R.T. (1988) Stable isotope studies in the Caledonides of S.W. Connemana, Ireland. Glasgow, 357 p. (Tese-Doutorado). University of Glasgow.

JOHAN, Z, \& JOHAN, V. (2001) Les micas de laa coupole granitique de Cínovec (Zinnwald), République tchèque: un nouvel aperçu sur la métallogènese de létain et du tungstene. Comples Rendus de l'Alademie des Sciences, Serie II. Sciences de la Terre el des Planetes, 332(5): 307-313.

JONES, J.P. (1985) The southern border of Guapore shield in western Brazil and Bolivia: na interpretation of its geologic evolution. Precambrian Researth, 28: 111-136. 
KLOOSTERMAN, J.B. (1967) Ring-complex in the Oriente Novo and Massangana granite complexes. Engenharia Minerayazo Motalurgia, 45(266): 73-77.

KLOOSTERMAN, JBB. (1968) Uma província do tipo Nigeriano no sul da Amazônia. Engenharia Mineraçũo Melalurgia, 49(278): 59-64 e 49(280): 167-168.

KLOOSTERMAN, J.B. (1970) A two fold analogy between the Nigerian and Amazonian tin provinces. In: TECHNICAL CONFERENCE ON TIN, 2, Bangkok, 196\%. Procedings, International Tin Council/Thailand Dep. Mineral Resource, v. 1, p. 193-221.

KORPERSHOEK, H.R, MOTA, E.R., KAJISHMM, T., SLVA, J.S.S. (1980) Nota preliminar sobre a jazida do Morro do Potosi (Jacundá, Rondônia, Brasil). In: CONGRESSO BRASILEIRO DE GEOLOGIA, 31., Balneário Camboriú, 1980. Anais. Balneário Camboriú, SBG, V. 3, p. 1574-1588.

KOVALINKO, V.I., KUZ'MIN, M.I., LETNIKOV, F.A. (1970) Magmatic origin of lithium- and fluorinebearing rare-metal gratnite. Doklady of the Academy of Sciences of the U.S.S.R. - Earth Sciences Sections, 190: $189-192$.

KOVALENKO, V.I. \& YARNOLYUK, V.V. (1995) Endogenous rare metal ore formations and rare metal metallogeny of Mongolia. Economic Geology, 90: 530-547.

KROGH, T.E. (1973) A low-contamination method for hidrothermal decomposition of zircon and extraction of $\mathrm{U}$ and $\mathrm{Pb}$ for isotopic age determinations. Geochim. Cosmochim. Aoka, 37(3): 485-494.

KROGH, TRE. (1982a) Improved accuracy of U/Pb dating by selection of more concordant fractions using a high gradient magnetic separation technique. Geocbim. Cosmochim. Acta, 46(4): 631-636.

KROGH, T.E. (1982b) Improved accuracy of U/Pb zircon ages by the creation of more concordant systems using air abrasion technique. Geochim. Cosmochim. Acka, 46(4): 637-649.

LAHTI, S.I. \& SUOMINEN, V. (1988) Occurrence, crystallography and chemistry of the fluoceritebastnaesite-cerianite intergrowth from the Fjälskär Granite, southwestern Finland. Bulletin of the Geological Sociely of Finland, 60(1): 45-53.

LEAL, J.W.I., SILVA, G.H., ABREU, A.S., LMMA, M.I.C. de (1976) Granito Serra da Providência. In: CONGRESSO BRASHEIRO DE GEOLOGIA, 29, 1976, Ouro Preto, Amai. Outo Preto, SBG, 1976, V. 4, p. 59-74.

LEAL, J.W.L., SIIVA, G.I., SANTOS, D.B., TEIXEIRA, W. LIMA, M.I.C., FERNANDES, C.A.C., pINTO, A.C. (1978) Geologia. In: Projeto RADAMBRASU. Folha SC.20 Porto Volho. Rio de Janeiro, DNPM/MME. p. 19-184.

LEFMANN, B. \& MAFIAWAT, C. (1989) Metallogeny of tin in central 'Thailand: A genetic concept. Genlogy, $17(5): 426-429$.

LEITCH, C.H.B. (1981) Secondary alkali feldspars in porphyry systems. CIM Bulletin, 74(831): 83-88.

LEITE JÚNIOR, W. B. (1992) O matijo Oriente Nono (RO) e a mineralização estano-tungstenifera associada. São Paulo, 173 p. (Dissertação - Mestrado). Instituto de Geociências, Universidade de Sĩo Paulo.

LETTE JÚNIOR, W.B. (2002) A Súte Intrusiva Santa Clara (RO) e a minetalizaçăo primária polimetálica (Sn, W, Nb, 'Ta, Zn, Cu e Pb) associada. Sào Paulo, 305 p. (T'ese -... Doutorado). Instituto de Geociências, Universidade de Sào Paulo.

LEITE JÚNIOR, W.B., BETTENCOURT, J.S., PAYOLLA, B.I. (1993) The Younger Granites of Rondônia and telated rare-metal mincralizations. In: WORKSHOP MAGMA (Magmatismo granítico e mincralizaçòes associadas), Rio de Janeiro, 1993. Resumos expandidos, roteiro de excursão e programa. Rio de Janciro, Academia Brasileira de Ciências. P. 69-70.

LETTE JÚNIOR, W.B., BETTENCOURT, J.S., PAYOI.LA, B.L. (1996) The alkaline sute of the Younger Rapakivi Ganites of Rondonia, Brazil. In: I HAAPALA, O.T. RÄMO, P. KOSUNEN (eds.) SYMPOSIUM ON RAPAKIVI GRANITES AND RELATED ROCKS. Abstrat Volume. University of Helsinki, University Press. Helsinki, Finland, pp. 49-50. 
LEITE JÚNIOR, W.B., BETTENCOURT, J.S., PAYOLJA, B.L. (2001a) 1.08-1.07 Ga A-type magmatism in the Rondonia Tin Province, SW Amazonian Craton, Brazil: petrologic and geochemical constraints. In: MINERALOGICAL ASSOCTATION OF CANADA ANNUAL METTING. Maio- 2001. Absiratze Volume 26. GSC, p. 85.

LEITE JÚNIOR, W.B., PAYOLLA, B.L., BETTENCOURT, J.S. (2000) Petrogenese of two Grenvillian tinbearing rapakivi suites in the Rondônia 'Tin Province, SW Amazonian Craton. In: INTERNATIONAI GEOLOGICAL CONGRESS, 31, Rio de Janeiro. Abstrats, CD ROM.

LETTE JÚNTOR, W.B., PAYOLLA, B.L., BETTENCOURT, J.S. (2001b) New K-Ar ages of the primary tin minctalization in the Rondonia Tin Province, Brazil. In: SOUTH AMERICAN SYMPOSIUM ON ISOTOPE GEOLOGY,5, Pucon, Chile. Extend Abstruts, CD-ROM.

LEVILLAIN, C. (1980) Etude statistique des variations de la teneur en $O H$ et F datns les micas. Titbermaks Mineralogische und Petrographische Mitteilungen, 27(3): 209-.223.

LITHERLAND, M., ANNELS, R.N., APPLETON, J.D., BERRANGE, J.P., BLOOMFIELD, K. BURTON, C.C., DARBYSHIRE, D.P.F., FLETCHER, C.J.N., HAWKINS, M.P., KLINCK, B. A., MrTCheLl, W.I., O'CONNOR, F.A., P'TFIELD, P.E.J., POWER, G., WEBB, B.C. (1986) The geology and mineral resources of the Bolivian precambrian stzield. Keyworth. British Geological Survey. 153p. (Overseas Memoir 9).

LITHERLAND, M., ANNELS, R.N., DARBYSHIRE, D.P., FLETCFER, C.J.N., HAWKINS, M.P., KLINCK, B.A., MITCHELL, W.I., O'CONNOR, E.A., PITFIELD, P.E.J., POWER, G., WEBB, B.C, (1989) The Proterozoic of eastern Bolivia and its telationship with the Andean mobile belt. Precambrian Research, 43: 157-174.

LITHERLAND, M. \& BLOOMFIELD, K. (1981) The proterozoic history of eastern Bolivia. Prectmbrian Research, 15: 157-179.

LOBATO, F.P.N.S., APPEL, L.E., GODOY, M.C.F.T. de, RITTER, J.E. (1966) Pesquisa de cassiterita no Território Federal de Rondônia. Relatório final. Rio de Janeiro, DNPM/DFPM, 1966, 209p. (Boletim 125).

LOISELLE, MLL. \& WONES, D.R. (1979) Characteristics and origin of anorogenic granites. Geological Sociely of America Abstruts with Programs, 11: 468.

LONDON, D., HERVIG, R.L., MORGAN, G.B., VI (1988) Melt-vapor solubilities and elemental partitioning in peraluminous granite-pegmatite systems: Eixperimental results with Macusani glass at 200 Mpa. Contributions to Mintralogy and Petrology, 99: 360-373.

LONDON, D., MORGAN, G.B., VI, BABB, H.A., LOOMIS, J.I.. (1993) Behaviour and effects of phosphorous in the system $\mathrm{Na}_{2} \mathrm{O}-\mathrm{K}_{2} \mathrm{O}-\mathrm{Al}_{2} \mathrm{O}_{3}-\mathrm{SiO}_{2}-\mathrm{P}_{2} \mathrm{O}_{5}-\mathrm{H}_{2} \mathrm{O}$ at $200 \mathrm{Mpa}\left(\mathrm{H}_{2} \mathrm{O}\right)$. Contributions 10 Mineralogy and Petrology, 113: 450-465.

LONDON, D., MORGAN, G.B., VI, HERVIG, R.L. (1989) Vapor-undersaturated experiments with Macusani glass $+\mathrm{H}_{2} \mathrm{O}$ at $200 \mathrm{Mpa}$, and the internal differentiation of granitic pegmatites. Contributions to Mineralogy and Petrology, 102: 1-17.

LUDWIG, K.R. (1999) User's Manual for Isoplot/Ex version 2.10: a Gecochronological Toolkit for Microsoft Excel. Berkeley Geachronology Center Special Publication no. 1 a.

MACAULAY, C.I., FALI.CK, A.E, HASZELDINE, R.S., GRAHAM, C.M. (2000) Methods of laaserbased stable isotope measurement applied to diagenetic cements and hydrocarbon reservoir quality. Catay Minerali, 35: 313-322.

MANIAR, P.D. \& PICCOLI, P.M. (1989) 'T'ectonic discrimination of granitoids. Geological Society of America Bulletin, 101: 635-643.

MANNING, D.A.C. (1981) The effect of fluorine on liquidus phase relationships in the system Qz-Ab-Or: with excess water at $1 \mathrm{~kb}$. Contributions to Mineralogy and Petrology, 76: 206-215. 
MANNING, D.A.C. \& EXLEY, C.S. (1984) The origins of late-stage tocks in the St. Austell granite - a re-interpretation. J. Geol. Soc. London, 141:581-591.

MARTIN, J.S. (1983) An experimental study of the effects of lithium on the granite system. Proceedings of the Ussher Societ $y, 5(4): 417-420$.

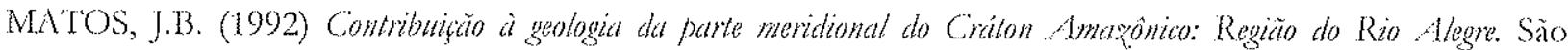
Paulo, 108 p. (Dissertaçào - Mestrado). Instituto de Geociências, Universidade de Sño Paulo.

MATOS, J.B., SCHORSCHER, J.H.D., GERALDES, M.C., SOUZA, M.Z.A. (2001) The Rio Alegre Volcanosedimentar Sequence (SW Amazonian Craton, Brazil): chemical and isotopes (U/Pb and $\mathrm{Sm} / \mathrm{Nd}$ ) constrains and tectonic implications. In: Bettencourt, J.S., Teixeira, W., Pacca, I.I.G., Geraldes, M.C., Sparrenberger, I. (eds.) WORKSHOP ON GEOLOGY OF THE SW AMAZONIAN CRATON: STATE-OF-TME-ART. São Paulo, August 10th-12 th 2001. Extended Abstrat Volume. p. 5659.

MATSUHISA, Y., GOLDSMITH, J.R., CLAYTON, R.N. (1979) Oxygen isotopic fractionation in the system quartz-albite-anothite-water. Geochimica et Cosmochimia Acka, 43: 1131-1140.

MENEZES, R.G. de, LOPES, I., BEZERRA, J.R.L. (1993) Folba Pontes e Lacerda 1:100000. Cart Geológica e Texto Explicativo. Brasília, CPRM-DNPM, 176 p. (Programa de Levantamentos Básicos).

MONTALVÃo, R.M.G. \& BEZERRA, P.E.L. (1985) Evvolução geotectônica do Cráton Amazônico (Amazônia Legal) durante o Atqueano e Proterozóico. In: SIMPÓSIO DE GEOLOGLA DA AMAZÔNIA, 2., Belém, 01 a 09/12, 1985. Anais. Belém, SBG, v. 1, p. 282-297.

MONTEIRO, H., MACEDO, P.M., SILVA, M.D., MORAES, A. A., MARCHETO, C.M.L. (1986) O greenstone belt do Alto Jauru. In: CONGRESSO BRASILERO DE GEOLOGIA, 34., 1986. Anais. p. $630-646$.

NABELEK, P.I., O'NEII, J.R., PAPIKE, J.J. (1983) Vapor phase exsolution as a controlling factor in hydrogen isotope variation in granitic rocks: 'The Notch Peak granitic rock, Utah. Eurth Planet. Sit. Lett., 66: $137-150$.

NELISON, M.J., BROCKMAN, G.F. (1977) 'The crror associated with point-counting. American Mineralogist, $62(11-12): 1238-1244$

NESBITT, R.W. (1964) Combined tock and thin section modal analysis. Am. Mineral., 49(7-8): 1131-1136.

NOCKOLDS, S.R. (1947) The relation between chemical composition and paragenesis in the biotite micas of igneous rocks. American Joumal of Science, 245(7): 401-420.

NOLD, J.I., ERICKSON, K.P. (1967) Changes in K-feldspar staining methods and adaptations for freld use. Am. Mineral, 52(9-10): 1575-1576.

OHMOTO, H. (1986) Stable Isotope Geochemistry of Ore Deposits. In: VALLEY, J.W., TAYLOR, H.P., O'NEIL, J.R, eds. Siable Liotopes in High Temperalure Geological Processes. Blacksburgh, Mineralogical Society of America, p. 491-559. (Reviews in Mineralogy, 16).

OKIDA, R. (2001) Aplicaçào do sensoreamet to remoto e aerogamaespectrometria ao estudo do controle estrutural dos granitos estaníferos de Rondônia. São Paulo, 2001. (Tese - Doutorado) - Instituto de Geociências, Universidade de São Paulo. 217 p.

O'NEIL, J.R. (1986) Theoretical and Experimental Aspects of Isotopic Fractionation. In: VALLEE, J.W., TAYLOR, H.P., O'NEIL, J.R, eds. Siable Isotopes in High Temperature Geological Processes. Blacksburgh, Mineralogical Society of America, p. 1-40. (Reviews in Mineralogy, 16).

ONEIL, J.R., CHAPPELL, B.W. (1977) Oxygen and hydrogen isotope relations in the Berridale Batholith. Geol. Soc. London J., 133: 559-571.

O'NEIL, J.R., SHAW, S.E., FLOOD, R.H. (1977) Oxygen and hydrogen isotopic compositions as indicators of granite genesis in the New England batholith, Australia. Contrib. Mineral. Petrol, 62: 313-328. 
O'NETL, J.R., TAYLOR, H.P., Jr. (1967) The oxygen isotope and cation exchange chemistry of feldspars. Am. Mineral, 52: 1414-1437.

PAYOLJA, B.L. (1994) As rochas graniticas e sieniticas das cachociras de Teotônio e Santo Antônio, Rio Madeira, Porto Velho, Rondônia: geologia, petrografia e geoquímica. Brasilia, 445 p. (Dissertaçào Mestrado) - Instituto de Geociências, Universidade de Brasília.

PAYOLLA, B.L., BETTENCOURT, J.S., EETTER, A.H., LEITE JÚNIOR, W.B. (2002b) Ptoveniência, idade deposicional e idade do metamorfismo de paragnaisses da região nordeste de Rondônia a partir de geocronologia U-Pb em zircoes e monazitas e isótopos Sm-Nd. In: CONGRESSO BRASLEERO DE GEOLOGIA, 41., Joño Pesson, 15 a 20/09/02. Anas. SBG/Núcleo Nordeste, p. 328.

PAYOLIAA, B.L., BET'TENCOURT, J.S., KOZUCH, M., LETTE JÚNIOR, W.B., FETTER, A.H., VAN SCHMUS, W.R. (2001a) Geological evolution of the basement tocks in the central-eastern part of the Rondônia Tin Province, SW Amazonian Craton, Brazil: U-Pb and Sm-Nd isotopic constraints. In: Bettencourt, J.S., Teixeira, W., Pacca, I.I.G., Geraldes, M.C., Sparrenberger, I. (eds.) WORKSHOP ON GEOLOGY OF THE SW AMAZONIAN CRATON: STATE-OF-THE-ART. São Paulo, August 10th-12 $2^{\text {th }}$, 2001. Extended Abstract Volume. p. 45-47.

PAYOLLA, B.L., BETTENCOURT', J.S, KOZUCH, M., LEITE JÚNIOR, W.B., FETTER, A.H., VAN SCHMUS, W.R. (2002b) Geological evolution of the basement rocks in the central-eastern part of the Rondônia Tin Province, SW Amazonian Craton, Brazil: U..Pb and Sm-Nd isotopic constraitsts. Precumbrian Research.

PAYOLLA, B.L., BETTENCOURT, J.S., LETTE JUNIOR, W.B., BASEI, M.A.S. (2001b) The Rio Crespo Intrusive Suite: geological U-Plo and Sm-Nd isotopic evidence for a major 1.43 Ga atc-related magmatism in the Rondonia State, SW Amazonia Craton, Brazil. In: Bettencourt, J.S., Teixeira, W., Pacca, I.I.G., Geraldes, M.C., Sparrenberger, I. (eds.) WORKSHOP ON GEOLOGY OF THE SW AMAZONIAN CRATON: STATE-OF-T'FE-ART. Sào Paulo, August 10th-12th, 2001. Extended Abstrat Volume. p. 96-99.

PAYOLLA, B.L, LETTE JÚNIOR, W.B, BETTENCOURT, J.S., PINHO, O.G. de (1991) Aspectos geológicos, petrográficos e litoquímicos do maciço Pedra Branca (RO): consideraçóes preliminares. In: SIMPÓSIO DE GEOLOGIA DA AMAZÔNIA, 3., Belém, 1991. Anati. Belém, SBG/Núcleo Norte. p. $100-116$.

PAYOLLA, B.L. \& PINHO, O.G. de (1981) Relatório finul do macigo Pedra Branat. Projeto Granito. Minctação Oriente Novo S/A. 69p.

PEARCE, J.A., HARRIS, N.B.W., TINDLE, A.G. (1984) Trace Element Discrimination Diagrams for the 'Tectonic Interpretation of Granitic Rocks. Journal of Petrology, 25(4): 956-983.

PICHAVANT, M. (1981) An experimental study of the effect of borot on a water saturated haplogranite a 1 kbar vapour pressure. Contributions to Mineralogy and Petrology, 76: 4.30-439.

PICHAVANT, M. (1987) Effects of B and $\mathrm{H} 2 \mathrm{O}$ on liquidus phase relations in the haplogranite system at 1 kbar. American Mineralogist, 72: 1056-1070.

PICHAVANT, M., RAMBOZ, C., WEISBROD, A. (1982) Fluid immiscibility in natural processes: use and misuse of fluid inclusion data. Chemical Geolog; 37: 1-27.

PINCKSTON, D.R \& SMTTH, D.G.W. (1995) Mineralogy of the Lake zone, Thor Lake rare-metals deposit, N.W.T., Canada. Canadian Journal of Earth Scientes, 32(4): 516-532.

PINFIO, O.G. de (1987) Geologia e mineralizajöes de estanbo no macizo Caritianas, RO. São Paulo, 1987. (Dissertaçào - Mestrado) -.. Instituto de Geociências, Universidade de Sào Paulo. 220 p.

POLLARD, P.J. (1983) Magmatic and postmagmatic processes in the formation of rocks associated with rare-element deposits. Instizute of Mining and Metallurgy Transations, Section B, 92: B1-B9.

POLI.ARD, P.J. (1995) Granites and related mineralization. Notes to accompany a short course presented at the Universidade Federal do Pará, Belém, Brazil, 22-24 Aogosto, 1995. 
POLLARD, P.J. \& TAYLOR, R.G. (1986) Progressive evolution of alteration and tin mineralization: Controls by interstitial permeability and fracture-related tapping of magtnatic fluid reservoirs in tin gratites. Eonomic Geology, 81: 1795-1800.

POLLARD, P.J., TAYLOR, R.G., CUFF, C. (1988) Genetic Modelling of Greisen-Style Tin Systems. In: HUTCHINSON, C.S. (ed.) Geology of Tin Deposits in Asia und the Pawific. Berlim, Springer-Verlag. (Mineral Concentrations and Hydrocarbon Accumulations in the ESCAP Region, Volume 3.),

PRIEM, H.N.A., BOEI.RIJK, N.A.T.M., HEBEDA, E.H., VERSCFURE, R.F., BON, E.F. (1966) Isotopic age of tin granites in Rondônia, N.W. Brazil. Geologie en Mijnboum, 45e: 191-192.

PRTEM, H.N.A., BOELRIK, N.A.M.M., HEBEDA, E.H., VERDUMEN, E. A.Th., VERSCHURE, R.H, BON, E.H. (1971) Granitic complexes and associated tin mineralization of Grenville age in Rondônia, western Brazil. Geological Sociely of Ameria Bulletin, 82: 1095-1102.

PRIEM, H.N.A., BON, E.H. VERDUMEN, E.A.Th., BETTENCOURT, J.S. (1989) Rb-St chronology of precambrian crustal evolution in Rondônia (western margin Braziliat craton). Journal of South American Earth Sciences, 2: 163-170.

PUPIN, J.P. (1980) 'Zircon and granite petrology. Conlributions lo Mineralogy and Pelrology, 73: 207-220.

RAMBOZ, C., PICHAVAN'T, M., WEISBROD, A. (1982) Fluid immiscibility in natural processes: use and misuse of fluid inclusion data. Chemical Geology, 37: 29-48.

RÄMÖ, O.T. \& HAAPALA, I. (1995) One hundred year of Rapakivi Granite. Mineralogy and Petrology, 52: 129-185.

RAMSAY, C.R., STOESER, D.B., DRYSDALL, A.R. (1986) Guidelines to classification and nomenclature of Arabian felsic plutonic rocks. Journal of African Earth Sicmes, 4: 13-20.

RICHARD, L.R. (1988-1997) Minpet - Mineralogical and Petrological Data Processing System.

RICFARDSON, J.M. (1988) Field and textural relationships of alteration and greisen-hosted mineralization at the East Kemptville tin deposit, Davis Lake complex, southwest Nova Scotia. In: R.P. TAYLOR \& D.F. STRONG (eds.) Reent Actutnces in the Geology of Gratnite-Reluted Mineral Deposits. Montréal, Canadian Institute of Mining and Metallutgy (Special Volume 39).

RIEDER, M. (1970) Chemical Composition and Physical Properties of Lithium-Iron Micas from the Krusné hory Mts. (Errgebirge). Part A: Chemical Composition. Contributions to Mineralogy and Petrology, 27: 131158.

RIMSTIDT, J.D. (1997) Gangue Mineral Transport and Deposition. In: Barnes, H.L.. (ed.) Geochemistry of Hydrothermal Ore Deposits. New York, John Wiley \& Sons, p. 487-516.

RIZZOTTO, G.J. (1999) Petrolgia e ambiente geotectônico do Grupo Nova Brasilândia - RO. Porto Alegre, 137p. (Dissertaçào-Mestrado). Instituto de Geociências, Universidade Federal do Rio Grande do Sul.

RIZZOTTTO, G.J. (2001a) Reavaliação do Ciclo Otogênico Sunsás/Aguapeí no sudoeste do Cráton Amazônico. In: Bettencourt, J.S., Teixeira, W., Pacca, I.I.G., Geraldes, M.C., Sparrenberger, I. (eds.) WORKSHOP ON GEOLOGY OF THE SW AMAZONIAN CRATON: STATE-OF-THE-ART. Sào Paulo, August 10 $10^{\text {th }}-12^{\text {th }}, 2001$. Extended Abstruct Volume. p. 66-70.

RIzZOTTIO, G.J. (2001b) Reavaliaçào do Ciclo Orogênico Sunsás/Aguapeí no sudoeste do Cráton Amazônico. In: SIMPÓSIO DE GEOLOGIA DA AMAZÔNIA, 7. cidade?, 04 a 09/11/01. Anais CD-ROMP cidade, SBG/Núcleo Norte.

RIYZOTTO, G.J., BETTENCOURT, J.S., TEIXEIRA, W., PACCA, I.I.G, D'AGRELLA FILFO, M.S. (2002a) Geologia e geocronologia da Súte Metamórfica Colorado, SE de Rondônia. In: CONGRESSO BRASIleiro DE GEOLOGIA, 4l., Joào Pesson, 15 a 20/09/02 Setembro, 2002. Anuis. Joào Pesson, SBG - Núcleo Nordeste, p. 331. 
RIZZOTTO, G.J., BETTENCOUR'T, J.S., 'TEIXEIRA, W., PACCA, M.I.G., D'AGRELLA FLLHO, M.S., VASCONCELOS, P., BASEI, M.A.S, ONOE, A.T., PASSARELLI, C.R. (2002b) Geologia c Geocronologia da Súte Metamórfica Colorado e suas Encaixantes, SE de Rondôtaia: Implicaçòes para a Exoluçăo Mesoproterozóica do SW do Cráton Amazônico. Geologia USP, Série Científica, 2: 41-55.

RIZZOTTO, G.J., CHEMALE JÚNIOR, F., LIMA, E.F. de, VAN SCYMUS, W.R., FETTER, A. (1999) Dados isotópicos $\mathrm{Sm} / \mathrm{Nd}$ e U/Pb das rochas da Seqüência Metaplutono-vulcanossedimentar Nova Brasilândia (SMNB) - RO. In: SIMPÓSTO DE GEOLOGIA DA AMAZONNIA, 6., Manaus, 1999. Bolutim de Resumos Expandidos. Manaus, SBG/Núcleo Norte, p. 490 493.

RIZZOTTO, G.)., SCANDOLARA, J.E., QUADROS, M.I. do E.S. (1996) Aspectos gerais da associaçăo mangerito-charnockito-granito (MCG) da porção oriental do sul de Rondônia. In: CONGRESSO BRASILEIRO DE GEOLOGIA, 39, Salvador, SBG/Núcleo Bahia-Sergipe, 1996, V.1, p. 35-37.

ROEDDER, E. (1962) Studies of fluid inclusions I: Low temperature application of a dual-purpose freezing and heating stage. Economic Geology, 57: 1045-1061.

ROEDDER, E. (1963) Studies of fluid inclusions II: Freezing data and their interpretation. Economic Geology, 58: $167-211$

ROEDDER, B. (1984) Fluid Inilusions. Blacksburgh, Mineralogical Society of America, 644p. (Reviews in Mineralogy, 12).

ROEDDER,E. (1992) Fluid inclusions evidence for immiscibility in magmatic differentiation. Geochimica ef Cosmoctimica Acka, 56: 5-20.

ROMANINI, S. (1982) Geologia e Geoquimica do Complexo Granitóde de Massangana e sua relapara com as mineralizą̧̃es de estanbo. Salvador, 85 p. (Dissertaçào - Mestrado). Instituto de Geociências, Universidade Federal da Bahia.

RUIZ, A.S. (1992) Contribuţ̧ăo à Geologia do Distrito da Caboeirinha, MT: Sào Paulo, 98p. (Dissertaçào Mestrado). Instituto de Geociências, Universidade de Sào Paulo.

SADOWSKI, G.R. \& BET"TENCOURT', J.S. (1996) Mesoproterozoic tectonic correlations between eastern Laturentia and the western border of the Amazon craton. Precambrian Reseumb, 76: 213-227.

SAES, G.S. (1999) Evoluçäo tectónica e paelogeográfica do aulacógeno Aguatpei (1,2-1,0 Ga) e dos terrenos do seut embasatmento na porgăo sul do Cráton Amazônico. São Paulo, 134 p. (T'ese - Doutorado). Instituto de Geociências, Universidade de São Paulo.

SAES, G.S. \& FRAGOSO CESAR, A.R.S. (1996) Acresçào de ternos mesoproterozóicos no SW da Amazônia. In: CONGRESSO BRASILEIRO DE GEOLOGIA, 39, Salvador. Anais, 6: 69-71.

SAES, G.S., FRAGOSO CESAR, A.R.S., LEIT'E, J.A.D. (2002) Litocronoestratigratia da sedimetataçào mesoproterozóica do sudoeste do Cráton Amazônico. In: CONGRESSO BRASILEIRO DE GEOLOGIA, 41., João Pessoa, 15 a 20/09/02. Anuis. SBG/Núcleo Nordeste, p. 333.

SAES, G.S., LEITE, J.A.D., ALVARENGA, C.J.S. (1992) Evoluçào tectono-sedimentar do Grupo Aguapé, Proterozóico médio na porção meridional do Cráton Amazônico: Mato Grosso e oriente boliviano. Revista Brasileira de Geociennias, 23: 31-37.

SAES, G.S., LETTE, J.A.D., WESKA, R.K. (1984) Geologia da Folha Jatru (SD.21-Y.C-III): Uma Síntese dos Conhecimentos. In: CONGRESSO BRASILETRO DE GEOLOGIA, 33, Rio de Janeiro. Anais, 5: 2193.2204

SANTOS, J.O.S. (1984) A parte setentrional do cráton Amazônico (Escudo das Guianas) e a bacia Amazônica. In: Schobbenchaus, C., Campos, D.A., Derze, F.R., Asmuz, M.E. (eds.) Geologia do Brasil. Brasilia. DNPM/Mme. p. $57-88$.

SANTOS, J.O.S., MARTMANN, L.A., GAUDETTE, H.E., GROVES, D.I., MC NAUGHTON, N.J, FLETCHER, I.R. (2000) A new understanding of the provinces of the Amazon Craton based on integration of field mapping and U-Pb and Sm-Nd geochronology. Gond. Res., 3: 453-488. 
SANTOS, J.O.S. \& LOGUÉRCIO, S.O.C. (1984) A parte meridional do cráton Amazônico (Escudo BrasilCentral). In: Schobbenhaus, C., Campos, D.A., Derze, F.R, Asmuz, M.E. (eds.) Geologia do Brasil. Brasília. DNDM/MME. p. 93-127.

SANTOS, J.O.S., RIZZOT'TO, G.A., HARTMANN, L.A., MCNAUGHTON, N.J., HLETCHER, I.R. (1999a) Duas Orogêneses Principais no Sudeste do Cráton Amazônico: Evidências através de Dataçōes U.Pb em Zircão (SHRIMP). In: SIMPÓSIO DE GEOLOGIA DA AMAZONNTA, 6., Manaus, 1999. Boletim de Resumos Expandidos. Manaus, SBG/Núcleo Norte, p. 506-509.

SANTOS, J.O.S., RIZZOTTO, G.A., HARTMANN, L.A., MCNAUGHTON, N.J., FLETCHER, I.R. (1999b) Two main orogenies in the southwestern Amazon Craton: Zircon U-Pb SHRIMP evidence. In: SOUTH AMERICAN SYMPOSIUM ON ISOTOPE GEOLOGY,2, Cordoba, 1999. Atkas. Cordoba, Servicio Geologico Y Minero Argentino, p. 357.360.

SANTOS, JO.S., RIZZO'T"TO, G.A., HAR'MANN, L.A., MCNAUGHTON, N.J., FLETCHER, T.R. (2001) Ages of sedimentary basins related to the Sunsas and Juruena orogenies, southwest Amazon Caton established by zircon U.Pb geochronology. In: Bettencourt, J.S., T'eixeira, W., Pacca, I.I.G., Geraldes, M.C., Sparrenberger, I. (eds.) WORKSHOP ON GEOLOGY OF THE SW AMAZONIAN CRATON: STATE-OF-THE-ART. São Paulo, August 10 ${ }^{\text {th }}-12^{\text {th }}$, 2001. Extended Abstrat Volume p. 114. 118.

SANTOS, J.O.S, RIZZOTTO, G.A., POTTER, P.E, HARTMANN, L.A., EASTON, R.M., MeNAUgFTON, N.J. (2002) The Sunsas Orogenic Cycle in western Amazon Craton, south America and correlation to the Grenville Cycle of Laurentia, based on $\mathrm{U}_{-} \mathrm{Pb}$ isotopic study of detrital and igneous zircons. In: CONGRESSO BRASILEIRO DE GEOLOGIA, 4l., Joăo Pessoa, 15 a 20/09/02. Andis. SBG/Núcleo Nordeste, p. 335.

SATO, K. TASSINARI, C.C.G. (1997) Principais eventos de acreçào continental no Cráton Amazônico baseados em idade-modelo $\mathrm{Sm}-\mathrm{Nd}$, calculada em evoluções de estágio único e estágio duplo. In: Costa, M.L. da, Angélica, R.S. (coords.) Contribuiçōes à Geologia da Amazônia. SIMPÓSIO DE: GEOLOGLA DA AMAZÔNIA, 5., Belém, 27 de maio a 2 de junho, 1996. Panorama do Conhecimento Geológico. p. 91-142.

SCANDOI.ARA, J. (1998) Mapa Geológico do Estado de Rondönica. Residência de Porto Velho/CPRM. (Escala $1: 1.000 .000)$.

SCANDOLARA, J. (1999a) A evoluçăo proterozóica de Rondônia, principais eventos e cronologia dos movimentos tectônicos. In: SIMPÓSIO DE GEOLOGIA DA AMAZÔNIA, 6., Manaus, 1999. Boletim de Resumos Expandidos. Manaus, SBG/Núcleo Norte, p. 255-258.

SCANDOLARA, J. (1999b) Geologia e Recursos Minerais do Estado de Rondonnia: texto explicativo e mapa geológico do Estado de Rondônia. Brasília/CPRM. (Escala 1:1.000.000).

SCANDOJ.ARA, J., AMORIM, J.I. (1999) A Faixa Móvel Guaporé, sua definição e inserção no contexto geotectônico do SW do Cráton Amazônico. In: SIMPÓSIO DE GEOLOGIA DA AMAZÔNIA, 6, Manaus, 1999. Boletim de Resumos Expandidos. Manaus, SBG/Núcleo Norte, p. 278-281.

SCANDOLARA, J.E., RIZZOTTO, G.J., AMORIM, J.L., QUADROS, M.L.E.S., BAHA, R.B.C. (2001) A evolução geológica do segmento sudoeste do Cráton Amazônico - estado de Rondônia e adjacências. In: Reis, N.J., Monteiro, M.A.S. (coords.) Contribuipöes á geologia da Amazónia, volume 2. SIMPOSIO DE GEOLOGIA DA AMAZÔNICA, 6., Manaus, 13 a 17/06/99. Manaus, SBG/Núcleo Norte, p. 251 340 .

SCHWARTZ, M.O. (1992) Geochemical criteria for distinguishing magmatic and metasomatic albite-entichment in granitoids - examples from the Ta-Li granite Yichun (China) and the Sn-W Tikus (Indonesia). Mineralium Deposita, 27: 101-108. 
SELTMANN, R. FÖRSTER, H-J, GOTTESMANN, B., SALA, M., WOLF, D., STEMPROK, M. (1998) The Zinnwald greisen deposit related to post-collisional A-type silicic magmatism in the Variscan Eastert Exzgebirge/Krusné Hory. In: Breiter, K. (ed.) GENETIC SIGNIFICANCE OF PHOSPHORUS IN FRACTIONATED GRANITES. Persłák, 1998. Exumsion Guide. Prague, Czech Geological Survey, p. 33-50.

SEREBRYAKOV, V.A. (1961) Autometasomatic alteration of granitoids and association of tin mineralization with the zone of sodium-potassium metasomatism. International Geology Revien, 3(2): 100113.

SHANNON, J.R., WALKER, B.M., CARTEN, R.B., GERAGHTY, E.P. (1982) Unidirectional solidification textures and their significance in determining telative ages of intrusions at the Fenderson Mine, Colorado. Goology, 10:293-297.

SHCFIERBA, G.N. (1970a) Greisens. International Geology Revien, 12(2): 114-150.

SHCHERBA, G.N. (1970b) Greisens. International Geology Rewien, 12(3): 239-255.

SHEPPARD, S.M.F. (1986) Characterization and Isotopic Variations in Natural Waters. In: VALLEEY, J.W., TAYLOR, H.P., O'NEIL, J.R, eds. Stable Isolopes in High Temperature Geological Processes. Blacksburgh, Mineralogical Society of America, p. 165-183. (Reviews in Mineralogy, 16).

SHEPPARD, S.M.F \& GLG, H.A. (1996) Stable isotope geochemistry of clay minerals. Clay Minerals, 31: 124.

SHEPPARD, S.M.F., HARRIS, C. (1985) Hydrogen and oxygen isotope geochemistry of Ascension Ishand lavas and granites: variation with crystal fractionation and interaction with sea water. Contrib. Mineral. Petrol., 91, 74-81.

SHEPPARD, S.M.F., NIELSEN, R.L., TAYLOR, H.P., Jr. (1969) Oxygen and hydrogen isotope tatios of clay minerals from porphyry copper deposits. Eion. Geol, 64: 755-777.

SOUZA, V.S., BOTELIIO, N.F. (2002a) O sistema vulcano-plutônico estanifero de Bom Futuro (RO). In: CONGresso BRASILetro DE GEOLOGIA, 41, Joño Pessoa, 2002. Anais. SBG/Núcleo Nordeste, p. 474.

SOUZA, V.S., BOTELHO, N.F. (2002b) Geologia do depósito de estanho do Bom Futuro (Rondônia) e composição dos fluidos nos sistemas de veios e greisens. In: Klein, E.I., Vasquez, M.l., Rosa-Costa, L.'T'. (eds.) Contribuiģos à geologia da Amarôniat, volume 3. SBG/Núcleo Norte, p.199-214.

SOUZA, A.E.P. \& HILDRED, P.R. (1980) Contribuiçào ao estudo da geologia do Grupo Aguapé, Mato Grosso. In: CONGRESSO BRASILEIRO DE GEOLOGIA, 31, Balneário de Cambotiú, 1980. Anais. $\mathrm{SBG}, 2: 587-598$.

SOUZA, E.C. \& MARQUES, W.J. (1974) Granito porfiroblástico de Santo Antònio - 'Território Federal de Rondonia, Brasil. CPRM, 11 p.

SOUZA, E.C. de, MELO, A.F., ADAMY, A., SOEIRO, R.S. (1975) Projeto Noroeste de Rondônia. Relatório Final. Porto Velho, DNPM/CPRM, 1975. 12V.

SOUZA, V.S., PONTES, R.M., MOURA, M.A. (2002) Inclusōes fluidas em topázio gemológico do Complexo Granítico de Massangana (RO). In: CONGRESSO BRASILEIRO DE GEOLOGIA, 41., Joào Pessoa, 15 a 20/09/02. Anais. SBG/Núcleo Nordeste, p. 410.

SPARRENBERGER, I. \& BET'TENCOURT, J.S. (2000) The tin mineralization at the Santa Barbara Massif, Rondônia Tin Province, Brazil. In: INTERNATIONAL GEOLOGICAL CONGRESS, 31., Rio de Janeiro, 6-17 Agosto, 2000. Abstrats CD-ROM. Rio de Janeiro, IUGS/SBG/SBGf/MME/CPRM/ PETROBRAS/DNPM/ANP/ANEEL/ABC.

SPARRENBERGER, I., BETTENCOURT, J.S. (2002a) O Maciço Granítico Santa Bárbara, Província Estanífera de Rondônia - Parte I. Caracterizaçào petrográfica e geoquímica. In: CONGRESSO BRASILEIRO DE GEOLOGIA, 41. João Pesson, 15 a 20/09/02 Setembro, 2002. Anais. Joào Pesson, SBG - Núcleo Nordeste, p. 475. 
SPARRENBERGER, I., BETTENCOURT, J.S. (2002b) O Maciço Granítico Santa Bárbara, Província Estanífera de Rondônia -.. Parte II. A mineralizaçào estanífera em greisens acamados. In: CONGRESSO BRASILETrO DE GEOLOGIA, 41., João Pessoa, 15 a 20/09/02. Anats. Joào Pessoa, SBG - Núcleo Nordeste, p. 475.

SPARRENBERGER, I., BETTENCOURT, J.S., TOSDAL, R.M., WOODEN, J.I. (2002c) Dataçoes U-Pb convencional versus SHIRTMP do maciço estanífero Santa Bárbara, Suíte Granitos últimos de Rondônia, Brasil. Geologia USP, Série Cientifica, 2: 79..94.

STEIGER, R.H. \& JÄGER, E. (1977) Subcommission on geochronology: Convention on the use of decay constants in geo- and costnochronology. Earth and Planettary Science Letters, 36(3): 359-362.

STEMPROK, M. (1987) Greisenization (a review). Geologische Rundschau, 76(1): 169-175.

STONE, M., EXI.EY, C.S., GEORGE, M.C. (1988) Compositions of trioctahedral micas in the Cornubian batholith. Mineralogical Magazine, 52: 175-192.

STYYES, M.T. \& YOUNG, B.R. (1983) Fluocerite and its alteration products from the Afu Hills, Nigeria. Mineralogical Magazine, 47(1): $41-46$.

SUZUOKI, T., EPSTEIN, S. (1976) Hydrogen isotope fractionation between OF-bearing minerals and water. Geochim. Cosmochim. Acta, 40: 1229-1240.

TASSINARI, C.C.G. (1996) O mapa geocronológico do cráton Amazônico no Brasil: revisão dos dados isotópicos. (Tese Livre Docência) - Instituto de Geociências, Universidade de São Paulo.

'TASSINARI, C.C.G., BETTENCOURT, J.S., GERALDES, M.C., MACAMBIRA, M.J.B., LAFON, J.M. (2000) The Amazonian Craton. In: U.G. Cordani, E.J. Milani, A. Thomaz Filho, D.A. Campos (eds.) Tectonic Evolution of South America. Rio de Janciro, 31st International Geological Congress, p. 41-95.

'TASSINARI, C.C.G., CORDANI, U.G., CORREIA, C.T., NUTMAN, A., KINNY, P., MARINS, C., DIAS NETO, C.M. (1999) Dating of granulites by SHIRIMP U-Pb systematics in Brazil: constraints for the age of the metamorphism of proterozoic orogenies. In: SOUTH AMERICAN SYMPOSIUM ON ISOTOPE GEOLOGY, 2, Cordoba, Attes, p. 371-373.

TAASSINARI, C.C.G., CORDANI, U.G., NUTMAN, A.P., VAN SCHMUS, W.R., BETTENCOURT, J.S., TAYLOR, P.N. (1996) Geochronological Systematics on Basement Rocks from the Rio Negro-Juruena Province (Amazonian Craton) and Tectonic Implications. International Geology Reyiezw, 38(2): 161-175.

TASSINARI, C.C.G., GERALDES, M.C., TEIXEIRA, W., NUTMAN, A.P. (2001) U/pto (conventional and SHRIMP) and Sm-Nd constraints on granitoids from westernmost sector of Mato Grosso State, SW Amazonian Carton: a probable extension of the Paragua Terrane of Bolivia into the Brazilian territory. In: Bettencourt, J.S., 'Teixeira, W., Pacca, I.I.G., Geraldes, M.C., Sparrenberger, I. (eds.) Geology of the SW Amazonian Craton: State-of-the-art. Igc-USP/IGCP 426, Extended Abstracts, p. 171175.

TASSINARI, C.C.G. \& MACAMBIRA, M.J.B. (1999) Geochtonological Provinces of the Amazonian Craton. Episodes, 22(3): 174-182.

TASSINARI, C.C.G., SIGA JÚNIOR, O., TEIXEIRA, W. (1984) Épocas metalogenćticas relacionadas à gratitogênese do Cráton Amazônico. In: CONGRESSO BRASILEIRO DE GEOLOGIA, 33, 1984, Rio de Janciro, Anais. Rio de Janeiro, SBG, 1984, p. 2963-2977.

TAYLOR, B.E. (1986) Magmatic Volatiles: Isotopic Variation of C, H, and S. In: VALLEEY, J.W., TAYLOR, H.P., O'NEI, J.R, eds. Stable Lsotopes in High Temperature Geologizal Processes. Blacksburgh, Mineralogical Society of Ametica, p. 185-225. (Reviews in Mineralogy, 16).

TAYLOR, B.E., EICHELBERGER, J.C., WESTRICH, H.R. (1983) Hydrogen isotopic evidence of thyolitic magma degassing during shallow intrusion and eruption. Nature, 306: 541-545.

TAYLOR, H.P., Jr. (1974) The application of oxygen and hydrogen isotope studies to problems of hydrothermal alteration and ore deposition. Econ. Geol, 69: 843-883. 
TAYLOR, H.P., Jr. (1979) Oxygen and hydrogen isotope relationships in hydrothermal mineral deposits. In: BARNES, H.L., ed. Geochemistry of Hydrothermat Ore Deposits, 2 ed. New York, J. Wiley and Sons, p. 236277.

TAYIOR, H.P., Jr., EPSTEIN, S. (1962) Relationship between ${ }^{18} \mathrm{O} / 16 \mathrm{O}$ ratios in coexisting minerals of igneous and metamorphic tocks, Part I. Geol. Soc. Am. Bull., 73: 461-480.

TAYLOR, H.P., Jr., FORESTER, R.W. (1971) Low ${ }^{18}$ O igneous rocks from the intrusive complexes of Skye, Mull and Ardnatmurchan, Western Scotland. J. Petrol, 12: 465-497.

TAYLOR, H.P., Jr., FORESTER, R.W. (1979) An oxygen and hydrogen isotope study of the Skacrgard intrusion and its country rock: a description of a 55-MY old fossil hydrothermal system. J. Petrol., 20: $355-419$.

TAYLOR, H.P., Jr., SHEPPARD, S.M.F. (1986) lgneous Rocks: I. Processes of Isotopic Fractionation and Isotope Systematics. In: VALLEY, J.W., TAYLOR, H.P., O'NEIL, J.R, eds. Stable Isotopes in High Temperature Geological Processes. Blacksburgh, Mineralogical Society of America, p. 227.271. (Reviews in Minesalogy, 16).

TAYLOR, R.G. \& POLLARD, P.J. (1988) Pervasive hydtothermal alteration in tin-bearing granites and implications for the evolution of ore-beating magmatic fluids. In: R.P. TAYLOR \& D.F. STRONG (eds.) Recent Advancer in the Geology of Granite-Related Mineral Deposits. Montréal, Canadian Institute of Mining and Metallurgy (Special Volume 39).

TAYLOR, R.P. (1992) The petrological and geochemical characteristics of the Pleasant Ridge zinnwalditetopaz graaniote, southera New Brunswick, and comparisons with other topaz-bearing felsic rocks. Canadian Mineralogiti, 30: 895-921.

TAYLOR, R.P. \& FALI.ICK, A.E. (1997) The evolution of fluorine-rich felsic magmas: source dichotomy, magmatic convergence and the origins of topaz granite. Terra Nona, 9: 105-108.

TEIXEIRA, W. \& TASSINARI, C.C.G. (1984) Caracterização geocronológica da província Rondoniana e suas implicaçòes geotectônicas. In: SYMPOSUM AMAZONICO, 2, Manaus, 1984. Lhas. Manaus, DNPM/MNE, p. 87-91.

TETXEIRA, W., TASSINARI, C.C.G., CORDANI, U.G., KAWASHTTA, K. (1989) A review of the geochronology of the Amazonian craton: tectonic implications. Precambrian Research, 42: 213-227.

TINDIE, A.G \& WEBB, P.C. (1990) Estimation of lithium contents in trioctahedral micas using tmicroprobe data: application to micas from granitic rocks. Eur. J. Mineral., 2: 595-610.

TISCHENDORF, G., FÖRSTER, H-J., GOTIESMANN, B. (1999) The correlation between lithium and magnesium in trioctahedral micas: Improved equations for $\mathrm{Li}_{2} \mathrm{O}$ estimation from $\mathrm{MgO}$ data. Mineralogical Maguzine, 63(1): 57-74.

TTSCHENDORF, G., GOTTESMANN, B., FÖRSTER, H-J., TRUMBULLL, R.B. (1997) On Li-bearing micas: estimating $\mathrm{Li}$ from electron microprobe analyses and an improved diagram for graphical representation. Mineralogical Magazine, 61: 809-834.

TOFIER, E., VAN DER PLUTJM, B.A., SCANDOLARA, J. GERAL.DES, M.C. (2000) Rodinia and the Amazonia-Laurentia connection: preliminary D.P.t results in western Brazil. In: GSA Annual Meeting. Denver. Abstract Volume.

TOHVER, E, VAN DER PLUUJM, B., SCANDOLARA, J., RIZZOT'O, GJ. (2001) A reassessment of the tectonics and paleogeography of the Grenwille-aged Sunsas-Aguapeí Belt, SW Amazon Craton: new paleomagnetic and ${ }^{40} \mathrm{Ar} /{ }^{39} \mathrm{Ar}$ data. In: Bettencourt, J.S., Teixeira, W., Pacca, I.I.G., Geraldes, M.C., Spartenberger, 1. (eds.) WORKSHOP ON GEOLOGY OF THE SW AMAZONIAN CRATON: STATE-OF-THE-ART. São Paulo, August 10 $0^{\mathrm{h}}$-12 $2^{\mathrm{h}}$, 2001. Extended Abstrat Volume. p. 151-154. 
TOSDAL, R.M., BETTENCOURT, J.S., LEITE JÚNIOR, W.B., PAYOLLA, B.L. (1995) Pb isotopic compositions from Middle Proterozoic Rondonian rapakivi massifs, southwestern matgin of the Amazon Craton, Brazil. In: SYMPOSIUM ON RAPAKIVI GRANITES AND RELATED ROCKS, 6., Belém, 1995. Abstrats. Belém, UFPA, p. 73-74.

TOSDAL, R.M., BETTENCOURT, J.S, LEITE JÚNIOR, W.B., PAYOLLA, B.L. (1996) U-Pb geochronologic framework of the mesoproterozoic rapakivi granites of the Rondonia Tin Province, Brazil. In: CONGRESSO BRASILEIRO DE GEOLOGIA, 39, 1996, Salvador, Anuis. Salvador, SBG/Núcleo Bahia-Sergipe, 1996, V. 6, p. 591-593.

TRUESDELL, A.H., WHITE, D.E. (1973) Production of superheated steam from vapor-dominated geothermal reservoirs. Geothermics, 2: 154-173.

TUTTLE, O.F. \& BOWEN, N.L. (1958) Origin of granite in the light of experimental studies in the system $\mathrm{NaAlSi}_{3} \mathrm{O}_{8}-\mathrm{KAISi}_{3} \mathrm{O}_{8}-\mathrm{SiO}_{2}-\mathrm{H}_{2} \mathrm{O}$. Geological Society of America Memoir, 74: 153.

VALLEY, J.W. (2001) Stable Isotope Thermometry at High Temperatures. In: Valley, J.W. \& Cole, D.R. (eds.) Stable Isotope Geochemistry. Blacksburg, Mineralogical Society of America. p. 365-413. (Reviews in Mineralogy and Geochemistry, 43).

VAN DEN KERKHOF, A.M. \& HEIN, U. (2001) Fluid inclusion petrography. Lithos, 55(1-4): 27-47.

VAN DER PLAS, L., TOBI, A.C. (1965) A chart for judging the reliability of point counting results. American Journal of Science, 263(1): 87-90.

VAN SCHMUS, W.R., GERALDES, M.C., KOZUCH, M., FETTER, A.H., TASSINARI, C.C.G., TEIXEIRA, W. (1998) $\mathrm{U} / \mathrm{Pb}$ and $\mathrm{Sm} / \mathrm{Nd}$ constraints on the age and origin of proterozoic crust in southwestern Mato Grosso, Brazil: Evidence for a $1450 \mathrm{Ma}$ magmatic arc in SW Amazonia. In: INTERNATIONAL SYMPOSIUM ON TECTONICS, no.?, Ouro Preto, 1998. Abstrat Volume. Ouro Preto, editora?, p. 121-125.

VAN SCHMUS, W.R., GERALDES, M.C., KOZUCH, M. FETTER, A.H., TASSINARI, C.C.G., TEIXEIRA, W. (1999) Jauru Terrane: A late Paleoproterozoic orogen in SW Amazon craton, Mato Grosso State, Brazil. In: EUROPEAN UNION GEOLOGY BIANNUAL MEETING, Streisburg. Abstrat Volume. Streisbutg, p. 56.

VENEZIANI, P., OKIDA, R., BETTENCOURT', J.S. (2001a) Movimentos tectônicos ao longo das principais linhas de fraquezas crustais na Província Estanifera de Rondônia (PER) e sua implicaçâo no alojamento dos maciços graníticos. In: Bettencourt, J.S., Teixeira, W., Pacca, I.I.G., Geraldes, M.C., Spartenberger, I. (eds.) WORKSHOP ON GEOLOGY OF THE SW AMAZONIAN CRATON: STATE-OF-THE-ART. Sào Paulo, August 10th-12th , 2001. Extended Abstract Volume. p. 105-109.

VENEZIANI,P., OKIDA, R., BETTENCOUR'T, J.S. (200tb) Controles Estruturais no Alojamento dos Granitos Estaníferos de Rondônia. In: SIMPÓSIO DE GEOLOGIA DA AMAZÔNIA, 7., 2001. Anair CD-ROM. SBG/Núcleo Norte.

VILL.ANOVA, M.T. \& FRANKE, N.D. (1995) Serra do Bom Futuro Rondônia: a Volcanic-breccia pipehosted tin mineralization. In: SYMPOSIUM ON RAPAKIVI GRANITES AND REIAATED ROCKS, 6., Belém, 1995. Abstracts. Belém, UFp A, p. 78-79.

VORMA, A. (1976) On the petrochemistry of rapakivi granites with special reference to the Laitila massif, southwestern Finland. Geological Survey of Finland Bulletin, 285, 98p.

WAGHORN, J.G. (1974) The geology of Rondonia (western Brazil), with special reference to the din-bearing complexes and placer deposits. Londres, 293p. (T'ese - Doutorado) - Faculty of Science, University of London.

WHALEN, J.B., CURRIE, KL., CHAPPELI, B.W. (1987) A-type granites: geochemical characteristics, discrimination and petrogenesis. Contributions to Mineralogy and Petrology, 95(4): 407 419.

WHITE, D.E, MUFFEER, L.J.P., TRUESDELL, A.H. (1971) Vapor-dominated hydrothermal systems compared with hot water systems. Econ. Geol., 66:75-97. 
WILCOX, R.E. (1984) Optical Properties of micas under the polarizing microscope. In: Bailey, S.W. ed. Micas. Blacksburg, Mineralogical Society of America, p. 183-200. (Reviews in Mineralogy, 13).

WILKINSON, J.). (2001) Fluid inclusions in hydrothermal ore deposits. Lithos, 55(1-4): 229-272.

WINCHELL, A.N. (1942) Further studies of the lepidolite sysytem. American Mineratogist, 27: 114-130.

YOKOI, O.Y., VIGLIO, E.P., JONES, J.P., FIGUEROA, L.A. (1987) Potosi - A Primary Tín Deposit in Rondonia. In: INTERNATTONAI, SYMPOSIUM ON GRANTTES AND ASSOCIATED MINERALIZATTONS, 1., Salvador, 1987. Extended Abstrats. Salvador, 1987, Superintendencia de Geologia e Recursos Minerais, p. 241-243.

XU, K.Q., ZHU, J.C., XU, S.J. (1987) Geological environments atd geochemical differences of W, Sn, $\mathrm{Nb} / \mathrm{Ta}$-bearing granitesand their related mineral deposits in South China. Inz: INT. SYMP. IGCP PROJECT 220, Guilin (China), 1987. Abstrats. China, Nonferrous Metals Society of Chita, Research Institute of Geology for Mineral Resources, p. 194-197.

ZHANG, L-G., LIU, J-X, CHEN, Z-S, ZHOU, H-B (1994) Experimental Investigations of Oxygen Isotope Fractionation in Cassiterite and Wolframite. Economic Geology, 89: 150-157.

ZHENG, Y.F. (1991) Calculation of oxygen isotope fanctionation in metal oxides. Geoctsim. Cosmochim. Alata, 55: $2299-2307$.

ZHENG, Y-F. (1993a) Calculation of oxygen isotope fractionation in anhydrous silicate minerals. Geochim. Cosmocbim. Acta, 57: 1079-1091.

ZFENG, Y-F. (1993b) Calculation of oxygen isotope fractionation in hydroxyl-bearing silicates. Earth Planet. Sir. Lett., 120: 247-263. 
ANEXO II 


\begin{tabular}{|c|c|c|c|c|c|c|c|c|}
\hline Amostra & & $A M-3 B$ & $A M-3 B$ & AM-3B & $A M-3 B$ & $\mathrm{AM}-3 \mathrm{~B}$ & $A M-3 B$ & $A M-3 B$ \\
\hline Ponto & & 1 & 15 & 2 & 16 & 3 & 4 & 5 \\
\hline \multirow[t]{15}{*}{ Descrição } & & núcleo & borda & núcleo & borda & radiada* & radiada* & radiada* \\
\hline & $\mathrm{SiO}_{2}$ & 46,923 & 47,295 & 47,065 & 46,724 & 46,929 & 46,524 & 46,216 \\
\hline & $\mathrm{TiO}_{2}$ & 0,003 & 0,056 & 0,020 & 0,000 & 0,000 & 0,000 & 0.053 \\
\hline & $\mathrm{Al}_{2} \mathrm{O}_{3}$ & 34,434 & $\begin{array}{r}32,216 \\
\end{array}$ & 33,322 & 36,544 & 31,677 & 33,666 & 33,269 \\
\hline & FeO & 3,086 & 4,311 & 3,658 & 0,327 & 4,198 & 3,578 & 3,643 \\
\hline & $\mathrm{MnO}$ & 0,361 & 0,468 & 0,353 & 0,572 & 0,519 & 0,401 & 0,465 \\
\hline & $\mathrm{MgO}$ & 0,007 & 0,005 & 0,011 & 0,005 & 0,005 & 0,017 & 0,026 \\
\hline & $\mathrm{Li}_{2} \mathrm{O}$ & n.d. & n.d. & n.d. & n.d. & n.d. & n.d. & n.d. \\
\hline & $\mathrm{CaO}$ & 0,010 & 0,000 & 0,008 & 0,036 & 0,000 & 0,034 & 0,042 \\
\hline & $\mathrm{Na}_{2} \mathrm{O}$ & 0,133 & 0,121 & 0.122 & 0,040 & 0,110 & 0,035 & 0,079 \\
\hline & $\mathrm{K}_{2} \mathrm{O}$ & 10,873 & 10,795 & 10,489 & 10,227 & 10,758 & 10,623 & 10,359 \\
\hline & $F$ & 1,242 & 1,220 & 7,192 & 0,344 & 1,582 & 1,004 & 1,388 \\
\hline & $\mathrm{Cl}$ & 0,010 & 0,000 & 0,005 & 0,000 & 0,003 & 0,000 & 0,014 \\
\hline & TOTAL & 97,082 & 96,487 & 96,245 & 94,819 & 95,781 & 95,882 & 95,554 \\
\hline & $\mathrm{O}=\mathrm{F}, \mathrm{Cl}$ & 0,525 & 0,514 & 0,503 & 0,145 & 0,667 & 0,423 & 0,588 \\
\hline \multicolumn{2}{|c|}{ Total corrigido para $\mathrm{F}$ e $\mathrm{Cl}$} & 96,557 & 95,973 & 95,742 & 94,674 & 95,114 & 95,459 & 94,966 \\
\hline & $\mathrm{Si}$ & 6,1939 & 6,3227 & 6,2698 & 6,1939 & 6,3230 & 6,2277 & 6,2097 \\
\hline & $\mathrm{Ti}$ & 0,0003 & 0,0056 & 0,0020 & 0,0000 & 0,0000 & 0,0000 & 0,0054 \\
\hline & $\mathrm{Al}^{\mathrm{T}}$ & 5,3567 & 5,0756 & 5,2314 & 5,7091 & 5,0298 & 5,3109 & 5,2680 \\
\hline & $A I^{\mathrm{NV}}$ & 1,8061 & 1,6773 & 1,7302 & 1,8061 & 1,6770 & 1,7723 & 1,7903 \\
\hline & $\mathrm{Al}^{\mathrm{V} / \mathrm{V}}$ & 3,5506 & 3,3983 & 3,5012 & 3,9030 & 3,3528 & 3,5386 & 3,4777 \\
\hline & $\mathrm{Fe}^{2+}$ & 0,3406 & 0,4819 & 0,4075 & 0,0362 & 0,4730 & 0,4005 & 0,4093 \\
\hline & $\mathrm{Mn}$ & 0,0404 & 0,0530 & 0,0398 & 0,0642 & 0,0592 & 0,0455 & 0,0529 \\
\hline & $\mathrm{Mg}$ & 0,0014 & 0,0010 & 0,0022 & 0,0010 & 0,0010 & 0,0034 & 0,0052 \\
\hline & $\mathrm{Li}$ & n.d. & n.d. & n.d. & n.d. & n.d. & nid. & n.d. \\
\hline & $\mathrm{Ca}$ & 0,0014 & 0,0000 & 0,0011 & 0,0051 & 0,0000 & 0,0049 & 0,0060 \\
\hline & $\mathrm{Na}$ & 0,0340 & 0,0314 & 0,0315 & 0,0103 & 0,0287 & 0,0091 & 0,0206 \\
\hline & K & 1,8308 & 1,8409 & 1,7824 & 1,7293 & 1,8489 & 1,8139 & 1,7754 \\
\hline & $F$ & 0,5184 & 0,5157 & 0,5021 & 0,1442 & 0,6740 & 0,4250 & 0,5897 \\
\hline & $\mathrm{Cl}$ & 0,0022 & 0,0000 & 0,0011 & 0,0000 & 0,0007 & 0,0000 & 0,0032 \\
\hline & Total & 14,3202 & 14,3278 & 14,2710 & 13,8934 & 14,4383 & 14,2408 & 14,3454 \\
\hline & $\begin{array}{l}\text { ocupação } \\
\text { octaédrica }(Y)\end{array}$ & 3,9333 & 3,9399 & 3,9527 & 4,0045 & 3,8860 & 3,9880 & 3,9505 \\
\hline & $\begin{array}{l}\text { ocupação } \\
\text { intercamadas }(X)\end{array}$ & 1,8662 & 1,8722 & 1,8150 & 1,7447 & 1,8777 & 1,8278 & 1,8021 \\
\hline & carga intercamadas & 1,8677 & 1,8722 & 1,8162 & 1,7499 & 1,8777 & 1,8327 & 1,8081 \\
\hline & carga tetraédrica & $-1,8061$ & $-1,6773$ & $-1,7302$ & $-1,8061$ & $-1,6770$ & $-1,7723$ & $-1,7903$ \\
\hline & carga octaédrica & $-0,5822$ & $-0,7107$ & $-0,5893$ & $-0,0880$ & $-0,8753$ & $-0,4854$ & 0,6107 \\
\hline & carga das camadas & $-2,3883$ & $-2,3879$ & $-2,3194$ & $-1,8940$ & $-2,5523$ & $-2,2577$ & $-2,4010$ \\
\hline & carga total & $-0,5207$ & $-0,5157$ & $-0,5033$ & $-0,1442$ & $-0,6747$ & $-0,4250$ & $-0,5929$ \\
\hline
\end{tabular}




\begin{tabular}{|c|c|c|c|c|}
\hline Amostra & & $A M-3 B$ & $A M-3 B$ & $A M-3 B$ \\
\hline Ponto & & 7 & 8 & 9 \\
\hline \multirow[t]{15}{*}{ Descrição } & & radiada** & radiada** & radiada* \\
\hline & $\mathrm{SiO}_{2}$ & 47,248 & 46,729 & 46,499 \\
\hline & $\mathrm{TiO}_{2}$ & 0,000 & 0,016 & 0,036 \\
\hline & $\mathrm{Al}_{2} \mathrm{O}_{3}$ & 33,181 & 32,166 & 37,530 \\
\hline & $\mathrm{FeO}$ & 3,620 & 3,607 & 0,428 \\
\hline & $\mathrm{MnO}$ & 0,498 & 0,492 & 0,497 \\
\hline & $\mathrm{MgO}$ & 0,005 & 0,001 & 0,032 \\
\hline & $\mathrm{L}_{2} \mathrm{O}$ & 0,006 & 0,006 & 0,006 \\
\hline & $\mathrm{CaO}$ & 0,004 & 0,000 & 0.043 \\
\hline & $\mathrm{Na}_{2} \mathrm{O}$ & 0,104 & 0,082 & 0,053 \\
\hline & $\mathrm{K}_{2} \mathrm{O}$ & 10,578 & 10,751 & 9,882 \\
\hline & $\bar{F}$ & 1,311 & 1,370 & 0,527 \\
\hline & $\mathrm{Cl}$ & 0,000 & 0,004 & 0,013 \\
\hline & TOTAL & 96,555 & 95,224 & 95,546 \\
\hline & $\mathrm{O}=\mathrm{F}, \mathrm{Cl}$ & 0,552 & 0,578 & 0,225 \\
\hline \multicolumn{2}{|c|}{ Total corrigido para $\mathrm{F} \mathrm{e} \mathrm{Cl}=$} & 96,003 & 94,646 & 95,321 \\
\hline & $\overline{\mathrm{Si}}$ & 6,2795 & 6,3115 & 6,1085 \\
\hline & $\mathrm{Tl}$ & 0,0000 & 0,0016 & 0,0036 \\
\hline & $\mathrm{Al}^{\top}$ & 5,1971 & 5,1200 & 5,8104 \\
\hline & $\mathrm{Al}^{\mathrm{N}}$ & 1,7205 & 1,6885 & 1,8915 \\
\hline & $\mathrm{Al}^{1 / 1}$ & 3,4765 & 3,4315 & 3,9189 \\
\hline & $\mathrm{Fe}^{2+r}$ & 0,4023 & 0,4074 & 0,0470 \\
\hline & $\mathrm{Mn}$ & 0,0561 & 0,0563 & 0,0553 \\
\hline & $\overline{\mathrm{Mg}}$ & 0,0010 & 0,0002 & 0,0063 \\
\hline & $\mathrm{Li}$ & n.d. & n.d. & n.d. \\
\hline & $\mathrm{Ca}$ & 0,0006 & 0,0000 & 0,0061 \\
\hline & $\overline{\mathrm{Na}}$ & 0,0268 & 0,0215 & 0,0135 \\
\hline & $\mathrm{k}$ & 1,7933 & 1,8523 & 1,6560 \\
\hline & $\mathrm{F}$ & 0,5510 & 0,5851 & 0,2189 \\
\hline & $\overline{\mathrm{Cl}}$ & 0,0000 & 0,0009 & 0,0029 \\
\hline & Total & 14,3075 & 14,3568 & 13,9284 \\
\hline & $\begin{array}{l}\text { ocupação } \\
\text { octaédrica }(Y)\end{array}$ & 3,9359 & 3,8970 & 4,0310 \\
\hline & $\begin{array}{l}\text { ocupaçăo } \\
\text { intercamadas }(X)\end{array}$ & 1,8207 & 1,8737 & 1,6755 \\
\hline & carga intercamadas & 1,8212 & 1,8737 & 1,6816 \\
\hline & carga tetraédrica & $-1,7205$ & $-1,6885$ & $-1,8915$ \\
\hline & carga octaédrica & $-0,6517$ & 0,7713 & $-0,0119$ \\
\hline & carga das carradas & $-2,3722$ & $-2,4598$ & $-1,9034$ \\
\hline & carga total & $-0,5510$ & $-0,5860$ & $-0,2218$ \\
\hline
\end{tabular}




\begin{tabular}{|c|c|c|c|c|c|c|c|}
\hline Amostra & & AM-14B & $A M-14 B$ & $\mathrm{AM}-14 \mathrm{~B}$ & AM-14B & 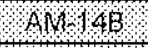 & $1 \mathrm{M} / 8 \mathrm{~B}$ \\
\hline Ponto & & 6 & 7 & 14 & 15 & 10 & 11 \\
\hline \multirow[t]{17}{*}{ Descrição } & & núcleo & borda & núcleo & borda & altorosao & alerasa \\
\hline & $\mathrm{SiO}_{2}$ & 41,177 & 41,045 & 40,941 & 40,232 & 4782 & 44660 \\
\hline & $\mathrm{TiO}_{2}$ & 0,074 & 0,000 & 0,207 & 0,099 & 0,000 & 0043 \\
\hline & $\mathrm{Al}_{2} \mathrm{O}_{3}$ & 22,720 & 23,988 & 22,609 & 23,097 & 3.439 & 3.647 \\
\hline & $\mathrm{FeO}$ & 18,309 & 18,126 & 17,551 & 17,334 & 4,030 & 8,642 \\
\hline & $\mathrm{MnO}$ & 1,288 & 1,356 & 1,224 & 1,321 & 0,52 & 0,535 \\
\hline & $\mathrm{MgO}$ & 0,029 & 0,073 & 0,065 & 0,053 & 6019 & 0,024 \\
\hline & $\mathrm{Li}_{2} \mathrm{O}$ & 0,755 & 0,755 & 0,755 & 0,755 & 0066 & 0,006 \\
\hline & $\mathrm{BaO}$ & 0,000 & 0,000 & 0,000 & 0,000 & 10 & $10 \mathrm{~d}$ \\
\hline & $\mathrm{Ca}$ & n.d. & n.d. & n.d. & n.d. & 0004 & 0,021 \\
\hline & $\mathrm{Na}_{2} \mathrm{O}$ & 0,169 & 0,074 & 0,233 & 0,151 & 004 & 0,068 \\
\hline & $\mathrm{K}_{2} \mathrm{O}$ & 9,827 & 9,768 & 9,515 & 9,513 & 10,563 & $10 \% 8$ \\
\hline & $F$ & 5,926 & 3,501 & 5,770 & 6,171 & 120 & 752, \\
\hline & $\mathrm{Cl}$ & 0,000 & 0,001 & 0,007 & 0,019 & 0,008 & 0005 \\
\hline & $\mathrm{Nb}_{2} \mathrm{O}_{5}$ & 0,000 & 0,000 & 0,002 & 0,000 & nd & 1.d \\
\hline & TOTAL & 100,274 & 98,687 & 98,879 & 98,745 & 9552 & 96130 \\
\hline & $\mathrm{O}=\mathrm{F}, \mathrm{Cl}$ & 2,495 & 1,474 & 2,431 & 2,603 & 6810 & 0642 \\
\hline \multicolumn{2}{|c|}{ Total corrigido para $\mathrm{F} \in \mathrm{Cl}=$} & 97,779 & 97,213 & 96,448 & 96,142 & 95042 & 94488 . \\
\hline & Si & 5,7925 & 5,8535 & 5,8142 & 5,7237 & 6424 & 6,0698 \\
\hline & $\mathrm{Ti}$ & 0,0078 & 0,0000 & 0,0221 & 0,0106 & 0,0000 & 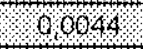 \\
\hline & $\mathrm{Al}^{\mathrm{T}}$ & 3,7666 & 4,0316 & 3,7839 & 3,8725 & 49815 & $535 \% 3$ \\
\hline & $\mathrm{Al}^{\mathrm{IV}}$ & 2,2075 & 2,1465 & 2,1858 & 2,2763 & 15878 & 19362 \\
\hline & $\mathrm{Al}^{\mathrm{VI}}$ & 1,5591 & 1,8851 & 1,5982 & 1,5961 & 3459 & 3,42 \\
\hline & $\mathrm{Fe}^{2+}$ & 2,1537 & 2,1615 & 2,0842 & 2,0621 & $0,48 \%$ & 0,5276 \\
\hline & $\mathrm{Mn}$ & 0,1534 & 0,1638 & 0,1472 & 0,1592 & 0,0515 & 0.0616 \\
\hline & $\mathrm{Mg}$ & 0,0061 & 0,0155 & 0,0138 & 0,0112 & 0.0034 & 0,0049 \\
\hline & $\mathrm{Li}$ & 0,4271 & 0,4330 & 0,4312 & 0,4319 & 0,0032 & 0,0030 \\
\hline & $\mathrm{Ba}$ & 0,0000 & 0,0000 & 0,0000 & 0,0000 & 100 & 10 \\
\hline & $\mathrm{Ca}$ & n.d. & n.d. & n.d. & n.d. & 0.0006 & 0003 \\
\hline & $\mathrm{Na}$ & 0,0461 & 0,0205 & 0,0642 & 0,0416 & $0,010 \%$ & 0,010 \\
\hline & $\bar{K}$ & 1,7634 & 1,7769 & 1,7237 & 1,7263 & 1618 & $\$ 7609$ \\
\hline & $F$ & 2,6360 & 1,5788 & 2,5911 & 2,7761 & 05132 & 0.654 \% \\
\hline & $\mathrm{Cl}$ & 0,0000 & 0,0002 & 0,0017 & 0,0046 & 80018 & 0,0012 \\
\hline & $\mathrm{Nb}$ & 0,0000 & 0,0000 & 0,0003 & 0,0000 & nd & 9.6 \\
\hline & Total & 16,7527 & 16,0354 & 16,6776 & 16,8198 & 14.255 & 14,6588 \\
\hline & $\begin{array}{l}\text { ocupação } \\
\text { octaédrica }(Y)\end{array}$ & 4,3072 & 4,6590 & 4,2970 & 4,2711 & $391 \%$ & $4028 \%$ \\
\hline & $\begin{array}{l}\text { ocupaçäo } \\
\text { intercamadas }(X)\end{array}$ & 1,8094 & 1,7974 & 1,7878 & 1,7680 & $1823 \%$ & 3810 \\
\hline & carga intercamadas & 1,8094 & 1,7974 & 1,7878 & 1.7680 & 1823712 & 17899139 \\
\hline & carga tetraédrica & $-2,2075$ & $-2,1465$ & $-2,1858$ & $-2,2763$ & 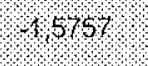 & w9300 \\
\hline & carga octaédrica & $-2,2379$ & $-1,2299$ & $-2,1939$ & $-2,2723$ & 6.7831 & 905100 \\
\hline & carga das camadas & $-4,4455$ & $-3,3764$ & $-4,3796$ & $-4,5487$ & 2,301 & $2,1,02$ \\
\hline & carga total & $-2,6360$ & $-1,5790$ & $-2,5918$ & $-2,7807$ & 0050 & 0,6553 \\
\hline
\end{tabular}




\begin{tabular}{|c|c|c|c|c|c|c|c|}
\hline Amostra & & AM-19 & $A M-19$ & $A M-19$ & $A M-19$ & $\mathrm{AM}-19$ & $A M-19$ \\
\hline Ponto & & 1 & 2 & 3 & 13 & 14 & 15 \\
\hline \multirow[t]{16}{*}{ Descrição } & & núcleo & int & borda & verde & $\begin{array}{l}\text { marrom- } \\
\text { clara }\end{array}$ & $\begin{array}{l}\text { marrom- } \\
\text { escura }\end{array}$ \\
\hline & $\mathrm{SiO}_{2}$ & 40,459 & 41,092 & 45,347 & 41,134 & 40,312 & 40,632 \\
\hline & $\mathrm{TiO}_{2}$ & 0,159 & 0,230 & 0,017 & 0,125 & 0,766 & 0,280 \\
\hline & $\mathrm{Al}_{2} \mathrm{O}_{3}$ & 23,317 & 23,278 & 27,967 & 22,663 & 22,212 & 22,799 \\
\hline & $\mathrm{FeO}$ & 19,640 & 17,376 & 11,480 & 17,671 & 18,975 & 17,860 \\
\hline & $\mathrm{MnO}$ & 1,362 & 1,618 & 1,087 & 1,341 & 1,327 & 1,632 \\
\hline & $\mathrm{MgO}$ & 0,062 & 0,058 & 0,031 & 0,064 & 0,051 & 0,043 \\
\hline & $\mathrm{Li}_{2} \mathrm{O}$ & n.d. & n.d. & n.d. & n.d. & n.d. & n.d. \\
\hline & $\mathrm{CaO}$ & 0,000 & 0,005 & 0,000 & 0,000 & 0,000 & 0,004 \\
\hline & $\mathrm{BaO}$ & 0,064 & 0,070 & 0,000 & 0,000 & 0,124 & 0,044 \\
\hline & $\mathrm{Na}_{2} \mathrm{O}$ & 0,332 & 0,205 & 0,095 & 0,290 & 0,154 & 0,165 \\
\hline & $\mathrm{K}_{2} \mathrm{O}$ & 9,289 & 9,330 & 10,044 & 9,423 & 9,175 & 9,234 \\
\hline & $F$ & 6,025 & 4,761 & 2,277 & 5,775 & 5,702 & 4,485 \\
\hline & $\mathrm{Cl}$ & 0,000 & 0,011 & 0,012 & 0,017 & 0,015 & 0,003 \\
\hline & TOTAL & 100,709 & 98,034 & 98,357 & 98,503 & 98,813 & 97,181 \\
\hline & $\mathrm{O}=\mathrm{F}, \mathrm{Cl}$ & 2,537 & 2,007 & 0,961 & 2,435 & 2,404 & 1,889 \\
\hline \multicolumn{2}{|c|}{ Total corrigido para $\mathrm{F}$ e $\mathrm{Cl}=$} & 98,172 & 96,027 & 97,396 & 96,068 & 96,409 & 95,292 \\
\hline & Si & 5,7116 & 5,8924 & 6,2014 & 5,8777 & 5,7876 & 5,8987 \\
\hline & $\mathrm{Ti}$ & 0,0169 & 0,0248 & 0,0017 & 0,0134 & 0,0827 & 0,0306 \\
\hline & $\mathrm{Al}^{\mathrm{T}}$ & 3,8792 & 3,9338 & 4,5073 & 3,8164 & 3,7582 & 3,9006 \\
\hline & $\mathrm{Al}^{\mathrm{IV}}$ & 2,2884 & 2,1076 & 1,7986 & 2,1223 & 2,2124 & 2,1013 \\
\hline & $\mathrm{Al}^{\mathrm{V}}$ & 1,5908 & 1,8262 & 2,7086 & 1,6942 & 1.5457 & 1,7993 \\
\hline & $\mathrm{Fe}^{2+}$ & 2,3184 & 2,0835 & 1,3128 & 2,1114 & 2,2780 & 2,1681 \\
\hline & $\mathrm{Mn}$ & 0,1628 & 0,1965 & 0,1259 & 0,1623 & 0,1614 & 0,2007 \\
\hline & $\mathrm{Mg}$ & 0,0130 & 0,0124 & 0,0063 & 0,0136 & 0,0109 & 0,0093 \\
\hline & $\mathrm{Li}$ & n.d. & n.d. & nid & n.d. & n.d. & n.d. \\
\hline & $\mathrm{Ca}$ & 0,0000 & 0,0008 & 0,0000 & 0,0000 & 0,0000 & 0,0006 \\
\hline & $\mathrm{Ba}$ & 0,0035 & 0,0039 & 0,0000 & 0,0000 & 0,0070 & 0,0025 \\
\hline & $\mathrm{Na}$ & 0,0909 & 0,0570 & 0,0252 & 0,0803 & 0,0429 & 0,0464 \\
\hline & $K$ & 1,6727 & 1,7066 & 1,7521 & 1,7175 & 1,6803 & 1,7100 \\
\hline & $F$ & 2,6895 & 2,1588 & 0,9846 & 2,6094 & 2,5886 & 2,0589 \\
\hline & $\mathrm{Cl}$ & 0,0000 & 0,0134 & 0,0139 & 0,0041 & 0,0182 & 0,0037 \\
\hline & Total & 16,5585 & 16,0838 & 14,9312 & 16,4063 & 16,4156 & 16,0299 \\
\hline & $\begin{array}{l}\text { octupação } \\
\text { octaédrica }(Y) \\
\end{array}$ & 4,1019 & 4,1433 & 4,1553 & 3,9949 & 4,0787 & 4,2079 \\
\hline & $\begin{array}{l}\text { ocupação } \\
\text { intercamadas }(X)\end{array}$ & 1,7671 & 1,7683 & 1,7773 & 1,7979 & 1,7301 & 1,7595 \\
\hline & $\begin{array}{l}\text { carga } \\
\text { intercamadas }\end{array}$ & 1,7706 & 1,7730 & 1,7773 & 1,7979 & 1,7371 & 1,7626 \\
\hline & carga tetraédrica & $-2,2884$ & $-2,1076$ & $-1,7986$ & $-2,1223$ & $-2,2124$ & $-2,1013$ \\
\hline & carga octaédrica & $-2,1717$ & $-1,8375$ & $-0,9772$ & $-2,2891$ & $-2,1315$ & $-1,7239$ \\
\hline & $\begin{array}{l}\text { carga das } \\
\text { camadas }\end{array}$ & $-4,4601$ & $-3,9451$ & 277758 & $-4,4114$ & $-4,3439$ & $-3,8252$ \\
\hline & carga total & $-2,6895$ & $-2,1721$ & $-0,9985$ & $-2,6135$ & $-2,6068$ & $-2,0625$ \\
\hline
\end{tabular}




\begin{tabular}{|c|c|c|c|c|c|}
\hline Amostra & & $A M-35$ & AM-35 & $A M-35$ & AM-35 \\
\hline Ponto & & 7 & 8 & 9 & 10 \\
\hline \multirow[t]{16}{*}{ Descrição } & & núcleo & borda & núcleo & borda \\
\hline & $\mathrm{SiO}_{2}$ & 40,657 & 40,152 & 46,803 & 39,926 \\
\hline & $\mathrm{TiO}_{2}$ & 0,045 & 0,035 & 0,000 & 0,054 \\
\hline & $\mathrm{Al}_{2} \mathrm{O}_{3}$ & 22,058 & 22,478 & 30,172 & 22,109 \\
\hline & $\mathrm{FeO}$ & 18,950 & 19,467 & 6,915 & 19,850 \\
\hline & $\mathrm{MnO}$ & 1,197 & 1,086 & 0,506 & 1,250 \\
\hline & $\mathrm{MgO}$ & 0,011 & 0,012 & 0,009 & 0,000 \\
\hline & $\mathrm{Li}_{2} \mathrm{O}$ & 0,504 & 0,504 & 0,006 & 0,504 \\
\hline & $\mathrm{CaO}$ & 0,000 & 0,000 & 0,000 & 0,006 \\
\hline & $\mathrm{BaO}$ & 0,000 & 0,097 & 0,092 & 0,000 \\
\hline & $\mathrm{Na}_{2} \mathrm{O}$ & 0,165 & 0,052 & 0,074 & 0,147 \\
\hline & $\mathrm{K}_{2} \mathrm{O}$ & 9,556 & 9,403 & 10,429 & 9,467 \\
\hline & $F$ & 6,717 & 4,745 & 1,935 & 4,144 \\
\hline & $\mathrm{Cl}$ & 0,029 & 0,022 & 0,012 & 0,004 \\
\hline & TOTAL & 99,889 & 98,053 & 96,953 & 97,461 \\
\hline & $\mathrm{O}=\mathrm{F}-\mathrm{Cl}$ & 2,835 & 2,003 & 0,817 & 1,746 \\
\hline \multicolumn{2}{|c|}{ Total corrigido para $\mathrm{F} \mathrm{e} \mathrm{Cl}$} & 97,054 & 96,050 & 96,136 & 95,715 \\
\hline & $\mathrm{Si}$ & 5,7610 & 5,8114 & 6,3151 & 5,8386 \\
\hline & $\mathrm{Ti}$ & 0,0048 & 0,0038 & 0,0000 & 0,0059 \\
\hline & $\overline{\mathrm{Al}^{\top}}$ & 3,6835 & 3,8341 & 4,7978 & 3,8102 \\
\hline & $\mathrm{Al}^{\mathrm{IV}}$ & 2,2390 & 2,1886 & 1,6849 & 2,1614 \\
\hline & $\mathrm{Al}^{\mathrm{V}}$ & 1,4444 & 1,6455 & 3,1129 & 1,6488 \\
\hline & $\mathrm{Fe}^{2+}$ & 2,2453 & 2,3560 & 0,7802 & 2,4273 \\
\hline & $\mathrm{Mn}$ & 0,1436 & 0,1331 & 0,0578 & 0,1548 \\
\hline & $\mathrm{Mg}$ & 0,0023 & 0,0026 & 0,0018 & 0,0000 \\
\hline & $\underline{\mathrm{Li}}$ & 0,2872 & 0,2933 & 0,0033 & 0,2964 \\
\hline & $\mathrm{Ca}$ & 0,0000 & 0,0000 & 0,0000 & 0,0009 \\
\hline & $\mathrm{Ba}$ & 0,0000 & 0,0055 & 0,0049 & 0,0000 \\
\hline & $\mathrm{Na}$ & 0,0453 & 0,0146 & 0,0194 & 0,0417 \\
\hline & $K$ & 1,7272 & 1,7360 & 1,7950 & 1,7659 \\
\hline & $F$ & 3,0096 & 2,1716 & 0,8256 & 1,9162 \\
\hline & $\mathrm{Cl}$ & 0,0348 & 0,0270 & 0,0137 & 0,0050 \\
\hline & Total & 16,9446 & 16,3890 & 14,6145 & 16,2629 \\
\hline & $\begin{array}{l}\text { ocupação } \\
\text { octaédrica }(Y)\end{array}$ & 4,1276 & 4,4343 & 3,9560 & 4,5332 \\
\hline & $\begin{array}{l}\text { ocupação } \\
\text { intercamadas }(X)\end{array}$ & 1,7725 & 1,7561 & 1,8192 & 1,8085 \\
\hline & $\begin{array}{l}\text { carga } \\
\text { intercamadas }\end{array}$ & 1,7725 & 1,7616 & 1,8241 & 1,8095 \\
\hline & carga tetraédrica & $-2,2390$ & $-2,1886$ & $-1,6849$ & $-2,1614$ \\
\hline & carga octaédrica & $-2,5779$ & $-1,7716$ & 0,9785 & $-1,5693$ \\
\hline & $\begin{array}{l}\text { carga das } \\
\text { camadas }\end{array}$ & $-4,8170$ & $-3,9602$ & $-2,6634$ & $-3,7307$ \\
\hline & carga total & $-3,0444$ & $-2,1986$ & $-0,8393$ & $-1,9212$ \\
\hline
\end{tabular}




\begin{tabular}{|c|c|c|c|c|c|}
\hline Amostra & & $\mathrm{AM}-41 \mathrm{~B}$ & AM-41B & AM-41B & AM- 418 \\
\hline Ponto & & 14 & 15 & 27 & 28 \\
\hline \multirow[t]{15}{*}{ Descriçäo } & & núcleo & borda & núcleo & borda \\
\hline & $\mathrm{SiO}_{2}$ & 40,046 & 39,618 & 40,019 & 39,835 \\
\hline & $\mathrm{TiO}_{2}$ & 0,037 & 0,027 & 0,000 & 0,020 \\
\hline & $\mathrm{Al}_{2} \mathrm{O}_{3}$ & 20,982 & 21,175 & 21,283 & 21,079 \\
\hline & $\mathrm{FeO}$ & 21,425 & 22,145 & 20,607 & 21,376 \\
\hline & $\mathrm{MnO}$ & 0,890 & 0,853 & 0,837 & 0,846 \\
\hline & $\mathrm{MgO}$ & 0,016 & 0,014 & 0,007 & $0,0 \uparrow 7$ \\
\hline & $\mathrm{Li}_{2} \mathrm{O}$ & 0,693 & 0,693 & 0,693 & 0,693 \\
\hline & $\mathrm{CaO}$ & 0,000 & 0,000 & 0,000 & 0,000 \\
\hline & $\mathrm{Na}_{2} \mathrm{O}$ & 0,227 & 0,230 & 0,242 & 0,231 \\
\hline & $\mathrm{K}_{2} \mathrm{O}$ & 9,720 & 9.577 & 9,682 & 9,480 \\
\hline & $\mathrm{F}$ & 5,378 & 5,202 & 5,868 & 5,836 \\
\hline & $\mathrm{Cl}$ & 0,015 & 0,064 & 0,018 & 0,021 \\
\hline & TOTAL & 99,429 & 99,598 & 99,256 & 99,434 \\
\hline & $\mathrm{O}=\mathrm{F}-\mathrm{Cl}$ & 2,268 & 2,205 & 2,475 & 2,462 \\
\hline \multirow[t]{23}{*}{ Total corrigido } & para $\mathrm{Fe} \mathrm{Cl}$ & 97,161 & 97,393 & 96,781 & 96,972 \\
\hline & $\mathrm{Si}$ & 5,7843 & 5,7270 & 5,7631 & 5,7445 \\
\hline & $\mathrm{Ti}$ & 0,0040 & 0,0029 & 0,0000 & 0,0022 \\
\hline & $\mathrm{Al}^{\mathrm{T}}$ & 3,5717 & 3,6074 & 3,6120 & 3,5823 \\
\hline & $\mathrm{Al}^{\mathrm{iV}}$ & 2,2157 & 2,2730 & 2,2369 & 2,2555 \\
\hline & $\mathrm{Al}^{\mathrm{Vl}}$ & 1,3560 & 1,3344 & 1,3751 & 1,3268 \\
\hline & $\mathrm{Fe}^{2+}$ & 2,5877 & 2,6768 & 2,4815 & 2,5776 \\
\hline & $\mathrm{Mn}$ & 0,1089 & 0,1044 & 0,1021 & 0,1033 \\
\hline & $\mathrm{Mg}$ & 0,0034 & 0,0030 & 0,0015 & 0,0037 \\
\hline & $\underline{\mathrm{Li}}$ & 0,4025 & 0,4029 & 0,4013 & 0,4019 \\
\hline & $\mathrm{Ca}$ & 0,0000 & 0,0000 & 0,0000 & 0,0000 \\
\hline & $\mathrm{Na}$ & 0,0636 & 0,0645 & 0,0676 & 0,0646 \\
\hline & $K$ & 1,7909 & 1,7659 & 1,7785 & 1,7438 \\
\hline & $F$ & 2,4563 & 2,3778 & 2,6721 & 2,6612 \\
\hline & $\mathrm{Cl}$ & 0,0184 & 0,0784 & 0,0220 & 0,0257 \\
\hline & Total & 16,7917 & 16,8111 & 16,9017 & 16,9107 \\
\hline & $\begin{array}{l}\text { ocupação } \\
\text { octaédrica }(Y)\end{array}$ & 4,4625 & 4,5244 & 4,3615 & 4,4155 \\
\hline & $\begin{array}{l}\text { ocupação } \\
\text { intercamadas }(X)\end{array}$ & 1.8544 & 1,8304 & 1,8461 & 1.8084 \\
\hline & $\begin{array}{l}\text { carga } \\
\text { intercamadas }\end{array}$ & 1,8544 & 1,8304 & 1,8461 & 1,8084 \\
\hline & carga tetraédrica & $-2,2157$ & $-2,2730$ & $-2,2369$ & $-2,2555$ \\
\hline & carga octaédrica & $-2,1135$ & $-2,0137$ & $-2,3033$ & $-2,2398$ \\
\hline & $\begin{array}{l}\text { carga das } \\
\text { camadas }\end{array}$ & $-4,3292$ & $-4,2866$ & $-4,5402$ & $-4,4953$ \\
\hline & carga total & $-2,4747$ & $-2,4562$ & $-2,6941$ & $-2,6869$ \\
\hline
\end{tabular}




\begin{tabular}{|c|c|c|c|c|c|}
\hline Amostra & & $\mathrm{AM}-52 \mathrm{Ba}$ & $\mathrm{AM}-52 \mathrm{Ba}$ & $A M-528 a$ & $\mathrm{AM}-52 \mathrm{Ba}$ \\
\hline Ponto & & 16 & 17 & 20 & 21 \\
\hline \multirow[t]{16}{*}{ Descrição } & & núcleo & borda & núcleo & borda \\
\hline & $\mathrm{SiO}_{2}$ & 34,713 & 35,457 & 34,932 & 35,767 \\
\hline & $\mathrm{TiO}_{2}$ & 2,597 & 2,875 & 2,810 & 2,926 \\
\hline & $\mathrm{Al}_{2} \mathrm{O}_{3}$ & 20,643 & 20,725 & 19,694 & 21,059 \\
\hline & $\mathrm{FeO}$ & 27,784 & 26,918 & 28,360 & 26,016 \\
\hline & $\mathrm{MnO}$ & 0,370 & 0,330 & 0,335 & 0,362 \\
\hline & $\mathrm{MgO}$ & 1,493 & 1,457 & 1,422 & 1,227 \\
\hline & $\mathrm{Li}_{2} \mathrm{O}$ & 0,084 & 0,084 & 0,084 & 0,084 \\
\hline & $\mathrm{BaO}$ & 0,022 & 0,087 & 0,075 & 0,022 \\
\hline & $\mathrm{Na}_{2} \mathrm{O}$ & 0,097 & 0,105 & 0.145 & 0,138 \\
\hline & $\mathrm{K}_{2} \mathrm{O}$ & 9,084 & 9,331 & 9,331 & 9,593 \\
\hline & $\mathrm{F}$ & 2,405 & 1,947 & 1,990 & 1,597 \\
\hline & $\mathrm{Cl}$ & 0,324 & 0,325 & 0,362 & 0,343 \\
\hline & $\mathrm{Nb}_{2} \mathrm{O}_{5}$ & 0,061 & 0,091 & 0,067 & 0,072 \\
\hline & TOTAL. & 99,677 & 99,732 & 99,607 & 99,206 \\
\hline & $\mathrm{O}=\mathrm{F}, \mathrm{Cl}$ & 1,086 & 0,893 & 0,920 & 0,750 \\
\hline \multicolumn{2}{|c|}{ Total corrigido para $\mathrm{F}$ e Cl } & 98,591 & 98,839 & 98,687 & 98,456 \\
\hline & $\mathrm{Si}$ & 5,2376 & 5,3229 & 5,3058 & 5,3756 \\
\hline & $T$ & 0,2947 & 0,3246 & 0,3210 & 0,3308 \\
\hline & $\mathrm{Al}^{\top}$ & 3,6707 & 3,6666 & 3,5253 & 3,7300 \\
\hline & $\mathrm{Al}^{\mathrm{IV}}$ & 2,7624 & 2,6771 & 2,6942 & 2,6244 \\
\hline & $\mathrm{Al}^{\mathrm{VI}}$ & 0,9083 & 0,9895 & 0,8311 & 1,1056 \\
\hline & $\mathrm{Fe}^{2+}$ & 3,5054 & 3,3790 & 3,6020 & 3,2695 \\
\hline & $\mathrm{Mn}$ & 0,0473 & 0,0420 & 0,0431 & 0,0461 \\
\hline & $\mathrm{Mg}$ & 0,3358 & 0,3261 & 0,3220 & 0,2749 \\
\hline & $\mathrm{Li}$ & 0,0510 & 0,0507 & 0,0513 & 0,0508 \\
\hline & $\mathrm{Ba}$ & 0,0013 & 0,0051 & 0,0045 & 0,0013 \\
\hline & $\mathrm{Na}$ & 0,0142 & 0,0153 & 0,0213 & 0,0201 \\
\hline & $\mathrm{K}$ & 1,7484 & 1,7868 & 1,8079 & 1,8391 \\
\hline & $F$ & 1,1475 & 0,9242 & 0,9558 & 0,7590 \\
\hline & $\mathrm{Cl}$ & 0,0829 & 0,0827 & 0,0932 & 0,0874 \\
\hline & $\mathrm{Nb}$ & 0,0104 & 0,0154 & 0,0115 & 0,0122 \\
\hline & Total & 16,1471 & 15,9414 & 16,0646 & 15,7968 \\
\hline & $\begin{array}{l}\text { ocupação } \\
\text { octaedrica }(Y)\end{array}$ & 5,1426 & 5,1119 & 5,1705 & 5,0777 \\
\hline & $\begin{array}{l}\text { ocupação } \\
\text { intercamadas }(X)\end{array}$ & 1,7638 & 1,8072 & 1,8337 & 1,8605 \\
\hline & $\begin{array}{l}\text { carga } \\
\text { intercamadas }\end{array}$ & 1,7651 & 1,8123 & 1,8381 & 1,8618 \\
\hline & carga tetraédrica & -2.7624 & $-2,6771$ & $-2,6942$ & $-2,6244$ \\
\hline & carga octaédrica & $-0,2681$ & $-0,1883$ & $-0,2373$ & $-0,1283$ \\
\hline & $\begin{array}{l}\text { carga das } \\
\text { camadas }\end{array}$ & $-3,0304$ & $-2,8654$ & $-2,9315$ & $-2,7527$ \\
\hline & carga total & $-1,2653$ & $-1,0531$ & $-1,0933$ & $-0,8909$ \\
\hline
\end{tabular}




\begin{tabular}{|c|c|c|c|c|c|}
\hline Amostra & & AM-53Ba & $\mathrm{AM}-53 \mathrm{Ba}$ & $\mathrm{AM}-53 \mathrm{Ba}$ & AM-53Ba \\
\hline Ponto & & 6 & 7 & 8 & 23 \\
\hline \multirow[t]{16}{*}{ Descrição } & & $\begin{array}{c}\text { mica } \\
\text { primária }\end{array}$ & mica sec. & mica sec. & $\begin{array}{c}\text { mica } \\
\text { primária }\end{array}$ \\
\hline & $\underline{\mathrm{SiO}_{2}}$ & 38,035 & 39,060 & 37,180 & 39,736 \\
\hline & $\mathrm{TiO}_{2}$ & 0,535 & 0,234 & 0,224 & 0,709 \\
\hline & $\mathrm{Al}_{2} \mathrm{O}_{3}$ & 19,795 & 21,259 & 19,674 & 21,684 \\
\hline & $\mathrm{FeO}$ & 25,318 & 21,729 & 24,476 & 19,906 \\
\hline & $\mathrm{MnO}$ & 0,925 & 1,361 & 1.564 & 0,910 \\
\hline & $\mathrm{MgO}$ & 0,338 & 0,287 & 0,300 & 0,300 \\
\hline & $\mathrm{Li}_{2} \mathrm{O}$ & 0,279 & 0,279 & 0,279 & 0,279 \\
\hline & $\mathrm{BaO}$ & 0,209 & 0,103 & 0,000 & 0,038 \\
\hline & $\mathrm{Na}_{2} \mathrm{O}$ & 0,121 & 0,116 & 0,084 & 0,083 \\
\hline & $\mathrm{K}_{2} \mathrm{O}$ & 9,340 & 9,381 & 9,103 & 9,344 \\
\hline & $\mathrm{F}$ & 5,052 & 4,343 & 4,561 & 4,420 \\
\hline & $\mathrm{Cl}$ & 0,036 & 0,024 & 0,046 & 0,017 \\
\hline & $\mathrm{Nb}_{2} \mathrm{O}_{5}$ & 0,028 & 0,017 & 0,001 & 0,000 \\
\hline & TOTAL & 100,011 & 98,193 & 97,492 & 97,426 \\
\hline & $\mathrm{O}=\mathrm{F}, \mathrm{Cl}$ & 2,135 & 1,834 & 1,931 & 1,865 \\
\hline \multicolumn{2}{|c|}{ Total corrigido para $\mathrm{F} \mathrm{e} \mathrm{Cl}$} & 97,876 & 96,359 & 95,561 & 95,561 \\
\hline & $\mathrm{Si}$ & 5,6124 & 5,7516 & 5,6251 & 5,8143 \\
\hline & $\mathrm{Ti}$ & 0,0594 & 0,0259 & 0,0255 & 0,0780 \\
\hline & $\mathrm{Al}^{\mathrm{T}}$ & 3,4423 & 3,6892 & 3,5078 & 3,7392 \\
\hline & $\mathrm{Al}^{\mathrm{IV}}$ & 2,3876 & 2,2484 & 2,3749 & 2,1857 \\
\hline & $\mathrm{Al}^{\mathrm{VI}}$ & 1,0548 & 1,4408 & 1,1329 & 1,5535 \\
\hline & $\mathrm{Fe}^{2+}$ & 3,1239 & 2,6755 & 3,0964 & 2,4356 \\
\hline & $\mathrm{Mn}$ & 0,1156 & 0,1697 & 0,2004 & 0,1128 \\
\hline & $\mathrm{Mg}$ & 0,0744 & 0,0630 & 0,0677 & 0,0654 \\
\hline & $\mathrm{Li}$ & 0,1656 & 0,1652 & 0,1697 & 0,1642 \\
\hline & $\mathrm{Ba}$ & 0,0121 & 0,0059 & 0,0000 & 0,0022 \\
\hline & $\mathrm{Na}$ & 0,0173 & 0,0166 & 0,0123 & 0,0118 \\
\hline & $K$ & 1,7580 & 1,7620 & 1,7568 & 1,7440 \\
\hline & $F$ & 2,3573 & 2,0222 & 2,1820 & 2,0451 \\
\hline & $\mathrm{Cl}$ & 0,0090 & 0,0060 & 0,0118 & 0,0042 \\
\hline & $\mathrm{Nb}$ & 0,0047 & 0,0028 & 0,0002 & 0,0000 \\
\hline & Total & 16,7519 & 16,3556 & 16,6557 & 16,2168 \\
\hline & $\begin{array}{l}\text { ocupação } \\
\text { octaédrica }(Y)\end{array}$ & 4,5936 & 4,5401 & 4,6926 & 4,4095 \\
\hline & $\begin{array}{l}\text { ocupação } \\
\text { intercamadas (X) }\end{array}$ & 1,7874 & 1,7845 & 1,7691 & 1.7580 \\
\hline & $\begin{array}{l}\text { carga } \\
\text { intercamadas }\end{array}$ & 1,7995 & 1,7905 & 1,7691 & 1,7602 \\
\hline & carga tetraédrica & $-2,3876$ & $-2,2484$ & $-2,3749$ & $-2,1857$ \\
\hline & carga octaédrica & $-1,8048$ & $-1,5925$ & $-1,6006$ & $-1,6355$ \\
\hline & $\begin{array}{l}\text { carga das } \\
\text { camadas }\end{array}$ & $-4,1924$ & $-3,8409$ & $-3,9755$ & $-3,8212$ \\
\hline & carga total & $-2,3929$ & $-2,0504$ & $-2,2065$ & $-2,0611$ \\
\hline
\end{tabular}




\begin{tabular}{|c|c|c|c|c|c|}
\hline Amostra & & AM-89 & AM-89 & AM-89 & AM-89 \\
\hline Ponto & & 9 & 15 & 12 & 16 \\
\hline \multirow[t]{15}{*}{ Descrição } & & núcleo & borda & núcleo & borda \\
\hline & $\mathrm{SiO}_{2}$ & 46,136 & 46,242 & 46,433 & 45,224 \\
\hline & $\mathrm{TiO}_{2}$ & 0,000 & 0,000 & 0,000 & 0,000 \\
\hline & $\mathrm{Al}_{2} \mathrm{O}_{3}$ & 33,096 & 33,247 & 31,652 & 31,166 \\
\hline & $\mathrm{FeO}$ & 3,091 & 2,667 & 4,314 & 3,875 \\
\hline & Mno & 0,629 & 0.547 & 0,515 & 0,811 \\
\hline & $\mathrm{MgO}$ & 0,026 & 0,010 & 0,000 & 0,011 \\
\hline & $\mathrm{Li}_{2} \mathrm{O}$ & 0,007 & 0,007 & 0,007 & 0,007 \\
\hline & $\mathrm{CaO}$ & 0,014 & 0,008 & 0,000 & 0,000 \\
\hline & $\mathrm{Na}_{2} \mathrm{O}$ & 0,089 & 0,105 & 0,097 & 0,112 \\
\hline & $\mathrm{K}_{2} \mathrm{O}$ & 10,416 & 10,347 & 10,523 & 10,789 \\
\hline & $\mathrm{F}$ & 0,981 & 0,831 & 1,164 & 0,888 \\
\hline & $\mathrm{Cl}$ & 0,004 & 0,000 & 0,000 & 0,004 \\
\hline & TOTAL & 94,489 & 94,011 & 94,705 & 92,887 \\
\hline & $\mathrm{O}=\mathrm{F}, \mathrm{Cl}$ & 0,414 & 0,350 & 0,490 & 0,375 \\
\hline \multicolumn{2}{|c|}{ Total corrigido para $\mathrm{F}$ e Cl } & 94,075 & 93,661 & 94,215 & 92,512 \\
\hline & $\mathrm{Si}$ & 6,2559 & 6,2797 & 6,3244 & 6,3011 \\
\hline & $\underline{\mathrm{Ti}}$ & 0,0000 & 0,0000 & 0,0000 & 0,0000 \\
\hline & $\mathrm{Al}^{\top}$ & 5,2887 & 5,3209 & 5,0807 & 5,1175 \\
\hline & $\mathrm{Al}^{\mathrm{IV}}$ & 1,7441 & 1,7203 & 1,6756 & 1,6989 \\
\hline & $\mathrm{Al}^{\mathrm{V} / \mathrm{t}}$ & 3,5446 & 3,6006 & 3,4050 & 3,4187 \\
\hline & $\mathrm{Fe}^{2+}$ & 0,3505 & 0,3029 & 0,4913 & 0,4515 \\
\hline & $\mathrm{Mn}$ & 0,0722 & 0,0629 & 0,0594 & 0,0957 \\
\hline & $\mathrm{Mg}$ & 0,0053 & 0,0020 & 0,0000 & 0,0023 \\
\hline & $L$ & 0,0038 & 0,0038 & 0,0038 & 0,0039 \\
\hline & Ca & 0,0020 & 0,0012 & 0,0000 & 0,0000 \\
\hline & $\mathrm{Na}$ & 0,0117 & 0,0138 & 0,0128 & 0,0151 \\
\hline & K & 1,8016 & 1,7924 & 1,8283 & 1,9175 \\
\hline & $F$ & 0,4206 & 0,3568 & 0,5013 & 0,3912 \\
\hline & $\mathrm{Cl}$ & 0,0009 & 0,0000 & 0,0000 & 0,0009 \\
\hline & Total & 14,2132 & 14,1364 & 14,3020 & 14,2969 \\
\hline & $\begin{array}{l}\text { ocupação } \\
\text { octaédrica }(Y)\end{array}$ & 3,9764 & 3,9722 & 3,9596 & 3,9721 \\
\hline & $\begin{array}{l}\text { ocupaçăo } \\
\text { intercamadas }(X)\end{array}$ & 1,8153 & 1,8073 & 1,8411 & 1,9327 \\
\hline & $\begin{array}{l}\text { carga } \\
\text { intercamadas }\end{array}$ & 1,8174 & 1,8085 & 1,8411 & 1,9327 \\
\hline & carga tetraédrica & $-1,7441$ & $-1,7203$ & $-1,6756$ & $-1,6989$ \\
\hline & carga octaédrica & $-0,5065$ & $-0,4589$ & $-0,6796$ & $-0,6411$ \\
\hline & $\begin{array}{l}\text { carga das } \\
\text { camadas }\end{array}$ & $-2,2506$ & $-2,1792$ & $-2,3552$ & $-2,3400$ \\
\hline & carga total & $-0,4332$ & $-0,3707$ & $-0,5141$ & $-0,4073$ \\
\hline
\end{tabular}




\begin{tabular}{|c|c|c|c|c|c|c|c|c|}
\hline Amostra & & $\mathrm{AM}-134$ & $\mathrm{AM}-134$ & $A M-134$ & $A M-134$ & $\mathrm{AM}-134$ & $\mathrm{AM}-134$ & $A M-134$ \\
\hline Ponto & & 1 & 2 & 3 & 4 & 8 & 9 & 10 \\
\hline \multirow[t]{16}{*}{ Descrição } & & núcleo & borda & núcleo & borda & núcleo & borda & reliquiar \\
\hline & $\mathrm{SiO}_{2}$ & 38,956 & 37,982 & 39,276 & 39,297 & 39,142 & 38,703 & 40,154 \\
\hline & $\mathrm{TiO}_{2}$ & 0,203 & 0,148 & 0,270 & 0,164 & 0,299 & 0,150 & 0,503 \\
\hline & $\mathrm{Al}_{2} \mathrm{O}_{3}$ & 21,424 & 21,823 & 22,050 & 22,191 & 22,037 & 21,726 & 21,556 \\
\hline & $\mathrm{FeO}$ & 21,632 & 24,403 & 21,399 & 21,282 & 21,542 & 22,805 & 20,834 \\
\hline & $\mathrm{MnO}$ & 0,869 & 0,924 & 0,885 & 0,848 & 0,915 & 0,837 & 0,817 \\
\hline & $\mathrm{MgO}$ & 0,051 & 0,040 & 0,047 & 0,020 & 0,051 & 0,076 & 0,052 \\
\hline & $\mathrm{Li}_{2} \mathrm{O}$ & 0,598 & 0,598 & 0,598 & 0,598 & 0,598 & 0,598 & 0,301 \\
\hline & $\mathrm{BaO}$ & 0,037 & 0,000 & 0,000 & 0,043 & 0,142 & 0,000 & 0,070 \\
\hline & $\mathrm{Na}_{2} \mathrm{O}$ & 0,169 & 0,239 & 0,235 & 0,137 & 0,186 & 0,267 & 0,166 \\
\hline & $\mathrm{K}_{2} \mathrm{O}$ & 9,348 & 9,175 & 9,113 & 9,481 & 9,245 & 8,823 & 9,491 \\
\hline & $\mathrm{F}$ & 5.805 & 4,291 & 5,252 & 4,355 & 5,566 & 4,790 & 4,982 \\
\hline & $\mathrm{Cl}$ & 0,022 & 0,035 & 0,031 & 0,093 & 0,017 & 0,029 & 0,018 \\
\hline & $\mathrm{Nb}_{2} \mathrm{O}_{5}$ & 0,028 & 0,008 & 0,000 & 0,000 & 0,021 & 0,028 & 0,051 \\
\hline & TOTAL & 99,142 & 99,666 & 99,156 & 98,509 & 99,761 & 98,832 & 98,995 \\
\hline & $\mathrm{O}=\mathrm{F}, \mathrm{Cl}$ & 2,449 & 1,815 & 2,218 & 1,855 & 2,347 & 2,023 & 2,102 \\
\hline \multicolumn{2}{|c|}{ Total corrigido para $\mathrm{Fe} \mathrm{Cl}$} & 96,693 & 97,851 & 96,938 & 96,654 & 97,414 & 96,809 & 96,893 \\
\hline & $\mathrm{Si}$ & 5,6547 & 5,5662 & 5,6764 & 5,7263 & 5,6383 & 5,6521 & 5,8058 \\
\hline & $T$ & 0,0222 & 0,0163 & 0,0293 & 0,0180 & 0,0324 & 0,0165 & 0,0547 \\
\hline & $\mathrm{Al}^{\mathrm{T}}$ & 3,6649 & 3,7690 & 3,7556 & 3,8109 & 3,7410 & 3,7391 & 3,6731 \\
\hline & $\mathrm{Al}^{\mathrm{IV}}$ & 2,3453 & 2,4338 & 2,3236 & 2,2737 & 2,3617 & 2,3479 & 2,1942 \\
\hline & $\mathrm{Al}^{\mathrm{VI}}$ & 1,3196 & 1,3352 & 1,4320 & 1,5372 & 1,3793 & 1,3912 & 1,4788 \\
\hline & $\overline{\mathrm{Fe}^{2+}}$ & 2,6256 & 2,9904 & 2,5861 & 2,5932 & 2,5948 & 2,7848 & 2,5189 \\
\hline & $\mathrm{Mn}$ & 0,1068 & 0,1147 & 0,1083 & 0,1047 & 0,1116 & 0,1035 & 0,1000 \\
\hline & $\mathrm{Mg}$ & 0,0110 & 0,0087 & 0,0101 & 0,0043 & 0,0110 & 0,0165 & 0,0112 \\
\hline & $\mathrm{Li}$ & 0,3491 & 0,3524 & 0,3476 & 0,3504 & 0,3464 & 0,3512 & 0,1750 \\
\hline & $\mathrm{Ba}$ & 0,0021 & 0,0000 & 0,0000 & 0,0025 & 0,0080 & 0,0000 & 0,0040 \\
\hline & $\mathrm{Na}$ & 0,0238 & 0,0340 & 0,0329 & 0,0194 & 0,0260 & 0,0378 & 0,0233 \\
\hline & $\mathrm{K}$ & 1,7309 & 1,7151 & 1,6800 & 1,7623 & 1,6987 & 1,6436 & 1,7505 \\
\hline & $F$ & 2,6645 & 1.9885 & 2,4002 & 2,0067 & 2,5353 & 2,2119 & 2,2778 \\
\hline & $\mathrm{Cl}$ & 0,0054 & 0,0087 & 0,0076 & 0,0230 & 0,0042 & 0,0072 & 0,0044 \\
\hline & $\mathrm{Nb}$ & 0,0046 & 0,0013 & 0,0000 & 0,0000 & 0,0034 & 0,0046 & 0,0083 \\
\hline & Total & 16,8656 & 16,5653 & 16,6341 & 16,4215 & 16,7511 & 16,5688 & 16,4068 \\
\hline & $\begin{array}{l}\text { ocupaçăo } \\
\text { octaèdrica }(Y)\end{array}$ & 4,4344 & 4,8178 & 4,5134 & 4,6077 & 4,4755 & 4,6637 & 4,3386 \\
\hline & $\begin{array}{l}\text { ocupação } \\
\text { intercamadas }(X)\end{array}$ & 1,7567 & 1,7491 & 1,7129 & 1,7841 & 1,7327 & 1,6814 & 1,7777 \\
\hline & $\begin{array}{l}\text { carga } \\
\text { intercamadas }\end{array}$ & 1.7589 & 1,7491 & 1.7129 & 1,7866 & 1,7407 & 1,6814 & 1,7817 \\
\hline & carga tetraédrica & $-2,3453$ & $-2,4338$ & $-2,3236$ & $-2,2737$ & $-2,3617$ & $-2,3479$ & 2,1942 \\
\hline & carga octaédrica & $-2,1164$ & $-1,3490$ & $-1,8300$ & $-1,5619$ & $-1,9513$ & $-1,5996$ & $-1,9095$ \\
\hline & $\begin{array}{l}\text { carga das } \\
\text { camadas }\end{array}$ & $-4,4617$ & $-3,7828$ & $-4,1536$ & $-3,8356$ & $-4,3130$ & $-3,9475$ & $-4,1038$ \\
\hline & carga total & $-2,7029$ & $-2,0338$ & $-2,4407$ & $-2,0490$ & $-2,5722$ & $-2,2662$ & $-2,3221$ \\
\hline
\end{tabular}




\begin{tabular}{|c|c|c|c|c|c|c|c|}
\hline Amostra & & AM-145 & $A M+145$ & AM-145 & $\mathrm{AM}-145$ & $\mathrm{AM}-145$ & AM-145 \\
\hline Ponto & & 7 & 8 & 14 & 15 & 20 & 21 \\
\hline \multirow[t]{16}{*}{ Descrição } & & núcleo & borda & núcleo & borda & núcleo & borda \\
\hline & $\mathrm{SiO}_{2}$ & 36,017 & 36,074 & 36,563 & 37,633 & 37,444 & 36,268 \\
\hline & $\mathrm{TiO}_{2}$ & 0,974 & 0,792 & 1,411 & 1,201 & 1,093 & 1,189 \\
\hline & $\mathrm{Al}_{2} \mathrm{O}_{3}$ & 19,746 & 19,624 & 19,293 & 20,068 & 20,015 & 19,674 \\
\hline & $\mathrm{FeO}$ & 29,142 & 28,470 & 27,891 & 26,272 & 26,725 & 28,366 \\
\hline & $\mathrm{MnO}$ & 0,811 & 0.720 & 0,722 & 0,743 & 0,639 & 0,699 \\
\hline & $\mathrm{MgO}$ & 0,263 & 0,279 & 0,269 & 0,248 & 0,263 & 0,305 \\
\hline & $\mathrm{Li}_{2} \mathrm{O}$ & 0,301 & 0,301 & 0,301 & 0,301 & 0,301 & 0,301 \\
\hline & $\mathrm{CaO}$ & 0,000 & 0,000 & 0,006 & 0,009 & 0,000 & 0,000 \\
\hline & $\mathrm{BaO}$ & 0,000 & 0,111 & 0,051 & 0,039 & 0,000 & 0,000 \\
\hline & $\mathrm{Na}_{2} \mathrm{O}$ & 0,183 & 0,173 & 0,133 & 0,139 & 0,170 & 0,178 \\
\hline & $\mathrm{K}_{2} \mathrm{O}$ & 9,144 & 9,184 & 9,242 & 9,376 & 9,407 & 9,288 \\
\hline & $\mathrm{F}$ & 4,310 & 4,322 & 3,660 & 4,292 & 4,481 & 3,974 \\
\hline & $\mathrm{Cl}$ & 0,164 & 0,162 & 0,062 & 0,069 & 0,076 & 0,061 \\
\hline & TOTAL & 101,055 & 100,212 & 99,604 & 100,390 & 100,614 & 100,303 \\
\hline & $\mathrm{O}=\mathrm{F}, \mathrm{Cl}$ & 1,852 & 1,856 & 1,555 & 1,823 & 1,904 & 1,687 \\
\hline \multicolumn{2}{|c|}{ Total corrigido para $\mathrm{F} \mathrm{e} \mathrm{Cl}$} & 99,203 & 98,356 & 98,049 & 98,567 & 98,710 & 98,616 \\
\hline & $\mathrm{Si}$ & 5,3547 & 5,3968 & 5,4947 & 5,5440 & 5,5149 & 5,4237 \\
\hline & $\mathrm{Ti}$ & 0,1089 & 0,0891 & 0,1595 & 0,1331 & 0,1211 & 0,1337 \\
\hline & $\mathrm{Al}^{\mathrm{T}}$ & 3,4597 & 3,4599 & 3,4169 & 3,4841 & 3,4741 & 3,4673 \\
\hline & $\mathrm{Al}^{\mathrm{IV}}$ & 2,6453 & 2,6032 & 2,5053 & 2,4560 & 2,4851 & 2,5763 \\
\hline & $\mathrm{Al}^{\mathrm{VI}}$ & 0,8145 & 0,8567 & 0,9116 & 1,0280 & 0,9890 & 0,8911 \\
\hline & $\mathrm{Fe}^{2+}$ & 3,6229 & 3,5615 & 3,5049 & 3,2363 & 3,2914 & 3,5471 \\
\hline & $\mathrm{Mn}$ & 0,1021 & 0,0912 & 0,0919 & 0,0927 & 0,0797 & 0,0885 \\
\hline & $\mathrm{Mg}$ & 0,0583 & 0,0622 & 0,0603 & 0,0545 & 0,0577 & 0,0680 \\
\hline & $\mathrm{Li}$ & 0,1800 & 0,1811 & 0,1819 & 0,1783 & 0,1783 & 0,1810 \\
\hline & $\mathrm{Ca}$ & 0,0000 & 0,0000 & 0,0010 & 0,0014 & 0,0000 & 0,0000 \\
\hline & $\mathrm{Ba}$ & 0,0000 & 0,0065 & 0,0030 & 0,0023 & 0,0000 & 0,0000 \\
\hline & $\mathrm{Na}$ & 0,0527 & 0,0502 & 0,0387 & 0,0397 & 0,0485 & 0,0516 \\
\hline & $K$ & 1,7341 & 1,7526 & 1,7717 & 1,7619 & 1.7673 & 1.7718 \\
\hline & $F$ & 2,0262 & 2,0446 & 1,7392 & 1,9993 & 2,0869 & 1,8792 \\
\hline & $\mathrm{Cl}$ & 0,2066 & 0,2054 & 0,0790 & 0,0861 & 0,0949 & 0,0773 \\
\hline & Total & 16,9063 & 16,9011 & 16,5426 & 16,6136 & 16,7149 & 16,6893 \\
\hline & $\begin{array}{l}\text { ocupaçäo } \\
\text { octaédrica }(Y)\end{array}$ & 4,8866 & 4,8418 & 4,9100 & 4,7229 & 4,7172 & 4,9094 \\
\hline & $\begin{array}{l}\text { ocupaçäo } \\
\text { intercamadas }(X)\end{array}$ & 1,7869 & 1,8093 & 1,8144 & 1,8053 & 1,8159 & 1,8234 \\
\hline & $\begin{array}{l}\text { carga } \\
\text { intercamadas }\end{array}$ & 1,7869 & 1,8158 & 1,8183 & 1,8089 & 1,8159 & 1,8234 \\
\hline & carga tetraédrica & $-2,6453$ & $-2,6032$ & $-2,5053$ & $-2,4560$ & $-2,4851$ & $-2,5763$ \\
\hline & carga octaédrica & $-1,3744$ & $-1,4625$ & $-1,1313$ & $-1,4384$ & $-1,5126$ & $-1,2036$ \\
\hline & $\begin{array}{l}\text { carga das } \\
\text { camadas }\end{array}$ & $-4,0197$ & $-4,0657$ & $-3,6365$ & $-3,8944$ & $-3,9977$ & $-3,7799$ \\
\hline & carga total & $-2,2328$ & $-2,2499$ & $-1,8182$ & $-2,0855$ & $-2,1818$ & $-1,9565$ \\
\hline
\end{tabular}




\begin{tabular}{|c|c|c|c|c|c|}
\hline Amostra & & AM-211A & AM-211A & AM-211A & AM-211A \\
\hline Ponto & & 1 & 2 & 3 & 4 \\
\hline \multirow[t]{15}{*}{ Descrição } & & núcleo & borda & núcteo & borda \\
\hline & $\mathrm{SiO}_{2}$ & 38,422 & 38,837 & 38,140 & 38,449 \\
\hline & $\mathrm{TiO}_{2}$ & 0,076 & 0,068 & 0,039 & 0,144 \\
\hline & $\mathrm{Al}_{2} \mathrm{O}_{3}$ & 21,078 & 21,186 & 21,204 & 21,228 \\
\hline & $\mathrm{FeO}$ & 24,301 & 23,336 & 23,579 & 22,903 \\
\hline & $\mathrm{MnO}$ & 1,474 & 1,556 & 1,405 & 1,457 \\
\hline & $\mathrm{MgO}$ & 0,003 & 0,009 & 0,002 & 0,021 \\
\hline & $\mathrm{Li}_{2} \mathrm{O}$ & n.d. & n.d. & n.d. & n.d. \\
\hline & $\mathrm{CaO}$ & 0,000 & 0,000 & 0,000 & 0,000 \\
\hline & $\mathrm{Na}_{2} \mathrm{O}$ & 0,255 & 0,246 & 0,304 & 0,231 \\
\hline & $\mathrm{K}_{2} \mathrm{O}$ & 9,142 & 9,133 & 9,070 & 9,199 \\
\hline & $F$ & 5,071 & 4,336 & 5,114 & 3,918 \\
\hline & $\mathrm{Cl}$ & 0,018 & 0,016 & 0,021 & 0,025 \\
\hline & TOTAL & 99,840 & 98,723 & 98,878 & 97,575 \\
\hline & $\mathrm{O}=\mathrm{F}, \mathrm{Cl}$ & 2,139 & 1,829 & 2,158 & 1,655 \\
\hline \multicolumn{2}{|c|}{ Total corrigido para $\mathrm{F} \mathrm{e} \mathrm{Cl}$} & 97,701 & 96,894 & 96,720 & 95,920 \\
\hline & $\mathrm{Si}$ & 5,6389 & 5,7341 & 5,6347 & 5,7401 \\
\hline & $\mathrm{Ti}$ & 0,0084 & 0,0076 & 0,0043 & 0,0162 \\
\hline & $\mathrm{Al}^{\mathrm{T}}$ & 3,6456 & 3,6864 & 3,6918 & 3,7348 \\
\hline & $\mathrm{Al}^{\mathrm{MV}}$ & 2,3611 & 2,2659 & 2,3653 & 2,2599 \\
\hline & $\mathrm{Al}^{\mathrm{Vl}}$ & 1,2845 & 1,4205 & 1,3264 & 1,4749 \\
\hline & $\mathrm{Fe}^{2+}$ & 2,9822 & 2,8811 & 2,9128 & 2,8591 \\
\hline & $\mathrm{Mn}$ & 0,1832 & 0,1946 & 0,1758 & 0,1842 \\
\hline & $\mathrm{Mg}$ & 0,0007 & 0,0020 & 0,0004 & 0,0047 \\
\hline & $\underline{\mathrm{Li}}$ & n.d. & n.d. & n.d. & n.d. \\
\hline & $\mathrm{Ca}$ & 0,0000 & 0,0000 & 0,0000 & 0,0000 \\
\hline & $\mathrm{Na}$ & 0,0363 & 0,0352 & 0,0435 & 0,0334 \\
\hline & $k$ & 1,7114 & 1,7201 & 1,7092 & 1,7518 \\
\hline & $F$ & 2,3533 & 2,0244 & 2,3890 & 1,8496 \\
\hline & $\mathrm{Cl}$ & 0,0045 & 0,0040 & 0,0053 & 0,0063 \\
\hline & Total & 16,5645 & 16,2893 & 16,5669 & 16,1802 \\
\hline & $\begin{array}{l}\text { ocupação } \\
\text { octaédrica }(Y)\end{array}$ & 4,4590 & 4,5057 & 4,4198 & 4,5391 \\
\hline & $\begin{array}{l}\text { ocupaçäo } \\
\text { intercamadas }(X)\end{array}$ & 1,7477 & 1,7553 & 1,7528 & 1,7852 \\
\hline & $\begin{array}{l}\text { carga } \\
\text { intercamadas }\end{array}$ & 1,7477 & 1,7553 & 1,7528 & 1,7852 \\
\hline & carga tetraédrica & $-2,3611$ & $-2,2659$ & $-2,3653$ & $-2,2599$ \\
\hline & carga octaédrica & $-1,7807$ & $-\uparrow .5530$ & $-1,8253$ & $-1,4146$ \\
\hline & $\begin{array}{l}\text { carga das } \\
\text { camadas }\end{array}$ & $-4,1418$ & $-3,8188$ & $-4,1906$ & $-3,6746$ \\
\hline & carga total & $-2,3941$ & $-2,0636$ & $-2,4378$ & $-1,8893$ \\
\hline
\end{tabular}




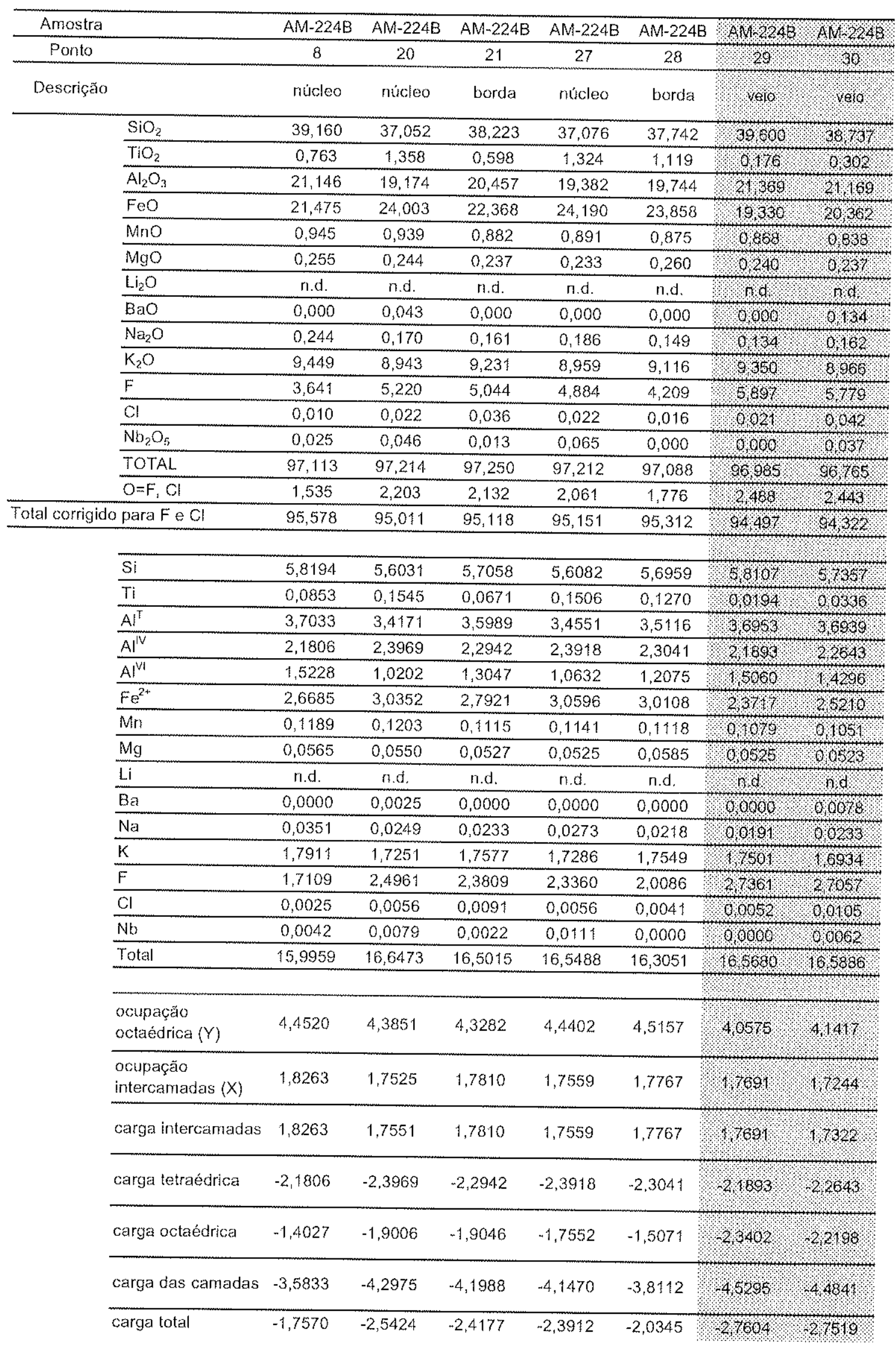


ANEXO III 
AM-14B - CAMPO 1 - QUARTZO - GRANITO ALBITIZADO SALMÄO - ESTÁGIO TRANSICIONAL

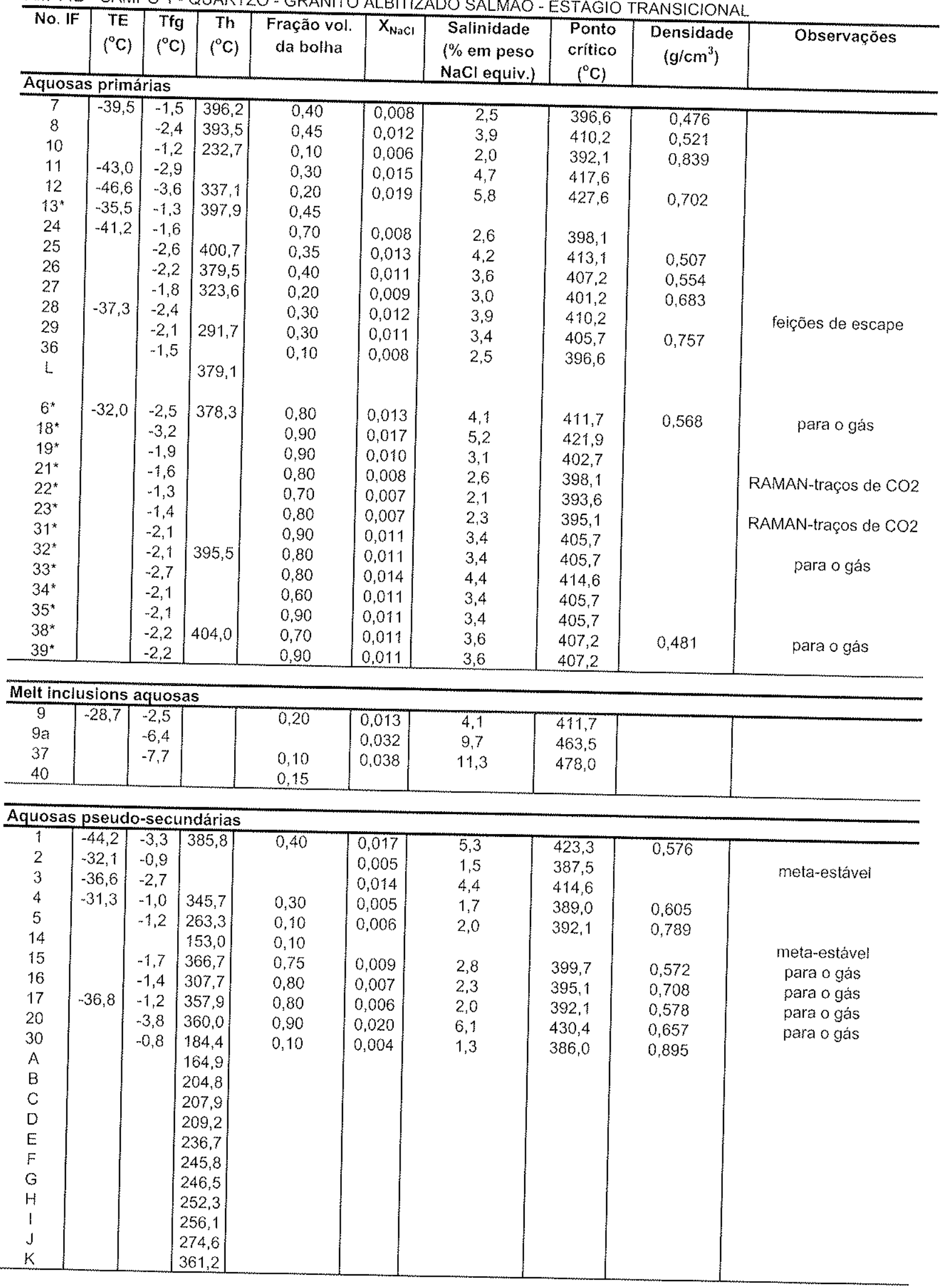


AM-14B - CAMPO 2 - QUARTZO - GRANITO ALBITIZADO SALMÃO - ESTÁGIO TRANSICIONAL

\begin{tabular}{|c|c|c|c|c|c|c|c|c|c|}
\hline No. If & $\begin{array}{c}\mathrm{TE} \\
\left({ }^{\circ} \mathrm{C}\right)\end{array}$ & $\begin{array}{l}\text { Tfg } \\
\left({ }^{\circ} \mathrm{C}\right)\end{array}$ & $\begin{array}{c}\mathrm{Th} \\
\left({ }^{\circ} \mathrm{C}\right)\end{array}$ & $\begin{array}{c}\text { Fração vol. } \\
\text { da bolha }\end{array}$ & $\mathrm{X}_{\mathrm{NaCl}}$ & $\begin{array}{l}\text { Salinidade } \\
\text { (\% em peso } \\
\mathrm{NaCl} \text { equiv.) }\end{array}$ & $\begin{array}{l}\text { Ponto } \\
\text { crítico } \\
\left({ }^{\circ} \mathrm{C}\right)\end{array}$ & $\begin{array}{c}\text { Densidade } \\
\left(\mathrm{g} / \mathrm{cm}^{3}\right)\end{array}$ & Observaçöes \\
\hline \multicolumn{10}{|c|}{ Aquosas pseudo-secundárias } \\
\hline 1 & $-34,3$ & $-1,4$ & & 0,50 & 0,007 & 2,3 & 395,1 & & \multirow{44}{*}{$\begin{array}{l}\text { homogeneiz, para o vapor } \\
\text { homogeneiz, para o vapor }\end{array}$} \\
\hline 2 & $-33,9$ & $-1,4$ & & 0,60 & 0,007 & 2,3 & 395,1 & & \\
\hline 3 & $-34,9$ & $-1,6$ & 185,5 & 0,10 & 0,008 & 2,6 & 398,1 & 0,903 & \\
\hline 4 & $-34,7$ & $-1,6$ & 203,2 & 0,15 & 0,008 & 2,6 & 398,1 & 0,884 & \\
\hline 5 & $-35,0$ & $-1,4$ & 373,2 & 0,45 & 0,007 & 2,3 & 395,1 & 0,542 & \\
\hline 6 & $-35,9$ & $-1,1$ & & 0,60 & 0,006 & 1,8 & 390,5 & & \\
\hline 7 & $-36,9$ & $-2,1$ & 394,9 & 0,45 & 0,011 & 3,4 & 405,7 & 0,505 & \\
\hline 8 & $-36,5$ & $-1,7$ & & 0,40 & 0,009 & 2,8 & 399,7 & & \\
\hline 9 & & $-1,4$ & & 0,10 & 0,007 & 2,3 & 395,1 & & \\
\hline 10 & & $-1,7$ & 158,6 & 0,10 & 0,009 & 2,8 & 399,7 & 0,932 & \\
\hline 11 & $-38,2$ & $-1,4$ & 331,2 & 0,35 & 0,007 & 2,3 & 395,1 & 0,654 & \\
\hline 12 & & $-2,5$ & 268,7 & 0,90 & 0,013 & 4,1 & 411,7 & 0,806 & \\
\hline 13 & & $-4,8$ & 355,9 & 0,80 & 0,025 & 7,5 & 443,8 & 0,694 & \\
\hline 14 & & $-3,0$ & & 0,90 & 0,015 & 4,9 & 419,0 & & \\
\hline 15 & $-38,8$ & $-1,4$ & 290,7 & 0,30 & 0,007 & 2,3 & 395,1 & 0,743 & \\
\hline 16 & & $-1,9$ & 254,9 & 0,15 & 0,010 & 3,1 & 402,7 & 0,817 & \\
\hline 17 & & $-1,8$ & 387,3 & 0,80 & 0,009 & 3,0 & 401,2 & 0,516 & \\
\hline $\begin{array}{l}18 \\
19\end{array}$ & $-32,0$ & $-1,8$ & 150,7 & 0,10 & & & & & \\
\hline $\begin{array}{l}19 \\
20\end{array}$ & $\begin{array}{l}-32,0 \\
-38,8\end{array}$ & $\begin{array}{l}-1,8 \\
-1,9\end{array}$ & $\begin{array}{l}150,7 \\
175,5\end{array}$ & 0,10 & 0,009 & 3,0 & 401,2 & 0,941 & \\
\hline $\begin{array}{l}20 \\
21\end{array}$ & $\begin{array}{l}-38,8 \\
-37,5\end{array}$ & $-1,9$ & & 0,15 & 0,010 & 3,1 & 402,7 & 0,917 & \\
\hline $\begin{array}{l}21 \\
22\end{array}$ & $\begin{array}{l}-37,5 \\
-35,0\end{array}$ & $-1,1$ & 185.2 & 0,10 & 0,010 & 3.1 & 402,7 & & \\
\hline $\begin{array}{l}22 \\
23\end{array}$ & & $-1,8$ & $\begin{array}{l}185,2 \\
180,6\end{array}$ & 0,10 & 0,006 & 1,8 & 390,5 & 0,898 & \\
\hline 23 & $-33,6$ & $-1,8$ & & 0,10 & 0,009 & 3,0 & 401,2 & 0,911 & \\
\hline 24 & & $\begin{array}{r}-1,0 \\
-18\end{array}$ & 382,4 & 0,45 & 0,009 & 3,0 & 401,2 & 0,530 & \\
\hline 25 & $\begin{array}{l}-34,7 \\
-35,0\end{array}$ & $-1,8$ & 330,9 & 0,35 & 0,009 & 3,0 & 401,2 & 0,666 & \\
\hline 26 & $-35,0$ & $-1,7$ & & 0,80 & 0,009 & 2,8 & 399,7 & & \\
\hline 27 & $-43,8$ & $-1,9$ & 183,9 & 0,10 & 0,010 & 3,1 & 402,7 & 0,908 & \\
\hline 28 & $-44,6$ & $-2,2$ & 219,5 & 0,10 & 0,011 & 3,6 & 407,2 & 0,872 & \\
\hline 29 & $-33,5$ & $-2,5$ & & 0,60 & 0,013 & 4,1 & 411,7 & & \\
\hline 30 & & $-2,7$ & 357,4 & 0,90 & 0,014 & 4,4 & 414,6 & 0,630 & \\
\hline 31 & $-38,2$ & $-1,2$ & 191,2 & 0,10 & 0,006 & 2,0 & 392,1 & 0,892 & \\
\hline 32 & & $-2,8$ & 378,7 & 0,45 & 0,014 & 4,5 & 416,1 & 0,578 & \\
\hline 33 & & $-2,2$ & 213,0 & 0,10 & 0,011 & 3,6 & 407,2 & 0,881 & \\
\hline 34 & $-42,5$ & $-2,1$ & 222,4 & 0,15 & 0,011 & 3,4 & 405,7 & 0,867 & \\
\hline 35 & & $-1,8$ & & 0,10 & 0,009 & 3,0 & 401,2 & & \\
\hline 36 & & $-1,7$ & & 0,10 & 0,009 & 2,8 & 399,7 & & \\
\hline 37 & & $-2,1$ & 224,8 & 0,10 & 0,011 & 3,4 & 405,7 & 0,864 & \\
\hline 38 & & $-2,1$ & 212,0 & 0,10 & 0,011 & 3,4 & 405,7 & & \\
\hline 39 & & $-2,2$ & 182,6 & 0,10 & 0,011 & 3,6 & 407,2 & & \\
\hline 40 & & $-2,2$ & & 0,15 & 0,011 & 3,6 & 407,2 & & \\
\hline 41 & & $-2,1$ & 186,9 & 0,10 & 0,011 & 3,4 & 405,7 & 0,907 & \\
\hline 42 & & & 158,6 & 0,10 & & & & & \\
\hline 43 & & $-2,1$ & & 0,15 & 0,011 & 3,4 & 405,7 & & \\
\hline 44 & & $-2,7$ & & 0,50 & 0,014 & 4,4 & 414,6 & & \\
\hline
\end{tabular}


AM-35 - CAMPO 1 - TOPÁZIO - GREISEN TABULAR - ESTÁGIO TRANSICIONAL

\begin{tabular}{|c|c|c|c|c|c|c|c|c|c|c|c|c|}
\hline Aquo-carbônicas & $\begin{array}{c}\text { TE } \\
\left({ }^{\circ} \mathrm{C}\right)\end{array}$ & $\begin{array}{l}\mathrm{Tfg} \\
\left({ }^{\circ} \mathrm{C}\right)\end{array}$ & $\begin{array}{l}\mathrm{TfCO} 2 \\
\left({ }^{\circ} \mathrm{C}\right)\end{array}$ & $\begin{array}{l}\mathrm{TffCl} \\
\left({ }^{\circ} \mathrm{C}\right)\end{array}$ & $\begin{array}{l}\text { Th } \\
\left({ }^{\circ} \mathrm{C}\right)\end{array}$ & $\begin{array}{l}\text { Fração vol. } \\
\text { da bolha }\end{array}$ & $\mathrm{X}_{\mathrm{NaCF}}$ & $\begin{array}{l}\text { Salinidade } \\
\text { (\% em peso } \\
\mathrm{NaCl} \text { equiv.) }\end{array}$ & $\begin{array}{l}\text { Ponto } \\
\text { crítico } \\
\left({ }^{\circ} \mathrm{C}\right) \\
\end{array}$ & $\begin{array}{c}\text { Densidade } \\
\left(\mathrm{g} / \mathrm{cm}^{3}\right)\end{array}$ & $\begin{array}{c}\text { Tfs } \\
\left({ }^{\circ} \mathrm{C}\right)\end{array}$ & O’bservaçōes \\
\hline 1 & $-31,2$ & & -56.9 & \multicolumn{9}{|c|}{\begin{tabular}{c|c} 
Aquo-carbônicas primárias \\
1 & $-31,2$
\end{tabular}} \\
\hline 4 & & & & 5,5 & $\begin{array}{l}388,2 \\
379,6\end{array}$ & 0.45 & & 7,1 & & & & RAMAN-com $\mathrm{CO}_{2}$ \\
\hline 5 & & & -56.9 & 6,1 & & $\begin{array}{l}0,30 \\
0,45\end{array}$ & & 8,3 & & & & \\
\hline 6 & & & $-56,8$ & 6.7 & & 0,45 & & 7,3 & & & & \\
\hline 7 & & & $-57,0$ & 6,8 & 348,2 & 0,30 & & 6,3 & & & & \\
\hline 8 & & & & 7,0 & & & & $\begin{array}{l}6,1 \\
5,8\end{array}$ & & & & \\
\hline 9 & $-27,6$ & $-8,4$ & $-56,8$ & 8.4 & 349,8 & 0,20 & & 3,2 & 3514 & & 3115 & \\
\hline 10 & & & $-56,8$ & 8,6 & 343,3 & 0,45 & & 2,8 & $00,4^{4}$ & & 341,5 & RAMAN-com $\mathrm{CO}_{2}$ e $\mathrm{CH}_{4}$ \\
\hline 11 & $-25,8$ & $-8,5$ & & 2,8 & & & & 12,2 & & & & \\
\hline 12 & $-25,6$ & & $-56,7$ & 8,9 & 348,1 & 0.45 & & 2,2 & & & & \\
\hline 13 & & & $-56,9$ & 6,9 & 349,0 & 0,40 & & 5,9 & & & & \\
\hline 14 & $-24,8$ & $-7,2$ & & & 336,6 & 0,20 & 0,036 & 10,7 & 472,5 & 0,782 & & \\
\hline 15 & $-26,9$ & $-6,2$ & & & & & 0,031 & 9,5 & 461,1 & & & \\
\hline 16 & $-29,6$ & $-5,7$ & & & 340,4 & 0,10 & 0,029 & 8,8 & 455,1 & 0,746 & & \\
\hline 17 & $-26,7$ & $-9,3$ & & & 362,7 & 0,10 & 0,045 & 13,2 & 494,7 & 0,775 & & \\
\hline 18 & $-27,4$ & $-6,7$ & & & 341,5 & 0,25 & 0,033 & 10,1 & 466,9 & 0,765 & & \\
\hline 19 & & & & 4,6 & 423,8 & 0,55 & & 9,7 & & & & homogeneizacāo para o gás \\
\hline 20 & & & & 6,6 & 351,5 & 0,25 & & 6,5 & & & & 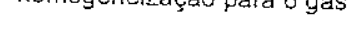 \\
\hline 21 & $-28,1$ & $-8,5$ & $-56,8$ & 6,8 & & 0,90 & & 6,1 & & & & \\
\hline $\begin{array}{l}22 \\
23\end{array}$ & & & & & & 0,90 & & & & & & \\
\hline & & & & & & 0,90 & & & & & & \\
\hline
\end{tabular}

Melt inclusions aquo-carbônicas

\begin{tabular}{|c|c|c|c|c|c|c|}
\hline $\begin{array}{r}2 \\
3 \\
\end{array}$ & $\begin{array}{r}-57,2 \\
-57,1 \\
\end{array}$ & $\begin{array}{r}0,3 \\
1,9 \\
\end{array}$ & & 0.10 & $\begin{array}{l}15,2 \\
13,4 \\
\end{array}$ & \\
\hline \multicolumn{7}{|c|}{ Sem elassificação } \\
\hline $\bar{A} 1 \bar{A}$ & & & 366,8 & 0,50 & & \\
\hline$A 1 B$ & & & 350,6 & 3,50 & & homogeneização para o gás \\
\hline 8 & & & 368,5 & & & \\
\hline c & & & 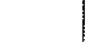 & & & \\
\hline DIA & & & 381,6 & & & \\
\hline D1B & & & 346,1 & & & \\
\hline$E$ & & & 352,4 & & & \\
\hline
\end{tabular}


AM-35 - CAMPO 2 - QUARTZO GREISEN TABULAR - ESTAGIO TRANSICIONAL

\begin{tabular}{|c|c|c|c|c|c|c|c|c|c|c|}
\hline No. If & $\begin{array}{c}\text { TE } \\
\left({ }^{\circ} \mathrm{C}\right)\end{array}$ & $\begin{array}{l}\text { Tfg } \\
\left({ }^{\circ} \mathrm{C}\right)\end{array}$ & $\begin{array}{c}\mathrm{TfCO} 2 \\
\left({ }^{\circ} \mathrm{C}\right)\end{array}$ & $\begin{array}{c}\text { Th } \\
\left({ }^{\circ} \mathrm{C}\right)\end{array}$ & $\begin{array}{c}\text { Fração vol. } \\
\text { da bolha }\end{array}$ & $\mathrm{X}_{\mathrm{NaCl}}$ & $\begin{array}{l}\text { Salinidade } \\
(\% \text { em peso } \\
\mathrm{NaCl} \text { equiv.) }\end{array}$ & $\begin{array}{l}\text { Ponto } \\
\text { crítico } \\
\left({ }^{\circ} \mathrm{C}\right) \\
\end{array}$ & $\begin{array}{c}\text { Densidade } \\
\left(\mathrm{g} / \mathrm{cm}^{3}\right)\end{array}$ & Observaçōes \\
\hline \multicolumn{11}{|c|}{\begin{tabular}{c|c} 
Aquosas secundárias \\
1
\end{tabular}} \\
\hline 1 & \multirow{6}{*}{$-37,6$} & $-0,2$ & \multirow{23}{*}{$-57,5$} & \multirow[t]{2}{*}{251,3} & 0,15 & 0,001 & 0,3 & 377,0 & \multirow[t]{2}{*}{0,790} & \multirow{15}{*}{ meta-estável } \\
\hline 2 & & $-0,2$ & & & 0,10 & 0,001 & 0,3 & 377,0 & & \\
\hline 3 & & $-0,4$ & & 266,9 & 0,25 & 0,002 & 0,7 & 380,0 & 0,766 & \\
\hline 4 & & $-0,4$ & & 215,2 & 0,10 & 0,002 & 0,7 & 380,0 & 0,851 & \\
\hline 5 & & $-4,2$ & & 207,7 & 0.10 & 0,022 & 6,7 & 435,8 & 0,912 & \\
\hline 6 & & $-0,5$ & & 175,7 & 0,10 & 0,003 & 0,8 & 381,5 & 0,902 & \\
\hline 7 & $-26,2$ & $-0,7$ & & & & 0,004 & 1,2 & 384,5 & & \\
\hline 8 & $-45,5$ & $-2,7$ & & 137,2 & 0,10 & 0,014 & 4,4 & 414,6 & 0,962 & \\
\hline 9 & $-26,4$ & $-0,5$ & & 162,5 & 0,10 & 0,003 & 0,8 & 381,5 & 0,916 & \\
\hline 10 & \multirow{3}{*}{$-27,1$} & $-0,8$ & & & & 0,004 & 1,3 & 386,0 & & \\
\hline 11 & & $-0,5$ & & & & 0,003 & 0,8 & 381,5 & & \\
\hline 12 & & $-0,5$ & & & & 0,003 & 0,8 & 381,5 & & \\
\hline 13 & \multirow{11}{*}{$\begin{array}{l}-35,2 \\
-28,9\end{array}$} & & & & 0,25 & & & & & \\
\hline $\begin{array}{l}14 \\
15\end{array}$ & & -03 & & & & & & & & \\
\hline 16 & & $-0,0$ & & 277,9 & 0,90 & 0,002 & 0,5 & 378,5 & & \\
\hline 17 & & & & 225,8 & 0,25 & & & & & \multirow{8}{*}{ homogeneização p/gás } \\
\hline 18 & & & & 282,0 & 0,20 & & & & & \\
\hline 19 & & & & 183,0 & 0,10 & & & & & \\
\hline 20 & & & & 177,2 & 0.10 & & & & & \\
\hline 21 & & & & & 0,10 & & & & & \\
\hline 22 & & & & 138,6 & & & & & & \\
\hline 23 & & & & 317,5 & & & & & & \\
\hline 24 & & & & 334,4 & & & & & & \\
\hline
\end{tabular}




\begin{tabular}{|c|c|c|c|c|c|c|c|c|c|}
\hline No. IF & $\begin{array}{c}\mathrm{TE} \\
\left({ }^{\circ} \mathrm{C}\right)\end{array}$ & $\begin{array}{l}\text { Tfg } \\
\left({ }^{\circ} \mathrm{C}\right)\end{array}$ & $\begin{array}{l}\text { Th } \\
\left({ }^{\circ} \mathrm{C}\right)\end{array}$ & $\begin{array}{c}\text { Fração vol. } \\
\text { da bolha }\end{array}$ & $\mathrm{X}_{\text {NaC1 }}$ & $\begin{array}{l}\text { Salinidade } \\
(\% \text { em peso } \\
\mathrm{NaCl} \text { equiv.) }\end{array}$ & $\begin{array}{l}\text { Ponto } \\
\text { crítico } \\
\left({ }^{\circ} \mathrm{C}\right)\end{array}$ & $\begin{array}{c}\text { Densidade } \\
\left(\mathrm{g} / \mathrm{cm}^{3}\right)\end{array}$ & Observaçōes \\
\hline \multicolumn{10}{|c|}{ Aquosas pseudo-secundárias } \\
\hline 1 & $-41,5$ & $-7,9$ & 333,9 & 0,20 & 0,039 & 11,6 & 480,2 & 0,799 & \\
\hline 2 & & $-1,0$ & 153,8 & 0,35 & 0,005 & 1.7 & 389,0 & 0,929 & \\
\hline 3 & $-41,7$ & $-8,3$ & 368,5 & 0,30 & 0,041 & 12,1 & 484,4 & 0,747 & \\
\hline 4 & $-35,0$ & $-7,8$ & 333,3 & 0,15 & 0,038 & 11,5 & 479,7 & 0,789 & \\
\hline 5 & $-37,3$ & $-7,3$ & 256,0 & 0,15 & 0,036 & 10,9 & 473,6 & 0,895 & \\
\hline 8 & $-37,5$ & $-8,3$ & 356,9 & 0,15 & 0,041 & 12,1 & 484,4 & 0,768 & \\
\hline 9 & $-28,1$ & $-7,9$ & 318,6 & 0,15 & 0,039 & 11,6 & 480,2 & 0,822 & \\
\hline 10 & $-40,8$ & $-8,2$ & 364,3 & 0,15 & 0,040 & 11,9 & 483,3 & 0,753 & \\
\hline 11 & $-40,8$ & $-6,2$ & 275,5 & 0.15 & 0,031 & 9,5 & 461,1 & 0,858 & \\
\hline 12 & $-40,0$ & $-5,7$ & 267,7 & 0,15 & 0,029 & 8,8 & 455,1 & 0,861 & \\
\hline 15 & $-46,7$ & $-5,7$ & 127,2 & 0,05 & 0,029 & 8,8 & 455,1 & 1,000 & \\
\hline 16 & $-32,4$ & $-6,6$ & & 0,15 & 0,033 & 10,0 & 465,8 & & \\
\hline 26 & $-40,6$ & $-9,0$ & 423,6 & 0,15 & 0,043 & 12,9 & 491,6 & 0,652 & \\
\hline 27 & {$\left[-39, \frac{1}{1}\right.$} & $-8,2$ & 340,1 & 0,15 & 0,040 & 11,9 & 483,3 & 0.794 & \\
\hline 28 & $-46,2$ & $-4,0$ & 189, & 0,15 & 0,021 & 6,4 & 433,1 & 0,926 & \\
\hline 29 & $-34,4$ & $-8, \hat{1}$ & 360,1 & 0,15 & 0,040 & 11,8 & 482,3 & 0,759 & \\
\hline 30 & $-30,2$ & $-8,1$ & 362,0 & 0,15 & 0,040 & 11,8 & 482,3 & 0,755 & \\
\hline 32 & $\mid-28,6$ & $-6,8$ & 140,5 & 0,15 & 0,034 & 10,2 & 468,1 & 0,999 & \\
\hline 33 & $-29,6$ & $-8,1$ & $35: 2$ & 0,15 & 0,040 & 11,8 & 482,3 & 0,774 & \\
\hline 38 & $-40,6$ & $-8,2$ & 352,0 & 0,15 & 0,040 & 11,9 & 483,3 & 0,774 & \\
\hline 40 & $-45,2$ & $-4,0$ & & 0,15 & $0,02 \hat{i}$ & 6,4 & 433,1 & & \\
\hline 41 & $-47,2$ & $-4,0$ & & 0,15 & 0,021 & 6,4 & 433,1 & & \\
\hline 42 & $-31,7$ & $-6,5$ & & 0,15 & 0,033 & 9,8 & 464,6 & & \\
\hline 43 & $-53,3$ & $-8,5$ & & 0,15 & 0,041 & 12,3 & 486,5 & & \\
\hline 45 & $-4 \uparrow, 0$ & $-8,1$ & & 0,35 & 0,040 & 11,8 & 482,3 & & \\
\hline 46 & $-33,3$ & $-7,9$ & 307,6 & 0,15 & 0,039 & 11,6 & 480,2 & 0,838 & \\
\hline 49 & $-43,4$ & $-3,7$ & & 0,15 & 0,019 & 5,9 & 429,0 & & \\
\hline A & & & 241,3 & 0,15 & & & & & \\
\hline B & & & 326,3 & 0,15 & & & & & \\
\hline \multicolumn{10}{|c|}{ Melt inclusion aquosa } \\
\hline 39 & $-32,9$ & $-2,2$ & & & 0,011 & 3,6 & 407,2 & & \\
\hline
\end{tabular}




\begin{tabular}{|c|c|c|c|c|c|c|c|c|c|}
\hline No. IF & $\begin{array}{l}\mathrm{TE} \\
\left\langle{ }^{\circ} \mathrm{C}\right\rangle\end{array}$ & $\begin{array}{l}\text { Tfg } \\
\left({ }^{\circ} \mathrm{C}\right)\end{array}$ & $\begin{array}{l}\mathrm{Th} \\
\left({ }^{\circ} \mathrm{C}\right)\end{array}$ & $\begin{array}{c}\text { Fração vol. } \\
\text { da bolha }\end{array}$ & $X_{\mathrm{NaCl}}$ & $\begin{array}{c}\text { Salinidade } \\
(\% \text { em peso } \\
\mathrm{NaCl} \text { equiv.) }\end{array}$ & $\begin{array}{c}\text { Ponto } \\
\text { critico } \\
\left({ }^{\circ} \mathrm{C}\right) \\
\end{array}$ & $\begin{array}{c}\text { Densidade } \\
\left(\mathrm{g} / \mathrm{cm}^{3}\right)\end{array}$ & Observaçöes \\
\hline \multicolumn{10}{|c|}{ Aquosas secundárias } \\
\hline 5 & $-31,2$ & $-7,2$ & 237,7 & & 0,036 & 10,7 & 472,5 & $\overline{0,914}$ & \\
\hline 7 & $-36,8$ & $-7,1$ & 217,9 & 0,15 & 0,035 & 10,6 & 471,4 & 0,932 & \\
\hline 13 & $-38,2$ & $-1,0$ & 207,7 & 0,15 & 0,005 & 1,7 & 389,0 & 0,870 & \\
\hline 14 & $-42,0$ & $-8,7$ & & 0,15 & 0,042 & $\{2,5$ & 488,6 & & \\
\hline 17 & $-36,9$ & $-7,6$ & 196,1 & 0,15 & 0,038 & 11,2 & 476,9 & 0,956 & \\
\hline 18 & $-24,7$ & $-7,1$ & 142,2 & 0,15 & 0,035 & 10,6 & 471,4 & 1,001 & \\
\hline 19 & $-32,2$ & -6.1 & 193,5 & 0,15 & 0,031 & 9,3 & 459,9 & 0,944 & \\
\hline 20 & $-33,5$ & $-7,3$ & 499,1 & & 0,036 & 10,9 & 473,6 & 0,997 & \\
\hline 21 & $-37,3$ & $-7,3$ & $\$ 41,7$ & & 0,036 & 10,9 & 473,6 & $\uparrow, 003$ & \\
\hline 22 & $-36,6$ & $-7,7$ & $\{45,2$ & & 0,038 & $i \uparrow, 3$ & 478,0 & 1,004 & \\
\hline 23 & $-30,3$ & $-7,5$ & १2,7 & & 0,037 & 11,1 & 475,8 & 0,995 & \\
\hline 24 & $-29,9$ & $-7,6$ & 152,4 & & 0,038 & $1 \uparrow, 2$ & 476,9 & 0,996 & \\
\hline 25 & $-41,7$ & $-0,6$ & & 0,15 & 0,003 & 1,0 & 383,0 & & \\
\hline 3 & $-40,4$ & $-7,2$ & & 0,15 & 0,036 & 10,7 & 472,5 & & \\
\hline 34 & $-28,6$ & $-7,2$ & 166,9 & 0,15 & 0,036 & 10,7 & 472,5 & 0,980 & \\
\hline 35 & $-23,1$ & $-7,5$ & & 0,15 & 0,037 & 11,1 & 475,8 & & \\
\hline 36 & $-42,3$ & $-2,2$ & & 0,15 & 0,011 & 3,6 & 407,2 & & \\
\hline 44 & $-42,8$ & & & 0.15 & & & & & \\
\hline 37 & $-38,6$ & $-1,0$ & & 0,15 & 0,005 & 1,7 & 389,9 & & \\
\hline 47 & $-39,4$ & $-1,3$ & & & 0,007 & 2,1 & 393,6 & & \\
\hline 48 & $-29,9$ & $.0,5$ & & 0.15 & 0,003 & 0,8 & 381,5 & & \\
\hline 50 & & $-0,9$ & 147,0 & & 0,005 & 1,5 & 387,5 & 0,935 & \\
\hline
\end{tabular}


AM-35 - CAMPO 4 - TOPÁZIO - GREISEN TABULAR - ESTAGIO TRANSICIONA

\begin{tabular}{|c|c|c|c|c|c|c|c|c|c|c|c|}
\hline No. IF & $\begin{array}{c}\mathrm{TE} \\
\left({ }^{\circ} \mathrm{C}\right)\end{array}$ & $\begin{array}{l}\text { Tfg } \\
\left({ }^{\circ} \mathrm{C}\right)\end{array}$ & $\begin{array}{c}\mathrm{TfCO} 2 \\
\left({ }^{\circ} \mathrm{C}\right)\end{array}$ & $\begin{array}{l}\mathrm{TfCl} \\
\left({ }^{\circ} \mathrm{C}\right)\end{array}$ & $\begin{array}{l}\text { Th } \\
\left({ }^{\circ} \mathrm{C}\right)\end{array}$ & $\begin{array}{c}\text { Fraçäo vol. } \\
\text { da bolha }\end{array}$ & $\mathbf{X}_{\mathrm{NaCl}}$ & $\begin{array}{c}\text { Salinidade } \\
(\% \text { em peso } \\
\mathrm{NaCl} \text { equiv.) }\end{array}$ & $\begin{array}{l}\text { Ponto } \\
\text { crítico } \\
\left({ }^{\circ} \mathrm{C}\right)\end{array}$ & $\begin{array}{c}\text { Densidade } \\
\left(\mathrm{g} / \mathrm{cm}^{3}\right\rangle\end{array}$ & Observaçôes \\
\hline \multicolumn{12}{|c|}{ Aquo-carbônicas primárias } \\
\hline 1 & $-32,6$ & $-7,8$ & $-56,7$ & 7,2 & 354,0 & 0,30 & & 5,4 & & & \\
\hline \multicolumn{12}{|c|}{ Aquosas primárias } \\
\hline 2 & $.42,6$ & $-0,3$ & & & 326,2 & 0,30 & 0,002 & 0,5 & 378,5 & 0,633 & \\
\hline 4 & & $-1,1$ & & & 211,3 & 0,30 & 0,006 & 1,8 & 390,5 & 0,867 & \\
\hline 5 & & $-0,3$ & & & 324,1 & 0.20 & 0,002 & 0,5 & 378,5 & 0,638 & \\
\hline 8 & & & & & 311,1 & 0,10 & & & & & \\
\hline 9 & & & & & 339,0 & 0,10 & & & & & \\
\hline 10 & & & & & & 0,10 & & & & & \\
\hline 11 & & & & & & 0,25 & & & & & \\
\hline 12 & & & & & & 0,10 & & & & & \\
\hline 13 & & & & & & 0.40 & & & & & \\
\hline 14 & & & & & & 0,40 & & & & & \\
\hline 15 & & & & & & 0,20 & & & & & \\
\hline 16 & & & & & & 0,05 & & & & & \\
\hline 17 & & & & & 352,8 & & & & & & \\
\hline
\end{tabular}

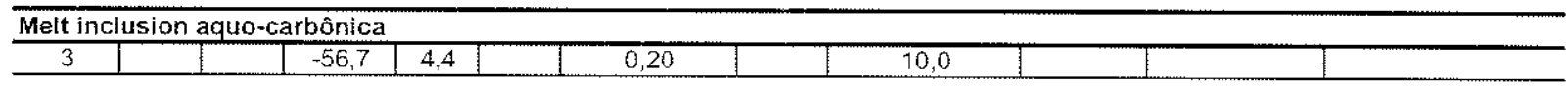

\begin{tabular}{|c|c|c|c|c|c|c|c|}
\hline \multicolumn{8}{|c|}{ Melt inclusions aquosas } \\
\hline $\begin{array}{l}6 \\
7\end{array}$ & $-27,1$ & $-0,6$ & $\begin{array}{l}0,10 \\
0,10\end{array}$ & 0,003 & 1,0 & 383,0 & 0,676 \\
\hline
\end{tabular}


AM-35 - CAMPO 5 - QUARTZO - GREISEN TABULAR - ESTAGIO TRANSICIONAL

\begin{tabular}{|c|c|c|c|c|c|c|c|c|c|c|c|}
\hline No.IF & $\begin{array}{l}\text { TE } \\
\left({ }^{\circ} \mathrm{C}\right)\end{array}$ & $\begin{array}{l}\mathrm{Tfg} \\
\left({ }^{\circ} \mathrm{C}\right)\end{array}$ & $\begin{array}{c}\mathrm{TfCO} 2 \\
\left({ }^{\circ} \mathrm{C}\right)\end{array}$ & $\begin{array}{l}\text { TfCl } \\
\left({ }^{\circ} \mathrm{C}\right)\end{array}$ & $\begin{array}{l}\text { Th } \\
\left({ }^{\circ} \mathrm{C}\right)\end{array}$ & $\begin{array}{c}\text { Fraçāo vol. } \\
\text { da bolha }\end{array}$ & $\overline{\mathrm{X}_{\mathrm{NaCl}}}$ & $\begin{array}{c}\text { Salinidade } \\
(\% \text { em peso } \\
\mathrm{NaCl} \text { equiv. }\end{array}$ & $\begin{array}{l}\text { Ponto } \\
\text { crítico } \\
\left({ }^{\circ} \mathrm{C}\right) \\
\end{array}$ & $\begin{array}{c}\text { Densidade } \\
\left(\mathrm{g} / \mathrm{cm}^{3}\right)\end{array}$ & Observaçöes \\
\hline \multicolumn{12}{|c|}{ Aquosas primárias 1} \\
\hline 11 & $-36,6$ & $-4,8$ & & & & & 0,025 & 7,5 & 443,8 & & \\
\hline 12 & $-35,1$ & $-3,8$ & & & & & 0,020 & 6,1 & 430,4 & & \\
\hline 13 & $-35,6$ & $-4,8$ & & & & & 0,025 & 7.5 & 443,8 & & \\
\hline 14 & $-38,1$ & $-5,3$ & & & & & 0,027 & 8,2 & 450,2 & & \\
\hline 16 & $-37,0$ & $-4,2$ & & & & & 0,022 & 6,7 & 435,8 & & \\
\hline 17 & $-33,6$ & $-4,1$ & & & & & 0,021 & 6,5 & 434,5 & & \\
\hline 18 & $-36,6$ & $-4,3$ & & & & & 0,022 & 6,8 & 437,2 & & \\
\hline 19 & $-37,3$ & $-3,5$ & & & & & 0,018 & 5,6 & 426,2 & & \\
\hline 20 & $-40,3$ & $-3,6$ & & & & & 0,019 & 5,8 & 427,6 & & \\
\hline 22 & & $-2,7$ & & & & & 0,014 & 4,4 & $4 \uparrow 4,6$ & & RAMAN- $\mathrm{COm} \mathrm{CO}_{2}$ \\
\hline 24 & & $-2,2$ & & & & 0,10 & 0.011 & 3,6 & 407,2 & & \\
\hline
\end{tabular}

\begin{tabular}{|c|c|c|c|c|c|c|c|c|c|}
\hline & & 52 & & & & & & & \\
\hline 1 & & $-0,7$ & 257,1 & 0,10 & 0,004 & $\overline{1,2}$ & 384,5 & 0,790 & \\
\hline 4 & & $-0,2$ & 311,6 & 0,40 & 0,001 & 0,3 & 377,0 & 0,666 & \\
\hline 5 & & $-0,7$ & 319,7 & 0,45 & 0,004 & 1,2 & 384,5 & 0,661 & \\
\hline 6 & & $-0,7$ & 306,3 & 0,20 & 0,004 & 1,2 & 384,5 & 0,692 & \\
\hline 7 & & $-0,4$ & 234,5 & 0,10 & 0,002 & 0,7 & 380,0 & 0,822 & necking down \\
\hline 8 & $-26,5$ & $-0,4$ & 295,7 & 0,15 & 0,002 & 0,7 & 380,0 & 0,708 & \\
\hline 10 & $-31,7$ & $-5,6$ & 331,9 & 0,20 & 0,028 & 8,6 & 453,9 & 0,760 & \\
\hline 23 & & $-0,4$ & & 0,10 & 0,002 & 0,7 & 380,0 & & \\
\hline 41 & $-52,4$ & $-19,5$ & 111,8 & 0,10 & 0,080 & 22,0 & 600,4 & 1,106 & RAMAN - sem $\mathrm{CO}_{2}$ e $\mathrm{CH}_{4}$ \\
\hline 42 & & $-0,4$ & 310,4 & 0,30 & 0,002 & 0,7 & 380,0 & 0,674 & \\
\hline 45 & & $-0,3$ & & 0,10 & 0,002 & 0,5 & 378,5 & & \\
\hline 46 & & $-0,5$ & & & 0,003 & 0,8 & 381,5 & & \\
\hline 47 & & $-0,3$ & 135,6 & 0,10 & 0,002 & 0,5 & 378,5 & 0,938 & \\
\hline 48 & & & & 0,90 & & & & & \\
\hline 50 & $-36,2$ & $-4,0$ & 200,2 & 0,0 & 0,021 & 6,4 & 433,1 & 0,917 & \\
\hline 51 & & $-0,4$ & 235,8 & 0,20 & 0,002 & 0,7 & 380,0 & 0,820 & \\
\hline 52 & & 0,8 & & 0,30 & 0,004 & 1,3 & 386,0 & & \\
\hline 53 & & $-5,0$ & 265,6 & 0,90 & 0,025 & 7,8 & 446,4 & 0,854 & para o gás/RAMAN-sem $\mathrm{CO}_{2} \in \mathrm{CH}_{4}$ \\
\hline 54 & & $-0,8$ & 272,2 & 0,15 & 0,004 & 1,3 & 386,0 & 0,765 & \\
\hline 55 & & $-5,0$ & & 0,90 & 0,025 & 7,8 & 446,4 & & para o gàs/RAMAN-sem $\mathrm{CO}_{2}$ e $\mathrm{CH}_{4}$ \\
\hline
\end{tabular}


AM-35 - CAMPO 5 - QUARTZO (coni)

\begin{tabular}{|c|c|c|c|c|c|c|c|c|c|c|c|}
\hline No. IF & $\begin{array}{l}\mathrm{TE} \\
\left({ }^{\circ} \mathrm{C}\right)\end{array}$ & $\begin{array}{l}\text { Tfg } \\
\left({ }^{\circ} \mathrm{C}\right)\end{array}$ & $\begin{array}{c}\mathrm{TfCO} 2 \\
\left({ }^{\circ} \mathrm{C}\right)\end{array}$ & $\begin{array}{l}\mathrm{TfCl} \\
\left({ }^{\circ} \mathrm{C}\right)\end{array}$ & $\begin{array}{l}\text { Th } \\
\left({ }^{\circ} \mathrm{C}\right)\end{array}$ & $\begin{array}{c}\text { Fração vol. } \\
\text { da bolha }\end{array}$ & $\mathrm{X}_{\mathrm{NaCl}}$ & $\begin{array}{l}\text { Salinidade } \\
\text { (\% em peso } \\
\text { NaCl equiv.) }\end{array}$ & $\begin{array}{l}\text { Ponto } \\
\text { crítico } \\
\left({ }^{\circ} \mathrm{C}\right) \\
\end{array}$ & $\begin{array}{c}\text { Densidade } \\
\left(\mathrm{g} / \mathrm{cm}^{3}\right)\end{array}$ & Observaçōes \\
\hline \multicolumn{12}{|c|}{ Aquo-carbōnicas primárias } \\
\hline 2 & & & & 7,3 & & & & 5,2 & & & \multirow{6}{*}{ RAMAN-com $\mathrm{CO}_{2} \in \mathrm{CH}_{4}$} \\
\hline 3 & $-28,2$ & & $-57,3$ & 5,4 & 378,6 & 0,30 & & 8,5 & & & \\
\hline 15 & & & $-57,2$ & & & & & & & & \\
\hline 43 & & & $-57,4$ & 7,0 & 358,5 & 0,45 & & 5,8 & & & \\
\hline 44 & & & -57.5 & 7,4 & 355,2 & 0,45 & & 5,1 & & & \\
\hline 49 & & & $-57,4$ & 6,9 & & 0,90 & & 5,9 & & & \\
\hline \multicolumn{12}{|c|}{ Aquosas secundárias 1} \\
\hline 9 & $-25,0$ & -0.1 & & & 298,6 & 0,30 & 0,001 & 0,2 & 375,6 & \multicolumn{2}{|l|}{0,693} \\
\hline \multicolumn{12}{|c|}{ Aquosas secundárias 2} \\
\hline 25 & $-36,0$ & $-0,7$ & & & 285,7 & 0,20 & 0,004 & 7,2 & 384,5 & 0,736 & \\
\hline 26 & & $-0,7$ & & & 164,4 & 0,10 & 0,004 & 1,2 & 384,5 & $0,9\} 6$ & \\
\hline 27 & & $-0,6$ & & & 174,3 & 0,10 & 0,003 & 1,0 & 383,0 & 0,904 & \\
\hline 28 & & $-0,7$ & & & & & 0,004 & 1,2 & 384,5 & & \\
\hline 29 & & $-0,1$ & & & & & 0,001 & 0,2 & 375,6 & & \\
\hline 30 & & $-0,8$ & & & & & 0,004 & 1,3 & 386,0 & & \\
\hline 31 & & $-0,6$ & & & & & 0,003 & 1,0 & 383,0 & & \\
\hline 32 & & $-0,9$ & & & & & 0,005 & 1,5 & 387,5 & & \\
\hline 33 & & $-1,0$ & & & & & 0,005 & 1,7 & 389,0 & & \\
\hline 34 & & $-0,8$ & & & & & 0,004 & 1,3 & 386,0 & & \\
\hline 35 & & $-0,6$ & & & & & 0,003 & 1,0 & 383,0 & & \\
\hline 36 & & $-0,8$ & & & & & 0,004 & 1,3 & 386,0 & & \\
\hline 37 & & $-0,7$ & & & 275,6 & & 0,004 & 1,2 & 384,5 & 0,756 & \\
\hline 38 & & $-1,3$ & & & & & 0,007 & 2,1 & 393,6 & & \\
\hline 39 & & $-1,1$ & & & & & 0,006 & 1,8 & 390,5 & & \\
\hline 40 & & $-1,1$ & & & & & 0,006 & 1,8 & 390,5 & & \\
\hline $\begin{array}{l}A \\
B\end{array}$ & & & & & $\begin{array}{l}102,5 \\
25,6\end{array}$ & & & & & & \\
\hline c & & & & & $\{37,0$ & & & & & & \\
\hline D & & & & & 137,4 & & & & & & \\
\hline$E$ & & & & & 137,5 & & & & & & \\
\hline$F$ & & & & & 150,8 & & & & & & \\
\hline $\begin{array}{l}G \\
H\end{array}$ & & & & & $\begin{array}{l}243,0 \\
253,6\end{array}$ & & & & & & \\
\hline 1 & & & & & 277,7 & & & & & & \\
\hline
\end{tabular}


AM-35 - CAMPO 6 - QUARTZO - GREISEN TAEULAR - ESTAGIO TRANSICIONAL

\begin{tabular}{|c|c|c|c|c|c|c|c|c|c|}
\hline No.IF & $\begin{array}{l}\mathrm{TE} \\
\left({ }^{\circ} \mathrm{C}\right)\end{array}$ & $\begin{array}{l}\text { Tfg } \\
\left({ }^{\circ} \mathrm{C}\right)\end{array}$ & $\begin{array}{l}\text { Th } \\
\left({ }^{\circ} \mathrm{C}\right)\end{array}$ & $\begin{array}{c}\text { Fração vol. } \\
\text { da bolha }\end{array}$ & $\mathrm{X}_{\mathrm{NaCl}}$ & $\begin{array}{c}\text { Salinidade } \\
(\% \text { em peso } \\
\text { NaCl equiv.) }\end{array}$ & $\begin{array}{l}\text { Ponto } \\
\text { crítico } \\
\left({ }^{\circ} \mathrm{C}\right) \\
\end{array}$ & $\begin{array}{c}\text { Densidade } \\
\left(\mathrm{g} / \mathrm{cm}^{3}\right)\end{array}$ & Observaçōes \\
\hline \multicolumn{10}{|c|}{ Aquosas primárias } \\
\hline 1 & & $-0,2$ & 213,0 & 0,10 & 0,001 & 0,3 & 377,0 & 0,851 & \multirow{22}{*}{$\begin{array}{c}\text { feiçōes de escape } \\
\text { para o gás } \\
\text { para o gás }\end{array}$} \\
\hline 2 & $-31,7$ & & & 0,30 & & & & & \\
\hline 4 & & & 197,6 & 0,10 & & & & & \\
\hline 7 & $-33,4$ & $-2,3$ & & 0,10 & 0,012 & 3,8 & 408,7 & & \\
\hline 8 & $-39,0$ & $-0,5$ & 332,6 & 0,30 & 0,003 & 0,8 & 381,5 & 0,623 & \\
\hline 9 & $-39,2$ & $-0,5$ & 344,3 & 0,40 & 0,003 & 0,8 & 381,5 & 0.592 & \\
\hline 10 & & $-2,5$ & 352,0 & 0,75 & 0,013 & 4,1 & 411,7 & 0,637 & \\
\hline 11 & & $-1,9$ & 401,0 & 0,60 & 0,010 & 3,1 & 402,7 & 0,478 & \\
\hline 12 & & $-1,1$ & & 0,55 & 0,006 & 1,8 & 390,5 & & \\
\hline 13 & & $-0,6$ & 234,8 & 0,20 & 0,003 & 1,0 & 383,0 & 0,825 & \\
\hline 14 & & $-0,4$ & 226,1 & 0,10 & 0,002 & 0,7 & 380,0 & 0,835 & \\
\hline 19 & & & 139,5 & 0,10 & & & & & \\
\hline 20 & & $-1,5$ & 368,2 & 0,70 & 0,008 & 2,5 & 396,6 & 0,560 & \\
\hline 21 & & $-2,1$ & 376,5 & 0,60 & 0,001 & 3,4 & 405,7 & 0,559 & \\
\hline 23 & & $-0,4$ & 273,5 & 0,20 & 0,002 & 0,7 & 380,0 & 0,753 & \\
\hline 24 & & $-4,7$ & 202,3 & 0,10 & 0.024 & 7,4 & 442,5 & 0,923 & \\
\hline 25 & & $-0,4$ & 290,4 & 0,10 & 0,002 & 0,7 & 380,0 & 0,719 & \\
\hline 26 & & $-1,4$ & 355,4 & 0,45 & 0,007 & 2,3 & 395,1 & 0,592 & \\
\hline 27 & & $-0,5$ & $\$ 91,9$ & 0,10 & 0,003 & 0,8 & 381,5 & 0,883 & \\
\hline 28 & & & & 0,40 & & & & & \\
\hline 29 & & & & 0,40 & & & & & \\
\hline 3$\}$ & & & 289,7 & & & & & & \\
\hline
\end{tabular}

\begin{tabular}{|c|c|c|c|c|c|c|c|}
\hline Melt in & aquo & & & & & & \\
\hline 3 & $-0,4$ & & 0,10 & 0,002 & 0,7 & 380,0 & 0,815 \\
\hline 17 & $-0,3$ & & 0,10 & 0,002 & 0,5 & 378,5 & 0,896 \\
\hline 22 & $-0,5$ & & 0,15 & 0,003 & 0,8 & 381,5 & \\
\hline Aquos & Járias & & & & & & \\
\hline 15 & & 143,1 & 0,10 & & & & \\
\hline 16 & & $14 \uparrow, 4$ & 0,10 & & & & \\
\hline 18 & & 151,1 & 0,10 & & & & \\
\hline
\end{tabular}

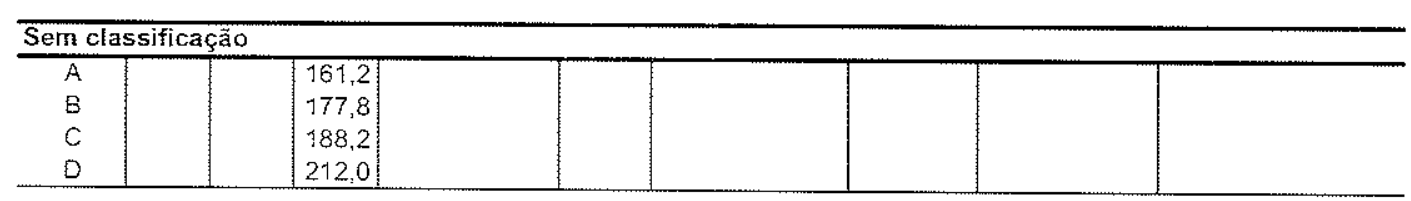


AM-130 - CAMPO 1- TOPÁZIO - STOCKWORK DE GREISEN- ESTȦGIO PÓS-MAGMÁTICO

\begin{tabular}{|c|c|c|c|c|c|c|c|c|c|c|c|c|c|c|c|c|}
\hline No. IF & $\begin{array}{c}\mathrm{TE} \\
\left({ }^{\circ} \mathrm{C}\right)\end{array}$ & $\begin{array}{l}\text { Tfg } \\
\left({ }^{\circ} \mathrm{C}\right)\end{array}$ & $\begin{array}{l}\mathrm{TfCO} 2 \\
\left({ }^{\circ} \mathrm{C}\right)\end{array}$ & $\begin{array}{l}\mathrm{TfCl} \\
\left({ }^{\circ} \mathrm{C}\right)\end{array}$ & $\begin{array}{c}\text { ThCO2 } \\
\left({ }^{\circ} \mathrm{C}\right)\end{array}$ & $\begin{array}{l}\text { Th } \\
\left({ }^{\circ} \mathrm{C}\right)\end{array}$ & $\begin{array}{c}\text { Fração vol. } \\
\text { da boitha }\end{array}$ & $X_{\mathrm{H} 2 \mathrm{O}}$ & $\overline{x_{C O Z}}$ & $\mathrm{X}_{\mathrm{NaCl}}$ & $\begin{array}{l}\text { Salinidade } \\
(\% \text { em peso } \\
\text { NaCl equiv.) }\end{array}$ & $\begin{array}{c}\text { Densidade } \\
\mathrm{H}_{2} \mathrm{O} \\
\left(\mathrm{g} / \mathrm{cm}^{3}\right) \\
\end{array}$ & $\begin{array}{l}\text { Ponto } \\
\text { crítico } \\
\left({ }^{\circ} \mathrm{C}\right) \\
\end{array}$ & $\begin{array}{c}\text { Densidade } \\
\mathrm{CO}_{2} \\
\left(\mathrm{~g} / \mathrm{cm}^{3}\right)\end{array}$ & $\begin{array}{c}\text { Densidade } \\
\text { total } \\
\text { (g/cm } 3) \\
\end{array}$ & Observaçöes \\
\hline \multicolumn{17}{|c|}{ Aquo-carbōnicas primárias } \\
\hline 2 & $\begin{array}{r}-34.6 \\
-34.9\end{array}$ & -6.0 & $\begin{array}{l}-56.0 \\
-56.7\end{array}$ & 3.1 & & $44,2.1$ & 0.20 & 0.894 & 0.079 & 0.027 & 8.9 & 1.058 & & 0.171 & 0.570 & hornog. ọ/gáshomog. por expanisão do CO2 \\
\hline 3 & & & & 7.5 & & & 0.50 & & & & 4.9 & & & & & \\
\hline 4 & -34.6 & & $-56,8$ & 4.3 & & 422.0 & 0.40 & & & & 10.1 & & & & & \\
\hline 6 & -34.4 & & -56.6 & 5.2 & & & 0.30 & & & & 8.8 & & & & & \\
\hline 7 & -33.8 & & -56.9 & 8.6 & & 364.8 & 0.55 & & & & 28 & & & & & homogeneiz. para o gás. próx. critico \\
\hline 8 & & & -56.9 & 7.3 & & 384.2 & 0.55 & & & & 5.2 & & & & & homogeneiz. para o gás \\
\hline 9 & & & & 7.9 & & & 0.50 & & & & 4.9 & & & & & \\
\hline 10 & & & -56.7 & 6.8 & & 408.2 & 0.55 & & & & $6 . \hat{1}$ & & & & & homogeneiz. para o gás \\
\hline 19 & & & & 6.9 & & 423.4 & 0.55 & & & & 5.9 & & & & & homogeneiz. para o gás \\
\hline 12 & -34.8 & & .56 .8 & 6.7 & 19.8 & & 0.45 & 0.920 & 0.061 & 0.019 & 6.3 & 1.038 & & 0.192 & 0.657 & \\
\hline 13 & -36.6 & -4.0 & & & & 415.6 & 0.40 & & & 0.021 & 6.4 & & & & & \\
\hline 16 & & & -57.5 & 7.9 & & 387.8 & 0.55 & & & & 4. & & & & & homogeneiz, para o gàs \\
\hline 19 & & & & 4.2 & & & 0.30 & & & & 10.3 & & & & & \\
\hline 20 & & & & 8.0 & & & 0.45 & & & & 3.9 & & & & & \\
\hline 22 & & & & 6.8 & & & 0.50 & & & & 6.1 & & & & & \\
\hline 29 & & & -57.7 & 6.3 & & & 0.35 & & & & 7.0 & & & & & \\
\hline 30 & $-35,7$ & & .57 .8 & 3.1 & & & 0.30 & & & & 11.8 & & & & & \\
\hline 32 & & & -57.8 & 7.2 & & 436.7 & 0.55 & & & & 5.4 & & & & & homogeneiz. para o gás \\
\hline 33 & & & -57.3 & $9, ?$ & & & 0.40 & & & & 1.8 & & & & & \\
\hline 36 & -36.5 & & -57.7 & 6.8 & 19.4 & 394.2 & 0.55 & 0.895 & 0.087 & 0.018 & 6.1 & 1.036 & & 0.189 & 0.571 & nomog. p/gás/homoc por expansāo do CO2 \\
\hline
\end{tabular}

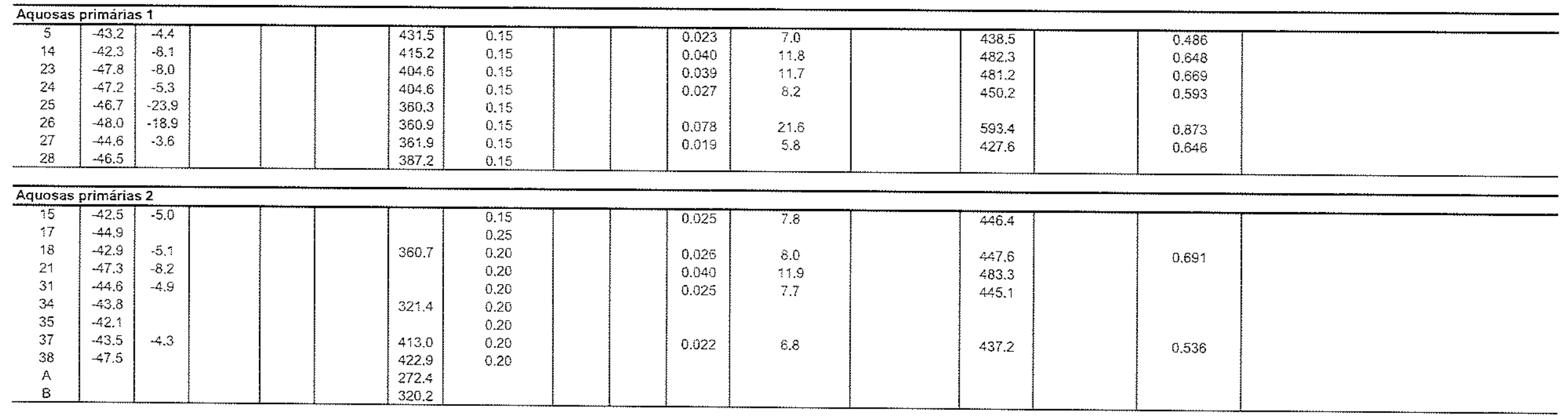




\begin{tabular}{|c|c|c|c|c|c|c|c|c|c|}
\hline No.IF & $\begin{array}{l}\mathrm{TE} \\
\left({ }^{\circ} \mathrm{C}\right)\end{array}$ & $\begin{array}{l}\mathrm{Tfg} \\
\left({ }^{\circ} \mathrm{C}\right)\end{array}$ & $\begin{array}{l}\text { Th } \\
\left({ }^{\circ} \mathrm{C}\right\rangle\end{array}$ & $\begin{array}{c}\text { Fração vol. } \\
\text { da botha }\end{array}$ & $\mathrm{x}_{\mathrm{NaCl}}$ & $\begin{array}{c}\text { Salinidade } \\
\text { (\% em peso } \\
\mathrm{NaCl} \text { equiv.) } \\
\end{array}$ & $\begin{array}{l}\text { Ponto } \\
\text { critico } \\
\left({ }^{\circ} \mathrm{C}\right) \\
\end{array}$ & $\begin{array}{c}\text { Densidade } \\
\left(\mathrm{g} / \mathrm{cm}^{3}\right)\end{array}$ & Observaçōes \\
\hline \multicolumn{10}{|c|}{ Aquosas secundärias } \\
\hline 1 & -38.8 & -0.5 & 260.3 & 0.10 & 0.003 & 0.8 & 381.5 & 0.780 & \\
\hline 2 & $-38,0$ & -2.1 & 214.7 & 0.15 & 0.011 & 3.4 & 405.7 & 0.877 & \\
\hline 3 & -39.2 & -0.4 & 159.7 & 0.10 & 0.002 & 0.7 & 380.0 & 0.917 & \\
\hline 4 & & -2.6 & 404.5 & 0.40 & 0.013 & 4.2 & 413.1 & 0.496 & \\
\hline 5 & & -0.4 & 177.2 & 0.10 & 0.002 & 0.7 & 380.0 & 0.899 & \\
\hline 6 & -47.2 & -0.4 & & 0.70 & 0,002 & 0.7 & & & \\
\hline 7 & & -0.6 & 298.7 & 0.20 & 0.003 & 1.0 & 383.0 & 0.706 & \\
\hline 8 & & -0.8 & 295.8 & 0.20 & 0.004 & $\uparrow, 3$ & 386.0 & 0.718 & \\
\hline 9 & $-24,8$ & & 124.2 & 0.10 & & & & & metê-estáve: \\
\hline 10 & & -1.8 & 415.1 & 0.60 & & & & & homog. próxina ao critico \\
\hline 11 & & -2.0 & 378.8 & 0.40 & $0.0 \div 0$ & 3,3 & 404.2 & 0.548 & \\
\hline 12 & & -2.5 & 407.5 & 0.40 & 0.013 & 4.1 & 411.7 & 0.482 & \\
\hline 13 & & -1.9 & 349.0 & 0.30 & 0.010 & 3.1 & 402.7 & 0.625 & \\
\hline $1 \frac{4}{4}$ & & -1.8 & 356.8 & 0.20 & 0.009 & 3.0 & 401.2 & 0.602 & \\
\hline 16 & & -1.9 & $4 \geqq 2.2$ & 0.50 & & & & & nomogeneiz. para o gás \\
\hline 17 & & -1.9 & 409.5 & 0.65 & & & & & homogeneiz. para o gás \\
\hline 18 & & -1.8 & 372.2 & 0.40 & 0.009 & 3.0 & 401.2 & 0.560 & \\
\hline 19 & & -1.7 & 299.8 & 0.20 & 0.009 & 28 & 399.7 & 0.732 & \\
\hline 20 & & .0 .5 & 161.6 & 0.10 & 0.003 & 0.8 & 381.5 & 0.916 & \\
\hline 23 & & -2.0 & 379.9 & 0.45 & 0.010 & 3.3 & 404.2 & 0.545 & \\
\hline 22 & & -2.7 & & 0.80 & 0.014 & 4.4 & 414.6 & & \\
\hline 23 & & .0 .5 & 335.4 & 0.20 & 0.003 & 0.8 & 381.5 & 0.615 & \\
\hline 24 & & -1.8 & 324.4 & 0.70 & 0.009 & 3.0 & 401.2 & 0.681 & homogeneiz. parã o gás \\
\hline 25 & & -3.8 & & 0.90 & 0.020 & 6.1 & 430.4 & 0.734 & \\
\hline
\end{tabular}




\begin{tabular}{|c|c|c|c|c|c|c|c|c|c|}
\hline No.IF & $\begin{array}{l}\mathrm{TE} \\
\left({ }^{\circ} \mathrm{C}\right)\end{array}$ & $\begin{array}{l}{ }^{\mathrm{Iffg}} \\
\left({ }^{\circ} \mathrm{C}\right)\end{array}$ & $\begin{array}{l}\text { Th } \\
\left({ }^{\circ} \mathrm{C}\right)\end{array}$ & $\begin{array}{c}\text { Fraçāo vol. } \\
\text { da botha }\end{array}$ & $x_{\text {NaCl }}$ & $\begin{array}{c}\text { Salinidade } \\
\text { (\% em peso } \\
\mathrm{NaCl} \text { equiv. }) \\
\end{array}$ & $\begin{array}{l}\text { Ponto } \\
\text { crítico } \\
\left({ }^{\circ} \mathrm{C}\right) \\
\end{array}$ & $\begin{array}{c}\text { Densidade } \\
\left(\mathrm{g} / \mathrm{cm}^{3}\right)\end{array}$ & Observaçōes \\
\hline \multicolumn{10}{|c|}{ Aquosas primárias } \\
\hline 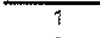 & -33.1 & .3 .8 & 432.8 & 0.50 & 0.020 & 6.1 & 430.4 & & \\
\hline 2 & $-33,6$ & -3.8 & $21 \div .1$ & 0.10 & 0.020 & 6.1 & 430.4 & 0.904 & \\
\hline 3 & -33.8 & -4.0 & 315.0 & 0.30 & 0.021 & 6.4 & 433.1 & 0.756 & \\
\hline 4 & & -4.0 & 327.9 & 0.30 & 0.023 & 6.4 & 433.1 & 0.731 & \\
\hline 5 & -34.2 & -2.3 & 371.1 & 0.55 & 0.012 & 3.8 & 408.7 & 0.581 & para ogás \\
\hline 6 & -33.9 & -4.0 & 386.6 & 0.30 & 0.02 & 6.4 & 433.1 & 0.597 & \\
\hline 7 & & -4.2 & & 0.20 & 0.022 & 8.7 & 435.8 & & \\
\hline 8 & -22.8 & .4 .9 & 403.5 & 0.40 & 0.025 & 7.7 & 445.1 & 0.583 & \\
\hline 9 & & -1.4 & 385.4 & 0.70 & 0.007 & 2.3 & 395.1 & 0.506 & \\
\hline 10 & -41.5 & $-4,0$ & 411.0 & 0.40 & 0.021 & 6.4 & 433.1 & 0.531 & \\
\hline 11 & -36.0 & -4.5 & 327.4 & 0.10 & 0.023 & 7.1 & 439.9 & 0.744 & \\
\hline 12 & & -3.5 & 179.6 & 0.10 & 0.002 & 5.6 & 425.2 & 0.931 & \\
\hline 13 & -47.6 & & 395.3 & 0.30 & & & & & \\
\hline 14 & -44.2 & .9 .3 & & 0.60 & 0.045 & 13.2 & 494.7 & & \\
\hline 15 & & -2.5 & & 0.70 & 0.013 & 4.9 & 411.7 & & \\
\hline 16 & -34.9 & -3.0 & & 0.10 & 0.015 & 4.9 & 419.0 & & \\
\hline 17 & -35.6 & -4.7 & 435.0 & 0.20 & 0.024 & 7.4 & 442.5 & 0.487 & \\
\hline 18 & & -5.5 & 305.1 & 0.10 & 0.028 & 8.5 & 452.7 & 0.804 & \\
\hline 19 & & & 425.3 & 0.20 & & & & & \\
\hline 20 & & -10.4 & 329.2 & 0.10 & 0.049 & 14.4 & 505.6 & 0.841 & \\
\hline 21 & & -5.2 & & 0.10 & 0.026 & 8.1 & 448.9 & & \\
\hline 22 & & -5.5 & & 0.10 & 0.028 & 8.5 & 452.7 & & \\
\hline 23 & -11.7 & -5.7 & & 0.10 & 0.029 & 8.8 & 455.1 & & \\
\hline 24 & -51.3 & -5.7 & 134.0 & 0.10 & 0.029 & 8.8 & 455.1 & 0.994 & \\
\hline 25 & & & & 0.30 & & & & & \\
\hline 26 & & & & 0.10 & & & & & \\
\hline 28 & -32.9 & -13.9 & & 0.10 & 0.062 & 17.7 & 540.0 & & \\
\hline$\hat{A}$ & & & 78,7 & 0.10 & & & & & meta-estável \\
\hline
\end{tabular}




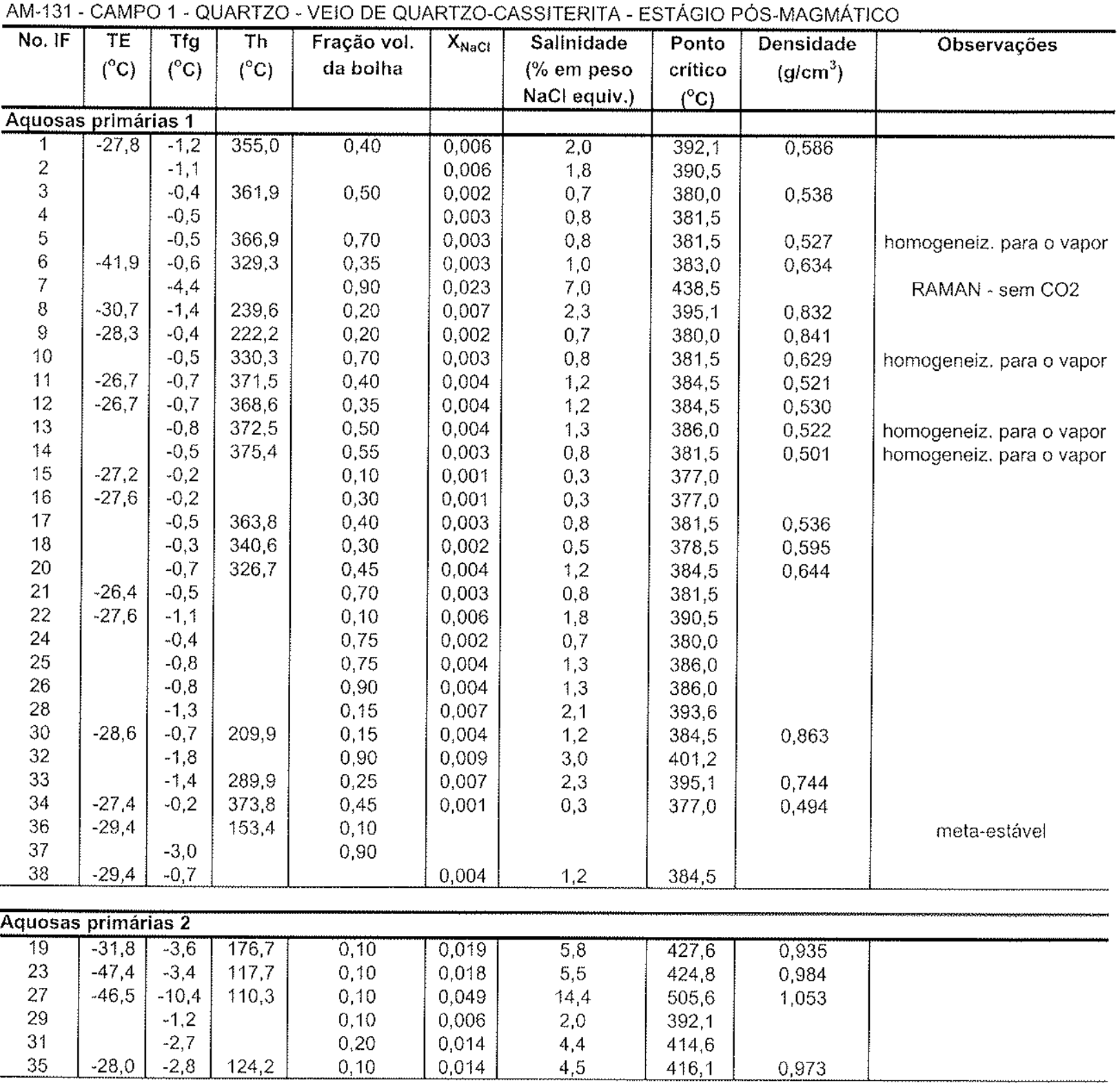




\begin{tabular}{|c|c|c|c|c|c|c|c|c|c|c|c|}
\hline No. IF & $\begin{array}{c}\mathrm{TE} \\
\left({ }^{\circ} \mathrm{C}\right)\end{array}$ & $\begin{array}{l}\text { Tfg } \\
\left({ }^{\circ} \mathrm{C}\right)\end{array}$ & $\begin{array}{c}\mathrm{TfCO} 2 \\
\left({ }^{\circ} \mathrm{C}\right)\end{array}$ & $\begin{array}{l}\mathrm{TfCl} \\
\left({ }^{\circ} \mathrm{C}\right)\end{array}$ & $\begin{array}{l}\text { Th } \\
\left({ }^{\circ} \mathrm{C}\right)\end{array}$ & $\begin{array}{l}\text { Fração vol. } \\
\text { da bolha }\end{array}$ & $\overline{X_{\mathrm{NaCl}}}$ & $\begin{array}{c}\text { Salinidade } \\
(\% \text { em peso } \\
\mathrm{NaCl} \text { equiv. }) \\
\end{array}$ & $\begin{array}{l}\text { Ponto } \\
\text { crítico } \\
\left({ }^{\circ} \mathrm{C}\right)\end{array}$ & $\begin{array}{c}\text { Densidade } \\
\left(\mathrm{g} / \mathrm{cm}^{3}\right)\end{array}$ & Observaçōes \\
\hline \multicolumn{12}{|c|}{\begin{tabular}{c|c|c|c}
\multicolumn{2}{|c|}{ Aquosas primárias (tipo 1) } \\
1 & $-42,3$ & $-4,0$ &
\end{tabular}} \\
\hline$\overline{\hat{1}}$ & $-42,3$ & $-4,0$ & & & 277,2 & 0,15 & 0,021 & 6.4 & 433,1 & 0,821 & \multirow{13}{*}{$\begin{array}{l}\text { RAMAN-sem } \mathrm{CO}_{2} \text { e } \mathrm{CH}_{4} \\
\text { homogeneizaçāo p/gás }\end{array}$} \\
\hline 2 & $-41,5$ & $-4,3$ & & & 246,3 & 0,30 & 0,022 & 6,8 & 437,2 & 0,869 & \\
\hline 5 & $-31,5$ & $-3,2$ & & & 283,3 & 0,15 & 0,017 & 5,2 & 421,9 & 0,796 & \\
\hline 8 & $-22,5$ & $-4,1$ & & & 258,8 & 0,15 & 0,021 & 6,5 & 434,5 & 0,849 & \\
\hline 9 & $-38,8$ & $-7,0$ & & & 260,8 & 0,20 & 0,035 & 10,5 & 470,3 & 0,886 & \\
\hline 10 & $-35,6 \mid$ & $-6,6$ & & & 347,9 & 0,20 & 0,033 & 10,0 & 465,8 & 0,751 & \\
\hline 13 & $-35,9$ & $-3,9$ & & & 326,7 & 0,20 & 0,020 & 6,3 & 431,7 & 0,731 & \\
\hline 14 & & $-6,6$ & & & 451,8 & 0,65 & 0,033 & 10,0 & 465,8 & 0,509 & \\
\hline 15 & & $-4,1$ & & & 356,9 & 0,40 & 0,021 & 6,5 & 434,5 & 0,672 & \\
\hline 16 & & $-7,8$ & & & & 0,70 & 0,038 & 11,5 & 479,1 & & \\
\hline 17 & $-50,0$ & & & & & 0,20 & & & & & \\
\hline 18 & $-38,4$ & $-4,1$ & & & & 0,10 & 0,021 & 6,5 & 434,5 & & \\
\hline 21 & $-40,2$ & $-5,0$ & & & 123,0 & 0,10 & 0,025 & 7,8 & 446,4 & 0,996 & \\
\hline \multirow{2}{*}{\multicolumn{12}{|c|}{\begin{tabular}{l|l|l|l|l|}
\multicolumn{4}{|c|}{ Aquosas primárias (tipo 2) } \\
11 & $-53,7$ & $-13,5$ &
\end{tabular}}} \\
\hline 11 & $-53,7$ & $-13,5$ & & & & 0,10 & 0,061 & 173 & & & \\
\hline 12 & $-52,6 \mid$ & $-14,8$ & & & 275,5 & 0,15 & 0,065 & 18,5 & $\begin{array}{l}536,0 \\
5490\end{array}$ & \multirow{3}{*}{$\begin{array}{l}0,988 \\
1,059\end{array}$} & meta-estável \\
\hline 22 & $-44,7$ & $-11,4$ & & & 112,6 & 0,20 & 0,053 & 15,4 & $\begin{array}{l}549,0 \\
5154\end{array}$ & & \\
\hline 24 & $-49,4$ & $-10,1$ & & & & 0,05 & 0,048 & 14,1 & $\begin{array}{l}515,4 \\
502,7\end{array}$ & & \\
\hline \multirow{2}{*}{\multicolumn{12}{|c|}{\begin{tabular}{c|c|c|}
\multicolumn{2}{|l|}{ Aquo-carbônicas primárias } \\
3 & -58.2
\end{tabular}}} \\
\hline & & & & & & & & & & & \\
\hline 4 & & & $-58,2$ & $\begin{array}{l}6,4 \\
6,8\end{array}$ & 397,3 & $\begin{array}{l}0,80 \\
0,60\end{array}$ & & 6,8 & & & \multirow[t]{2}{*}{ homogeneização p/gás } \\
\hline \multirow{2}{*}{\multicolumn{12}{|c|}{\begin{tabular}{l}
\multicolumn{3}{|l|}{ Secundárias } \\
6
\end{tabular}}} \\
\hline & & & & & & & & & & & \\
\hline 6 & $-27,3$ & $-\hat{-1,0}$ & & & 163,7 & 0,10 & 0,005 & 7,7 & 389,0 & 0,920 & \\
\hline $\begin{array}{l}19 \\
20\end{array}$ & -397 & $-1,8$ & & & 2711 & $\begin{array}{l}0,50 \\
0.5\end{array}$ & 0,009 & 3,0 & 401,2 & & \\
\hline & & & & & & & 0,003 & 0,8 & 381,5 & 0,760 & \\
\hline
\end{tabular}


$\frac{\text { AM-134 - CAMPO 2 - TOPÁZIO - ALBITA-MICROCLINIO GRANITO BRANCO - ESTAGIO MAGMÁTICO }}{\text { NO.IF }}$

\begin{tabular}{|c|c|c|c|c|c|c|c|c|c|c|c|c|c|c|c|c|c|}
\hline No. IF & $\begin{array}{c}\mathrm{TE} \\
\left({ }^{\circ} \mathrm{C}\right)\end{array}$ & $\begin{array}{l}\text { Tfg } \\
\left.f^{\circ} \mathrm{C}\right)\end{array}$ & $\begin{array}{c}\mathrm{TfCO} 2 \\
\left({ }^{\circ} \mathrm{C}\right)\end{array}$ & $\begin{array}{l}\mathrm{TfCl} \\
\left({ }^{\circ} \mathrm{C}\right)\end{array}$ & $\begin{array}{l}\text { Tfh } \\
\left({ }^{\circ} \mathrm{C}\right)\end{array}$ & $\begin{array}{c}\text { ThCO2 } \\
\left({ }^{\circ} \mathrm{C}\right)\end{array}$ & $\begin{array}{l}\text { Th } \\
\left({ }^{\circ} \mathrm{C}\right)\end{array}$ & $\begin{array}{c}\text { Fraçāo vol. } \\
\text { da bolha }\end{array}$ & $\mathrm{X}_{\mathrm{H} 2 \mathrm{O}}$ & $x_{\mathrm{cOZ}}$ & $X_{\text {NaCl }}$ & $\begin{array}{c}\text { Salinidade } \\
(\% \text { em peso } \\
\mathrm{NaCl} \text { equiv.) } \\
\end{array}$ & $\begin{array}{c}\text { Densidade } \\
\mathrm{H}_{2} \mathrm{O} \\
\left(\mathrm{g} / \mathrm{cm}^{3}\right) \\
\end{array}$ & $\begin{array}{c}\text { Ponto } \\
\text { crítico } \\
\left({ }^{\circ} \mathrm{C}\right) \\
\end{array}$ & $\begin{array}{c}\text { Densidade } \\
\mathrm{CO}_{2} \\
\left(\mathrm{~g} / \mathrm{cm}^{3}\right\rangle \\
\end{array}$ & 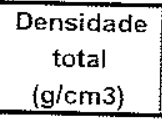 & Observaçōes \\
\hline 1 & $\frac{\text { Ibonic }}{-32,1}$ & \multicolumn{16}{|c|}{\begin{tabular}{l|l|l}
$\left({ }^{\circ} \mathrm{C}\right)$ & $\left(\mathrm{g} / \mathrm{cm}^{3}\right\rangle$ & $(\mathrm{g} / \mathrm{cm} 3)$ \\
\end{tabular}} \\
\hline 2 & $-38,2$ & & $-57,0$ & 7,8 & & 10,9 & $\begin{array}{l}553,0 \\
440,3\end{array}$ & $\begin{array}{l}0,60 \\
0,55\end{array}$ & 0,902 & 0,079 & 0,019 & 6,5 & 1,039 & & 0,139 & 0,499 & homogeneização p/gás \\
\hline 3 & & & $-56,8$ & 8,3 & & & & 0,90 & & & & $\begin{array}{l}4,3 \\
3,4\end{array}$ & & & & & homogeneização p/gás \\
\hline 4 & $-24,6$ & $-8,8$ & & & $-1,5$ & & 371,7 & 0,30 & & & & $\begin{array}{c}3,4 \\
25,7\end{array}$ & & & & & homogeneização p/gàs \\
\hline $\begin{array}{l}5 \\
6\end{array}$ & $\left|\begin{array}{l}-25,4 \\
-33\end{array}\right|$ & $-3,3$ & & & & & 377,9 & 0,30 & & & 0,017 & 5,3 & & & & & salinidade calculada pelo hidrato \\
\hline 7 & $\left|\begin{array}{l}-33,9 \\
-33,9\end{array}\right|$ & $\begin{array}{r}-7,6 \\
-80\end{array}$ & & & $-4,5$ & & 364,5 & 0,35 & & & & 25,0 & & 423,3 & & 0,597 & \\
\hline 8 & $|-2,9|$ & $\begin{array}{l}-8,0 \\
-2,6\end{array}$ & & & $-3,2$ & & 364,5 & 0,40 & & & & 25,3 & & & & & necking down \\
\hline 9 & & & & 4,0 & & & $\begin{array}{l}433,1 \\
3620\end{array}$ & 0,30 & & & & 4,2 & & & & & escano \\
\hline 10 & $-34,9$ & $-9,1$ & & 3,4 & & & $\begin{array}{l}362,0 \\
364,9\end{array}$ & $\begin{array}{l}0,30 \\
0,40\end{array}$ & & & & $\begin{array}{l}10,6 \\
114\end{array}$ & & & & & escape \\
\hline in & & $-2,6$ & & & & & 374,6 & 0,25 & & & & 4,2 & & & & & necking down \\
\hline $\begin{array}{l}12 \\
13\end{array}$ & & & & 8,2 & & & 363,5 & 0,70 & & & & 3,6 & & & & & \\
\hline 14 & -374 & & & 7,8 & & & 356,3 & 0,70 & & & & 4,3 & & & & & homogeneização p/gás \\
\hline & & & & 3,6 & & & 366,0 & 0,30 & & & & 11,2 & & & & & $\begin{array}{c}\text { homogeneização p/gás } \\
\text { necking down }\end{array}$ \\
\hline \multirow{2}{*}{\multicolumn{18}{|c|}{\begin{tabular}{l|l|l|}
\multicolumn{3}{|c|}{ Sem classificação } \\
A
\end{tabular}}} \\
\hline A & & & & & & & 378,1 & & & & & & & & & & \\
\hline B & & & & & & & 378,0 & & & & & & & & & & \\
\hline
\end{tabular}


AM-134 - CAMPO 3 - QUARTZO - ALBITA-MICROCLINIO GRANITO BRANCO - ESTAGIO MAGMÁTICO

\begin{tabular}{|c|c|c|c|c|c|c|c|c|c|c|c|}
\hline No. IF & $\begin{array}{l}\mathrm{TE} \\
\left({ }^{\circ} \mathrm{C}\right)\end{array}$ & $\begin{array}{l}\mathrm{Tfg} \\
\left({ }^{\circ} \mathrm{C}\right)\end{array}$ & $\begin{array}{l}\mathrm{TfCl} \\
\left({ }^{\circ} \mathrm{C}\right)\end{array}$ & $\mathrm{Tfh}$ & $\begin{array}{l}\text { Th } \\
\left({ }^{\circ} \mathrm{C}\right)\end{array}$ & $\begin{array}{l}\text { Fração vol. } \\
\text { da bolha }\end{array}$ & $X_{\mathrm{NaCl}}$ & $\begin{array}{c}\text { Salinidade } \\
(\% \text { em peso } \\
\mathrm{NaCl} \text { equiv. }) \\
\end{array}$ & $\begin{array}{c}\text { Ponto } \\
\text { crítico } \\
\left({ }^{\circ} \mathrm{C}\right) \\
\end{array}$ & $\begin{array}{c}\text { Densidade } \\
\left(\mathrm{g} / \mathrm{cm}^{3}\right)\end{array}$ & Observaçōes \\
\hline \multicolumn{12}{|c|}{\begin{tabular}{l|l|l|l|l|l}
\multicolumn{2}{|c|}{ Aquos as primárias (tipo 1) } \\
7 & &
\end{tabular}} \\
\hline $\begin{array}{c}7 \\
10 \\
A \\
B \\
C \\
D \\
E \\
F\end{array}$ & & & & & $\begin{array}{l}261,3 \\
435,9 \\
384,3 \\
225,1\end{array}$ & $\begin{array}{l}0,10 \\
0,65 \\
0,45 \\
0,45 \\
0,90 \\
0,10\end{array}$ & & & & & RAMAN-sem $\mathrm{CO}_{2}$ e $\mathrm{CH}_{4}$ \\
\hline
\end{tabular}

Aquosas primárias (tipo 2 )

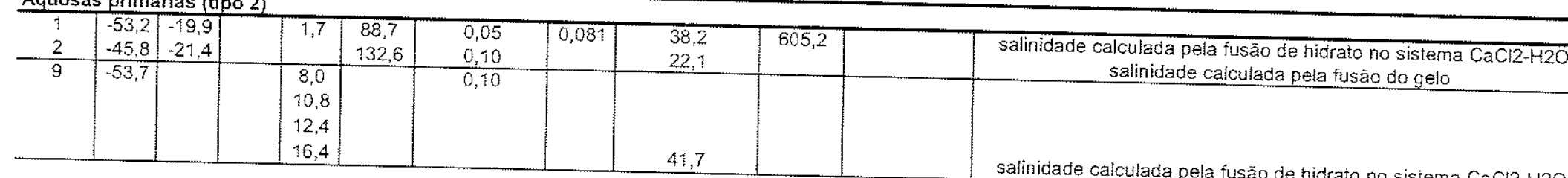

Aquosas primárias (tipo 3 )

\begin{tabular}{|c|c|c|c|c|c|c|c|c|c|c|c|}
\hline \multirow{2}{*}{\multicolumn{12}{|c|}{\begin{tabular}{l|l} 
Aquosas primárias (tipo 3) \\
8 & $-42,3$
\end{tabular}}} \\
\hline 8 & $-42,3$ & 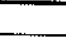 & 4 & $-21,7$ & 329,3 & 0.10 & & 29,6 & & & \\
\hline & & & & & & & & & & & salnidade calculada pela fusão de hidrato no sisterna $\mathrm{CaCl} 2-\mathrm{H} 2$ \\
\hline \multirow{2}{*}{\multicolumn{12}{|c|}{\begin{tabular}{l|l|l|} 
Aquo-carbônicas primárias \\
3
\end{tabular}}} \\
\hline 3 & & & 3,2 & & & 0,90 & & 117 & & & \\
\hline & & & & & & & & 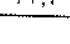 & & & RAMAN-com $\mathrm{CH}_{4}$ \\
\hline \multirow{2}{*}{\multicolumn{12}{|c|}{\begin{tabular}{l|l} 
Secundárias \\
4 & $-21,1$
\end{tabular}}} \\
\hline 4 & -21.1 & $-0,2$ & & & 256,2 & 0,20 & 0,001 & 0,3 & 377,0 & 0,782 & \\
\hline 5 & $-38,4$ & $-0,3$ & & & 380,0 & 0,40 & 0,002 & 0,5 & 378,5 & 0,926 & 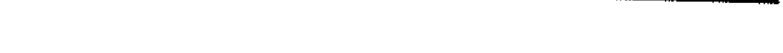 \\
\hline 6 & $1-40,4$ & $-0,5$ & & & 274,0 & 0,25 & 0,003 & 0,8 & 381,5 & 0,755 & \\
\hline
\end{tabular}




\begin{tabular}{|c|c|c|c|c|c|c|c|c|c|}
\hline No. IF & $\begin{array}{c}\mathrm{TE} \\
\left({ }^{\circ} \mathrm{C}\right)\end{array}$ & $\begin{array}{l}\mathrm{Tfg} \\
\left({ }^{\circ} \mathrm{C}\right)\end{array}$ & $\begin{array}{c}\text { Th } \\
\left({ }^{\circ} \mathrm{C}\right)\end{array}$ & $\begin{array}{c}\text { Fração vol. } \\
\text { da bolha }\end{array}$ & $\mathrm{X}_{\mathrm{NaCl}}$ & $\begin{array}{l}\text { Salinidade } \\
\text { (\% em peso } \\
\text { NaCl equiv.) }\end{array}$ & $\begin{array}{l}\text { Ponto } \\
\text { crítico } \\
\left({ }^{\circ} \mathrm{C}\right) \\
\end{array}$ & $\begin{array}{c}\text { Densidade } \\
\left(\mathrm{g} / \mathrm{cm}^{3}\right)\end{array}$ & Observaçōes \\
\hline \multicolumn{10}{|c|}{\begin{tabular}{c|c|c}
\multicolumn{2}{|c}{ Aquosas primárias } \\
1 & $-36,3$ & $-0,5$
\end{tabular}} \\
\hline 1 & $-36,3$ & $-0,5$ & 145,6 & 0,10 & 0,003 & 0,8 & 381,5 & 0,932 & \multirow{26}{*}{ homog. p/gás/RAMAN-sem $\mathrm{CO}_{2}$ e $\mathrm{CH}_{4} / \mathrm{Th}>\mathrm{T}$ crítico } \\
\hline 2 & & $-1,3$ & 284,0 & 0,30 & 0,007 & 2,1 & 393,6 & 0,754 & \\
\hline 3 & $-37,3$ & $-1,0$ & 174,4 & 0,20 & 0,005 & 1,7 & 389,0 & 0,909 & \\
\hline 4 & $-34,8$ & $-1,3$ & $\uparrow 61,2$ & 0,15 & 0,007 & 2,1 & 393,6 & 0,925 & \\
\hline 5 & & $-1,1$ & 381,2 & 0,40 & 0,006 & 1,8 & 390,5 & 0,507 & \\
\hline 6 & & $-1,4$ & 317,8 & 0,50 & 0,007 & 2,3 & 395,1 & 0,685 & \\
\hline 7 & & $-1,0$ & & 0,10 & 0,005 & 1,7 & 398,0 & & \\
\hline 8 & & $-1,1$ & & 0,20 & 0,006 & 1,8 & 390,5 & & \\
\hline 9 & & $-1,1$ & & 0,10 & 0,006 & 1,8 & 390,5 & & \\
\hline 10 & $-39,2$ & $-1,1$ & 224,3 & 0,20 & 0,006 & 1,8 & 390,5 & 0,849 & \\
\hline 11 & $-37,4$ & $-2,3$ & 220,0 & 0,10 & 0,012 & 3,8 & 408,7 & 0,873 & \\
\hline 12 & $-38,5$ & $-1,0$ & & 0,15 & 0,005 & 1,7 & 389,0 & & \\
\hline 14 & $-36,5$ & $-1,3$ & & 0,40 & 0,007 & 2,1 & 393,6 & & \\
\hline 15 & & $-1,3$ & 334,3 & 0.20 & 0,007 & 2,1 & 393,6 & 0,643 & \\
\hline 16 & & $-1,2$ & 219,1 & 0,10 & 0,006 & 2,0 & 392,1 & 0,858 & \\
\hline 17 & & $-1,2$ & 173,7 & 0,20 & 0,006 & 2,0 & 392,1 & 0,911 & \\
\hline 18 & & $-1,3$ & 289,9 & 0,30 & 0,007 & 2,1 & 393,6 & 0,742 & \\
\hline 19 & & $-1,3$ & 325,4 & 0,30 & 0,007 & 2,1 & 393,6 & 0,665 & \\
\hline 20 & $-37,4$ & $-1,3$ & & 0,35 & 0,007 & 2,1 & 393,6 & & \\
\hline 21 & $-41,2$ & $-1,7$ & 407,7 & 0,70 & 0,009 & 2,8 & 399,7 & & \\
\hline 22 & & $-1,5$ & 382,3 & 0,40 & 0,008 & 2,5 & 396,6 & 0,519 & \\
\hline 23 & & $-3,4$ & 415,2 & 0,70 & 0,018 & 5,5 & 424,8 & 0,495 & \\
\hline 24 & & $-3,1$ & & 0,65 & 0,016 & 5,0 & 420,5 & & \\
\hline 25 & & $-1,0$ & 185,4 & 0,10 & 0,005 & 1,7 & 389,0 & 0,896 & \\
\hline 27 & $-39,1$ & $-1,0$ & 156,7 & 0,10 & 0,005 & 1,7 & 389,0 & 0,927 & \\
\hline 30 & & $-1,1$ & 410,8 & 0,45 & 0,006 & 1,8 & 390,5 & & \\
\hline \multirow{2}{*}{\multicolumn{10}{|c|}{\begin{tabular}{c}
\multicolumn{3}{|c|}{ Aquosas secundárias } \\
13
\end{tabular}}} \\
\hline 13 & $-47,0$ & & & & & & & & \\
\hline 26 & $-48,4$ & & 94,2 & $\begin{array}{l}0,10 \\
0,10\end{array}$ & 0,067 & 18,9 & 554,2 & 1,099 & \multirow{6}{*}{$\begin{array}{l}\text { meta-estável } \\
\text { meta-estável }\end{array}$} \\
\hline 28 & $-54,7$ & $-12,2$ & 102,7 & 0,10 & 0,056 & 16,1 & 523,3 & 1.072 & \\
\hline 29 & $-57,9$ & $-13,8$ & & 0,10 & 0,062 & 17,6 & 539,0 & 1,072 & \\
\hline 31 & $-51,8$ & $-14,2$ & 147,4 & 0,05 & 0,063 & 17,9 & 543,0 & 1,052 & \\
\hline 32 & $-49,2$ & $-10,8$ & 101,9 & 0,10 & 0,051 & 14,8 & 509,6 & 1,062 & \\
\hline 33 & $-51,4$ & $-14,1$ & 107,8 & 0,10 & 0,063 & 17,9 & 542,0 & 1,081 & \\
\hline
\end{tabular}


AM-168A- CAMPO 1- TOPAZZIO - BOLSAO OE QUARTZO - ESTAGIO TRANSICIONAL

\begin{tabular}{|c|c|c|c|c|c|c|c|c|c|c|}
\hline No, IF & $\begin{array}{l}\mathrm{TE} \\
\left({ }^{\circ} \mathrm{C}\right)\end{array}$ & $\begin{array}{l}\mathrm{r}_{\mathrm{fg}} \\
\left({ }^{\circ} \mathrm{C}\right)\end{array}$ & $\begin{array}{c}\mathrm{Th} \\
\left({ }^{\circ} \mathrm{C}\right)\end{array}$ & $\mathrm{X}_{\mathrm{NaCl}}$ & $\begin{array}{l}\text { Salinidade } \\
(\% \text { em peso } \\
\mathrm{NaCl} \text { equiv. }\end{array}$ & $\begin{array}{l}\text { Ponto } \\
\text { critlco } \\
\left({ }^{\circ} \mathrm{C}\right)\end{array}$ & $\begin{array}{c}\text { Densldade } \\
\left(\mathrm{g} / \mathrm{cm}^{3}\right)\end{array}$ & $\begin{array}{l}\text { Tfs1 } \\
\left({ }^{\circ} \mathrm{C}\right)\end{array}$ & $\begin{array}{l}\mathrm{Tfs} 2 \\
\left({ }^{\circ} \mathrm{C}\right)\end{array}$ & Observaçöes \\
\hline \multicolumn{11}{|c|}{ 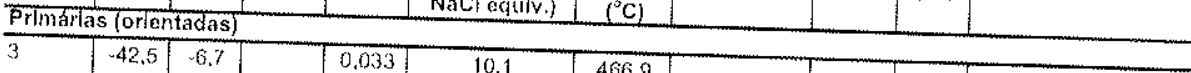 } \\
\hline 3 & $-42,5$ & -6.7 & & 0.033 & 10.1 & 466.9 & & & & \\
\hline 7 & 37,9 & 7.1 & & 0.035 & 10,6 & 471,4 & & & & \\
\hline $\begin{array}{l}8 \\
9\end{array}$ & $\begin{array}{r}-36,2 \\
-33,3\end{array}$ & $\begin{array}{l}-6,9 \\
-7,2\end{array}$ & & $\begin{array}{l}0,034 \\
0,036\end{array}$ & $\begin{array}{l}10.4 \\
10.7\end{array}$ & $\begin{array}{l}469,2 \\
472,5\end{array}$ & & & & \\
\hline
\end{tabular}

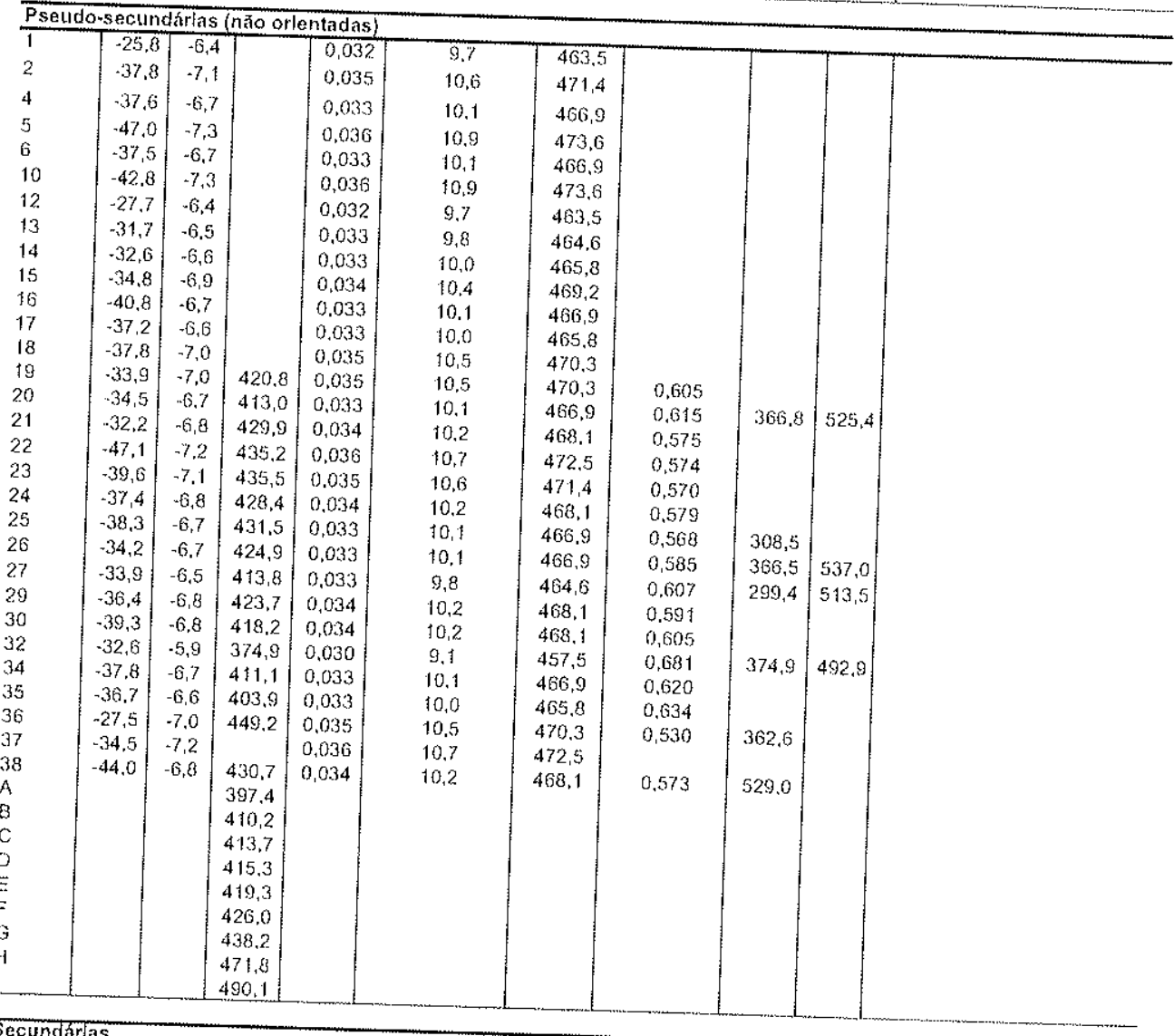

Secundarlas

\begin{tabular}{|c|c|c|c|c|c|c|c|c|c|c|}
\hline No. IF & $\begin{array}{c}\mathrm{TE} \\
\left({ }^{\circ} \mathrm{C}\right)\end{array}$ & $\begin{array}{l}\mathrm{Tfg} \\
\left\langle{ }^{\circ} \mathrm{C}\right\rangle\end{array}$ & $\begin{array}{c}\text { Th } \\
\left({ }^{\circ} \mathrm{C}\right)\end{array}$ & $\mathrm{X}_{\mathrm{NaCl}}$ & $\begin{array}{l}\text { Salinidade } \\
\text { (\% em peso } \\
\mathrm{NaCl} \text { equilv.) }\end{array}$ & $\begin{array}{l}\text { Ponto } \\
\text { critlco } \\
\left({ }^{\circ} \mathrm{C}\right) \\
\end{array}$ & $\begin{array}{c}\text { Densldade } \\
\left(\mathrm{g} / \mathrm{cm}^{3}\right)\end{array}$ & $\begin{array}{l}\text { Tfs } 1 \\
\left({ }^{\circ} \mathrm{C}\right)\end{array}$ & $\begin{array}{l}\text { Tfs } 2 \\
\left({ }^{\circ} \mathrm{C}\right)\end{array}$ & Observaçōes \\
\hline $\begin{array}{l}28 \\
31\end{array}$ & & & 464,7 & & & & & & & nảo homogeneizou até 598.7 \\
\hline 33 & -36.7 & $-8,6$ & 450,2 & 0.042 & 12.4 & 487.5 & 0,578 & & & \\
\hline $\begin{array}{l}39 \\
40\end{array}$ & $-35,1$ & -7.5 & & 0,037 & 11,1 & 475,8 & & & & \\
\hline $\begin{array}{l}40 \\
41\end{array}$ & $\begin{array}{l}-36,2 \\
-34,5\end{array}$ & $-20,8$ & & 0,084 & 22.9 & 616.2 & & & & \\
\hline 42 & $-28,5$ & -7.2 & & 0,036 & 10,7 & 472,5 & & & & \\
\hline 43 & $-34,8$ & & & & & & & & & \\
\hline $\begin{array}{l}45 \\
46\end{array}$ & $\begin{array}{l}-38.1 \\
-36,1\end{array}$ & $\begin{array}{l}-23,3 \\
-16,7\end{array}$ & & 0,071 & 20,0 & 568.9 & & & & \\
\hline
\end{tabular}


AM-168A - CAMPO 2 - TOPAZIO - BOLSÃO DE QUARTZO - ESTAGIO TRANSICIONAL

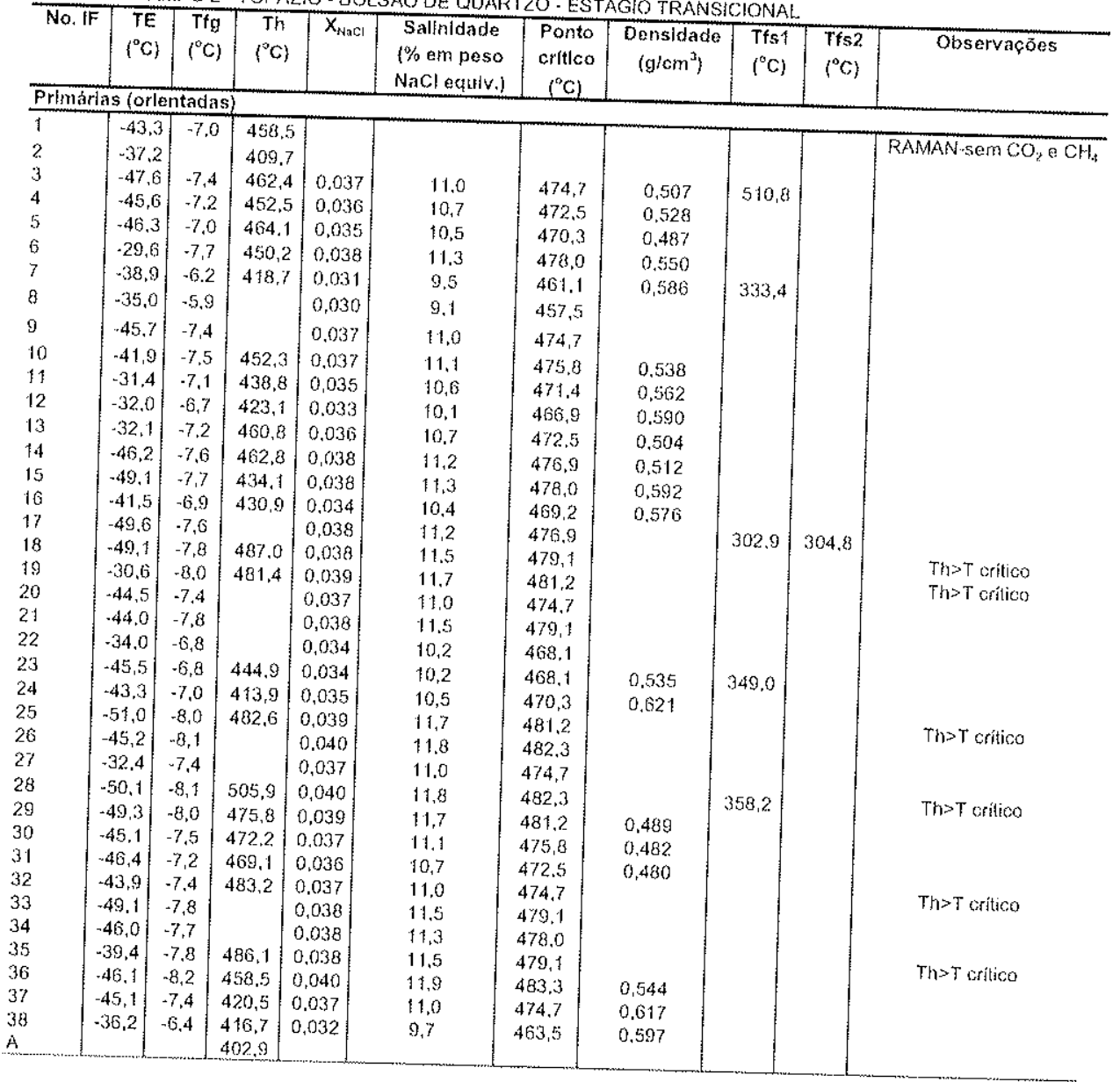


AM- $\$ 68 A$ - CAMPO 3 - TOPAZZIO - BOLSĀO DE QUARTZO - ESTÁGIO TRANSICIONAL

\begin{tabular}{|c|c|c|c|c|c|c|c|c|c|c|c|}
\hline No. F F & $\begin{array}{c}\mathrm{TE} \\
\left({ }^{\circ} \mathrm{C}\right)\end{array}$ & $\begin{array}{l}f_{f g} \\
\left({ }^{\circ} \mathrm{C}\right)\end{array}$ & $\begin{array}{l}\mathrm{Th} \\
\left({ }^{\circ} \mathrm{C}\right)\end{array}$ & $\mathrm{X}_{\mathrm{NaCl}}$ & $\begin{array}{l}\text { Sallnidade } \\
(\% \text { em peso } \\
\mathrm{NaCl} \text { equiv.) }\end{array}$ & $\begin{array}{l}\text { Ponto } \\
\text { crítico } \\
\left({ }^{\circ} \mathrm{C}\right)\end{array}$ & $\begin{array}{c}\text { Densldade } \\
\left(g / \mathrm{cm}^{3}\right)\end{array}$ & $\begin{array}{l}\text { Tfs1 } \\
\left({ }^{\circ} \mathrm{C}\right)\end{array}$ & $\begin{array}{l}\mathrm{Tfs} ? \\
\left({ }^{\circ} \mathrm{C}\right)\end{array}$ & $\begin{array}{l}\text { Tfs } \\
(" \mathrm{C})\end{array}$ & Observaçōes \\
\hline \multicolumn{12}{|c|}{ 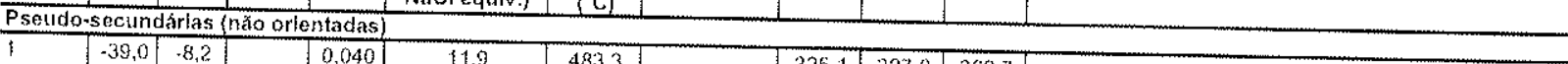 } \\
\hline 1 & $-39,0$ & $.8,2$ & & 0,040 & 11.9 & 483,3 & & 325,1 & 327,0 & 362,7 & \multirow{7}{*}{$\begin{array}{c}\text { Homogeneizaçāo p/vapor. Th>T crítico. } \\
\text { Thr }>\text { T critico. }\end{array}$} \\
\hline 2 & $-44,4$ & $-8,4$ & 562.8 & 0.041 & 12.2 & 485.4 & & & & & \\
\hline 3 & $-23,5$ & $\cdot 7,5$ & 488,3 & 0,037 & 11.1 & 475,8 & & & & & \\
\hline 4 & $-40,8$ & $-7,6$ & 468.7 & 0,038 & 11,2 & 476,9 & 0.495 & 412,9 & & & \\
\hline 5 & $-39,4$ & $-7,9$ & 486,1 & 0,039 & 11,6 & 480,2 & & 300.0 & & & \\
\hline 6 & $-37,9$ & -7.6 & 477,2 & 0,038 & 11,2 & 476,9 & & 345,9 & 368.3 & & \\
\hline 7 & $-37,6 \mid$ & $-7,8$ & 465,7 & 0.038 & 11,5 & 479,1 & 0,511 & & & & \\
\hline 8 & -38.0 & .7 .5 & 488,7 & 0,037 & 11,1 & 475,8 & & & & & \multirow{7}{*}{$\begin{array}{l}\text { RAMAN-Sem } \mathrm{CO}_{2} \text { e } \mathrm{CH}_{4} \text {. Th>T uritico. } \\
\text { RAMAN-sem } \mathrm{CO}_{2} \text { e } \mathrm{CH}_{1} \text { sólido te calcita, Th>T critico. } \\
\text { Th>T critico. } \\
\text { Th>T critico. } \\
\text { Th>T critico. } \\
\text { Th>T oritico. }\end{array}$} \\
\hline 9 & -35.9 & $\cdot 7,8$ & 503,0 & 0,038 & 11.5 & 479,1 & & & & & \\
\hline 10 & $-35,3$ & -7.6 & 486,5 & 0,038 & 11,2 & 476,9 & & & & & \\
\hline 11 & -34.5 & $-7,5$ & 486,6 & 0.037 & 11.1 & 475,8 & & & & & \\
\hline 12 & -48.8 & $-7,9$ & 487.3 & 0,039 & 11,6 & 480.2 & & & & & \\
\hline 13 & $-36,8$ & $-7,8$ & 488,1 & 0,038 & 11.5 & 479,1 & & & & & \\
\hline 14 & $-37,9$ & -7.4 & 472.4 & 0.037 & 11,0 & 474.7 & 0,477 & & & & \\
\hline 15 & $-30,3$ & -7.6 & 480.8 & 0,038 & 11,2 & 476,9 & & 372.5 & & & \multirow[t]{12}{*}{ Th>T critico. } \\
\hline 16 & -38.6 & -7.4 & & 0,037 & 11,0 & 474.7 & & & & & \\
\hline 17 & $-32,7$ & $.7,4$ & 466,1 & 0.037 & 11.0 & 474,7 & 0,496 & \multirow{3}{*}{381.8} & & & \\
\hline 18 & $\cdot 36,3$ & -7.4 & 470,4 & 0,037 & 11,0 & 474,7 & 0,483 & & & & \\
\hline 10 & $-48,1 \mid$ & -7.7 & 466.1 & 0.038 & 11.3 & 478.0 & 0.506 & & & & \\
\hline 20 & $-38,1$ & $\cdot 7,4$ & 464,1 & 0.037 & $\$ 1,0$ & 474,7 & 0,502 & \multirow{3}{*}{$\begin{array}{l}348,5 \\
371,3 \\
449,4\end{array}$} & & & \\
\hline 21 & $-35,7$ & $-7,4$ & 473,0 & 0,037 & 11,0 & 474,7 & 0.476 & & & & \\
\hline 22 & $-35,1$ & $\cdot 7,4$ & 468.9 & 0,037 & $\$ 1,0$ & 474,7 & 0.488 & & & & \\
\hline 23 & -34.7 & -7.6 & 465,3 & 0,038 & 11,2 & 476.9 & 0.505 & & & & \\
\hline 24 & $-33,8$ & -7.9 & 465,3 & 0,039 & $\begin{array}{l}11,6 \\
11,2\end{array}$ & 480,2 & 0,515 & & & & \\
\hline 25 & $-34,9$ & $-7,6$ & 476.8 & $\begin{array}{l}0,038 \\
0,038\end{array}$ & $\begin{array}{l}11,2 \\
11.2\end{array}$ & 476,9 & $\begin{array}{l}0.472 \\
0.490\end{array}$ & & & & \\
\hline 26 & $-37,1$ & $-7,6$ & 470.4 & $\begin{array}{l}0,038 \\
0,034\end{array}$ & & 476,9 & $\begin{array}{l}0,490 \\
0,499\end{array}$ & & & & \\
\hline 27 & $-37,6$ & $-6,9$ & 458,8 & $\begin{array}{l}0,034 \\
0,039\end{array}$ & $\begin{array}{l}10,4 \\
11,7\end{array}$ & 469,2 & 0,499 & & & & \multirow{5}{*}{$\begin{array}{c}\text { Th>T crítico. } \\
\text { Th>T crilico. } \\
\text { Th>T critico. } \\
\text { Homogeneicaçato p/vatpor. Th>T crílico. }\end{array}$} \\
\hline 28 & $-45,8$ & $-8,0$ & 503.4 & $\begin{array}{l}0,038 \\
0,038\end{array}$ & $\begin{array}{l}11,7 \\
11,5\end{array}$ & 481,2 & & & & & \\
\hline $\begin{array}{l}29 \\
30\end{array}$ & $\begin{array}{l}-35,6 \\
-426\end{array}$ & -7.8 & $\begin{array}{l}505,3 \\
500,6\end{array}$ & $\begin{array}{l}0,038 \\
0,039\end{array}$ & $\begin{array}{l}11,5 \\
11.7\end{array}$ & 479.1 & & & & & \\
\hline $\begin{array}{l}30 \\
31\end{array}$ & $\begin{array}{r}-42,6 \\
-36,7\end{array} \mid$ & $\begin{array}{r}-8,0 \\
-7,9\end{array}$ & $\begin{array}{l}500,6 \\
525,5\end{array}$ & 0,039 & 11,6 & $\begin{array}{l}481,2 \\
480,2\end{array}$ & & & & & \\
\hline A & & & 447.9 & & & & & & & & \\
\hline
\end{tabular}


AM-168A - CAMPO 4 - TOPAZIO - BOLSAO DE QUARTZO - ESTAGIO TRANSICIONAL

\begin{tabular}{|c|c|c|c|c|c|c|c|c|c|c|c|}
\hline No. F F & $\begin{array}{c}\mathrm{TE} \\
\left({ }^{\circ} \mathrm{C}\right)\end{array}$ & $\begin{array}{l}\mathrm{Tfg} \\
\left({ }^{\circ} \mathrm{C}\right)\end{array}$ & $\begin{array}{c}\mathrm{Th} \\
\left({ }^{\circ} \mathrm{C}\right)\end{array}$ & $\begin{array}{l}\mathrm{TfCl} \\
\left({ }^{\circ} \mathrm{C}\right)\end{array}$ & $\begin{array}{c}\mathrm{PfCO} \\
\left({ }^{\circ} \mathrm{C}\right)\end{array}$ & $\mathrm{X}_{\mathrm{NaCA}}$ & $\begin{array}{l}\text { Sallnidade } \\
\text { (\% em peso } \\
\text { NaCi equtv.) }\end{array}$ & $\begin{array}{l}\text { Ponto } \\
\text { critico } \\
\left({ }^{\circ} \mathrm{C}\right)\end{array}$ & $\begin{array}{c}\text { Densidade } \\
\left(\mathrm{g} / \mathrm{cm}^{3}\right)\end{array}$ & $\begin{array}{l}\text { Tfs } 1 \\
\left({ }^{\circ} \mathrm{C}\right)\end{array}$ & Observaçōes \\
\hline \multicolumn{12}{|c|}{\begin{tabular}{l|l|l|l|}
\multicolumn{2}{|c|}{ Prlmálas (orientadas) } \\
2 & -47.4 & -7.6 & 493,7
\end{tabular}} \\
\hline 2 & -47.4 & $-7,6$ & 493,7 & & & 0,038 & 11,2 & 476.9 & \multirow{12}{*}{0,511} & \multirow{12}{*}{465,7} & \multirow{12}{*}{ gyás } \\
\hline 3 & $-35,1$ & $-7,6$ & 481,0 & & & 0,038 & 11.2 & 476.9 & & & \\
\hline 4 & .37 .1 & -7.6 & 478.9 & & & 0,038 & 11,2 & 476,9 & & & \\
\hline 6 & -40.7 & $-7,9$ & 491,8 & & & 0.039 & 11,6 & 480,2 & & & \\
\hline 7 & $-35,1$ & & 405.2 & & & & & & & & \\
\hline 11 & $-40,3$ & -7.7 & 464,4 & & & 0,038 & 11,3 & 478,0 & & & \\
\hline 12 & $-33,8$ & 8,2 & & & & 0.040 & 11,9 & 483.3 & & & \\
\hline 13 & $-38,1$ & -8.4 & & & & 0,041 & 12,2 & 485,4 & & & \\
\hline 14 & $-36,8$ & 8.6 & & & & 0,042 & 12,4 & 487,5 & & & \\
\hline 15 & $-26,83$ & -10.9 & & & & $0,05 \uparrow$ & 14.9 & $\$ 10.6$ & & & \\
\hline $\begin{array}{l}16 \\
A\end{array}$ & -37.2 & .8 .5 & 4678 & & & 0.041 & 12,3 & 486,5 & & & \\
\hline \multirow{2}{*}{\multicolumn{12}{|c|}{ 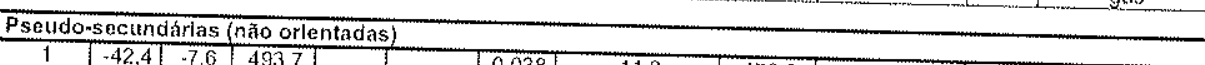 }} \\
\hline & & & & & & & & & & & \\
\hline 1 & $-42,4$ & $.7,6$ & 49.3 .7 & & & 0,038 & 11,2 & 476,9 & & \multirow{6}{*}{$\begin{array}{l}357,4 \\
510,7\end{array}$} & \multirow{6}{*}{ gás } \\
\hline 5 & $-37,8$ & $-7,6$ & 491.2 & & & 0.038 & 11.2 & 476,9 & & & \\
\hline 8 & $-24,5$ & & 572,7 & & & & & & & & \\
\hline 9 & -32.7 & -7.7 & 509.1 & & & 0,038 & 11,3 & 478,0 & & & \\
\hline 10 & $\cdot 38,5$ & $-7,6$ & 481,0 & & & 0,038 & 11,2 & 476,9 & & & \\
\hline $\begin{array}{l}21 \\
B\end{array}$ & $-33,8$ & -8.2 & 484,1 & & & 0.040 & 11,9 & 483.3 & & & \\
\hline
\end{tabular}

Aquo-carbônlcas (pseudo-secundárias)

\begin{tabular}{l|l|l|l|l|l|l|l|l|l}
\hline 22 & $-25,6$ \\
23 & & & 6,2 & $-61,3$ & & 7,1 & & & \\
5,6 & 8,1 & & & \\
\hline
\end{tabular}

\begin{tabular}{l|l|l|l|l|l|l|l|l|l|l}
\hline Secundárias & \\
\hline 17 & & $-8,6$ \\
18 & $-39,8$ & $-8,8$ \\
19 & $-43,4$ & $-8,8$ & & & & 0,042 & 12,4 & 487,5 & & \\
20 & $-45,5$ & $-10,6$ & & & 0,043 & 12,6 & 489.6 & & \\
\hline
\end{tabular}


AM-168A - CAMPO 5 - TOPAZIO - BOLSAO DE QUARTZO - ESTÁGIO TRANSICIONAL

\begin{tabular}{|c|c|c|c|c|c|c|c|c|c|}
\hline No. IF & $\begin{array}{l}\text { TE } \\
\left({ }^{\circ} \mathrm{C}\right)\end{array}$ & $\begin{array}{l}\text { Tf } g \\
\left({ }^{\circ} \mathrm{C}\right\rangle\end{array}$ & $\begin{array}{l}\text { Th } \\
\left({ }^{\circ} \mathrm{C}\right)\end{array}$ & $X_{N_{3 A C F}}$ & $\begin{array}{l}\text { Sallnidade } \\
\text { (\% em peso } \\
\text { NaCl equiv.) }\end{array}$ & $\begin{array}{l}\text { Ponto } \\
\text { critlco } \\
\left({ }^{\circ} \mathrm{C}\right) \\
\end{array}$ & $\begin{array}{c}\text { Densidade } \\
\left(\mathrm{g} / \mathrm{cm}^{3}\right)\end{array}$ & $\begin{array}{l}\text { Tfst } \\
\left({ }^{\circ} \mathrm{C}\right)\end{array}$ & Ohservaçōes \\
\hline \multicolumn{10}{|c|}{$\begin{array}{c}\text { Primárlas (orlentadas) } \\
1\end{array}$} \\
\hline 1 & $-37,9$ & $-7,3$ & 467,3 & 0,036 & 10,9 & 473.6 & 0.489 & 498,3 & \\
\hline 2 & -48.9 & $\cdot 7,2$ & 469,7 & 0,036 & 10,7 & 472.5 & 0,478 & & \\
\hline 3 & $.42,4$ & $-5,9$ & 457,6 & & & & & & \\
\hline $\begin{array}{l}4 \\
5\end{array}$ & $\begin{array}{l}-34,8 \\
-41,7\end{array}$ & $\begin{array}{l}-6,2 \\
-7,2\end{array}$ & $\begin{array}{l}462.5 \\
4734\end{array}$ & & & & & 404.2 & \\
\hline $\begin{array}{l}5 \\
6\end{array}$ & $\begin{array}{l}-41,7 \\
.37,7\end{array}$ & $-6,6$ & 464,2 & 0,033 & 10,0 & 465.8 & 0.472. & 3773 & \\
\hline 10 & & & & & & & & 310,3 & \\
\hline 11 & & & & & & & & 359.9 & \\
\hline $\begin{array}{l}15 \\
18\end{array}$ & & & 470,2 & & & & & & \\
\hline $\begin{array}{l}18 \\
30\end{array}$ & & & 462.5 & & & & & 528,1 & \\
\hline
\end{tabular}

Secundărlas

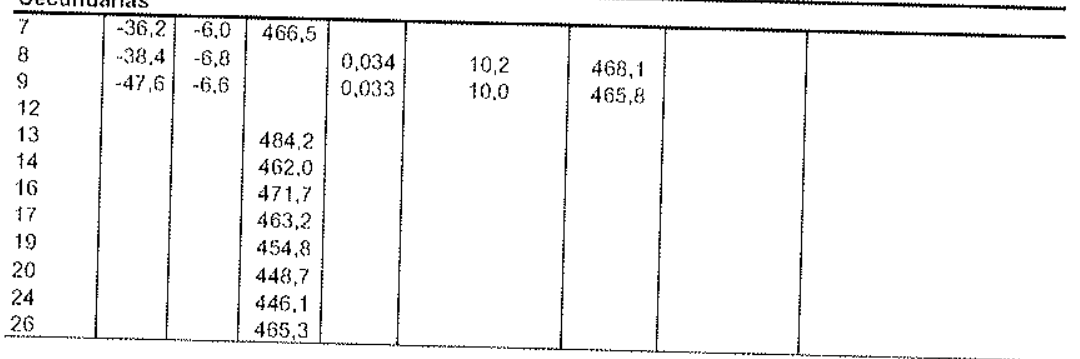


AM-168C - CAMPO 1 - QUARTZO

\begin{tabular}{|c|c|c|c|c|c|c|c|c|c|c|c|c|c|c|c|c|}
\hline Aquo-C & {$\left[\begin{array}{c}T E \\
\left({ }^{\circ} \mathrm{C}\right)\end{array}\right.$} & $\begin{array}{l}\text { Tfg } \\
\left({ }^{\circ} \mathrm{C}\right)\end{array}$ & $\begin{array}{c}\text { TfCO2 } \\
\left\langle{ }^{\circ} \mathrm{C}\right\rangle\end{array}$ & $\begin{array}{l}\text { TfCl } \\
\left({ }^{\circ} \mathrm{C}\right)\end{array}$ & $\begin{array}{c}\text { ThCO2 } \\
\left({ }^{\circ} \mathrm{C}\right)\end{array}$ & $\begin{array}{l}\text { Th } \\
\left({ }^{\circ} \mathrm{C}\right)\end{array}$ & $\begin{array}{c}\text { Fração vol. } \\
\text { da bolha }\end{array}$ & $\overline{x_{220}}$ & $\overline{X_{\mathrm{CO} 2}}$ & $X_{\mathrm{NaCl}}$ & $\begin{array}{c}\text { Salinidade } \\
\text { (\% em peso } \\
\mathrm{NaCl} \text { equiv.) }\end{array}$ & $\begin{array}{c}\text { Densidade } \\
\mathrm{H}_{2} \mathrm{O} \\
\left(\mathrm{g} / \mathrm{cm}^{3}\right) \\
\end{array}$ & $\begin{array}{c}\text { Ponto } \\
\text { crítico } \\
\left({ }^{\circ} \mathrm{C}\right) \\
\end{array}$ & $\begin{array}{c}\text { Densidade } \\
\mathrm{CO}_{2} \\
\left(\mathrm{~g}^{\prime} / \mathrm{cm}^{3}\right)\end{array}$ & $\begin{array}{c}\text { Densidade } \\
\text { total } \\
(\mathrm{g} / \mathrm{cm} 3) \\
\end{array}$ & Observaçōes \\
\hline \multicolumn{13}{|c|}{\begin{tabular}{|c|c|c|c|c}
$\mathrm{NaCl}$ equiv. $)$ & $\left(\mathrm{g} / \mathrm{cm}^{3}\right\}$ & $\left({ }^{\circ} \mathrm{C}\right)$ & $\left(\mathrm{g} / \mathrm{cm}^{3}\right)$ & $(\mathrm{g} / \mathrm{cm} 3)$ \\
\end{tabular}} & & & & \\
\hline 2 & $\begin{array}{l}-31,5 \\
-36,4\end{array}$ & & -58.3 & 6.2 & & & 0.50 & & 0.054 & 0.020 & 6.5 & 1.039 & & 0.256 & 0.765 & \\
\hline 9 & & & -58.3 & 3,4 & & 409.8 & 0.45 & & & & 1.1 .4 & & & & & \\
\hline 11 & -31.5 & & $\begin{array}{r}-58.2 \\
-583\end{array}$ & 6.8 & 15.9 & & 0.60 & 0.889 & 0,093 & 0.018 & 6.1 & 1.036 & & 0.186 & 0.514 & \\
\hline 15 & $-37,6$ & & -58.3 & 2.8 & & & $\begin{array}{l}0.50 \\
0.45\end{array}$ & & & & 9.4 & & & & 0.584 & necking down \\
\hline & & & & & & & & & & & 12.8 & & & & & \\
\hline
\end{tabular}

\begin{tabular}{|c|c|c|c|c|c|c|c|c|c|}
\hline \multirow{2}{*}{\multicolumn{10}{|c|}{\begin{tabular}{l|l|l|} 
Aquosas secundárias \\
3
\end{tabular}}} \\
\hline 3 & $-32,6$ & .8 .5 & & & & & & & \\
\hline 4 & -43.9 & & 372.8 & $\begin{array}{l}0.15 \\
0.20\end{array}$ & 0.041 & 12.3 & 486,5 & 0.950 & \\
\hline 5 & $-22.4 \mid$ & $-6,6$ & 275.5 & 0,10 & 0033 & & & & \\
\hline 6 & -40.9 & $-8,8$ & $2 \preccurlyeq 5.1$ & 0.15 & 0.033 & 10.0 & 465.8 & 0.863 & \\
\hline 7 & $-27,1$ & -4.4 & 139,4 & 0.10 & 0.043 & 12,6 & 489.6 & 0,949 & \\
\hline 8 & $-2 \uparrow, 8$ & $-4,2$ & 130.9 & 0.10 & 0.023 & 7.0 & 438.5 & 0.977 & \\
\hline 12 & -44.6 & -12.3 & 368.9 & 0.20 & 0.022 & 8.7 & 435.8 & 0.962 & \\
\hline 13 & -34.9 & -10.2 & 327.7 & 0.30 & 0,056 & 16.2 & 524,2 & 0,808 & \\
\hline 14 & -30.1 & -8.7 & 188.9 & 0.15 & 0.046 & 14.2 & 503.7 & $0.84 i$ & \\
\hline 16 & -40.8 & -9.2 & 139.7 & 0.10 & 0.042 & 12.5 & 488.6 & 0.973 & \\
\hline 17 & -32.0 & -7.9 & 233.2 & 0.20 & 0,044 & 13,1 & 493.7 & 1,021 & \\
\hline 18 & & & 388.5 & & 0.039 & 11.6 & 480.2 & 0.925 & \\
\hline \multirow{2}{*}{\multicolumn{10}{|c|}{ melt inclusion ou hipersalina }} \\
\hline $\bar{A}$ & & & & & & & & & \\
\hline$B$ & & & $\begin{array}{l}42.2 \\
423.2\end{array}$ & $\begin{array}{l}0.60 \\
0.70\end{array}$ & & & & & homogeneizaçāo para o gás \\
\hline D & & & & 0.50 & & & & & homogeneizaçăo para o gàs \\
\hline $\mathrm{E}$ & & & 307.5 & 0.75 & & & & & \\
\hline $\mathrm{F}$ & & & 507.5 & $\begin{array}{l}0.25 \\
0.40\end{array}$ & & & & & \\
\hline $\begin{array}{l}\mathrm{G} \\
\mathrm{H}\end{array}$ & & & 361.9 & 0.30 & & & & & \\
\hline 1 & & & 296.6 & 0.45 & & & & & \\
\hline 3 & & & 369.8 & & & & & & \\
\hline
\end{tabular}




\begin{tabular}{|c|c|c|c|c|c|c|c|c|c|c|}
\hline No. IF & $\begin{array}{c}\mathrm{TE} \\
\left({ }^{\circ} \mathrm{C}\right) \\
\end{array}$ & $\begin{array}{l}\mathrm{Tfg} \\
\left\langle{ }^{\circ} \mathrm{C}\right\rangle\end{array}$ & $\begin{array}{l}\text { Th } \\
\left.{ }^{\circ} \mathrm{C}\right\rangle\end{array}$ & $\begin{array}{c}\text { Fração vol. } \\
\text { da bolha }\end{array}$ & $\mathrm{X}_{\mathrm{NaCl}}$ & $\begin{array}{c}\text { Salinidade } \\
\text { (\% em peso } \\
\mathrm{NaCl} \text { equiv. }\end{array}$ & $\begin{array}{l}\text { Ponto } \\
\text { critico } \\
\left({ }^{\circ} \mathrm{C}\right) \\
\end{array}$ & $\begin{array}{c}\text { Densidade } \\
\left(\mathrm{g} / \mathrm{cm}^{3}\right)\end{array}$ & $\begin{array}{l}\text { Tfs } \\
\left.\rho^{\circ} \mathrm{C}\right)\end{array}$ & Observações \\
\hline \multicolumn{11}{|c|}{\begin{tabular}{c|c|c|c|} 
Aquosas secundárias \\
1
\end{tabular}} \\
\hline 1 & -40.9 & -10.6 & 156.6 & 0.10 & 0.050 & 14.6 & 507.6 & 1.018 & \multirow{23}{*}{389.3} & \multirow{23}{*}{$\begin{array}{l}\text { necking down } \\
\text { necking down } \\
\text { necking down }\end{array}$} \\
\hline 2 & -45.9 & -9.8 & 158.6 & 0.10 & 0.047 & 13,7 & 499.7 & 1.010 & & \\
\hline 3 & .37 .1 & -9.7 & 197.9 & 0.10 & 0.046 & 13.6 & 498.7 & 0.972 & & \\
\hline 4 & -43.0 & -10.4 & 163.7 & 0.10 & 0.049 & 14.4 & 505.6 & 1.010 & & \\
\hline 5 & -39.1 & $\cdot 9.5$ & 104.7 & & 0.046 & 13.4 & 496.7 & 1.050 & & \\
\hline 6 & -26.3 & -7.3 & 105.6 & 0.10 & 0.036 & 0.9 & 473.6 & 1.031 & & \\
\hline 7 & -29.5 & -7.0 & 144.4 & 0.10 & 0.035 & 10.5 & 470.3 & 0.998 & & \\
\hline 8 & -34.1 & -6.3 & 208.6 & 0.10 & 0.032 & 9.0 & 462.3 & 0.933 & & \\
\hline 9 & -27.7 & -6.2 & 228.4 & 0.10 & 0.031 & 9.5 & 461.1 & 0.913 & & \\
\hline 10 & -43.6 & -10.0 & 253.0 & 0.15 & 0.048 & $\uparrow 3.9$ & 501.7 & 0.924 & & \\
\hline $1 \hat{1}$ & -38.8 & $-\$ 0.5$ & 296.3 & 0.30 & 0.050 & $\$ 4.5$ & 506.6 & 0.883 & & \\
\hline 12 & -38.4 & -10.1 & 182.2 & 0.10 & 0.048 & 14.1 & 502.7 & 0.991 & & \\
\hline 13 & -36.8 & -9.8 & & 0.10 & 0.047 & 13.7 & 499.7 & & & \\
\hline 14 & -31.9 & -9.4 & & & 0.045 & $\because 3.3$ & 495.7 & & & \\
\hline 15 & -29.5 & -9.6 & & 0.15 & 0.046 & 13.5 & 497.7 & & & \\
\hline 16 & .33 .2 & -6.5 & & & 0.033 & 9.8 & 464.6 & & & \\
\hline 17 & -48.8 & -7.4 & & & 0.037 & 11.0 & 474,7 & & & \\
\hline \$8 & -26.8 & -8.7 & 245.7 & 0.20 & 0.046 & 13.6 & 498.7 & 0.929 & & \\
\hline A & & & 120.9 & & & & & & & \\
\hline B & & & 135.2 & & & & & & & \\
\hline C & & & 177.0 & & & & & & & \\
\hline D & & & 188,1 & & & & & & & \\
\hline $\begin{array}{l}E \\
F\end{array}$ & & & $\begin{array}{l}193.6 \\
305.1\end{array}$ & & & & & & & \\
\hline
\end{tabular}


AM-168C - CAMPO 3 - QUARTZO - BOLSÃO DE QUARTZO - ESTAGGO TRANSICIONAL

\begin{tabular}{|c|c|c|c|c|c|c|c|c|c|c|c|c|c|c|c|c|}
\hline No. IF & $\left.\begin{array}{c}\mathrm{TE} \\
\left({ }^{\circ} \mathrm{C}\right)\end{array}\right]$ & $\begin{array}{l}\text { Ifg } \\
\left({ }^{\circ} \mathrm{C}\right)\end{array}$ & $\begin{array}{c}\text { TfCO2 } \\
\left({ }^{\circ} \mathrm{C}\right)\end{array}$ & $\begin{array}{l}\text { TfCl } \\
\left({ }^{\circ} \mathrm{C}\right)\end{array}$ & $\begin{array}{c}\text { ThCO2 } \\
\left({ }^{\circ} \mathrm{C}\right)\end{array}$ & $\begin{array}{c}\mathrm{Th} \\
\left\langle{ }^{\circ} \mathrm{C}\right\rangle\end{array}$ & $\begin{array}{l}\text { Fração vol. } \\
\text { da bolha }\end{array}$ & $\mathrm{X}_{\mathrm{H} 2 \mathrm{O}}$ & $\mathrm{X}_{\mathrm{COZ}}$ & $\mathrm{X}_{\mathrm{NaCl}}$ & $\begin{array}{c}\text { Salinidade } \\
\text { (\% em peso } \\
\text { NaCl equiv.) } \\
\end{array}$ & $\begin{array}{c}\text { Densidade } \\
\mathrm{H}_{2} \mathrm{O} \\
\left(\mathrm{g} / \mathrm{cm}^{3}\right) \\
\end{array}$ & $\begin{array}{l}\text { Ponto } \\
\text { crítico } \\
\left({ }^{\circ} \mathrm{C}\right) \\
\end{array}$ & $\begin{array}{c}\text { Densidade } \\
\mathrm{CO}_{2} \\
\left(\mathrm{~g}^{\prime} \mathrm{cm}^{3}\right) \\
\end{array}$ & $\begin{array}{c}\text { Densidade } \\
\text { total } \\
\text { \{g/cm3 } \\
\end{array}$ & Observaçöes \\
\hline \multicolumn{17}{|c|}{\begin{tabular}{l|l|l|l|l|l|}
\multicolumn{1}{|c|}{ Aquo-carbóninicas secundárias } \\
5 & -33.9 & -11.6 & -58.9
\end{tabular}} \\
\hline $\begin{array}{l}5 \\
6\end{array}$ & -33.9 & -11.6 & $\begin{array}{l}-58.1 \\
-58.1\end{array}$ & 1.8 & 19.8 & & 0.90 & 0,884 & 0.073 & 0.043 & \multirow{5}{*}{$\begin{array}{l}13.5 \\
11.8 \\
15.4 \\
14.0 \\
12.1 \\
\end{array}$} & \multirow[t]{5}{*}{1.094} & & \multirow[t]{5}{*}{0.192} & \multirow[t]{5}{*}{0.643} & \\
\hline $\begin{array}{c}6 \\
10\end{array}$ & & & $\begin{array}{l}-58.1 \\
-58.2\end{array}$ & $\begin{array}{l}3.1 \\
0.1\end{array}$ & & & $\begin{array}{l}0.90 \\
0.90\end{array}$ & & & & & & & & & \\
\hline 23 & -36.8 & & -58.3 & 1.4 & & 280.6 & 0.45 & & & & & & & & & \\
\hline 24 & -35.7 & & -58.1 & 2.9 & & & 0.40 & & & & & & & & & \\
\hline 25 & -27.0 & & -57.8 & 4.5 & 20.9 & 234.4 & 0.40 & & & & & & & & & \\
\hline \multirow{2}{*}{\multicolumn{17}{|c|}{$\begin{array}{l}\text { Aquosas secundárias } \\
1|-38.5|-10.9 \mid\end{array}$}} \\
\hline 1 & -38.5 & -10.9 & & & & & & & & & & & & & & \\
\hline 2 & -39.2 & -9.9 & & & & 1458 & 0,20 & & & 0.052 & 14.9 & & 510.6 & & 0.874 & \\
\hline 3 & -40.3 & -0.8 & & & & $\begin{array}{r}13.6 \\
2123\end{array}$ & $\begin{array}{l}0.10 \\
0.10\end{array}$ & & & 0.047 & १3.8 & & 500.7 & & 1.022 & \\
\hline 4 & -39.9 & -10.1 & & & & & 0.10 & & & 0.051 & 14,8 & & 509.6 & & 0.966 & \\
\hline 7 & -39.4 & -10.9 & & & & 156.4 & 0.10 & & & 0.048 & 14.1 & & 502.7 & & & \\
\hline 8 & $-31,6$ & -10.1 & & & & 272.9 & 0.15 & & & $\begin{array}{l}0.051 \\
0.048\end{array}$ & 14.9 & & 510.6 & & 1.020 & \\
\hline 9 & -40.1 & -9.7 & & & & 187.4 & 0.10 & & & 0.046 & $i 4.1$ & & 502.7 & & 0.905 & \\
\hline 11 & -40.1 & -9.9 & & & & 135.1 & 0.20 & & & 0.046 & 13.6 & & 498.7 & & 0.983 & \\
\hline 12 & -39.3 & -9.6 & & & & 267.8 & 0.10 & & & $\begin{array}{l}0.047 \\
0.046\end{array}$ & 13.8 & & 500.7 & & 1.030 & \\
\hline 13 & $-41,8$ & -10.4 & & & & 149,8 & 0.10 & & & $\begin{array}{l}0.046 \\
0.049\end{array}$ & 13.5 & & 497.7 & & 0.906 & \\
\hline 14 & -43.8 & $-1\} .5$ & & & & 288.3 & 0.15 & & & $\begin{array}{l}0.049 \\
0.053\end{array}$ & 14.4 & & 505.6 & & 1.022 & \\
\hline 15 & -42.6 & \begin{tabular}{|l|} 
\\
\end{tabular} & & & & 238.4 & 0.20 & & & 0.053 & 15.5 & & $5 \uparrow 6.4$ & & 0.901 & \\
\hline 16 & -43.4 & -10.5 & & & & 196.3 & 0.10 & & & 0.052 & 15.1 & & 512.5 & & 0.946 & \\
\hline 17 & -41.9 & -11.2 & & & & 298.4 & 0.25 & & & 0.050 & 14.5 & & 506.6 & & 0.981 & \\
\hline 18 & -23.8 & -6.6 & & & & 293.8 & 0.25 & & & 0.052 & 15.2 & & 513,5 & & 0.887 & \\
\hline 19 & -41.4 & -11.8 & & & & 269.7 & 0.10 & & & 0.033 & 10.0 & & 465.8 & & 0.839 & \\
\hline 20 & -49.9 & -9.6 & & & & $\$ 50,2$ & 0.10 & & & 0.055 & 15.8 & & 519.3 & & 0.922 & \\
\hline 21 & $-45,3$ & $\mid-12,8$ & & & & 157.1 & 0.10 & & & 0.646 & 13.5 & & 497.7 & & 1.015 & \\
\hline 22 & -45.7 & -12.0 & & & & 102,2 & 0.10 & & & 0.058 & 16.7 & & $52 S .1$ & & 1.034 & \\
\hline 26 & -45.5 & -11.6 & & & & & 0.15 & & & 0.055 & 16.0 & & 521.3 & & 1.071 & \\
\hline 27 & -42.7 & -7.7 & & & & 166.7 & 0.10 & & & 0.054 & 15.6 & & 517.4 & & & \\
\hline 28 & -40.3 & -8.6 & & & & 138.6 & 0.10 & & & $\begin{array}{l}0.038 \\
0.042\end{array}$ & $\begin{array}{r}71.3 \\
12.4\end{array}$ & & $\begin{array}{l}478.0 \\
487.5\end{array}$ & & $\begin{array}{l}0.985 \\
1.017\end{array}$ & \\
\hline
\end{tabular}


AM-158C - CAMPO 4 - QUARTZO - BOLSÄO DE QUARTZO - ESTÁGIO TRANSICIONAL

\begin{tabular}{|c|c|c|c|c|c|c|c|c|c|c|c|c|c|c|c|c|}
\hline No. IF & $\begin{array}{c}T E \\
\left({ }^{\circ} \mathrm{C}\right)\end{array}$ & $\begin{array}{l}\text { Tfg } \\
\left({ }^{\circ} \mathrm{C}\right)\end{array}$ & $\begin{array}{c}\mathrm{TfCO} 2 \\
\left({ }^{\circ} \mathrm{C}\right\rangle\end{array}$ & $\begin{array}{l}\text { TfCI } \\
\left({ }^{\circ} \mathrm{C}\right)\end{array}$ & $\begin{array}{c}\mathrm{ThCO} 2 \\
\left\langle{ }^{\circ} \mathrm{C}\right\rangle\end{array}$ & $\begin{array}{l}\text { Th } \\
\left({ }^{\circ} \mathrm{C}\right\rangle\end{array}$ & $\begin{array}{c}\text { Fração vol. } \\
\text { da botha }\end{array}$ & $\mathrm{X}_{\mathrm{H} 2 \mathrm{O}}$ & $\mathrm{x}_{\mathrm{CO} 2}$ & $\mathrm{X}_{\mathrm{A} 3 \mathrm{CS}}$ & $\begin{array}{c}\text { Salinidade } \\
(\% \text { em peso } \\
\mathrm{NaCl} \text { equiv.) }\end{array}$ & $\begin{array}{c}\text { Densidade } \\
\mathrm{H}_{2} \mathrm{O} \\
\left\{\mathrm{g}^{\prime} \mathrm{cm}^{3}\right) \\
\end{array}$ & $\begin{array}{l}\text { Ponto } \\
\text { critico } \\
\left({ }^{\circ} \mathrm{C}\right)\end{array}$ & $\begin{array}{c}\text { Densidade } \\
\mathrm{CO}_{2} \\
\left(\mathrm{~g} / \mathrm{cm}^{3}\right) \\
\end{array}$ & $\begin{array}{c}\text { Densidade } \\
\text { total } \\
\{g / \mathrm{cm} 3\} \\
\end{array}$ & Observaçöes \\
\hline \multicolumn{17}{|c|}{ Aquo-carbônicas primárias } \\
\hline 1 & .35 .6 & -12.5 & .58 .1 & 3.8 & 30.0 & 206.4 & 0.35 & 0.852 & 0.116 & 0.032 & 10.9 & 1.074 & & 0.596 & 0.906 & homog. por contraçẫo do $\mathrm{CO}_{2}$ \\
\hline 5 & & & .58 .2 & 4.2 & & 420.0 & 0.60 & & & & 10.3 & & & & & homogeneização para o gás \\
\hline 12 & -39.6 & & -58.2 & 4.0 & & 5240 & 0.50 & & & & 10.6 & & & & & 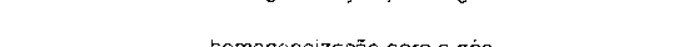 \\
\hline $\begin{array}{l}13 \\
14\end{array}$ & $\begin{array}{r}-35.9 \\
-48.3\end{array}$ & -18.1 & -58.3 & 3.8 & & $\begin{array}{l}524,0 \\
365.8\end{array}$ & $\begin{array}{l}0.70 \\
0.40\end{array}$ & & & 0.076 & $\begin{array}{l}10.9 \\
21.0\end{array}$ & & 584.3 & & 0863 & $\begin{array}{l}\text { homogeneizaçăo para o gès } \\
\text { RAMAN - sólico é calcita/com CO. }\end{array}$ \\
\hline$\$ 5$ & -24.8 & & -58.4 & 7.6 & 30.3 & & 0.40 & 0.897 & 0.089 & 0.014 & 4.7 & 1.025 & & 0.357 & 0.758 & RAMAN - com $\mathrm{CO}_{2}$ e traços de $\mathrm{CH}_{4}$. Homog por expansão do $\mathrm{CO}_{2}$ \\
\hline 16 & & & & & 30.2 & & & & & & & & & & & \\
\hline 22 & -31.8 & & & 3.7 & 29.4 & 410.2 & 0.45 & 0.869 & 0.098 & 0.033 & 11.0 & 1.075 & & 0.323 & 0.736 & nomog por exparsăo do $\mathrm{CO}_{2}$ \\
\hline 23 & & & -58.2 & & & & & & & & & & & & & RAMAN-Com $\mathrm{CO}_{2}$ \\
\hline \multicolumn{17}{|c|}{ Aquosas primárias } \\
\hline$\frac{2}{2}$ & -36.9 & -9.1 & & & & 104.2 & 0.10 & & & 0.044 & $\overline{13.0}$ & & 492.7 & & 1.047 & \\
\hline 3 & $-39,0$ & -9.4 & & & & 104.2 & 0.10 & & & 0.045 & 13.3 & & 495.7 & & 1.050 & \\
\hline 4 & -38.1 & -6.6 & & & & 97.6 & 0.10 & & & 0.033 & 10,0 & & 465.8 & & 1.030 & \\
\hline 6 & -39.8 & -9.7 & & & & & 0.10 & & & 0.046 & 13.6 & & 498.7 & & & \\
\hline 7 & -41.3 & -9.8 & & & & 144.1 & 0.10 & & & 0.047 & 13.7 & & 499.7 & & 1.022 & \\
\hline 8 & -35.7 & -5.2 & & & & 229.6 & 0,30 & & & 0.026 & 8.1 & & 448.9 & & 0.900 & \\
\hline $\mathrm{g}$ & -40.2 & -8.8 & & & & 188.8 & 0.20 & & & 0.043 & 12.6 & & 489.6 & & 0.974 & \\
\hline 10 & -38.9 & -9.4 & & & & 316.9 & 0.30 & & & 0.045 & 13.3 & & 495.7 & & 0.845 & \\
\hline 11 & -40.9 & -9.4 & & & & 137.4 & 0.15 & & & 0.045 & 13.3 & & 495.7 & & 1.024 & \\
\hline 17 & -33.8 & -4.6 & & & & & 0.20 & & & 0,024 & 7.3 & & 441.2 & & & \\
\hline 18 & -31.9 & -3.0 & & & & 136.0 & 0.20 & & & 0.015 & 4.9 & & 419.0 & & 0.966 & \\
\hline 19 & -32.9 & $-10,3$ & & & & 370.1 & 0.30 & & & 0.048 & 14.1 & & 502.7 & & 0.776 & \\
\hline 20 & $-40,8$ & -7.6 & & & & 100.0 & 0.10 & & & 0.038 & 11.2 & & 476.9 & & 1.037 & \\
\hline
\end{tabular}


AM-213 - CAMPO 1- QUARTZO - PEGAMTITO - ESTAGIO TRANSICIONAL.

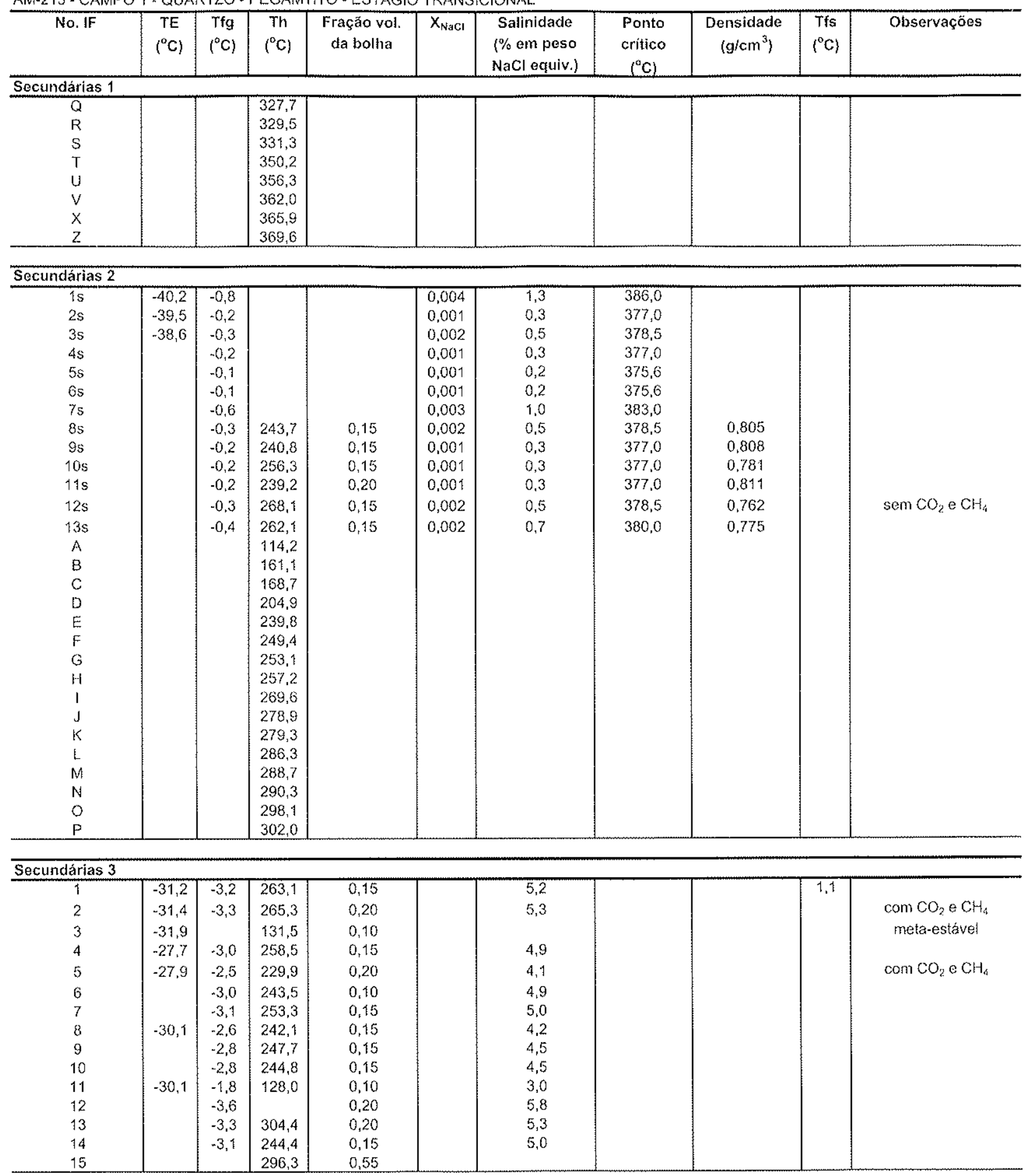




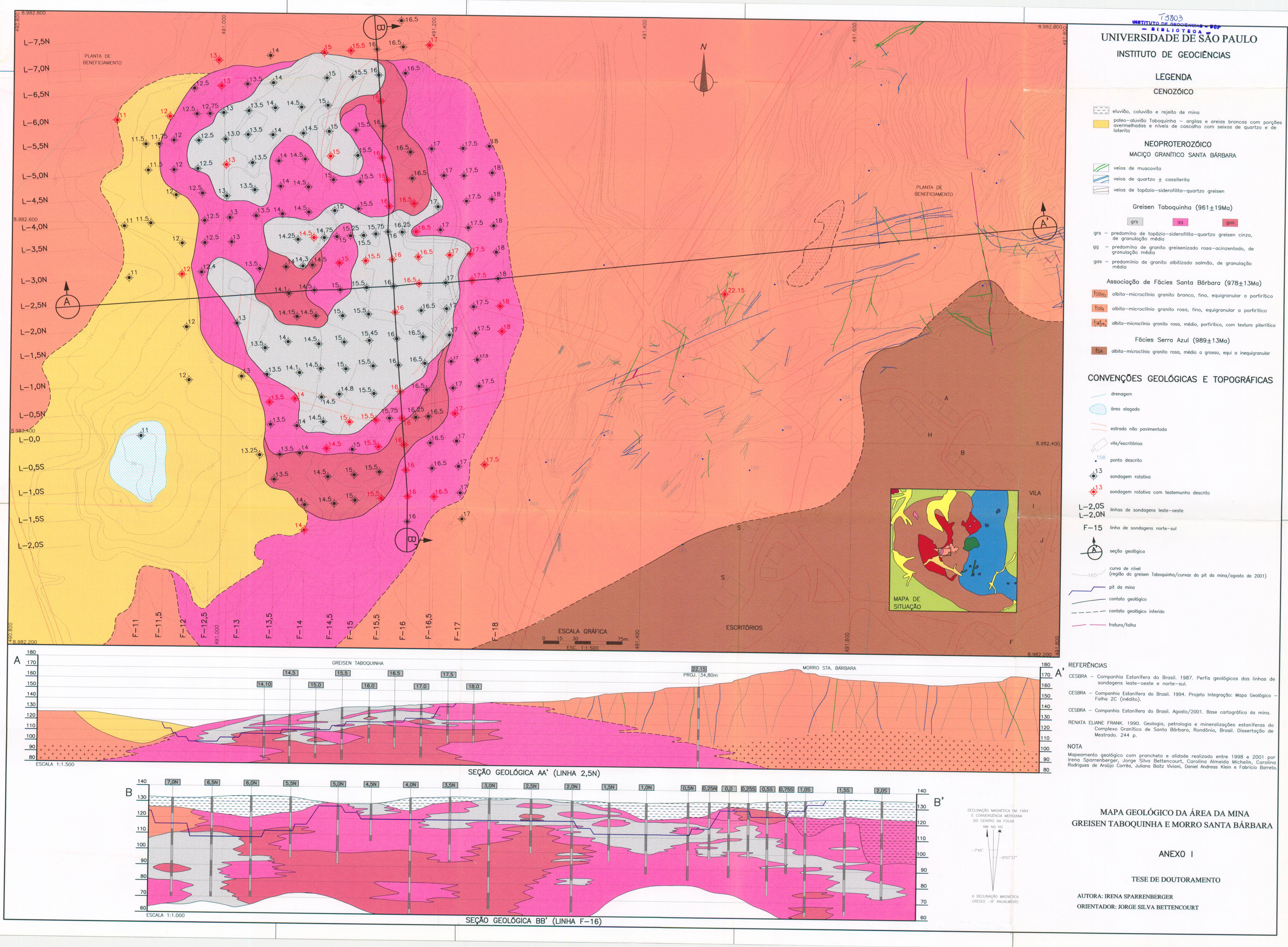

